Nenhum homem realmente produtivo pensa como se estivesse escrevendo uma dissertação. 


\section{UNIVERSIDADE DE SÃO PAULO ESCOLA DE EDUCAÇÃO FÍSICA}

Edilamar Menezes de Oliveira

\section{O SISTEMA RENINA ANGIOTENSINA NO TREINAMENTO FÍSICO}

São Paulo

2010 
Oliveira, Edilamar Menezes

O Sistema Renina e Angiotensina no treinamento fisico/

Edilamar Menezes de Oliveira. - São Paulo: [s.n.], 2010.

$\mathrm{xi}, 300 \mathrm{p}$.

Tese (Livre-Docência)- Escola de Educação Física e Esporte da Universidade de São Paulo.

1. Treinamento Físico 2. Hipertrofia Cardíaca 3. Sistema Renina Angiotensina 4. Esteróide Anabolizante I. Título 


\section{DEDICO ESSA TESE}

Aos meus pais que sempre foram presença forte, madura, e incentivadora na minha vida profissional

Especialmente dedico essa Tese ao MEU PAI, que não tive a chance de me despedir nos seus últimos momentos. 


\section{DEDICO ESSA TESE ESPECIALMENTE AOS MEUS ALUNOS}

$\mathrm{e}$

\section{AGRADEÇO}

Por terem entendido o tempo que fiquei no Pós-doutorado.

Por vencerem todas as barreiras e contratempos de ter uma orientadora distante, neste período da formação de vocês.

Por terem mostrado o quanto são adultos e responsáveis

Por terem sido unidos, pela lealdade e a dedicação que tiveram com seus projetos

VOCÊS FORAM

${ }^{\diamond}$ BRILHANTES ${ }^{\diamond}$ 


\section{AGRADECIMENTOS}

Agradeço à DEUS por me dar um caminho tão bonito para trilhar, no qual faço com muito prazer a minha caminhada diária. 


\section{AGRADECIMENTOS}

Ao Sérgio, pelos anos que trilhamos juntos esse caminho e por ter superado seus limites e ter nos dado a oportunidade de vivermos juntos o melhor anos das nossas vidas. Por tudo AMOR, obrigada.

A toda a minha família, pela presença constante em todos os momentos, o incentivo, afeto e AMOR INCONDICIONAL que temos uns pelos outros.

A todos vocês, gostaria de dizer, que se hoje tivesse a oportunidade de escolher uma família para nascer, ainda escolheria a que a tenho.

Vocês são realmente ESPECIAIS. 


\section{AGRADECIMENTOS}

Ao Prof Dr. José Eduardo Krieger, pelas orientações, por ter contribuído positivamente na minha formação acadêmica e pela maneira autêntica e sem restrições, que sempre me disponibiliza seu laboratório e acolhe meus alunos.

Ao Dr Ian Phillips, por ter aceito a supervisão de meu estágio de Pósdoutorado. Por conduzir e orientar meu trabalho de forma tão competente e por todo o apoio que venho recebendo, desde que renornei ao Brasil. Obrigada pela amizade e confiança depositada no meu trabalho. A Blanca pela convivência alegre e prazerosa, além da comida gostosa sempre oferecida.

Ao Prof. Dr. Carlos Eduardo Negrão, por ter me dado apoio constante desde que ingressei na EEFE-USP. Pelas colaborações e a influência positiva que exerce no nosso laboratório. Pelo seu exemplo de força, de vontade de construir sempre, de dedicação à ciência, pelo exemplo à ser seguido.

As Profs. Dras. Cláudia Irigoyen e Kátia D'Angelis, pelas colaborações, pelo carinho e amizade. A Cláudia, especialmente, pela influência boa que você é na minha carreira acadêmica e por ter acolhido alguns de meus alunos nos momentos que precisaram, enquanto eu estava no meu pós-doutorado.

Ao Prof Dr Eduardo Moacir Krieger, pelos ensinamentos e o exemplo de carreira científica, e pela disponibilidade de seu laboratório.

Ao Prof Dr. Dalton Vassallo pelas colaborações e incentivo na minha vida profissional e agora dos meus alunos também.

Ao Prof. Dr. João José Freitas Sarkis (in memmorium), pela contribuição importante na minha formação científica, pelos ensinamentos que ficaram e pela grande amizade. 
A Profa. Dra. Taís Tinucci, por todos os bons momentos de nosso convívio diário, pela relação de confiança e pela amizade ao longo destes 12 anos. Pela responsabilidade assumida pelos meus alunos, perante a Pós-graduação e à FAPESP, no período de meu afastamento para o pós-doutorado. Por acolher meus alunos sempre.

A Profa. Dra. Patrícia Brum, pelas colaborações, pela amizade e prazeroso convívio diário que temos dividindo um mesmo laboratório. Pelo apoio e incentivo para eu realizasse um estágio de Pós-doutoramento e mostrar a importância dessa etapa para o meu crescimento científico. Pelo exemplo que você é para todos os nossos alunos, de competência e dedicação.

Ao Prof. Dr. Paulo Ramires, pelo prazer de trabalharmos juntos, pela relação de confiança, amizade e carinho que temos. Por dividirmos nossas atribuições acadêmicas tão tranquilamente e pelas colaborações científicas. Por você ser sempre tão solícito e dedicado aos alunos dos nossos laboratórios. Obrigado por dividirmos tão armoniozamente um laboratório, disciplinas de graduação e pós-graduação.

Ao Dr. Alexandre Pereira, do Laboratório de Genética e Cardiologia Molecular do InCor pelas colaborações e a atenção dispensada ao meu aluno Cléber durante meu afastamento.

Aos meus colegas de Departamento, por terem unanimente concordado com meu afastamento para o estágio de Pós-doutorado e a agradável convivência.

A Shirley, por toda a sua compência profissional e por ser sempre solicita e dedicada as nossas vidas.

Aos meus alunos, mais uma vez, um especial agradecimento. A todos os alunos, os atuais e a todos que já orientei, muito obrigada por terem contribuído nesta Tese de Livre-docência. Obrigada pela relação de confiança e o prazer que é nosso trabalho no dia a dia. Acredito que podemos ser mais que um orientador científico na vida de vocês, que podemos contribuir numa fase de vida de tantas indefinições, mas por outro lado de tantos sonhos e objetivos que estão sendo traçados. 
Procuro sempre mostrar que a vida científica não é fácil, mas pode ser muito prazerosa. Obrigada pela contribuição de todos organizando figuras, analisando resultados, finalizando experimentos e contribuindo na finalização deste trabalho. Vocês fazem a diferença!

Agradecimentos especiais ao Diego Barretti pela colocação de todas as referências e especialmente ao Tiago Fernandes pela organização primorosa com que sempre faz as sua tarefas e não foi diferente nessa Tese, pela organização das figuras e formatação final do trabalho. Obrigada pelo tempo dispendido e o prazer que foi ter vocês ao meu lado auxíliando em tudo.

A TODOS os alunos dos nossos laboratórios, pela agradável convivência. Vocês são o nosso incentivo para a busca de novos conhecimentos.

Aos técnicos de nossos laboratórios a Marcele Coelho, a Katt Mattos a Glória Mota, e agora também o Alex, pelo trabalho sério de vocês no dia a dia com os alunos. Vocês são de fundamental importância para o bom andamento do nosso trabalho. Obrigada pela dedicação de vocês.

Ao Luciano, pelo cuidado com os animais e organização de tudo no biotério.

Aos colegas e alunos do Laboratório de Experimentação e do Laboratório do Krieger, pela receptividade e auxílio aos meus alunos e pela agradável convivência com vocês.

À Maúde, Renata, Silvana e a Isabel Cristina pela amizade e atenção especial sempre recebida por vocês.

Aos alunos orientados no EUA, Dafina Ibrani e Aftab Hammad, com os quais muito aprendi. Por terem tornado minha vida mais alegre e o laboratório mais prazeroso de trabalhar, também pela grande amizade que ficou entre nós.

Àos técnicos do laboratório nos Estados Unidos (Keping and Leping) pelo auxílio e apoio na execução do meu trabalho. 
À Direção do KGI e aos funcionários pelo excelente trabalho e atenção que sempre me dispensaram.

Ào Internacional Place, nas pessoas da Charlene e do Donald, por toda a atenção e auxílio recebido.

Ào Dr. Tang, pela colaboração importante no delineamento do projeto de Pós-doutorado

À todos os colegas e alunos do KGI, pela convivência armoniosa e atenção recebida, principalmente da Bárbara

À Escola de Educação Física e Esporte da USP por ser esse lugar onde tenho prazer em trabalhar e desenvolver todas as minhas atividades, pelos incentivos na minha vida científica e ao apoio recebido. A todos os funcionários, pela contribuição do trabalho de vocês.

À Comissão de Pós-Graduação, por ser sempre prestativa com os alunos e comigo durante meu afastamento.

A FAPESP, pelo Auxílio a Projetos Concedidos e bolsas dos alunos.

CNPq e a CAPES, pelas bolsas recebidas durante minha formação acadêmica e a Bolsa de Pós-doutorado concedida . Pela Bolsa de Produtividade em Pesquisa e Projetos financiados e a CAPES pelas Bolsas concedidas aos alunos.

A todos, que de uma forma ou de outra contribuíram para o desenvolvimento dos resultados apresentados nesta Tese de Livredocência. 


\section{SUMÁRIO}

LISTA DE ABREVIATURAS

APRESENTAÇÃO DA TESE

Parte 1. Participação do SRA na Hipertrofia Cardíaca Excêntrica Induzida pelo Treinamento Físico Aeróbio, na Eritropoiese e na Hipertrofia Cardíaca Concêntrica Induzida pelo Treinamento Físico de Força ou Resistido..

Parte 2. Participação do SRA-Aldosterona em Patologias Cardiovasculares: Efeitos do Treinamento Físico Aeróbio

Parte 3. Perspectivas Futuras

PARTE 1. Participação do SRA na Hipertrofia Cardíaca Excêntrica Induzida pelo Treinamento Físico Aeróbio, na Eritropoiese e na Hipertrofia Cardíaca Concêntrica Induzida pelo Treinamento Físico de Força ou Resistido

1. Estudo 1: Participação do SRA local e sistêmico na hipertrofia fisiológica induzida pelo treinamento físico aeróbio

1.1 Material e Métodos

1.1.1 Treinamento físico dos animais

1.1.2 Animais de experimentação............................................................. 20

1.1.3 Medida direta da pressão arterial e da freqüência cardíaca .................... 21

1.1.4 Amostras de soro e tecidos ............................................................... 22

1.1.5 Morfologia cardíaca................................................................... 22

1.1.6 Medida da atividade da renina plasmática.......................................... 22

1.1.7 Medida da atividade da citrato sintase ................................................ 22

1.1.8 Análise estatística ........................................................................ 23

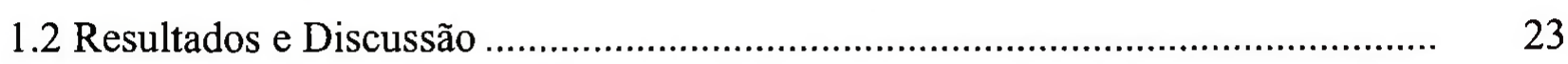

1.2.1 Peso corporal ................................................................................. 23

1.2.2 Marcadores de treinamento físico.......................................................... 23

1.2.3 Medidas hemodinâmicas ................................................................. 24

1.2.4 Hipertrofia cardíaca e inibição do SRA local ........................................ 25

1.2.5 Dissociação do SRA local do sistêmico ................................................ 29

1.3 Material e Métodos ..................................................................................... $\quad 32$

1.3.1 Animais de experimentação............................................................... 32

1.3.2 Protocolo de treinamento físico aeróbio ............................................. 32

1.3.3 Medida direta da pressão arterial e da freqüência cardíaca ................... 32 
1.3.5 Atividade da enzima conversora de angiotensina cardíaca e no soro..... $\quad 32$

1.3.6 Atividade da enzima conversora de angiotensina 2 cardíaca ................. 33

1.3.7 Medida da atividade da renina plasmática............................................ 33

1.3.8 Microarray microRNAs .................................................................. 33

1.3.9 Determinação da expressão gênica ...................................................... 33

1.3.10 Análise da expressão protéica por western blotting ............................ 36

1.3.11 Medida de angiotensina II cardíaca .............................................. 37

1.3.12 Análise estatística ................................................................... 37

1.4 Resultados e Discussão .......................................................................... $\quad 38$

1.4.1 Pressão arterial e freqüência cardíaca............................................... 38

1.4.2 Hipertrofia cardíaca ................................................................... 38

1.4.3 Marcadores moleculares de hipertrofia cardíaca patológica ................. 39

1.4.4 Atividade da enzima conversora de angiotensina cardíaca e no soro..... $\quad 40$

1.4.5 Expressão gênica dos componentes do SRA ........................................ 42

1.4.6 Expressão protéica dos componentes do SRA....................................... 43

1.4.7 Análises dos microRNAs................................................................. 49

2. Estudo 2: Influência do $\mathrm{N}$ domínio da enzima conversora de angiotensina na eritropoiese induzida pelo treinamento físico aeróbio e no consumo de oxigênio............... 54

2.1 Material e Métodos ................................................................................... 59

2.1.1 Animais de experimentação................................................................. 59

2.1.2 Protocolo de treinamento físico aeróbio ............................................. 60

2.1.3 Confirmação da participação do SRA: inibição da ECA........................ 61

2.1.4 Determinação da atividade dos terminais N e C-dom e total da ECA..... 61

2.1.5 Medida da atividade da citrato sintase............................................... 62

2.1.6 Contagem de reticulócitos e índices hematimétricos.............................. 62

2.1.7 Avaliação da meia-vida das hemácias ................................................ 63

2.1.8 Ensaio clonogênico ......................................................................... 63

2.1.9 Protocolo de avaliação de esforço máximo ............................................ 63

2.1.10 Avaliação do consumo de oxigênio ..................................................... 64

2.1.11 Medida direta da pressão arterial e da freqüência cardíaca .................. 64

2.1.12 Morfologia cardíaca......................................................................... 65

2.1.13 Análise estatística ...................................................................... 65

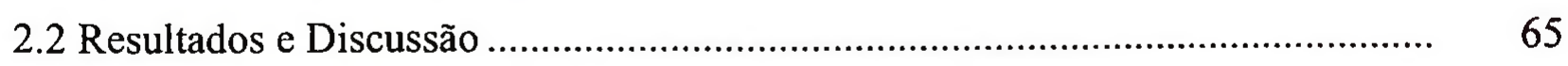

2.2.1 Peso corporal ............................................................................. 65

2.2.2 Esforço máximo.............................................................................. 66

2.2.3 Consumo máximo de oxigênio ....................................................... 66 


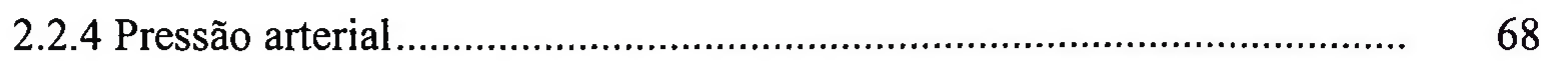

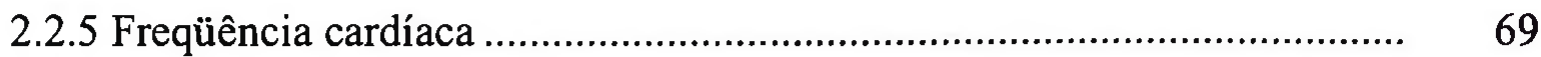

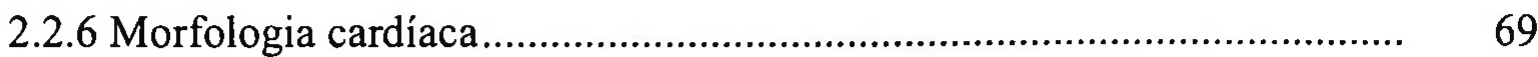

2.2.7 Atividade dos terminais $\mathrm{N}$ e C-dom e total da ECA............................ $\quad 70$

2.2.8 Medida de unidade formadora de colônia ............................................ 71

2.2.9 Medida de reticulócitos.................................................................... 72

2.2.10 Hematócrito e hemoglobina............................................................. 75

2.2.11 Meia-vida da hemácia................................................................ $\quad 75$

3. Estudo 3: Participação do SRA na hipertrofia fisiológica induzida pelo treinamento físico de força e via de sinalização ativada pelo receptor................................................. 88

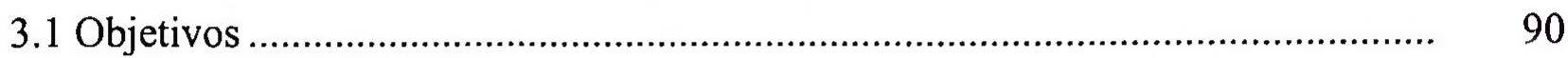

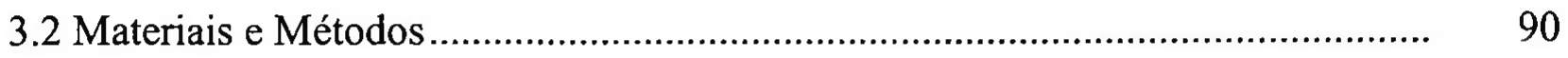

3.2.1 Animais de experimentação.......................................................... 90

3.2.2 Protocolo de treinamento dos animais................................................ 91

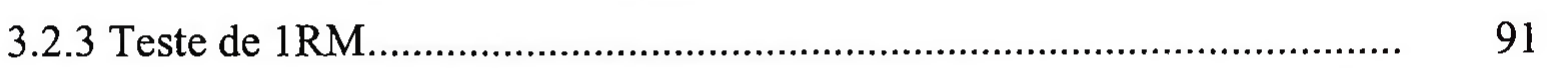

3.2.4 Medida direta da pressão arterial e freqüência cardíaca ........................ 91

3.2.5 Quantificação das catecolaminas plasmáticas ...................................... 93

3.2.6 Morfologia cardíaca................................................................... 93

3.2.7 Análise estatística ..................................................................... 93

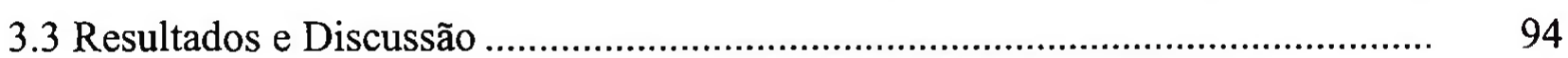

3.3.1 Peso do músculo esquelético .......................................................... 96

3.3.2 Peso do coração ........................................................................... 96

3.3.3 Pressão arterial ................................................................................ 96

3.3.4 Medida de catecolaminas plasmáticas e peso das adrenais ................... 98

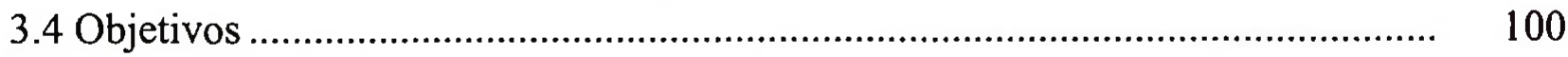

3.5 Material e Métodos .................................................................................. 101

3.5.1 Animais de experimentação............................................................ 101

3.5.2 Protocolo de treinamento dos animais ............................................. 101

3.5.3 Morfologia cardíaca...................................................................... 101

3.5.4 Morfometria cardíaca...................................................................... 101

3.5.5 Medidas hemodinâmicas ............................................................. 102

3.5.6 Avaliação da morfometria e função ventricular pelo ecocardiograma.... 102

3.6 Resultados e Discussão ........................................................................ 103

3.6.1 Acompanhamento da medida de repetição máxima (RM) .................... 103

3.6.2 Medida direta da pressão arterial e freqüência cardíaca ........................ 104

3.6.3 Hipertrofia cardíaca .................................................................... 106

3.7 Materias e Métodos ............................................................................... 112 
3.7.1 Animais de experimentação............................................................ 112

3.7.2 Protocolo de treinamento dos animais................................................ 113

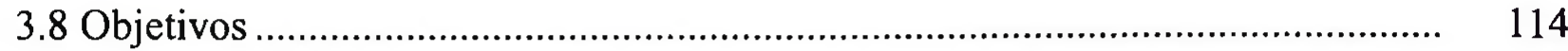

3.9 Resultados e Discussão ............................................................................... 115

3.9.1 Teste de 1 RM......................................................................... 117

3.9.2 Medidas hemodinâmicas ............................................................. 118

3.9.3 Função ventricular .......................................................................... 119

3.9.4 Hipertrofia cardíaca ...................................................................... 120

3.9.5 Atividade da renina plasmática........................................................ 122

3.9.6 Atividade da enzima conversora de angiotensina............................... 123

3.9.7 Expressão das proteínas do SRA ..................................................... 123

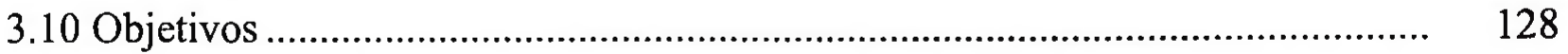

3.11 Material e Métodos ................................................................................ 129

3.11.1 Animais de experimentação.............................................................. 129

3.11.2 Protocolo de exercício físico de força ................................................ 129

3.11.3 Análise da expressão protéica.......................................................... 130

3.11.4 Análise estatística ....................................................................... 131

3.12 Resultados e Discussão ........................................................................ 131

PARTE 2. Participação do SRA-Aldosterona em Patologias Cardiovasculares: efeitos do treinamento físico aeróbio

4. Estudo 4: Efeitos dos Esteróides Anabolizantes associados ao treinamento físico sobre o SRA-Aldosterona cardíaco e fluxo sanguíneo ..................................................... 136

4.1 Material e Métodos ............................................................................. 138

4.1.1 Protocolo experimental.............................................................. 138

4.1.2 Treinamento dos animais ................................................................. 139

4.1.3 Avaliação hemodinâmica e da função ventricular.................................. 140

4.1.4 Medida direta da pressão arterial e da freqüência cardíaca .................... 141

4.1.5 Amostras de soro e tecidos ............................................................ 141

4.1.6 Morfologia cardíaca.................................................................... 142

4.1.7 Morfometria cardíaca...................................................................... $\quad 142$

4.1.8 Dosagem de hidroxiprolina............................................................. 142

4.1.9 Determinação da atividade da enzima conversora de angiotensina........ 143

4.1.10 Medida da atividade da renina plasmática ......................................... 143

4.1.11 Medida da testosterona plasmática ................................................... 144

4.1.12 Determinação da expressão gênica ...................................................... 144 
4.1.13 Immunohistoquímica ............................................................... 144

4.1.14 Análise estatística .................................................................. 145

4.2 Resultados e Discussão ............................................................................... 145

4.2.1 Níveis plasmáticos de testosterona .................................................... 145

4.2.2 Medidas hemodinâmicas ................................................................. 146

4.2.3 Peso corporal dos animais ............................................................... 146

4.2.4 Hipertrofia cardíaca ......................................................................... 148

4.2.5 Características do colágeno cardíaco ................................................. 149

4.2.6 Sistema Renina Angiotensina .......................................................... 154

4.2.7 Avaliação da função ventricular ........................................................ 157

4.3 Materiais e Métodos ........................................................................... 162

4.3.1 Protocolo experimental................................................................... 162

4.3.2 Expressão gênica cardíaca ................................................................ 164

4.3.3 Transcrição reversa (RT-PCR) ....................................................... 165

4.3.4 Avaliação eletroforética dos produtos de amplificação......................... 166

4.3.5 Análise estatística ....................................................................... 166

4.4 Resultados e Discussão .............................................................................. 167

4.4.1 Pressão arterial e fequência cardíaca ................................................... 167

4.4.2 Função ventricular ......................................................................... 169

4.4.3 Hipertrofia cardíaca .................................................................... 172

4.4.4 Diâmetro dos cardiomiócitos ............................................................. 173

4.4.5 Colágeno cardíaco ....................................................................... 175

4.4.6 Sistema Renina Angiotensina cardíaco ........................................... 178

4.4.7 Fatores inflamatórios cardíacos ...................................................... 184

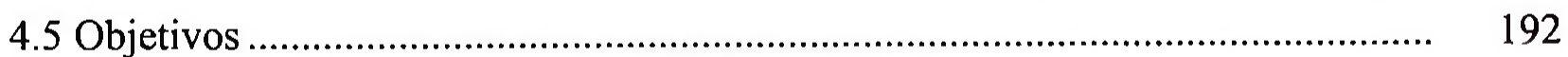

4.6 Materiais e Métodos ............................................................................ 192

4.6.1 Grupos e seqüência experimental ....................................................... 192

4.6.2 Histomorfometria do colágeno perivascular....................................... 193

4.6.3 Quantificação do número de capilares no músculo esquelético ............. 193

4.6.4 Hipertrofia vascular ........................................................................ 194

4.6.5 Hipertrofia muscular esquelética ......................................................... 194

4.6.6 Determinação do fluxo sangüíneo para o coração e músculo esquelético pela utilização da técnica das microesferas coloridas.................... 194

4.6.7 Determinação do número de microesferas e do fluxo sangüíneo ............ 198

4.6.8 Análises bioquímicas ......................................................................... 199

4.6.9 Análise estatística ......................................................................... 202

4.7 Resultados e Discussão ................................................................................... 202

4.7.1 Hipertrofia cardíaca ................................................................... 202 
4.7.2 Fluxo sangüíneo coronário ............................................................. 203

4.7.3 Morfometria cardíaca.................................................................... 208

4.7.4 Hidrólise de nucleotídeos ................................................................... 214

4.7.5 Fluxo sanguíneo para o músculo esquelético ...................................... 221

4.7.6 Morfologia muscular esquelética - hipertrofia..................................... 222

4.7.7 Morfometria muscular esquelética - número de capilares por fibra ....... 222

4.7.8 Expressão de VEGF............................................................................ 224

5. Estudo 5: Efeitos do treinamento físico aeróbio sobre a angiogênese na hipertensão arterial

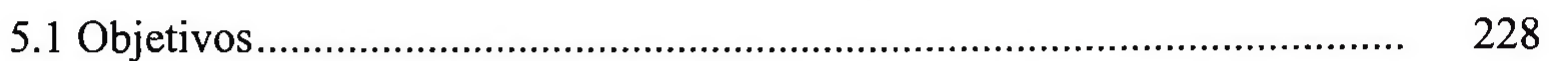

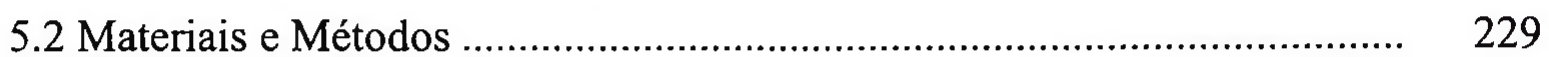

5.2.1 Animais de experimentação.............................................................. 229

5.2.2 Protocolo de treinamento físico aeróbio ................................................. 230

5.2.3 Avaliação da pressão arterial e freqüência cardíaca de repouso.............. 230

5.2.4 Protocolo de avaliação da tolerância ao esforço físico máximo.............. 230

5.2.5 Protocolo de medida do consumo máximo de oxigênio .......................... 231

5.2.6 Avaliação da caracterização histoquímica do músculo esquelético ........ 232

5.2.7 Determinação da área de secção transversa e tipos de fibras musculares ......................................................................................... 234

5.2.8 Análise da razão capilar por fibra ...................................................... 235

5.2.9 Extração das células mononucleadas da medula óssea........................... 235

5.2.10 Extração das células mononucleadas do sangue periférico ................... 236

5.2.11 Quantificação das células progenitoras endoteliais na medula óssea....

5.2.12 Ensaio de envelhecimento celular associado à atividade da $\beta$ galactosidase

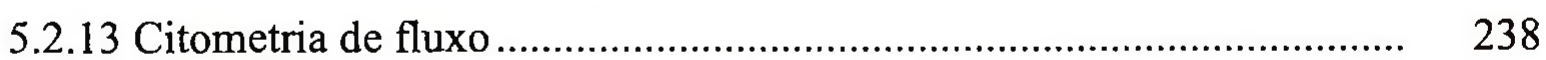

5.2.14 Avaliação funcional de formação de unidade formadora de colônia ....

5.2.15 Avaliação funcional de formação de tubos como capilares sobre matrigel.

5.2.16 Western Blotting.

5.2.17 Análise estatística ..................................................................... 240

5.3 Resultados e Discussão................................................................... 240

PARTE 3. Perspectivas Futuras.

6. Identificar microRNAs diferencialmente expressos na hipertrofia cardíaca cardíaca fisiológica, que possam ser potencialmente alvos para terapia gênica com sense e/ou antisense para microRNAs em patologias cardíacas 


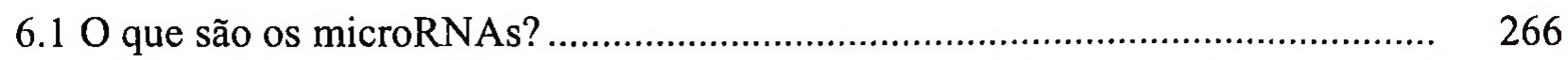

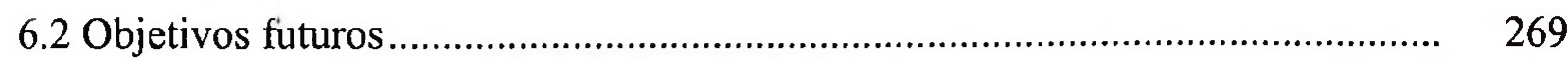

6.3 Resultados preliminares ......................................................................... $\quad 270$

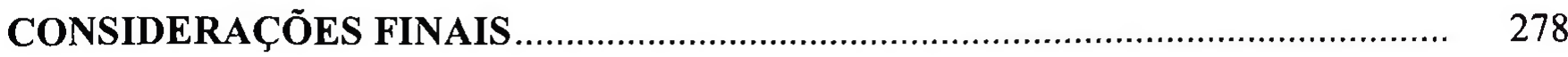

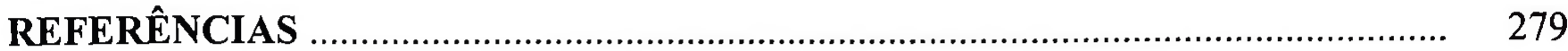




\section{LISTA DE ABREVIAÇÕES}

1RM

2,3 DPG

$11 \beta$-HSD

${ }^{51} \mathrm{Cr}$

Ac-SDKP

ADP

AGT

AKT

$\mathrm{AMPc}$

ANF

ANG (1-7)

ANG (1-9)

ANG I

ANG II

ANOVA

ARP

AT1

AT2

ATP

BFU-E

CFU-E

CFU-GM

$\mathrm{CHCM}$

$\mathrm{CO}_{2}$

$\mathrm{CoA}$

CPE

CPV

CTGF

CYP11B2

DA

DCV
Repetição máxima

Gliceraldeído

$11 \beta$-hidroxisteroide dehidrogenase

Cromo radioativo

acetyl-seryl-aspartyl-lysyl-proline

Adenosina di-fosfato

Angiotensinogênio

Proteina quinase $B$

Monofostato de adenosina cíclico

Fator natriurético atrial

Angiotensina (1-7)

Angiotensina (1-9)

Angiotensina I

Angiotensina II

Análise de variância

Atividade da renina plasmática

Receptor de ANG II do subtipo 1

Receptor de ANG II do subtipo 2

Adenosina tri-fosfato

Unidade formadora de bursts de eritrócitos

Unidade formadora de colônia de eritrócitos

Unidade formadora de colônia de granulócitos e monócitos

Concentração de Hemoglobina corpuscular média

Gás carbônico

Coenzima A

Células progenitoras endoteliais

Colágeno perivascular

Fator de crescimento de tecido conectivo

Gene da aldosterona sintase

dopamine

Doenças casdiovasculares 
DDiaVE

DEPC

DMEM

DP

$\mathrm{dP} / \mathrm{dt}$ negativa

$\mathrm{dP} /$ dt positiva

DSisVE

EA

ECA

ECA2

ECA3

ECO

EDTA

eNOS

E-NPP

E-NTPDase

EPI

EPM

ES

FACS

FC

FCV

FEj

FEn

$\mathrm{FeO}_{2}$

$\mathrm{FiO}_{2}$

FITC

GAPDH

HA

$\mathrm{Hb}$

$\mathrm{HE}$

HPLC

HSC

iNOS
Diâmetro diastólico do ventrículo esquerdo

Dietil pirocarbonato

Meio de Eagle modificado por Dulbecco

Desvio padrão

Derivada de relaxamento do ventrículo esquerdo

Derivada de contração do ventrículo esquerdo

Diâmetro sistólico do ventrículo esquerdo

Esteróides anabolizantes

Enzima conversora de angiotensina I

Enzima conversora de angiotensina 2

Enzima conversora de angiotensina 3

Ecocardiografia

Ácido etilenodiaminotetracético

Óxido nítrico sintase endotelial

Ecto-nucleotídeo pirofosfatase fosfodiesterase

Ecto-nucleosídeo trifosfato difosfoidrolase

Adrenalina

Erro padrão da média

Estímulo elétrico

Separação de célula ativada por fluorescência

Freqüência cardíaca

Fração do volume de colágeno

Fração de ejeção

Fração de encurtamento

Frações expiradas de oxigênio

Fração inspirada de oxigênio

Isotiocianato de fluresceína

Gliceraldeído-3-fosfato desidrogenase

Hipertensão arterial

Hemoglobina

Hematoxilina e eosina

Cromatografia líquida de alta performace

Células tronco hematopoiéticas

Óxido nítrico sintase induzível 
LDL

LIN4

LOS

$\mathrm{miR}$

$\mathrm{MC}$

MMP-1

MNC

MVE

NE

NEP

$\mathrm{NO}$

$\mathrm{O}_{2}$

$\mathrm{OH}-\mathrm{Pro}$

$\mathrm{p}-\mathrm{OHHgBz}$

P1

P2

PA

PAD

PAM

PAS

PAS

PBS

$\mathrm{PC}$

PCP

PCR

PDF

PDI

PEP

$\mathrm{Pi}$

PI3K

PKC

PMSF

PPVEDia

PPVESis
Lipoproteína de baixa densidade

Lineage-deficient-4

Losartan

MicroRNA

Massa corporal

Metaloproteinases 1

Células mononucleares

Massa do ventrículo esquerdo

noradrenalina

Endopeptidade neutra

Óxido nítrico

Oxigênio

Concentração de hidroxiprolina

Para-hidroxi mercurio benzoato

Protocolo de treinamento de natação 1

Protocolo de treinamento de natação 2

Pressão arterial

Pressão arterial diastólica

Pressão arterial média

Periodic Acid Schiff

Pressão arterial sistólica

Solução tampão fosfato

Peso corporal

Prolil-carboxi peptidase

Reação de polimerase em cadeia

Pressão diastólica final de ventrículo esquerdo

Pressão diastólica inicial de ventrículo esquerdo

Prolil-endopeptidase

Fosfato inorgânico

Fosfatidilinositol-3 quinase

Proteína quinase $\mathrm{C}$

Fenil metil sulfonil fluoreto

Parede posterior do ventrículo esquerdo em diástole

Parede posterior do ventrículo esquerdo em sístole 


\begin{tabular}{|c|c|}
\hline $\mathrm{rC} / \mathrm{F}$ & Razão Capilar/Fibra \\
\hline $\mathrm{RM}$ & Receptores de mineralocorticóides \\
\hline RNA & Ácido ribonucléico \\
\hline RT & Transcrição reversa \\
\hline SA & Sedentário anabolizante \\
\hline $\mathrm{SAE}$ & Sedentário anabolizado tratado com espironolactona \\
\hline SAL & Sedentário anabolizado tratado com losartan \\
\hline $\mathrm{SC}$ & Sedentário controle \\
\hline SDS-PAGE & Sodium Dodecyl Sulfate Polycrylamide Gel Electrophoresis \\
\hline SHR & Ratos espontaneamente hipertensos \\
\hline SHR-T & Ratos espontaneamente hipertensos treinado \\
\hline S-iECA & Sedentário tratado com inibidor da ECA \\
\hline SIVEDia & Espessura do septo interventricular na diástole \\
\hline SIVESis & Espessura do septo interventricular na sístole \\
\hline SRA & Sistema Renina Angiotensina \\
\hline $\mathrm{T} 1-\mathrm{iECA}$ & Treinado tratado com inibidor da ECA \\
\hline T2-iECA & Treinado tratado com inibidor da ECA \\
\hline TA & Treinado anabolizante \\
\hline TAE & Treinado anabolizado tratado com espironolactona \\
\hline TAL & Treinado anabolizado tratado com losartan \\
\hline $\mathrm{TC}$ & Treinado controle \\
\hline $\mathrm{TF}$ & Treinamento físico \\
\hline TGF $\beta$ & Fator de crescimento transformador beta \\
\hline TR & Treinado \\
\hline VD & Ventrículo direito \\
\hline VE & Ventrículo esquerdo \\
\hline VEc & Ventilação constante \\
\hline VEGF & Fator de crescimento vascular endotelial \\
\hline VEGFR1 & Receptor de crescimento vascular endotelial tipo 1 \\
\hline VEGFR2 & Receptor de crescimento vascular endotelial tipo 2 \\
\hline $\mathrm{VO}_{2}$ & Consumo de oxgênio \\
\hline WKY & Wistar kyoto \\
\hline WKY-T & Wistar kyoto treinado \\
\hline$\alpha-\mathrm{MHC}$ & $\alpha$-miosina de cadeia pesada \\
\hline
\end{tabular}


$\beta$-gal $\quad \beta$-galactosidase

$\beta$-MHC $\quad \beta$-miosina de cadeia pesada. 


\title{
O SISTEMA RENINA ANGIOTENSINA NO TREINAMENTO FÍSICO
}

\author{
APRESENTAÇÃO DA TESE
}

Esta Tese de Livre Docência está apresentada na seguinte sequência:

\section{Parte 1. Participação do SRA na Hipertrofia Cardíaca Excêntrica Induzida pelo Treinamento Físico Aeróbio, na Eritropoiese e na Hipertrofia Cardíaca Concêntrica Induzida pelo Treinamento Físico de Força ou Resistido.}

\section{Estudo 1.}

Participação do SRA local e sistêmico na hipertrofia fisiológica induzida pelo treinamento fisico aeróbio foi demonstrada pelos seguintes estudos:

- Oliveira EM, Sasaki MS, Cerencio M, Barauna VG, Krieger JE. Local renin-angiotensin system regulates LV hypertrophy induced by swimming training independent of circulating renin: a pharmacological study. J Renin Angiotensin Aldosterone Syst.10(1):15-23, 2009.

- Fernandes T, Hashimoto NY, Magalhães FC, Carmona AK, Krieger JE, Phillips MI, Oliveira EM. Aerobic exercise training induced LVH involves regulatory microRNAs, decreases ACEANG II with synergistic regulation of ACE2-ANG (1-7). Submetido para publicação. Hypertension, 2010.

\section{Estudo 2.}

Influência do $N$ dominio da enzima conversora de angiotensina na eritropoiese induzida pelo treinamento fisico aeróbio e no consumo de oxigênio.

- Trabalho de tese de doutorado que está sendo finalizada. 


\section{Estudo 3.}

Caracterização do modelo treinamento e a participação do SRA na hipertrofía fisiológica induzida pelo treinamento fisico de força e via de sinalização ativada pelo receptor de angiotensina ATl foram demonstradas pelos seguintes estudos:

- Barauna VG, Batista-Junior ML, Costa Rosa LFBP, Casarini DE, Krieger JE e Oliveira EM. Cardiovascular adaptations in rats submitted to a resistance-training model. Clinical and Experimental Pharmacology and Physiology 32: 249-254, 2005.

- Barauna VG, Rosa KT, Irigoyen MC e Oliveira EM. Effects of resistance training on ventricular function and hypertrophy in a rat model. Clinical Medicine \& Research, 5 (2): 114$120,2007$.

- Barauna VG; Magalhães FC; Krieger JE e Oliveira EM. AT1 receptor participates in the cardiac hypertrophy induced by resistance training in rats. Am J Physiol Regulatory Integrative Comp Physiol 295:381-387, 2008.

- Melo SFS, Amadeu MA; Magalhães FC; Fernandes T; Carmo EC; Barretti DLM; Brum PC e Oliveira EM. AT1 receptor-AKT-mTOR signaling pathway is activated by a session of strength exercise. Submetido para publicação. Am J Physiol Regulatory Integrative Comp Physiol, 2010.

\section{Parte 2. Participação do SRA-Aldosterona em Patologias Cardiovasculares: efeitos do treinamento físico aeróbio.}

\section{Estudo 4.}

Efeitos dos Esteróides Anabolizantes associados ao treinamento fisico sobre o SRA-Aldosterona cardíaco e fluxo sanguineo foi demonstrada pelos seguintes estudos:

- Rocha FL, Carmo EC, Roque FR, Hashimoto NY, Rossoni LV, Frimm C, Anéas I, Negrão CE, Krieger JE e Oliveira EM. Anabolic Steroids Induce Cardiac Renin-Angiotensin System and 
Impair the Beneficial Effects of Aerobic Training in Rats. Am J Physiol. Heart Circ Physiol 293: H3575-H3583, 2007.

- Carmo ECC, Fernandes T, Koike D, Silva Junior ND, Mattos KC, Rosa KT, Barretti DLM, Melo SFS, Wichi RB, Irigoyen MC, Oliveira EM. Anabolic steroid plus exercise training: increase Renin Angiotensin Aldosterone System and inflammatory markers. Submetido para publicação. J Cell Mol Cardiol, 2010.

- Roque FR, De Angelis K, Soci UPR, Coelho MA, Irigoyen MC, Sarkis JJF, Oliveira EM. Chronic use of anabolic steroid associated with aerobic exercise training impairs coronary blood flow in normotensive rats. Submetido para publicação. Am J Physiol. Heart Circ Physiol, 2010.

- Soci UPR, Redondo FRR, Fernandes T, De Angelis K, Irigoyen MC, Coelho M, Oliveira EM. Esteróides anabolizantes inibem a angiogênese induzida pelo treinamento físico de natação em músculo sóleo de ratos normotensos. Rev. Bras. Educ. Fís. Esporte, v.23, n.3, p.195-209, jul./set. 2009.

\section{Estudo 5.}

Efeitos do treinamento fisico aeróbio sobre a angiogênese na hipertensão arterial:

- Fernandes T e Oliveira EM. Efeito do treinamento físico aeróbio sobre as células progenitoras endoteliais derivadas da medula óssea em ratos espontaneamente hipertensos (SHR). Artigo em preparação.

\section{Parte 3. Perspectivas Futuras.}




\section{INTRODUÇÃO AO SISTEM RENINA ANGIOTENSINA}

O sistema renina angiotensina (SRA) corresponde a um complexo sistema hormonal cujo papel fundamental está relacionado com o controle da pressão arterial e homeostasia hidroeletrolítica do organismo $[1,2]$. Classicamente, o SRA é entendido como um sistema endócrino cuja substância ativa, angiotensina II (Ang II), é a responsável pela maioria dos efeitos fisiológicos observados. Entre os diversos componentes do SRA, a enzima conversora de angiotensina I (ECA) parece particularmente importante como mediadora e reguladora da produção de Ang II no coração, na medida em que possui um amplo espectro de expressão no endotélio de todos os vasos sanguíneos deste órgão, bem como em miócitos e fibroblastos cardíacos.

Essa visão clássica do SRA, onde o sistema seria essencialmente dependente da existência do hormônio circulante para produzir seus efeitos fisiológicos, tem sido profundamente modificada nos últimos anos. Hoje, o SRA é visto de forma mais ampla, onde a multiplicidade de funções do sistema é produto também da ação "parácrina" e "autócrina" da Ang II e de alguns de seus metabólitos produzidos localmente em vários tecidos [3]. A utilização de métodos bioquímicos aliados a técnicas modernas de biologia molecular permitiu evidenciar a existência de muitos componentes do SRA em tecidos periféricos. A deteç̧ão de um ou mais mRNAs destes componentes (angiotensinogênio, renina, enzima conversora e receptores de Ang II) em vários tecidos como glândulas adrenais, rins, coração, vasos e cérebro deram suporte à existência de SRA locais [4]. A Figura 1 mostra, portanto, essa visão clásica do Sistema Renina Angiotensina. 


\section{Sistema Renina Angiotensina Clássico}

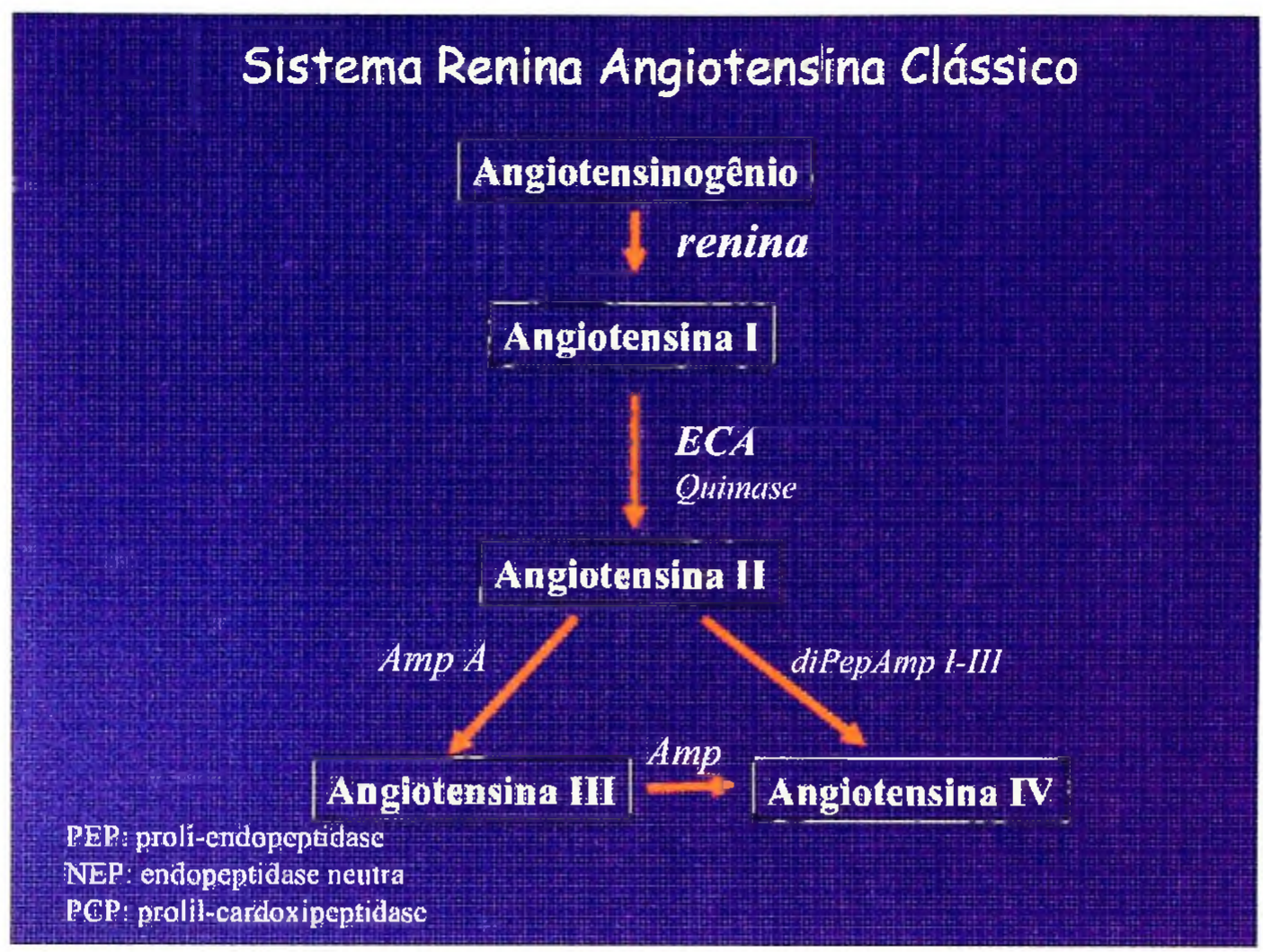

Figura 1. Visão clássica do Sistem Renina Angiotensina

\section{O novo Sistema Renina Angiotensina}

Principalmente na última década, os conhecimentos sobre o SRA foram consideravelmente expandidos e a identificação de novos peptídeos angiotensinérgicos biologicamente ativos e de outros componentes desse sistema ampliaram de forma significativa o conceito do mesmo.

Este novo capítulo da história do SRA, claramente configura uma segunda via do sistema, do qual emergem a ECA2 [5, 6] e a Ang (1-7) [7]. A ECA2, por gerar um potente vasodilatador, a Ang (1-7), e por hidrolisar a Ang II, contrabalançando os efeitos vasopressores da ECA mediados pela Ang II. Esse novo sistema está representado esquematicamente na Figura 2. 


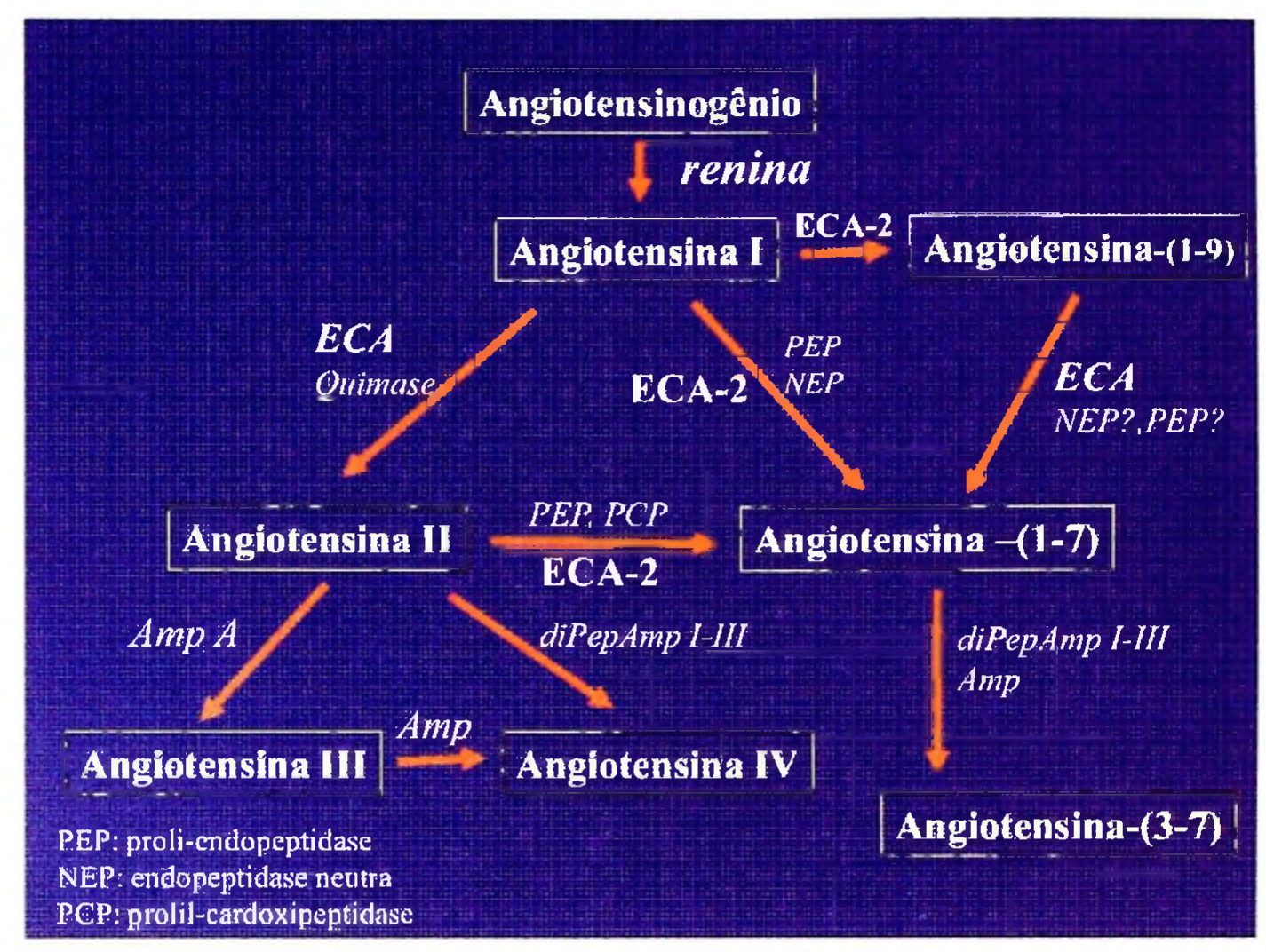

Figura 2. Novo Sistema Renina Angiotensina

Em 2000, Tipnis et al [6]. descreveram pela primeira vez uma protease clonada de uma biblioteca de cDNA de células obtidas de um paciente com linfoma. Devido à seqüência genômica ter várias semelhanças estruturais com o gene da ECA humana, denominou-na ACEH (do inglês, angiotensin converting enzyme homolog). Neste mesmo ano, Donoghue et al [5]. clonaram, de uma biblioteca de cDNA preparada com tecido ventricular de um paciente com insuficiência cardíaca, uma outra proteína idêntica à ECAH a qual foi chamada de ECA2 (do inglês, angiotensin converting enzyme-2).

A ECA2 é uma metaloprotease de 805 aminoácidos que apresenta homologia considerável com a ECA. Atua, porém, como uma carboxipeptidase e não como uma dipeptidilcarboxipeptidase à semelhança da ECA, e foi inicialmente descrita sua expressão no coração, rins e testículos, sendo predominantemente no endotélio das coronárias, vasos intrarenais e no epitélio dos túbulos renais. Como já mencionado, a ECA2 exibe atividades bioquímicas muito distintas da ECA, convertendo a Ang I em Ang (1-9) [5, 8]. 
A Ang (1-9), cujas ações não foram ainda bem definidas, é hidrolisada pela ECA em Ang (1-7). Outra ação da ECA2 é a hidrólise da Ang II, com remoção de um aminoácido, produzindo, a partir daí, a Ang (1-7) [9].

A ação catalítica da ECA2 tem eficiência aproximadamente 500 vezes maior quando o substrato é a Ang II, em comparação à sua ação sobre a Ang I. Além disso, a ECA2 é 10 a 600 vezes mais eficiente que a prolil endopeptidase e a prolil-carboxipeptidase, respectivamente, para gerar Ang (1-7) a partir da Ang II [10]. Diferentemente da ECA, não hidrolisa Ang I à Ang II e sua atividade enzimática não é inibida por inibidores da ECA [9]. Portanto, a ECA-2 é efetivamente um inibidor da formação de Ang II por estimular vias alternativas de degradação de Ang I. A ação da ECA-2 produzindo Ang (1-7), um potente vasodilatador, pode contrabalançar as ações da Ang II. A Ang (1-7) é um potente vasodilatador não só em preparações isoladas, como em vários modelos experimentais e ainda quando testada em seres humanos [11]. Contribui também para a neoangiogênese de processos cicatriciais, de processos inflamatórios crônicos e do crescimento de tumores [12]. É, além disso, um importante co-regulador da pressão arterial. Alé disso, a Ang (1-7) potencializa os efeitos da bradicinina [13].

Uma maior ativação da via Ang II/ receptor AT1 leva ao predomínio de efeitos vasoconstritores, proliferativos e hipertróficos, enquanto a maior ativação da via Ang (1-7)/ receptor MAS leva a efeitos vasodilatadores, anti-proliferativos e anti-hipertróficos. Assim, o eixo Ang (1-7)/ receptor MAS é uma importante via contraregulária ao eixo Ang II/ receptor AT1, entretanto o balanço entre estas duas vias é importante para a homestasia cardiovascular.

Além desta importante via contra regulatória das ações da Ang II, novos componentes tem sido descobertos neste sistema: novos receptores como AT3 e AT4 [14], receptor MAS [15] e receptores para renina [16] e ainda outra ECA chamada de ECA3. Além destas novas ECAs (ECA2 e ECA3), foi demostrado que ECA apresenta uma pequena porção intracelular com três sítios de serina, os quais podem ser passíveis de fosforilação desencadeando uma sinalização intracelular. A fosforilação da ECA resulta em aumento de expressão da própria ECA [17].

Ainda, existem outras vias, neste mesmo sistema, e entre as mais importantes podemos citar: a conversão de Ang I a Ang II por enzimas como catepsina G e quimases [18, 19] e a formação direta de Ang II a partir do angiotensinogênio por enzimas como a Tonina e a Elastase [20, 21]. Assim, uma visão atualizada do SRA está apresentada na Figura 3. 


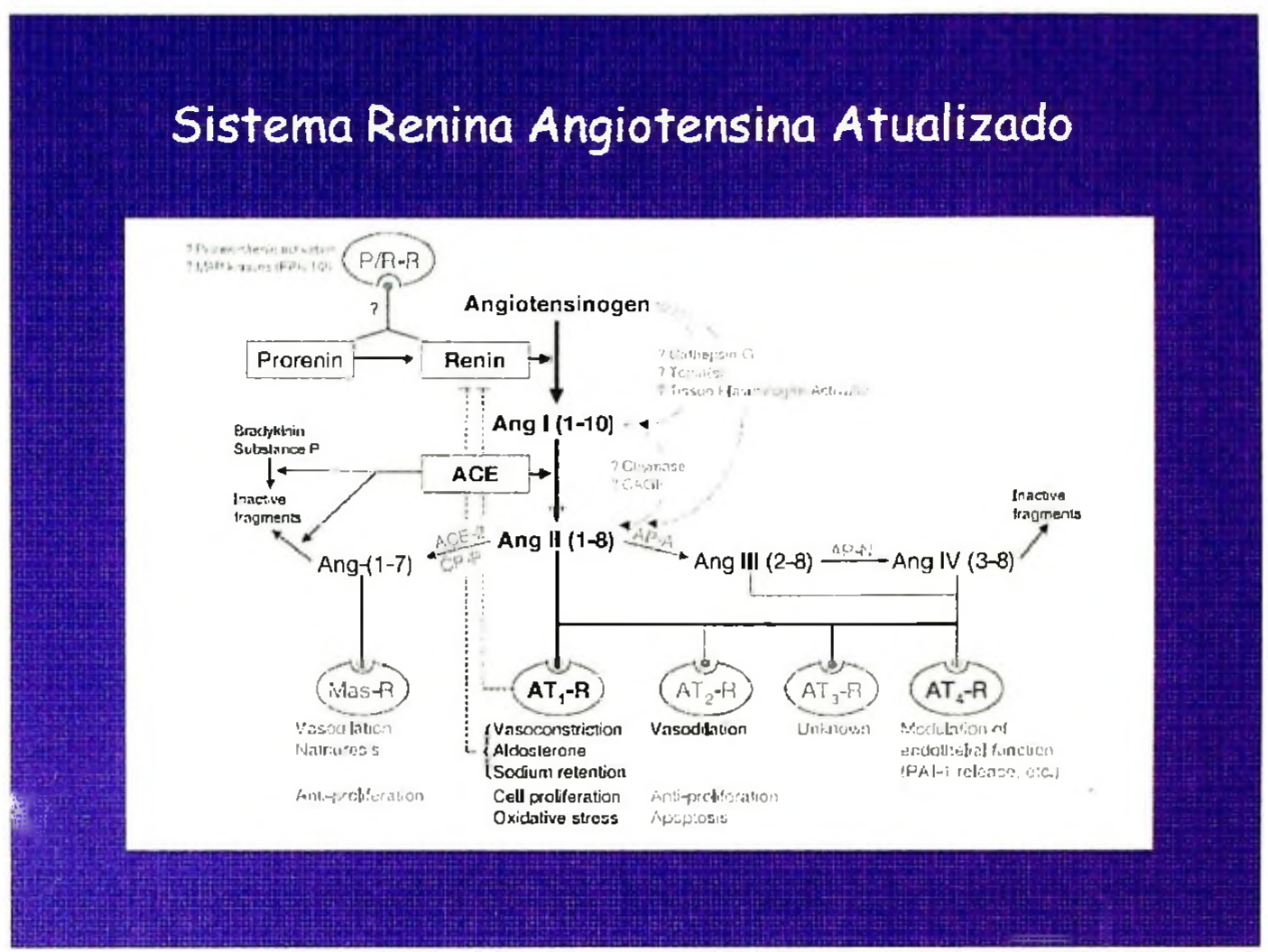

Figura 3. Visão atualizada do Sistema Renina Angiotensina. O SRA clássico está destacado em negrito e os novos componentes em cinza. ACE=Enzima Conversora de Angiotensina, Ang=Angiotensina, AP-A/AP-N= Aminopeptidase e Aminopeptidase $\mathrm{N}$, ATxR=Subtipos de receptores de Angiotensina, $\mathrm{CP}-\mathrm{P}=$ Carboxipeptidase $\mathrm{M}, \mathrm{P} / \mathrm{R}-\mathrm{R}=\mathrm{Receptor}$ de Renina/Pro-renina, PAI-1=Inibidor do ativador de plasminogênio [22].

\section{Sistema Renina Angiotensina cardíaco}

O coração pode formar Ang I localmente e convertê-la em Ang II, a qual pode chegar a atingir concentrações duas a três vezes superiores às encontradas no plasma [3]. Existem evidências de que o SRA plasmático pode ser, principalmente, importante na estabilidade hemodinâmica aguda, enquanto o SRA cardíaco estaria mais envolvido na manutenção hemodinâmica e mudanças estruturais à longo prazo. Cada vez é mais demonstrado na literatura que os SRAs locais podem ser regulados de forma diferente do SRA sistêmico. Particularmente, estes são resultados que temos obtido como efeitos do treinamento físico aeróbio e resistido da hipertrofia cardíaca.

A mais importante evidência para um SRA local no coração é a presença de ECA [23, 24], a atividade de renina [25] e mRNA para renina e angiotensinogênio [26] em células cardíacas. 
A presença de Ang I, Ang II e de receptores para Ang II já foi identificada em fibroblastos e miócitos de ratos neonatais [27]. É evidente que as ações locais dependem da presença de quantidades relevantes destes receptores, aos quais a Ang II se liga, levando às ações fisiológicas ou fisiopatológicas. Alguns trabalhos têm demonstrado que o aumento crônico da expressão e da atividade da ECA dentro da faixa fisiológica (2 a 3 vezes) poderia resultar num aumento paralelo da produção de Ang II tecidual [28]. Da mesma forma, o aumento na expressão da ECA cardíaca, secundário a uma sobrecarga pressórica, está associado a um aumento da conversão de Ang I em Ang II na microcirculação intramiocárdica [29]. A Ang II seria então translocada para o interstício e se ligaria a receptores do tipo $\mathrm{AT}_{1}$ localizados em miócitos e fibroblastos, principalmente $[30,31]$.

Um conjunto de evidências sugere ainda que a Ang II no coração pode agir como um fator de crescimento [32], aumentando a produção de uma variedade de proteínas que estão relacionadas com a hipertrofia cardíaca [33]. A ligação da Ang II a receptores nos miócitos resultaria num aumento da contratilidade e da resposta hipertrófica, enquanto que em fibroblastos seria desencadeada uma resposta de hiperplasia associada a um fenótipo secretor de colágeno [34-36].

A hipertrofia cardíaca ocorre em resposta a uma sobrecarga de pressão ou volume imposta ao coração em situações fisiopatológicas tais como, hipertensão arterial, infarto do miocárdio ou de hiperatividade simpática. Um dos aspectos que tem sido bem evidenciado é a participação do SRA no desenvolvimento e manutenção destas patologias. Entretanto, a hipertrofia cardíaca também ocorre como resposta fisiológica normal devido à sobrecarga de trabalho imposta pelo exercício tanto aeróbio como resistido.

\section{Hipertrofia cardíaca}

Hipertrofia cardíaca é definida como um aumento na massa muscular do miocárdio devido, primariamente, ao aumento no tamanho dos miócitos [37]. A hipertrofia do miocárdio é um importante mecanismo compensatório a um aumento de carga pressórica ou volumétrica imposta ao coração que ocorre à medida que o órgão necessita de um ajuste para suportar novas cargas de trabalho [38]. 
O treinamento físico crônico produz aumento na massa muscular do ventrículo esquerdo. Monganroth et al., (1975) [39], foram os primeiros a mostrarem que essa hipertrofia era dependente do tipo de exercício realizado, sendo que exercícios aeróbios como nadar ou correr, nos quais ocorre sobrecarga de volume ou de pré-carga sobre o miocárdio induzem o desenvolvimento de hipertrofia excêntrica. Nesse tipo de hipertrofia ocorre a adição de novos sarcômeros em série nos miócitos resultando em aumento da câmara cardíaca [40].

Já o treinamento resistido, apesar de causar sobrecarga pressórica ou aumento de póscarga sobre o miocárdio, semelhante ao que ocorre em algumas patologias como na hipertensão, leva o miocárdio a desenvolver hipertrofia fisiológica concêntrica. Nesta situação ocorrem aumentos proporcionais na espessura da parede do ventrículo esquerdo, sem diminuição da câmara cardíaca e sem prejuízo da função sistólica ou diastólica [41]. Essas diferenças, provavelmente, são devidas ao fato de que, enquanto na hipertensão o coração trabalha continuamente contra uma pós-carga aumentada, no treinamento resistido esse estímulo ocorre, apenas, durante o período de realização do exercício (1 a 2 horas por dia e 3 a $5 x /$ semana $)$. Um esquema mostrando os principais passos envolvidos nestes dois tipos de hipertrofia está representado na Figura 4.

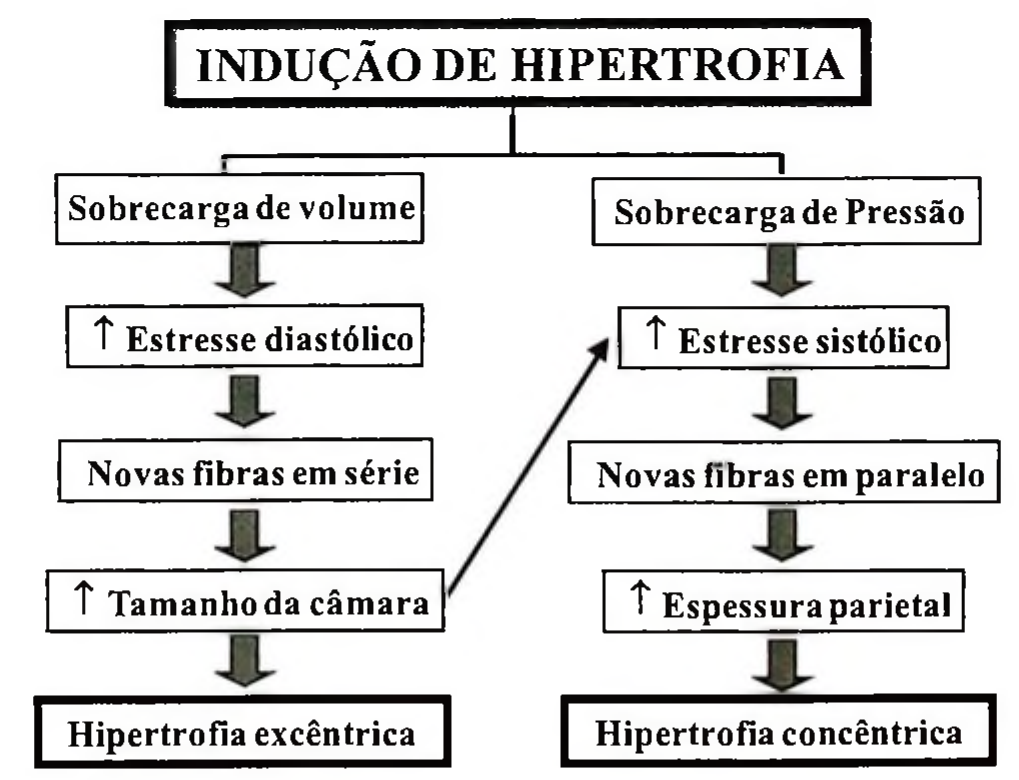

Figura 4. Fluxo de eventos notados na hipertrofia cardíaca excêntrica e concêntrica, induzida por sobrecarga. 
A massa do ventrículo esquerdo em atletas submetidos ao treinamento resistido pode aumentar devido ao aumento na espessura da parede do septo ventricular [42] ou ainda, ao aumento nas dimensões internas $[43,44]$. Porém existem estudos mostrando que não há aumento na massa ventricular esquerda, entretanto, esses resultados divergentes têm sido atribuídos a grande variabilidade nos tipos e intensidade de treinamentos que os atletas realizam $[45,46]$. $\mathrm{O}$ aumento na espessura da parede do ventrículo ocorre devido à sobrecarga pressórica, a qual induz aumento no número de miofibrilas em paralelo resultando em aumento no diâmetro dos miócitos [40].

A grande maioria dos estudos realizados com humanos, a técnica utilizada para determinar o grau da hipertrofia ventricular é a ecocardiografia. Apesar de estudos da literatura mostrarem aumento na espessura tanto da parede posterior do ventrículo esquerdo (VE) como do septo intraventricular durante a diástole [42-44], esses valores raramente excedem os limites da normalidade e são geralmente inferiores aos encontrados em estados patológicos como, por exemplo, na estenose aórtica [46].

A hipertrofia cardíaca não é controlada somente por fatores hemodinâmicos, mas também por fatores neuro-humorais e genéticos. Ainda, tem sido demonstrado que a função endócrina do coração desempenha um importante papel no desenvolvimento da hipertrofia cardíaca [47]. Estes aspectos foram revisados por nós, em revistas nacionais. Entretanto, a participação destes sistemas no controle e na manutenção da hipertrofia fisiológica ainda não está bem elucidada.

\section{Sistema Renina Angiotensina e desempenho físico}

O gene da ECA, um componente importante do SRA, está sendo um dos genes mais estudados deste sistema devido a um importante polimorfismo encontrado. Este polimorfismo do gene da ECA humana consiste na presença (inserção, alelo I) ou ausência (deleção, alelo D) de um fragmento de 287 pares de bases [48]. O alelo D foi associado a uma maior concentração da ECA circulante e no miocárdio. Inicialmente os autores hipotetizaram que, se o SRA cardíaco seria um regulador importante da hipertrofia do ventrículo esquerdo, portanto o alelo $\mathrm{D}$ estaria associado a maior massa do VE. Posteriormente foi visto que não se correlacionava, uma vez que 
a hipertrofia de VE é influenciada por um grande número de fatores ambientais e biológicos como, por exemplo, exercício, idade, sexo e pressão sangüínea [49].

A última década foi muito importante na demonstração da participação do SRA, principalmente do gene da ECA, no desempenho fisico do atleta. Um importante trabalho publicado na Nature em 1998, monstrou que o genótipo do gene da ECA está relacionado com melhor desempenho físico do atleta. Este estudo mostrou que indivíduos com genótipo II ou DI apresentam maior desempenho ao treinamento físico aeróbio ou "endurance" [49]. Posteriormente, o mesmo grupo de Londres, mostrou que a presença do genótipo II confere uma eficiência mecânica aumentada no músculo esquelético humano [50]. Outros estudos têm mostrado que o genótipo DD da ECA estaria relacionado com a hipertrofia do VE induzida pelo treinamento físico $[49,51]$. Entretanto, os trabalhos que relacionam esse polimorfismo com a hipertrofia do ventrículo ainda são controversos na literatura [52].

Embora as funções do SRA circulante e em alguns sistemas como o renal e o cardíaco estejam bem estabelecidas na literatura, somente recentemente o SRA local na medula óssea tem despertado interesse. O SRA via Ang II, exerce função no crescimento e proliferação celular em diversos tecidos agindo como um fator de crescimento local e várias revisões têm sugerido que o SRA local também exerceria funções proliferativas em células presentes na medula óssea [53, $54]$.

Vários estudos vêm corroborando a hipótese de um SRA local ativo na medula óssea. Mrug et al. (1997) [55] demonstraram a presença de mRNA de receptores AT1 em HSC (Hematopoietic Stem Cells ou Células Tronco Sanguíneas) isoladas da circulação de humanos e que a ação da Ang II via receptores AT1 nestas células estimulou a diferenciação e a formação de colônias. Mais tarde, Rodgers et al. (2000) [56] estenderam os achados do estudo anterior para HSC medulares in vitro. Em ambos os estudos, o bloqueio dos receptores AT1 inibiu a proliferação das HSC, sugerindo que esta regulação seria por meio da ação da Ang II via AT1. Além dos efeitos que o SRA exerce sobre células tronco medulares via Ang II, foi descrito um tetra peptídeo, N-acetyl-seryl-aspartyl-lysyl-proline (Ac-SDKP), que é inativado pelo domínio catalítico terminal-N da ECA e que tem efeito inibidor sobre a proliferação de HSC [57]. Este tetra peptídeo previne o recrutamento de HSC para fase-S do ciclo celular, mantendo-as na faseG0 [58]. A ação deste tetra peptídeo parece ser via um receptor de membrana e reduz a 
proliferação celular via regulação de moduladores do ciclo celular como p53, p2 $7^{\text {kipl }}$ e p2 $1^{\text {cipl }}$ [59]. Portanto, vem sendo demonstrado que o SRA por meio da produção de Ang II e da inativação do tetra peptídeo Ac-SDKP tem papel fundamental na proliferação e recrutramento HSC.

Assim, nesta tese de Livre Docência mostaremos inicialmente a participação do SRA:

- na hipertrofia cardíaca fisiológica induzida pelo treinamento físico aeróbio;

- e na sequência, como o $\mathrm{C}$ e $\mathrm{N}$ domínios da enzima conversora de angiotensina podem influenciar na eritropoiese com o treinamento físico aeróbio e sua relação com o consumo de oxigênio.

- na hipertrofia cardíaca fisilógica induzida pelo treinamento físico de força.

\section{PARTE 1. Participação do SRA na Hipertrofia Cardíaca Excêntrica Induzida pelo Treinamento Físico Aeróbio, na Eritropoiese e na Hipertrofia Cardíaca} Concêntrica Induzida pelo Treinamento Físico de Força ou Resistido.

Inicialmente, investimos longo tempo no estbelecimento dos modelos de hipertrofia cardíaca. Neste sentido, tivemos várias preocupações na caracterização dos protocolos de treinamento, mas o que mais me preocupava era que os resultados obtidos como resposta ao treinamento fisico fossem fidedignos, principalmente relacionados ao grau de hipertrofia, que se repetissem nos diferentes grupos de animais que fossem treinados ao longo do tempo.

Outro fato importante, a hipertrofia cardíaca promovida pelo treinamento físico é dependente do tipo de treinamento. Assim, iniciamente dediquei-me a caracterizar os protocolos de treinamento fisico aeróbio por natação, com dois volumes de treinamento, com o objetivo de obter diferentes magnitudes de hipertrofia Cardíaca do tipo eXCÊNTRICA. Ao mesmo tempo caracterizamos um modelo de treinamento fisico de força para ratos, com objetivo de estudarmos a hipertrofia CardíaCa do tipo conCÊnTriCa. Desta forma, ao longo do tempo ficamos com os dois tipos de hipertrofias cardíaca fisiológica (concêntriaca e excêntrica) muito bem caracterizados em nosso laboratório para os estudos seguintes. 
Sabe-se que o treinamento físico aeróbio, além de induzir hipertrofia cardíaca, promove uma série de adaptações cardiovasculares que são benéficas ao organismo como um todo. Assim, esses protocolos uma vez caracterizados foram importantes para entendermos os efeitos promovidos pelo treinamento físico aeróbio por natação, principalmente sobre o SRA no animal normal. Apartir desse conhecimento solidificado, poderíamos utilizá-los para o estudo dos efeitos do treinamento físico em diferentes patologias, e para estudar efeitos do uso de anabolizantes associado ao treinamento físico.

O modelo desenvolvido para treinamento físico de força tem um ponto importante; neste protocolo, diferente do que ocorre com atletas ou indivíduos que treinam força, em que há uma associação de componentes dinâmico e estático (aeróbio e anaeróbio), neste protocolo os animais realizam somente exercício estático. Portanto, sendo desta forma, um importante modelo para estudar os efeitos do treinamento físico de força, sobre o sistema cardiovascular, isoladamente.

Assim na sequência deste trabalho de tese serão apresentados os trabalhos publicados, submetidos para publicação, trabalhos que estamos finalizando de escrever os manuscritos e resultados que compõem as dissertações e teses que estão em andamento no laboratório.

\section{Estudo 1.}

Participação do SRA local e sistêmico na hipertrofia fisiológica induzida pelo treinamento fisico aeróbio foi demonstrada pelos seguintes estudos:

- Oliveira EM, Sasaki MS, Cerencio M, Barauna VG, Krieger JE. Local renin-angiotensin system regulates LV hypertrophy induced by swimming training independent of circulating renin: a pharmacological study. J Renin Angiotensin Aldosterone Syst.10(1):15-23, 2009.

- Fernandes T, Hashimoto NY, Magalhães FC, Carmona AK, Krieger JE, Phillips MI, Oliveira EM. Aerobic exercise training induced LVH involves regulatory microRNAs, decreases ACEANG II with synergistic regulation of ACE2-ANG (1-7). Submetido para publicação. Hypertension, 2010. 


\section{Estudo 2.}

Influência do $N$ dominio da enzima conversora de angiotensina na eritropoiese induzida pelo treinamento fisico aeróbio e no consumo de oxigênio.

- Trabalho de tese de doutorado que está sendo finalizado.

\section{Estudo 3.}

Caracterização do modelo treinamento e a Participação do SRA na hipertrofía fisiológica induzida pelo treinamento fisico de força e via de sinalização ativada pelo receptor de angiotensina ATl foram demonstradas pelos seguintes estudos:

- Barauna VG, Batista-Junior ML, Costa Rosa LFBP, Casarini DE, Krieger JE e Oliveira EM. Cardiovascular adaptations in rats submitted to a resistance-training model. Clinical and Experimental Pharmacology and Physiology 32: 249-254, 2005.

- Barauna VG; Rosa KT; Irigoyen MC e Oliveira EM. Effects of resistance training on ventricular function and hypertrophy in a rat model. Clinical Medicine \& Research, 5 (2): 114$120,2007$.

- Barauna VG; Magalhães FC; Krieger JE e Oliveira EM. AT1 receptor participates in the cardiac hypertrophy induced by resistance training in rats. Am J Physiol Regulatory Integrative Comp Physiol 295:381-387, 2008.

- Melo SFS, Amadeu MA; Magalhães FC; Fernandes T; Carmo EC; Barretti DLM; Brum PC e Oliveira EM. AT 1 receptor-AKT-mTOR signaling pathway is activated by a session of strength exercise. Submetido para publicação. Am J Physiol Regulatory Integrative Comp Physiol, 2010. 


\section{Estudo 1: Participação do SRA local e sistêmico na hipertrofia fisiológica induzida pelo treinamento físico aeróbio foi demonstrada pelos seguintes estudos:}

- Oliveira EM, Sasaki MS, Cerencio M, Barauna VG, Krieger JE. Local renin-angiotensin system regulates LV hypertrophy induced by swimming training independent of circulating renin: a pharmacological study. J Renin Angiotensin Aldosterone Syst. 10(1):15-23, 2009.

- Fernandes T, Hashimoto NY, Magalhães FC, Carmona AK, Krieger JE, Phillips MI, Oliveira EM. Aerobic exercise training induced LVH involves regulatory microRNAs, decreases ACEANG II with synergistic regulation of ACE2-ANG II (1-7). Submetido para publicação. Hypertension, 2010.

Para estes estudos construimos um Sistema de Natação para ratos, baseado em um sistema que já havia sido desenvolvido para camundongos, pela aluna Fabiana Evangelista, no Instituto do Coração, na época, aluna de mestrado do Prof. José Eduardo Krieger.

Este sistema foi confeccionado em vidro transparente, para que os animais possam ser observados durante o treinamento e apresenta duas fileira compostas de 7 raias individuais para 0 treinamento. As rais individuais são importantes, porque os animais não conseguem apoiar-se uns nos outros, como em sistemas em que os animais treinam todos juntos. Ainda, o fato de ser de vidro, o sistema não apresenta nenhum tipo de ranhura onde os animais possam apoiar-se.

Dentro da piscina estão submersos na água dois sistemas de aquecimento, um em cada ponta da piscina e um sistema de circulação de água para que o aquecimento seja uniforme em todo o sistema. Os animais treinam com sobrecarga de $5 \%$ do peso corporal, desta forma não tem a possibilidade destes boiarem. As dimensões do sitema e características estão descritas em Oliveira et al., 2009 [60]. 


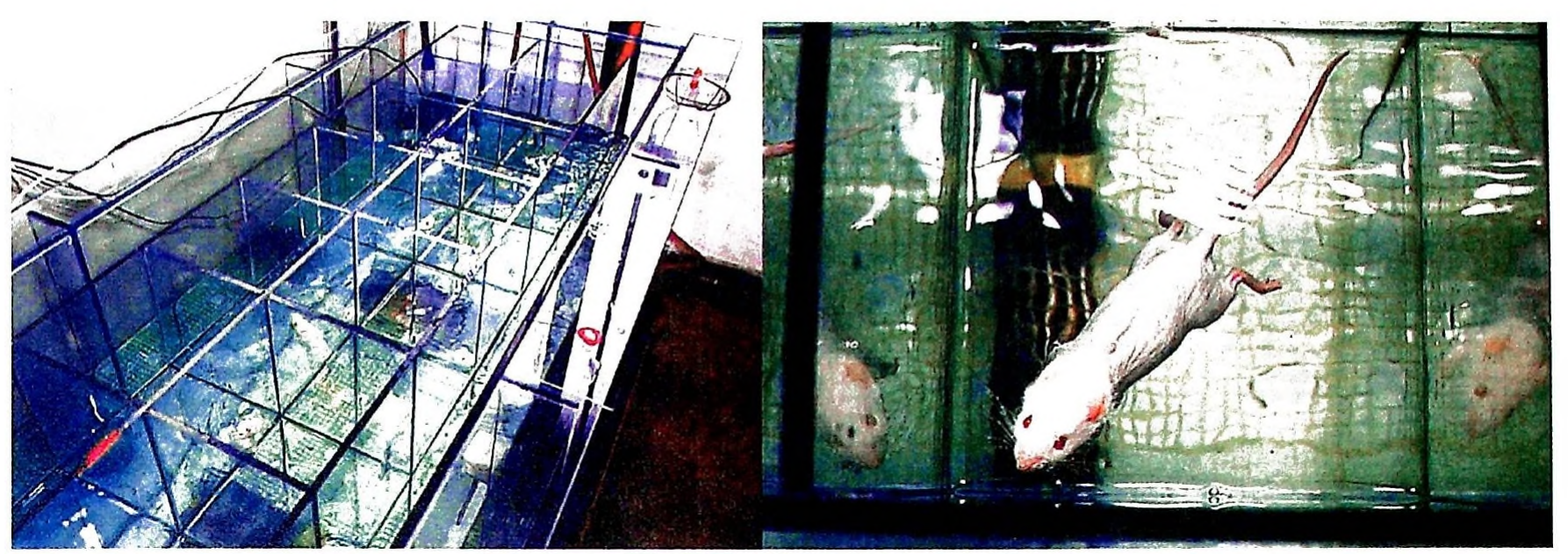

Figura 5. Aparato de treinamento físico de natação para ratos.

Neste estudo utilizamos ratas Wistar e treinamento físico por natação, por um mesmo motivo. O treinamento físico por natação promove hipertrofia cardíaca mais acentuada, do que o treinamento físico em esteira, no qual essa adaptação ao treinamento nem sempre é observada. Assim como, fêmeas apresentam um maior grau de hipertrofia cardíaca, do que machos, quando treinados com o mesmo protocolo de treinamento físico.

Resultados da literatura mostram que pode existir diferenças entre gênero, uma vez que os hormônios sexuais são responsáveis por diversas ações já conhecidas, como o desenvolvimento da maturidade sexual e outras ainda pouco elucidadas.

Uma vez que, estudaremos os efeitos do treinamento físico sobre o SRA em fêmeas, as seguintes considerações são oportunas. Camundongos fêmeas, apresentam a atividade da ECA plasmática $60 \%$ menor do que nos machos, indicando dimorfismo sexual [61], os autores sugerem que estes dados podem ser devido, em parte, a uma redução na expressão gênica e atividade da ECA induzida pelos estrógenos. Embora alguns estudos mostrem que os estrógenos aumentem a renina e o angiotensinogênio circulante [62, 63], os efeitos cardiovasculares benéficos dos estrógenos podem ser mediada pela diminuição na atividade da ECA, com consequente redução nos níveis circulantes de Ang II (vasoconstritor), diminuição no metabolismo da bradicinina (vasodilatador) e aumento na produção de Ang (1-7), produzindo efeitos cardiovasculares benéficos nas fêmeas. Entretanto, estes estudos foram realizados com ratas ovaretomizadas com terapia de reposição hormonal $[64,65]$ e não durante o cicclo estral normal. 
Seltzer et al., (1992) [64] mostraram que não ocorre alterações na atividade da ECA circulante com o ciclo estral normal, sugerindo que a atividade da ECA atenuada ocorre somente com exposição crônica a estrôgenos em doses acima da concentração endógena. Ainda, os níveis de Ang I e Ang II não variam durante as fazes do ciclo estral (proestro, estro e diestro) no plasma e no coração de ratas normotensas [63]. No coração não ocorreram alterações, mesmo em ratas hipertensas transgênicas para o gene da renina (TGR(mRen-2)27). Chung et al., 1999, [66] mostraram que em mulheres jovens saudáveis a influência da fase menstrual ou uso de contraceptivos orais não alteram a função e estrutura do VE.

De forma geral, em fêmeas normotensas os hormônios sexuais não apresentam uma influência sobre o SRA nas diferentes fases do ciclo estral, portanto este parece não ser um fator importante para a utilização de fêmeas, no nosso procolo experimental, para estudar a participação do SRA na hipertrofia fisiológica.

Resultados do nosso laboratório mostram a diferença no percentual de hipertrofia entre machos e fêmeas, treinados com o protocolo P1 (Figura 6).

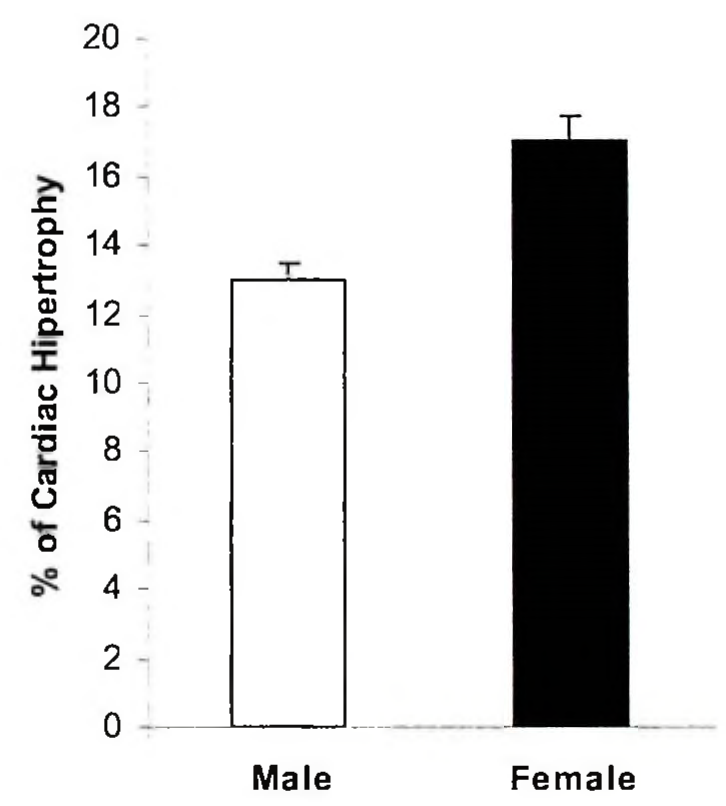

Figura 6. Percentual de hipertrofia cardíaca de machos e fêmeas. 


\subsection{Materiais e Métodos}

\subsubsection{Treinamento físico dos animais.}

O treinamento físico de natação foi realizado segundo protocolo de Medeiros et al., 2004 [67], o qual foi denominado, por nós, de P1, como pode ser visto abaixo. Os animais treinavam com água aquecida e circulante no sistema, com temperatura entre $30-32^{\circ} \mathrm{C}$.

Para obtermos diferentes graus de hipetrofia os animais foram treinados por dois diferentes protocolos de treinamento físico, variando o volume de treinamento.

- Protocolo 1 (P1): os animais foram treinados durante 10 semanas, sessões de $60 \mathrm{~min}, 1$ vezes ao dia, 5 vezes/semana, com aumento gradual da sobrecarga de trabalho (peso na cauda em porcentagem do peso corporal). Foi realizada uma adaptação crescente até atingir $5 \%$ do peso corporal (Medeiros et al., 2004) [67].

- Protocolo 2 (P2): Neste protocolo de treinamento os animais treinaram até a $8{ }^{a}$ semana com o mesmo protocolo acima (P1), sendo o treinamento da $9^{\mathrm{a}}$ e $10^{\mathrm{a}}$ semanas conforme descrito abaixo. $\mathrm{Na} 9^{\mathrm{a}}$ semana os animais treinaram 2 vezes ao dia, sessões de $60 \mathrm{~min}$ com intervalo de 4 horas entre as sessões. $\mathrm{Na} 10^{\mathrm{a}}$ semana treinaram 3 vezes ao dia, sessões de $60 \mathrm{~min}$ com intervalo de 4 horas entre as sessões. Este protocolo de treinamento tem sido demonstrado como moderado, numa faixa de intensidade entre $50 \%$ e $65 \%$ do $\mathrm{VO}_{2}$ máx. Este protocolo foi utilizado com o intuito de mimetizar um treinamento de alto nível.

Gostaria de salientar, que esta é a primeira vez que este Protocolo 2 está sendo usado, portanto sendo caracterizado por nós, com o objetivo de obter uma hipetrofia cardíaca mais robusta e aproximar a um treinamento de atletas de elite.

O protocolo utilizado foi caracterizado como treinamento de baixa a moderada intensidade e longa duração, sendo efetivo na promoção de adaptações cardiovasculares e no aumento da capacidade oxidativa muscular, determinado pela medida da atividade da citrato sintase (uma enzima regulatória do Ciclo de Krebs). Os ratos foram identificados e pesados semanalmente, para a correção da sobrecarga de treinamento em função do aumento do peso corporal. 


\subsubsection{Animais de experimentação}

No primeiro trabalho, demostramos com tratamento farmacológico com Enalapril (inibidor da ECA) e Losartan (antagonista do receptor AT1), que o SRA participa da hipertrofia cardíaca promovida pelo treinamento físico aeróbio por natação. Ainda, mostramos com o uso da dieta rica em sal (para inibir a liberação de renina renal), que esse mecanismo de hipertrofia é independente do SRA sistêmico, que o mecanismo de regulação é local. Para isso realizamos os seguintes grupos experimentais:

\section{Grupos Experimentais 1:}

Sedentário:

Grupo S: Sedentário

Grupo S-iECA: Sedentário tratado com inibidor da ECA (Enalapril 60mg/Kg/dia)

Treinado:

Grupo T1: Treinado (Protocolo 1)

Grupo T1-iECA: Treinado tratado com inibidor da ECA (Enalapril)

Grupo T2: Treinado (Protocolo 2)

Grupo T2-iECA: Treinado tratado com inibidor da ECA (Enalapril)

\section{Grupos Experimentais 2:}

Sedentários:

Grupo S: Sedentário

Grupo S-Los: Sedentário tratado com antagonista do receptor AT1 (Losartan $20 \mathrm{mg} / \mathrm{Kg} / \mathrm{dia})$

Treinados:

Grupo T1: Treinado (Protocolo 1)

Grupo T1-Los: Treinado tratado com antagonista do receptor AT1 (Losartan)

Grupo T2: Treinado (Protocolo 2)

Grupo T2-Los: Treinado tratado com antagonista do receptor AT1 (Losartan) 


\section{Grupos Experimentais 3:}

Sedentários:

Grupo S: Sedentário

Grupo Sal: Sedentário tratado com dieta alta em sal ( $1 \%$ de $\mathrm{NaCl}$ na água).

\section{Treinados:}

Grupo T1: Treinado (Protocolo 1)

Grupo T1-Sal: Treinado tratado com dieta alta em sal ( $1 \%$ de $\mathrm{NaCl}$ na água)

Grupo T2: Treinado (Protocolo 2)

Grupo T2-Sal: Treinado tratado com dieta alta em sal ( $1 \%$ de $\mathrm{NaCl}$ na água).

Os animais receberam os tratamentos na água de beber desde o início do treinamento. Para estudarmos o SRA local foi utilizado o tratamento com dieta rica em sal ( $1 \%$ de $\mathrm{NaCl}$ na água) onde foi inibida a liberação de renina renal e conseqüentemente de todo o SRA circulante $[68,69]$. Para avaliarmos a participação de um dos receptores de Ang II na hipertrofia desenvolvida durante o treinamento físico foi administrado um antagonista do receptor de Ang II do subtipo 1 (AT1), o Losartan (20 mg/Kg/dia) [70] e para avaliarmos a participação da ECA na hipertrofia foi administrado Enalapril $(60 \mathrm{mg} / \mathrm{Kg} / \mathrm{dia})$ [71], um inibidor da enzima. Foram escolhidas estas doses por já estarem descritas na literatura como suficientes para bloquear o SRA sem interferir na pressão arterial.

\subsubsection{Medida direta da pressão arterial e da freqüência cardíaca}

Após o período de treinamento físico, os animais foram canulados e mantidos em gaiolas individuais, nas quais ficaram pelo menos por 24 horas antes de iniciar o experimento de registro da pressão arterial e freqüência cardíaca. A cânula que estava no animal foi conectada a um tubo de polietileno (PE 100) e este a um transdutor eletromagnético (P23 Db; Gould-Statham) que, por sua vez, foi conectado a um amplificador (General Purpose Amplifier-Stemtech, Inc.). O sinal analógico da pressão arterial foi convertido para digital (Stemtech, Inc.), registrado em tempo real em microcomputador com Sistema CODAS analisado através do programa compatível com Windows, com uma freqüência de amostragem de $1000 \mathrm{~Hz}$ por canal. A partir deste programa foi 
obtido batimento-a-batimento os valores de pressão sistólica (PAS), diastólica (PAD) e média (PAM).

\subsubsection{Amostras de soro e tecidos}

Ao final do protocolo os animais foram decapitados e o sangue foi coletado com EDTA $7,5 \%(50 \mu \mathrm{l} / \mathrm{ml}$ de sangue) para dosagem da renina plasmática. As amostras eram mantidas no gelo e rapidamente centrifugadas $(3.000 \mathrm{rpm} \times 10 \mathrm{~min})$ e mantidas a $-20{ }^{\circ} \mathrm{C}$. O músculo sóleo da pata direita dos animais foi retirado e rapidamente congelado em nitrogênio líquido e armazenado em frezzer $-80^{\circ} \mathrm{C}$

\subsubsection{Morfologia cardíaca}

O coração foi removido da cavidade torácica e dissecado para separarmos o VE (parede livre do ventrículo esquerdo e septo), VD (ventrículo direito) e átrios (átrio direito e esquerdo).

A hipertrofia cardíaca era avaliada pesando-se os ventrículos esquerdo e direito separadamente (peso úmido). Os resultados foram expressos pela relação entre o peso do ventrículo esquerdo e ventrículo direito pelo peso corporal do rato $(\mathrm{mg} / \mathrm{g})$.

\subsubsection{Medida da atividade da renina plasmática (ARP)}

A ARP foi determinada por radioimunoensaio utilizando kit comercial (REN-CT2, CIS bio international). Este ensaio permite uma medida indireta da ARP. Os resultados eram quantificados em Contador Gama de mesa e expressos como ng de Ang I liberados por $\mathrm{ml}$ por hora $(\mathrm{ng} / \mathrm{m} / \mathrm{h} \mathrm{de}$ Ang I).

\subsubsection{Medida da atividade da citrato sintase}

A medida da atividade da citrato sintase foi realizada no homogeneizado do músculo sóleo direito dos animais, em espectrofotômetro conforme descrito por Srere (1969) [72]. Esta medida é utilizada como um marcador de metabolismo oxidativo muscular.

O músculo sóleo foi homogeneizado com tampão fosfato (PBS) na proporção de 1:10 (1g de tecido: $10 \mathrm{ml}$ de PBS). As amostras foram centrifugadas a $3000 \mathrm{rpm}$, durante $10 \mathrm{mi} \mathrm{a} 4^{\circ} \mathrm{C}$. O sobrenadante foi retirado e utilizado para medida da atividade enzimática. 
A cinética enzimática foi realizada em espectrofotômetro e foi determinada pela quantificação da intensidade de cor formada pela reação entre a Coenzima $A(C o A)$ e o ácido oxalacético na presença de DTNB. A leitura foi realizada a $25^{\circ} \mathrm{C}$, durante um intervalo de 160 segundos, em $412 \mathrm{~nm}$. A atividade da enzima foi determinada pela diferença entre a absorbância inicial e a final, dividido pela diferença de tempo de absorbância. Os resultados foram expressos $\mu \mathrm{mol} / \mathrm{ml} / \mathrm{mg}$ de proteína. Esta medida mostra a efetividade do protocolo de treinamento, e mostra que $o$ aumento da frequência de treinamento com natação, permite um significativo condicionamento aeróbio.

A proteína foi determinada pelo método de Bradford (1976) [73], utilizando como padrão albumina bovina (BSA, $1 \mathrm{mg} / \mathrm{ml})$.

\subsubsection{Análise estatística}

Foi realizada análise de varância de uma via (ANOVA). Em casos de diferenças significantes entre os grupos de cada protocolo de treinamento físico, foi realizado como post-hoc o teste de Turkey. Para todas as análises foi adotado como nível de significância $\mathrm{P}<0,05$.

\subsection{Resultados e Discussão}

\subsubsection{Peso corporal}

O peso corporal dos animais não foi diferente nos grupos sedentários e treinados antes e após o período de treinamento. Assim como, os tratamentos não influenciaram no peso corporal dos animais durante todo o período do protocolo experimental (Tabela 2).

\subsubsection{Marcadores de treinamento físico}

Os resultados obtidos neste estudo mostram que o treinamento realizado foi eficaz em promover adaptações cardiovasculares (bradicardia de repouso) e metabólicas (aumento na atividade da citrato sintase no músculo esquelético), decorrentes do treinamento fisico aeróbio.

Todos os grupos treinados apresentaram bradicardia de repouso (Tabela 1). O exercício físico aeróbio crônico diminui a freqüência cardíaca (FC) tanto de repouso como em cargas submáximas [74-77]. Isso é um indicativo de que, para um mesmo exercício, está havendo menor 
gasto energético pelo coração, portanto ocorre uma melhora na eficiência do trabalho cardíaco [78].

Assim como no músculo esquelético, o treinamento físico aeróbio também promove adaptações bioquímicas no coração, como aumento do metabolismo oxidativo do miocárdio a partir de modificações metabólicas, como o aumento na atividade de enzimas oxidativas e aumento no número e tamanho das mitocôndrias das células do miocárdio [79]. Além dos efeitos do condicionamento físico sobre o coração, as adaptações promovidas na musculatura periférica influenciam indiretamente a performance cardíaca [80]. Como exemplos podem citar diminuição de triglicerídeos, diminuição do LDL-colesterol Stone [76], aumento da sensibilidade à insulina [81]. A mais relevante, porém é o aumento do consumo máximo de oxigênio, encontrado tanto em humanos $[82,83]$ como em animais experimentais Schaible [84].

Um dos marcadores de adaptação do músculo esquelético ao condicionamento aeróbio é o aumento na capacidade oxidativa muscular concomitante com o aumento na capacidade aeróbia de trabalho. A atividade da citrato sintase tem sido mostrada aumentada no músculo sóleo, o qual apresenta predomínio de fibras vermelhas-oxidativas. Neste estudo foi observado aumento na atividade da enzima de $41 \%$ no grupo T1 e 106\% no grupo T2, comparados ao grupo sedentário. Estes resultados mostram que os animais apresentaram melhora do condicionamento físico ao final do protocolo de treinamento.

\subsubsection{Medidas hemodinâmicas}

Os resultados observados na frequência cardíaca foram discutidos acima. Não foram observadas alterações na pressão arterial em nenhum dos grupos estudados (Tabela 1). Estes resultados foram importantes, porque mostram que a dose de inibidor da ECA (enalapril; $20 \mathrm{mg} / \mathrm{Kg} / \mathrm{dia}$ ) e do antagonista dos receptores AT1 (losartan; $60 \mathrm{mg} / \mathrm{Kg} / \mathrm{dia}$ ), assim como o sal na dieta ( $1 \%$ de sal), não alteraram esses parâmetros hemodinâmicos, principalmente a pressão arterial, conforme o esperado. 
Tabela 1. Parâmetros Hemodinâmicos

\begin{tabular}{lrlccl}
\hline Grupos & $n$ & $\begin{array}{c}\text { PAS, } \\
\mathrm{mmHg}\end{array}$ & $\begin{array}{c}\text { PAD, } \\
\mathrm{mmHg}\end{array}$ & $\begin{array}{c}\text { PAM, } \\
\mathrm{mmHg}\end{array}$ & $\begin{array}{c}\text { FC, } \\
\text { batimentos/min }\end{array}$ \\
\hline Sedentary & 15 & $125.6 \pm 9.2$ & $97.7 \pm 12.1$ & $107.5 \pm 10.6$ & $348.3 \pm 14.5$ \\
T1 & 13 & $125.7 \pm 10.4$ & $95.7 \pm 9.3$ & $106.2 \pm 8.4$ & $300.8 \pm 13.0 \mathrm{a}, \mathrm{b}, \mathrm{c}, \mathrm{d}$ \\
T2 & 12 & $126.2 \pm 10.4$ & $102.0 \pm 8.3$ & $110.3 \pm 8.4$ & $304.8 \pm 15.3 \mathrm{a}, \mathrm{b}, \mathrm{c}, \mathrm{d}$ \\
S-ACEi & 6 & $119.2 \pm 12.6$ & $91.6 \pm 14.1$ & $101.8 \pm 12.8$ & $325.0 \pm 6.4$ \\
T1-ACEi & 5 & $109.3 \pm 9.0$ & $89.6 \pm 12.5$ & $97.3 \pm 8.9$ & $315.6 \pm 6.3 \mathrm{a}, \mathrm{b}$ \\
T2-ACEi & 5 & $109.3 \pm 7.6$ & $88.1 \pm 7.5$ & $95.5 \pm 6.5$ & $291.8 \pm 11.8 \mathrm{a}, \mathrm{b}, \mathrm{e}$ \\
S-Los & 5 & $119.1 \pm 10.0$ & $89.5 \pm 7.45$ & $100.6 \pm 8.8$ & $353.6 \pm 17.1$ \\
T1-Los & 5 & $115.1 \pm 6.4$ & $87.6 \pm 11.3$ & $98.7 \pm 9.6$ & $311.6 \pm 15.8 \mathrm{a}, \mathrm{c}$ \\
T2-Los & 6 & $110.6 \pm 11.3$ & $86.3 \pm 6.2$ & $95.6 \pm 9.8$ & $320.0 \pm 10.2 \mathrm{a}, \mathrm{c}$ \\
S-Salt & 8 & $124.4 \pm 14.3$ & $92.4 \pm 12.1$ & $103.3 \pm 12.4$ & $326.2 \pm 15.4$ \\
T1-Salt & 5 & $121.2 \pm 9.8$ & $101.1 \pm 5.4$ & $107.8 \pm 6.0$ & $302.3 \pm 10.1 \mathrm{a}, \mathrm{d}$ \\
T2-Salt & 5 & $103.5 \pm 15.6$ & $90.9 \pm 12.5$ & $95.5 \pm 13.2$ & $268.2 \pm 13.6 \mathrm{a}, \mathrm{d}, \mathrm{f}, \mathrm{g}$ \\
\hline
\end{tabular}

Tabela 1: Valores são expressos como média \pm desvio padrão da média; n: número de ratos. T1: animais treinados com protocolo 1; T2: animias treinados com protocolo 2; S-ACEi: sedentário tratado com inibidor da ECA (Enalapril $60 \mathrm{mg} / \mathrm{L}$ ); T1-ACEi: treinado com protocolol e tratado com inibidor da ECA (Enalapril); T2-ACEi: treinado com protocolo 2 e tratado com inibidor da ECA (Enalapril); S-Los: sedentário tratado com antagonista do receptor AT1 (Losartan $20 \mathrm{mg} / \mathrm{Kg} / \mathrm{dia}$ ); T1-Los: treinado com protocolo 1 e tratado com antagonista do receptor AT1 (Losartan); T2-Los: treinado com protocolo 2 e tratado com antagonista do receptor AT1 (Losartan); S-Salt: sedentário tratado com sal (1\%); T1-Salt: treinado com protocolo 1 e tratado com sal (1\%); T2-Salt: treinado com protocolo 2 e tratado com sal $(1 \%)$. a $\mathrm{P}<0.05$ vs. S; b $\mathrm{P}<0.05$ vs. S-ACEi; c $\mathrm{P}<0.05$ vs. S-Los; $\mathrm{d} \mathrm{P}<0.05$ vs. S-Salt; e $\mathrm{P}<0.05$ vs. T1-ACEi; f $\mathrm{P}<0.05$ vs T1-Salt; g $\mathrm{P}<0.05$ vs. T2.

\subsubsection{Hipertrofia cardíaca e inibição do SRA local}

A Tabela 2 mostra os resultados do peso das câmaras (VE, VD e átrios) corrigidos pelo peso corporal, para todos os grupos estudados. 
Tabela 2. Peso Corporal, Peso do VE, VD e Átrios corrigidos pelo Peso Corporal.

\begin{tabular}{lcclll}
\hline & & $\begin{array}{c}\mathrm{PC} \\
\mathrm{g}\end{array}$ & $\begin{array}{l}\mathrm{VE} / \mathrm{PC}, \\
\mathrm{mg} / \mathrm{g}\end{array}$ & $\begin{array}{c}\mathrm{VD} / \mathrm{PC}, \\
\mathrm{mg} / \mathrm{g}\end{array}$ & $\begin{array}{c}\mathrm{AT} / \mathrm{PC}, \\
\mathrm{mg} / \mathrm{g}\end{array}$ \\
\hline Grupo 1: & & & & & \\
\hline Sedentary & 6 & $223.2 \pm 7.5$ & $1.99 \pm 0.153$ & $0.532 \pm 0.058$ & $0.130 \pm 0.032$ \\
S-ACEi & 5 & $227.9 \pm 14.7$ & $2.05 \pm 0.039$ & $0.489 \pm 0.026$ & $0.134 \pm 0.015$ \\
T1 & 7 & $229.2 \pm 15.9$ & $2.39 \pm 0.081 \mathrm{a}$ & $0.584 \pm 0.039$ & $0.166 \pm 0.022$ \\
T1-ACEi & 6 & $217.0 \pm 23.5$ & $2.22 \pm 0.061$ & $0.578 \pm 0.033$ & $0.161 \pm 0.020$ \\
T2 & 7 & $205.6 \pm 15.0$ & $2.60 \pm 0.126 \mathrm{a}, \mathrm{b}$ & $0.636 \pm 0.065 \mathrm{~d}$ & $0.182 \pm 0.023 \mathrm{~d}$ \\
T2-ACEi & 6 & $204.7 \pm 13.9$ & $2.44 \pm 0.118 \mathrm{a}, \mathrm{c}$ & $0.633 \pm 0.023 \mathrm{~d}$ & $0.159 \pm 0.023$ \\
\hline Grupo 2: & & & & & \\
Sedentary & 5 & $228.6 \pm 17.7$ & $1.93 \pm 0.09$ & $0.513 \pm 0.081$ & $0.137 \pm 0.008$ \\
S-Los & 5 & $238.1 \pm 11.4$ & $1.84 \pm 0.090$ & $0.499 \pm 0.035$ & $0.132 \pm 0.020$ \\
T1 & 6 & $222.0 \pm 7.2$ & $2.25 \pm 0.130 \mathrm{e}$ & $0.565 \pm 0.021$ & $0.139 \pm 0.026$ \\
T1-Los & 6 & $235.3 \pm 9.8$ & $2.03 \pm 0.100 \mathrm{f}$ & $0.543 \pm 0.070$ & $0.137 \pm 0.030$ \\
T2 & 6 & $223.7 \pm 12.4$ & $2.47 \pm 0.072 \mathrm{e}, \mathrm{f}$ & $0.631 \pm 0.050 \mathrm{e}$ & $0.167 \pm 0.023$ \\
T2-Los & 6 & $206.6 \pm 9.4$ & $2.09 \pm 0.055 \mathrm{~g}$ & $0.621 \pm 0.063 \mathrm{e}$ & $0.167 \pm 0.015$ \\
\hline Grupo 3: & & & & & \\
Sedentary & 7 & $247.0 \pm 22.3$ & $2.16 \pm 0.060$ & $0.540 \pm 0.060$ & $0.130 \pm 0.030$ \\
S-Salt & 7 & $258.1 \pm 22.9$ & $2.33 \pm 0.122 \mathrm{~h}$ & $0.572 \pm 0.066$ & $0.127 \pm 0.016$ \\
T1 & 5 & $240.3 \pm 10.8$ & $2.64 \pm 0.088 \mathrm{i}$ & $0.594 \pm 0.063$ & $0.176 \pm 0.015$ \\
T1-Salt & 6 & $229.2 \pm 17.3$ & $2.82 \pm 0.144 \mathrm{i}$ & $0.719 \pm 0.043 \mathrm{k}, 1$ & $0.204 \pm 0.015 \mathrm{~m}$ \\
T2 & 6 & $238.8 \pm 10.0$ & $2.85 \pm 0.089 \mathrm{i}, \mathrm{j}$ & $0.677 \pm 0.071 \mathrm{k}$ & $0.208 \pm 0.018 \mathrm{~m}$ \\
T2-Salt & 6 & $245.1 \pm 17.5$ & $2.94 \pm 0.201 \mathrm{i}, \mathrm{j}$ & $0.729 \pm 0.073 \mathrm{k}, 1$ & $0.201 \pm 0.027 \mathrm{~m}$ \\
\hline
\end{tabular}

Tabela 2: Valores são expressos como média \pm desvio padrão da média; n: número de ratos. PC: peso corporal; VE: ventrículo esquerdo, VD: ventrículo direito, AT: átrio. T1: animais treinados com protocolo 1; T2: animias treinados com protocolo 2; S-ACEi: sedentário tratado com inibidor da ECA (Enalapril $60 \mathrm{mg} / \mathrm{L}$ ); T1-ACEi: treinado com protocolol e tratado com inibidor da ECA (Enalapril); T2-ACEi: treinado com protocolo 2 e tratado com inibidor da ECA (Enalapril); S-Los: sedentário tratado com antagonista do receptor AT1 (Losartan $20 \mathrm{mg} / \mathrm{Kg} / \mathrm{dia}$ ); T1-Los: treinado com protocolo 1 e tratado com antagonista do receptor AT1 (Losartan); T2-Los: treinado com protocolo 2 e tratado com antagonista do receptor AT1 (Losartan); S-Salt: sedentário tratado com sal (1\%); T1-Salt: treinado com protocolo 1 e tratado com sal (1\%); T2Salt: treinado com protocolo 2 e tratado com sal (1\%). Grupo 1: a $\mathrm{P}<0.001$, d $\mathrm{P}<0.05$ vs. S e SACEi; b $\mathrm{P}<0.01$ vs. T1; c $\mathrm{P}<0.05$ vs. T2. Grupo 2: e $\mathrm{P}<0.05$ vs. $\mathrm{S}$ e $\mathrm{S}-\mathrm{Los} ; \mathrm{f} \mathrm{P}<0.05$ vs. T1; $\mathrm{g}$ $\mathrm{P}<0.05$ vs. T2. Grupo 3 : h $\mathrm{P}<0.05$ vs. S; i $\mathrm{P}<0.001$ vs. S e S-Salt; $\mathrm{j}<0.05$ vs. T1; $\mathrm{k} P<0.05$ vs. S; $1 \mathrm{P}<0.005$ vs. S-Salt; $\mathrm{m} \mathrm{P}<0.005$ vs. S. 
Conforme pode ser observado na Figura 7, a hipertrofia do VE foi de 20\% no grupo T1 e $30 \%$ no grupo T2 $(\mathrm{p}<0,05)$. O tratamento com enalapril não preveniu a hipertrofia do VE no grupo $\mathrm{T} 1$, entretanto preveniu $39 \%$ da hipertrofia do VE no grupo T2 $(\mathrm{p}<0,05)$. O tratamento com losartan preveniu $41 \%$ no grupo T1 e $50 \%$ no grupo T2 (p<0,05).

A hipertrofia do VD foi de $10 \%$ no grupo $\mathrm{T} 1$ e $23 \%$ no grupo $\mathrm{T} 2$. Estes resultados confirmam resultados prévios da literatura, que mostraram em atletas, que a hipertrofia de VD é uma adaptação normal ao treinamento físico em indivíduos saudáveis [85].

A

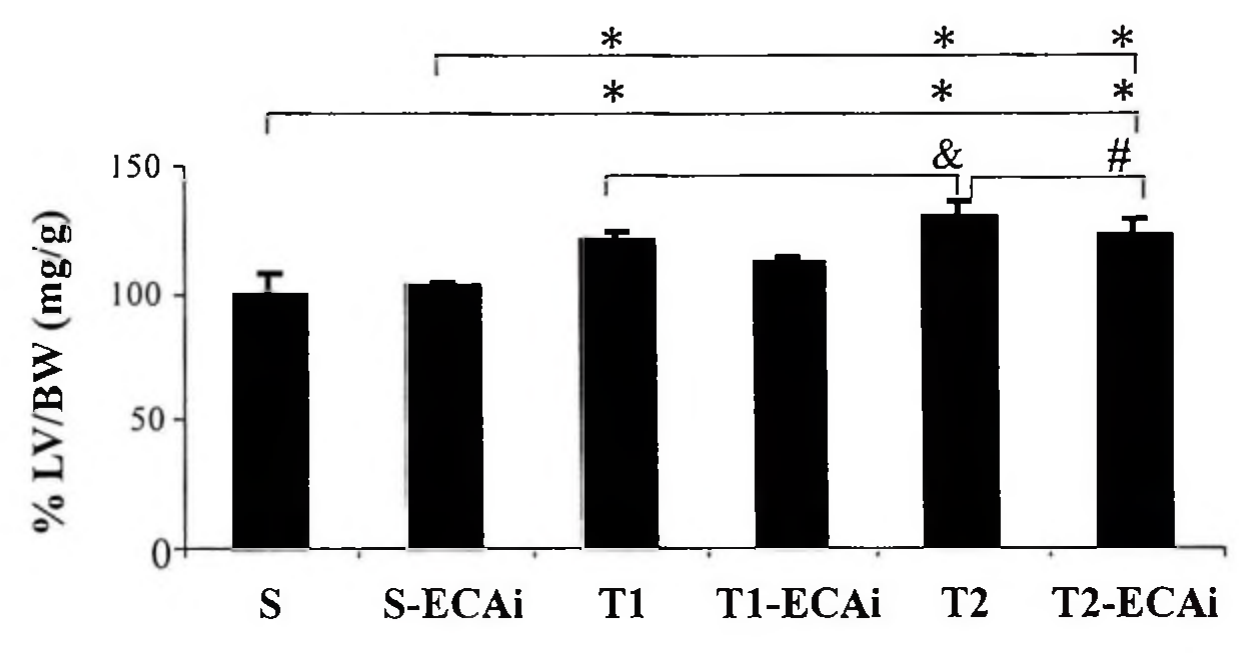

B

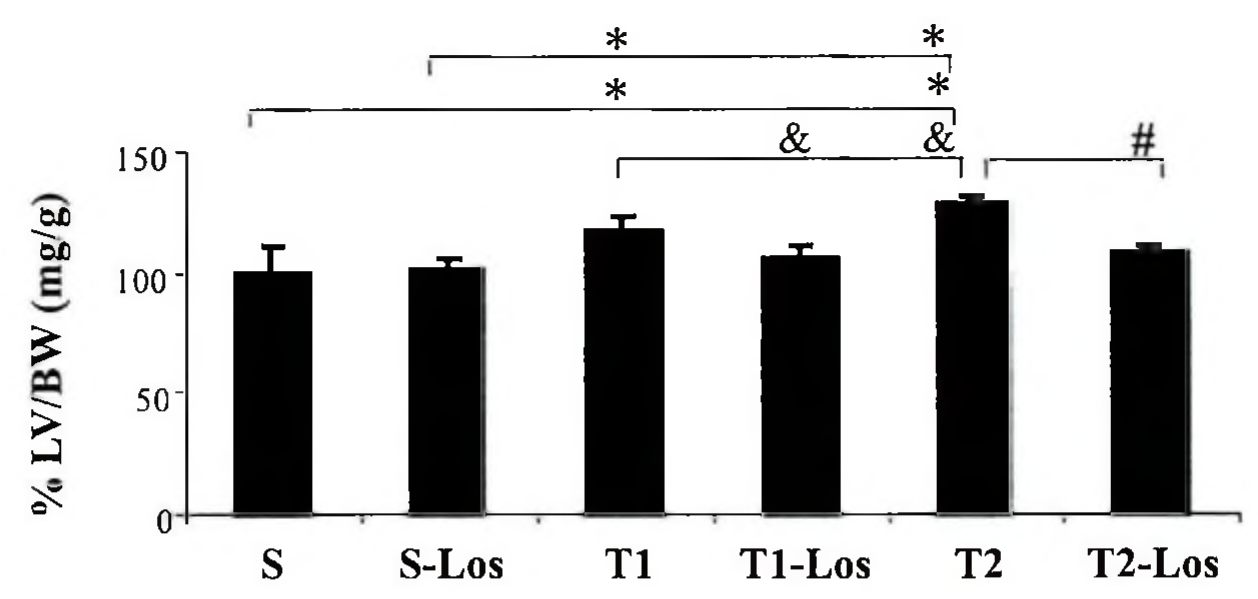

Figura 7. A- Efeitos sobre o peso do ventrículo esquerdo corrigido pelo peso corporal total (\% LVW/BW, mg.g-1) de 2 protocolos de treinamento físico de natação e tratamento com inibidor da enzima conversora de angiotensina (ACEi-enalapril), combinado ou não com treinamento, em ratas Wistar. Resultados são expressos como média \pm desvio padrão da média. S: sedentário; S-ACEi: sedentário tratado com inibidor da ECA (Enalapril 60mg/L); T1: animais treinados com protocolo 1; T1-ACEi: treinado com protocolo 1 e tratado com inibidor da ECA (Enalapril); T2: animais treinados com protocolo 2; T2-ACEi: treinado com protocolo 2 e tratado com inibidor da ECA (Enalapril). ${ }^{*} \mathrm{P}<0.001$ vs. $\mathrm{S}$ and $\mathrm{S}-\mathrm{ACEi}, \# \mathrm{P}<0.01$ vs $\mathrm{T} 1, \& \mathrm{P}<0.05$ vs. T2. 
B- Efeitos sobre o ventrículo esquerdo corrigido pelo peso corporal total $(\% \mathrm{LVW} / \mathrm{BW}$, mg.g-1) de 2 protocolos de treinamento físico de natação e tratamento com antagonista do receptor AT1 (Los-Losartan), combinado ou não com treinamento, em ratas Wistar. Resultados são expressos como média \pm desvio padrão da média. S: sedentário; S-Los: sedentário tratado com antagonista do receptor AT1 (Losartan $20 \mathrm{mg} / \mathrm{Kg} / \mathrm{dia}$ ); $\mathrm{Tl}$ : animais treinados com protocolo 1; T1-Los: treinado com protocolo 1 e tratado com antagonista do receptor AT1 (Losartan); T2: animias treinados com protocolo 2; T2-Los: treinado com protocolo 2 e tratado com antagonista do receptor AT1 (Losartan). ${ }^{*} \mathrm{P}<0.05$ vs. S and S-ACEi, $\& \mathrm{P}<0.05$ vs T1, $\# \mathrm{P}<0.05$ vs. T2.

Os inibidores da ECA inibem a conversão da Ang I para o potente vasocontritor Ang II. Além de catalisar a conversão de Ang I para Ang II, a ECA degrada a bradicinina, que é um potente vasodilatador endógeno, consequentemente a inibição da enzima potencializa os efeitos deste peptídeo. No entanto, os inibidores da ECA não promovem uma completa inibição da formação de Ang II, uma vez que não inibem vias alternativas de geração de Ang II como das serino-proteases (catepsina G e tonina) e ainda, catepsina A e quimase. Urata $\mathrm{H}$ et al., 1990, mostraram que a quimase pode clivar a Ang I em Ang II independente da ECA, principalmente no coração e vasos. Ainda, Wei C-C et al., 2002 [86], mostraram que animais knockout para o gene da ECA apresentam aumento na atividade da quimase cardíaca e renal e níveis de Ang II, nesses tecidos assim como no pulmão, iguais aos dos animais normais (wild-type). Estes dados sugerem que a ECA é essencial para a geração de Ang II no espaço vascular, entretanto a quimase pode determinar um importante mecanismo de manutenção dos níveis teciduais de Ang II em steady-state.

A principal ação do losartan é decorrente do bloqueio do receptor, do tipo AT1a, da Ang II. Vários estudos mostram a ação trófica da Ang II sobre o miocárdio [87], conforme mostramos anteriormente. Por outro lado, o receptor AT1 pode ser ativado por estresse mecânico independente da ação da Ang II [88], o que pode explicar o fato de não ocorrer uma inibição total da hipetrofia com o tratamento com losartan. Essa é uma possibilidade que consideramos fortemente, uma vez que os resultados observados para ECA local cadíaca diminuiu com o treinamento, e esse efeito foi mais pronunciado no grupo T2 (resultados apresentados no próximo estudo).

Assim, os resultados mostrados nas figuras 7A e 7B mostram a participação do SRA na hipertrofia cardíaca fisiológica decorrente do treinamento físico por natação. 


\subsubsection{Dissociação do SRA local do sistêmico}

A atividade da renina plasmática foi aumentada somente no grupo T2, comparado ao sedentário e ao grupo T1. Este resultado está de acordo com a literatura, uma vez que somente foi obervado aumento da renina plasmática com treinamentos com alta carga de trabalho [89]. Por outro lado, a atividade da renina plasmática foi totalmente inibida nos grupos tratados com sal, conforme o esperado, uma vez que a dieta alta em sal inibe a liberação da renina renal. Entretanto, a hipertrofia cardíaca não foi inibida pelo tratamento com sal, conforme observados com o tratamanto com losartan e enalapril.

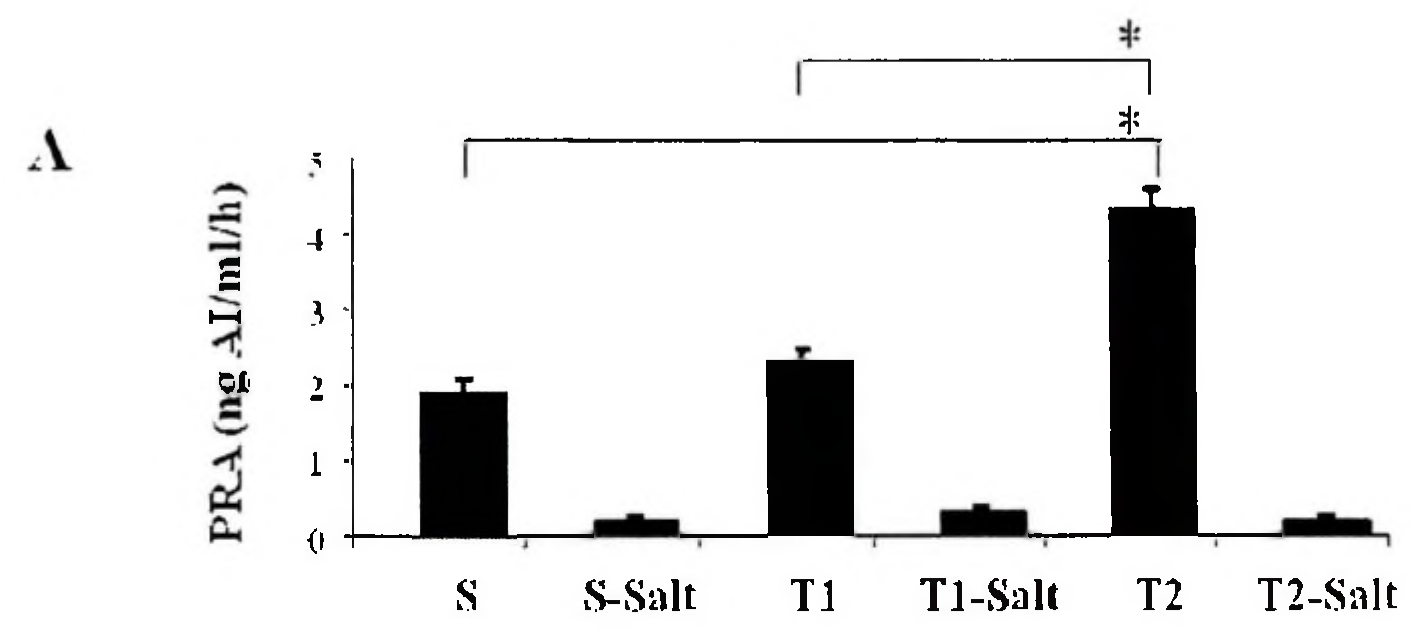

B

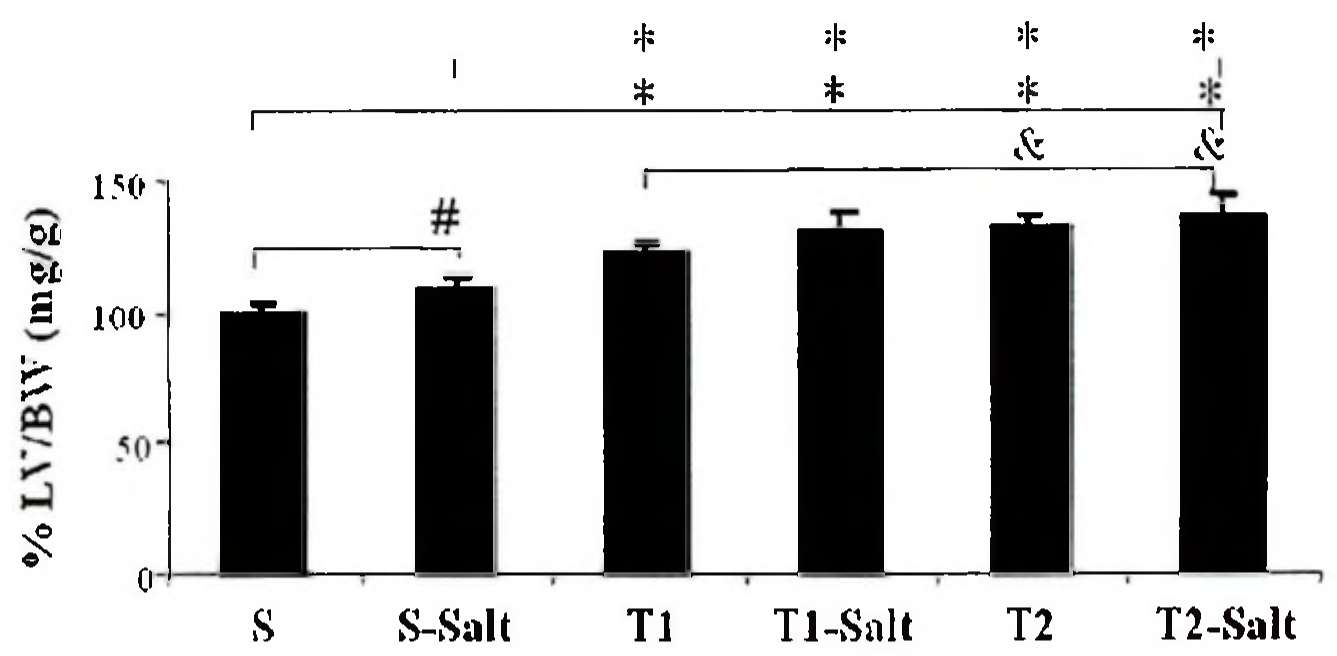

Figura 8. A- Efeitos sobre a atividade da renina plasmática (PRA) de 2 protocolos de treinamento físico de natação e tratamento com dieta de sal (Salt) combinada ou não com treinamento, em ratas Wistar. Resultados são expressos como média \pm desvio padrão da média. S: sedentário; S-Salt: sedentário tratado com sal (1\%); T1: animais treinados com protocolo 1; T1-Salt: treinado com protocolo 1 e tratado com sal (1\%); T2: animais treinados com protocolo 2; T2-Salt: treinado com protocolo 2 e tratado com sal $(1 \%)$. ${ }^{*}<0.01$ vs. S e T1. B- Efeitos sobre o 
peso do ventrículo esquerdo corrigido pelo peso corporal total (\% LVW/BW, mg.g-1) de 2 protocolos de treinamento físico de natação e tratamento com dieta de sal (Salt) combinada ou não com treinamento, em ratas Wistar. Resultados são expressos como média \pm desvio padrão da média. S: sedentário; S-Salt: sedentário tratado com sal (1\%); T1: animais treinados com protocolo 1; T1-Salt: treinado com protocolo 1 e tratado com sal (1\%); T2: animais treinados com protocolo 2; T2-Salt: treinado com protocolo 2 e tratado com sal $(1 \%)$. ${ }^{*} \mathrm{P}<0.001$ vs. S e SSalt; $\# \mathrm{P}<0.05$ vs. S; \&P<0.05 vs. T1.

A dieta alta em sal é uma manobra que permite dissociar o SRA sistêmico do local, por inibição SRA sistêmico. Por outro lado, a concentração de sódio pode modular a massa cardíaca. Neste estudo foi observado aumento de $8 \%$ de hipertrofia do VE no grupo tratado com sal, em relação ao grupo controle (S). Estes resultados estão de acordo com dados da literatura que mostram que o tratamento com sal pode resultar em hipertrofia cardíaca, independente do aumento nos níveis pressóricos [90,91]. Entretanto, estes estudos mostram aumento nos receptores AT1, o que pode explicar a indução da hipertrofia.

Os resultados mostraram que a hipertrofia aumentou $22 \%$ no grupo T1 e $31 \%$ no grupo T1-Sal e aumentou 32\% no grupo T2 e 36\% no grupo T2-Sal, quando a hipetrofia foi comparada ao grupo controle (S). Assim, estes resultados mostram que a hipertrofia cardíaca observada no grupo T1 para T1-Sal e T2 para T2-Sal, somaram aproximadamente o mesmo valor observado com a dieta alta em sal somente. Os efeitos destes dois procedimentos foram somatórios. Resultados similares foram observados para o VD.

Assim, o treinamento físico por natação induziu hipertrofia cardíaca, mesmo quando a atividade da renina plasmática foi inibida pela dieta alta em sal, sugerindo a dissociação entre a ativação sistêmica e local do SRA no treinamento físico. Resultados semelhantes foram observados com ratos com nefrectomia bilateral, que também mostraram que o SRA local pode ser regulado independente do sistêmico e pode contribuir para a resposta hipetrófica [92].

Desta forma, estes resultados em conjunto mostram que estes dois protocolos de treinamento físico aeróbio, utilizados neste estudo, induzem diferentes magnitudes de hipertrofia. Usando inibidores específicos, enalapril e losartan, demonstramos que o SRA tem um papel importante na hipetrofia cardíaca induzida pelo treinamento. Usando sobrecarga salina crônica, demonstramos que a hipertrofia fisiológica induzida pelo treinamento físico por natação é regulada localmente independente do SRA sitêmico. 
Assim, com tratamento farmacológico mostramos que a hipertrofia cardíaca fisiológica induzida pelo treinamento físico aeróbio por natação é regulada pelo SRA local independente do sistêmico, uma vez que a resposta hipertrófica foi mantida, mesmo quando a atividade da renina plasmática foi inibida pelo tratamento crônico com sal. Estes resultados foram publicados por Oliveira et al. [60].

O passo seguinte seria, portanto, mostrarmos o comportamento ou a participação dos componentes do SRA nestes dois diferentes índices de hipertrofia cardíaca induzidos pelo treinamento físico. Assim, na sequência estudamos a participação do SRA local na hipertrofia cardíaca, através do estudo dos dois eixos do sistema. O novo eixo do SRA cardíaco que inclui a enzima conversora de angiotensina 2 (ECA2), tem um papel essencial na formação de Ang (1-7), se opondo as ações do SRA clássico. A ECA2 é um regulador essencial da função do coração [9] e está implicada na vasodilatação e no controle da fibrose [93-95]. Resultados prévios sugerem que a ECA2 mantém um importante balanço entre os níveis de Ang II e Ang(1-7), favorecendo a homeostase cardiovascular. Entretanto, o papel do treinamento físico sobre o eixo ECA2-Ang (17) cardíaco é desconhecido.

Descoberta recentemente, a expressão gênica é regulada por uma nova classe de RNAs chamados de microRNAs (miRNAs). Os miRNAs são RNAs endógenos, pequenos e não codificantes para proteínas, que atuam como reguladores negativos da expressão gênica pela inibição da tradução ou a promoção da degradação de mRNAs do gene alvo. Os estudos recentes tem mostrado diferentes papéis para os miRNAs em diferentes doenças cardiovasculares e na LVH patológica $[96,97]$, porém os miRNAs podem ser importantes para o desenvolvimento normal e para o processo fisiológico como a LVH induzida pelo treinamento físico aeróbio (nesta parte do estudo foram inseridas metodologia que aprendi no meu estágio de pós-doutoramento nos Estados Unidos, e que serão apresentados na última parte desta tese).

Interessantemente, nós mostramos que o bloqueio do receptor AT1 impede a LVH fisiológica induzida pelo treinamento resistido (conforme será mostrado mais a frente nesta tese [98] assim como pelo treinamento físico aeróbio [60]. Além disso, o treinamento físico aeróbio promoveu LVH por ativação do SRA cardíaco independente do sistêmico [21]. Entretanto, as adaptações bioquímicas e moleculares do treinamento físico aeróbio sobre o SRA cardíaco não 
foram investigadas. Nós hipotetizamos que o treinamento físico altera os microRNAs específicos que regulam genes cardíacos alvo do SRA e o balanço dos genes clássicos do SRA (ECA) e dos genes novos do SRA (ECA2) contribui para a LVH fisiológica.

\subsection{Material e Métodos}

\subsubsection{Animais de experimentação}

Foram utilizados ratas Wistar. Os animais foram provenientes do Biotério Central do Instituto de Ciências Biomédicas da Universidade de São Paulo. As ratas estavam pesando entre 180 e 220 g no início do protocolo. Elas foram mantidas em gaiolas com 3 a 4 ratas, em local com temperatura ambiente entre $22-24^{\circ} \mathrm{C}$ e luz controlada em ciclo invertido de 12 horas (claroescuro), alimentados com ração e água à vontade.

Os animais foram aleatoriamente divididos em 3 grupos experimentais, cada um com 14 ratas: sedentário controle (SC), treinado natação protocolo 1 (P1) e treinado natação protocolo 2 (P2). Cada grupo foi subdividido em 2 grupos, um para estudos hemodinâmicos, bioquímicos e moleculares, e o outro para estudos morfológicos e histológicos.

\subsubsection{Protocolo de treinamento físico aeróbio}

Metodologia descrita conforme estudo anterior.

\subsubsection{Medida direta da pressão arterial e da freqüuência cardíaca}

Metodologia descrita conforme estudo anterior.

\subsubsection{Morfologia cardíaca}

Metodologia descrita conforme estudo anterior.

\subsubsection{Atividade da enzima conversora de angiotensina cardíaca e no soro}

A atividade da ECA foi determinada no tecido cardíaco e soro usando substrato específico AbzFRK(Dnp)P-OH para medida contínua da fluorescência de acordo com Alves et al. [99]. A atividade da ECA no coração foi expressa como $\mathrm{uF} / \mathrm{min} / \mathrm{mg}$ de proteína x 1000 . A concentração 
de proteína foi determinado pelo método de Bradford [73]. Já para o soro foi expressa como $\mathrm{uF} / \mathrm{min} / \mathrm{ml} \times 1000$.

\subsubsection{Atividade da enzima conversora de angiotensina 2 cardíaca}

A atividade da ECA2 foi determinada no tecido cardíaco pelo mesmo método descrito acima. Entretanto, este método usou um peptídeo fluorescente Abz-APK (Dnp)-OH em tampão 0,2 M Tris- $\mathrm{HCl}, 200 \mathrm{mM} \mathrm{NaCl}, 2 \mu \mathrm{g}$ BSA, $\mathrm{pH}$ 7,5 o qual é hidrolisado com alta afinidade pela ECA2 (Kcat/Km = 3,5 x 104 M-1.s-1). A atividade da ECA2 foi expressa UF/mg de proteína ( $\mathrm{m} \mathrm{mUF}=$ nmol of Abz-APK (Dnp)-OH hidrolisado por minuto).

\subsubsection{Medida da atividade da renina plasmática}

Metodologia descrita conforme estudo anterior.

\subsubsection{Microarray microRNAs}

Para estudar os microRNAs que apresentam como genes alvo as proteínas do SRA, inicialmente fizemos o microRNAs microarray. Foi feito um pool de RNAs de dois animais para cada Array. 349 microRNAs foram analisados com uma plataforma Agilent (LC Science LLC, Houston, TX), baseado no Sistema Sanger miRBase Release 13.0. Com o uso de ferramentas de bioinformática (programa TargetScan e miRBase) selecionamos os microRNAs que apresentam como alvo proteínas do SRA.

\subsubsection{Determinação da expressão gênica}

A expressão gênica relativa para ECA, ECA2, AT1a e AT2 no ventrículo esquerdo foi analisada por real time RT-PCR, conforme descrito abaixo:

\section{1) Extração do RNA total}

Todo o procedimento foi realizado com a utilização de luvas, materiais e soluções autoclavados que foram reservados para RNA, pela técnica de CHOMCZYNSKI \& SACCHI (1987) [100]. Amostras de tecido cardíaco das ratas foram mantidas em freezer $-80^{\circ} \mathrm{C}$. Aproximadamente $0,50 \mathrm{~g}$ de tecido foi homogeneizado em $5 \mathrm{~mL}$ de TRIzol®Reagent 
(Invitrogen). A extração foi realizada conforme as instruções do fabricante. O TRIzol ${ }^{\circledR}$ Reagent, uma solução monofásica de fenol e guanidina isotilcianato corresponde a uma variação do método desenvolvido por Chomczynski \& Sacchi (1987) [100]. O RNA precipitado foi lavado com etanol $70 \%$ para eliminar resíduos de fenol e sal, e solubilizado em água tratada com dietil pirocarbonato (DEPC). A concentração das amostras de RNA total foi determinada por espectrofotometria no comprimento de onda de $260 \mathrm{~nm}$. Ainda a concentração de RNA foi determinada em A280nm e a qualidade das amostras foi analisada pela relação das leituras de A260nm e A280nm, que foi aproximadamente 2. A integridade da amostra foi verificada através de eletroforese em gel de agarose $1 \%$, contendo $0,5 \mu \mathrm{g} / \mathrm{mL}$ de brometo de etídeo. O gel foi imerso em tampão TAE $1 \mathrm{X}$ e a eletroforese realizada a 100 Volts por aproximadamente 20 minutos. A Integridade das amostras foi avaliada pela análise da intensidade das bandas correspondentes às subunidades do RNA ribossomal $28 \mathrm{~S}$ e $18 \mathrm{~S}$. Amostras que apresentaram algum grau de degradação foram descartadas.

\section{2) Síntese de cDNA}

Para a síntese de cDNA foram utilizados $2 \mu \mathrm{g}$ de RNA total, extraídos a partir de tecido cardíaco das ratas. As amostras foram incubadas com $0,5 \mu \mathrm{g} / \mathrm{mL}$ de oligo dT12-18 a $65^{\circ} \mathrm{C}$ por 5 minutos, para se obter a primeira fita de cDNA. A transcrição reversa das amostras foi realizada em um volume total de $20 \mu \mathrm{L}$ contendo $3 \mathrm{U}$ de RNAsin (PROMEGA, Madison, USA), $10 \mathrm{mM}$ de dNTPs, 0,1 M de DTT, 1X tampão da enzima, e 2,5U de SuperScript Reverse Transcriptase II (Invitrogen, Brasil). Após incubação por 1 hora a $42^{\circ} \mathrm{C}$, a temperatura foi elevada a $95^{\circ} \mathrm{C}$ por 5 minutos e as amostras rapidamente colocadas em gelo para desnaturação de híbridos RNA-cDNA formados e inativação da enzima utilizada na reação. O cDNA obtido foi estocado no freezer a $20^{\circ} \mathrm{C}$ até a realização da reação de PCR em tempo-real.

\section{3) PCR em tempo-real (reação de polimerase em cadeia em tempo-real)}

O real-time PCR foi feito pelo sistema da deteç̧ão do produto específico amplificado no equipamento ABI 7700 (Applied-Biosystems) na presença do composto fluorescente SYBRGreen I. A otimização da reação do real-time PCR foi feita conforme as instruções do fabricante (Applied-Biosystems, boletim do usuário $\mathrm{n}^{\circ} 2$, aplicado ao protocolo SYBR-Green I), corrigido 
para volume final de $20 \mu \mathrm{l}$ por reação. As condições de PCR foram padrão (protocolo do kit SYBR-Green I master mix) e todos os reagentes foram fornecidos pelo kit, inclusive a enzima polimerase AmpliTaq-Gold (Applied-Biosystems). Depois da otimização, os primers foram utilizados na concentração de $200 \mathrm{nM}$ para a detecção e a quantificação relativa da expressão dos genes da ciclofilina (gene controle-interno). A expressão gênica foi realizada no tecido cardíaco e os primer utilizados foram:

Os primers foram desenhados usando o programa Primer 3 software (http://frodo.wi.mit.edu/cgi-bin/primer3/primer3 www.cgi). A sequência do DNA foi obtida do GenBank, e os primers foram feitos em exons separados para distinguir por tamanho o produto do PCR derivado do cDNA, de contaminações com DNA genômica.

Os primers utilizados foram:

$\boldsymbol{\alpha}$-MHC: sense: 5'-CgA gTC CCA ggT CAA CAA g-3', antisense: 5'-Agg CTC TTT CTg CTg gAC C-3';

ß-MHC: sense: 5'-CAT CCC CAA TgA gAC gAA g-3', antisense: 5'-Agg CTC TTT CTg CTg gAC A-3';

ANF: sense: 5'- CTT Cgg ggg TAg gAT TgA C-3', antisense: 5'-CTT ggg ATC TTT TgC gAT CT-3';

skeletal $\boldsymbol{\alpha}$-actin: sense: 5'-ACC ACA ggC ATT gTT CTg gA-3', antisense: 5'-TAA ggT AgT CAg TgA ggT CC-3';

ACE: sense 5'-CAg gAA CgT ggA ACT Tgg A-3' e anti-sense 5'-CTT TgA Cgg AAg CAT CAC C-3';

ACE2: (sense: 5' CAT Tgg AgC AAg TgT Tgg ATC TT 3', antisense: 5' gAg CTA ATg CAT gCC ATT CTC A 3';

AT1a: sense 5'-CAC AAC CCT CCC AgA AAg Tg-3' e anti-sense 5'-Agg gCC ATT TTg TTT TTC Tg-3';

AT2: sense 5'-gCT ggg ATT gCC TTA ATg A-3' anti-sense 5'-CTT ggT CACA ggg TAA TTC Tg-3'.

Ciclofilina: sense: 5'-AAT gCT ggA CCA AAC ACA AA -3', antisense: 5'-CCT TCT TTC ACC TTC CCA AA -3 ' 
Cada amostra de coração foi analisada em triplicate. A expressão relativa dos genes estudados foi comparada com a expressão gênica dos controles após normalização dos valores pelo gene da ciclofilina $(\Delta \mathrm{CT})$. A expressão gênica foi calculada usando as diferenças em valores

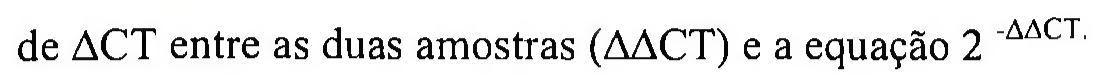

Os experimentos de Real Time PCR foram realizados no Laboratório de Genética e Cardiologia Molecular do Instituto do Coração em colaboração com o Prof. Dr. José Eduardo Krieger.

\subsubsection{Análise da expressão protéica por western blotting}

A expressão protéica para ECA, ECA2, Ang II, Ang (1-7), receptores AT1 e AT2 no ventrículo esquerdo foi analisada por western blotting. $O$ tecido cardíaco foi homogeneizado em tampão de lise hipotônico contendo tampão fosfato de potássio $50 \mathrm{mM}(\mathrm{pH} 7,0)$, sucrose $0,3 \mathrm{M}$, DTT 0,5mM, EDTA $1 \mathrm{mM}$ (pH 8,0), PMSF 0,3mM, NaF $10 \mathrm{mM}$ e coquetel de inibidor de fosfatase (1:100). O sobrenadante foi transferido para tubos de $1,5 \mathrm{ml}$ e a concentração de proteína, das amostras, analisada pelo método de Bradford [73]. Alíquotas foram armazenadas em freezer $-80^{\circ} \mathrm{C}$ até o momento de serem utilizadas.

A análise dos níveis protéicos foi realizada pela técnica de western blotting. Para isso, foi utilizada a técnica de Eletroforese em Gel de Poliacrilamida (SDS-PAGE), que consiste na migração de moléculas com carga, numa solução, pela aplicação de um campo elétrico no aparelho para minigel (Mini Protean). Posteriormente, as proteínas são transferidas para uma membrana de nitrocelulose (Amersham Biosciences, Piscataway, NJ), do mesmo modo que foram separadas no SDS-PAGE. As membranas foram coradas com Ponceau S, para a verificação das bandas protéicas obtidas pela eletroforese.

A fim de bloquear ligações inespecíficas, a membrana foi incubada em solução contendo caseína, proteína que compete com os sítios de ligação e reduz a absorção inespecífica de conjugados da peroxidase.

A membrana de nitrocelulose foi incubada com o anticorpo primário que se liga à proteína que se pretende detectar, formando um complexo anticorpo-proteína. Depois de lavar a membrana para remover o anticorpo não ligado, ela foi exposta ao anticorpo secundário 
conjugado a horseadish peroxidase (HRP), direcionado a porções espécies-específicas do anticorpo primário.

Foram utilizados como anticorpos primários mouse anti-AT1 receptor monoclonal e rabbit anti-AT2 receptor polyclonal (1:1000 e 1:800, respectivamente; Abcam, Cambridge, UK), mouse anti-ECA clone 2E2 monoclonal (1:1000, Chemicon International, CA, USA), rabbit antiAng (1-7) (doado pela Dra. Preene Senanayake), goat anti-ECA2 e anti-Ang I/II polyclonal (1:1000 e 1:500, respectivamente; Santa Cruz Biotechnology Inc., CA, USA). Em seguida as mesmas foram lavadas $3 \times 10$ min com TBS- $\mathrm{T}$, incubadas por 2 horas com os respectivos anticorpos secundários (IgG, Amersham Biosciences, EUA) conjugados à peroxidase. Posteriormente visualizadas e quantificadas (número de pixels) pelo sistema Image, fornecido gratuitamente pela NIH (EUA) via internet. Essas análises foram realizadas em nosso laboratório. A proteína alfa-tubulina foi utilizada como normalizador.

\subsubsection{Medida de angiotensina II cardíaca}

Os corações foram homogeneizados em tampão de lise (PBS $0,1 \mathrm{M}$, sacarose $0,34 \mathrm{M}$ e $\mathrm{NaCl}$ 0,3M) contendo uma mistura de inibidores de proteases e angiotensinases (parahidroximercuriobenzoato (p-OHHgBz) $1 \mathrm{mM}$; fenilmetilsulfonilfluoreto (PMSF) $1 \mathrm{mM}$; pepstatina A $1 \mathrm{mM}$; orto-fenantrolina $30 \mathrm{mM}$ e ácido etilenodiaminotetraacético (EDTA) 10 $\mathrm{mM}$ ). As amostras foram mantidas no gelo e rapidamente centrifugadas $10.000 \mathrm{rpm}, 4^{\circ} \mathrm{C}, 10 \mathrm{~min}$. O sobrenadante foi coletado e passado através de uma coluna de fenil sílica ( coluna Sep-Pak C18, Waters), e os peptídeos adsorvidos à coluna foram eluidos com etanol. O material eluído foi seco à vácuo, $4^{\circ} \mathrm{C}$ e ressuspenso em tampão. A Ang II foi determinada por método de ELISA, de acordo com as intruções do fabricante (SPI-BIO). A concentração de proteína foi determinada pelo método de Bradford, 1976, usando albumina bovina (BSA, 1mg/ml) como padrão.

\subsubsection{Análise estatística}

Foi feita uma análise descritiva dos dados coletados, os quais estão expressos como média \pm desvio padrão. Os resultados foram comparados por meio de análise de variância (ANOVA) de uma via, com medidas repetidas quando couber. O nível de significância adotado foi de $5 \%$. 


\subsection{Resultados e Discussão}

\subsubsection{Pressão arterial e freqüência cardíaca}

A tabela 3 sumariza a pressão arterial sistólica (PAS), a pressão arterial diastólica (PAD), a pressão arterial média (PAM) e da freqüência cardíaca (FC) dos grupos SC, P1 e P2. Não há diferença da pressão arterial entre os três grupos estudados. Entretanto, a FC diminuiu

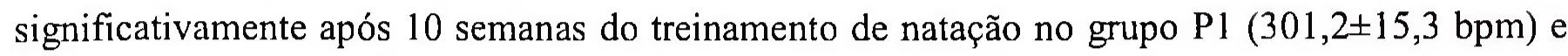
no grupo P2 (309 $\pm 14 \mathrm{bpm})$, comparado ao grupo SC $(344,8 \pm 12,1 \mathrm{bpm}, \mathrm{P}<0,05)$. A bradicardia de repouso nos animais treinados indica que o condicionamento aeróbio foi alcançado com estes dois protocolos do treinamento físico aeróbio.

Tabela 3. Pressão arterial e freqüência cardíaca.

\begin{tabular}{ccccc}
\hline & PAS, mmHg & PAD, mmHg & PAM, mmHg & FC, bpm \\
\hline SC & $1276 \pm 3.9$ & $97.6 \pm 10.3$ & $113.5 \pm 7.3$ & $344.8 \pm 12.1$ \\
P1 & $123.3 \pm 8.5$ & $96.4 \pm 5.2$ & $110.7 \pm 6.7$ & $301.2 \pm 15.3^{*}$ \\
P2 & $123.0 \pm 8.4$ & $94.3 \pm 8.9$ & $108.3 \pm 9.0$ & $309.0 \pm 14.0^{*}$ \\
\hline
\end{tabular}

Média \pm desvio padrão. PAS: pressão arterial siatólica; PAD: pressão arterial diastólica; PAM: pressão arterial média; FC: freqüência cardíaca. Diferença signifícante vs. ${ }^{*} \mathrm{SC}, \mathrm{P}<0,05$.

\subsubsection{Hipertrofia cardíaca}

O peso corporal (PC) pré e pós treinamento físico de natação foi similar entre todos os grupos estudados. A relação do VE e do VD/PC (mg/g) foi usada como um índice da hipertrofia. Os valores que se referem ao $\mathrm{PC}$, o VE/PC e o VD/PC em todos os grupos estão sumarizados na Tabela 2. A hipertrofia do VE obtida pelo protocolo de treinamento P1 e do P2 foi 13\% $(2,8 \pm 0,14 \mathrm{mg} / \mathrm{g} ; \mathrm{P}<0,05)$ e $27 \%(3,2 \pm 0,12 \mathrm{mg} / \mathrm{g} ; \mathrm{P}<0,01)$, respectivamente, comparado ao grupo de SC $(2,5 \pm 0,06 \mathrm{mg} / \mathrm{g})$. A hipertrofia do VD obtida pelo protocolo de treinamento P1 e P2 foi $15 \%(0,68 \pm 0,06 \mathrm{mg} / \mathrm{g} ; \mathrm{P}<0,05)$ e $35 \%(0,80 \pm 0,08 \mathrm{mg} / \mathrm{g} ; \mathrm{P}<0,01)$, respectivamente, comparado ao grupo SC $(0,59 \pm 0,04 \mathrm{mg} / \mathrm{g})$. O aumento na relação de VE/PC observada com treinamento de 


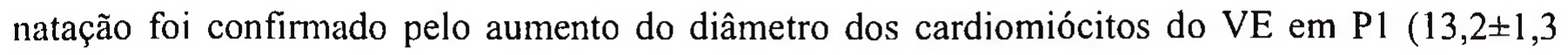
$\mu \mathrm{g})$ e o grupo $\mathrm{P} 2(14,4 \pm 1,3 \mu \mathrm{g})$ comparado ao grupo SC $(11 \pm 1,1 \mu \mathrm{g}) \mathrm{P}<0,05$ (Tabela 4).

Tabela 4. Hipertrofia cardíaca e diâmetro dos cardiomiócitos.

\begin{tabular}{ccccc}
\hline & PC, $\mathbf{g}$ & VE/PC, $\mathbf{m g} / \mathbf{g}$ & VD/PC, $\mathbf{m g} / \mathbf{g}$ & Diâmetro Cardiomiócito, $\boldsymbol{\mu g}$ \\
\hline SC & $245.8 \pm 9.4$ & $2.5 \pm 0.06$ & $0.59 \pm 0.04$ & $11 \pm 1.1$ \\
P1 & $232.2 \pm 6.4$ & $2.8 \pm 0.14^{*} \dagger$ & $0.68 \pm 0.06^{* \dagger}$ & $13.2 \pm 1.3^{*}$ \\
P2 & $234.7 \pm 17.3$ & $3.2 \pm 0.12_{+}^{+}$ & $0.80 \pm 0.08_{\ddagger}^{+}$ & $14.4 \pm 1.3^{*}$ \\
\hline
\end{tabular}

Média \pm desvio padrão. PC: peso corporal; VE: peso do ventrículo esquerdo; VD: peso do ventrículo direito. Diferença significante vs. * $\mathrm{SC}, \mathrm{P}<0,05, \dagger \mathrm{P} 2 . \mathrm{P}<0,05 ; \ddagger \mathrm{SC}, \mathrm{P}<0,01$.

\subsubsection{Marcadores moleculares de hipertrofia cardíaca patológicas}

Este dois protocolos de treinamento físico promoveram hipetrofia cardíaca sem a ativação de marcadores de hipertrofia cardíaca patológica. Os níveis dos mRNAs dos 4 genes estudados foram avaliados no VE de animais sedentários (SC) e treinados (P1 e P2) por RT-PCR em Tempo Real. A hipertrofia cardíaca patológica tem sido associada com o aumento da expressão de genes fetais, tais como o fator natriurético atrial (ANF) e $\alpha$-actina esquelética, assim como aumento da $\beta$-miosina de cadeia pesada ( $\beta$-MHC). Neste estudo demonstramos, inclusive, que ocorre um aumento da $\alpha$-miosina de cadeia pesada $(\alpha-\mathrm{MHC})$ em relação à $\beta$-MHC e diminuição da $\alpha$-actina esquelética, os quais foram diminuidos em relação ao aumento da hipertrofia, comparando os grupos P1 com o P2. A Figura 9 mostra que o treinamento físico de natação não modificada a expressão do gene ANF. Similarmente, no grupo P1 não houve alteração nos níveis de expressão do gene da $\alpha$-actina esquelética e da $\alpha / \beta$ - MHC, porém no grupo P2 foi observada redução de $53 \%$ e aumento de $98 \%$ na expressão da $\alpha$ - actina esquelética e da $\alpha / \beta-\mathrm{MHC}$, respectivamente comparados ao grupo $\mathrm{SC}(\mathrm{P}<0,05)$.

Assim, ao contrário do que ocorre na hipertrofia cardíaca patológica, essa hipertrofia fisiológica não está associada com ativação de genes fetais, tais como o ANF, $\alpha$-actina esquelética e $\beta$-MHC. Mesmo no grupo P2, não houve ativação de marcadores patológicos de hipertrofia cardíaca. 


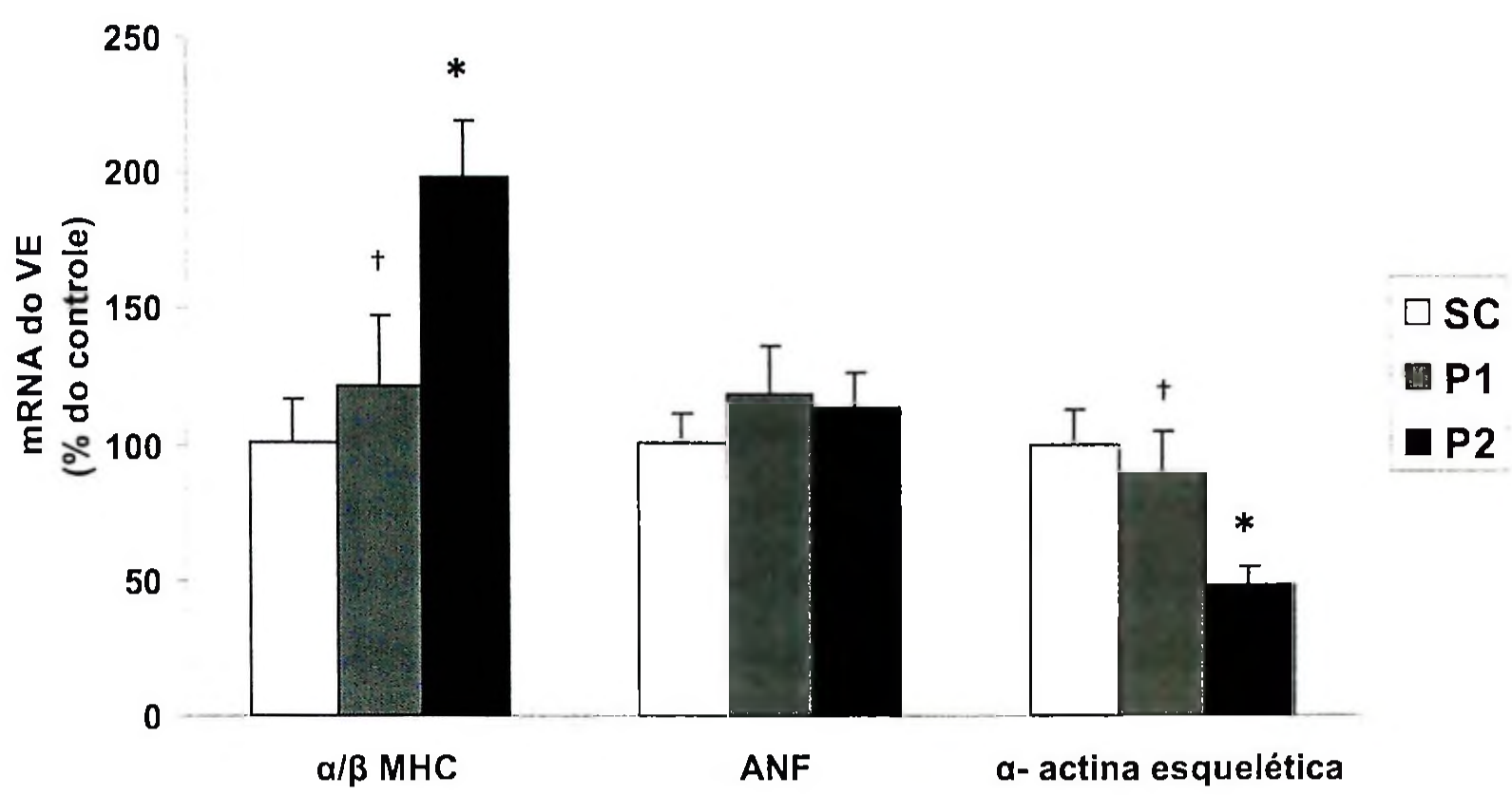

Figura 9. Efeito do treinamento físico de natação sobre a expressão gênica de marcadores moleculares de hipertrofia cardíaca patológicas. Os genes alvos foram normalizados pelo mRNA da ciclofilina. Grupos: SC- sedentário, P1- protocolo de treinamento de natação 1 e P2protocolo de treinamento de natação 2. Média \pm desvio padrão. Diferença significante vs. *SC, $+\mathrm{P} 2, \mathrm{P}<0,05$.

\subsubsection{Atividade da enzima conversora de angiotensina cardíaca e no soro.}

Para avaliar o papel do treinamento físico de natação sobre SRA sistêmico, nós medimos a atividade da ECA no soro e a atividade da renina no plasma, duas enzimas importantes envolvidas na síntese sistêmica de Ang II. A Figura 10A mostra que a atividade da ECA no soro estava aumentada $3,8 \%$ no P1 ( $\mathrm{P}=\mathrm{NS})$ e $23,5 \%$ no $\mathrm{P} 2(\mathrm{P}<0,05)$ comparados ao grupo SC. Paralelamente, sconforme observado na figura 10A, a atividade da renina plasmática também foi aumentada $20 \%$ no P1 ( $\mathrm{P}=\mathrm{NS})$ e $126 \%$ no $\mathrm{P} 2(\mathrm{P}<0,01)$ comparado ao grupo SC. Note que SRA sistêmico não estava modificado no grupo P1; este efeito foi observado somente com aumento do volume de treinamento representada pelo grupo de $\mathrm{P} 2$.

Em contraste, a Figura 10B mostra que a atividade ECA cardíaca local estava reduzida $11 \%(\mathrm{P}=\mathrm{NS})$ e $15 \%(\mathrm{P}=\mathrm{NS})$ no $\mathrm{VD}$ e no $\mathrm{VE}$, respectivamente, no grupo $\mathrm{P} 1$ e $32 \%(\mathrm{P}<0,05)$ e $40 \%(\mathrm{P}<0,05)$ no $\mathrm{VD}$ e no $\mathrm{VE}$, respectivamente, no grupo do $\mathrm{P} 2$ comparado ao grupo SC. Interessantemente, a Figura 10B também mostra que a atividade da ECA2 no VE estava aumentada $12 \%$ em P1 (1,708 $\pm 354 \mathrm{uF} / \mathrm{min} / \mathrm{mg}, \mathrm{P}=\mathrm{NS})$ e $41 \%$ no P2 $(2,160 \pm 218 \mathrm{uF} / \mathrm{min} / \mathrm{mg}$, $\mathrm{P}<0,01)$ quando comparado com o grupo SC $(1,531 \pm 174 \mathrm{uF} / \mathrm{min} / \mathrm{mg})$. 
A

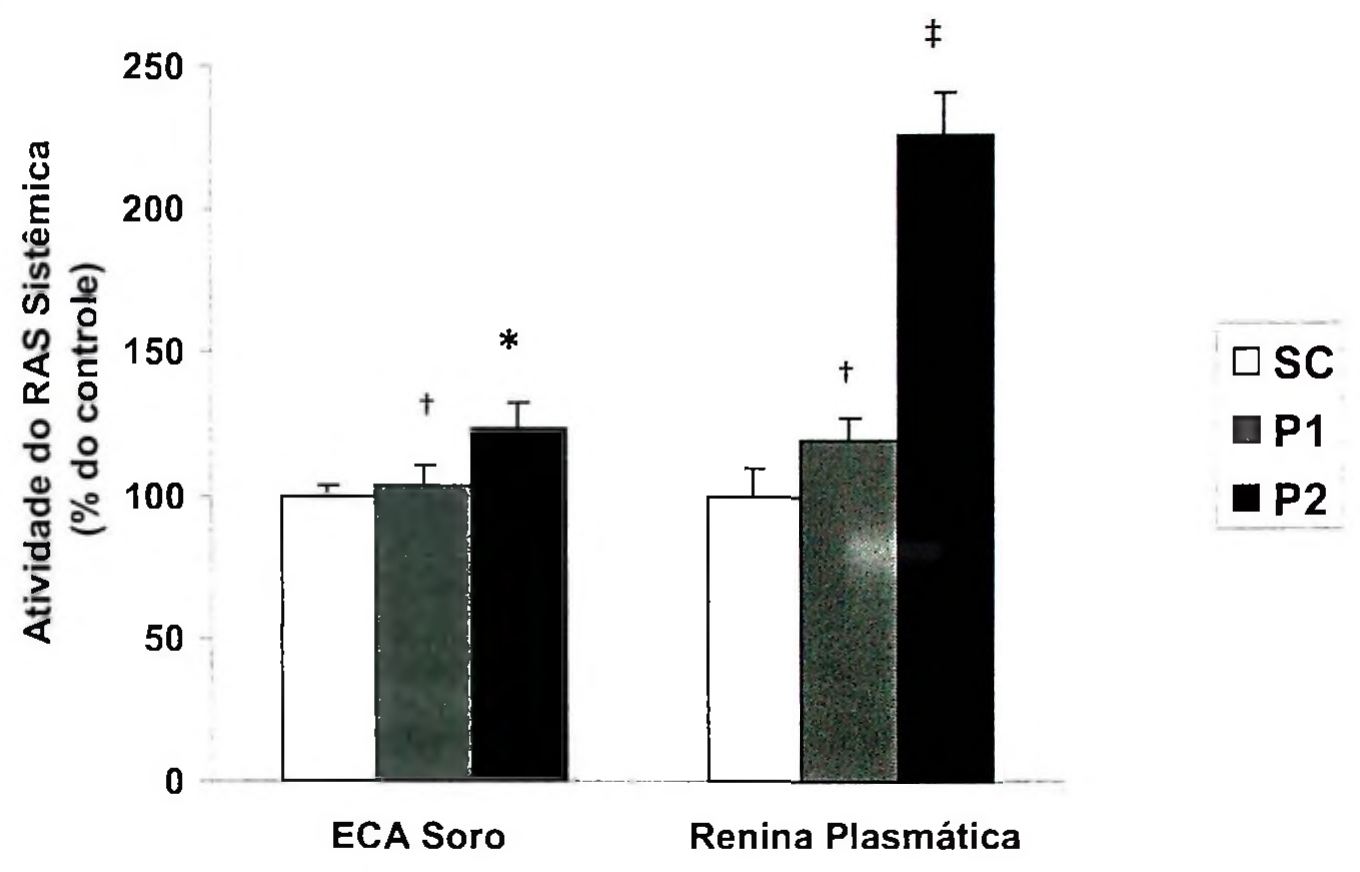

B

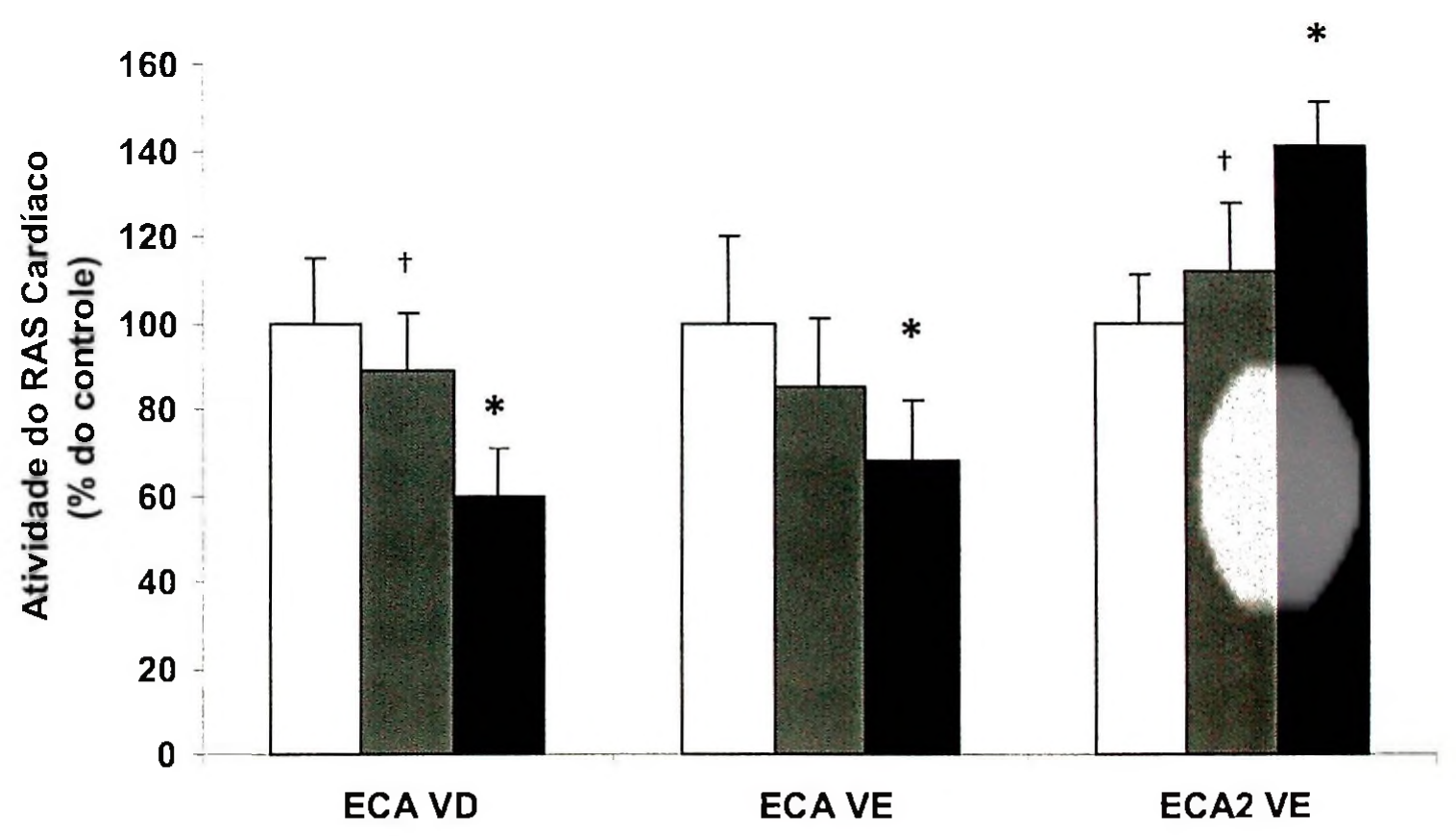

Figura 10. Efeito do treinamento físico de natação sobre a atividade do SRA sistêmico e cardíaco. A: atividade da ECA no soro e atividade da renina no plasma. B: atividade da ECA no ventrículo direito (VD), atividade da ECA no ventrículo esquerdo (VE) e atividade da ECA2 no ventrículo esquerdo (VE). Grupos: SC- sedentário, P1- protocolo de treinamento de natação 1 e P2- protocolo de treinamento de natação 2 . Média \pm desvio padrão. Diferença significante vs. ${ }^{*} \mathrm{~S}$, $\dagger \mathrm{T} 2, \mathrm{P}<0,05 ; \ddagger \mathrm{SC}, \mathrm{P}<0,01$. 


\subsubsection{Expressão gênica dos componentes do SRA}

Para testar se o treinamento físico de natação modula a expressão gênica do SRA cardíaco, nós avaliamos por RT-PCR em Tempo Real a expressão dos genes da ECA, da ECA2 e dos receptores AT1 e AT2 no coração.

Embora não significativos, os níveis do mRNA da ECA mostraram uma pequena diminuição e os niveis de mRNA para ECA2 um pequeno aumento em ambos grupos treinados (dados não mostrados). A expressão de gene do receptor AT1 aumentou em P1 $(69 \%, \mathrm{P}<0,05)$ e P2 (99\%, P<0,01) quando comparado com o grupo SC (Figura 11A). Assim como, a expressão gênica do receptor AT2 foi aumentada 26\% (P=NS) no P1 e 332\% no P2 $(\mathrm{P}<0,001)$, ainda a expressão do grupo P1 foi diferente do grupo P2 (P<0,001) (Figura 11B).

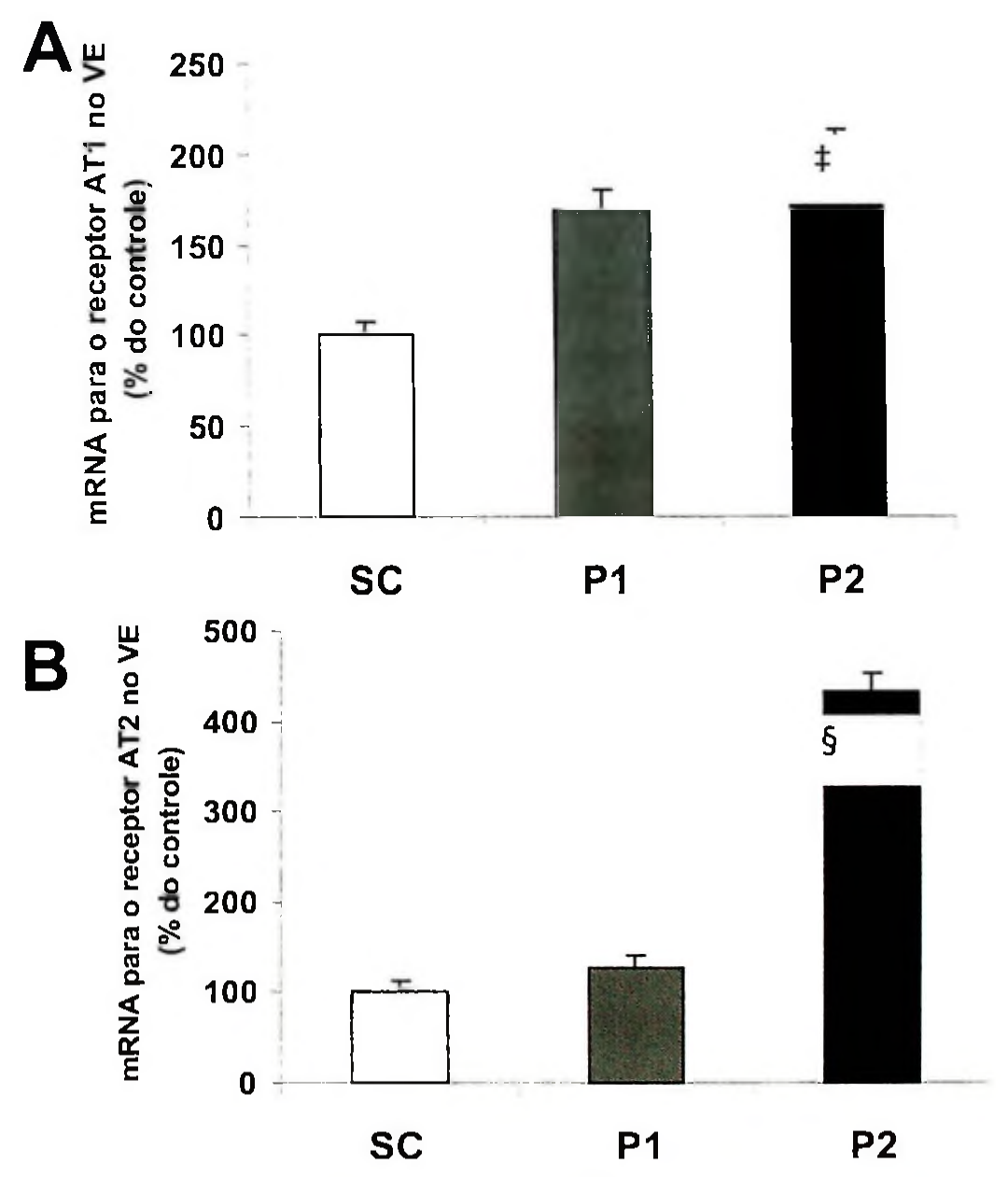

Figura 11. Efeito do treinamento físico de nataçầd sobre a expressão gênica dos receptores AT1 (A) e AT2 (B) cardíaco. Os genes alvos foram normalizados pelo gene da ciclofilina cardíaca. Grupos: SC- sedentário, P1- protocolo de treinamento de natação 1 e P2- protocolo de treinamento de natação 2 . Média \pm desvio padrão. Diferença significante vs. $* \mathrm{~S}, \mathrm{P}<0,05 ; \ddagger \mathrm{S}, \mathrm{P}<$ 0,$01 ; \S \mathrm{S}, \mathrm{P}<0,001$ and $\| \mathrm{T} 2, \mathrm{P}<0,001$. 


\subsubsection{Expressão protéica dos componentes do SRA}

Resultados semelhantes foram obtidos para a expressão de proteína do SRA determinada por western blotting. A Figura 12B, mostra que o treinamento físico reduziu a expressão proteica da ECA cardíaca $22 \%(\mathrm{P}=\mathrm{NS})$ no $\mathrm{P} 1$ e em $31 \%$ no $\mathrm{P} 2(\mathrm{P}<0,05)$ comparado ao grupo SC. Uma vez que, a ECA é a principal enzima responsável pela geração da Ang II, esta redução foi seguida por uma diminuição dos níveis de Ang II de $26 \%(\mathrm{P}=\mathrm{NS})$ no P1 e em $44 \%$ no P2 $(\mathrm{P}<0,05)$ comparado ao grupo SC (Figura 12C). Além disso, a concentração de Ang II avaliada por ELISA confirmou esta redução com $26 \%$ em P1 (2,32 $\pm 0,55$ pg/mg, P=NS) e 46\% no P2 $(1,71 \pm 0,40$ $\mathrm{pg} / \mathrm{mg}, \mathrm{P}<0,05)$ quando comparado ao grupo SC $(3,15 \pm 1,35 \mathrm{pg} / \mathrm{mg}$ ) (Figura 12D), indicando uma atenuação do eixo ECA-Ang II induzida pelo treinamento físico de natação. 

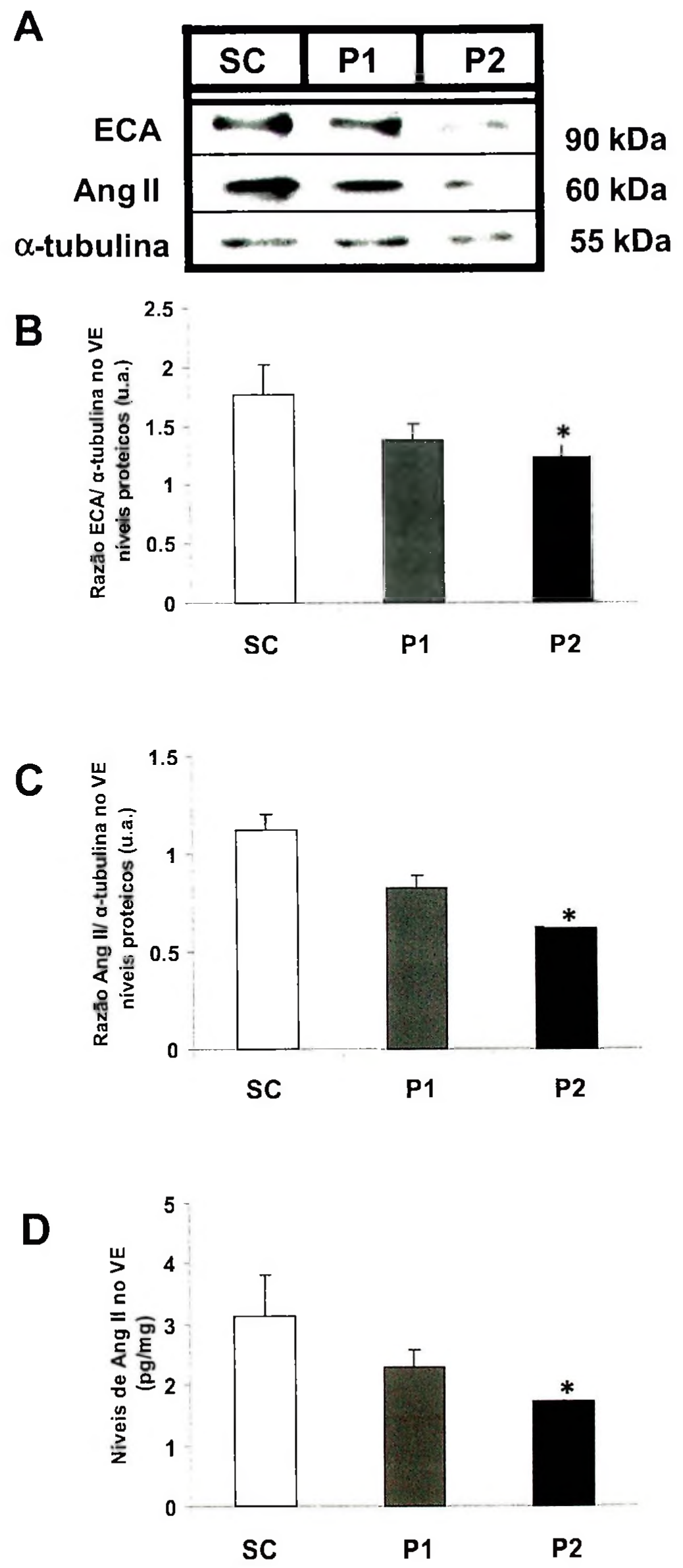
Figura 12. Efeito do treinamento físico de natação sobre o eixo clássico ECA-Ang II no coração. Média \pm desvio padrão. A: blots representativos da ECA, Ang II e $\alpha$-tubulina dos grupos SC, P1 e P2. B-C: expressão protéica da ECA e Ang II analisadas por western blot, respectivamente. As bandas alvo foram normalizadas pela $\alpha$-tubulina cardíaca. $D$ : concentração do peptídeo Angiotensina II no coração analisada por ELISA. Diferença significante vs. *S, P < 0,05 .

O treinamento físico de natação também apresenta um efeito sobre a expressão protéica do eixo novo do SRA, representado pela ECA2 e Ang (1-7) no coração. Conforem observado na Figura 13B, o treinamento de natação aumentou a expressão protéica da ECA2 em ambos os grupos treinados (68\% no P1 e $91 \%$ no $\mathrm{P} 2, \mathrm{P}<0,05)$, comparado com o grupo SC. A formação do Ang (1-7) foi aumentada (55\% no P1, P=NS e em $81 \%$ no P2, $\mathrm{P}<0,05$; Figura $13 \mathrm{C}$ ) comparada ao grupo SC. A Figura 13D mostra aumento da razão Ang (1-7)/Ang II em ambos os grupos treinados ( $80 \%$ no $\mathrm{P} 1$, no $\mathrm{P}<0,05$ e $190 \%$ no $\mathrm{P} 2, \mathrm{P}<0,01)$ comparado com o grupo SC, sugerindo aumento da formação de Ang (1-7) a partir de Ang II mediada pelo treinamento aeróbio. 
A

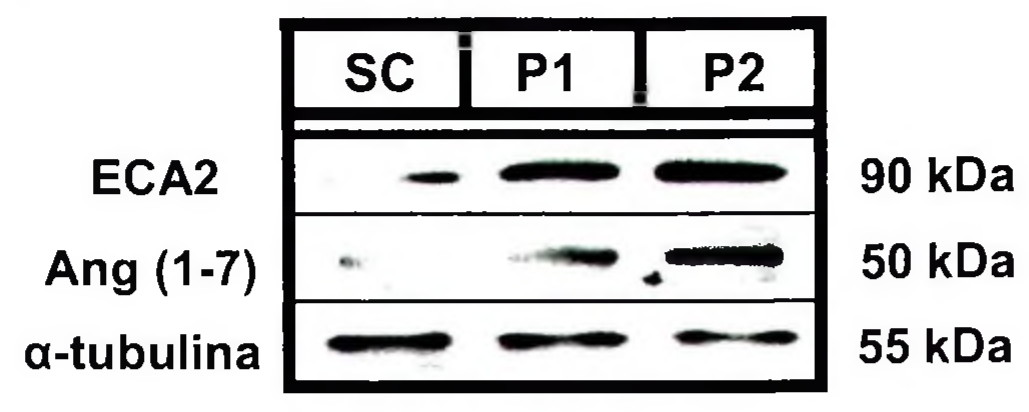

B

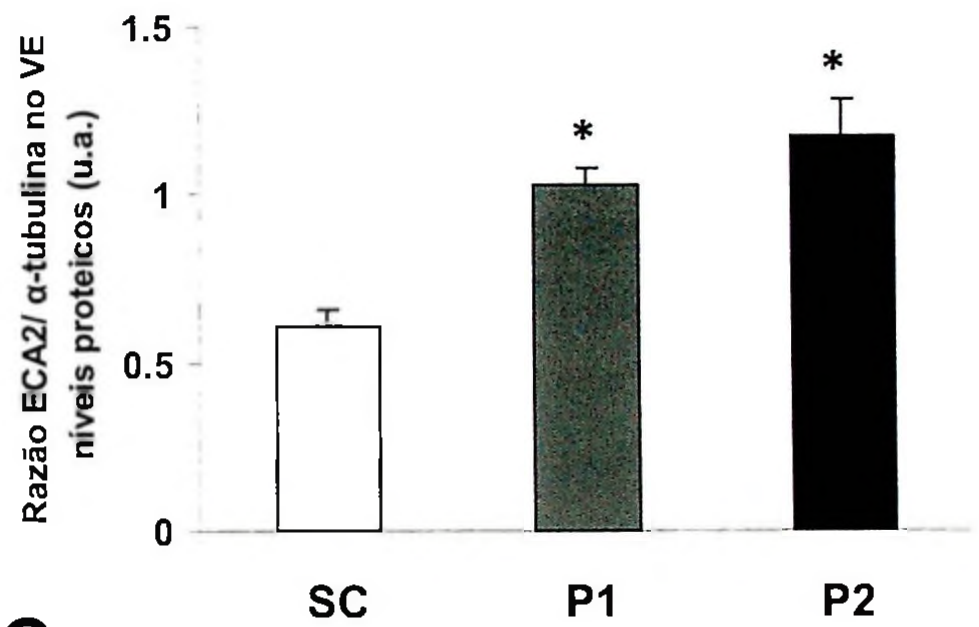

C



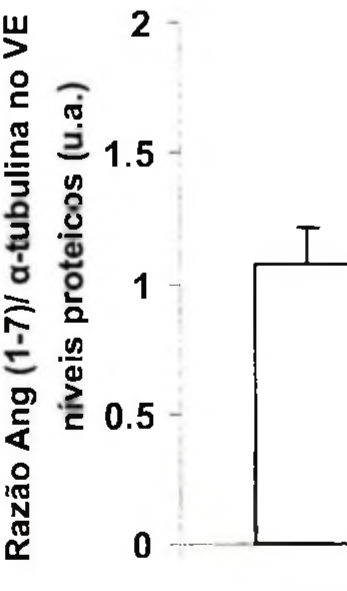

D 3.5

SC

P1

P2

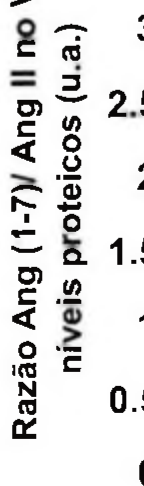

SC

SC

P1

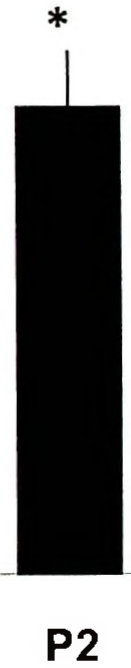

P1

P2

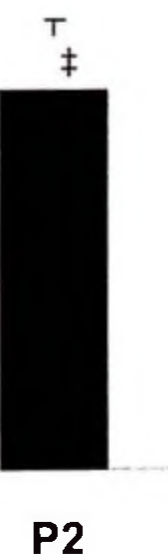


Figura 13. Efeito do treinamento físico de natação sobre o novo eixo ECA2-Ang (1-7) no coração. Média \pm desvio padrão. A: blots representativos da ECA2, Ang (1-7) e $\alpha$-tubulina dos grupos SC, P1 e P2. B-C: expressão protéica da ECA2 e Ang (1-7) analisadas por western blot, respectivamente. As bandas alvo foram normalizadas pela $\alpha$-tubulina cardíaca. D- Formação de Ang (1-7) a partir de Ang II representada pela razão Ang (1-7)/ Ang II. Diferença significante vs. $* \mathrm{~S}, \dagger \mathrm{T} 2, \mathrm{P}<0,05 ; \ddagger \mathrm{S}, \mathrm{P}<0,01$.

A expressão protéica do receptor AT1, em acordo com o aumento dos níveis de mRNA do receptor, foi 2,4 vezes maior no $\mathrm{P} 1(\mathrm{P}<0,05)$ e 3,0 vezes maior no $\mathrm{P} 2(\mathrm{P}<0,05)$ comparado ao grupo SC (figura 14B). A expressão proteica do receptor AT2 foi 1,6 vezes maior no $\mathrm{P} 1$ ( $\mathrm{P}=\mathrm{NS}$ ) e 2,2 vezes maior no $\mathrm{P} 2(\mathrm{P}<0,05)$ (Figura $14 \mathrm{C}$ ), de acordo com o aumento no mRNA de AT2 no coração. 

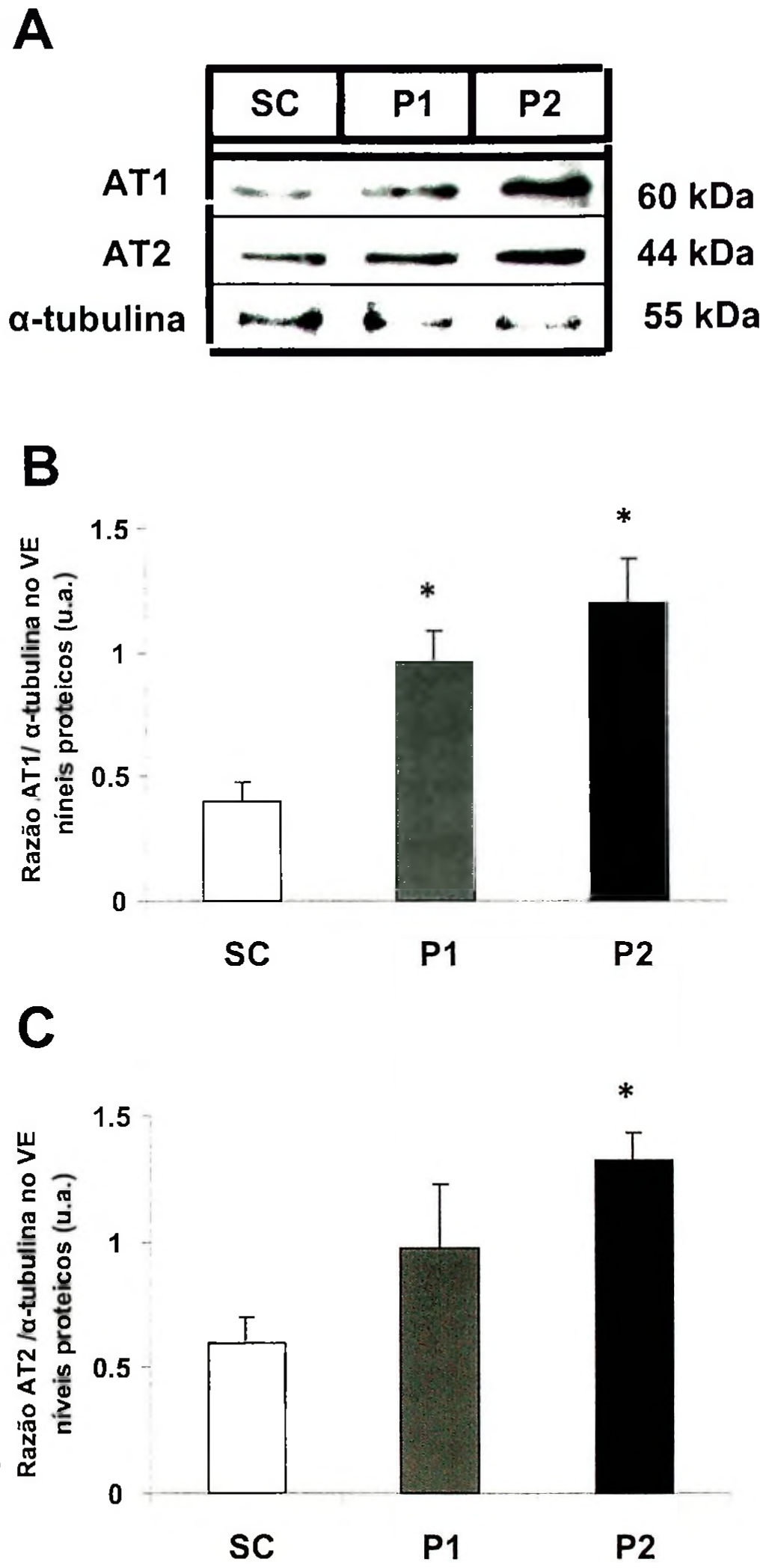

Figura 14. Efeito do treinamento físico de natação sobre a expressão protéica dos receptores AT1 (B) e AT2 (C). A: blots representativos de AT1, AT2 e $\alpha$-tubulina dos grupos SC, P1 e P2. As bandas alvo foram normalizadas pela $\alpha$-tubulina cardíaca. Média \pm desvio padrão. Diferença significante vs. ${ }^{*} \mathrm{~S}, \mathrm{P}<0,05$. 


\subsubsection{Análises dos microRNAs}

Estudamos os microRNAs (miR 27a, 27b, 145 e 150), os quais podem regulam a via clássica e a via nova do SRA, nos animais treinados.

A análise dos microRNAs foi restrita para aqueles microRNAs que tiveram uma mudança significativa nos grupos treinados comparados ao grupo controle e que são alvos para os genes do SRA.

A Figura 15A mostra os microRNAs que apresentam como alvo o gene a ECA: miR 27a e 27 b aumentaram a expressão gênica $(26 \%$ e $27 \%)$ e $(45 \%$ e $83 \%)$ nos grupos T1 e T2, respectivamente, $\mathrm{P}<0,05$, comparados ao sedentário controle. Ainda, o grupo T1 foi diferente do $\mathrm{T} 2(\mathrm{P}<0,01)$.

A Figura 15B mostra o microRNA que apresentam como alvo o gene da ECA2: a expressão gênica do miR150, aumentou $38 \%$ no grupo $T 2$ comparado ao controle $(\mathrm{P}<0,05)$. A expressão gênica do microRNA145 aumentou $15 \%$ e $47 \%$ nos grupos T1 e T2, respectivamente $(\mathrm{P}<0,05)$, comparados ao grupo controle. Ainda, para os dois microRNAs alvos da ECA2, o grupo $\mathrm{T} 1$ foi diferente do $\mathrm{T} 2(\mathrm{P}<0,01)$.

A Figura 15C mostra o microRNA que apresentam como alvo os genes do receptor AT1: a expressão gênica do microRNA350 aumentou 55\% e 64\% nos grupos T1 e T2, respectivamente $(\mathrm{P}<0,05)$, comparados ao grupo controle. 

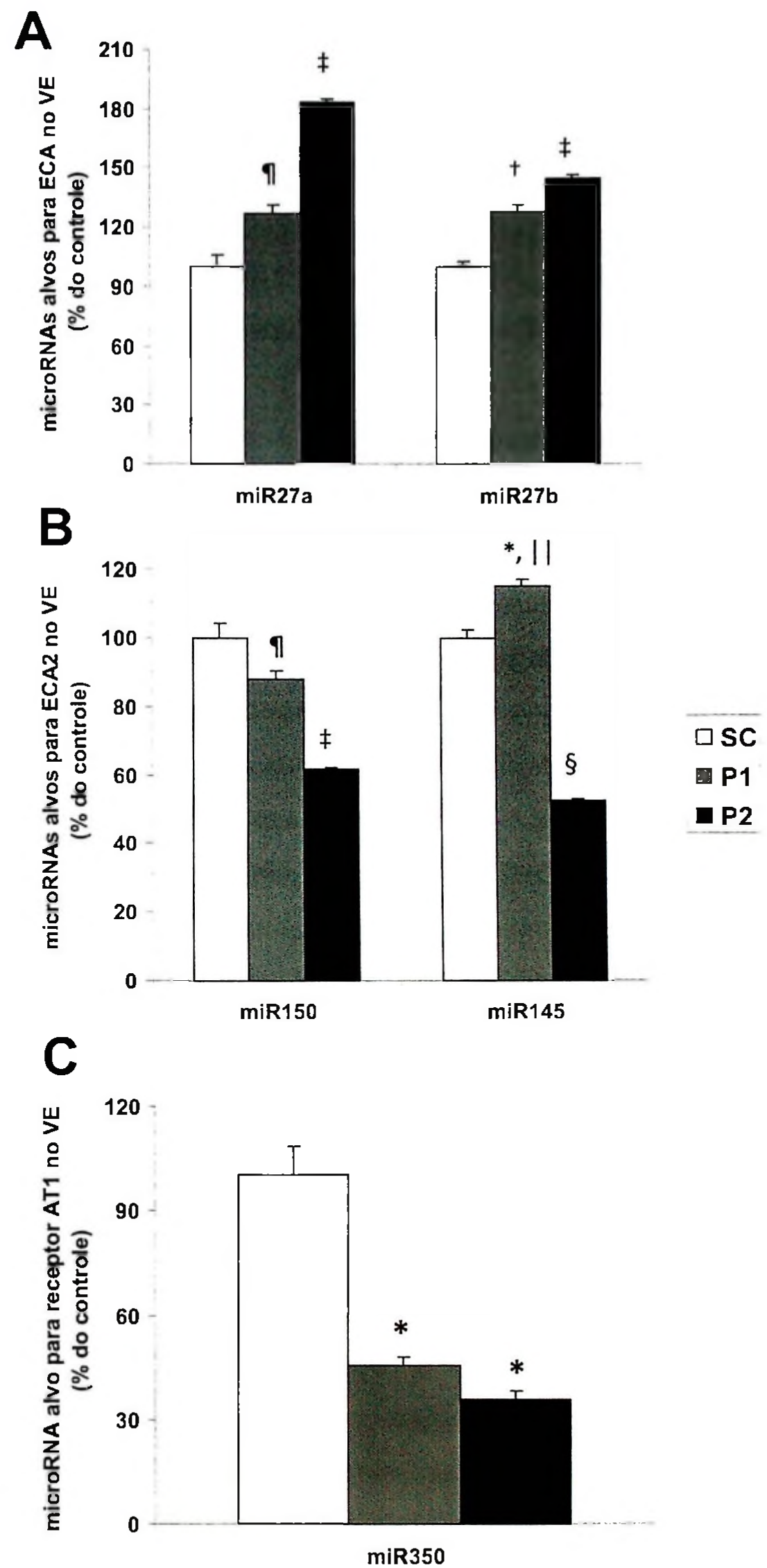

Figura 15. Efeito do treinamento físico de natação sobre específicos microRNAs alvos para genes do SRA. A: microRNAs associados com a ECA: miR27a and miR27b. B: microRNAs associados com a ECA2: miR150 and miR145. C: microRNA associado com o AT1 receptor: miR350. Média \pm desvio padrão. Diferença significante vs. ${ }^{*} \mathrm{~S}, \dagger \mathrm{T} 2, \mathrm{P}<0,05 ; \ddagger \mathrm{S}, \mathrm{P}<0,01 ; \S \mathrm{S}$,

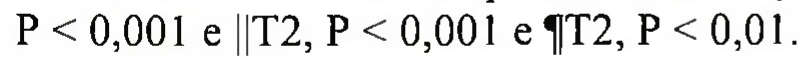


Estes resultados mostram que o treinamento físico por natação 1) induziu hipertrofia no VE; 2) não está relacionado com marcadores de hipertrofia cardíaca patológica; 3) diminui a a ECA e a Ang II cardíaca; 4) aumenta a expressão de receptores AT1 e AT2; 5) aumenta a atividade e a expressão da ECA2 podendo aumentar a formação de Ang (1-7); altera micro RNAs alvos de genes do SRA.

Ao contrário de marcadores de hipertrofia patológica [101], a hipertrofia fisiológica mostrada neste estudo não está associada com a ativação de genes fetais como, do fator natriuretic atrial (ANF), da $\alpha$-actina esquelética e da miosina de cadeia pesada ( $\beta$-MHC). Mesmo no grupo treinado com o protocolo P2, não foi observado marcador patológico de hipertrofia.

Além disso, o estudo confirmou as adaptações associadas ao treinamento como a bradicardia de repouso, que indica que o condicionamento aeróbio foi atingido [60,67].

O Ang II tem sido mostrado como um potente fator trófico para os cardiomiócitos, entretanto, vários modelos de animais transgênicos com aumento de formação de Ang II local cardíaca não mostraram hipertrofia, porém apresentaram fibrose e hipertrofia cardíaca somente quando os níveis de Ang II circulante aumentam resultando em aumento da pressão arterial [102, 103]. Xiao et al., [104] mostraram que camundongos que superexpressam ECA cardíaca, a Ang II cardíaca aumentada não está associada com hipertrofia cardíaca. Além disso, também foi mostrado que animais com diferente número de cópias do gene da ECA, um, dois, três ou quatro cópias do gene, que a magnitude da hipertrofia do VE induzida pelo treinamento físico por natação não foi correlacionado com os níveis da enzima [105]. Assim, estes dados em conjunto com os obtidos no presente estudo mostram que a Ang II não é um fator trófico direto para o miocárdio.

O treinamento físico por natação aumenta a expressão do receptor AT1 no coração e promove hipertrofia do VE fisiológica sem a participação da Ang II. Os resultados do presente estudo, corroboram com resultados prévios que mostramos que estes receptores aumentam com o treinamento resistido [98] e que o tratamento com o antagonista do receptor AT1, losartan, bloqueia a hipertrofia do VE promovida pelo treinamento físico com estes dois protocolos de natação [60]. Assim, há evidências de que o SRA cardíaco apresenta um papel crítico neste modelo de hipertrofia fisiológica. Um mecanismo pelo qual a superexpressão do receptor AT1 causa essa hipertrofia pode ser porque o receptor AT1 apresenta um efeito de transativação sobre 
o receptor do fator de crescimento epidermal (EGFR) [106]. A inibição do EGFR previne a hipertrofia do VE induzida por Ang II em ratos [107]. Zou et al., [88] mostraram in vivo e in vitro que o estresse mecânico ativa o receptor AT1 por mudança conformacional do sétimo domínio transmenbrana do receptor ATlindependente de Ang II. Assim, o receptor funciona como um sensor mecânico ao estresse independentemente da Ang II.

Nós demontramos aqui pela primeira vez, que o treinamento físico aeróbio aumenta a expressão gênica e proteica do AT2 no VE. Estudos mostram que os receptores AT1 e AT2 apresentam funções opostas no coração embora tenha afinidade por um mesmo ligante [102, 108]. Os receptores AT2 aumento a geração de NO e bradicinina, induzindo vasodilatação [109]. Yang, demonstrou que animais trnsagênicos que superexpressam o receptor AT2 apresentam função cardíac preservada após o infarto do miocárdio. Nossos resultados sugerem que o receptor AT2 possa ter um papel cardioprotetor e estar envolvido nos efeitos vasodilatores promovidos pelo treinamento físico. Esta resposta ao treinamento poderia aumentar o transporte sanguíneo e de oxigênio para miocárdio permitindo melhor performace do miocárdio durante o treinamento.

Segundo nosso conhecimento, essa é a primeira vez que está sendo demostrado os efeitos do treinamento físico aeróbio sobre a ECA2 e Ang (-7) no coração de ratos normotensos. O presente estudo mostra que comparados aos sedentários controles, os animais treinados apresntaram aumento na atividade e expressão proteica da ECA no VE aumentando a Ang (1-7). A ECAZcliva a Ang I gerando o peptídeo inativo Ang (1-9), entretanto a enzima apresenta uma afinidade de 500x maior pela Ang II formando o peptídeo vasodilatador Ang (1-7) [110-112]. Na hipertensão, a diminuição da expressão gênica e proteica da ACE-2 leva ao aumento dos níveis de Ang II e pode reduzir o fluxo sanguíneo para o miocárdio preferencialmente via vasoconstrição coronária ou disfunção microcirculatória. Entretanto, com o uso de inibidores da ECA ou bloqueadores de receptores AT1, a ECA2 foi aumentada [111, 113, 114]. Animais transgênicos que superexpressam ECA2 cardíaca por transfecção com lentivirus mostraram regressão da hipertrofia cardíaca em animais hipertensos [93]. Ishiyama et al. [115] mostraram que o uso de antagonistas de receptor AT1 aumentaram a razão das concentrações plasmáticas de Ang (1-7)/Ang II, sugerindo aumento na geração de Ang (1-7) proveniente da Ang II. Além disso, Crckower et al., [9] mostraram que camundongos com a deleção de ECA2 apresentaram elevados níveis de Ang II cardíaca e plasmática, juntamente com melhora na contratilidade 
cardíaca mostraram maior dilatação na câmara cardíaca. Desta forma, o aumento da ECA2 pode ser um fator protetor contra a hipertrofia do VE por reduzir os níveis de Ang II e aumentar a formação de Ang (1-7) [93-95, 115]. Os efeitos vasodilatadores do eixo ECA2-Ang (1-7) são mediados pela liberação de diferentes fatores vasoativos, provavelmente NO, prostaglandinas e bradicinina [116].

Assim, pelo qual o treinamento físico aeróbio pode prevenir ou ser um tratamento não farmacológico numa patologia do VE pode ser por diminuição da resistência vascular e consequentemente aumento no fluxo cardíaco, em parte, devido a reduçào na ECA e nos níveis de Ang II e aumento na Ang (1-7) por elevada expressão da ECA2. Nossos resultaos mostram que o treinamento físico por natação promoveu aumento na razão Ang (1-7)/Ang II no coração mostrando aumento de uma via vasodilatadora e diminuição de uma via vasocontritora.

Este estudo também revela um potencial mecanismo molecular para estes resultados. Os microRNAs apresentam como alvos múltiplos genes, entretanto os genes alvos são controlados por específicos microRNAs $[96,97]$. Em ratos, miR27a e miR27b são alvos para o gene da ECA, os quais foram significativamente aumentados nos animais treinados. Ambos, tiveram maior expressão com o aumento do volume de treinamento. A expressão aumentada indica inibição dos genes alvos pelo miRNA. Isto parece ser o caso com esses dois miRNAs com a ECA, que aumentou $22 \%(\mathrm{P} 1)$ e $31 \%$ (P2) comparada com o controle, enquanto miR27a aumentou $26 \%$ (P1) e $88 \%$ (P2) comparado com o controle e o miR $27 \mathrm{~b}$ aumentou $27 \%$ (P1) e $44 \%$ no (P2). Pelo mesmo princípio, diminuida expressão nos miRNAs reflete aumentada expressão dos genes alvos, o que parece ser o caso para a expressão gênica dos receptors AT1, onde o treinamento diminuiu o miR350, o qual apresenta o receptor AT1 como como gene alvo. Os miRNAs 145 e 145 apresentam com gene alvo a ECA2, e no grupo T2, onde a ECA2 apresentou maior expression, ambos os miRNAs apresentaram menor nível de expressão comparados com os grupos controle ou $\mathrm{T} 1$, indicando que o aumento do volume de treinamento interefere com a expressão dos miR145 e miR150.

O exercício físico é bem reconhecido como um fator importante do estilo de vida para melhorar as condições cardiovasculares. Este estudo revela alguns dos mecanismos bioquímicos e moleculares envolvidos na hipertrofia cardíaca fisiológica decorrente do treinamento aeróbio 
Portanto, destes resultados podemos sugerir que a hipertrofia cardíaca induzida pelo treinamento físico aeróbio envolve a regulação de microRNAs, que apresentam como alvos genes do SRA. O aumento do receptor AT1, sem a participação da Ang II, está envolvido na hipetrofia cardíaca. O aumento da ECA2, Ang (1-7) e receptores AT2 no coração com o treinamento, sugere que a via não clássica contrabalança a via clássica do SRA cardíaco, na hipertofia fisiológica. Assim, estes efeitos contra-regulatórios aumentam a vasodilatação permitindo aumento de fluxo sanguíneo e aumentando o aporte de oxigênio e metabólico para o músculo cardíaco no exercício, em resposta a maior demanda aeróbia.

\section{Estudo 2: Influência do $N$ domínio da enzima conversora de angiotensina na eritropoiese induzida pelo treinamento físico aeróbio e no consumo de oxigênio.}

O treinamento físico aeróbico regular acarreta diversas adaptações, dentre as quais podese destacar aquelas que ocorrem no sistema cardiovascular que, em última análise, têm como objetivo aumentar o transporte e extração de oxigênio e melhorar o fluxo sanguíneo para o miocárdio e principalmente para musculatura esquelética ativa durante a atividade física. Alguns trabalhos recentes têm mostrado que o treinamento físico promove um maior recrutamento de células tronco da medula, as quais podem estar envolvidas nestas adaptações.

Células tronco são células que têm a capacidade de se diferenciar em um ou mais tipos celulares maduros (Figura 1). Células tronco hematopoiéticas (HSC, do inglês: hematopoietic stem cells) são células que têm a capacidade de se diferenciar em células sanguíneas como neutrófilos, monócitos/macrófagos, basófilos, eosinófilos, eritrócitos, plaquetas, mastócitos, células dendríticas e linfócitos T e B [117]. Em humanos e ratos, as HSC se caracterizam pela expressão de marcadores de membrana como $\mathrm{CD} 34\left(\mathrm{CD} 34^{+}\right)$, que é um marcador de células progenitoras hematopoiéticas, e ausência de expressão de CD38 (CD38'), que é um marcador de linfócitos ativados e marcador de células plasmáticas e de CD45 (CD45), que é um marcador para células sanguíneas diferenciadas $[117,118]$. Podem, ainda, apresentar CD133, que é um marcador hematopoiético e não-hematopoiético de células tronco mais imaturas [117]. 


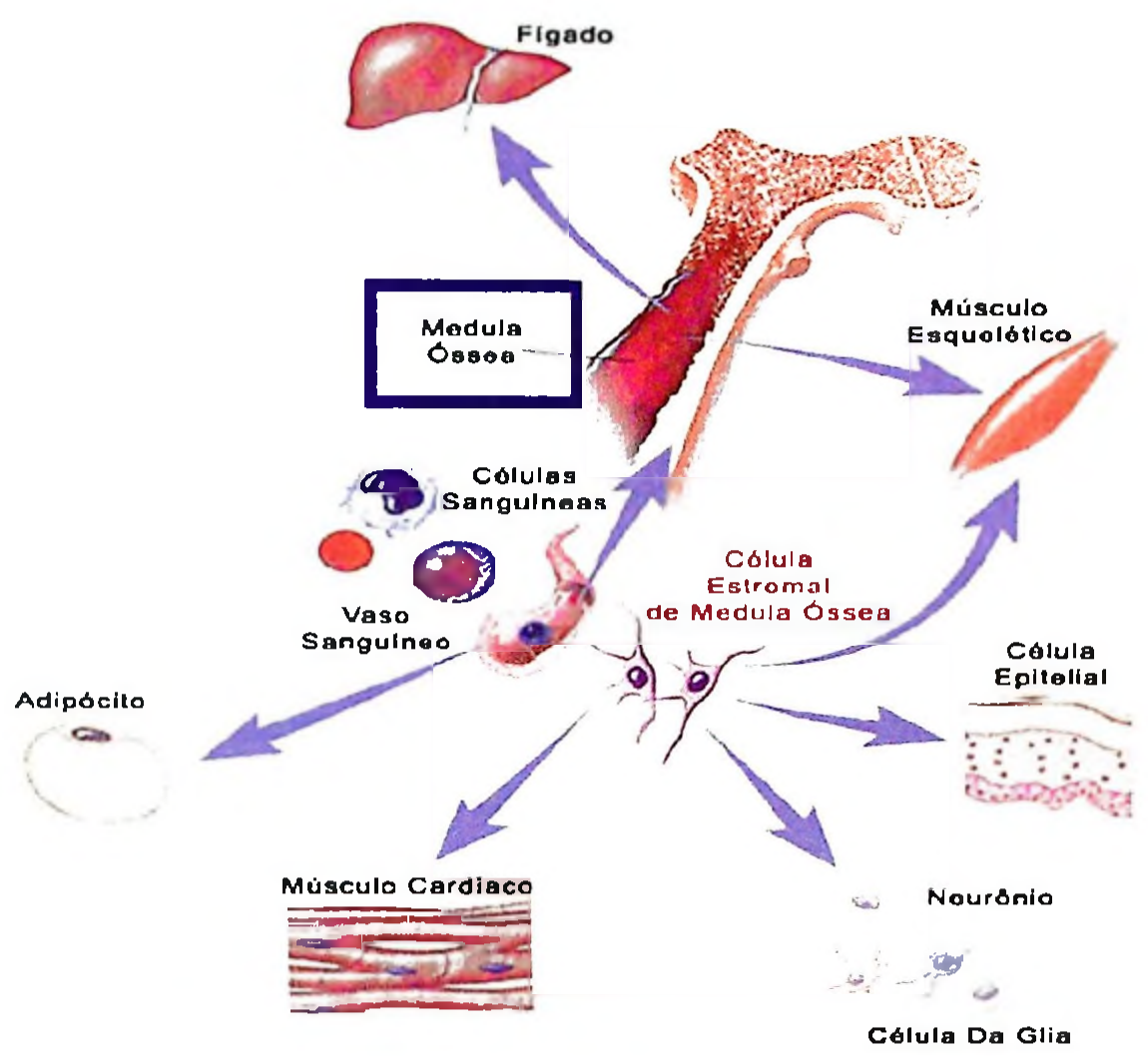

Figura 1. Células tronco adultas derivadas da medula óssea. As células tronco da medula óssea são células indiferenciadas que podem se renovar e reproduzir indefinidamente e, sob certos estímulos, se transformar em células especializadas de diferentes tecidos ou órgãos.

Estudos recentes vêm mostrando que o exercício físico exerce efeitos sobre HSC. Trabalhos feitos tanto com uma sessão aguda de exercício, quanto com o estímulo crônico do treinamento observaram maior liberação para a circulação e maior funcionalidade de células tronco de origem medular. Entretanto, a maioria desses estudos investigou células tronco endoteliais [119-123] e a literatura acerca dos efeitos do treinamento físico sobre as HSC é escasso.

Poucos estudos são encontrados na literatura que observaram que o exercício físico modula as HSC. Morici et al. (2005) [118] observaram aumento no número de HSC circulantes e de fatores angiogênicos após o exercício agudo supramáximo. Além disso, esses autores observaram que a funcionalidade das HSC era maior após o exercício. Os possíveis efeitos do treinamento físico sobre HSC foram estudos por [124]. Foi observado neste estudo que o número de células $\mathrm{CD} 4^{+}$era 3 a 4 vezes maior em corredores treinados em comparação a sedentário 
controle, sugerindo que o treinamento físico regular pode aumentar o recrutamento de HSC. [125] observaram que indivíduos idosos apresentavam pequeno aumento nas HSC induzido pelo exercício físico agudo em comparação a indivíduos jovens e que 8 semanas de treinamento aeróbico não causava alteração no número basal ou no número induzido pelo exercício das HSC. Recentemente, Wardyn et al. (2008) [126] relataram que a porcentagem de células CD $34^{+}$na circulação periférica não era diferente entre sujeitos treinados e não-treinados, entretanto, os sujeitos do estudo foram classificados de acordo com a atividade física habitual, e, portanto, não foi empregado protocolo de treinamento para adaptar os indivíduos. Portanto, a literatura é escassa acerca dos efeitos do treinamento físico sobre o número de HSC e nenhum estudo foi encontrado que relacionou o treinamento físico com a funcionalidade das HSC.

O SRA é um sistema extremamente complexo que atua em diversos tecidos e sistemas do organismo $[110,127]$. Conforme descrevemos anteriormente, o SRA clássico tem como produto final à formação de angiotensina II (Ang II), que é o principal peptídeo efetor do sistema clássico. A Ang II é um octapeptídeo formado pela ação da enzima ECA sobre o decapeptídeo Ang I, que por sua vez é formado pela ação da enzima renina sobre o angiotensinogênio (Agt).

Dada a importância da ECA neste trabalho, vale fazermos algumas considerações sobre a enzima. A ECA (EC 3.4.15.1) é uma dipeptidil dipeptidase carboxi-terminal cujos substratos principais são Ang I e a bradicinina, mas também hidrolisam outros peptídeos, como a substância $\mathrm{P}$ e o tetra peptídeo $\mathrm{N}$-acetyl-seryl-aspartyl-lysyl-proline (Ac-SDKP). A enzima, ao clivar o dipeptídeo carboxi-terminal de seus dois principais substratos, leva a formação de Ang II, um potente vasoconstritor e inativa o vasodepressor bradicinina levando à formação de peptídeos inativos. A enzima apresenta um baixo $\mathrm{Km}$ para a bradicinina $(0,2 \mathrm{mmol} / \mathrm{L})$ e alto para a Ang I $(16 \mathrm{mmol} / \mathrm{L})$, assim a enzima apresenta maior afinidade pela bradicinina do que pela Ang $\mathrm{I}$.

O cDNA desta enzima consiste de 4142 nucleotídeos que codifica para 1313 aminoácidos [128]. A ECA é uma glicoproteína integral de membrana ancorada na bicamada lipídica através de uma sequência de aminoácidos hidrofóbicos (17 aminoácidos), localizados na extremidade Cterminal (Figura 2). A orientação da enzima na membrana ocorre de tal forma que seus sítios catalíticos, presentes na porção amino-terminal, estão expostos na superfície extracelular [129$131]$. 
A principal característica observada ao analisar a sequência de aminoácidos da enzima é o alto grau de homologia interna, com a presença de dois sítios ativos, sugerindo uma possível duplicação de um gene ancestral durante a evolução [131].

A

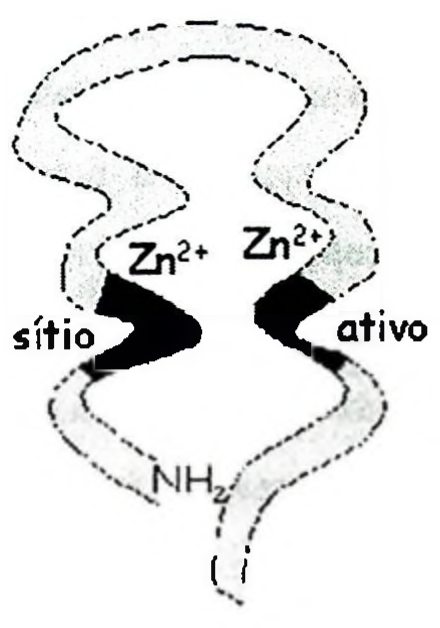

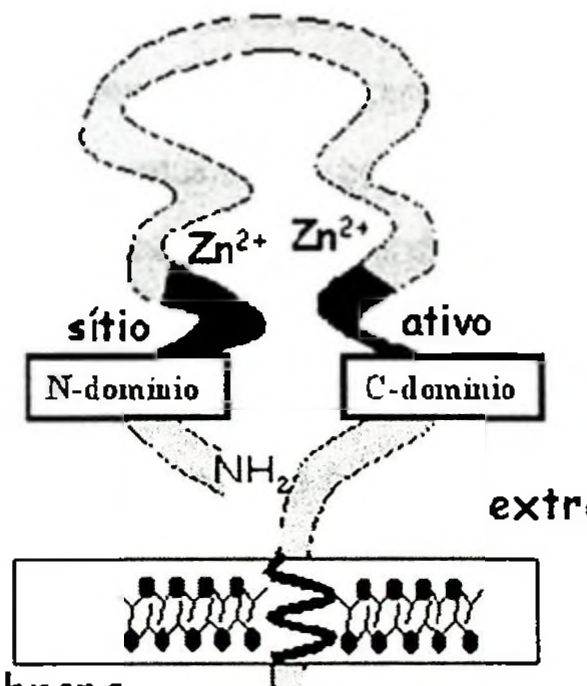

membrana
B

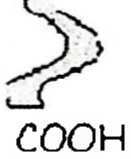

C

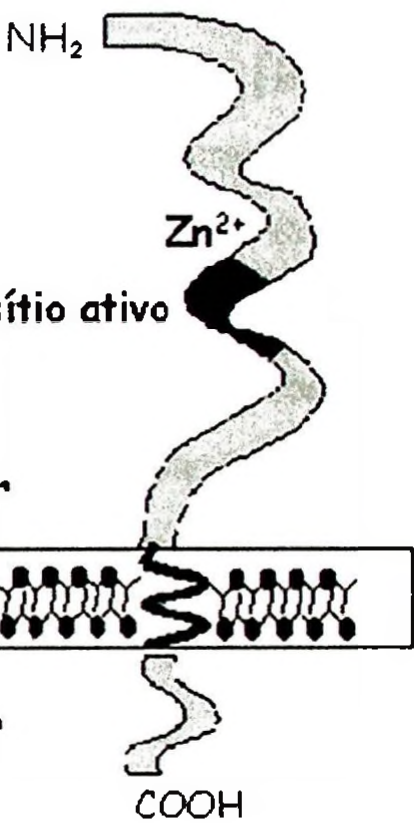

Figura 2. Representação da estrutura e conformação da ECA derivada do plasma (A), células somáticas (B) e testicular (C), mostrando os sítios catalíticos, os sítios de ligação de zinco, as extremidades amino (-NH2) e carboxi-terminais $(-\mathrm{COOH})$.

Nos mamíferos a ECA é encontrada na forma de duas isoenzimas distintas. A isoenzima endotelial (aproximadamente 180.000 daltons), que está presente em todo o organismo e é composto de dois domínios altamente similares, cada um mantendo um sítio catalítico funcional [131]. A outra isoenzima (aproximadamente 110.000 daltons) é encontrada exclusivamente no testículo e com exceção de mais ou menos 67 aminoácidos no N-terminal, é idêntica ao domínio C-terminal endotelial [132]. Através de experimentos utilizando técnicas de Southern blotting e clonagem gênica foi demonstrado que o mRNA para a ECA somática e germinativa são transcritos de um único gene [133]. 
Uma característica que parece comum para a ECA purificada dos diferentes tecidos é a presença de um átomo de zinco por mol de enzima [134]. A dependência funcional de ânions monovalentes, especialmente de íons cloro, também é uma característica para os diferentes tecidos, embora a magnitude do efeito ativador do cloro dependa do $\mathrm{pH}$ e do substrato utilizado para o ensaio [135].

Existem grandes evidências de que a ECA circulante seja derivada da forma ancorada à membrana pela perda da extremidade hidrofóbica C-terminal [136]. O processo de clivagem e secreção envolve a presença de uma metaloprotease denominada $A C E$-secretase $[137,138]$. Embora a ECA seja encontrada no plasma, a concentração da enzima neste compartimento corresponde a uma pequena fração da encontrada nos diferentes tecidos.

Embora as funções do SRA circulante e em alguns sistemas como o renal e o cardíaco estejam bem estabelecidas na literatura, somente recentemente o SRA local na medula óssea tem despertado interesse. O SRA via Ang II, exerce função no crescimento e proliferação celular em diversos tecidos agindo como um fator de crescimento ou citocina local e várias revisões têm sugerido que o SRA local também exerceria funções proliferativas em células presentes na medula óssea Haznedaroglu $[53,139]$.

Vários estudos vêm corroborando a hipótese de um SRA local ativo na medula óssea. Mrug et al. (1997) [55] demonstraram a presença de mRNA de receptores AT1 em HSC isoladas da circulação de humanos e que a ação da Ang II via AT1 nestas células estimulou a diferenciação e a formação de colônias. Mais tarde, Rodgers et al. (2000) [56] estenderam os achados do estudo anterior para HSC medulares in vitro. Em ambos os estudos, o bloqueio dos receptores AT1 inibiu a proliferação das HSC, sugerindo que esta regulação seria por meio da ação da Ang II via AT1.

Além dos efeitos que o SRA exerce sobre células tronco medulares via Ang II, foi descrito um tetra peptídeo, $\mathrm{N}$-acetyl-seryl-aspartyl-lysyl-proline (Ac-SDKP), que é inativado pelo domínio catalítico N-terminal da ECA e que tem efeito inibidor sobre a proliferação de HSC [57, 140]. Este tetra peptídeo previne o recrutamento de HSC para fase-S do ciclo celular, mantendoas na fase-G0 [58]. A ação deste tetra-peptídeo parece ser via um receptor de membrana e reduz a proliferação celular via regulação de moduladores do ciclo celular como p53, p2 $7^{\text {kipl }}$ e p2 $1^{\text {cipl }}$ 
[59]. Portanto, parece que o SRA por meio da produção de Ang II e da inativação do tetra peptídeo Ac-SDKP tem papel fundamental na proliferação e recrutamento HSC.

Estudos realizados no nosso laboratório sugerem que algumas das adaptações sobre a funcionalidade das HSC induzidas pelo treinamento físico envolveriam o SRA. Interessantemente, recentemente foi detectada a expressão de mRNA de componentes do SRA, como o Agt, a renina, a ECA, e dos receptores AT1 e AT2 em células na medula óssea de ratos [141], além da produção de Ang II por essas células, o que sugere um SRA local ativo na medula óssea também nesses animais.

Embora existam evidências que o treinamento físico regular induza maior liberação de HSC para a circulação e estas células apresentem maior funcionalidade, em revisão recente foi sugerido que, embora diversos mecanismos tenham sido propostos para explicar o aumento de células tronco com o treinamento físico, nenhuma explicação mecanicista foi encontrada que seja responsável por tal efeito Witkowski [142]. Além disso, embora seja sabido que exista o SRA local na medula óssea e que este está provavelmente relacionado com a proliferação e diferenciação de HSC [53], não se sabe os efeitos do treinamento físico sobre o SRA local na medula óssea e de que forma este sistema estaria envolvido na proliferação de células tronco medulares. Dado a vasta literatura existente acerca dos efeitos do SRA sobre proliferação e atividade de células tronco, é, portanto, possível que o aumento desses parâmetros com o treinamento físico seja, pelo menos parcialmente, ligado ao SRA local na medula óssea.

Tendo em vista o exposto acima, consideramos que seria importante estudarmos os mecanismos pelos quais o SRA modula a proliferação, recrutamento e funcionalidade das células tronco hematopoiéticas como resposta ao treinamento físico regular.

Assim, nosso objetivo foi verificar os efeitos do treinamento físico aeróbico sobre o número a funcionalidade de HSC e a possível participação do SRA nesta adaptação, principalmente através da hidrólise do tetra peptídeo Ac-SDKP pelo $\mathrm{N}$-dom da ECA e relacionarmos com a melhora no desempenho fisico.

\subsection{Material e Métodos}

\subsubsection{Animais de experimentação}


Foram utilizadas ratas Wistar com 60 dias de vida, pesando entre 180 e 200 g no início do protocolo. Os animais foram mantidos em gaiolas com 3 a 4 ratas, com ciclo claro-escuro de $12 \mathrm{~h}$ invertido, alimentadas com ração e água à vontade. Os animais foram aleatoriamente divididos em 3 grupos experimentais conforme descrito abaixo:

\section{Grupo Experimental 1:}

- Sedentário (SC, $\mathrm{n}=7$ )

- Treinado Protocolo $1(\mathrm{P} 1, \mathrm{n}=7)$

- Treinado Protocolo 2 (P2, n=7)

\subsubsection{Protocolo de treinamento físico aeróbio}

Os animais foram treinados pelo mesmo protocolo descrito no Estudo 1.

- Protocolo 1 (P1): os animais foram treinados durante 10 semanas, sessões de $60 \mathrm{~min}, 1$ vez ao dia, 5 vezes/semana, com aumento gradual da sobrecarga de trabalho (peso na cauda em porcentagem do peso corporal). Foi realizada uma adaptação crescente até atingir $5 \%$ do peso corporal [67].

- Protocolo 2 (P2): Neste protocolo de treinamento os animais treinaram até a $8^{\text {a }}$ semana com o mesmo protocolo acima (P1). Já na $9^{\mathrm{a}}$ semana os animais treinaram 2 vezes ao dia, sessões de 60 min com intervalo de 4 horas entre as sessões. Na $10^{a}$ semana treinaram 3 vezes ao dia, sessões de $60 \mathrm{~min}$ com intervalo de 4 horas entre as sessões. Este protocolo de treinamento tem sido demonstrado como moderado, numa faixa de intensidade entre $50 \%$ e $65 \%$ do $\mathrm{VO}_{2}$ máx. Este protocolo foi utilizado com o intuito de mimetizar um treinamento de alto nível.

O protocolo utilizado foi caracterizado como treinamento de baixa a moderada intensidade e longa duração, sendo efetivo na promoção de adaptações cardiovasculares e no aumento da capacidade oxidativa muscular, determinado pela medida da atividade da citrato sintase (uma enzima regulatória do Ciclo de Krebs). Os animais foram identificados e pesados semanalmente, para a correção da sobrecarga de treinamento em função do aumento do peso corporal.

Após o período de treinamento os animais foram decapitados, o sangue heparinizado foi coletado para as dosagens bioquímicas, as amostras mantidas no gelo e rapidamente centrifugadas $(3000 \mathrm{rpm} \times 10 \mathrm{~min})$ e armazenadas $\mathrm{a}-80^{\circ} \mathrm{C}$. 


\subsubsection{Confirmação da participação do SRA: inibição da ECA}

O tetra-peptídeo hemorregulador negativo Ac-SDKP é clivado preferencialmente pelo sítio catalítico N-terminal da ECA, com afinidade cerca de 50 vezes maior do que o sítio catalítico C-terminal. Assim, foram medidas as atividades dos dois sítios catalíticas da ECA (N e $\mathrm{C}$ terminal), com o uso de substratos específicos para os mesmo. A atividade do N-dom aumentada poderia estar relacionada com maior proliferação das HSC e aumento da eritropoiese. Para investigar essa hipótese, animais foram tratados com captopril, inibidor da ECA, e subdivididos em 4 grupos, conforme descrito abaixo:

\section{Grupo Experimental 2:}

- Sedentário controle (sedentário, $\mathrm{n}=7$ )

- Sedentário tratado com inibidor da ECA (Captopril): (sedentário captopril, $\mathrm{n}=7$ )

- Treinado Protocolo 2 (P2): (treinado, n=7)

- Treinado Protocolo 2 (P2) tratado com Captopril (treinado captopril, $n=7$ ).

Este inibidor foi escolhido porque apresenta maior seletividade para inibição do sítio catalítico $\mathrm{N}$-terminal, com cerca de 16 vezes maior afinidade por esse sítio catalítico, do que pelo C-terminal. Assim como foi medida a atividade total da ECA somática com Hip-His-Leu, um subtrato que é hidrolisado igualmente pelos dois domínios da enzima.

A inibição da ECA foi realizada pelo tratamento de $10 \mathrm{mg} \cdot \mathrm{Kg}^{-1} \cdot \mathrm{d}^{-1}$ de captopril na água que os animais consomem. Esta dose não é hipotensiva em animais normotensos e não altera a concentração plasmática de Ang II [143].

\subsubsection{Determinação da atividade dos terminais N e C-dom e total da ECA}

Foi determinada a atividade dos terminais N-dom e C-dom da ECA na circulação. Ainda, foi medida a atividade total da enzima. A separação do plasma sanguíneo foi feita por centrifugação.

Para a determinação da atividade do terminal $\mathrm{C}$ e $\mathrm{N}$ foram utilizados $2 \mu \mathrm{L}$ da amostra os quais foram incubados com o substrato de Abz-LFK (Dnp)P-OH e Abz-SDK (Dnp)P-OH respectivamente [144], $15 \mu \mathrm{M}(\mathrm{Abz}=$ ortho - aminobenzol; Dnp = dinitrophenil $)$ em tampão Tri- 
$\mathrm{HCl} 0,1 \mathrm{M}$ contendo $\mathrm{NaCl} 50 \mathrm{mM}$ e $\mathrm{ZnCl}_{2} 10 \mu \mathrm{M}$, pH 7,0, num volume final de reação de 200 $\mu \mathrm{L}$. A atividade enzimática foi determinada de forma contínua em fluorímetro $\left(\lambda_{\mathrm{cm}}=420 \mathrm{~nm}\right.$ e $\lambda_{\mathrm{ex}}=320 \mathrm{~nm}$ ). Como controle negativo, a hidrólise dos domínios foi inibida no soro com $0,5 \mu \mathrm{M}$ de captopril.

Para a atividade total da ECA foram utilizados $2 \mu \mathrm{L}$ de soro os quais foram incubados com o substrato Hip-His-Leu conforme metodologia descrita por [145].

\subsubsection{Determinação da atividade da Citrato Sintase.}

Metodologia conforme descrita anteriormente.

\subsubsection{Contagem de reticulócitos e índices hematimétricos}

Os reticulócitos refletem a reatividade da medula óssea, e são considerados a penúltima fase de maturação eritrocitária. Aparecem transitoriamente, em pequeno número, no sangue periférico, constituindo entre $0,5-1,0 \%$ do total de hemácias maduras, sendo potanto um bom indicador da atividade da medula óssea.

Foram determinados os índices hematimétricos no sangue perifério e a concentração de hemoglobina em aparelho de contagem celular eletrônico específico para sangue de pequenos animais, e a contagem de reticulócitos no Laboratório Clínico do Hospital Veterinário da USP. O sangue foi colhido com anticoagulante, citrato de sódio $0,5 \%$. Após a colheita do sangue, 2 a 3 gotas do mesmo foi misturada com a mesma proporção de solução de azul brilhante de cresil $1 \%$. A mistura foi aquecida por $20 \mathrm{~min}$ em banho maria à $37^{\circ} \mathrm{C}$. Após misturar e fazer esfregaço de maneira usual em lâminas de vidro as lâminas foram observadas em microscópio sob imersão. Foram contadas 1000 hemácias em cada campo e contados os reticulócitos presentes.

O número de reticulócitos por 1000 hemácias é igual ao \% de reticulócitos. Os resultados também podem ser expressos por $\mathrm{mm}^{3}$ de sangue (\% de reticulócitos $\mathrm{x}$ número total de eritrócitos $/ \mathrm{mm}^{3}=$ número de reticulócitos $/ \mathrm{mm} 3$ de sangue). Os valores normais são de 25.000 a $50.000 / \mathrm{mm}^{3}$ de sangue. Neste trabalho, uma vez que, o número total de hemácias não variou significantemente entre os grupos, os resultados foram expressos em $\%$ de reticulócitos. 


\subsubsection{Avaliação da meia-vida das hemácias}

Medimos a meia-vida das hemácias por marcação das hemácias utilizando Cromo radioativo $\left({ }^{51} \mathrm{Cr}\right)$. O procedimento é realizado através da administração endovenosa do radiofármaco, e são realizadas coletas do sangue no dia da administração e em dias subseqüentes até o prazo máximo de 14 dias. O sangue foi processado de maneira a permitir determinar a quantidade de material radioativo nas hemácias. Vale ressaltar que este procedimento é realizado em exames clínicos rotineiramente nos Hemocentros e os riscos associados a ele são mínimos.

Estes resultados foram realizados em colaboração com o Laboratório de Hematologia do Hemocentro do Hospital das Clínicas da USP.

\subsubsection{Ensaio clonogênico}

Para verificar os efeitos do treinamento físico sobre a funcionalidade das HSC circulantes e medulares, foram realizados ensaios clonogênicos. Para estas análises foram coletados $5 \mathrm{~mL}$ de sangue em tubos heparinizados ou medula óssea os quais foram centrifugados com Ficoll (Histopaque 1077, Sigma) e as células mononucleares (MNC) foram isoladas por gradiente de densidade.

O ensaio clonogênico de eritrócitos (BFU-E), granulócitos e monócitos (CFU-GM) e granulócitos, eritrócitos, monócitos e megacariócitos (CFU-GEMM) foram realizados de acordo com Morici et al. (2005). As MNC foram cultivadas em placas de cultura e para o ensaio BFU-E foram adicionados $3 \mathrm{U}$ de Epo humano recombinado e $50 \mathrm{ng} \cdot \mathrm{mL}^{-1}$ de fator de célula tronco humano recombinado. Para o ensaio de CFU-GM foram adicionados $10 \mathrm{ng} \cdot \mathrm{mL}^{-1}$ de fator estimulante de colônia de granulócitos-macrófagos humano recombinado e $10 \mathrm{ng} \cdot \mathrm{mL}^{-1}$ de fator estimulante de colônia de granulócitos e para o ensaio de CFU-GEMM foram adicionados todos os fatores de crescimento utilizados para BFU-E e CFU-GM [118].

\subsubsection{Protocolo de avaliação de esforço máximo}

Para realização do protocolo de avaliação do esforço físico máximo, os animais foram posicionados individualmente sobre a esteira rolante. Imediatamente após o posicionamento do animal foi iniciado o teste de esforço. A velocidade inicial foi de $6 \mathrm{~m} / \mathrm{min}$ (sem inclinação), que constitui em um protocolo escalonado com incrementos de velocidade de $3 \mathrm{~m} / \mathrm{min}$ a cada $3 \mathrm{~min}$, 
até que fosse atingida a velocidade máxima suportada pelos animais. O critério para a determinação da exaustão do animal e interrupção do teste foi o momento em que o rato não foi mais capaz de correr dentro da caixa metabólica mediante o incremento de velocidade da esteira.

Esta avaliação foi feita pré e pós o período de treinamento, para comparar a resposta de desempenho do animal entre os grupos. Embora o teste em esteira não seja específico ao treinamento físico realizado no presente estudo, utilizamos esse teste para auxiliar na verificação da eficácia do treinamento físico como predição de uma melhora na capacidade de realização de esforço. Foram comparados o tempo $(\mathrm{min})$ e a distância $(\mathrm{m})$ percorrida.

\subsubsection{Avaliação do consumo de oxigênio}

Todos os animais foram submetidos à avaliação da capacidade física máxima, por meio de respirometria aberta, antes e após o período de treinamento. A determinação metabólica de consumo de oxigênio foi de acordo com o método descrito por Brooks e White (1978) [146]. O $\mathrm{VO}_{2}$ foi continuamente avaliado por meio de uma caixa metabólica conectada a um sensor de oxigênio (Ametek N-22M-S-3 $3^{\mathrm{A}} / \mathrm{I}$ ) que analisa, continuamente, as amostras das frações expiradas de oxigênio $\left(\mathrm{FeO}_{2}\right)$, bem como os valores das concentrações ambientais de oxigênio $\left(\mathrm{FiO}_{2}\right)$. Posteriormente, os valores de $\mathrm{VO}_{2}$ de cada animal foram calculados pela seguinte fórmula matemática:

$\mathrm{VO}_{2}\left(\mathbf{m l O}_{2} \cdot \mathbf{k g}^{-1} \cdot \mathbf{m i n}^{-1}\right)=\operatorname{VEc}\left(\mathrm{FiO}_{2}-\mathrm{FeO}_{2}\right) / \mathrm{PC}$, onde:

VEc $=$ Ventilação constante $(\mathrm{mL} / \mathrm{min})=$ Fluxo da bomba de sucção

$\mathrm{FiO}_{2}=$ Fração inspirada de $\mathrm{O}_{2}$

$\mathrm{FeO}_{2}=$ Fração expirada de $\mathrm{O}_{2}$

$\mathrm{PC}=$ Peso corporal do animal $(\mathrm{kg})$

\subsubsection{Medida direta da pressão arterial e da freqüência cardíaca}

Metodologia conforme descrita anteriormente 


\subsubsection{Morfologia cardíaca}

Ao final do protocolo experimental os animais foram decapitados, o coração foi removido da cavidade torácica e dissecado para separarmos o VE (parede livre do VE e septo).

A hipertrofia cardíaca foi avaliada pesando-se o VE (peso úmido). Os resultados foram expressos pela relação entre o peso do ventrículo esquerdo pelo peso corporal do rato (mg/g). Além disso, a hipertrofia cardíaca foi avaliada pelo peso do VE sobre o comprimento da tíbia do animal $(\mathrm{mg} / \mathrm{mm})$.

\subsubsection{Análise estatística}

Foi feita uma análise descritiva dos dados coletados, os quais estão expressos como média \pm desvio padrão. Os resultados foram comparados por meio de análise de variância (ANOVA) de 1 ou 2 vias, com medidas repetidas quando couber. O nivel de significância adotado foi de 5\%.

\subsection{Resultados e Discussão}

\subsubsection{Peso corporal}

O peso corporal (PC) inicial e final dos animais está demonstrado na Figura 3. Os grupos não eram diferentes antes e nem após o protocolo experimental. A figura também mostra que todos os grupos tiveram aumento de PC significativo no final do protocolo em relação ao início do protocolo.

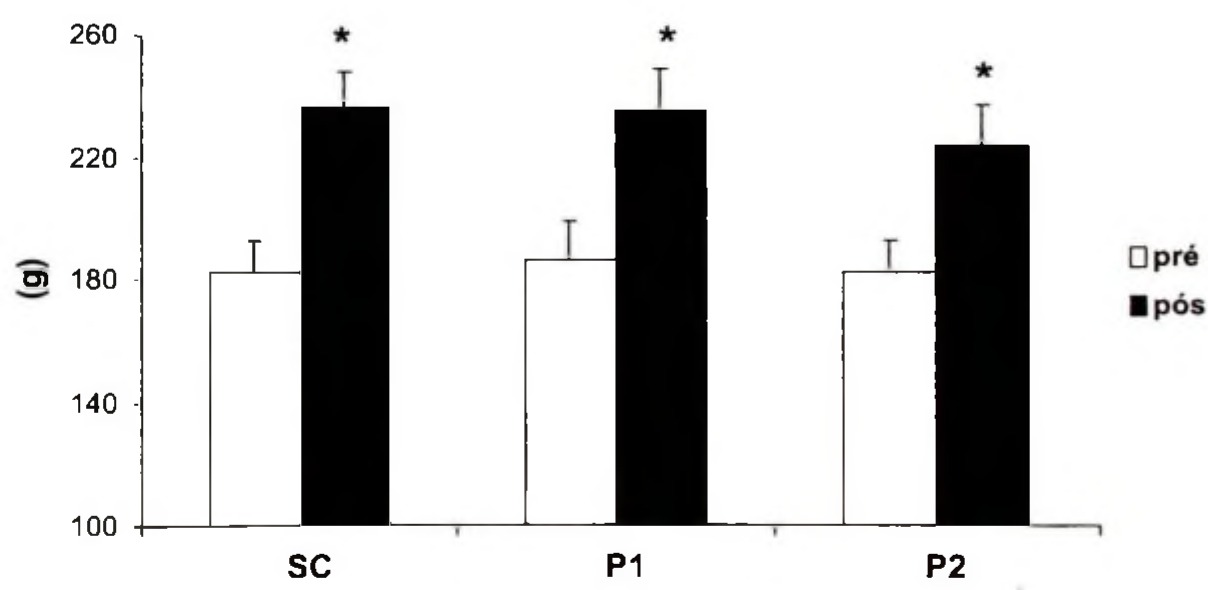

Figura 3. Peso corporal (PC) inicial e final. Média \pm desvio padrão. Análise de variância de duas vias, com post-hoc de Tukey, $\mathrm{p}<0,001^{*}$ vs. SC pré, P1 pré e P2 pré. Barras brancas referentes ao periodo pré e preto pós protocolo experimental. 
A evolução do PC ao longo das semanas do protocolo está representada na Figura 4. Todos os grupos tiveram aumento da massa corporal de forma semelhante, durante todo o protocolo experimental, não houve diferença entre os grupos nas semanas. O PC passa a ser diferente do inicial após a quinta semana do protocolo experimental, para todos os grupos.

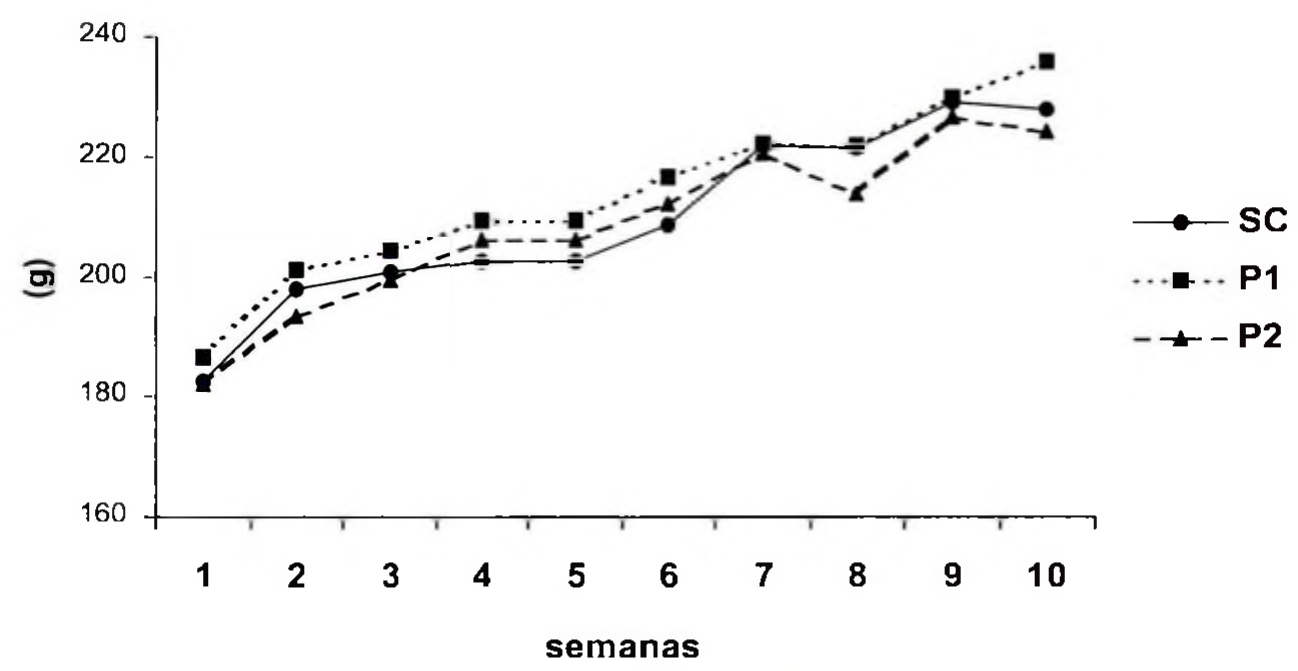

Figura 4. Evolução do peso corporal durante o protocolo experimental. Média. Análise de variância de duas vias para medidas repetidas. Linha cheia com círculo fechado representa SC, linha pontilhada com quadrado cheio representa treinado P1 e linha tracejada com triângulo cheio representa $\mathrm{P} 2$.

\subsubsection{Esforço máximo}

A avaliação do esforço máximo está demonstrada na Figura 5, dada pelo tempo de duração total do teste de esforço no início e no final do protocolo experimental. No início os grupos apresentavam o mesmo desempenho físico e houve uma melhora significativa de desempenho dos animais que treinaram, P1 e P2, em relação a eles mesmos antes do treinamento e aos controles tanto no início quanto ao final do protocolo. O grupo controle obteve o mesmo resultado do teste inicial e os grupos treinados tiveram um aumento médio de $20,7 \%$ e $29,4 \%$, P1 e $\mathrm{P} 2$ respectivamente. 


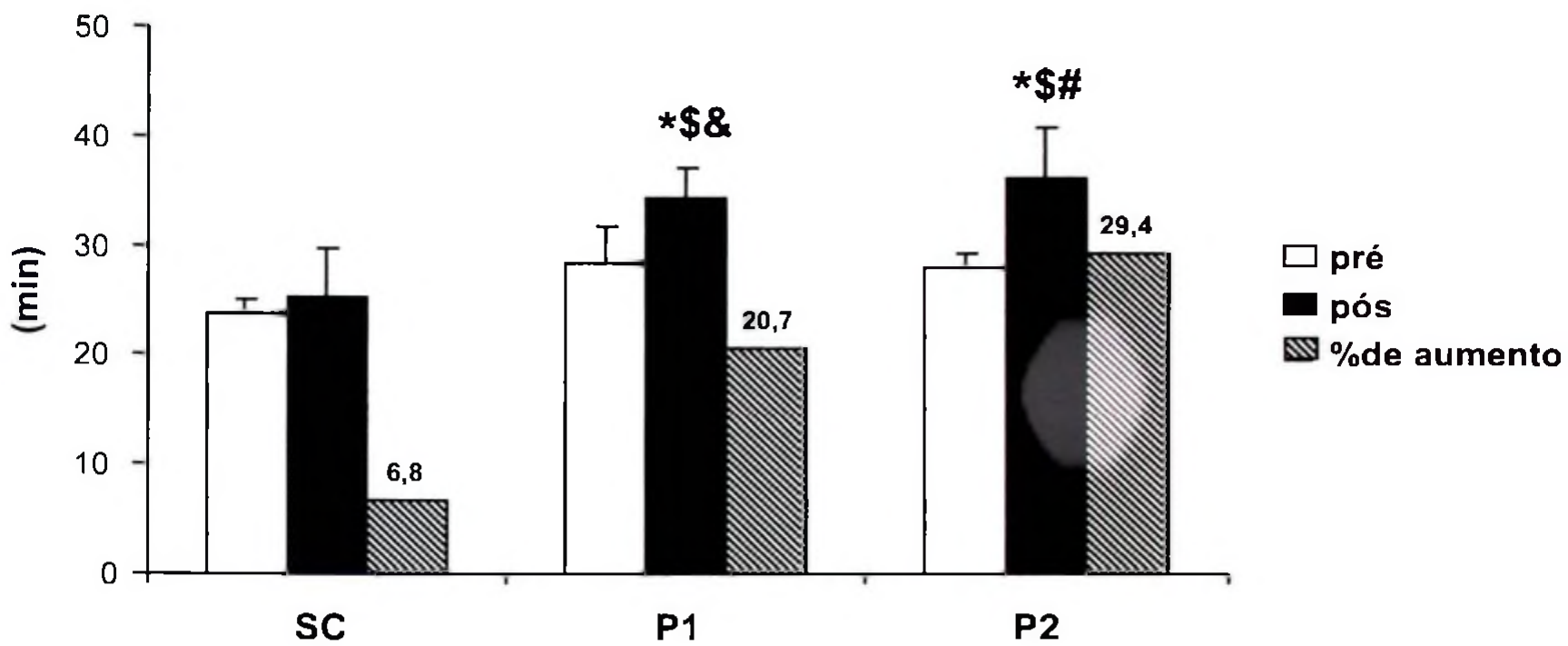

Figura 5. Tempo total de teste máximo. Média \pm desvio padrão. Análise de variância de duas vias para dados pareados, com post-hoc de Tukey, $p<0,001^{*}$ vs. SC pré; $p<0,005^{\mathrm{s}}$ vs. SC pós; $\mathrm{p}<0,005^{\#}$ vs. P1 pré e P2 pré; $\&$ p $<0,05$ vs. P1 pré e P2 pré. Barras brancas referentes ao início e pretos ao final do protocolo experimental, barras achuradas referentes ao percentual de aumento da média do tempo total do teste máximo final em relação á média do teste inicial.

\subsubsection{Consumo máximo de oxigênio}

A Figura 6 mostra a diferença do $\mathrm{VO}_{2 \text { máx }}$. entre os grupos treinados e seu grupo controle após período experimental, com valores maiores para os grupos treinados.

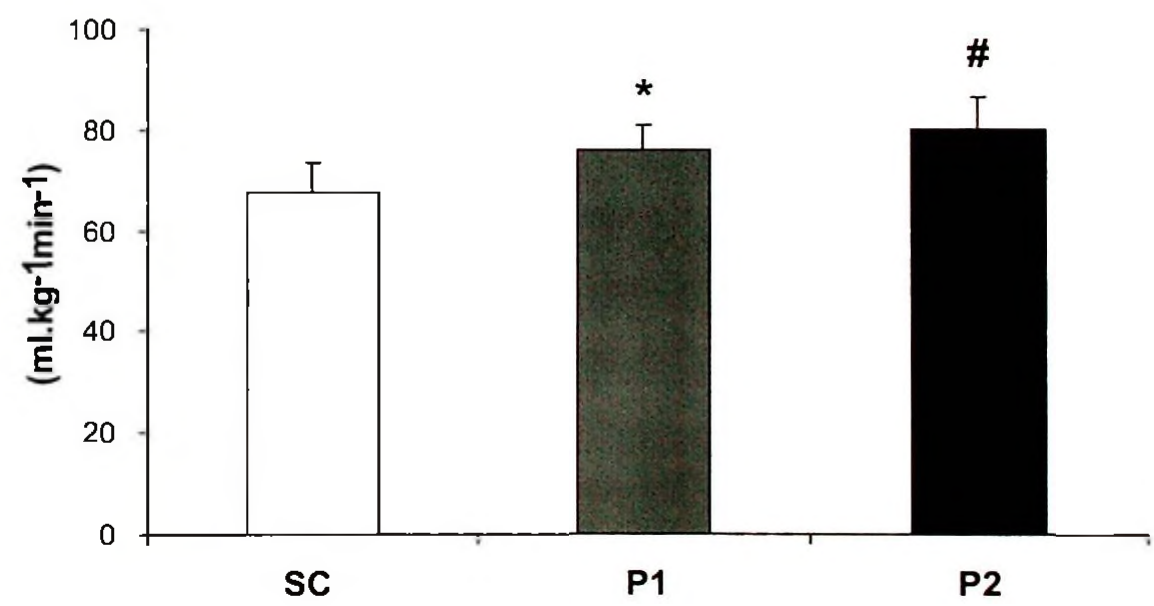

Figura 6. Consumo máximo de oxigênio após período experimental. Média \pm desvio padrão. Análise de variância de uma via, com post-hoc de Tukey, $\mathrm{p}<0,05 *$ vs. SC; $\mathrm{p}<0,01^{\#}$ vs. SC. 


\subsubsection{Pressão arterial}

A pressão arterial média não foi diferente entre os grupos treinados e controle sedentário ao final do protocolo, como pode ser visto na Figura 7.

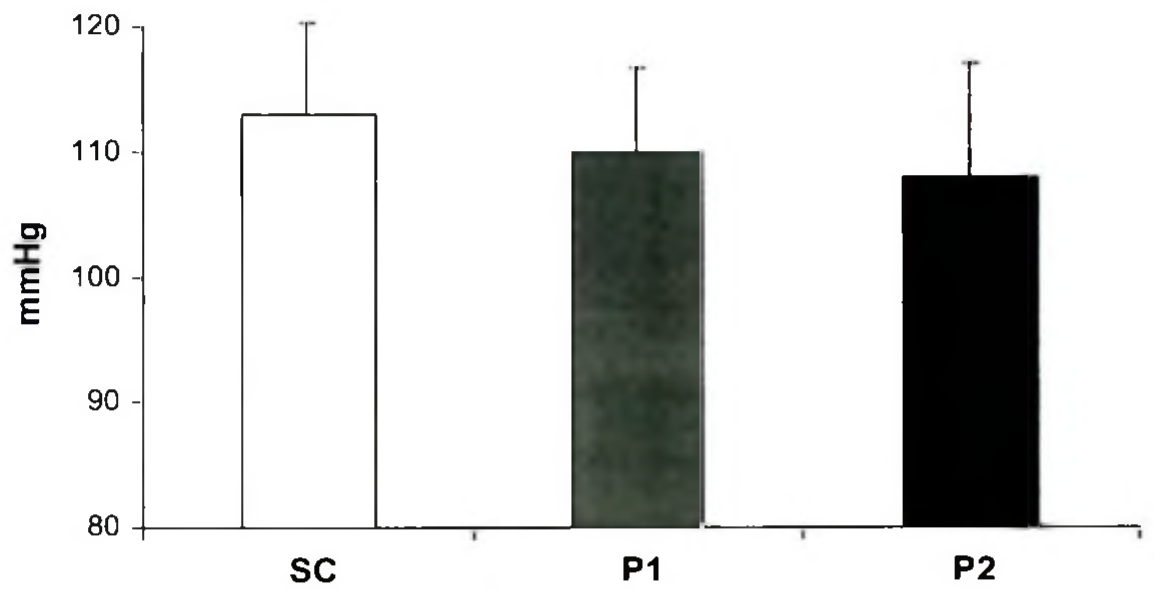

Figura 7. Pressão Arterial Média (PAM) em repouso ao final do protocolo experimental. Média \pm desvio padrão. Análise de variância de uma via, com post-hoc de Tukey.

\subsubsection{Freqüência cardíaca}

A freqüência cardíaca de repouso dos grupos treinados diminuiu em relação ao grupo controle, mas não foi diferente entre P1 e P2, após o período experimental, como demonstrado na Figura 8. Essa redução é denominada de bradicardia de repouso.

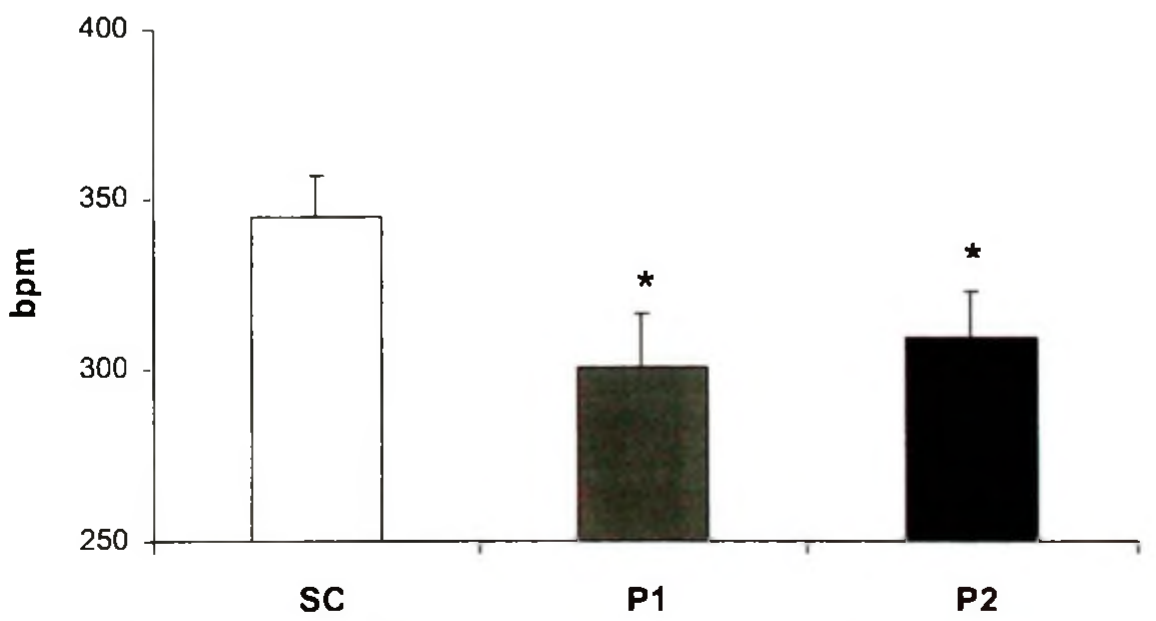

Figura 8. Freqüência cardíaca (FC) em repouso com os animais acordados ao final do protocolo experimental. Média \pm desvio padrão. Análise de variância de uma via, com post-hoc de Tukey, $\mathrm{p}<0,05 *$ vs. SC. 


\subsubsection{Morfologia cardiaca}

A Figura 9 mostra os valores obtidos pela medida direta do peso úmido do VE corrigidos pelo peso corporal (VE/PC). O treinamento induziu hipertrofia cardíaca nos dois grupos. P1 teve aumento de $13 \%$, já $\mathrm{P} 2$ obteve $28 \%$ em relação ao SC. A medida de peso úmido mostra que a hipertrofia de P2 é significativamente maior que a de P1. Além disso, a Figura 10 mostra uma correlação direta entre o melhor consumo de oxigênio e a uma maior magnitude da hipertrofia cardíaca.

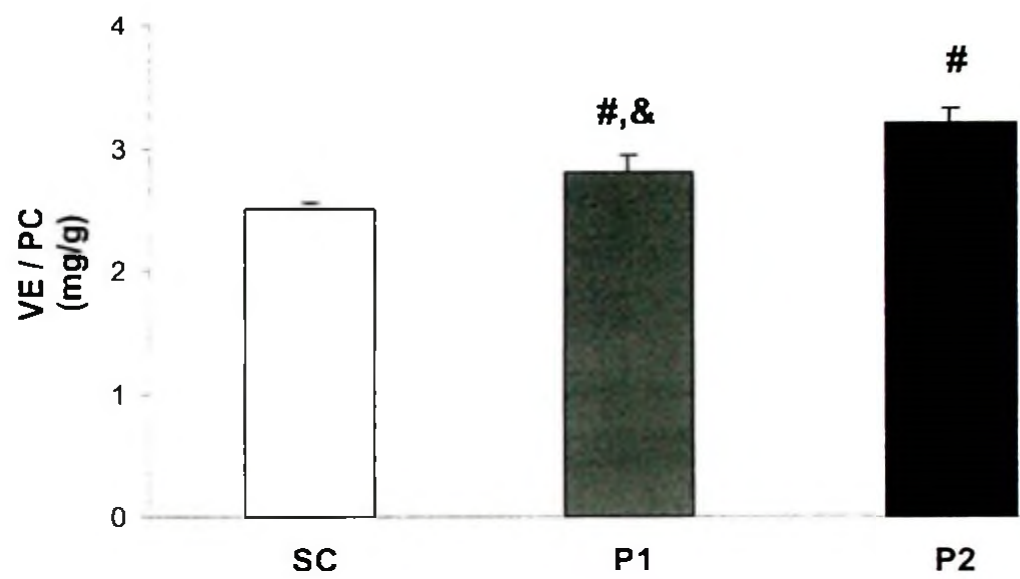

Figura 9. Massa ventricular esquerda, dados obtidos a partir do peso úmido do ventrículo esquerdo corrigidos pelo peso corporal. Média \pm desvio padrão. Análise de variância de uma via, com post-hoc de Tukey; $<<0,01^{\#}$ vs. SC; $\mathrm{p}<0,01$ \& vs. P2.

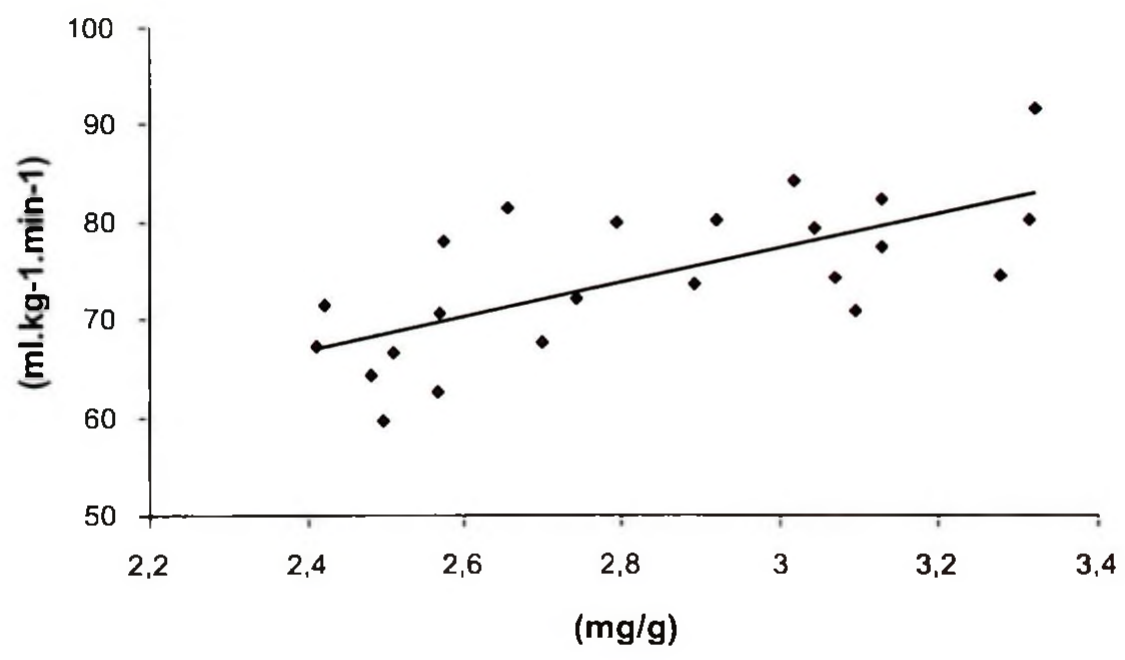

Figura 10. Consumo máximo de oxigênio pelo índice de massa do ventrículo esquerdo, dados obtidos a partir do peso úmido do ventrículo esquerdo pelo peso corporal. Média. $\mathrm{R}=0,69$. Correlação de Pearson, $\mathrm{p}<0,05$. 


\subsubsection{Atividade dos terminais $\mathrm{N}$ e C-dom e total da ECA}

A Figura 11 mostra que a atividade total da ECA circulante, do domínio catalítico Nterminal, que é responsável pela hidrólise de Ac-SDKP, e do domínio C-terminal estava aumentado nos animais treinados, sendo este aumento mais pronunciado com protocolo 2 (P2) quando comparados com o sedentário controle.

A

200

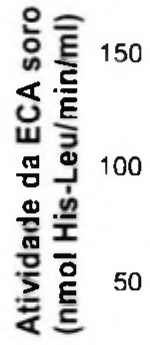

B

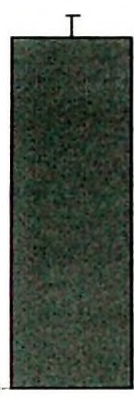

P1

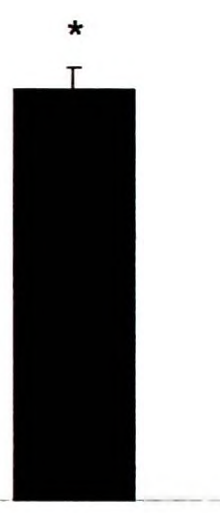

P2
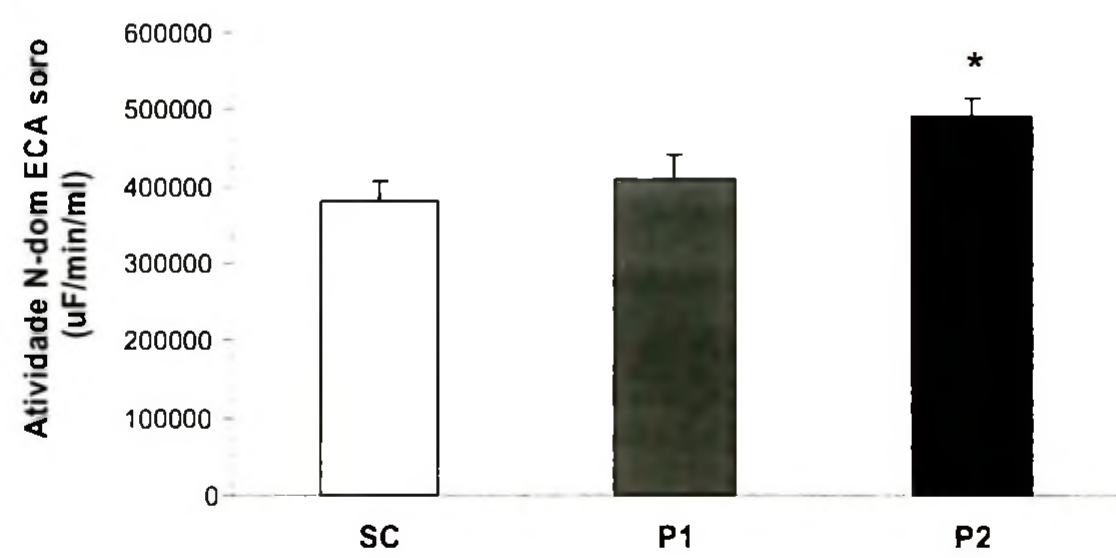

C

400000

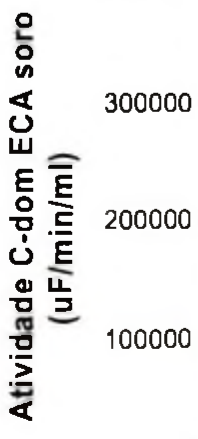

0
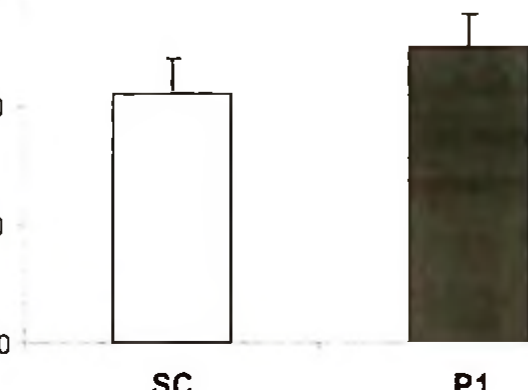

P1

P2 
Figura 11. Atividade da enzima conversora de angiotensina 1 (ECA) total (A), no domínio catalítico $\mathbf{N}$-terminal (B) e no domínio catalítico C-terminal (C) no soro. Média \pm desvio padrão. Análise de variância de uma via, com post-hoc de Tukey; $\mathrm{p}<0,05^{\circ}$ vs. SC.

\subsubsection{Medida de unidade formadora de colônia}

É possível, portanto, que a maior atividade do domínio N-terminal da ECA induzido pelo treinamento físico reduza a concentração de Ac-SDKP, o que levaria a uma maior proliferação das HSC na medula óssea. Para análise da maior proliferação das HSC quantificamos o número de Unidades Formadoras de Colônia (BFU-E, unidades formadoras de bursts de eritrócitos), em cultura celular das células mononucleadas isoladas da medula óssea. A Figura 12 mostra que a proliferação de HSC era aumentada após 10 semanas de treinamento de natação (grupo SC: 1,33 $\pm 1,15$ unidades, $\mathrm{P} 1: 2,0 \pm 1,2$ unidades e $\mathrm{P} 2: 4,67 \pm 2,89$ unidades, $\mathrm{p}<0,05)$. No grupo treinado com o protocolo 2 os resultados foram mais acentuados.

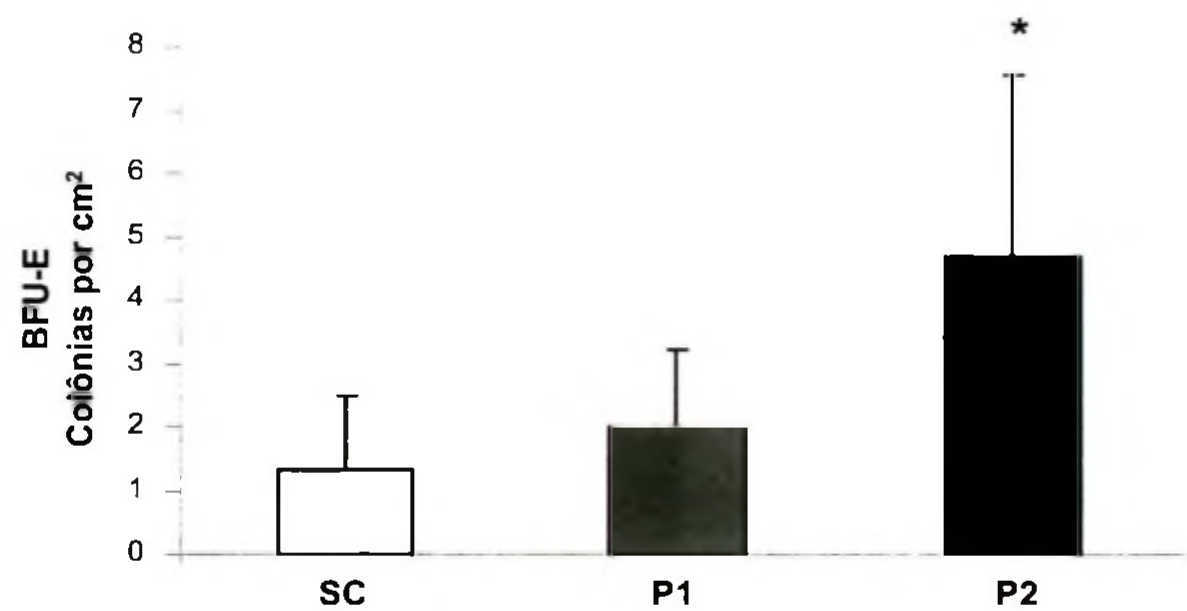

Figura 12. Unidades formadoras de colônia. Média \pm desvio padrão. Análise de variância de uma via, com post-hoc de Tukey, $\mathrm{p}<0,05 *$ vs. SC.

A maior proliferação das HSC na medula, associado ao fato de que o Ac-SDKP pode ser um dos fatores responsáveis por manter as células sanguineas na medula até sua completa maturação, pode promover uma maior liberação das células da medula para a circulação sanguinea. 


\subsubsection{Medida de reticulócitos}

Uma diminuição do Ac-SDKP na circulação poderia promover uma liberação de hemácias para a circulação ainda não completamente maduras. Para isso quantificamos o número de reticulócitos na circulação sanguínea, por meio de técnica histológica. A reticulocitose é um indicador da taxa de eritropoiese.

A Figura 13A mostra um aumento na taxa de reticulocitose no grupo P2 comparado ao grupo controle (SC: $0.82 \pm 0.45 \%, \mathrm{P} 1: 2.1 \pm 1.0 \%$, P2: $5.05 \pm 1.58 \%$ ). Ainda foi observada a presença de macrócitos policromatófilos na circulação sanguínea (Figura 13B), mais um indicador da presença de hemácias jovens na circulação. Hemácias policromatófilas são hemácias cujo citoplasma ainda contém restos de substâncias basófilas (RNA) e apresentam uma coloração variável entre rosa-acinzentado e o azul-acinzentado. No sangue periférico, estas existem numa proporção de $2 \%$ do total de hemácias. Correspondem as substâncias granulofilamentosas (reticulócitos), nas preparações supravitais (azul brilhante de cresil). O aumento dos policromatófilos ou a policromatofilia, coexistem com a reticulócitose nos casos de super atividade da medula óssea. Estes efeitos podem estar relacionados com o maior recrutamento de HSC em decorrência do treinamento. A medida de reticulócitos é a mais utilizada como índice de eritropoiese. 

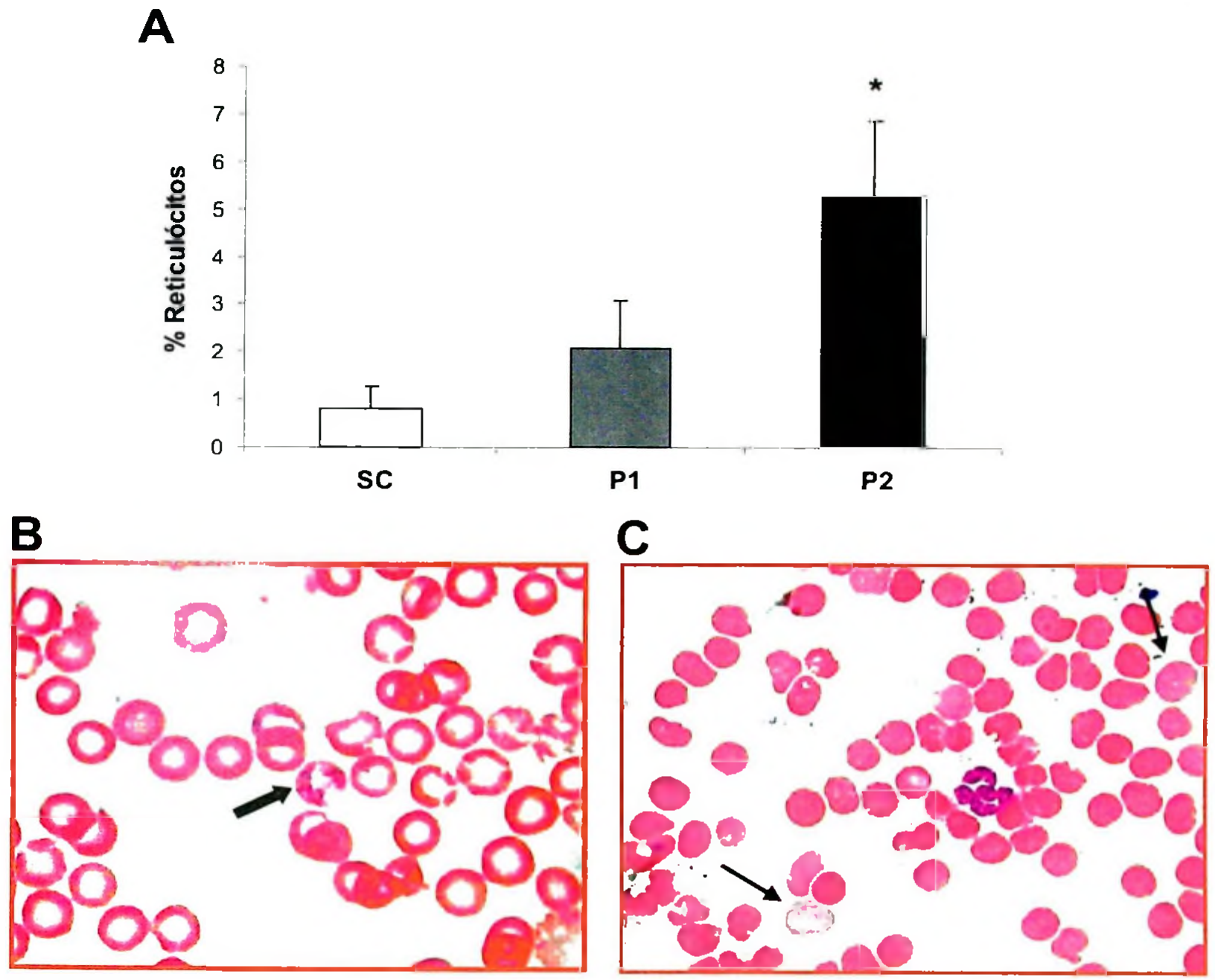

Figura 13. Percentual de reticulócitos $(\mathrm{A})$, imagem representativa de uma lâmina de sangue periférico corado com azul brilhante de cresil mostrando a presença de reticulócitos (B) imagem representativa de uma lâmina de sangue periférico corado com azul brilhante de cresil mostrando a presença de hemácias policromatófilas (C). Média \pm desvio padrão. Análise de variância de uma via, com post-hoc de Tukey, $\mathrm{p}<0,05 *$ vs. SC.

\subsubsection{Hematócrito e hemoglobina}

Conforme observado na figura anterior, sugerem que a eritropoiese esteja aumentada nos animais treinados. Baseados nestes resultados investigaram se o hematócrito (percentual de eritrócitos no sangue periférico) e a hemoglobina estariam aumentados como efeito do treinamento físico. 


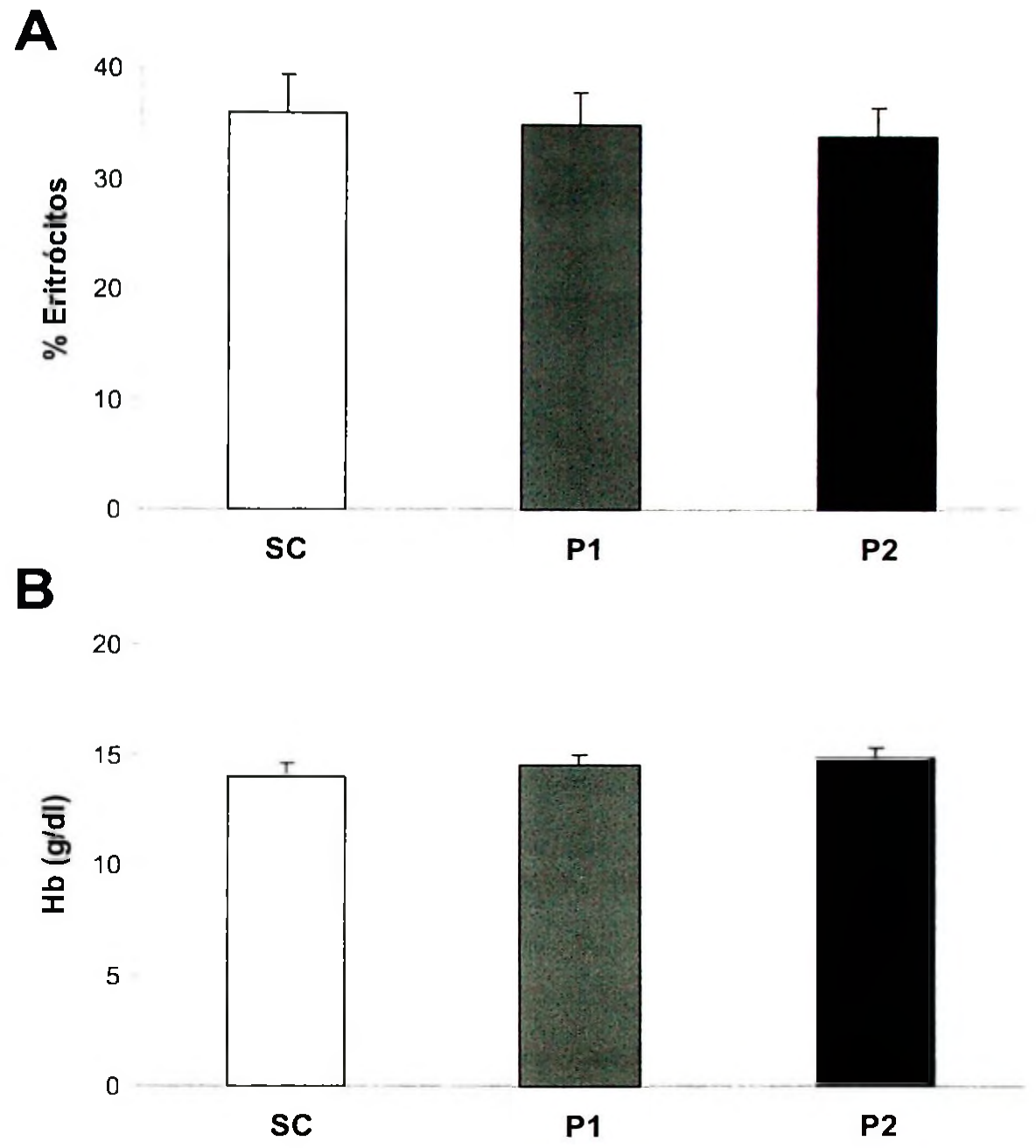

Figura 14. Medida do hematócrito (A) e hemoglobina (B). Média \pm desvio padrão. Análise de variância de uma via, com post-hoc de Tukey.

Ainda, realizamos o hemograma (Tabela 1) e os índices eritrocitários dos animais. Os resultados mostram que não houve alterações destes parâmetros com o treinamento físico. 


\begin{tabular}{llll} 
& \multicolumn{1}{c}{ SC } & \multicolumn{1}{c}{ P1 } & \multicolumn{1}{c}{ P2 } \\
\hline Hemácias & 6.000 .000 & 5.700 .00 & 5.800 .00 \\
Leucócitos & 6.560 & 6.270 & 5.960 \\
Neutrófilos Seg & 41 & 41 & 41 \\
Linfócitos & 53 & 51 & 54 \\
Monócitos & 5,5 & 5,5 & 6,0 \\
Eosinófilos & 0,4 & 2,5 & 1,0 \\
\hline
\end{tabular}

Tabela 1. Hemograma. Valor total de eritrócitos em $\mathrm{mm}^{3}$. Contagem total de leucócitos em $\mathrm{mm}^{3}$. Contagem diferencial dos leucócitos e expressa em percentual do total de leucócitos contados $(\%)$.

Os índices eritrocitários mostram que não houve alterações no VCM (volume corpuscular médio), ou seja, no volume médio do eritrócito (SC: $23 \mu 3$; P1: $25 \mu 3 ; \mathrm{P} 2: 26 \mu 3$ ), $\mathrm{HbCM}$ (Hb corpuscular média), ou seja, peso médio de Hb contida em cada eritrócito (SC: $23 \mu \mu \mathrm{g}$; P1: 25 $\mu \mu \mathrm{g}$; P2: $26 \mu \mu \mathrm{g}$ ), assim como na CHCM (concentração de Hb corpuscular média), ou seja na quantidade de $\mathrm{Hb}$ por volume globular, o que determinada a concentração de $\mathrm{Hb}$ no eritrócito independente de seu tamanho (SC: 37\%; P1: 39\%; P2: 40\%).

Entretanto, como pode ser observado, não houve aumento do hematócrito e da hemoglobina (Figura 14 A e B, respectivamente), desta forma é possivel que a meia-vida das hemácias esteja diminuída. Embora a redução na meia-vida das hemácias, em indivíduos treinados, já tenha sido descrito anteriormente na literatura [147], esse fenômeno não está bem estabelecido e pode ser um importante mecanismo adaptativo induzido pelo treinamento físico que envolveria o recrutamento de HSC.

\subsubsection{Meia-vida da hemácia}

Avaliamos a meia-vida das hemácias nos animais treinados e sedentários. Observa-se na Figura 15 que a meia-vida das hemácias de ratos submetidos ao treinamento de natação foi reduzida (SC: $9.2 \pm 1.7, \mathrm{P} 1: 12 \pm 0.5$ dias e P2: $6.5 \pm 0.7$ dias, $\mathrm{p}<0,05$ comparando $\mathrm{SC} v s$. $\mathrm{P} 2$ ). 

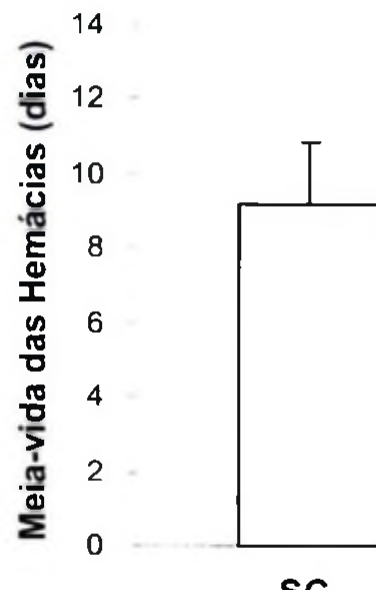

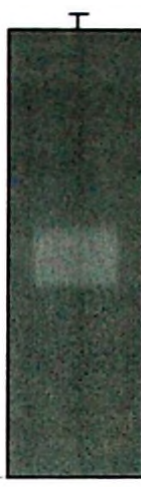

P1

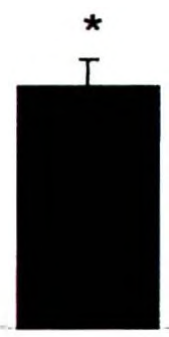

P2

Figura 15. Meia-vida das hemácias em ratas controle (SC), treinadas em natação por 10 semanas (P1) ou treinadas por 8 semanas +2 semanas com aumento na freqüência de treinamento (P2). ${ }^{*} \mathrm{p}<0,05$.

É interessante ressaltar que apenas nos animais que treinaram com maior volume de treinamento (P2) foram observadas as adaptações no sistema hematopoiético. Somente nesse grupo foi observado aumento da atividade do sítio catalítico N-terminal da ECA, aumento na proliferação de HSC, aumento da reticulocitose e redução da meia-vida das hemácias. Estes resultados indicam que um treinamento regular não induz adaptações no sistema eritropoiético, mas um treinamento de maior volume de treinamento diário, como o realizado no grupo P2, induz adaptações importantes na eritropoiese. Este treinamento pode ser comparado em grau de adaptação ao treinamento de alto nível em humanos, no qual os atletas realizam mais de uma sessão se treino por dia.

Como somente no grupo P2 observamos essas adaptações no sistema eritropoiético, na segunda parte deste estudo os experimentos foram realizados somente com o grupo P2, denominado agora de treinado.

O próximo passo foi avaliar por meio de qual mecanismo o treinamento físico aumenta a eritropoiese e reduz à meia-vida das hemácias. Como a atividade do sítio catalítico $\mathrm{N}$-terminal da ECA estava aumentado após o treinamento físico e este sítio é responsável pela clivagem do tetrapeptídeo Ac-SDKP, cuja ação sobre as HSC é de inibição da proliferação, investigamos a 
possibilidade de que o sítio catalítico $\mathrm{N}$-terminal da ECA estivesse envolvido nessas adaptações induzidas pelo treinamento fisico. Para avaliarmos essa possibilidade usamos um inibidor da atividade da ECA, o captopril. Este inibidor tem cerca de 16 vezes mais afinidade pelo $\mathrm{N}$ terminal da ECA e, na dose dada aos animais, não altera a concentração de Ang II e a pressão arterial nos animais, embora aumente a concentração de Ac-SDKP no plasma, indicando sua especificidade em inibir o sítio catalítico N-terminal da ECA [143].

Os resultados obtidos nesta segunda parte do estudo indicam que o peso corporal dos animais tratados com captopril, os treinados e os treinados e tratados com captopril não foi diferente antes e após o periodo experimental (Figura 16).

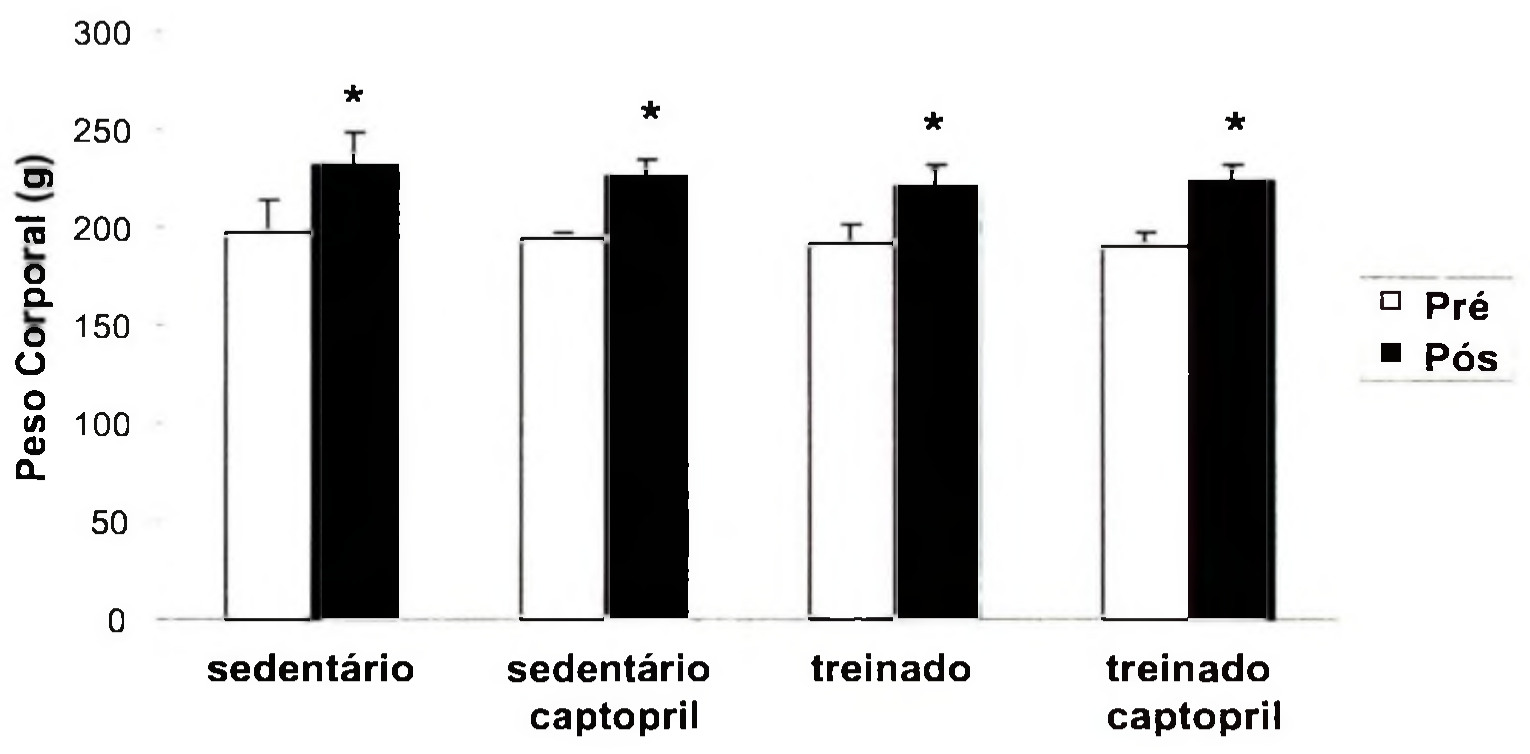

Figura 16. Peso corporal pré (barra branca) e pós (barra preta) o periodo de treinamento físico. Média \pm desvio padrão. ${ }^{*}$ p<0,05 em comparação ao mesmo grupo pré treinamento.

Para demonstrar a eficiência do protocolo de treinamento, realizamos diversas análises (morfométricas, bioquímicas, físiológicas e funcionais) nos animais. A Figura 17A mostra a freqüência cardíaca antes e após o período de treinamento nos quatro grupos analisados. Os resultados mostram que não houve diferença entre os valores de repouso entre os grupos antes do protocolo de treinamento. Entretanto, observa-se bradicardia de repouso, mesmo com o tratamento com captopril, após o protocolo experimental. Conforme mostramos anteriormente, a bradicardia de repouso é um marcador cardiovascular de treinamento físico aeróbio. Ainda, 
mostramos também aumento na atividade da citrato sintase (figura 17B) no músculo sóleo dos animais treinados, que é um marcador metabólico de treinamento aeróbio.

A atividade da enzima citrato sintase é um indicador de adaptação ao treinamento aeróbio. Os grupos treinados apresentaram maior atividade desta enzima no sóleo em comparação aos grupos controle mesmo com o tratamento com captopril. Estes resultados são importantes, porque o tratamento com a droga não interferiu no desempenho físico.
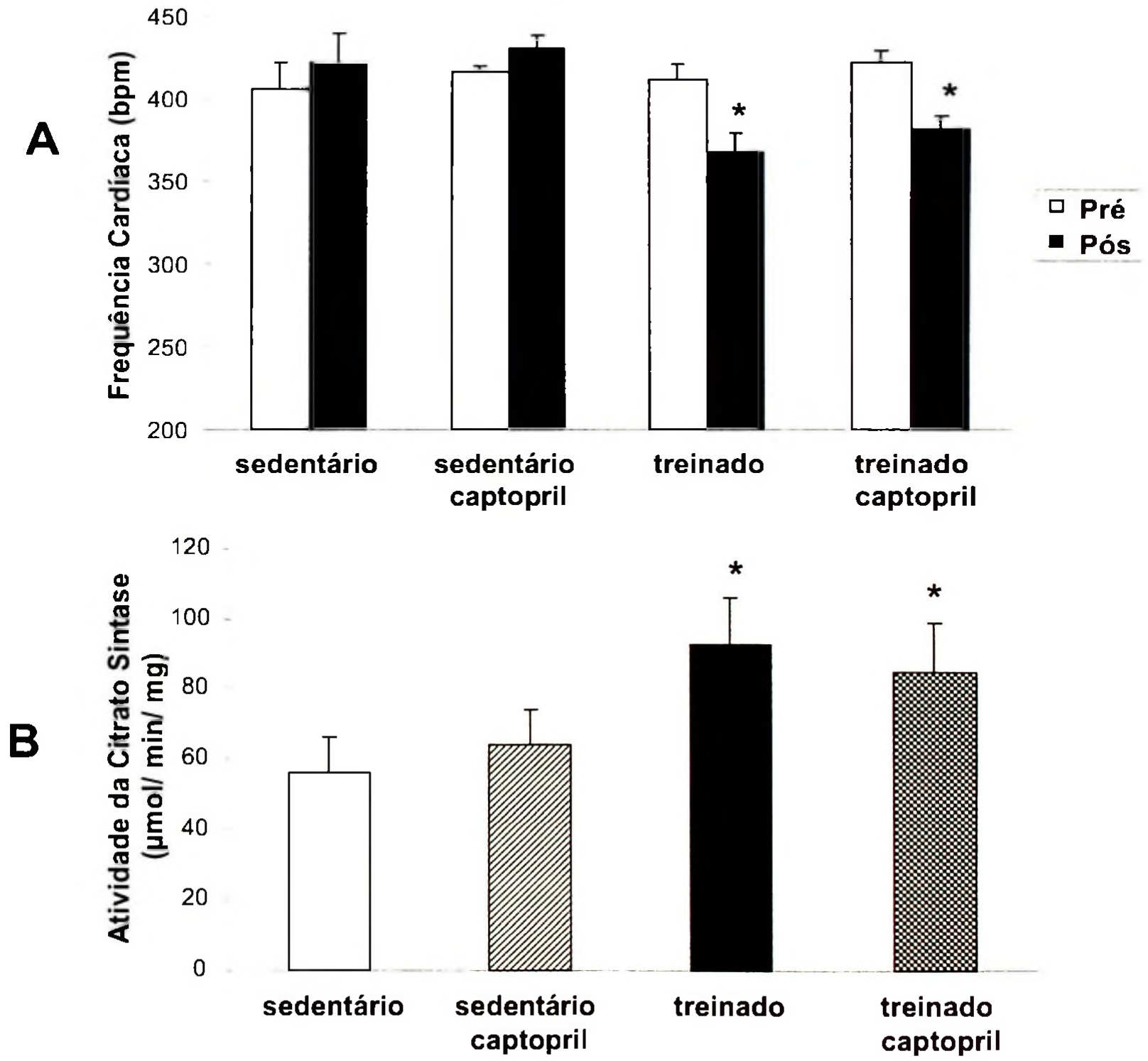

Figura 17. Marcadores de treinamento aeróbio. Freqüência cardíaca (A) e atividade da enzima citrato sintase (B). Média \pm desvio padrão. ${ }^{*} \mathrm{p}<0,05$ em comparação ao sedentário. 
A Figura 18 mostra a relação entre o peso do ventrículo esquerdo e o comprimento da tibia. Este índice é usado como um índice de hipertrofia cardíaca. Pode ser observado que ambos os grupos treinados apresentaram valores significativamente mais altos de hipertrofia cardíaca do que os sedentários.

Peso do VE em relação ao comprimento da tíbia mostra que o treinamento físico foi efetivo em promover hipertrofia cardíaca, a qual não foi prevenida pelo tratamento com o captopril, na dose utilizada.

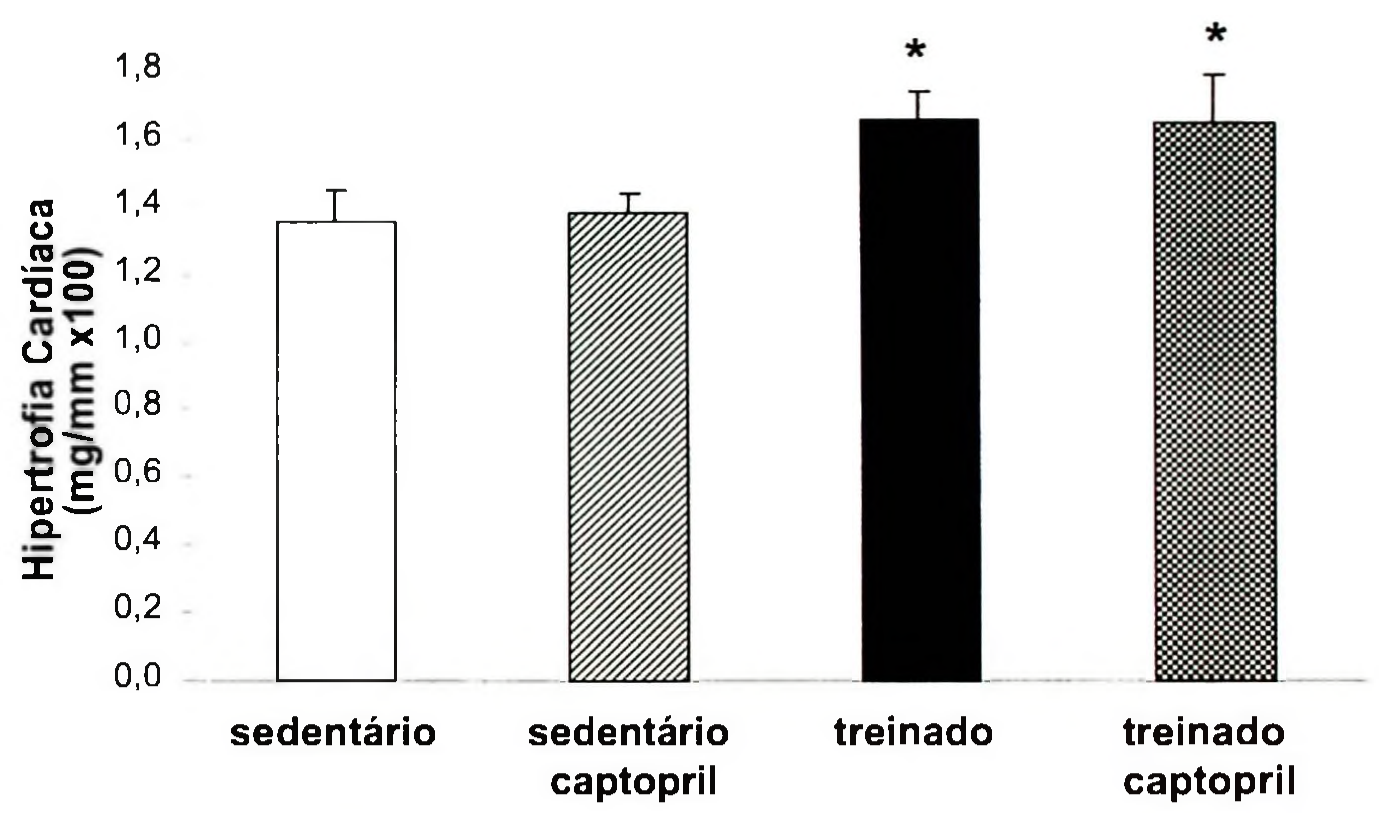

Figura 18. Índice de hipertrofia cardíaca avaliada a partir do peso úmido do ventrículo esquerdo corrigidos pelo comprimento da tíbia. Média \pm desvio padrão. ${ }^{*} \mathrm{p}<0,05 \mathrm{em}$ comparação ao sedentário.

O teste máximo em esteira foi realizado como um marcador funcional de adaptação dos animais ao treinamento. A Figura 19 mostra que antes do periodo de treinamento não havia diferenças entre os grupos analisados, entretanto, após o treinamento, os grupos treinados realizaram a corrida por mais tempo (Figura 19A) e correram por maior distância (Figura 19B). 
A

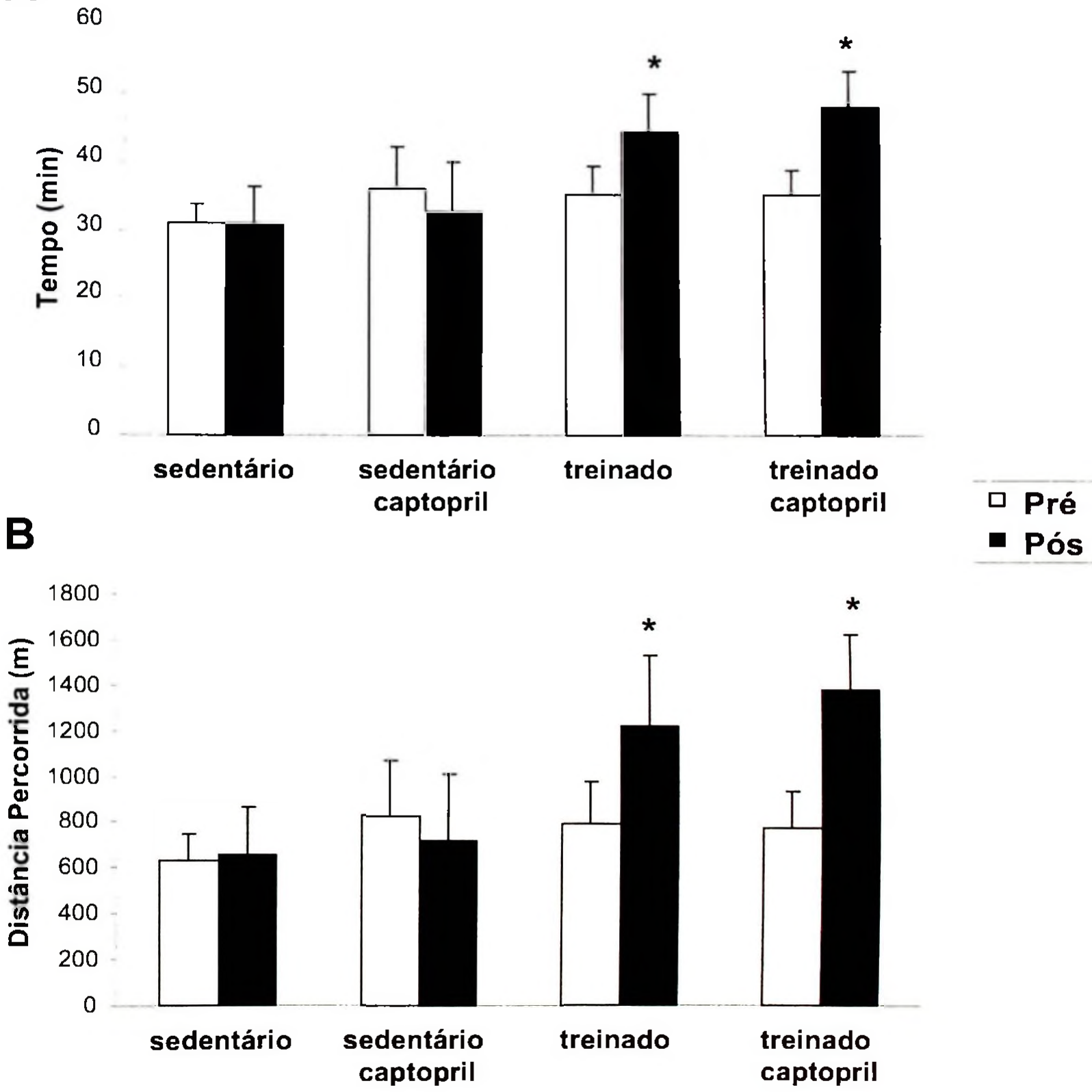

Figura 19. Valores de tempo (A) e distância (B) durante o teste máximo em esteira antes e após o período de treinamento físico aeróbico. Média \pm desvio padrão. ${ }^{*} \mathrm{p}<0,05 \mathrm{em}$ comparação ao sedentário. 
Assim, estes resultados mostram que o protocolo de treinamento foi efetivo em induzir adaptações características do treinamento físico aeróbio nos animais estudados, sem que o tratamento interferisse no desempenho físico dos animais.

A fim de verificar o efeito do tratamento com captopril sobre a PA, realizamos a medida da pressão caudal dos animais antes e após o periodo de tratamento (Figura 20). As figuras 7A, B e C mostram que as PAS, PAD e PAM não foram diferentes entre os grupos, antes ou após o treinamento e estas variáveis não foram alteradas pelo tratamento.

Com o mesmo intuito foi averiguado o efeito do tratamento com captopril sobre a atividade da ECA e seus domínios catalíticos, realizamos ensaios enzimáticos com substratos especificos para cada um dos terminais da ECA e para a ECA circulante no soro dos animais (Figura 21). Observa-se nas Figuras 21B e C que a atividade do sítio C-terminal e total da ECA, respectivamente, não foram diferentes entre os animais sedentários controle e os tratados com captopril e os treinados tratados com captopril; entretanto, o treinamento físico induziu redução da atividade desta enzima no soro. A atividade N-terminal da ECA esta mostrada na Figura $21 \mathrm{~A}$. Pode-se observar que a atividade deste terminal estava aumentada com o treinamento e que o tratamento com captopril inibiu completamente este aumento. 
A
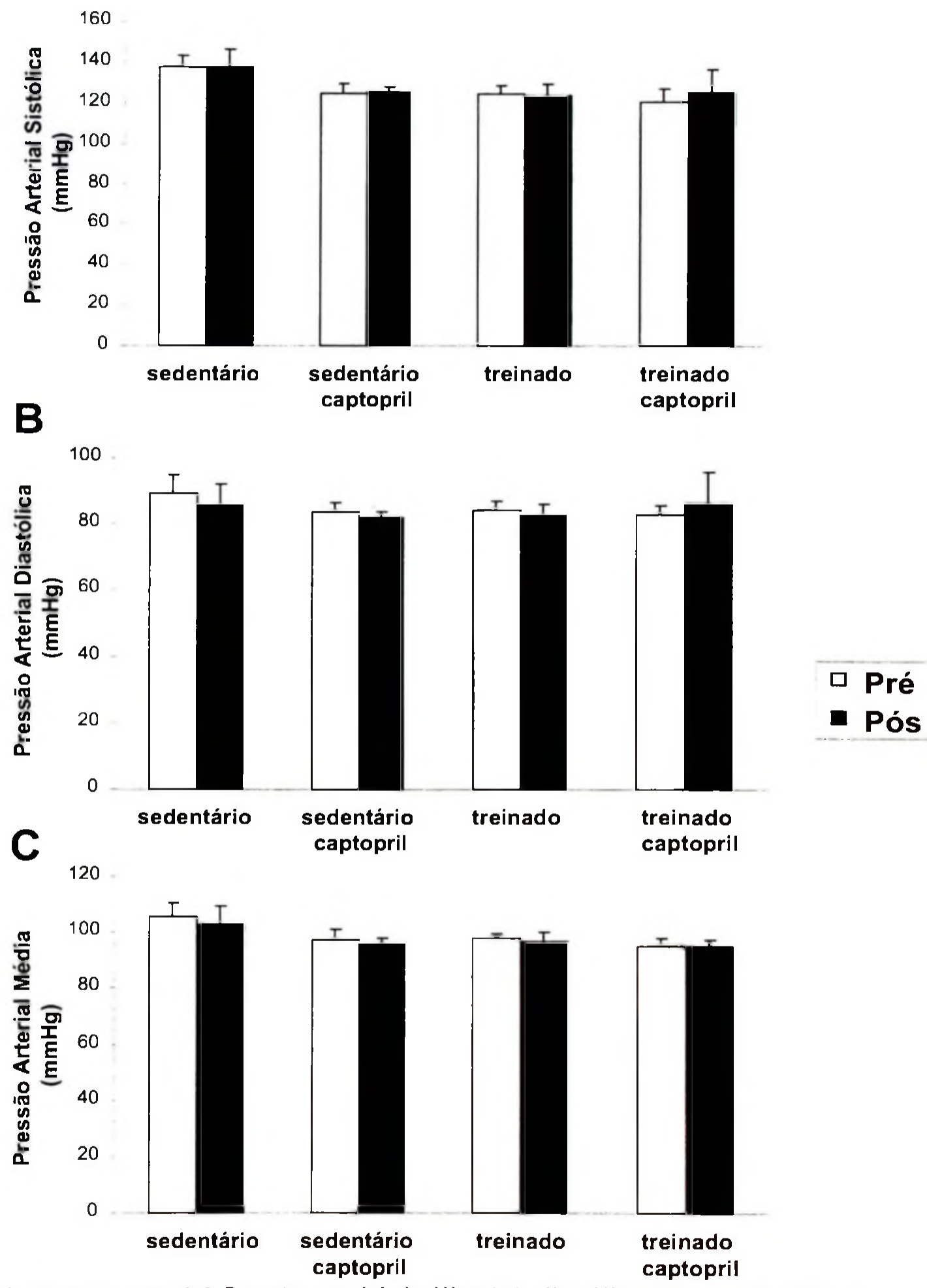

Figura 20. Pressão arterial. Pressão arterial sistólica (A), diastólica (B) e média (C) antes e após o período de treinamento fisico aeróbico. Média \pm desvio padrão. 
A
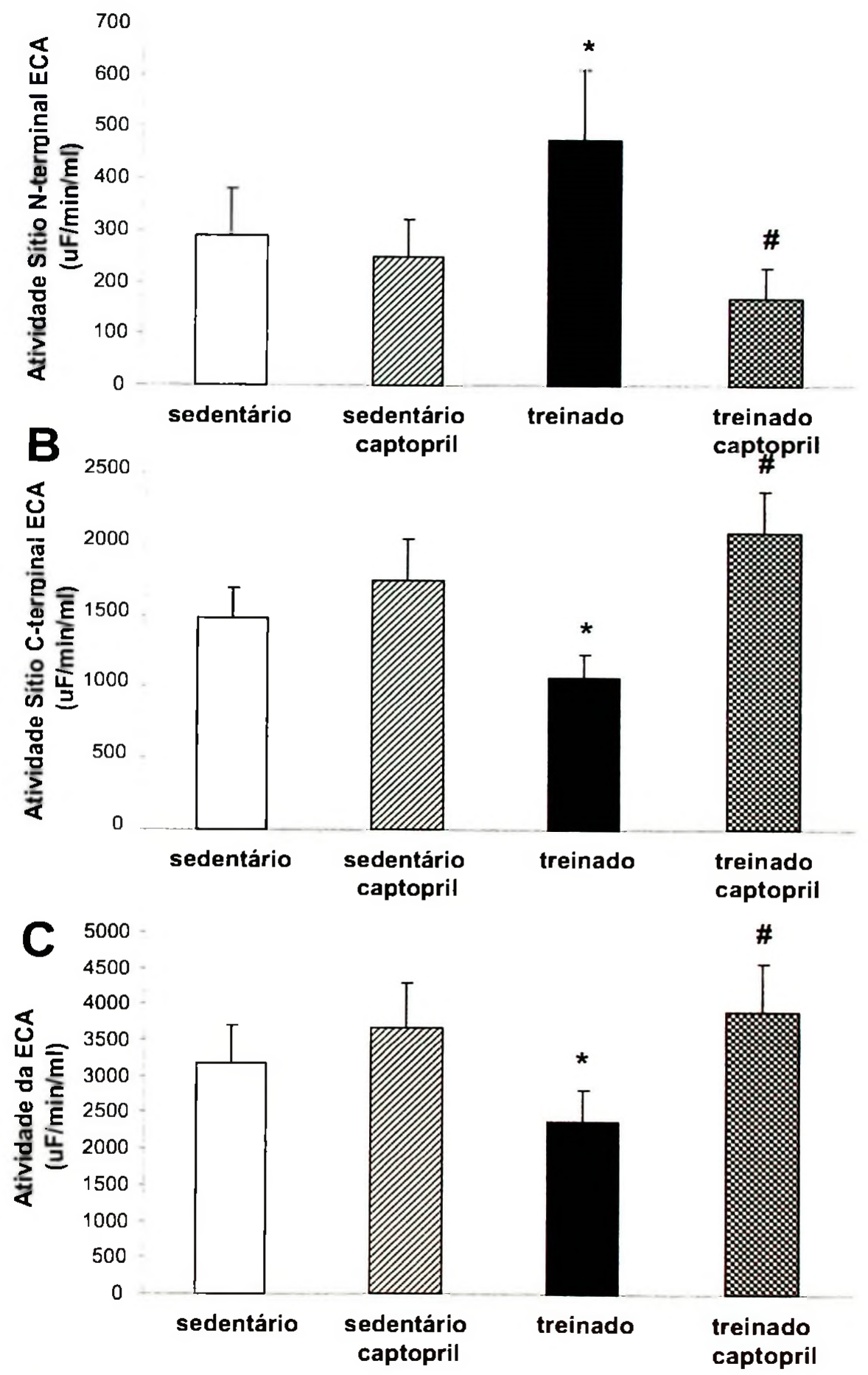

Figura 21. Atividade do sítio catalítico N-terminal (A), C-terminal (B) da ECA e da ECA circulante (C) no soro dos animais. Média \pm desvio padrão. ${ }^{*} p<0,05$ em comparação ao sedentário; \# $\mathrm{p}<0,05$ em comparação ao grupo treinado. 
Estes resultados mostram que o treinamento fisico foi eficaz em aumentar a atividade $\mathrm{N}$ terminal da ECA, como mostrado anteriormente, e o tratamento com captopril foi eficiente em inibir este aumento no grupo treinado e tratado com esta droga. Portanto, estes resultados mostram que os efeitos observados sobre os parâmetros hematológicos podem ter sido dependentes da maior atividade do N-dom da ECA levando a diminuição da concentração do peptídeo hemorregulador Ac-SDKP.

A fim de verificar os efeitos do treinamento físico sobre os parâmetros hematológicos, principalmente, sobre a eritropoiese, analisamos o hematócrito e a reticulocitose nos animais estudados (Figura 22). Nestes experimentos, tivemos como objetivos, principalmente, comprovar a participação do $\mathrm{N}$-dom com o tratamento com captopril.

$\mathrm{Na}$ figura 22A, observa-se que o tratamento com captopril reduziu o hematócrito apenas no grupo sedentário, não havendo diferenças entre os valores dos demais grupos. A reticulocitose é um dos indicadores mais comuns de eritropoiese. Pode-se observar que a concentração de reticulócitos foi aumentada com o tratamento com captopril nos animais sedentários, e o treinamento também induziu aumento nos valores de reticulócitos circulantes, resultado que já havíamos observado anteriormente. O tratamento com captopril no grupo treinado inibiu completamente a reticulocitose induzida pelo treinamento, o que indica que a eritropoiese neste grupo foi inibida (Figura 22B). 
A

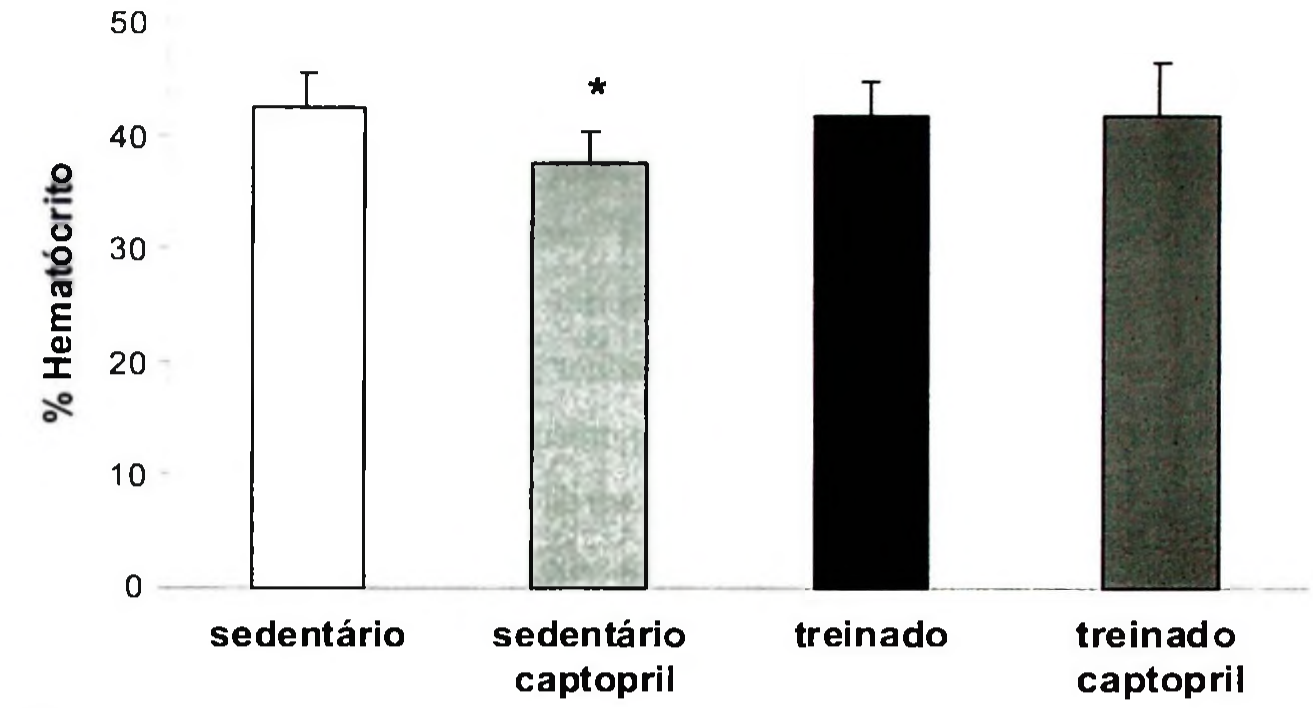

B

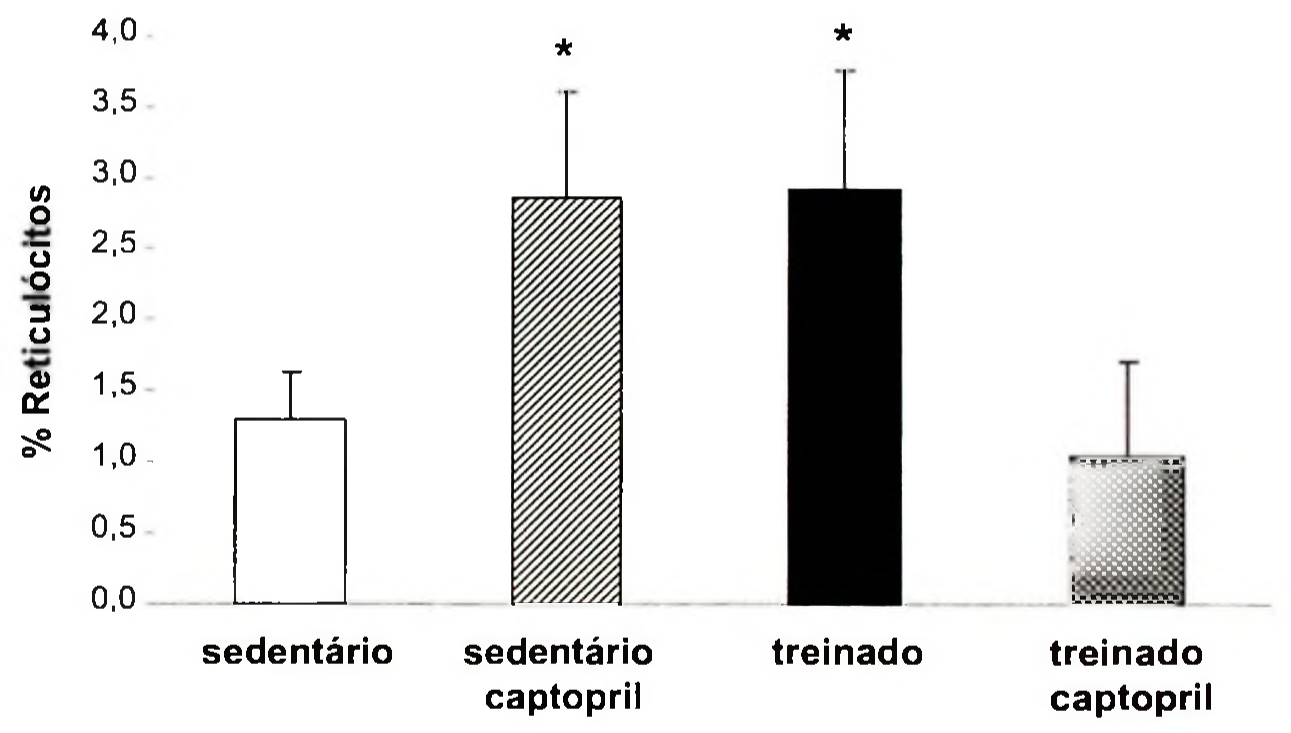

Figura 22. Valores de hematócrito (A) e reticulocitose (B) nos grupos estudados. Média \pm desvio padrão. * $\mathrm{p}<0,05$ em comparação ao grupo sedentário e treinado captopril.

Concluindo, podemos dizer que o treinamento físico aeróbio realizado neste estudo promoveu adaptações benéficas sobre o sistema cardiovascular e muscular esquelético. Estas adaptações foram associadas à melhora de desempenho físico, que é dependente da capacidade de transporte e liberação de oxigênio na musculatura ativa durante o treinamento. 
Nossos resultados mostram que algumas dessas adaptações, mais especificamente as relacionadas a parâmetros hematológicos, estão relacionadas ao aumento no número e proliferação das HSC. Além disso, os resultados sugerem que essas adaptações nas HSC podem ser devido a maior atividade do SRA, mais especificamente do aumento da atividade do sítio catalítico N-terminal da ECA circulante, sobre o peptideo hemorregulador Ac-SDKP. Um resultado importante neste estudo é a diminuição da meia-vida das hemácias em função do treinamento. Embora este fenômeno já tenha sido observado anteriormente [147], no presente estudo descrevemos um possível mecanismo pelo qual essa diminuição ocorre e salientamos que esse pode ser um mecanismo envolvido na melhora de desempenho físico.

Desta forma, apresentamos abaixo um modelo teórico (Figura 23), que descreve uma sequência esquemática dos passos descritos neste estudo e resultados encontrados.

O modelo teórico sugerido no presente estudo para a redução da meia-vida das hemácias relaciona-se com o efeito do treinamento aumentando a atividade do domínio $\mathrm{N}$-terminal da ECA, com subseqüente redução na concentração do tetra-peptídeo hemorregulador AcSDKP. A redução deste peptídeo retira a inibição sobre a proliferação das HSC, o que leva a maior taxa eritropoiética, evidenciada pela reticulocitose encontrada nos animais treinados. Hemácias mais jovens na circulação apresentam uma alta concentração 2,3 DPG, um metabólito da glicólise que reduz a ligação $\mathrm{O}_{2}$-hemoglobina. Essa afinidade reduzida permite que a hemoglobina libere o oxigênio eficientemente na musculatura ativa durante o treinamento físico. A maior eficiência de chegada do oxigênio nos tecidos durante o treinamento físico aumenta o aporte de nutrientes o que potencializa o desempenho físico. 


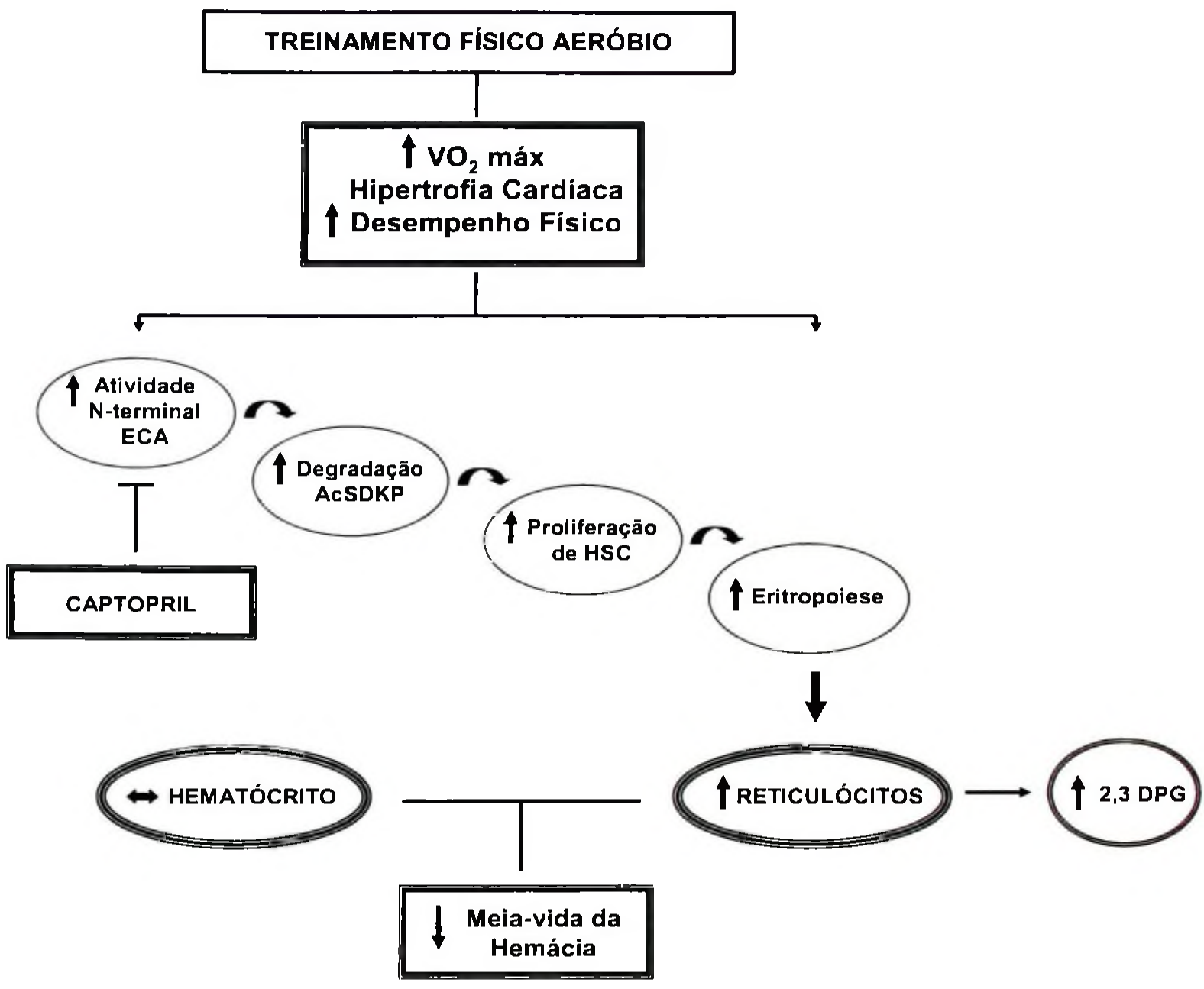

Figura 23. O treinamento físico aeróbio causa diversas adaptações no organismo que aumentam a capacidade de transportar e utilizar oxigênio. $O$ aumento da atividade do sítio $\mathrm{N}$-terminal da ECA com resposta ao treinamento físico, pode reduzir a concentração do tetrapeptídeo Ac-SDKP e aumentar a eritropoiese. Um indicativo de aumento na eritropoiese foi a não alteração no hematócrito com redução da meia-vida das hemácias. Utilizamos o captopril com a finalidade de inibir a atividade $\mathrm{N}$-terminal da ECA, demonstrando o possível mecanismo de aumento da eritropoiese via participação do SRA induzida pelo treinamento. Esse mecanismo pode estar envovido na melhora do desempenho físico.

Desta forma, neste estudo 2 estamos demonstrando que o SRA, por uma maior atividade do N-domínio da ECA pode estar relacionado com um melhor desempenho físico em ratos. 


\section{Estudo 3: Participação do SRA na hipertrofia fisiológica induzida pelo treinamento físico de força e via de sinalização ativada pelo receptor foi demonstrada pelos seguintes estudos:}

- Barauna VG, Batista-Junior ML, Costa Rosa LFBP, Casarini DE, Krieger JE e Oliveira EM. Cardiovascular adaptations in rats submitted to a resistance-training model. Clinical and Experimental Pharmacology and Physiology 32: 249-254, 2005.

- Barauna VG; Rosa KT; Irigoyen MC e Oliveira EM. Effects of resistance training on ventricular function and hypertrophy in a rat model. Clinical Medicine \& Research, 5 (2): 114$120,2007$.

- Barauna VG, Magalhães FC, Krieger JE e Oliveira EM. AT1 receptor participates in the cardiac hypertrophy induced by resistance training in rats. Am J Physiol Regulatory Integrative Comp Physiol 295:381-387, 2008.

- Melo SFS, Amadeu MA; Magalhães FC; Fernandes T; Carmo EC; Barretti DLM; Brum PC e Oliveira EM. AT1 receptor-AKT-mTOR signaling pathway is activated by a session of strength exercise. Submetido para publicação. Am J Physiol Regulatory Integrative Comp Physiol, 2010.

Para estes estudos construimos um Sistema de Treinamento de Força para ratos baseado num modelo descrito por Tamaki et. al., 1992 [148]. Entre os modelos encontrados na literatura optamos por este pela semelhança biomecânica no exercício proposto para ratos, como o realizado por humanos com o treinamento de força ou resistido (exercício de agachamento).

O aparato de treinamento (Figura 1), consiste de um sistema de madeira, no qual colocase na aste de madeira as anilhas com pesos conhecidos. O animal é preso nesta aste de madeira ficando com as patas traseiras sobre uma superficie de metal. Um estimulador elétrico é 
conectado a superfície de metal, quando o estimulador é ligado o animal realiza o exercício de agachamento.

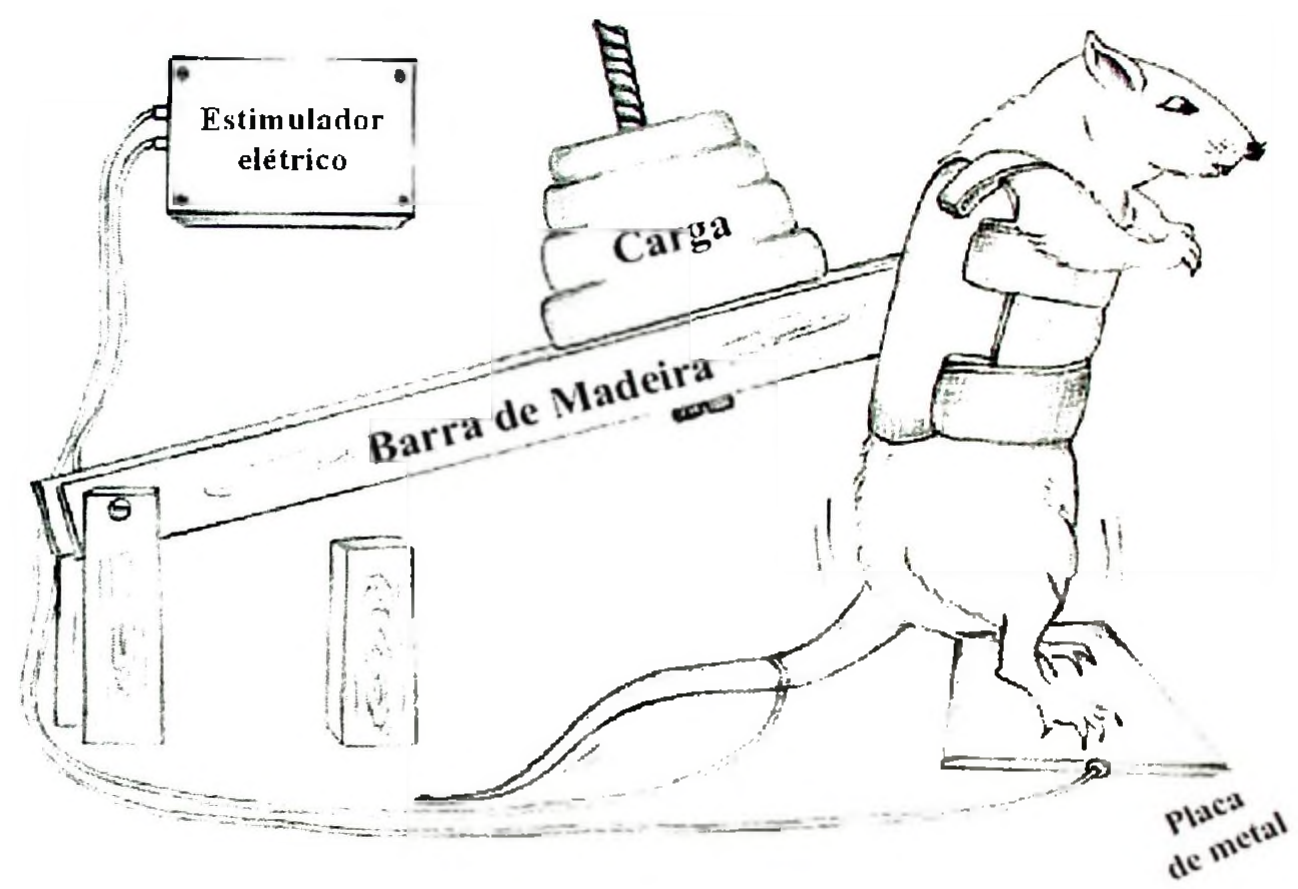

Figura 1. Esquema do aparato de treinamento.

Inicialmente, na literatura, esse modelo foi desenvolvido para comparar as adaptações metabólicas do músculo esquelético entre o treinamento resistido e o de velocidade, em ratos [148]. Também foi usado para estudar o turnover de massa óssea nessa modalidade de treinamento [149, 150] e posteriormente por Yaspelkis et al. 2002 [151], para estudar a influência do treinamento resistido sobre a captação de glicose e sensibilidade a insulina.

Apesar de o modelo ser efetivo em induzir hipertrofia músculo-esquelética e alterações enzimáticas semelhantes às encontradas em humanos, até 2005 nenhum trabalho havia sido desenvolvido com o objetivo de estudar as adaptações cardiovasculares. Assim, depois de muitos testes de protocolos e adaptações no modelo, estabelecemos um protocolo de treinamento para 
estudarmos as adaptações fisiológicas que ocorrem no sistema cardiovascular com o treinamento de força.

Inicialmente, padronizamos o modelo de treinamento e na sequência buscamos entender como estavam as adaptações estruturais, morfológicas e função cardíaca. Posterirmente, estudados a participação do SRA na hipetrofia fisiológica concêntrica e as vias de sinalização envolvidas neste processo.

\subsection{Objetivos}

Padronizar um modelo experimental de treinamento de força para ratos que resulte em adaptações fisiológicas do sistema cardiovascular, especialmente a hipertrofia cardíaca.

Estudar alterações nas variáveis hemodinâmicas e as adaptações estruturais no coração induzidas pelo treinamento físico em ratos machos Wistar normotensos.

- Analisar as medidas hemodinâmicas, no repouso, através da medida direta da pressão arterial e freqüência cardíaca nos animais treinados e sedentários.

- Determinar o grau de hipertrofia cardíaca induzida pelo treinamento físico, através da relação peso do coração/peso corporal,

- Peso do músculo plantaris e das adrenais corrigidos pelo peso corporal.

- Determinada a concentração de catecolminas plasmáticas por método de HPLC (Cromatografia Liquída de Alta Performace)

- Acompanhar a diferença de 1RM entre os grupos controles e treinado.

- Verificar a evolução do peso corporal semanalmente.

\subsection{Materiais e Métodos}

\subsubsection{Animais de experimentação}

Foram utilizados ratos Wistar, pesando entre 300 e $400 \mathrm{~g}$, com 14 semanas de idade, provenientes do Biotério Central da USP. Os animais foram divididos, aleatoriamente, em 3 grupos como descrito abaixo. Os animais foram mantidos em gaiolas, separados por grupos, em local com temperatura ambiente entre $22-24^{\circ} \mathrm{C}$ e com luz controlada em ciclo de 12 horas (claroescuro). Água e comida foram administradas ad libitum. Os ratos foram identificados e pesados semanalmente. 


\subsubsection{Protocolo de treinamento dos animais}

\section{Grupos Experimentais:}

Nesse estudo foram utilizados quatro grupos de animais:

- Grupo Controle Sedentário: CO

- Grupo Controle Estímulo Elétrico: ES

- Grupo Treinado: TR

-Controle: grupo mantido Sedentário, que realizaram o movimento de agachamento no aparato de treinamento 2 vezes na semana, sem carga.

-Treinamento: 4 séries de 12 repetições com intervalo de 1 min e 30 s, estímulo de $28 \mathrm{v}$, 0,3 de duração, 3 s de intervalo e realizado 5 vezes por semana. Sobrecarga entre $65-75 \%$ de 1 RM. Os animais foram adaptados por duas semanas antes do início do treinamento. O exercício físico foi realizado cinco vezes por semana, durante oito semanas. O teste de 1RM foi realizado antes do periodo de treinamento, após 2, 4, 8 e 12 semanas de treinamento.

O grupo controle estímulo elétrico foi usado como controle dos experimentos, onde animal recebia o estímulo elétrico e realizada o movimento do treinamento sem carga. Este grupo foi realizado para analisarmos os efeitos do estímulo elétrico.

Os animais foram adaptados por duas semanas antes de começar o protocolo experimental.

\subsubsection{Teste de 1RM}

Após a medida da carga máxima para execução de uma única repetição do movimento (1RM) no aparato de treinamento, o protocolo foi estabelecido para $65-75 \%$ de $1 \mathrm{RM}$ para os animais treinado. $\mathrm{O}$ teste de $1 \mathrm{RM}$ foi repetido por 3 dias consecutivos, para estabelecer a carga máxima. O grupo ES recebeu a mesma intensidade de estímulo e realizou o mesmo número de séries e repetições que o grupo TR, porém sem a carga. O RM foi determinado a cada duas semanas para o ajuste da carga de treinamento. Os resultados estão apresentados na Tabela 1.

\subsubsection{Medida direta da pressão arterial e freqüência cardíaca}

Para medida direta da pressão arterial (PA) e freqüência cardiaca (FC), foi inserida uma cânula (PE-50) na artéria carótida com os animais sob anestesia (ketamina $90 \mathrm{mg} / \mathrm{Kg}$ e xilasina 
$10 \mathrm{mg} / \mathrm{KG}$, intraperitonial). As cânulas foram heparinizadas e preenchidas com soro fisiológico e a extremidade externa ocluída. Para facilitar o manuseio com o animal acordado, os catéteres foram dirigidos pelo tecido subcutâneo por meio de um trocater, e exteriorizados no dorso do animal.

Para o registro da PA os animais foram mantidos em gaiolas individuais, nas quais permaneceram por pelo menos 12 horas antes de iniciar o experimento. A cânula foi conectada a um tubo de polietileno (PE-100) e este a um transdutor eletromagnético (P23 Db; GouldStatham) que estava conectado a um amplificador (General Purpose Amplifier-Stemtech, Inc.). O sinal analógico da PA foi convertido para digital (Stemtech, Inc.), registrado em tempo real em microcomputador com Sistema CODAS com freqüência de amostragem de $2000 \mathrm{~Hz} /$ canal e analisado através do programa compatível com Windows. A partir deste programa obtiveram-se batimento a batimento os valores de pressão sistólica (PAS), diastólica (PAD) e calculou-se, então, a pressão média (PAM) $(\mathrm{PAM}=(\mathrm{PAS}-\mathrm{PAD}) / 3+\mathrm{PAD})$.

O mesmo procedimento de registro foi utilizado tanto no grupo de treinamento crônico quando nos animais que realizaram apenas uma sessão do treinamento. Entretanto, para os animais que treinaram por oito semanas, o registro foi realizado em repouso por um período de 30 min enquanto para os animais de uma sessão, o registro foi feito durante a realização de uma série. A Figura 2 é um exemplo de uma das séries de treinamento. Podem ser observados claramente os 12 picos pressóricos correspondentes ás 12 repetições realizadas.

Assim, realizamos inicialmente uma série de experimentos e observamos as respostas cardiovasculares, nos ratos, semelhantes às encontradas em humanos como, por exemplo, aumento agudo da pressão arterial, durante a realização das séries do exercício (Figura 2) e hipertrofia cardíaca com um mês de treinamento. 


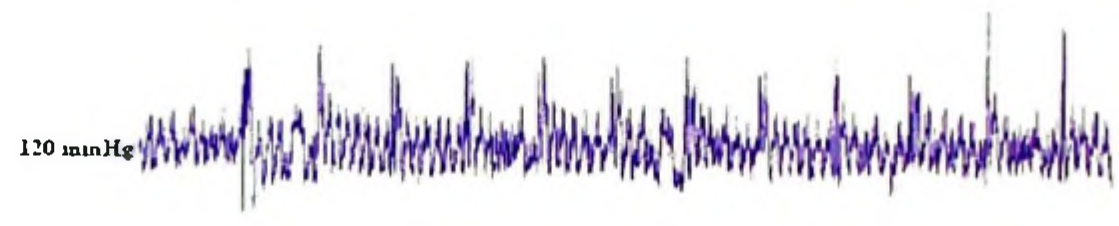

Figura 2- Exemplo do registro da pressão arterial durante a realização de uma série de 12 repetições, de treinamento de um animal. Podem ser observados os 12 picos de pressão durante o levantamento da carga.

\subsubsection{Quantificação das catecolaminas plasmáticas}

Estas análises foram realizadas em colaboração com o Laboratório da Professora Dra Dulce Casarine, da disciplina de Nefrologia da Universidade Federal de São Paulo.

As catecolaminas, noradrenalina (NE), adrenalina (EPI) e dopamine (DA) foram medidas por HPLC (Cromatografia Líquida de Alta Performance). Essa análise foi usada como uma mediade de estresse dos animais, uma vez que usamos o estímulo elétrico.

\subsubsection{Morfologia cardíaca}

Ao final do protocolo experimental os animais foram decapitados e o coração removido da cavidade torácica e dissecado para separarmos o VE (parede livre do ventrículo esquerdo e septo) e VD (ventrículo direito) dos átrios (átrios direito e esquerdo)

A hipertrofia cardíaca foi avaliada pesando-se os ventrículos esquerdo e direito (peso úmido). Os resultados serão expressos pela relação entre o peso dos ventrículos pelo peso corporal do animal $(\mathrm{mg} / \mathrm{g})$

\subsubsection{Análise estatística}

Os resultados estão apresentados como média \pm EPM. O PC, RM e RM/PC foram analisados por ANOVA de duas vias. Os demais resultados foram analisados por ANOVA de 
uma via. Foram considerados significantes valores de $\mathrm{P}<0,05$. O pos-hoc de Tukey foi usado para comparações individuais entre as médias, quando as alterações foram significante na ANOVA.

\subsection{Resultados e Discussão}

O peso corporal dos animais no início do protocolo foi igual em todos os grupos (Tabela 1). No final do protocolo de treinamento o grupo TR aumento $4 \%(P>0,05)$, o grupo ES aumentou $5 \%(\mathrm{P}=0,058)$ e o grupo $\mathrm{CO}$ aumentou $8 \%(\mathrm{P}<0,01)$ o peso corporal, em relação ao início do protocolo.

Tabela1. Peso Corporal e $1 \mathrm{RM}$ absoluto in primeira e quarta semanas de treinamento, Peso das câmara cardíacas, adrenais e do plantaris corrigidos pelo peso corporal. Frequência cardíaca.

\begin{tabular}{|c|c|c|c|c|}
\hline & & $\mathrm{CO}$ & $\mathbf{E S}$ & $\mathbf{T R}$ \\
\hline \multirow[t]{2}{*}{ Peso Corporal (g) } & 1a. Semana & $379 \pm 6,9$ & $374 \pm 11.5$ & $385 \pm 4.1$ \\
\hline & 4a. Semana & $413 \pm 5,3^{\dagger}$ & $394 \pm 8,6$ & $402 \pm 4,2$ \\
\hline Átrios (mg/g) & 4a. Semana & $0,15 \pm 0,011$ & $0,14 \pm 0,013$ & $0,15 \pm 0,013$ \\
\hline Ventriculo Direito (mg/g) & 4a. Semana & $0,59 \pm 0,03$ & $0,55 \pm 0,04$ & $0,53 \pm 0,02$ \\
\hline Ventriculo Esquerdo (mg/g) & 4a. Semana & $2,05 \pm 0,02$ & $2,05 \pm 0,05$ & $2,30 \pm 0,03^{*}$ \\
\hline Peso do Plantáris $(\mathrm{mg} / \mathrm{g})$ & 4a. Semana & $0,41 \pm 0,02$ & $0,40 \pm 0,013$ & $0,44 \pm 0,01 * *$ \\
\hline \multirow[t]{2}{*}{ I RM (g) } & la. Semana & $491 \pm 53,7$ & $519 \pm 47,2$ & $531 \pm 63,3$ \\
\hline & 4a. Semana & $619 \pm 44$ & $625 \pm 61,2$ & $833 \pm 49,5^{\ddagger}$ \\
\hline Frequência Cardiaca (bpm) & 4a. Semana & $364 \pm 6,3$ & $357 \pm 10,6$ & $333 \pm 8,8$ \\
\hline Peso das Adrenais $(\mathrm{mg} / \mathrm{g})$ & 4a. Semana & $0,17 \pm 0,04$ & $0,17 \pm 0,03$ & $0,17 \pm 0,01$ \\
\hline
\end{tabular}

CO, Controle; ES, Estímulo Elétrico; TR, Treinado; 1RM, repetição máxima;PC, peso corporal; $\mathrm{VE}$, ventrículo esquerdo. Resultados estão apresentados como média \pm DP. $n=8$ cada grupo. O PC e a relação RM/PC foram obtidos na la. e 4a. semanas após o protocol de treinamento. ${ }^{\top} P<0,05$ comparação do $P C$ do grupo CO na 4a semana vs. a la. semana (CO vs TR e ES no final do protocolo). ${ }^{*} P<0,01$ comparação VE/PC do grupo TR vs CO e ES. ${ }^{* *} P<0,05$ comparação do peso do plantáris do grupo TR vs CO e ES. ${ }^{\ddagger} P<0,05$ comparação de 1 RM do grupo TR na 4 a semana vs a la semana (TR vs CO e ES no final do protocolo).

O teste de IRM foi expresso pelo peso absoluto e relativo ao peso corporal. A tabela 1 mostra os valores do RM absolute antes (primeira semana) e após o treinamento (quarta semana). Todos os grupos começaram o treinamento com 1RM igual ( $515 \pm 128 \mathrm{~g}$ ). Entretanto, o valor de 1RM após o treinamento aumentou somente no grupo TR (CO, 26\%; ES, 20\% ambos $\mathrm{P}>0,05 ; \mathrm{TR}, 56 \% \mathrm{P}<0,01)$. Como o peso corporal pode influenciar nessa variável, o $\mathrm{RM}$ foi corrigido pelo peso corporal (1RM/PC, g/g). 
A figura 3, mostra os valores de RM/PC. Os resultados observados foram semelhantes aos valores absolutos, onde o aumento do RM foi observado somente no grupo TR.

\author{
$\square$ 1a Semana $\square$ 4a Semana
}

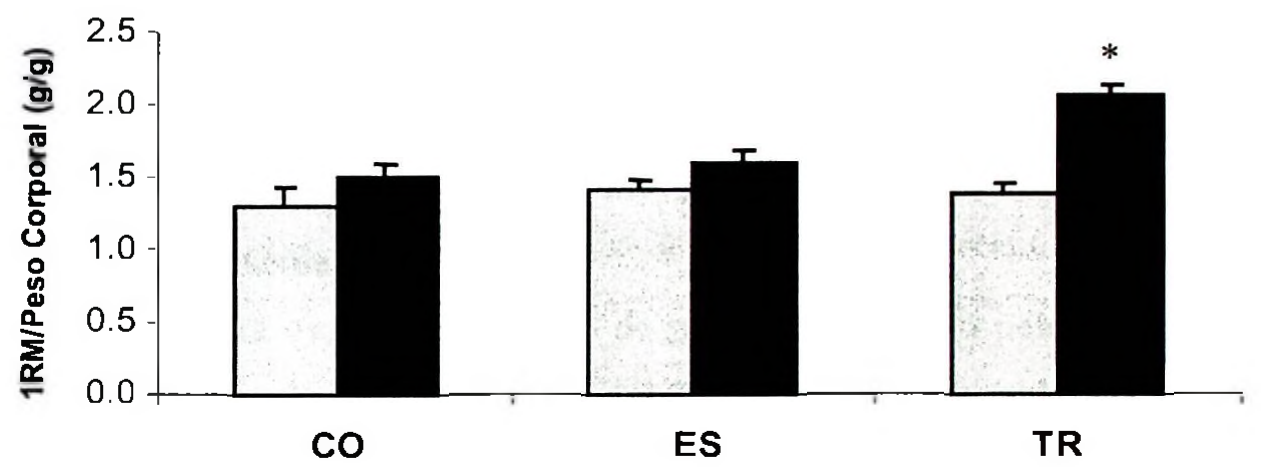

Figure 3. RM relative ao PC de todos os grupos antes (primeira semana) e após (quarta semana) do treinamento resistido. $\mathrm{CO}$, controle; ES, Estímulo Elétrico; TR, treinado. Os resultados estão apresentados como médiatDP. $\mathrm{n}=8$ cada grupo. * $\mathrm{P}<0,01$ comparação do $\mathrm{RM} / \mathrm{PC}$ do grupo TR na 4a semana vs. a la. semana e o TR vs. CO e ES no final do protocolo.

Assim, o teste de 1RM é muito utilizado como marcador da evolução do treinamento e como forma de mensurar a carga de treinamento. Os animais iniciavam o protocolo com carga de aproximadamente 2,6 vezes o peso corporal e terminaram, um mês após, com uma carga de aproximadamente 4,5 vezes o peso corporal. Desta foram, esses resultados mostram a eficácia e a evolução do treinamento com a sobrecarga utilizada e demonstrar que não era devido a maturação dos animais.

Diferentemente dos exercícios aeróbios que geralmente utilizam a FC ou o consumo de oxigênio como parâmetros para determinar sua intensidade, no treinamento com pesos o RM é a medida indireta utilizada para medir a força muscular e assim determinar a carga de treinamento. O RM pode ser definido como a carga máxima para a execução de uma única repetição do movimento. Sendo o aumento da força muscular uma adaptação direta do treinamento de força, o RM aumenta com o treinamento devido ao aumento da massa muscular, seja por hipertrofia ou hiperplasia. 
Trabalhos feitos com humanos descreveram que o aumento na força, representado pelo $\mathrm{RM}$, nas primeiras semanas de treinamento deve-se a adaptação neuro-muscular (maior número e sincronização no recrutamento das fibras musculares). Já a partir do segundo ou terceiro mês o aumento da força pode ser atribuido, como sendo predominantemente devido, à hipertrofia ou hiperplasia. Tanto em humanos como em animais o teste de IRM é muito utilizado como marcador da evolução do treinamento e como forma de mensurar a carga de treinamento.

Desta foram, esses resultados mostram a eficácia e a evolução do treinamento com a sobrecarga utilizada e demonstrar que não era devido a maturação dos animais.

\subsubsection{Peso do músculo esquelético}

A tabela 1, mostra os valores do peso do plantáris corrigido pelo peso corporal. Como esperado, o peso do músculo aumentou $6,5 \%$ e $9,2 \%$ quando comparado aos grupos $\mathrm{CO}$ e $\mathrm{ES}$, respectivamente $(\mathrm{P}<0,05)$. Entretanto, não foram observadas diferenças entre os grupos $\mathrm{CO}$ e ES.

Estes resultados estão de acordo com o fato do músculo plantáris ser um músculo com predomínio de fibras brancas, com metabolismo glicolítico, portanto sofrem maiores adaptações com o treinamento de força.

\subsubsection{Peso do coração}

$\mathrm{Na}$ sequência, analizamos se este treinamento seria efetivo em induzir hipertrofia cardíaca. Após um mês de treinamento foi observada hipertrofia de $12 \%$ no VE, analisada pelo peso do VE/peso corporal (mg/g; $\mathrm{P}<0,01$ ), quando comparados aos grupos $\mathrm{CO}$ e $\mathrm{ES}$, enquanto no peso do VD e átrios não foram encotradas alterações. Assim, este estudo mostrou que esse modelo de treinamento resistido pode promover adaptações no sistema cardiovascular, a semelhança do que ocorre com humanos. Entretanto, estes resultados não nos permitem dizer o tipo de hipetrofia que ocorre, assim mais análises são necessárias para determinarmos se esse protocolo de treinmento leva ao desenvolvimento de hipertrofia cardíaca concêntrica.

\subsubsection{Pressão arterial}

Vinte quatro horas após a última sessão de treinamento, a PA e FC foram analisadas por medida direta. Os resultados da figura 4, mostram queda da pressão arterial diastólica e média de 
repouso no grupo treinado, após 4 semanas de treinamento. Os valores dos grupos CO e ES forem similares para todas as medidas. Foi observada uma redução não significante nas PAS de $10 \%$ comparado aos grupos CO e ES (P>0,05). As PAD e PAM diminuiram 14\% e 13\%, respectivamente, comparadas aos grupos $\mathrm{CO}$ e ES $(\mathrm{P}<0,05)$. Enquanto, não foi observada bradicardia de repouso nos grupos treinados (Tabelal). A frequência cardíaca diminuiu, não significativamente, $8 \%$ no grupo TR comparado ao grupo $\mathrm{CO}(\mathrm{P}=0,062)$ e $6 \%$ comparado ao grupo $\mathrm{ES}(\mathrm{P}=0,075)$.

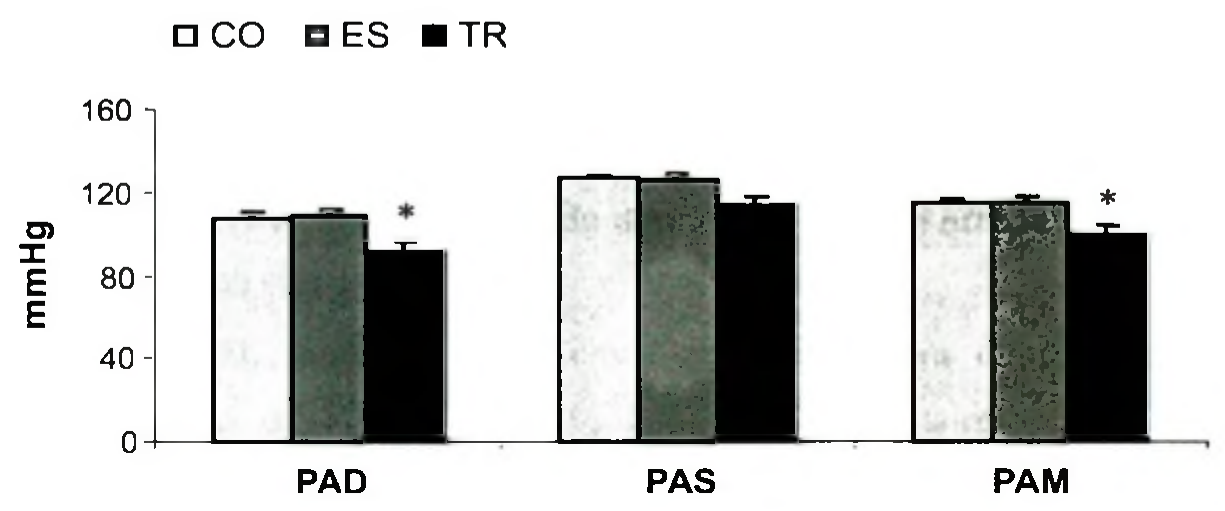

Figura 4. Pressão Arterial Sistólica, Diastólica e Média após 4 semanas de treinamento. Os resultados estão apresentados como média \pm DP. ${ }^{*} P<0,05 . n=8$ cada grupo. Controle, (cinza claro); Estímulo Elétrico (ES), (cinza escuro); Treinado (preto).

As adaptações que ocorrem na PA e FC com o treinamento de força talvez sejam as mais diversas devido a grande diferença nos protocolos experimentais, principalmente na intensidade e duração do treinamento.

As hipóteses iniciais de que atletas que realizam treinamento de força apresentavam hipertensão já foram esclarecidas na literatura e mostradas que estavam associadas ao uso de esteróides, overtraining crônico e aumento muito grande da massa muscular $[152,153]$.

Em sua maioria, os estudos transversais têm claramente demonstrado que atletas de alto nível têm tanto a PAS quanto a PAD dentro dos limites da normalidade, porém alguns estudos têm mostrado valores abaixo da média[154-156]. E, uma meta-análise com estudos que realizavam treinamento resistido mostram que a diminuição da PA é mais comumente observada nos primeiros meses de treinamento, quando comparados com trabalhos que realizavam 
protocolos mais prolongados Stone [76, 157]. Alguns pesquisadores têm sugerido que a diminuição da PA, provavelmente está relacionada com a diminuição da gordura corporal ou alteração na estimulação simpatoadrenal [158]. Dois estudos do mesmo grupo tentaram explicar os mecanismos dessa diminuição da PA $[159,160]$. Os autores mediram a atividade nervosa simpática, mas nenhuma diferença foi encontrada entre os grupos, apesar de o grupo treinado ter apresentado menor PA. Baseado em resultados in situ [161], foi discutida a hipótese de que a diminuição na PA seja decorrente de uma grande síntese de Oxido Nítrico (NO) em repouso, uma vez que esse tipo de treinamento é caracterizado por elevações intermitentes da PA durante o exercício devido a maior resistência periférica pode ocorrer maior ativação da NO sintase como resposta ao shear stress. O grupo sugere que possa ocorrer uma hipersensibilização do sistema resultando na menor PA em repouso. Usando esse mesmo modelo de treinamento demonstramos que uma sessão única de treinamento resisitido diminuiu a pressão arterial em ratos SHR e esse efeito foi mediado por NO [162].

Com relação á FC, alguns estudos envolvendo protocolos de treinamento curto têm demonstrado diminuição da FC de até 13\% [78], porém a maioria dos estudos mostram diminuição, mas não significante na FC [163-165]. Os mecanismos envolvidos na diminuição da FC esão associados a uma combinação de três fatores: redução da frequência intrínseca do coração, diminuição do tônus simpático e aumento do tônus parassimpático.

Embora não sido observado diminuição da PAS e FC com o treinamento, o duplo-produto (PAS X FC) diminuiu 18\% no grupo TR em comparação com o grupo $\mathrm{CO}(\mathrm{P}<0,05$, resultados não mostrados). O duplo-produto é um índice de trabalho cardíaco. Assim, esse protocolo de exerç̧io pode levar uma melhora da função cardiovascular e pode ser usado como um tratamento não farmacológico para prevenção de doenças cardiovasculares.

\subsubsection{Medida de catecolaminas plasmáticas e peso das adrenais}

As catecolaminas, noradrenalina (NE), adrenalina (EPI) e dopamine (DA) foram medidas por HPLC (Figura 5). O peso das adrenais corrigidos pelo peso corporal está apresentado na Tabela 1 e não foram modificados com esse protocolo de treinamento. 
A

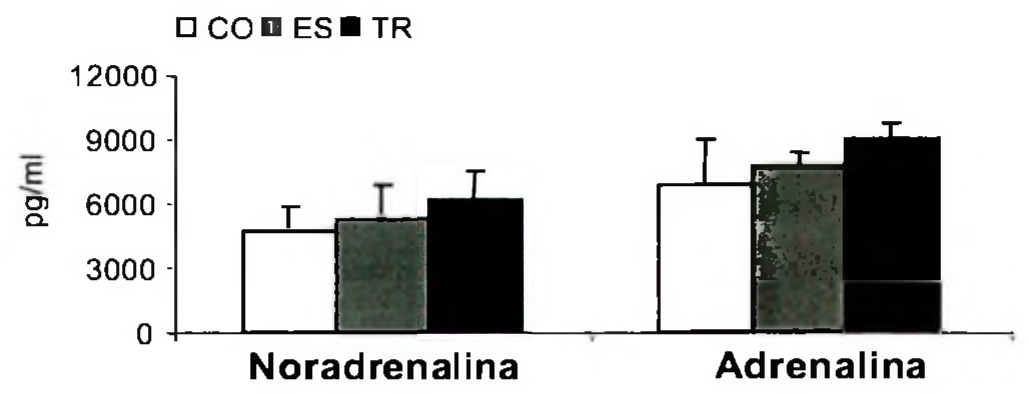

B

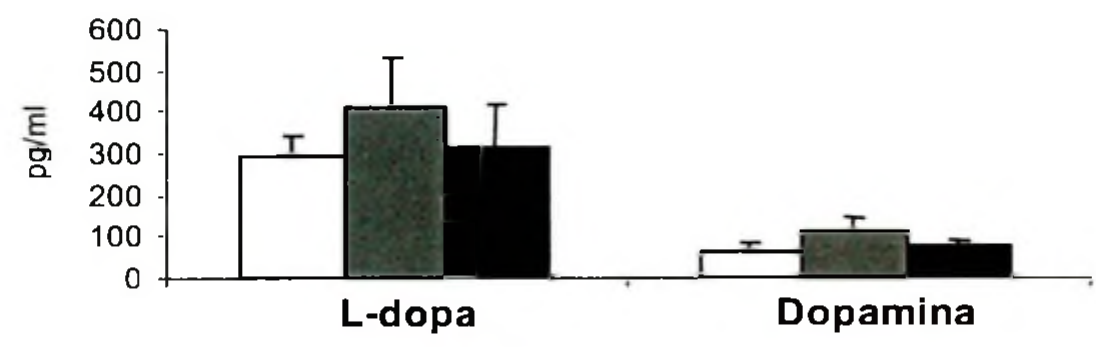

Figura 5. (A) Adrenalina e Noradrenalina, (B) L-Dopa e Dopamina. Os resultados estão apresentados média \pm SD, não significantes. Controle, (branco); Estímulo Elétrico (ES), (cinza); Treinado (preto).

Uma vez que, os animais recebiam um estímulo elétrico durante o treinamento, investigamos se ocorria estresse nos animais por destas duas análises. Assim, quantificamos as catecolaminas plasmáticas nos três grupos estudados, ou seja, nos animais que receberam o estímulo elétrico e treinaram sem a carga, animais que receberam o estímulo elétrico e treinaram com carga e comparamos com os animais sedentários. Os resultados da Figura 5 mostraram que não houve aumento nos niveis de catecolaminas circulantes, quando comparamos os três grupos. Outro resultado que está de acordo com aos resultados das catecolaminas plasmáticas, foi o peso das adrenais, no qual não foi observado aumento (Tabela 1).

Os trabalhos prévios publicados na literatura que utilizaram esse modelo não fizeram essas análises, assim neste estudo mostramos que estes dois indices de estresses foram inalterados no final do periodo de treinamento. Assim, a estimulação elétrica não foi associada 
com alterações nos niveis plasmáticos de catecolaminas, um marcador de atividade simpática [166] hipertrofia da adrenal.

Desta forma, estes resultados em conjunto mostram que o protocolo do treinamento resistido realizado neste modelo proposto para estudo leva ao desenvolvimento de hipertrofia cardíaca e diminuição da pressão arterial de repouso. As adaptações cardiovasculares observadas se devem ao treinamento e não aao possivel esstresse que o modelo de treinamento poderia proporcionar aos animais, como observado pela não alterção nos níveis de catecolaminas e peso das adrenais. Embora muitas destas adaptações ao treinamento resitido já tenham sido bem descritas para humanos, nós fomos os primeiros a mostrar em animais. Assim, este pode ser um bom modelo para estudos mais invasivos e em nivel celular e molecular para investigar os mecanismos envolvidos na hipertrofia cardíaca físiológica concênctrica.

Esses resultados nos deixaram seguros para utilizar esse modelo para os próximos estudos e estes resultados foram publicados por [167].

Nosso próximo passo foi verificar por quanto tempo os animais teriam que ser treinados até que estas adaptações fossem estabelecidas, principamente a hipertrofia cardiaca. Para isso, os animais foram treinados com o mesmo protocolo de treinamento por 3 meses.

\subsection{Objetivos}

Estudar neste modelo experimental de treinamento de força para ratos, as adaptações fisiológicas do sistema cardiovascular, especialmente a hipertrofia cardíaca, ao longo do tempo.

Estudar alterações as variáveis hemodinâmicas e as adaptações estruturais no coração induzidas pelo treinamento físico em ratos machos Wistar, por um período de 3 meses.

- Analisar as medidas hemodinâmicas, no repouso, através da medida direta da pressão arterial e freqüência cardiaca nos animais treinados e sedentários.

- Analisar a função sistólica e diastólica através de Ecodopplercardiografia.

- Acompanhar o grau de hipertrofia cardíaca induzida pelo treinamento físico, através da relação peso do coração/peso corporal, da medida do diâmetro dos miócitos e do Ecocardiografia.

- Determinar o tipo de hipertrofia cardiaca induzida neste modelo de treinamento físico. 
- Determinar a relação entre o número de capilares por área no coração.

- Acompanhar a diferença de IRM entre o grupo controle e treinado ao longo dos 3 meses de treinamento.

- Verificar a evolução do peso corporal semanalmente.

\subsection{Materiais e Métodos}

\subsubsection{Animais de experimentação}

Foram utilizados ratos Wistar, pesando entre 200 e $300 \mathrm{~g}$, provenientes do Biotério Central da USP. Os animais foram divididos, aleatoriamente, em 4 grupos como descrito abaixo. Os animais foram mantidos em gaiolas, separados por grupos, em local com temperatura ambiente entre $22-24^{\circ} \mathrm{C}$ e com luz controlada em ciclo de 12 horas (claro-escuro). Água e comida foram administradas ad libitum. Os ratos foram identificados e pesados semanalmente.

\subsubsection{Protocolo de treinamento dos animais}

Nesse estudo foram utilizados quatro grupos de animais:

- Grupo Co 1: Controle - Sedentário um mês

- Grupo Co3: Controle - Sedentário três meses

- Grupo Tr1: Treinado - um mês

- Grupo Tr 3: Treinado - três meses.

Protocolo de treinamento físico conforme descrito anteriormente.

\subsubsection{Morfologia cardíaca}

Esta análise foi realizada conforme descrito anteriormente

\subsubsection{Morfometria cardíaca}

O coraçao foi fixado em folmaldeído $6 \%$ e após a inclusão em parafina foram realizados cortes histológicos de $5 \mu \mathrm{m}$ de espessura, na posição da base do músculo papilar, que foram corados com hematoxilina e eosina (HE) ou com Periodic Acid Schiff (PAS) para visualização em microscópio óptico utilizando objetiva de imersão com aumento de 40x. Os miócitos selecionados para determinação do diâmetro apresentavam núcleo bem visivel e membrana 
celular intactos. Já os campos selecionados para determinar o número de capilares, eram aqueles que continham o maior numero de fibras transversais, geralmente na região do músculo papilar. A imagem do cardiomiócito foi obtida na tela do computador e o diâmetro transversal da cada miócito cardíaco isolado foi traçado manualmente utilizando-se o mouse do computador. A linha traçada atravessou o centro do núcleo do miócito e com a imagem digitalizada o computador calculou a área traçada através de um programa comercial (Quantimet 500, Cambridge Instruments). Foram determinados aproximadamente 20 campos visuais para cada corte histológico. O numero de capilares foi determinado em uma média de 5 a 8 campos visuais.

\subsubsection{Medidas hemodinâmicas}

PA e FC foram determinadas conforme descrito anteriormente.

\subsubsection{Avaliação da morfometria e Função ventricular pelo Ecocardiograma}

A avaliação da função ventricular foi realizada através de avaliação ecocardiográfica. As medidas ecocardiográficas seguiram as recomendações do Comitê de Padronização do modo $\mathrm{M}$ da Sociedade Americana de Ecocardiografia [168, 169]. É importante salientar que a acurácia e reprodutibilidade do exame ecocardiográfico transtorácico em estimar o tamanho e a função do ventrículo esquerdo em roedores têm sido confirmadas em uma série de estudos [170].

O exame ecocardiográfico transtorácico foi realizado após o período de treinamento físico ou sedentarismo nos grupos controle e treinado por oito semanas. Os exames foram realizados por um único observador, cego para o grupo de animais, e em cada exame foi coletado um total de cinco medidas para cada variável, sendo calculados posteriormente, a média, o desvio padrão e o erro padrão dessas medidas. O exame ecocardiográfico foi realizado com os animais anestesiados (ketamina $90 \mathrm{mg} / \mathrm{Kg}$ e xilasina $10 \mathrm{mg} / \mathrm{Kg}$, intraperitonial). Este animal anestesiado foi colocado em decúbito dorsal em uma mesa cirúrgica apropriada para o posicionamento do transdutor no hemitórax esquerdo do animal. Foi utilizado o equipamento SEQUOIA 512 (ACUSON Corporation, Mountain View, CA), com transdutor de $15 \mathrm{MHz}$. As imagens foram realizadas com freqüência de cerca de $10 \mathrm{MHz}$, para a otimização da resolução e a penetração no animal. Para registro das imagens foi utilizado gel de transmissão para ultrassom de viscosidade média/ alta (General Imaging Gel, ATL. Reedsville, USA). As imagens foram 
armazenadas em fitas de videocassete (Sony SVO-9500 MD), em discos ópticos (Sony 128Mb) e em papel fotográfico, geradas através da impressão colorida (Sony, Color Video Printer Mavigraph UP-5600 MDU).

A partir da visualização do ventrículo esquerdo (corte transversal) ao nível dos músculos papilares foi realizado o modo $\mathrm{M}$ e obtida às medidas das seguintes variáveis: diâmetro diastólico (DDiaVE) e sistólico (DSisVE) do ventrículo esquerdo, a espessura do septo interventricular na diástole (SIVEDia), a espessura do septo interventricular na sístole (SIVESis) e da parede posterior do ventrículo esquerdo em sístole (PPVESis) e diástole (PPVEDia). A função sistólica foi determinada pela fração de encurtamento (FEn) e fração de ejeção (FEj). Já as imagens obtidas através do Doppler foram utilizadas para determinar a função diastólica (pico de velocidade da onda $E$, pico de velocidade da onda $A$ e relação E/A). Além disso, calculamos a massa do ventrículo esquerdo (MVE) segundo orientação da Sociedade Americana de Ecocardiografia [168, 169], que estima a MVE através da utilização da seguinte fórmula matemática: $\mathrm{LVM}=\left[(\mathrm{DDVE}+\mathrm{SIV}+\mathrm{PP})^{3}-(\mathrm{DDVE})^{3}\right] \times 1,047$, onde $1,047\left(\mathrm{mg} / \mathrm{mm}^{3}\right)$ correspondem a densidade do miocárdio.

\subsection{Resultados e Discussão}

\subsubsection{Acompanhamento da medida de repetição máxima (RM).}

A figura 6A mostra os valores absolutos do RM dos grupos e a figura $6 \mathrm{~B}$ mostra os valores de RM corrigidos pela massa corporal. A primeira medida foi realizada no início do experimento, a segunda após quinze dias, depois de 1 mês , 2 meses e no $3^{\circ}$ mês de treinamento.

A figura 6A, mostra o aumento progressivo de carga absoluta, significantemente diferente, do teste de 1RM no grupo treinado. O peso corporal dos animais não variou ao longo do protocolo experiemntal conforme pode ser observado na Tabela 1, desta forma observa-se um aumento de carga absoluta e relativa (Figura 6B) ao longo dos 3 meses de treinamento. Os grupos CO e TR tiveram o mesmo RM antes do começo do protocolo experimental. Após 15 dias, o grupo TR aumentou o RM 76\% em relação ao teste inicial. Ao final do primeiro mês o grupo TR leventou uma carga de $1488 \pm 83 \mathrm{~g}$ e de $2350 \pm 108 \mathrm{~g}$ no final dos 3 meses de treinamento, o que representa 4,7 e 6,7 vezes o peso corporal de 1 e de 3 meses de treinamento, respectivamente. 
Nosso objetivo com esse resultado foi de mostrar a eficácia e a evolução do treinamento com a sobrecarga utilizada e demonstrar que não era devido a maturação dos animais. Como nos dois protocolos o aumento do RM nos grupos treinados foi maior que do grupo controle, acreditamos que a sobrecarga escolhida teve alguns efeitos sobre a musculatura esquelética.

A

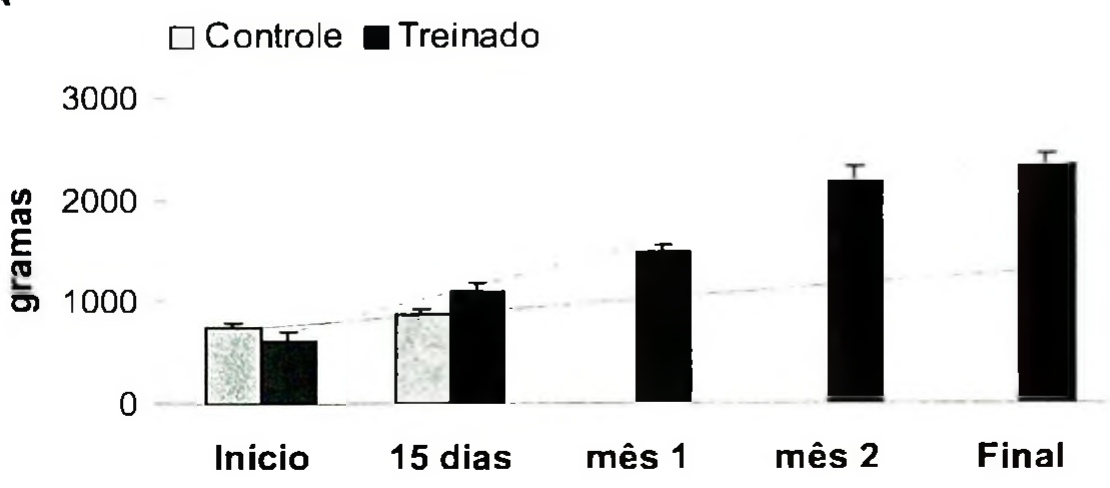

B

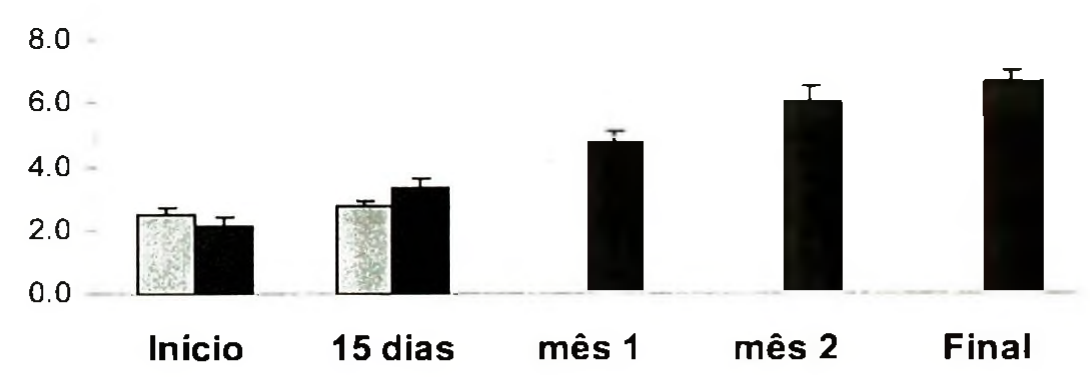

Figura 6A: Valor absoluto do RM. 6B: Relação RM/Massa corporal. Controle, $\mathrm{n}=8$; Treinado, $n=12$. Grupos de três meses. Valores expressos como média e desvio padrão.

\subsubsection{Medida direta da pressão arterial e freqüência cardíaca.}

Neste estudo, mais uma vez, os resultados de PA e FC foram consistentes com os observados anteriormente. Foi observada queda da pressão arterial com um mês de treinamento, porém ao final dos três meses de treinamento não foi observado queda nestes índices. A FC não foi alterada, conforem já havíamos observado anteriormente.

No grupo treinado de 1 mês, as figuras 7-1A, 7-1B, e 7-2 apresentam, respectivamente, os valores de PA e FC em repouso registrados com animal acordado por aproximadamente 30 
min. Essa análises foram realizadas ao final do período de treinamento. O grupo $\operatorname{Tr} 1$ apresentou diminuição da PAS, PAD e PAM $(15,8 \%, 18,8 \%$ e 17,3\%; p<0,01) em relação ao Co 1 e uma diminuição também na FC, porém não foi estatisticamente diferente $(7,4 \% ; p=0,10)$. No grupo de três meses, não houve diferença na PAS $(123,3 \pm 9,6 \mathrm{mmHg} \times 121,6 \pm 8,4 \mathrm{mmHg}), \operatorname{PAD}(97,4 \pm$ $8,6 \mathrm{mmHg} \times 94,7 \pm 9 \mathrm{mmHg})$, PAM e FC $(323,8 \pm 21,6 \mathrm{bpm} \times 317,6 \pm 33,4 \mathrm{bpm})$ entre os grupos Co 3 e $\operatorname{Tr} 3$.

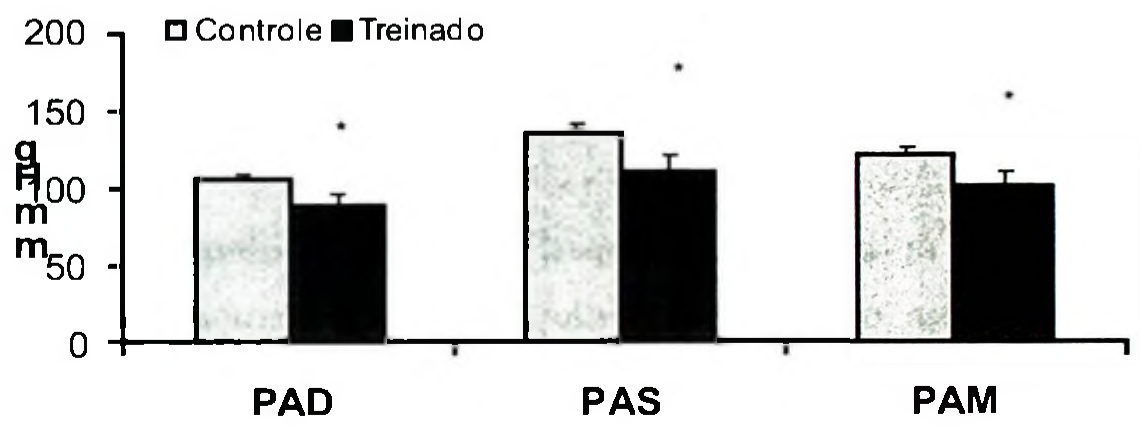

Figura 7-1A. Medidas de $\mathrm{PA}$ em repouso. Registro em animais acordados após Imês de treinamento. Co, $n=7$ e $\operatorname{Tr}, n=7$. Dados expressos como média e desvio padrão. (*) $p<0,01$.

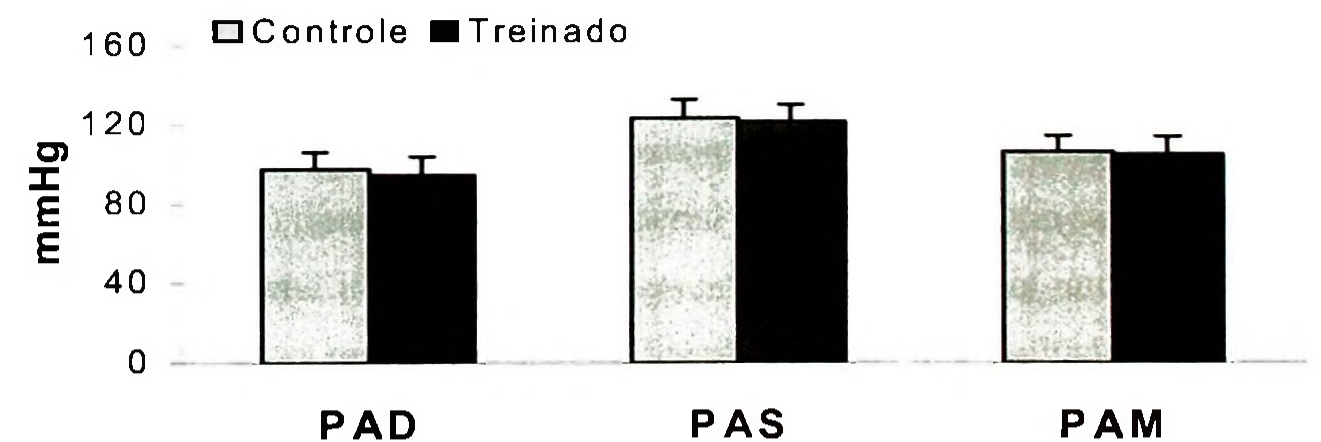

Figura 7-1B. Valores de PA em repouso. Registro em animais acordados após três meses de treinamento. $\mathrm{Co}, \mathrm{n}=6$ e $\mathrm{Tr}, \mathrm{n}=8$. Dados expressos como média e desvio padrão. 


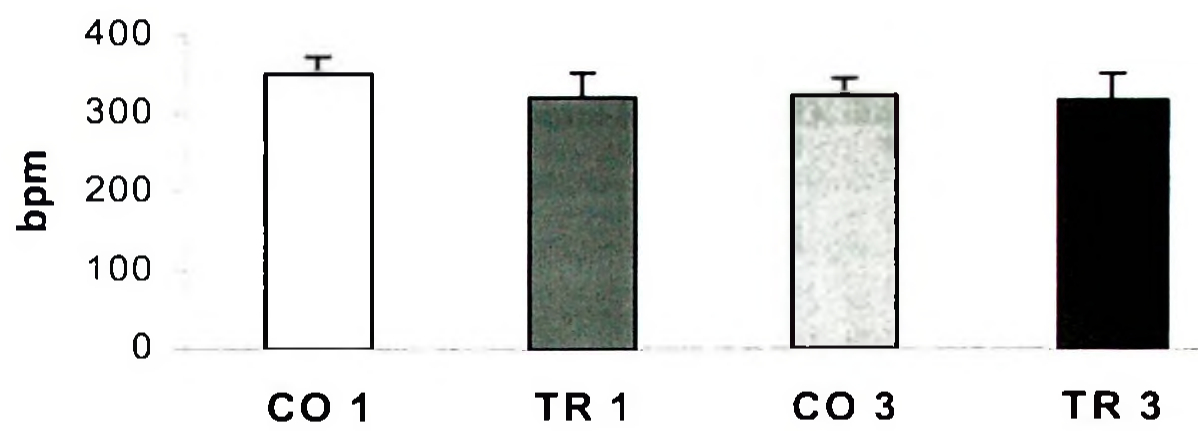

Figura 7-2. Medida de Freqüência Cardíaca. Animais acordados após 1 mês (Co $1, n=7$ e $\mathrm{Tr}$ $1, n=7$ ) ou três meses (Co 3, n=6 e $\mathrm{Tr}, \mathrm{n}=8$ ). Dados expressos como média e desvio padrão.

Resultados da pressão arterial e frequência cardiaca já discutimos anterioremnte. Conforme citado anteriormente resultados observados em um estudo de meta-análise, com estudos que realizavam treinamento resistido, foi mostrado que a diminuição da PA é comumente observada nos primeiros meses de treinamento. Da mesma forma, foram os resultados que encontramos neste estudo. No primeiro mês de treinamento foi obserdada queda da pressão arterial, e esse resultado confirmou o que já haviamos encontrado anteriormente. Entretanto, essa queda não foi mantida por um período mais prolongado, ou seja, até os três mese de treinamento, no animal normal. Assim, esses resultados corroboram dados mostrados anteriormente na literatura. Queiroz, AC et. al., 2009, [171] demonstraram que uma sessão aguda de treinamento resistido (50\% de $1 \mathrm{RM})$ diminuiu a pressão arterial clínica de indivíduo saudáveis e normotensos, e foi mais acentuada nos indivíduos que apresentavam níveis mais altos na pressão antes do treinamento. Assim, esses resultados estão de acordo com nossos resultados prévios e com dados da literatura.

Desta forma, estes resultados foram importantes, porque corroboram com os resultados encontrados nossos estudos prévios e mostram que este modelo e protocol de treinamento são confiáveis para investigação experimental.

\subsubsection{Hipertrofia cardíaca}

A hipertrofia cardíaca e a função ventricular foram acompanhadas com medidas por ecocardiografia durante os três meses do periodo experimental. Ao final do protocolo 
experimental utilizamos 3 diferentes métodos para determinar a hipertrofia cardíaca: 8A e B, massa so VE e Relação Parede/Cavidade medidos através do Ecocardiograma, $8 \mathrm{C}$, peso úmido dos ventrículos (peso do VE/peso corporal (mg/g), e 8D, diâmetro dos miócitos.

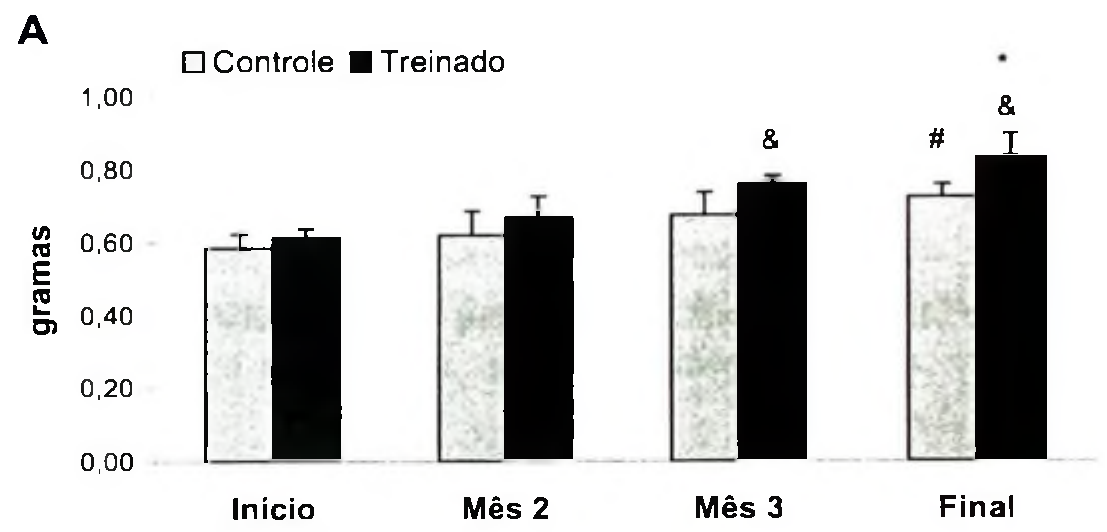

$\mathbf{B}$

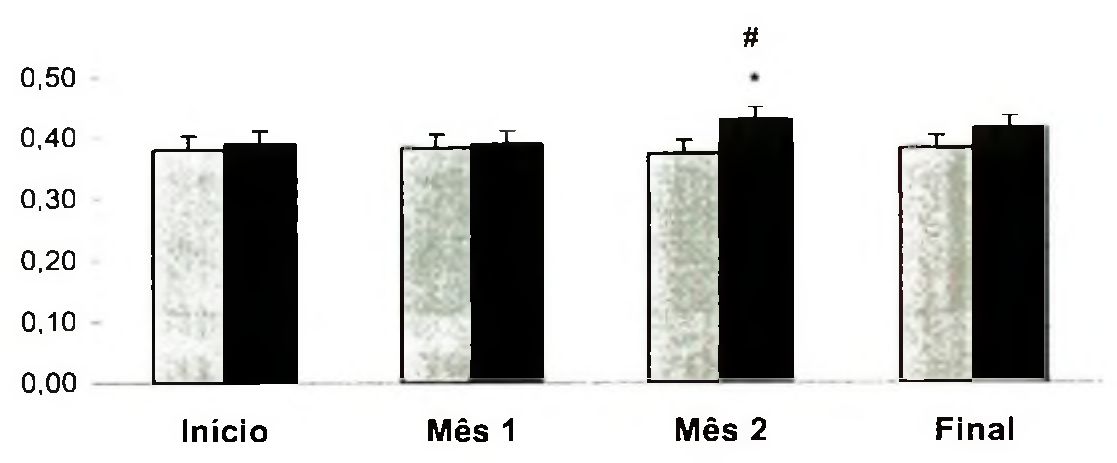

Figura 8A: Massa do VE. 8B: Relação paredes/cavidade. Valores calculados por fórmulas matemáticas apartir do Ecocardiograma. Figura 8A: \& $\mathrm{p}<0,01 \operatorname{Tr} \mathrm{x} \operatorname{Tr}$ no início; \# $\mathrm{p}<0,05$ Co $\mathrm{x}$ Co no início; ${ }^{*} \mathrm{p}<0,01$ Co $\mathrm{x}$ Tr. Figura 8B: \# $\mathrm{p}<0,05 \operatorname{Tr} \times \operatorname{Tr}$ no início e ${ }^{*} \mathrm{p}<0,01$ Co $\mathrm{x} \operatorname{Tr}$. Controle, $n=6$; Treinado, $n=6$. Dados expressos como média e desvio padrão. 


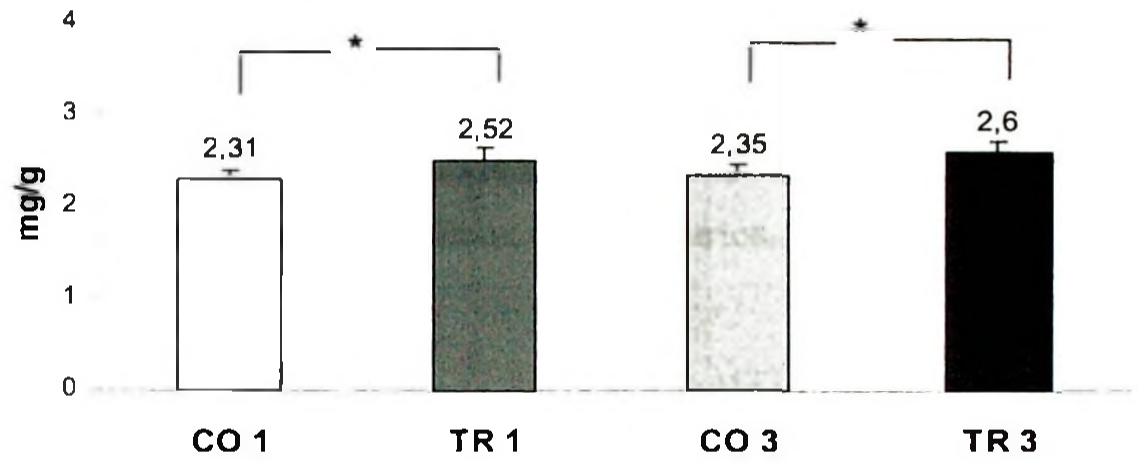

Figura 8C: Peso do VD+VE corrigido pela Massa Corporal. Co 1, $n=6$ e $\operatorname{Tr} 1, n=6$ (grupo quatro semanas); Co $3, n=6$ e $\operatorname{Tr} 3, n=8$ (grupo três meses). Dados expressos como média e desvio padrão. $\left({ }^{*}\right) \mathrm{p}<0,01$.

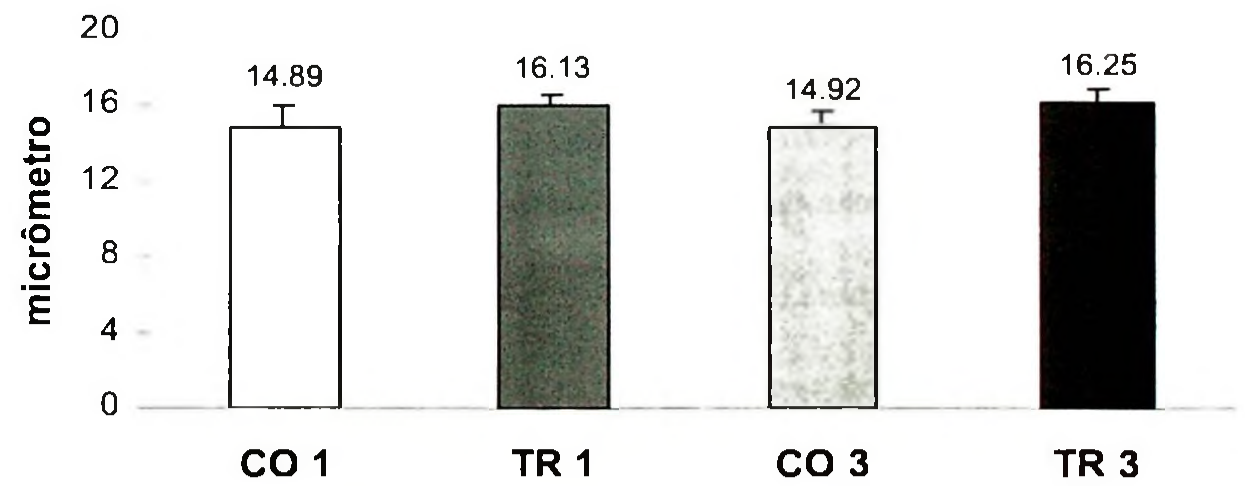

Figura 8D: Medida do diâmetro dos miócitos. Co $1, \mathrm{n}=6$ e $\operatorname{Tr} 1, \mathrm{n}=5$ (grupo de quatro semanas), $\mathrm{p}=0.056$. Co $3, \mathrm{n}=6$ e $\operatorname{Tr} 3, \mathrm{n}=6$ (grupo de três meses), $\mathrm{p}<0.05$ Dados expressos como média e desvio padrão.

Com um mês de treinamento obtivemos resultado semelhante pelos três métodos, sendo $8 \%$ na massa do VE pelo ecocardiograma, $8,8 \%$ pelo peso úmido e $8,3 \%$ pelo diâmetro dos cardiomiócitos. Com três meses de treinamento a hipertrofia foi maior, porém os valores obtidos foram um pouco diferentes, quando comparamos os resultados com essas três metodologias. Os resultados foram de $16 \%$ pela massa do VE pelo ecocardiograma, $11 \%$ pelo peso úmido e $9 \%$ pelo diâmetro dos cardiomiócitos. Esses valores de hipertrofia são semelhantes aos encontrados 
com humanos, não em valores absolutos, mas por estarem dentro dos limites da normalidade, ou seja, abaixo de valores encontrados em situações patológicas.

Pela medida obtida no ecocardiograma foi possivel separar a hipertrofia do septo interventricular da hipertrofia da parede livre do VE, observar a cavidade do VE e através dessa relação diferenciar entre hipertrofia excêntrica ou concêntrica.

Tabela2. Estrutura Cardíaca dos grupos Controle e Treinado nos 3 meses de treinamento.

Controle $(\mathbf{n}=8)$

Data

$0(\mathrm{mo})$

$1(\mathrm{mo})$

$2(\mathrm{mo}) \quad 3(\mathrm{mo})$

$\mathbf{0}(\mathrm{mo})$

$1(\mathrm{mo})$

2 (mo)

3 (mo)

\begin{tabular}{|c|c|c|c|c|c|c|c|c|}
\hline$\overline{D i a V E . c m ~}$ & $0.73 \pm 0.06$ & $0.72 \pm 0.05$ & $0.75 \pm 0.04$ & $0.77 \pm 0.03$ & $0.71 \pm 0.03$ & $0.72 \pm 0.04$ & $0.72 \pm 0.02$ & $0.75 \pm 0.03$ \\
\hline PPDia, $\mathrm{cm}$ & $0.138 \pm 0.008$ & $0.138 \pm 0.004$ & $0.140 \pm 0.002$ & $0.143 \pm 0.005$ & $0.138 \pm 0.005$ & $0.140 \pm 0.002$ & $0.155 \pm 0.005$ & $0.155 \pm 0.004$ \\
\hline jIVEDia,cm & $0.138 \pm 0.007$ & $0.138 \pm 0.004$ & $0.140 \pm 0.001$ & $0.143 \pm 0.006$ & $0.138 \pm 0.004$ & $0.140 \pm 0.002$ & $0.155 \pm 0.004^{*}$ & $0.155 \pm 0.005$ \\
\hline MVE, g & $0.59 \pm 0.04$ & $0.62 \pm 0.07$ & $0.68 \pm 0.06$ & $0.72 \pm 0.03$ & $0.61 \pm 0.02$ & $0.67 \pm 0.06$ & $0.76 \pm 0.02 *$ & $0.84 \pm 0.06$ \\
\hline ERP $g$ & $0.38 \pm 0.023$ & $0.38 \pm 0.022$ & $0.37 \pm 0.022$ & $0.37 \pm 0.024$ & $0.39 \pm 0.02 i$ & $0.39 \pm 0.022$ & $0.43 \pm 0.024^{*}$ & $0.42 \pm 0.022^{\star}$ \\
\hline
\end{tabular}

DDiaVE diâmetro diastólico do VE no final da diástole; PPDia, espessura da parede posterior do VE na diástole; SIVEDia , a espessura do septo interventricular na diástole ; LVM, left ventricular mass; $\mathrm{ERP}$, espessura relativa da parede. Results are presented as mean $\pm \mathrm{SD}$. ${ }^{*} \mathrm{P}<0.05, \mathrm{TR} \times \mathrm{CO}$ grupo da mesma idade.

A Tabela 2, mostra aumento do septo inter ventricula, da parede posterior e da espessura relativa da parede do VE a partir do segundo mês de treinamento, sem alteração no diâmetro diastólico do VE no final da diástole. Desta forma, caracterizando a hipertrofia como concêntrica, sem alteração no tamanho da câmara cardíaca. 
Tabela 3. Peso Corporal, Frequência Cardíaca e Função Cardíaca do grupos controle e treinados nos 3 meses de treinamento.

\begin{tabular}{|c|c|c|c|c|c|c|c|c|}
\hline \multirow[b]{2}{*}{ Dados } & \multicolumn{4}{|c|}{ Controle $(n=8)$} & \multicolumn{4}{|c|}{ Trainado $(n=12)$} \\
\hline & $0(\mathrm{mo})$ & $1(\mathrm{mo})$ & $2(\mathrm{mo})$ & $3(\mathrm{mo})$ & $0(\mathrm{mo})$ & $1(\mathrm{mo})$ & $2(\mathrm{mo})$ & $3(\mathrm{mo})$ \\
\hline $\mathrm{PC}, \mathrm{g}$ & $306 \pm 24$ & $326 \pm 23$ & $368 \pm 28$ & $370 \pm 21$ & $302 \pm 19$ & $321 \pm 24$ & $347 \pm 23$ & $350 \pm 37$ \\
\hline FC. bpm & $408 \pm 33$ & $420 \pm 15$ & $400 \pm 36$ & $423 \pm 21$ & $420 \pm 13$ & $410 \pm 17$ & $422 \pm 14$ & $417 \pm 19$ \\
\hline FEj VE, \% & $54.8 \pm 1.9$ & $55.1 \pm 1.8$ & $53.7 \pm 1.6$ & $52.3 \pm 0.9$ & $52.6 \pm 1.8$ & $54.9 \pm 1.9$ & $54.5 \pm 1.9$ & $52.7 \pm 0.9$ \\
\hline FEn VE, \% & $24.8 \pm 1.1$ & $24.9 \pm 1$ & $24.1 \pm 1$ & $23.3 \pm 0.4$ & $23.3 \pm 1.1$ & $24.8 \pm 1.1$ & $24.5 \pm 1.2$ & $23.5 \pm 0.5$ \\
\hline $\begin{array}{l}\text { VEFC, } \\
\text { circ/sec }\end{array}$ & $19.7 \pm 1.7$ & $20.2 \pm 0.8$ & $20.8 \pm 1.7$ & $17.4 \pm 0.5$ & $18.5 \pm 0.6$ & $21.1 \pm 0.5$ & $17.5 \pm 1.8$ & $17.6 \pm 0.8$ \\
\hline TRIV, ms & $20.8 \pm 3.1$ & $21 \pm 1.2$ & $20.4 \pm 1.5$ & $21 \pm 1$ & $19.7 \pm 2.1$ & $20.3 \pm 1$ & $22.4 \pm 1.6$ & $22 \pm 1.6$ \\
\hline
\end{tabular}

PC, Peso Corporal; FC, Frequência Cardiaca; Fej VE, Fração de Ejeção do Ventrículo Esquerdo; Fen VE, Fração de Encurtamento do Ventrículo Esquerdo; VEFC, Velocidade de Encurtamento das Fibras Circunferenciais; e TRIV, tempo de Relaxamento Isovolumétrico.

A função sistólica foi avaliada pela fração de encurtamento do VE (FEn), fração de ejeção (FEj) e pela velocidade média de encurtamento da fibras circuferenciais (VME). Os resultados estão apresentados na Tabela 3. Em nenhum dos três índices de função sistólica foram encontradas diferenças entre os grupos ou dentro do grupo ao longo do três meses de treinamento.

Para a determinação da função diastólica utilizamos o tempo de relaxamento isovolúmico (TRIV) e a velocidade de enchimento do VE sem distinção de enchimento rápido ou lento (foi usada a velocidade de fluxo mitral, que não variou entre os grupos). Os resultados estão mostrados na Tabela 3. Nestes resultados também não encontramos diferenças nos dois índices de função diastólica entre os grupos controle e treinado ou dentro do mesmo grupo ao longo dos três meses.

Outro resultado que também segue os estudos com humanos é a hipertrofia proporcional entre o septo intraventricular e a parede livre do VE. Essa hipertrofia nesse tipo de exercício 
deve-se, geralmente, às elevações intermitentes da PA durante a realização dos exercícios [172]. Alguns estudos descrevem esse espessamento como desproporcional o que possivelmente poderia indicar uma hipertrofia patológica [44]. Os estudos que mostram esse tipo de resultado são poucos e não mostram que possa ter algum efeito sobre a função ventricular.

O diâmetro da cavidade do VE é, talvez, um dos resultados mais interessantes. Existe uma grande preocupação com o diâmetro da cavidade ventricular de atletas que realizam treinamento de força, pois essa modalidade é caracterizada por uma sobrecarga pressórica no coração, como ocorre em algumas situações patologias, que levam o indivíduo a desenvolver hipertrofia concêntrica com diminuição da cavidade ventricular e conseqüentemente menor volume diastólico final. Nossos resultados não indicam nenhuma alteração no diâmetro da cavidade do VE ao longo dos três meses de treinamento. Sendo, então, as paredes mais espessas, a relação PPDia + SIvDia / DDiaVE ficou maior. Esses dois resultados em conjunto nos levam a classificar esse tipo de hipertrofia como concêntrica mostrando portanto que houve um aumento desproporcional das paredes do VE em relação ao diâmetro de sua cavidade. Apesar dessa classificação como concêntrica, não há diminuição da cavidade do VE como ocorrem em situações patológicas. Esses resultados corroboram com dados já existentes na literatura com humanos $[173,174]$.

A quantificação dos capilares cardíacos foi mais um indicio de que essa hipertrofia não foi patológica. Mesmo com três meses de treinamento, nenhuma diferença foi encontrada entre o grupo controle e treinado mostrando que o aporte de sangue ao músculo cardíaco não foi prejudicado. Como esse é o primeiro modelo utilizando essa forma de treinamento em animais, nenhum dado na literatura foi encontrado com treinamento de força.

Ainda foi analisada função ventricular pela fração de encurtamento, fração de ejeção (ambas são indices de função sistólica) e relação $\mathrm{E} / \mathrm{A}$ (índice de função diastólica). Concomitante ao exame ecocardiográfico, foi feito o registro de eletrocardiograma de maneira a garantir a mesma freqüência cardíaca em todos os grupos experimentais. Os resultados mostraram que não houve alterações na função sistólica e diastólica durante o período dos três meses de treinamento.

Os resultados publicados na literatura com humanos ainda são poucos, mas os nossos resultados estão em concordância com os mesmos $[44,175]$. Apesar de não termos encontrado 
nenhuma alteração em repouso, não podemos descartar a hipótese de que podem haver alterações funcionais durante a realização do exercício.

Assim, mostramos que o treinamento de força levou ao desenvolvimento de hipertrofia cardiaca concêntrica, mas com o tamanho da cavidade, da função ventricular e número de capilares preservado. Estes resultados estão de acordo com resultados encontrados para humanos na literatura, e desta forma estes foram estes resultados reforçaram a possibilidade de uso deste modelo para o estudo da hipertrofia ventricular fisiológica concêntrica. Este resultados foram publicados por Barauna et al., 2007 [176].

Uma vez conhecidos os efeitos promovidos por esse treinamento, e sabendo-se que no treinamento de força ocorre sobrecarga pressórica e que em determinadas patologias como na hipertensão arterial, a hipertrofia cardíaca é decorrente da mesma sobrecarga com a ativição do SRA, nosso próximo estudo foi testar a hipótese de que o SRA, através do receptor de Ang II do subtipo 1 (AT1) participe do desenvolvimento da hipertrofia cardíaca induzida pelo treinamento físico resistido em ratos Wistar.

Há um grande número de evidências, de que a Ang II produzida localmente no miocárdio contribua para o desenvolvimento da hipertrofia cardiaca em ratos espontaneamente hipertensos ou com constrição da aorta. Também tem sido demonstrado que a Ang II estimula a sintese protéica e o crescimento celular diretamente em miócitos via receptores AT1 [32, 177]. Essas evidências mostram a importância desse sistema na hipertrofia cardíaca patológica. Por outro lado, não está clara a participação do SRA no desenvolvimento da hipetrofia fisiológica como demonstrada pelo treinamento físico de força.

\subsection{Materiais e Métodos}

\subsubsection{Animais de experimentação}

Para esse estudo os animais foram distribuídos aleatoriamente entre os grupos abaixo descritos ( $n=8$ para cada grupo):

\section{Grupo Experimental 1:}

Grupo CO: Sedentário Controle

Grupo $\mathrm{CO}+\mathrm{SAL}$ : Sedentário Controle tratado com $\mathrm{NaCl} 1 \%$

Grupo TR: Treinado 
Grupo TR + SAL: Treinado tratado com $\mathrm{NaCl} 1 \%$

\section{Grupo Experimental 2:}

Grupo CO: Sedentário Controle

Grupo CO + LOS: Sedentário Controle tratado com Losartan (antagonista dos receptores de Ang II do subtipo 1)

Grupo TR: Treinado

Grupo TR + LOS: Treinado tratado com Losartan

Os animais receberam os tratamentos na água de beber desde o início da fase de adaptação, assim, quando o protocolo de treinamento iniciou-se, o sistema já estava inibido. Para estudarmos o SRA local foi utilizado o tratamento com dieta rica em sal ( $1 \%$ de $\mathrm{NaCl}$ na água) onde foi inibida a liberação de renina renal e conseqüentemente de todo o SRA circulante [68, 69]. Para avaliarmos a participação de um dos receptores de Ang II na hipertrofia desenvolvida durante o treinamento físico foi administrado um antagonista do receptor de Ang II do subtipo 1 (AT1), o Losartan $(20 \mathrm{mg} / \mathrm{Kg}$ ) [70]. Ambas as doses foram escolhidas por já estarem descritas na literatura como suficientes para bloquear o SRA sem interferir na pressão arterial. Mesmo assim a pressão arterial foi avaliada após o periodo experimental como será demonstrado na sessão de resultados. Entretanto, nós não sabiamos se essas doses interfeririam na pressão arterial desenvolvida durante a realização do exercício físico. Para responder essa questão, 12 animais foram divididos em três grupos: $\mathrm{CO}, \mathrm{n}=4$; Losartan, animais que foram tratados com losartan, $\mathrm{n}=4$; e Sal, animais que tiveram adicionado em sua água de beber $1 \%$ de $\mathrm{NaCl}, \mathrm{n}=4$. Após duas semanas de tratamento, a pressão arterial foi registrada durante a realização de uma sessão de treinamento, que consistiu em três séries de 12 repetições do movimento no aparato de treinamento.

\subsubsection{Protocolo de treinamento dos animais}

O protocolo de treinamento foi o mesmo utilizado nos trabalhos anteriores e os animais foram adaptados ao sistema de treinamento por 2 semanas e o protocolo de treinamento foi realizado por 10 semanas. 
Todas as metodologia já foram descritas anteriormente.

\subsection{Objetivos}

Assim, os como objetivos especificos deste estudo foram:

- Determinar o grau de hipertrofia cardiaca induzida pelo TR pela relação do peso do VE pelo peso corporal e por Ecocardiograma;

- Determinar a função sistólica e diastólica através do Ecocardiograma;

- Analisar as medidas hemodinâmicas, pressão arterial e freqüência cardiaca, através de medida direta nos animais durante a realização de uma sessão de treinamento e após o protocolo de TR;

- Verificar a participação do receptor AT1 na hipertrofia desenvolvida pelo treinamento resistido com a utilização de Losartan (antagonista do receptor de Ang II do subtipo 1, AT 1).

- Verificar a regulação dos componentes do SRA local na hipertrofia desenvolvida pelo treinamento resistido com a utilização de dieta rica em sal ( $1 \% \mathrm{de} \mathrm{NaCl}$ na água de beber para inibir a liberação de renina renal).

- Caracterizar a regulação dos componentes do SRA:

- Quantificar por técnica de Western blotting a Ang II local no coração e os receptores de Ang II AT1 e AT2.

- Determinar a atividade da ECA circulante e local no coração e ainda determinar a atividade da ECA nos rins e pulmão;

- Determinar a atividade da renina plasmática.

- Acompanhar a evolução de 1RM entre os grupos treinados. O RM será utilizado como marcador de evolução do treinamento nessa modalidade de treinamento físico.

\subsection{Resultados e Discussão}

Os resultados a seguir mostram a pressão arterial (PA) durante uma sessão de treinamento.

As Figuras 9A, 10A e11A mostram a PA absoluta atingida, respectivamente, na primeira, segunda e terceira séries de treinamento. As figuras representam a média da PA antes de iniciar 
cada repetição e o pico pressórico atingido durante a realização de cada uma das 12 repetições. Nota-se que não houve diferença entre os grupos, em nenhum momento, durante as três séries. Já as Figuras 9B, 10B e $11 \mathrm{~B}$ mostram o quanto à pressão arterial variou em cada repetição de cada uma das três séries entre o período antes de iniciar uma repetição e o pico atingido em cada repetição. Mais uma vez não houve diferença entre os grupos em nenhum momento. Além de mostrar que as doses não interferiram na pressão arterial desenvolvida durante a realização do exercício, as Figuras 9, 10 e 11 comprovam, mais uma vez, a resposta pressórica dessa modalidade de treinamento físico em um modelo animal semelhante à encontrada em humanos.
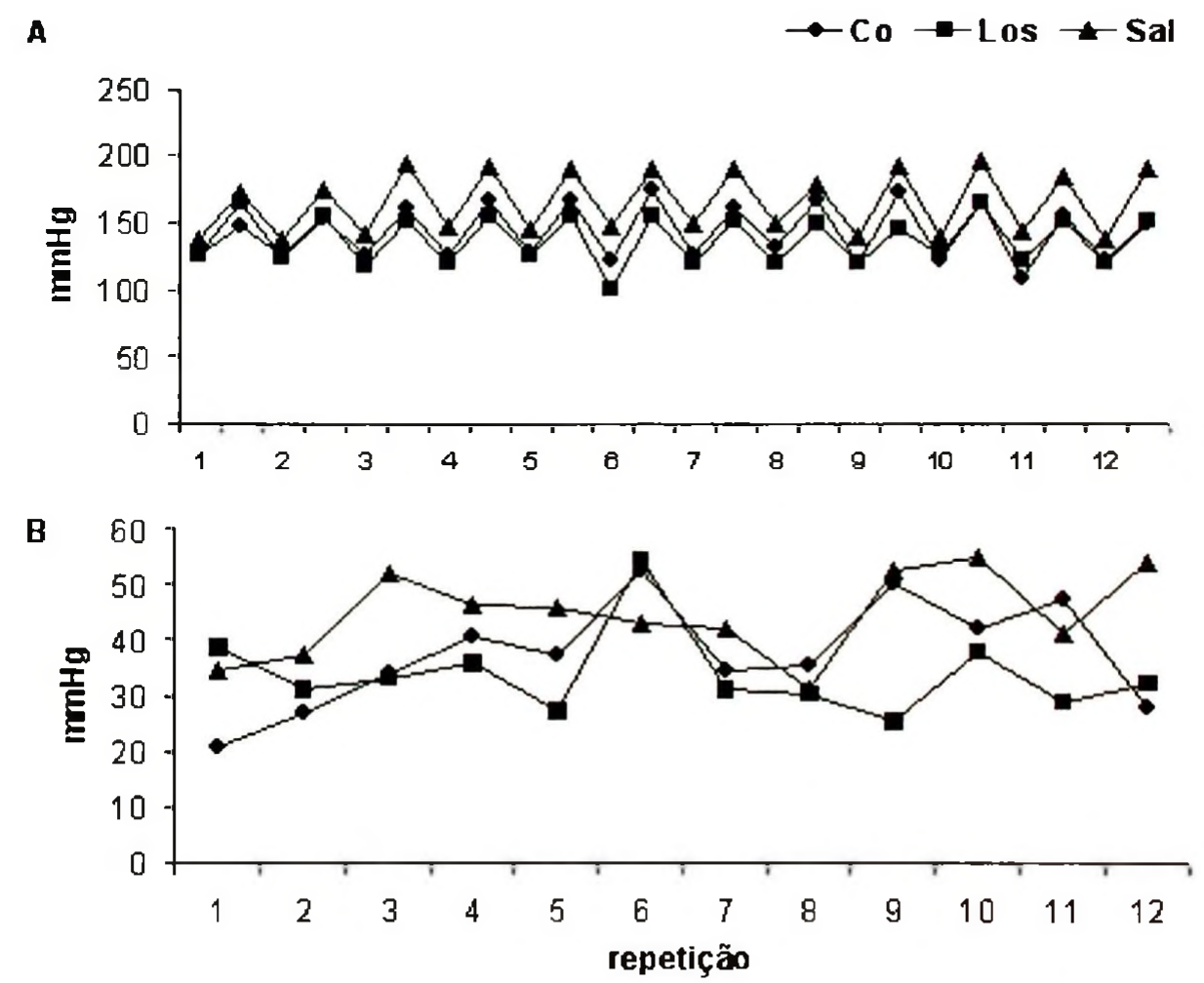

Figura 9. Resposta aguda da pressão arterial durante a realização da primeira série de exercício resistido. A: Valores absolutos de pressão arterial. Painel B: Variação da pressão arterial antes de iniciar cada repetição e o pico de pressão atingido em cada repetição. Os dados foram analisados pela análise de variância (ANOVA) de um caminho para medidas repetidas. 
A
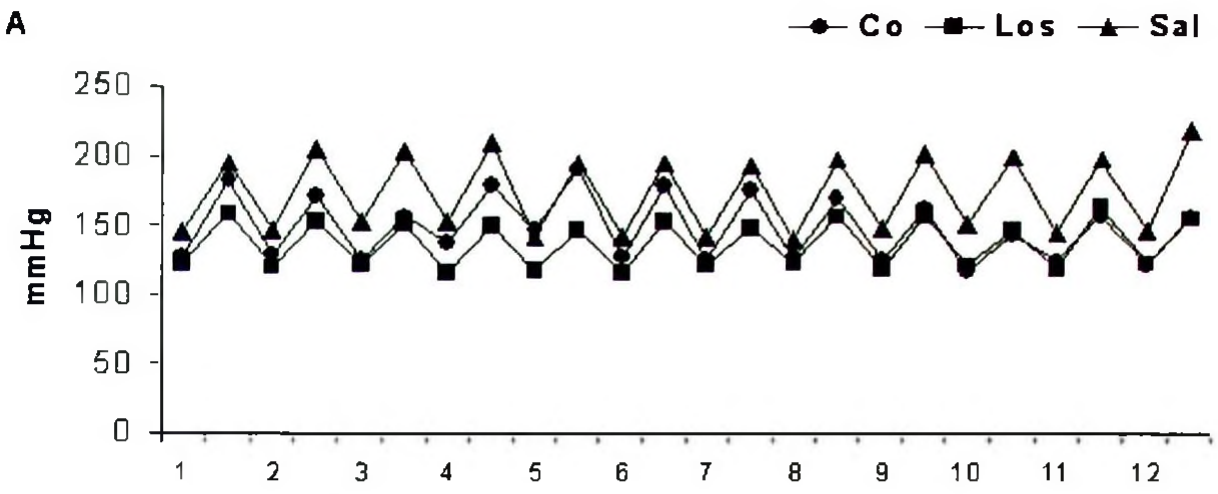

$\mathbf{B}$

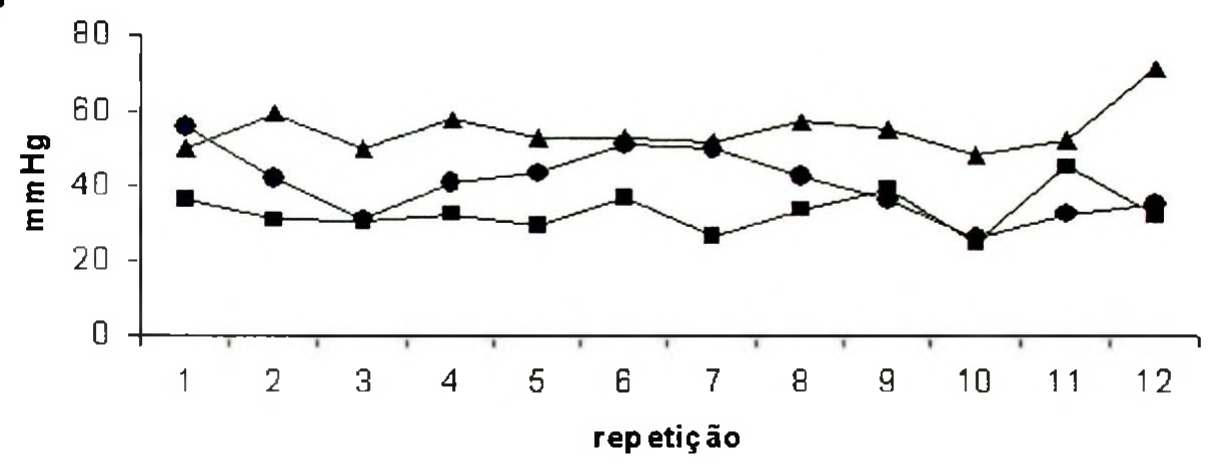

Figura 10. Resposta aguda da pressão arterial durante a realização da segunda série de exercício resistido. A: Valores absolutos de pressão arterial. B: Variação da pressão arterial antes de iniciar cada repetição e o pico de pressão atingido em cada repetição. Os dados foram analisados pela análise de variância (ANOVA) de um caminho para medidas repetidas. 

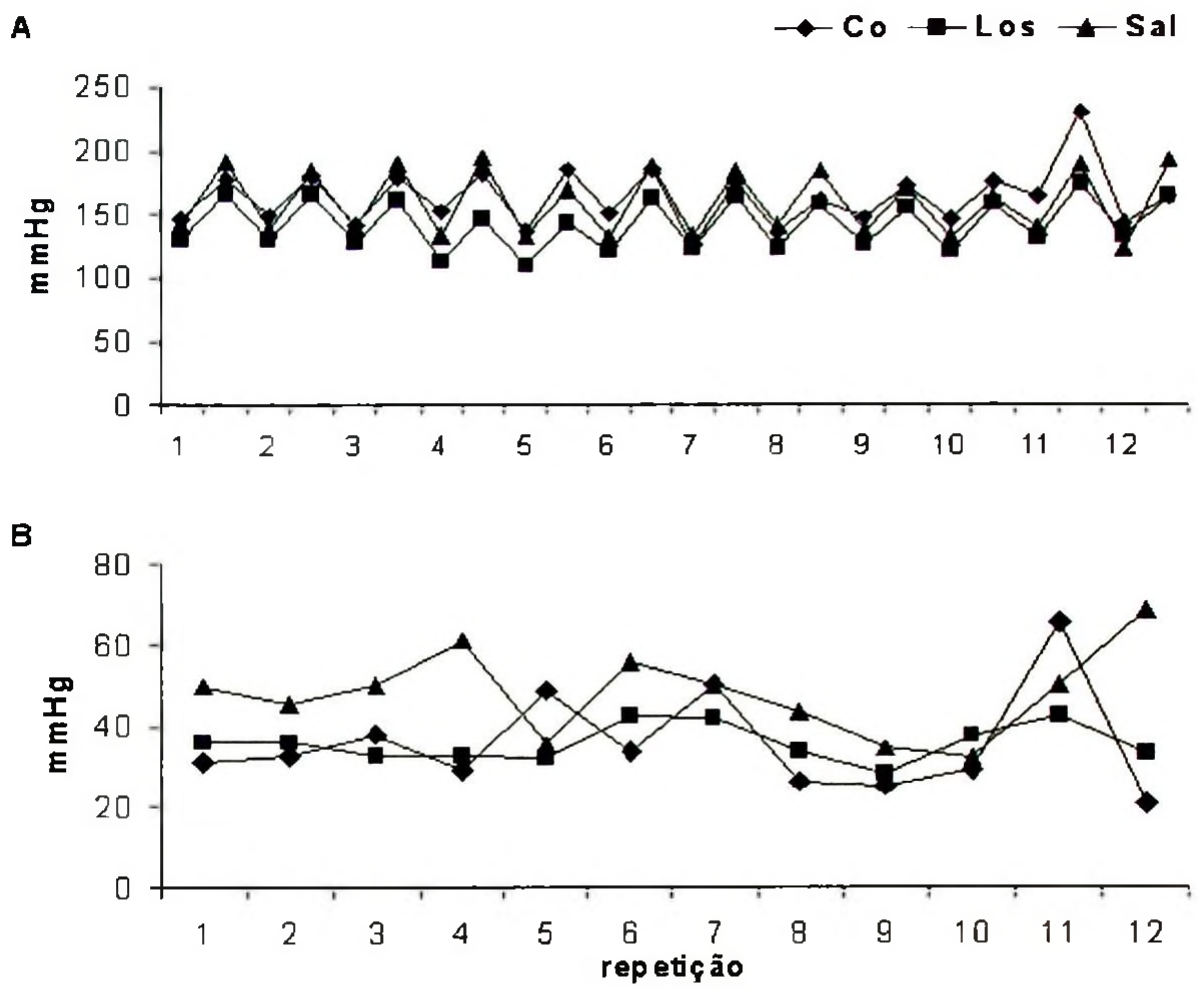

Figura 11. Resposta aguda da pressão arterial durante a realização da terceira série de exercício resistido. A: Valores absolutos de pressão arterial. B: Variação da pressão arterial entre de iniciar cada repetição e o pico de pressão atingido em cada repetição. Os dados foram analisados pela análise de variância (ANOVA) de um caminho para medidas repetidas.

Estes resultados iniciais foram importantes para demonstrar que o tratamento com losartan e sal, na dose utilizada, não interferem com o pico de pressão arterial desenvolvimento durante o treinamento.

\subsubsection{Teste de 1 RM}

A Figura 12 mostra o crescimento da carga elevada no teste de 1RM nos experimentos realizados no início do protocolo, com duas semanas, quatro semanas e ao final das oito semanas de treinamento. Observa-se que os três grupos de animais treinados iniciaram o protocolo com uma mesma carga e terminaram com cargas semelhantes entre os grupos, mas aproximadamente $115 \%$ maiores do que do início do protocolo. Para todos os grupos, a carga atingida em cada teste foi sempre maior que a carga do teste anterior, entretanto, não houve diferença entre os grupos para as cargas atingidas em cada teste. Relacionado com o peso corporal, nota-se que os 
animais iniciaram o protocolo com carga de aproximadamente 2,6 vezes o peso corporal e terminaram com aproximadamente 5,5 vezes o peso corporal.

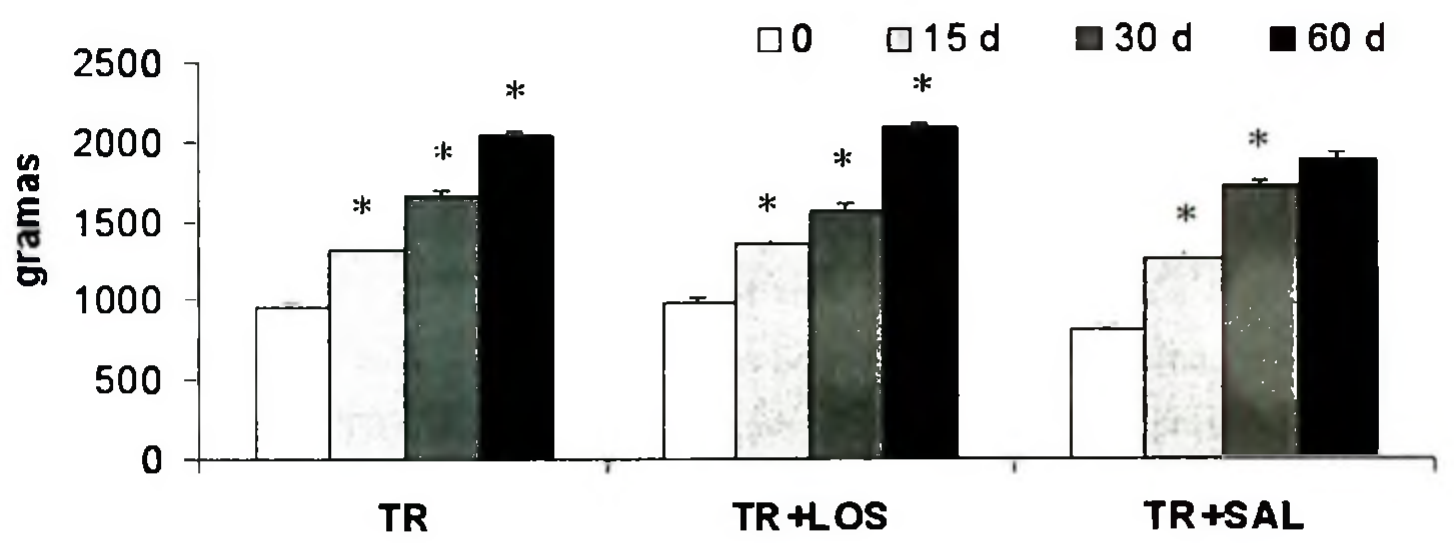

Figura 12. Evolução da carga do teste de 1RM. Os dados foram analisados pela análise de variância de 1-caminho para medidas repetidas com post-hoc de Duncan. ${ }^{*} \mathrm{p}<0,05$ vs o teste anterior.

\subsubsection{Medidas hemodinâmicas}

A Tabela 4 mostra os valores da medida direta da PAM e FC após as oito semanas de treinamento. Não houve diferença entre os grupos em nenhum dos dois parâmetros. $O$ fato da PAM não ter sido menor nos grupos tratados com Losartan ou maior nos grupos tratados com Sal confirmam os dados da literatura, que as doses utilizadas não interferem nas variáveis hemodinâmicas e conseqüentemente na sobrecarga cardiovascular.

Tabela 4. Pressão Arterial Média e Freqüência Cardíaca após oito semanas de treinamento.

\begin{tabular}{lcccccc}
\hline \multicolumn{1}{c}{ Medida } & CO & CO + LOS CO + SAL & TR & \multicolumn{2}{c}{ TR + LOS TR + SAL } \\
\hline Frequencia Cardiaca (bpm) & $341 \pm 8$ & $387 \pm 11$ & $344 \pm 10$ & $325 \pm 11$ & $377 \pm 28$ & $326 \pm 9$ \\
Pressão Arterial Média (mmHg) & $108 \pm 2$ & $109 \pm 4$ & $108 \pm 1$ & $106 \pm 1$ & $109 \pm 3$ & $104 \pm 3$ \\
\hline
\end{tabular}

Resultados estão apresentados como Média \pm Erro Padrão. Dados analisados pela análise de variância de 2-caminhos com post-hoc de Duncan. 


\subsubsection{Função ventricular}

A Tabela 5 resume os resultados da função ventricular analisada pela fração de encurtamento, fração de ejeção (ambas são função sistólica) e relação E/A (função diastólica). Concomitante ao exame ecocardiográfico, foi feito o registro de eletrocardiograma de maneira a garantir a mesma freqüência cardíaca em todos os grupos experimentais. $O$ resultado de freqüência cardíaca também está mostrado na Tabela 5 e não foi diferente entre os grupos.

Não houve diferença entre os grupos com relação a função sistólicas, porém, tanto os animais que só receberam a dieta salina quando os animais que receberam a dieta associada ao treinamento apresentaram menor relação das ondas E/A. Essa relação foi ainda menor no grupo $\mathrm{CO}+\mathrm{SAL}$ em relação ao TR+SAL, o que indica que o TR foi eficaz em prevenir, pelo menos parcialmente, essa deficiência diastólica apresentada pela dieta de $\mathrm{NaCl} 1 \%$.

Tabela 5. Freqüência Cardíaca e índices de função sistólica e diastólica obtidos pelo exame ecocardiográfico.

\begin{tabular}{ccccccc}
\hline Medida & CO & CO+LOS & CO+SAL & TR & TR+LOS & TR+SAL \\
\hline FC (bpm) & $241 \pm 4$ & $249 \pm 10$ & $240 \pm 16$ & $230 \pm 9$ & $245 \pm 13$ & $232 \pm 12$ \\
Funçao Sistólica: & & & & & & \\
FEn (\%) & $35,2 \pm 0,8$ & $36 \pm 2$ & $33,4 \pm 1,1$ & $36,8 \pm 1$ & $32,8 \pm 1,8$ & $36,2 \pm 1,4$ \\
FEj (\%) & $71,8 \pm 1,4$ & $71 \pm 2,5$ & $67,8 \pm 1,5$ & $72,2 \pm 1,2$ & $68,5 \pm 2,5$ & $72,4 \pm 1,8$ \\
VCF (m/ms) & $0,0045 \pm 0,00013,0043 \pm 0,00010,0043 \pm 0,0002], 0045 \pm 0,0002], 0043 \pm 0,00010,0048 \pm 0,0002$ \\
Função Diastólica: & & & & & & \\
Onda E (m/s) & $0,571 \pm 0,012$ & $0,624 \pm 0,010$ & $0,572 \pm 0,023$ & $0,570 \pm 0,017$ & $0,581 \pm 0,019$ & $0,553 \pm 0,013$ \\
Onda A (m/s) & $0,315 \pm 0,008$ & $0,348 \pm 0,009$ & $0,419 \pm 0,015$ & $0,306 \pm 0,008$ & $0,324 \pm 0,012$ & $0,360 \pm 0,014$ \\
Relação E/A & $1,81 \pm 0,015$ & $1,79 \pm 0,025$ & $1,37 \pm 0,027^{*}$ & $1,87 \pm 0,052$ & $1,79 \pm 0,036$ & $1,55 \pm 0,048^{*} \#$ \\
\hline
\end{tabular}

Média \pm Erro Padrão. Dados analisados pela análise de variância de 2-caminho com post-hoc de Duncan. ${ }^{*} \mathrm{p}<0,05$ vs $\mathrm{CO}, \mathrm{TR}, \mathrm{CO}+\mathrm{LOS}$ e TR+LOS; \# $\mathrm{p}<0,05$ vs $\mathrm{CO}+\mathrm{SAL}$

Do ponto de vista clínico, alguns trabalhos já haviam observado uma correlação positiva entre a excreção de sódio e a deficiência no enchimento ventricular. Apesar dos nossos resultados não terem identificado hipertrofia cardíaca no grupo $\mathrm{CO}+\mathrm{SAL}$, outros autores [178] descreveram essa disfunção diastólica em ratos que ingeriam $\mathrm{NaCl} 1 \%$ como conseqüência do 
desenvolvimento da hipertrofia cardíaca e não que a hipertrofia ocorra por mecanismo compensatório deste déficit.

Esse dado reforça o fato de que possa estar ocorrendo um acúmulo de tecido fibroso no coração como sugerido em estudos experimentais que observaram o aumento no mRNA para colágeno no VE [179] e aumento na concentração de hidroxiprolina [180]. Dados da literatura mostram que a fibrose intersticial difusa interfere no relaxamento ventricular [181].

Apesar desse modelo de exercício físico não melhorar a função diastólica como já descrito na literatura [182] e observado nos nossos resultados, o treinamento resistido parece reverter parcialmente esse prejuízo de relaxamento induzido pela administração de $\mathrm{NaCl} 1 \%$, como demonstrado pela relação E/A do grupo TR+SAL.

\subsubsection{Hipertrofia cardíaca}

A Figura 13 mostra os valores da massa do VE estimada pelo Ecocardiograma a partir da espessura da parede posterior, espessura do septo interventricular e diâmetro da cavidade obtido pelo modo $M$ do exame (TABELA 3). A massa do VE foi 12,3\% maior no grupo TR em relação ao $\mathrm{CO}$; a dieta de $\mathrm{NaCl} 1 \%$ aumentou a massa do $\mathrm{VE}$ em 12,6\% (CO+SAL x CO); e o treinamento associado á dieta de $\mathrm{NaCl} 1 \%$ aumentou a massa do VE em 22,2\% (TR+SAL x CO).

Não houve alteração no grupo CO+LOS e o tratamento com losartan inibiu completamente o aumento na massa do VE com o treinamento, como demonstrado pelo grupo TR+LOS. Analisando separadamente a espessura da parede posterior, do septo e a cavidade, somente o grupo TR+SAL mostrou aumento significativo em relação ao controle. O grupo TR e o CO+SAL, apesar de aumentarem a massa do VE, não tiveram aumento estatisticamente significante, quando as diferentes partes do coração foram analisadas separadamente (TABELA 3). Ainda, tanto o grupo CO+SAL, quanto o grupo TR+SAL mostraram aumento na espessura relativa da parede, o que caracteriza a hipertrofia cardíaca nesses grupos como concêntrica.

Ainda, observamos que mesmo sendo uma hipertrofia cardíaca concêntrica não ocorrem mudanças nos marcadores de hipertrofia cardíaca patológica como FNP (fator natriurético atrial) e razão $\alpha$-MCP (miosina de cadeia pesada) pela $\beta$-MCP [98], portanto essa hipertrofia cardíaca é caracterizada como fisiológica (resultados não mostrados). 


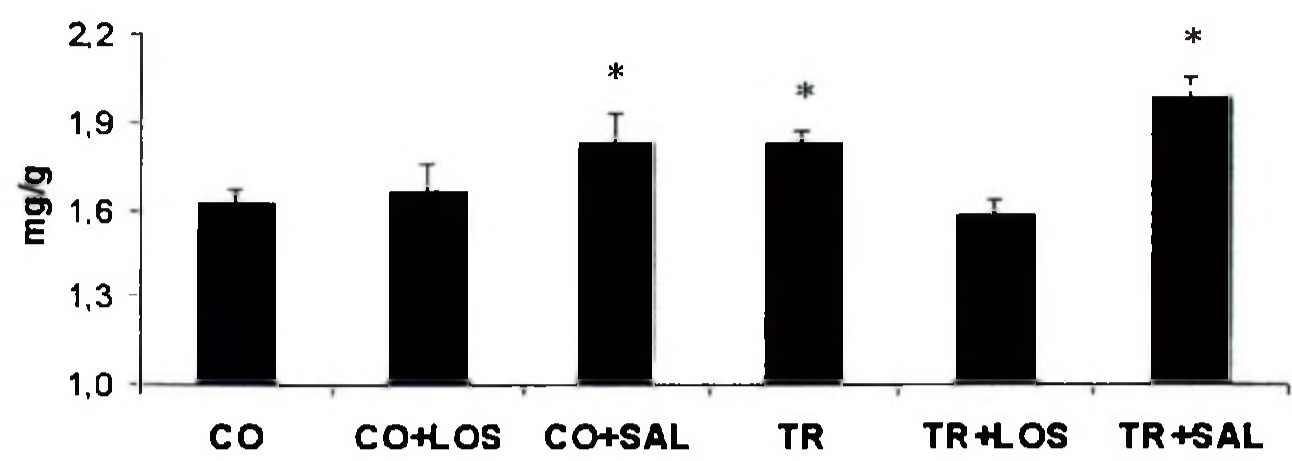

Figura 13. Massa do Ventrículo Esquerdo obtida pelo exame Ecocardiográfico. Os dados foram analisados pela análise de variância de 2 -caminhos com post-hoc de Duncan. ${ }^{*} \mathrm{p}<0,05$ vs grupo $\mathrm{CO}$.

Tabela 6. Espessura da Parede Posterior do VE (PPVEDia/PC), do Septo Interventricular (SIVEDia/PC) e da Cavidade Ventricular (VEDia/PC) corrigido pelo Peso Corporal.

\begin{tabular}{ccccccc}
\hline Medida & CO & CO+LOS & CO+SAL & TR & TR+LOS & TR+SAL \\
\hline PPVEDia / PC (cm/ $/ \mathrm{Kg})$ & $0,343 \pm 0,011$ & $0,338 \pm 0,011$ & $0,376 \pm 0,018$ & $0,363 \pm 0,009$ & $0,339 \pm 0,016$ & $0,394 \pm 0,015^{*}$ \\
SIVEDia / PC $(\mathrm{cm} / \mathrm{Kg})$ & $0,342 \pm 0.012$ & $0,339 \pm 0,010$ & $0,376 \pm 0,019$ & $0,364 \pm 0,009$ & $0,339 \pm 0,017$ & $0,394 \pm 0,014^{*}$ \\
VEDia / PC $(\mathrm{cm} / \mathrm{Kg})$ & $1,95 \pm 0.04$ & $1,98 \pm 0,06$ & $2,01 \pm 0,06$ & $2,04 \pm 0,04$ & $1,99 \pm 0,03$ & $2,12 \pm 0,07^{*}$ \\
ERP & $0,355 \pm 0,017$ & $0,344 \pm 0,015$ & $0,373 \pm 0,009^{*}$ & $0,358 \pm 0,010$ & $0,339 \pm 0,018$ & $0,375 \pm 0,024^{*}$
\end{tabular}

Média \pm Erro Padrão. Dados analisados pela análise de variância de 2-caminhos com post-hoc de Duncan. ${ }^{*} \mathrm{p}<0,05$ vs. grupo CO.

Já a Figura 14 mostra que o treinamento resistido induziu aumento na medida direta do VE corrigida pelo peso corporal (VE/PC) de $8,5 \%$ (TR vs CO) e de $10,6 \%$ no grupo treinado que recebia a dieta de $\mathrm{NaCl} 1 \%(\mathrm{TR}+\mathrm{SAL}$ vs CO). Além disso, o tratamento com Losartan inibiu totalmente a hipertrofia cardíaca induzida pelo treinamento como demonstrado pelo grupo TR+LOS. Nota-se também que não houve diferença entre nenhum dos grupos controle, tratados ou não (CO vs $\mathrm{CO}+\mathrm{LOS}$ vs $\mathrm{CO}+\mathrm{SAL})$. 


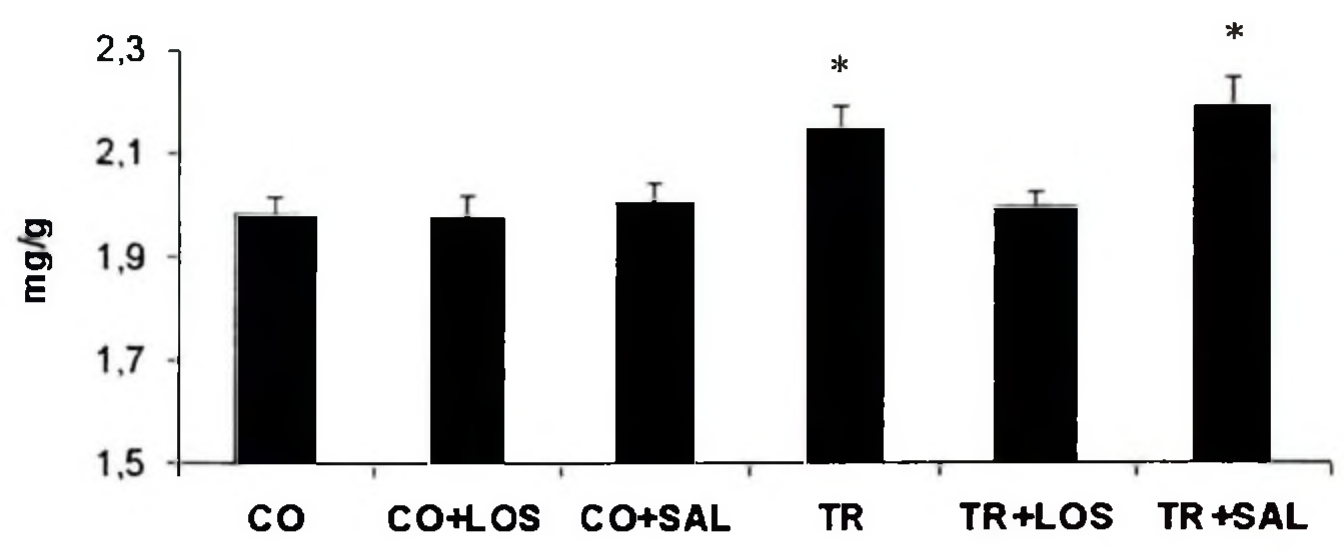

Figura 14. Massa ventricular obtida pela relação peso do VE/PC. Os dados foram analisados pela análise variância de 2 -caminhos com post-hoc de Duncan. ${ }^{*} \mathrm{p}<0,05$ vs CO, CO+LOS, CO+SAL e TR+LOS.

\subsubsection{Atividade da renina plasmática}

Como esperado, o tratamento com Sal inibiu quase que completamente a liberação e a atividade da renina plasmática (CO+SAL e TR+SAL vs. CO) e, também como esperado, o tratamento com o antagonista dos receptores AT1, Losartan, aumentou muito a atividade da renina plasmática (Figura 15).

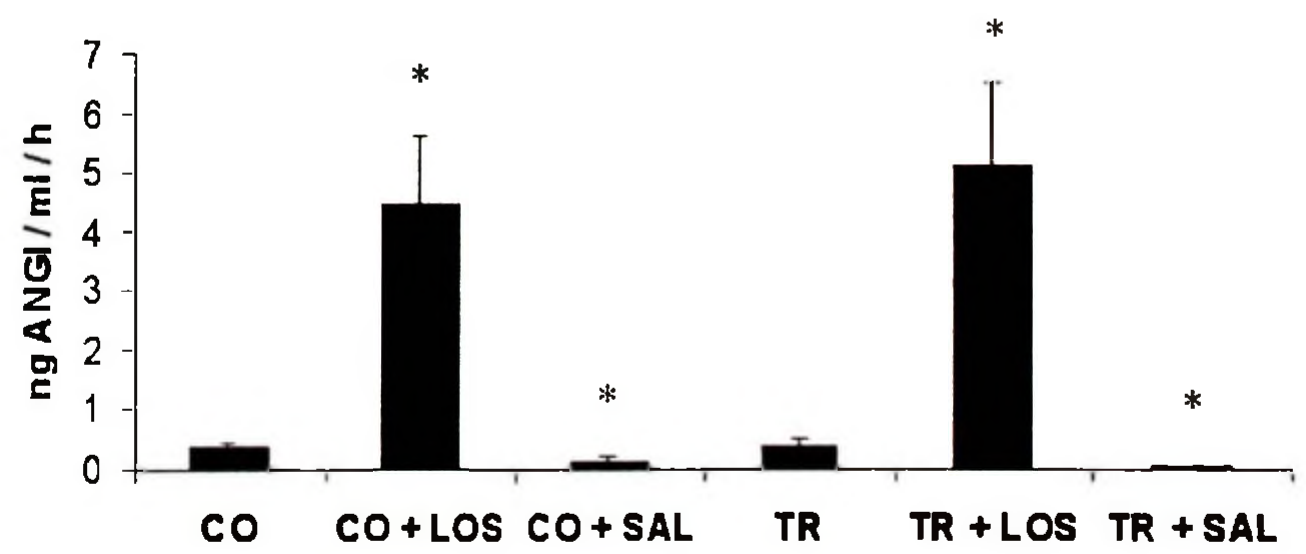

Figura 15. Atividade da Renina plasmática. Os dados foram analisados pela análise variância de 2-caminhos com post-hoc de Duncan. * $\mathrm{p}<0,05$ vs CO e TR. 


\subsubsection{Atividade da anzima conversora de angiotensina}

A Tabela 7 mostra a atividade da ECA no soro, pulmão, coração (VE) e rins. Nenhuma diferença foi encontrada na atividade enzimática entre os grupos no coração. Nos rins e pulmão, a única diferença estatística foi observada entre os grupos TR+SAL e CO+LOS. Já no soro, ambos os grupos treinado e sedentário que receberam o tratamento com Losartan, estavam com a atividade menor em relação a todos os outros grupos.

Tabela 7. Atividade da ECA Sistêmica e Local em diferentes tecidos.

\begin{tabular}{|c|c|c|c|c|c|}
\hline Grupo: & Tecido: & $\begin{array}{c}\text { Pulmão } \\
(\mathrm{UF} / \mathrm{min} / \mathrm{mg} / \mathrm{ml})\end{array}$ & $\begin{array}{c}\text { Rim } \\
(\mathrm{UF} / \mathrm{min} / \mathrm{mg} / \mathrm{ml})\end{array}$ & $\begin{array}{c}\text { Coração } \\
\text { (UF/min/mg/ml) }\end{array}$ & $\begin{array}{c}\text { Soro } \\
(\mathrm{NF} / \mathrm{min} / \mathrm{mg} / \mathrm{ml})\end{array}$ \\
\hline $\mathrm{CO}$ & & $176409 \pm 7888$ & $45123 \pm 3280$ & $15014 \pm 1109$ & $1793242 \pm 50891$ \\
\hline CO+LOS & & $214714 \pm 27523$ & $31107 \pm 4568$ & $15552 \pm 1498$ & $1350290 \pm 35729^{*}$ \\
\hline $\mathrm{CO}+\mathrm{SAL}$ & & $148158 \pm 14980$ & $52937 \pm 33956$ & $15557 \pm 308$ & $1745756 \pm 105147$ \\
\hline TR & & $170354 \pm 15616$ & $42309 \pm 4457$ & $15248 \pm+661$ & $1748543 \pm+69766$ \\
\hline TR+LOS & & $196614 \pm 15603$ & $49572 \pm 8450$ & $14087 \pm 1186$ & $1379356 \pm 85485^{*}$ \\
\hline$T R+S A L$ & & $159232 \pm 23094 \#$ & $55041 \pm 7213 \&$ & $15328 \pm 534$ & $1748284 \pm 99242$ \\
\hline
\end{tabular}

Os dados estão expressos como média \pm erro padrão. Dados analisados pela análise de variância de 2-caminhos com post-hoc de Duncan. ${ }^{*} \mathrm{p}<0,05$ vs. CO, TR, CO+SAL e TR+SAL; \# e \& $\mathrm{p}<$ 0.05 vs $\mathrm{CO}+\mathrm{LOS}$.

\subsubsection{Expressão das proteínas do SRA}

A Figura 16 mostra a expressão local no coração dos dois principais subtipos de receptores de Ang II, AT1 e AT2, e a expressão local também no coração, do peptídeo Ang II, nos grupos TR e CO. Os resultados mostraram o aumento de $31 \%$ na expressão dos receptores AT1. Não houve diferença na expressão do AT2 ou na expressão e concentração da Ang II no coração. 
A
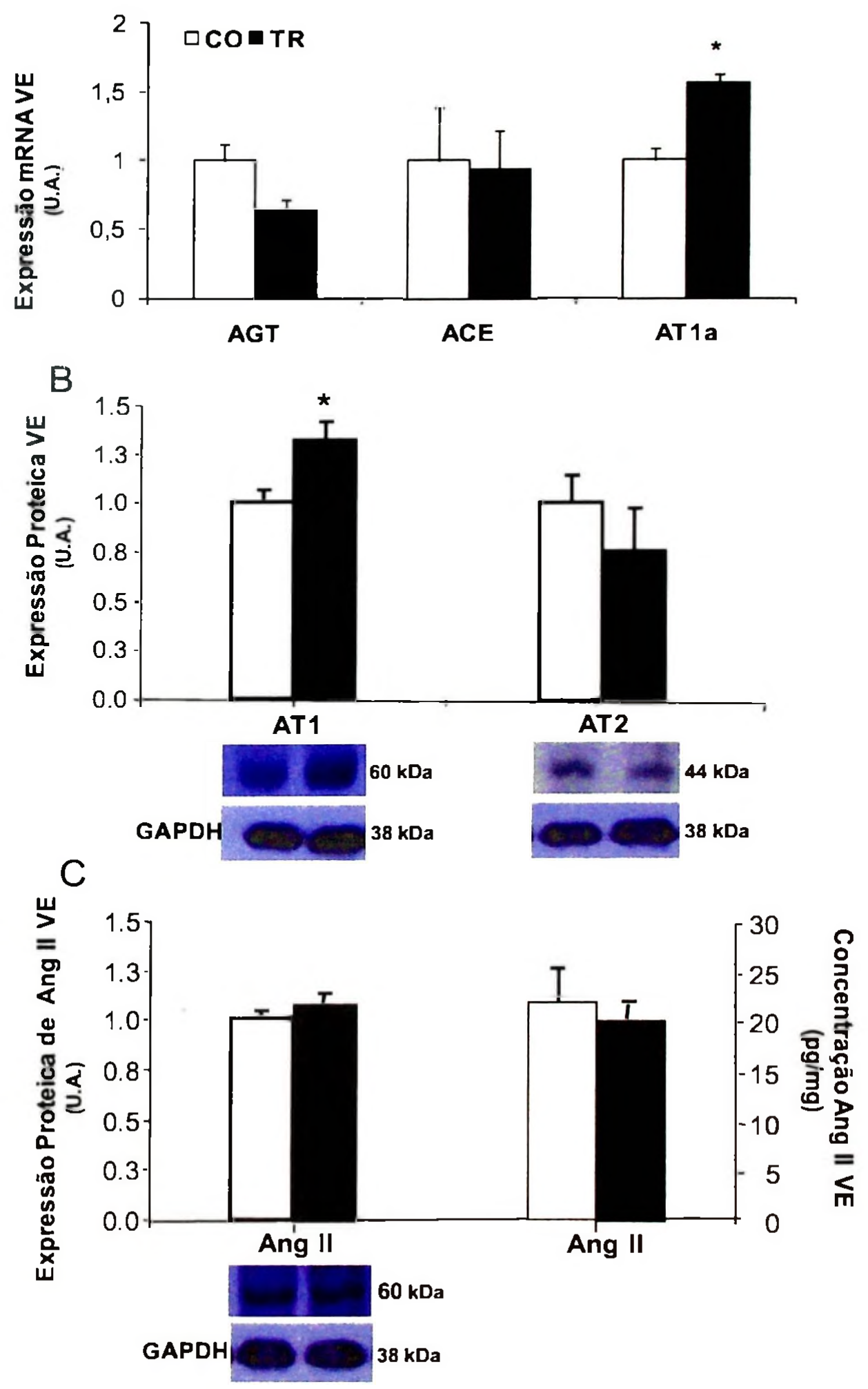
Figure 16. Efeitos do treinamento resistido sobre a expressão gênica e proteica. A) Efeitos do treinamento resistido sobre a expressão gênica do receptor AT1, ECA, e Angiotensinogênio (AGT) no ventrículo esquerde de ratos. Quantificação do AGT, ECA e ATl, respectivamente (normalizado pelo gene da ciclofilina). B) Efeitos do treinamento de resistência sobre a expressão de proteica dos receptores AT1 e AT2 no ventrículo esquerdo de ratos. Painel superior: quantificação da expressão proteica dos receptors AT1 e AT2, respectivamente (normalizados pelo gene do GAPDH). Painel inferior: Western blotting representative dos receptors AT1 e AT2. C) Concentração de Ang II no coração analisada por Western blotting (barras da esquerda) e por Imunoreatividade (barras da direita). Resultados apresentados como média \pm DP de 6 animais em cada grupo. ${ }^{*} \mathrm{P}<0.05 \mathrm{vs}$. grupo CO.

A participação do SRA ficou evidenciada pelas respostas de hipertrofia cardíaca dos grupos TR+SAL e TR+LOS. A participação do SRA local cardiaco seria a hipótese mais plausível, uma vez que a inibição da atividade da renina plasmática ( $T R+S A L)$ manteve o grau de hipertrofia cardíaca encontrado no grupo TR e foi bloqueada pelo uso do antagonista dos receptores AT1 (TR+LOS). Existe um grande número de evidências mostrando que a Ang II produzida localmente está diretamente envolvida na indução da hipertrofia cardiaca. Inibidores da ECA e antagonistas de receptores ATl previnem ou diminuem a hipertrofia cardíaca em humanos [183] e reduzem ou causam regressão da hipertrofia cardíaca em modelo experimental de coartação da aorta [184], mesmo em doses que não reduzem a pressão arterial [185]. Em alguns modelos experimentais, a regressão da hipertrofia cardíaca não está correlacionada com reduções na PA ou com a concentração plasmática de Ang II, mas com a redução na concentração cardíaca de Ang Il $[92,186,187]$. Entretanto, os dados da atividade da ECA e a concentração de Ang II local no coração não alterada questionam a participação do SRA local.

$\mathrm{O}$ aumento na atividade da ECA cardíaca não seria o fator fundamental para comprovar a participação do SRA local na hipertrofia cardíaca, uma vez que a Ang II pode ser formada por vias alternativas [188] ou mesmo dentro da célula [189] e ser liberada devido ao estresse mecânico sobre os cardiomiócitos [190,191]. Entretanto, essa hipótese também não parece estar ocorrendo, e mais uma vêz porque a concentração de Ang II no coração do grupo TR não está alterada em relação ao grupo $\mathrm{CO}$.

[192] questionaram a capacidade da Ang II liberada localmente, em resposta ao estiramento, em cultura de cardiómicitos em ativar a via de sinalização intracelular do receptor AT1. Apesar de constatarem a liberação de Ang II, os autores demonstraram que a concentração 
é muito baixa e não seria capaz de ativar a ERK 1/2, uma das principais vias da sinalização da hipertrofia cardiaca do receptor ATl [193]. Segundo esse trabalho, o estiramento de cardiomiócitos em cultura aumenta a concentração de $0,7 \times 10^{-12} \mathrm{M}$ para $2,0 \times 10^{-12} \mathrm{M}$, porém somente a partir de concentrações entre $10^{-11}$ e $10^{-10}$ são capazes de induzir a fosforilação das ERKs 1/2. Ainda, nesse trabalho foi demonstrado também que em cardiomiócitos de camundongos sem a expressão do angiotensingênio, o estiramento foi capaz de ativar a ERK $1 / 2$ tanto em neonatos quanto em adultos. Além disso, os autores ainda demonstraram que a hipertrofia cardíaca induzida por sobrecarga pressórica nesses animais foi prevenida com o tratamento de antagonista do receptor AT1. Já o estiramento, em células COS-7 com expressão aumentada dos receptores AT1, em meio de cultura sem Ang II, ativou essa via. Essa terceira hipótese pode explicar nossos resultados, que mostram, portanto, que a hipertrofia cardíaca induzida pelo treinamento resistido pode ocorrer através da ativação dos receptores AT1 pelo estresse mecânico, sem a necessidade do seu ligante Ang II. Essa hipótese é reforçada em nossos resultados pelo aumento da expressão proteica dos receptores ATl com o TR.

Apesar de ainda ser muito debatida na literatura a ação dos receptores de Ang II do subtipo Il (AT2), acredita-se que seus efeitos sejam contrários aos do AT1 e, portanto, esses seriam anti-hipertróficos. Uma diminuição da sua expressão no coração do grupo TR também poderia explicar a hipertrofia cardiaca encontrada, entretanto isso não foi observado.

Assim, poderiamos resumir os principais resultados encontrados nesta parte do estudo dizendo que treinamento resistido induziu hipertrofia cardiaca sem alterações na função ventricular. A hipertrofia cardiaca foi prevenida pelo uso do antagonista do receptor AT1 (Losartan) e foi observado um aumento de $31 \%$ na expressão protéica dos receptores AT1 com o treinamento. Todos os outros componentes do sistema estudados como, por exemplo, a expressão protéica dos receptores AT2, da Ang II cardiaca, a atividade da ECA em diversos tecidos e da renina plasmática não se modificaram com o treinamento. Além disso, essa hipertrofia cardíaca não foi alterada pela administração de $\mathrm{NaCl} 1 \%$, dose suficiente para inibir quase que totalmente a atividade da renina circulante, sugerindo que o mecanismo de regulação da hipertrofia cardíaca seja local e não sistêmico.

Esses resultados sugerem que o receptor AT1 participa da hipertrofia cardiaca induzida pelo treinamento resistido sem a necessidade da presença da angiotensina II. Um possivel 
mecanismo seria a ativação direta dos receptores ATl pelo estiramento mecânico dos cardiomiócitos.

Em conclusão, os resultados mostraram que:

O protocolo de treinamento resistido utilizado foi eficiente em induzir adaptações no músculo cardíaco, como sugerido pelo resultado de hipertrofia cardíaca analisada pela relação peso do VE/PC.

A utilização do antagonista do receptor AT1 (Losartan) inibiu a hipertrofia cardíaca, aumentou a atividade da renina plasmática e diminuiu a atividade da ECA circulante;

A administração de $\mathrm{NaCl} 1 \%$ manteve a hipertrofia cardíaca nos animais treinados mesmo com a inibição da renina plasmática;

Não houve alteração nos componentes do SRA, que foram estudados, nos animais do grupo treinado (atividade da renina, atividade da ECA, expressão cardíaca de AT2 e Ang II), exceto o aumento observado na expressão do receptor AT1.

Portanto, os resultados mostram que o TR levou ao desenvolvimento de hipertrofia cardíaca com a participação dos receptores AT1, possivelmente devido ao estresse mecânico sobre os cardiomiócitos e não pela participação dos componentes circulantes do SRA. Estes resultados foram publicados por Barauna et al., 2008 [98].

Uma vez que, os resultados mostraram a participação dos receptores AT1 na hipertrofia cardíaca induzida pelo treinamento resistido, a qual não apresenta características patológicas, nosso próximo objetivo foi investigar qual a via de sinalização intracelular que está sendo ativa pelo receptor AT1 nesta hipetrofia.

Um dos pontos fundamentais a ser atingido para o desenvolvimento da hipertrofia nos cardiomiócitos é o balanço positivo entre a síntese e a degradação de proteinas sarcoméricas. Esses mecanismos iniciam através de sinais bioquímicos que são mediados por receptores, canais iônicos ou por proteínas ancoradas na membrana, como as integrinas. De forma geral, receptores do tipo tirosina quinase são associados com a hipertrofia cardiaca fisiológica, enquanto, receptores acoplados a proteína $\mathrm{G}$ estão relacionados com a hipertrofia patológica [194, 195]. O receptor AT1 é um receptor acoplado a proteína $\mathrm{G}$, entretanto observamos com esse treinamento uma hipertrofia cardíaca fisiológica [98]. 
Vários estudos têm sido conduzidos utilizando o treinamento fisico aeróbio para mostrar a importância da via do receptor de tirosina quinase, o qual leva ativação da via PI3K-Akt-mTOR no desenvolvimento da hipertrofia cardiaca fisiológica [196-198], No entanto, ainda não estão bem descritos os mecanismos de sinalização celular da hipertrofia cardíaca induzida pelo treinamento físico de força, quando relacionados com a participação do receptor AT1 o qual está, classicamente, envolvido com a hipertrofia cardíaca patológica.

Assim, na sequência deste estudo, examinamos as prováveis vias de sinalização celular envolvida com a hipertrofia cardíaca fisiológica, como a via da PI3K-Akt-mTOR e o envolvimento do receptor AT1 nesta via. Resultados da literatura mostram uma relação da via fisiológica de hipertrofia PI3K-Akt-mTOR com o receptor AT1 [199]. Os autores observaram que a Ang II foi responsável por aumentar a atividade da PI3-K e a fosforilação da AKT, a qual foi bloqueada pelo wortmannin um inibidor da PI3-K, o mesmo acontecendo com o bloqueio do receptor AT1 pelo valsartan, o qual também diminui a ativação da PI3-K/AKT pela Ang II. Através de diversos experimentos foi mostrado que algumas isoformas de PKCs, as quais podem ser ativadas pelo receptor AT1, também são capazes de, independentemente da PI3-K, ativar a mTOR via PKC/c-Raf/MEK/ERK [200].

Além da via da PI3K-Akt-mTOR outras vias que podem ser ativadas pelo receptor ATI e estar envolvida com a hipertrofia cardíaca fisiológica provocada pelo treinamento de força é a via das MAPKs, uma classe de proteínas classificadas em três categorias, a família da c-Jun NH2terminal kinase (JNK), a família da quinase regulada extracelularmente (ERK) e a família da p38. Essas proteínas são conhecidas por participarem da ativação de determinados fatores de transcrição responsáveis por numerosos processos fisiológicos tais como proliferação, diferenciação, inflamação, apoptose e hipertrofia [201]. Atualmente, não se sabe se existe relação direta da JNK, ERK e p38 nas adaptações provocadas pelo exercício físico ou em situações patológicas. Contudo, algumas evidências têm mostrado que estas quinases podem ter múltiplas funções na regulação gênica em resposta ao exercício físico [202].

\subsection{Objetivos}

Com isso, nosso objetivo foi estudar as vias celulares relacionadas com o aumento da síntese de proteína que são ativas com o exercício físico de força e a participação do receptor 
AT I na ativação dessas vias intracelular em ratos submetidos a uma sessão aguda de exercício de força.

Desta forma, verificamos através da expressão protéica, por técnica de Western blotting, a fosforilação das MAPKs: ERK, P38, JNK e AKT/mTor após 5 e 30 minutos da realização de um protocolo de exercício de força.

\subsection{Materiais e Métodos}

\subsubsection{Animais de experimentação}

Para esse protocolo experimental foram realizados os seguintes grupos de animais:

- controle $(\mathrm{CO}, \mathrm{n}=6)$,

- controle losartan (CO Los, $n=6$ ),

- exercitado e sacrificado 5 min após o exercício (Exe $5, \mathrm{n}=6$ ),

- tratado com losartan, exercitado e sacrificado 5 min após o exercicio (Exe 5 Los, $n=6$ ),

- exercitado e sacrificado 30 min após o exercício (Exe 30, $n=6$ ),

- tratado com losartan, exercitado e sacrificado 30 min após o exercício (Exe 30 Los, $n=6$ ).

O losartan $(20 \mathrm{mg} / \mathrm{Kg})$ foi colocado na água de beber dos animais com dose que sabidamente bloqueia o receptor AT1, sem interferir na pressão arterial [70], durante a semana que antecedeu ao protocolo de exercício. Todos os animais foram alojados em gaiolas individuais, receberam água e ração própria ad libitum, foram mantidos em ambiente com temperatura média de aproximadamente $25^{\circ} \mathrm{C}$ e submetidos a um regime de 12 horas claro/escuro, durante o período do experimento.

\subsubsection{Protocolo de exercício físico de força.}

Os animais foram adaptados ao aparato de treinamento por 4 dias, $1 \mathrm{x} / \mathrm{dia}$, com um dia de recuperação entre o terceiro e o quarto dia. Os animais foram colocados no sistema de treinamento e adaptados com 4 séries de 12 repetições, com intervalo de 1 min e 30 s. No dia seguinte ao último dia de adaptação foi realizado um teste de 1RM.

Quarenta e oito horas após o teste os animais realizaram a sessão de exercício de força com sobrecarga de $80 \%$ de 1RM. Após a sessão, cada animal foi anestesiado com éter e decapitado, o coração do animal foi retirado e as câmaras separadas em ventrículo esquerdo (VE) 
e ventrículo direito (VD) para pesagem e somente o VE foi colocado em solução tampão, homogeneizado e adequadamente armazenadas em freezer $\left(-20^{\circ} \mathrm{C}\right)$ para posterior análise.

\subsubsection{Análise da expressão protéica}

As amostras coletadas foram imediatamente homogeneizadas em tampão de extração contendo um coquitel de inibidores de angiotensinases e proteases (Trisma base $100 \mathrm{mM}$, SDS $10 \%$, para-hidroximercuriobenzoato (p-OHHgBz) $1 \mathrm{mM}$; fenilmetilsulfonilfluoreto (PMSF) $1 \mathrm{mM}$; pepstatina A $1 \mathrm{mM}$; orto-fenantrolina $30 \mathrm{mM}$ e ácido etilendinitrolotetracético (EDTA) $10 \mathrm{mM}$ ) e colocadas em banho a $100^{\circ} \mathrm{C}$ por $10 \mathrm{~min}$. As amostras foram mantidas no gelo e centrifugadas (3.000 rpm X $10 \mathrm{~min}$ ) e mantidas a $-20^{\circ} \mathrm{C}$. Os homogenatos foram centrifugados por $40 \mathrm{~min}$, a $12.000 \mathrm{rpm}$, a $4^{\circ} \mathrm{C}$. O sobrenadante foi retirado, diluído em tampão Laemmli na proporção de 1:4 e aquecidos em água fervente por 5 min [203] para ser posteriormente submetido à eletroforese em gel de poliacrilamida (SDS-PAGE 8\%) no aparelho para minigel (Mini-Protean).

A transferência das proteinas separadas no gel foi feita eletricamente para uma membrana de nitrocelulose utilizando-se um aparelho da Bio-Rad por aproximadamente $2 \mathrm{~h}$ sob 120 volts [204]. As membranas foram bloqueadas pela incubação com $10 \mathrm{ml}$ de solução bloqueadora (leite desnatado Molico $5 \%$, Tris $10 \mathrm{mM}, \mathrm{NaCl} 150 \mathrm{mM}$ e Tween $200,02 \%$ ) a $4^{\circ} \mathrm{C}$ overnight ou por $2 \mathrm{~h}$ na temperatura ambiente. Estas membranas foram posteriormente incubadas a $4^{\circ} \mathrm{C}$ com $\mathrm{o}$ anticorpo para AKT total e AKT fosforilada, mTOR total e mTOR fosforilada, ERK total e ERK fosforilada, P38 total e P38 fosforilada, JNK total e JNK fosforilada (abcam) (1:1000) diluído em solução bloqueadora (leite desnatado Molico 3\%, Tris 10mM, NaCl 150 mM e Tween 20 0,02\%).

A seguir, as membranas foram lavadas três vezes por dez minutos com solução basal. As bandas existentes nas membranas incubadas foram visualizadas através do uso do Kit para deteç̧ão por quimioluminescência. O método de quimioluminescência consiste nos seguintes passos: após incubação da membrana com o anticorpo primário, a membrana foi novamente incubada por $1 \mathrm{~h}$ com $\mathrm{o}$ anticorpo secundário anti-rabbit marcado com HRP (horseradish peroxidase) em solução bloqueadora (1:2000). A seguir, as membranas foram lavadas novamente três vezes com solução basal e incubadas com $1 \mathrm{ml}$ de cada um dos dois reagentes do kit por 1 minuto, e a seguir os filmes de raio-X foram expostos às membranas. Esta exposição pode durar 
entre 30 segundos e dois minutos. Para quantificar a intensidade das bandas nas auto-radiografias, as figuras escaneadas foram analisadas utilizando o programa de análise de densitometria óptica Scion lmage, fornecido gratuitamente pela NIH (USA) via internet.

\subsubsection{Análise estatística}

A comparação entre os grupos foi feita pela ANOVA two-way. O teste de pos hoc de Duncan foi usado para comparação entre as medias, quando foram observadas mudanças significante com ANOVA. Foi adotado para todos os experimentos um $p \leq 0,05$ de significância. Todos os resultados estão apresentados na forma de média \pm desvio padrão.

\subsection{Resultados e Discussão}

A Figura 17 demonstra o resultado da fosforilação da proteína AKT(Ser $\left.{ }^{473}\right)$ no ventrículo esquerdo de ratos. No grupo Exe 5 e Exe 30 houve um aumento de 62,6\% e 62,4\% na fosforilação da proteína AKT, quando comparado ao grupo controle, respectivamente, sendo este efeito bloqueado pelo losartana no grupo Exe 5 Los $(60,6 \%)$ e Exe 30 Los $(78,5 \%)$. Estes resultados monstram que o receptor ATl desempenha uma importante função na ativação da AKT após uma sessão de exercício de força (Figura 17 A-B, $\mathrm{P}<0,05$ ). 
$1 \mathrm{~A}$

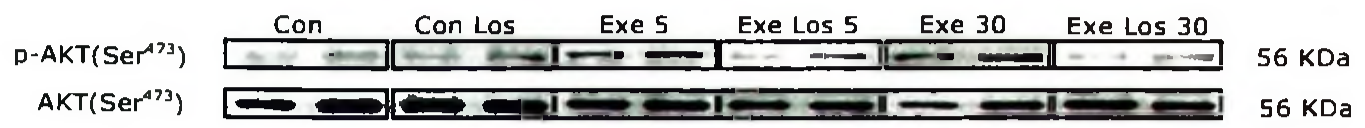

1B

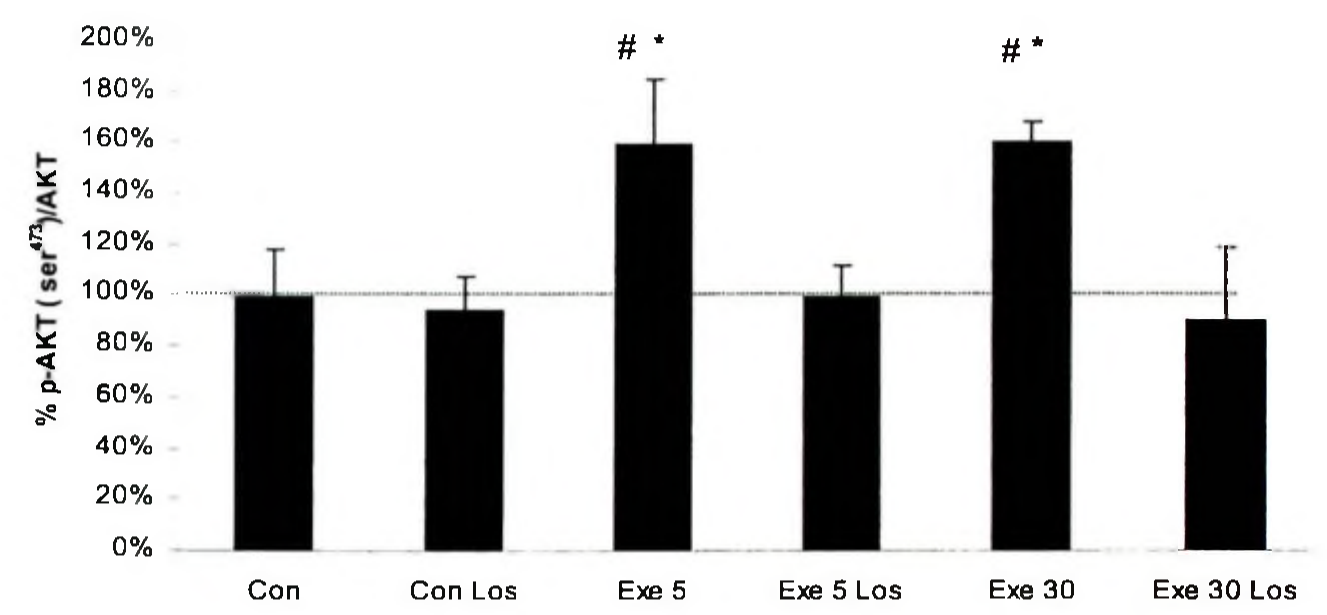

Figura 17. A. Bandas representativas do Western blotting das proteínas totais e fosforilada. Con, controle; Exe 5, exercitado e sacrificado 5 minutos após o exercício; Exe 30, exercitado e sacrificado 30 minutos após o exercício; con Los, controle Losartana; Exe 5 Los, tratado com losartana, exercitado e sacrificado 5 minutos após o exercício; Exe 30 Los, tratado com losartana, exercitado e sacrificado 30 minutos após o exercício B. Efeito de uma sessão de exercício de força na fosforilaçaõ da AKT(Ser ${ }^{473}$ ) no VE (normalizados pela proteína total). Dados estão expressos como média \pm desvio padrão, com 6 animais em cada grupo. ${ }^{*} \mathrm{P}<0,05$ vs. grupos cont ou cont los. \#P $<0,05$ vs. grupos Exe 5 ou Exe 30 Los.

A proteína mTOR, alvo de fosforilação da proteína AKT aumentou $64,5 \%$, somente no grupo Exe 30, quando comparado com o grupo controle (Figura $18 \mathrm{~A}-\mathrm{B}, \mathrm{P}<0,05$ ), sendo observada uma diferença na fosforilação da mTOR entre o grupo Exe 30 e o grupo Exe 30 Los $(67,8 \%)$, indicando que o receptor ATl participa da ativação da AKT/mTOR após uma sessão de exercício de força. 


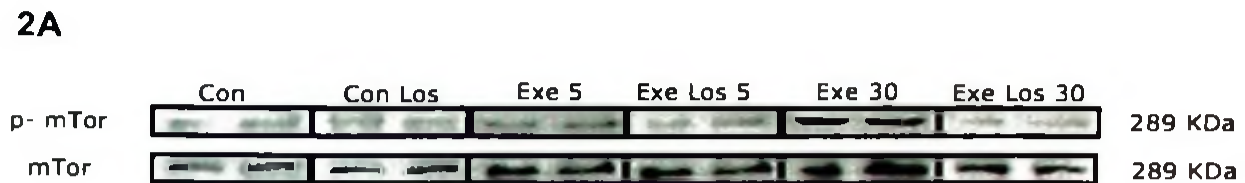

2B

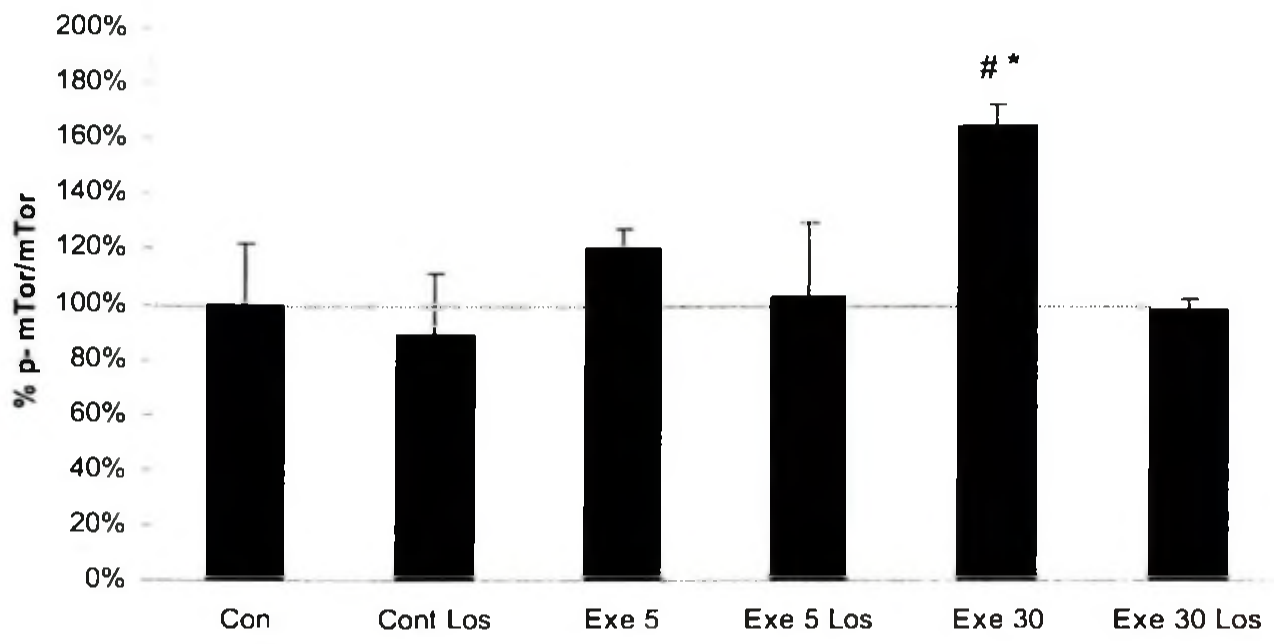

Figura 18. A. Bandas representativas do Western bloting das proteinas totais e fosforilada. Con, controle; Exe 5, exercitado e sacrificado 5 minutos após o exercício; Exe 30, exercitado e sacrificado 30 minutos após o exercício; Con Los, controle Losartana; Exe 5 Los, tratado com losartana, exercitado e sacrificado 5 minutos após o exercício; Exe 30 Los, tratado com losartana, exercitado e sacrificado 30 minutos após o exercício B. Efeito de uma sessão de exercício de força na fosforilaçaõ da mTor no VE (normalizados pela proteína total). Dados estão expressos como média \pm desvio padrão, com 6 animais em cada grupo. ${ }^{*} \mathrm{P}<0,05$ vs. grupos cont ou cont los. \#P<0,05 vs. grupos Exe 5 ou Exe 30 Los.

Com relação a proteína ERK 1/2, somente no grupo Tre 30 ocorreu aumento de $39 \%$ na fosforilação desta proteína comparada ao grupo controle, além de uma diferença de $39 \%$ deste grupo em relação ao grupo Tre Los 30 . Ainda, ocorreu um aumento de $55 \%$ na fosforilação da proteina P38 em relação ao controle no grupo Tre 5.

Assim, resumidamente os resultados mostraram que no grupo Tre 5 ocorreu um aumento de 54\% na fosforilação da proteina AKT e da P38 em relação ao controle. Já no grupo Tre 30 ocorreu um aumento significativo na fosforilação da AKT e ERK $1 / 2$ em relação ao grupo 
controle e ao grupo Tre 30 Los. A proteína mTOR teve a fosforilação aumentada somente no grupo Tre 30 em relação ao grupo controle. Para a proteína JNK não foi observada nenhuma diferença significativa entre os grupos.

Assim, estes resultados demonstrou que uma sessão de exercício de força foi capaz de ativar AKT, mTOR e ERK $1 / 2$ no coração dos animais. O bloqueio do receptor AT 1 por losartan foi capaz de inibir a ativação destas proteínas. Assim, podemos concluir que o receptor ATl tem uma participação na transdução para ativação da via AKT, mTOR e ERK 1/2 após uma sessão de exercício de força. Ainda, esta via de sinalização pode ser uma das vias responsáveis pelo desenvolvimento da hipertrofia cardíaca com o treinamento de força, uma vez que conforme observado anteriormente, o aumento da expressão protéica do receptor AT1 no coração foi bloqueado pelo uso de losartan, em animais treinados por 2 meses. Estes resultados estão sendo submetidos para publicação Melo, SFS, 2010.

Desta forma, neste Estudo 3 podemos concluir que o treinamento físico resistido ou de força em ratos Wistar leva ao desenvolvimento de hipetrofia cardíaca fisiológica (sem marcadores patológicos de hipertrofia) concêntrica. Essa hipetrofia foi acompanhada de aumento no diâmetro dos cardiomiócito, e com o tamanho da câmara cardíaca e função ventricular preservadas, analisadas pelo ecocardiograma. A hipertrofia foi dependente da ativação dos receptores ATl e sem o aumento de Ang II. Assim, estes resultados apontam para que o mecanismo de ativação dos receptores AT1 seja pelo estresse mecânico sobre os cardiomiócitos, ativando a via de sinalização AKT-PI3K-mTor e ERK1/2 levando ao aumento de sintese protéica. 


\section{Parte 2. Participação do SRA-Aldosterona em Patologias Cardiovasculares: efeitos do treinamento físico aeróbio.}

\section{Estudo 4.}

Efeitos dos Esteróides Anabolizantes associados ao treinamento fisico sobre o SRA-Aldosterona cardiaco e fluxo sanguineo foi demonstrada pelos seguintes estudos:

- Rocha FL, Carmo EC, Roque FR, Hashimoto NY, Rossoni LV, Frimm C, Anéas I, Negrão CE, Krieger JE e Oliveira EM. Anabolic Steroids Induce Cardiac Renin-Angiotensin System and Impair the Beneficial Effects of Aerobic Training in Rats. Am J Physiol. Heart Circ Physiol 293: H3575-H3583, 2007.

- Carmo ECC, Fernandes T, Koike D, Silva Junior ND, Mattos KC, Rosa KT, Barretti DLM, Melo SFS, Wichi RB, Irigoyen MC, Oliveira EM: Anabolic steroid plus exercise training: increase Renin Angiotensin Aldosterone System and inflammatory markers. Submetido para publicação, J Cell Mol Cardiol, 2010.

- Roque FR, De Angelis K, Soci UPR, Coelho MA, Irigoyen MC, Sarkis JJF, Oliveira EM. Chronic use of anabolic steroid associated with aerobic exercise training impairs coronary blood flow in normotensive rats. Am J Physiol. Heart Circ Physiol, 2010.

- Soci UPR, Redondo FRR, Femandes T, De Angelis K, Irigoyen MC, Coelho M, Oliveira EM. Esteróides anabolizantes inibem a angiogênese induzida pelo treinamento físico de natação em músculo sóleo de ratos normotensos. Rev. Bras. Educ. Fis. Esporte, v.23, n.3, p.195-209, jul./set. 2009.

\section{Estudo 5.}

Efeitos do treinamento fisico aeróbio sobre a angiogênese na hipertensão arterial. 
- Fernandes T e Oliveira EM. Efeito do treinamento físico aeróbio sobre as células progenitoras endoteliais derivadas da medula óssea em ratos espontaneamente hipertensos (SHR). Artigo em preparação.

\section{Estudo 4: Efeitos dos Esteróides Anabolizantes associados ao treinamento físico sobre o SRA-Aldosterona cardíaco e fluxo sanguíneo.}

Esteróides são hormônios produzidos pelo córtex da supra-renal, ou pelas gônadas, os quais são responsáveis por diversas funções no organismo, tais como controle metabólico ou de características sexuais. Os esteróides anabolizantes (EA) são drogas sintéticas derivadas da testosterona, muito utilizados na clínica médica, mas também no meio esportivo devido à suas propriedades anabólicas, as quais são maximizadas nestas substâncias [205, 206].

$\mathrm{Na}$ clínica médica são usadas em doses terapêuticas para o tratamento de doenças como anemias por estimularem a eritropoiese [207], no tratamento de atrofia muscular, uma vez que melhoram o balanço nitrogenado em estados catabólicos [208], no hipogonadismo masculino [209] e osteoporose [205]. No entanto, essas drogas estão sendo usadas de maneira indiscriminada em doses elevadas por muitos atletas e praticantes de atividade física com a intenção de aumentar a realização de trabalho físico ou melhorar o desempenho atlético [210], uma vez que seus componentes atuam sobre o anabolismo protéico, contribuindo para o aumento da força, potência, massa muscular e também auxiliam na redução da gordura corporal [206, 211]. Além disso, também foi relatado que os EA exercem influência sobre o sistema nervoso central, levando os indivíduos a suportarem maior carga de treinamento fisico [153, 212], diminuem a ação catabólica dos corticosteróides [213] e melhoram a função muscular aumentando a sintese protéica [214, 215].

No entanto, os efeitos adversos dessas drogas vêm sendo estudados ao longo dos anos em diversos sistemas do organismo, e tem sido demonstrado que doses em excesso podem trazer diversos efeitos colaterais, prejudiciais ao organismo [216-218]. Segundo WILSON (1988) [219], esses efeitos estão relacionados a tumores no figado, devido alterações bioquímicas no tecido hepático, sobrecarga renal, devido a retenção hídrica, câncer de próstata e efeitos masculinizantes 
em mulheres promovidos pelo engrossamento da voz e aumento de pelos faciais, dentre outros. Contudo, destacam-se principalmente as alterações relacionadas a estrutura e função do sistema cardiovascular [153, 220].

Tem sido relatado que a associação de exercício fisico e EA podem resultar em alterações no funcionamento do sistema cardiovascular [217, 220-222], apesar de um número reduzido de estudos não encontrarem modificações funcionais ou estruturais no sistema [223, 224]. A maioria dos estudos demonstrou que esta associação pode levar a prejuízos tanto estruturais como funcionais sobre este sistema [221, 222, 225-227]. Estes prejuizos estão relacionados com alteração no perfil lipídico, promovido por elevação nos níveis de LDL colesterol e diminuição dos niveis de HDL colesterol, possibilitando o desenvolvimento de aterosclerose, presença de arritmias cardíacas, causadas por distúrbio de condução decorrente de alterações no sistema nervoso autônomo, formação de trombose arterial, aumento dos niveis pressóricos, diminuição na função ventricular esquerda, aumento da massa cardíaca (hipertrofia cardíaca), insuficiência cardíaca, etc.

Assim, uma das alterações importantes e que deve ser melhor compreendida no sistema cardiovascular, é o provável desenvolvimento de hipertrofia cardíaca, que é uma modificação estrutural da musculatura cardiaca e que pode ocorrer pela interação entre os EA e exercício físico. Quanto a esta alteração os estudos são controversos, pois enquanto alguns estudos relatam a redução do peso do VE e não observam hipertrofia cardíaca em decorrência da associação de EA com treinamento aeróbio [221, 228-230]), outros estudos demonstram aumento da massa ventricular esquerda [231] e aumento da espessura do septo e parede ventricular em atletas e animais experimentais submetidos ao tratamento com EA e treinamento físico [222]. Estas divergências podem ocorrer devido às diferenças nos tipos de drogas e nas dosagens utilizadas $\mathrm{e}$ aos diferentes regimes e condições de treinamento físico empregados.

Existem, entretanto, alguns estudos histológicos sobre a ultraestrutura miocárdica, com EA e exercício físico, onde foi observada lesão ultraestrutural similar àquelas encontradas durante a insuficiência cardíaca crônica e sobrecarga de pressão crônica (estenose aórtica) Porém, os mecanismos responsáveis pelas respostas ligadas ao remodelamento cardíaco devido ao uso de EA associados com o treinamento físico, ainda não estão bem elucidados. Também não parece muito 
claro o quanto o processo hipertrófico induzido por esteróide anabolizante estaria afetando a função ventricular.

Em casos de hipertrofia cardiaca induzida por situações patológicas, como por exemplo, aumento da sobrecarga pressórica, na hipertensão arterial, ou estenose aórtica, foi demonstrado que havia uma maior formação de colágeno com aumento da fibrose cardíaca, resultando em disfunção ventricular [232]. E tem sido relatado que o SRA local, especialmente através da angiotensina II, exerce um importante papel na fisiopatogênese da hipertrofia cardíaca, levando a hipertrofia de cardiomiócitos e a fibrose miocárdica [35]. Conforme já mencionamos anteriormente, estudos prévios mostram que o SRA cardíaco é ativado na hipertrofia cardíaca patológica resultante de sobrecarga pressórica e insuficiência cardíaca [233].

Uma vez que este sistema atua no controle e funcionamento do sistema cardiovascular e todos os seus componentes são expressos no miocárdio, o objetivo deste estudo inicial foi avaliar os efeitos do treinamento físico aeróbio, dos esteróides anabolizantes, bem como a combinação de ambos, sobre a hipertrofia cardíaca e função ventricular. Avaliar a participação do SRA sobre o processo de hipertrofia cardíaca e a possibilidade de aumento na deposição de colágeno no miocárdio, influenciando nos índices de função ventricular.

Para isso realizamos a sequência de experimentos abaixo descritas.

\subsection{Materiais e Métodos}

\subsubsection{Protocolo experimental}

Os animais foram divididos em 6 grupos, sendo dois grupo sedentários e dois treinados, os quais foram treinados em dois diferentes tempos, conforme descrição abaixo:

\section{Sedentários: $\mathbf{4 2}$}

Grupo SC-Sedentário controle $(\mathrm{n}=7)$

Grupo SA- Sedentário Anabolizante $(\mathrm{n}=7)$

Grupo SALos-SA tratado com Losartan $(n=7)$
Treinados: $\mathbf{4 2}$

Grupo TC- Treinado controle $(n=7)$

Grupo TA- Treinado Anabolizante $(n=7)$

Grupo TALos- TA tratado com Los $(n=7)$

Os animais foram mantidos em gaiolas, separados por grupos (sedentários e treinados), em biotério com temperatura ambiente entre $22-24^{\circ} \mathrm{C}$ e com luz controlada em ciclo de 12 horas 
(claro-escuro). Água e comida foram administradas ad libitum. Os ratos eram identificados e pesados semanalmente.

Os animais tratados com EA eram tratados no periodo da tarde duas vezes por semana, com injeção subcutânea, do esteróide androgênico decanoato de nandrolona (Deca-durabolin), na dose de $5 \mathrm{mg} / \mathrm{Kg}$ em cada aplicação, totalizando $10 \mathrm{mg} / \mathrm{Kg} / \mathrm{semana}$. Os animais controle receberam somente o veículo oleoso (óleo vegetal). A dosagem administrada neste estudo equivale a utilizada por usuários abusivos destas substâncias, sendo equivalente a $700 \mathrm{mg} /$ semana em um indivíduo com $70 \mathrm{Kg}$, o que representa o equivalente a 100 vezes a dosagem terapêutica [234].

Para avaliarmos a participação do SRA na hipertrofia cardíaca foi administrado um antagonista do receptor de Ang II do subtipo 1 (AT1), o Losartan (20 mg/Kg/dia) [70].

\subsubsection{Treinamento dos animais}

O treinamento fisico realizado foi o mesmo descrito anteriormente como Protocolo 1 (P1), foi realizado 5 vezes por semana, durante 10 semanas, com duração de 60 minutos, e aumento gradual da sobrecarga de trabalho (peso na cauda - \% do peso corporal) até se atingir 5\% do peso corporal em um sistema de natação com a água aquecida a $30-32^{\circ} \mathrm{C}$. Este protocolo é caracterizado como treinamento de baixa intensidade e longa duração, sendo efetivo na promoção de adaptações cardiovasculares e no aumento da capacidade oxidativa muscular [67].

Após 10 semanas de treinamento foram realizadas as medidas hemodinâmicas, os animais foram sacrificados e amostras de tecidos, soro e plasma eram adequadamente coletadas e armazenadas em freezer $\left(-80^{\circ} \mathrm{C}\right)$ até serem analisadas. Essas amostras foram utilizadas para $\mathrm{O}$ estudo do SRA.

Os métodos utilizados nestes estudos foram:

- As medidas hemodinâmicas foram avaliadas:

Medida direta da PA (mmHg) e FC (bpm) por cateterismo da carótida

Avaliação dos índices de função ventricular por caterismo do VE

a) Pressão Diastólica Inicial de VE (PDI) (mmHg)

b) Pressão Diastólica Final de VE (PDF) ( $\mathrm{mmHg}$ )

c) Derivada de contração do VE (dP/dt positiva) $(\mathrm{mmHg} / \mathrm{seg})$ 
d) Derivada de relaxamento do VE ( $\mathrm{dP} / \mathrm{dt}$ negativa) $(\mathrm{mmHg} / \mathrm{seg})$

- Hipertrofia Cardíaca foi avaliada:

a) Análise morfológica - indice de hipertrofia cardíaca peso úmido (VE+VD)/peso corporal) $(\mathrm{mg} / \mathrm{g})$.

b) Análise morfométrica - técnicas histológicas.

hipertrofia do cardiomiócito - diâmetro de miócitos $(\mu \mathrm{M})$

- Quantificação do Colágeno Cardíaco foi avaliada por:

a) Quantificação da fração do volume de colágeno Intersticial (FVC) para avaliação da fibrose cardiaca - Técnica Histológica.

b) Dosagem da Hidroxiprolina para quantificação proteica do colágeno total - Método Bioquímico

c) Determinação da Expressão Relativa do Gene do Colágeno Tipo I e III - Técnica de Real Time PCR (RT-PCR)

- Avaliação do Sistema Renina-Angiotensina:

Foi avaliado pela inibição do SRA com o antagonista do receptor AT1 - Losartan

a) Determinação da Atividade da Renina Plasmática -técnica de radioimunoensaio.

b) Determinação da Atividade da ECA no coração e no soro-medida fluorimétrica.

c) Determinação da Expressão do Gene da ECA -técnica de Real Time PCR (RT-PCR).

d) Quantificação da Ang II - Método himunoistoquímica e Elisa.

\subsubsection{Avaliação hemodinâmica e da função ventricular}

Esta análise foi realizada em colaboração com a Profa. Luciana Venturini, do Departamento de Fisiologia do ICB-USP.

Para realização do cateterismo do ventrículo esquerdo os animais foram anestesiados com ketamina/ xilazina/ acetopromazina $(0,7 / 0,2 / 0,1 \mathrm{v} / \mathrm{v} ; 0,06 \mathrm{ml} / \mathrm{kg}, \mathrm{I}$.M.) e, foram mantidos em respiração espontânea. Após perda completa dos reflexos de dor, foi realizada uma incisão mediana na região ventral do pescoço, com afastamento da musculatura e, dissecção seguida de isolamento da artéria carótida direita. A artéria carótida direita foi ligada com um fio de algodão 
em sua porção cefálica e um catéter de polietileno (PE-50), preenchido com salina heparinizada $(100 \mathrm{U} / \mathrm{ml})$, foi introduzido em direção a aorta. Em seguida, o registro direto da pressão arterial pulsátil foi realizado através da conexão da cânula arterial ao transdutor de pressão (Gould P23.XL) acoplado ao pré-amplificador (Carrier Gould). Após a estabilização do sinal de pressão arterial e freqüência cardíaca o catéter foi introduzido em direção ao ventrículo esquerdo, sendo em seguida posicionado nesta câmara para a realização dos registros hemodinâmicos.

Os registros foram realizados em um polígrafo (Gould, TA 8000, 8 canais, Cleveland, $\mathrm{OH}$, USA) e, foram registrados os parâmetros de pressão sistólica do VE (PSVE), pressão diastólica inicial (PDi) e pressão diastólica final (PDf) do ventrículo esquerdo, assim como as primeiras derivadas temporais positiva $(\mathrm{dP} / \mathrm{dt}+)$ e negativa $(\mathrm{dP} / \mathrm{dt}-)$. As derivadas temporais foram determinadas através de uma função diferencial realizada por um pré-amplificador (differentiador Gould) que primeiramente captava os sinais das pressões sistólica e diastólica do ventriculo esquerdo e, em seguida os diferenciava em $\mathrm{dP} / \mathrm{dt}$ positiva, equivalente a rampa de subida de desenvolvimento de pressão e, $\mathrm{dP} / \mathrm{dt}$ negativa, equivalente a rampa de decremento da pressão ventricular.

Os registros hemodinâmicos foram realizados com os animais anestesiados e após a realização o catéter foi posicionado na artéria carótida, firmemente amarrado e, as partes mais proximais foram exteriorizadas, através do tecido subcutâneo, no dorso do animal onde foram fixados com sutura para realização das medidas arteriais.

\subsubsection{Medida direta da pressão arterial e da freqüência cardíaca}

Conforme metodologia descrita anteriormente.

\subsubsection{Amostras de soro e tecidos}

Ao final do protocolo os animais foram decapitados e o sangue coletado sem anticoagulante para dosagem da ECA, e com EDTA 7,5\% (50 $\mu \mathrm{l} / \mathrm{ml}$ de sangue) para dosagem da renina plasmática. As amostras eram mantidas no gelo e rapidamente centrifugadas (3.000 rpm X $10 \mathrm{~min}$ ) e mantidas a $-20^{\circ} \mathrm{C}$. Os tecidos coletados foram rapidamente congelados em nitrogênio líquido e mantidos congelados em freezer a $-70^{\circ} \mathrm{C}$ até serem feitas as análises bioquímicas e moleculares. 


\subsubsection{Morfologia cardíaca}

Conforme metodologia descrita anteriormente.

\subsubsection{Morfometria cardíaca}

Outro protocolo foi realizado e outro grupo de animais foi treinado com o mesmo número de ratos em cada grupo, para realização das análises morfométricas. O coração foi fixado em formaldeído $6 \%$ e após a inclusão em parafina foram realizados cortes histológicos de $7 \mu \mathrm{m}$ de espessura, na posição da base do músculo papilar. Para verificação do diâmetro dos miócitos, os corações foram corados com hematoxilina e eosina (HE) para visualização das estruturas celulares. Dois cortes para cada animal foram selecionados aleatoriamente para visualização em microscópio óptico, utilizando objetiva de imersão com aumento de $400 x$. Os miócitos selecionados para determinação do diâmetro deviam apresentar núcleo bem visível e membrana celular intacta. A imagem do cardiomiócito foi obtida na tela do computador e o diâmetro transversal de cada cardiomiócito isolado foi traçado manualmente utilizando-se o mouse do computador. A linha traçada atravessava o centro do núcleo do miócito e com a imagem digitalizada o computador calculava a área traçada. Através de um programa comercial (Quantimet 500, Cambridge Instruments) foram determinados aproximadamente 20 campos visuais para cada corte histológico.

Para quantificação do colágeno cardíaco os corações foram corados com picrosirius red [235]. A fibrose miocárdica foi determinada sob aumento microscópico de 20 vezes e luz polarizada. Este esperimentos foram realizados em colaboração com o Laboratório do Dr. Clóvis Frimm na Faculdade de Medicina da USP.

A fração de volume do colágeno (FVC) foi calculada pela razão percentual da área do tecido miocárdico corado positivamente para as fibras colágenas (quantidade absoluta de colágeno) e a área total do tecido miocárdico em cada região ventricular examinada (quantidade absoluta de colágeno e miócitos), campo a campo. Um número de 15 a 20 campos foram examinados na amostra de cada um dos animais.

\subsubsection{Dosagem de hidroxiprolina}

A concentração de hidroxiprolina (OH-Pro) foi determinada a partir da homogeinização do tecido cardíaco, conforme descrito por Bergman I and Loxley R, 1970 [236]. O material estocado 
a $-20^{\circ} \mathrm{C}$ era descongelado à temperatura ambiente e hidrolizado com $1 \mathrm{ml}$ de ácido clorídrico $8 \mathrm{~N}$, em estufa a $115^{\circ} \mathrm{C}$ por um período de 16-18 horas. Após, procedeu-se a neutralização do material, a qual foi realizada pela adição progressiva de hidróxido de sódio $(\mathrm{NaOH})$, para oxidação do anel da OH-Pro. Na sequência foi utilizada uma solução oxidante que era composta de cloramina $\mathrm{T}$ e tampão de citrato, após a oxidação foi utilizado um reagente de cor, chamado reagente de Ehrlich, e a OH-Pro foi determinada espectrofotometro num comprimento de onda de $558 \mathrm{~nm}$, após $\mathrm{lh}$ na temperatura ambiente. A concentração de $\mathrm{OH}$-Pro foi determinada em duplicatas e usada uma curva de calibração de 0,5 a $5 \mu \mathrm{g}$ de 1-hidroxiprolina. Os resultados são apresentados como $\mathrm{mg} / \mathrm{g}$ de OH-Pro. A massa de colágeno foi deteminada multiplicando a quantidade de $\mathrm{OH}$-Pro por 7,46 [237].

\subsubsection{Determinação da atividade da enzima conversora de angiotensina}

A atividade da enzima foi determinada em homogeneizados de coração e no soro. A dosagem da atividade enzimática foi realizada de acordo com OLIVEIRA et al. (2000) [145]. Foram incubados $20 \mu \mathrm{l}$ de amostra de tecido e $10 \mu \mathrm{l}$ de soro com $480 \mu \mathrm{l}$ ou $490 \mu \mathrm{l}$ de Hip-His-Leu $(5 \mathrm{mM})$ por $15 \mathrm{~min}$ para soro e por $30 \mathrm{~min}$ para os demais tecidos à $37^{\circ} \mathrm{C}$. Após esse tempo a reação é paralisada pela adição $1,2 \mathrm{ml}$ de $\mathrm{NaOH} 0,34 \mathrm{~N}$. O produto da reação, His-Leu, é medido fluorimetricamente (365 nm para excitação e $495 \mathrm{~nm}$ para emissão) após a adição de $100 \mu 1$ de uma solução de $o$-phthaldialdehyde ( $2 \%$ em metanol) cuja reação é interrompida após 10 min com a adição de $200 \mu \mathrm{l}$ de $\mathrm{HCl}(3 \mathrm{~N})$ e posterior centrifugação $(3000 \mathrm{rpm}$, por $10 \mathrm{~min}$., temperatura ambiente). Nos brancos (To), o homogeneizado dos tecidos e soro foram adicionados após o término da reação com $\mathrm{NaOH}$, com o objetivo de corrigir a fluorescência intrínseca das amostras. Todos os ensaios foram realizados em triplicatas. Em todos os experimentos foram feitas curvaspadrão, relacionando intensidade de fluorescência com a quantidade de produto formado (HisLeu). Os resultados eram expressos em nMoles His-Leu/ $\mathrm{min} / \mathrm{mg}$ de proteina para os tecidos ou nMoles His-Leu/min/ml para o soro. A proteína era determinada pelo método de Bradford (1976) [73] em espectrofotômetro, utilizando como padrão albumina bovina (BSA, Img/ml).

\subsubsection{Medida da atividade da renina plasmática (ARP)}

Conforme metodologia descrita anteriormente. 


\subsubsection{Medida da testosterona plasmática}

A determinação da testosterona plasmática será realizada utilizando-se o kit $C O A T$ - $A$ COUNT Total Testosterone da Diagnostic Products Corporation (humano).

\subsubsection{Determinação da expressão gênica}

A expressão dos genes da ECA, receptores AT1a, AT2 e colágeno do tipo I e do tipo III no coração foram determinadas por técnica de Reat Time-PCR, conforme metodologia descrita anteriormente.

Os primers utilizados foram:

ACE: sense 5'-CAg gAA CgT ggA ACT Tgg A-3' e anti-sense 5'-CTT TgA Cgg AAg CAT CAC C-3';

COL1a1 (Col I): sense 5'-AgA gAg CAT gAC CgA Tgg A-3' e anti-sense 5'-gAg gTT gCC AgT CTg TTg g-3';

COL3a1(Col III): sense 5'-AAg gTC CAC gAg gTg ACA A-3' e anti-sense 5'-Agg gCC Tgg ACT ACC AAC T-3';

AT1a: sense $5^{\circ}$-CAC AAC CCT CCC AgA AAg Tg-3' e anti-sense 5'-Agg gCC ATT TTg TTT TTC Tg-3';

AT2: sense 5'-gCT ggg ATT gCC TTA ATg A-3' anti-sense 5'-CTT ggT CACA ggg TAA TTC Tg-3'.

\subsubsection{Immunohistoquímica}

Ang II foi determinada por técnica de imunoistoquímica no tecido cardíaco no grupos SC, SA, TC e TA. O tecido cardiaco foi retirado dos blocos de parafina em xileno e rehidratados em etanol. A imunoreatividade foi obtida por incubação dos cortes histológicos com tampão citrate $0,01 \mathrm{M}, \mathrm{pH} 6,0$, e aquecidos por $5 \mathrm{~min}$ em forno de micro ondas. A presence da Ang II foi avaliada no VE usando um anticorpo anti-Ang II rabbit (1:400, Península, Belmont, CA). O antígeno foi marcado por fast red dye, e os anticorpos específicos e secundários foram estabelecidos como controles positivos e negativos. As imagens foram obtidas com um sistema de análise morfométrica de imagens acoplado a um computado (Leica Quantimet 500, 
Cambridge, UK). O número de sinais positive nos cardiomiócitos foi avaliada e expressa como células imunireativas para Ang II/ $\mathrm{mm}^{2}$.

\subsubsection{Análise estatística}

Todos os resultados foram analisados por meio da análise de variância de dois fatores (ANOVA Two-Way) e as médias comparadas pelo teste de Tukey de múltiplas comparações, sendo aceito como valores significativos um $\mathrm{p}<0,05$. Os resultados foram expressos em médias $\mathrm{e}$ desvio padrão.

\subsection{Resultados e Discussão}

\subsubsection{Niveis plasmáticos de testosterona.}

A determinação da testosterona plasmática (ng/dL) foi utilizada como um indicativo da eficácia do tratamento com anabolizante. Os niveis plasmáticos de testosterona foram superiores nos grupos que receberam a droga, SA $(85,3 \pm 39,3)$ e TA $(102,6 \pm 18,3)$, comparados aos grupos SC $(13,4 \pm 6,5)$ e TC $(20,5 \pm 9,9)$ como apresentado na figura 1.

\section{Testosterona Plasmática}

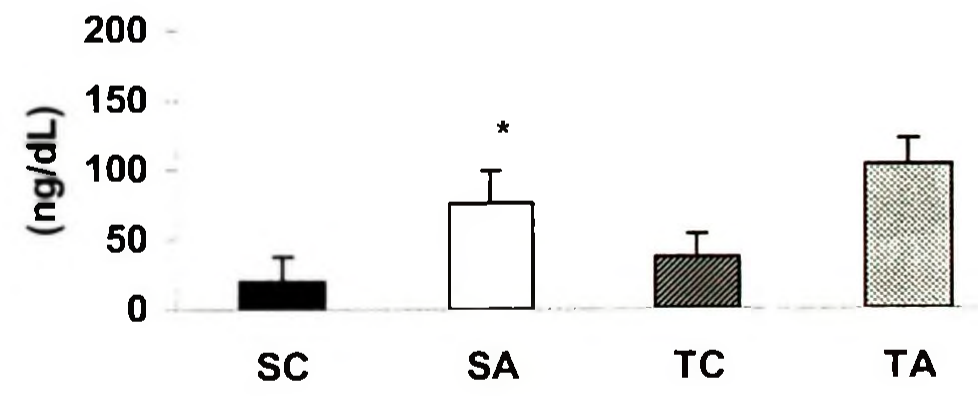

Figura 1. Níveis plasmáticos de testosterona (ng/dL). Sedentário controle $(\mathrm{SC}, \mathrm{n}=5)$, sedentário anabolizante $(\mathrm{SA}, \mathrm{n}=6)$, treinado controle $(\mathrm{TC}, \mathrm{n}=5)$ e treinado anabolizante $(\mathrm{TA}, \mathrm{n}=5) .\left(^{*}\right)$ Diferença significante entre os grupos que receberam anabolizante, SA e TA, comparado com os grupos controles $\mathrm{SC}$ e $\mathrm{TC}, \mathrm{p}<0,05$. Os resultados estão apresentados como média \pm desvio padrão. 


\subsubsection{Medidas hemodinâmicas}

A tabela 1 sumariza os resultados de freqüência cardíaca (FC), pressão arterial diastólica (PAD), pressão arterial sistólica (PAS) e pressão arterial média (PAM), após o protocolo experimental. $\mathrm{O}$ treinamento fisico e o treinamento físico associado com esteróide anabolizante promoveram redução da $\mathrm{FC}$ em comparação com o grupo controle. Ocorreu também redução da PAD no grupo TA comparado ao grupo SC, porém, em relação aos valores de PAS e PAM não houve diferença significativa entre os grupos. A redução da FC de repouso é um marcador cardiovascular de adaptação ao treinamento fisico, ou seja de condicionamento aeróbio.

Tabela 1. Efeito do esteróide anabolizante, exercício fisico e esteróide anabolizante associado ao exercício físico sobre a freqüência cardíaca (FC), pressão arterial sistólica (PAS), pressão arterial diastólica (PAD) e pressão arterial média (PAM).

\begin{tabular}{ccccc}
\hline FC (bpm) & $\begin{array}{c}\text { PAS } \\
(\mathrm{mmHg})\end{array}$ & $\begin{array}{c}\text { PAD } \\
(\mathrm{mmHg})\end{array}$ & $\begin{array}{c}\text { PAM } \\
(\mathrm{mmHg})\end{array}$ \\
\hline SC $(\mathrm{n}=5)$ & $328 \pm 16$ & $116 \pm 8$ & $97 \pm 6$ & $107 \pm 5$ \\
SA $(\mathrm{n}=5)$ & $299 \pm 37$ & $119 \pm 2$ & $93 \pm 4$ & $107 \pm 3$ \\
TC $(\mathrm{n}=5)$ & $286 \pm 15^{*}$ & $118 \pm 14$ & $88 \pm 10$ & $103 \pm 11$ \\
TA $(\mathrm{n}=5)$ & $268 \pm 19^{*}$ & $108 \pm 6$ & $81 \pm 5^{*}$ & $95 \pm 5$ \\
\hline
\end{tabular}

Os valores estão expressos em média \pm desvio padrão; $n=$ no. de ratos. $\mathrm{SC}$, sedentário controle; $\mathrm{SA}$, sedentário anabolizante; TC, treinado controle; TA, treinado anabolizante. ${ }^{*} \mathrm{P}<0,05$ : vs controle.

\subsubsection{Peso corporal dos animais}

A tabela 2 sumariza os resultados referentes ao peso corporal (PC) inicial e final dos animais, gordura intraperitoneal, peso dos ventrículos esquerdo e direito (VE+VD) ao final do protocolo e o diâmetro dos cardiomiócitos. 
Tabela 2 - Efeito do exercício físico, administração de esteróide anabolizante e a combinação de ambos sobre o PC inicial e final, gordura intraperitoneal, peso VE+VD, peso VE+VD/PC e diâmetro dos cardiomiócitos.

\begin{tabular}{|c|c|c|c|c|c|c|}
\hline & $\begin{array}{l}\text { (Inicial) } \\
\text { PC (g) }\end{array}$ & $\begin{array}{l}\text { (Final) } \\
\mathrm{PC}(\mathrm{g})\end{array}$ & $\begin{array}{c}\text { Gordura } \\
\text { Intraperitoneal } \\
\text { (mg) }\end{array}$ & $\begin{array}{c}V E+V D \\
(g)\end{array}$ & $\begin{array}{c}V E+V D / P C \\
(\mathrm{mg} / \mathrm{g})\end{array}$ & $\begin{array}{c}\text { Diâmetro } \\
\text { cardiomiócitos } \\
(\mu)\end{array}$ \\
\hline $\begin{array}{l}\text { SC } \\
(n=6)\end{array}$ & $240 \pm 26$ & $396 \pm 26$ & $2.6 \pm 0.8$ & $1.00 \pm 0.03$ & $2.5 \pm 0.1$ & $6.7 \pm 0.2$ \\
\hline $\begin{array}{l}\text { SA } \\
(n=7)\end{array}$ & $235 \pm 19$ & $354 \pm 26$ & $1.2 \pm 0.7^{*}$ & $0.96 \pm 0.1$ & $2.7 \pm 0.1^{*}$ & $6.9 \pm 0.3$ \\
\hline $\begin{array}{l}\text { TC } \\
(n=6)\end{array}$ & $238 \pm 18$ & $351 \pm 21$ & $1.2 \pm 0.5^{*}$ & $1.01 \pm 0.1$ & $2.9 \pm 0.2 *$ & $7.6 \pm 0.5^{*}+$ \\
\hline $\begin{array}{l}\text { TA } \\
(n=7)\end{array}$ & $235 \pm 20$ & $321 \pm 22^{*}$ & $0.7 \pm 0.2^{*}$ & $0.99 \pm 0.1$ & $3.1 \pm 0.1 * \#$ & $7.6 \pm 0.6^{*}+$ \\
\hline
\end{tabular}

Valores são médis $\pm \mathrm{DP} ; \mathrm{n}$, no de ratos. $\mathrm{PC}=$ peso corporal; $\mathrm{VE}+\mathrm{VD}=$ peso do coração; $\mathrm{VE}+\mathrm{VD} / \mathrm{PC}=$ razão entre o peso do coração e o peso corporal. * vs $\mathrm{SC}, P<0.05$; " vs SA e TC, $P<0.05 ;^{+}$vs SA, $P<0.05$.

Os resultados demonstram que o PC inicial dos animais foi igual entre os grupos no início do protocolo, porém, no final do protocolo, houve redução significativa do peso corporal nos grupos SA, TC e TA, quando comparados ao grupo SC.

Outro dado interessante foi o menor peso corporal encontrado no grupo treinado e no grupo que apenas recebeu anabolizante em relação ao grupo controle, este resultado pode ser explicado pela menor quantidade de gordura intraperitonial encontrada nestes grupos, demonstrando que o programa de treinamento físico aeróbio empregado foi efetivo para controlar e reduzir os níveis de gordura corporal e que os esteróides anabolizantes, podem estar levando a redução no tecido adiposo, provavelmente por promover uma maior atividade metabólica, corroborando com dados da literatura que demonstram que o aumento de andrógenos promove maior degradação de triglicerídeos do tecido adiposo [238]. Este resultado também confirma a perda de gordura corporal observada em atletas que fazem uso destas drogas. Quando foram associados os dois 
tratamentos EA mais treinamento físico a redução da gordura intraperitonial foi ainda maior em comparação com o grupo controle, porém não foi uma redução significativa em comparação com o grupo treinado e com o grupo que apenas recebeu o esteróide.

\subsubsection{Hipertrofia cardíaca}

Os resultados apresentados na figura 2 , mostram na figura $2 \mathrm{~A} \%$ de hipertrofia e na figura 2B o \% de inibição com o uso do antagonista dos receptores AT 1 o losartan.

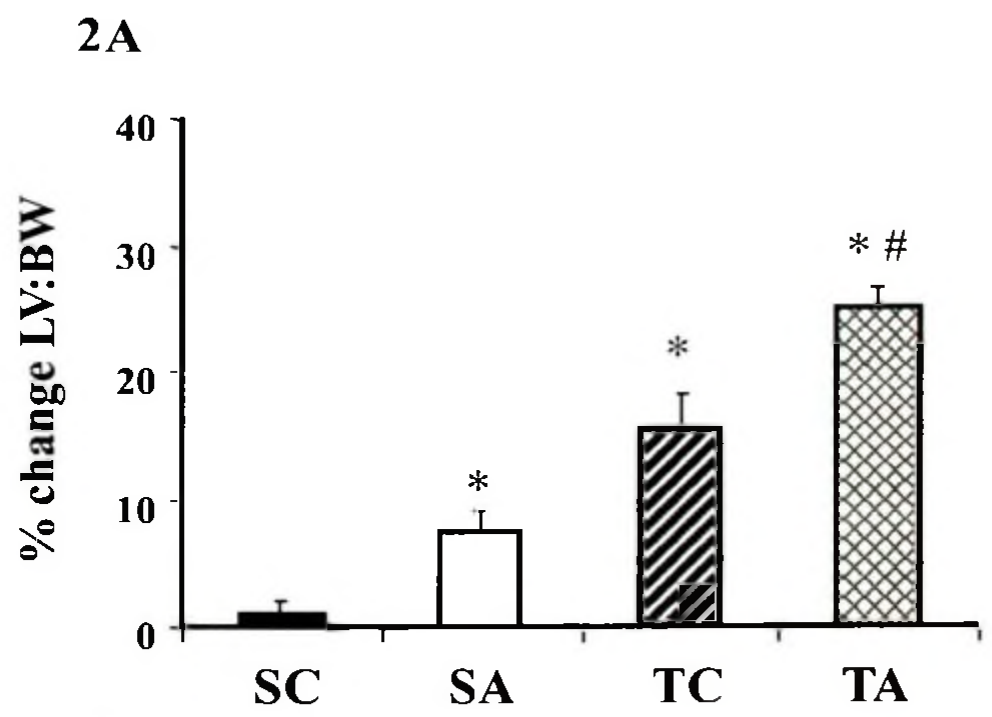

\section{B}

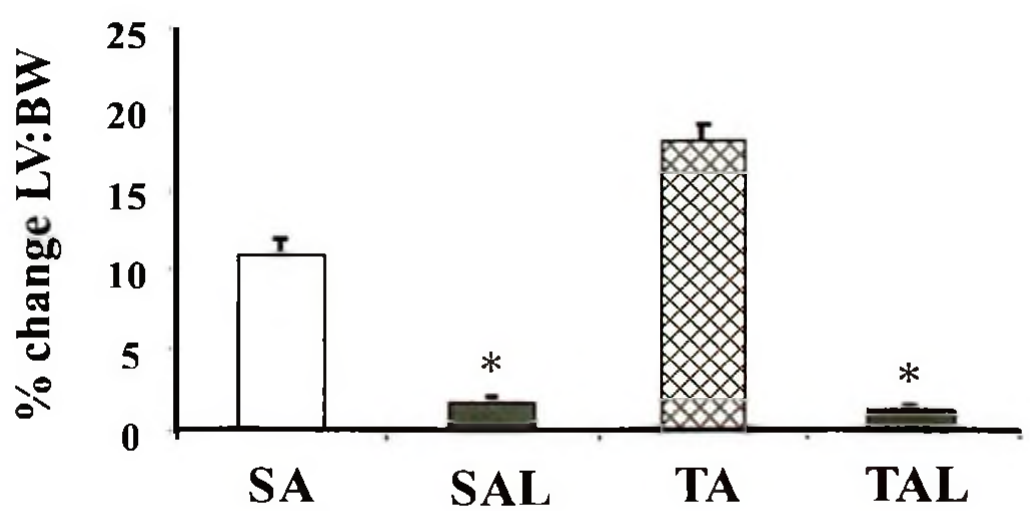

Figura 2. Efeitos do tratamento EA, treinamento físico e do tratamento com losartan sobre a hipertrofia cardíaca. Os resultados estão apresentados em percentual do Peso do Ventrículo 
Esquerdo normalizado pelo Peso Corporal, PVE/PC (mg/g), (\%change LV:BW, mg/g). 2A. Grupo tratado com anabolizante e treinado. Controle (SC), tratado com anabolizante (SA), treinado (TC), treinado + anabolizante (TA). * vs grupo controle (SC), $P<0.05$. " vs grupo anabolizante (SA) e grupo treinado (TC), $P<0,05$. 2B. Grupo tratado com anabolizante e tratado com Losartan. Grupo anabolizante (SA), tratado com anabolizante + losartan (SAL), treinado + anabolizante (TA) e treinado + anabolizante e tratado com losartan (TAL) (\% hipertrofia - \%change LV:BW, mg/g). * vs grupo anabolizante (SA) e grupo treinado + anabolizante (TA), $\mathrm{P}<0,05$.

Não foi observada alteração no peso absolute do VE em nenhum dos grupos estudados. Entretanto, o peso do VE normalizado pelo PC, o qual foi usado como índice de hipertrofia (\% de hipertrofia do VE/PC, mg/g), foi significativamente aumentado nos grupos SA, TC e TA (8\%, $16 \%$ e $24 \%$, respectivamente; $\mathrm{P}<0,05$ ), conforme mostrado na figura $2 \mathrm{~A}$. Ainda, o $\%$ de hipertrofia observada no grupo TA foi maior do que no grupo SA e TC (15\% e $7 \%$, respectivamente; $\mathrm{P}<0,05)$.

$O$ tratamento com losartan preveniu a hipertrofia do VE nos grupos SAL e TAL. O peso do VE normalizado pelo PC, o qual foi usado como índice de hipertrofia (\% Change LVW:BW, $\mathrm{mg} / \mathrm{g})$ foi significantemente maior nos grupos SA e TA $(2,3 \pm 0,12$ e 2,4 $\pm 0,13 \mathrm{mg} / \mathrm{g})$ comparados

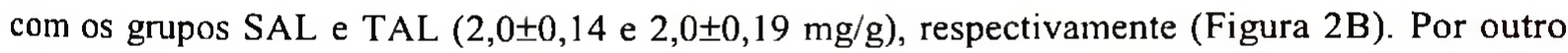
lado, o diâmetro dos cardiomiócito $(\mu \mathrm{m})$ nos grupos treinados, aumentou significantemente independente do tratamento com anabolizante, porém nenhuma alteração foi observada somente com o tratamento com o anabolizante (Tabela 2).

\subsubsection{Características do colágeno cardíaco}

O colágeno é uma parte integral da matriz extracelular do coração, e o remodelamento do colágeno miocárdio inclui acúmulo ou degradação anormal no tecido.

Fatores hemodinâmicos ou locais podem estar envolvidos no desequilibrio entre o crescimento dos cardiomiócitos e o turnover do colágeno cardíaco. As fibras de colágeno do tipo I e III são as maiores proteínas estruturais da matrix de colágeno cardíaco. O colágeno do tipo I é formado por um colágeno grosso e sua presença determina a complacência do tecido miocárdico ou a complacência ventricular. O colágeno do tipo III é forma do uma fina rede reticular e é mais distensível que o colágeno do tipo I, determinando maior complacência ao tecido cardíaco [239] 
Assim, para determinarmos os efeitos dos EA sobre o tecido cardíaco e associarmos se estes efeitos de alguma forma influenciariam na função ventricular colágeno cardíaco foi avaliado pela fração do volume de colágeno (FVC), expressão gênica do colágeno do tipo I e do tipo III por Real Time PCR e pela quantificação da OH-Pro.

Os resultados mostrados na Figuara 3, mostram a quantificação do colágeno pela FVC e pela $\mathrm{OH}-\mathrm{Pro}$. 
$3 \mathbf{A}$
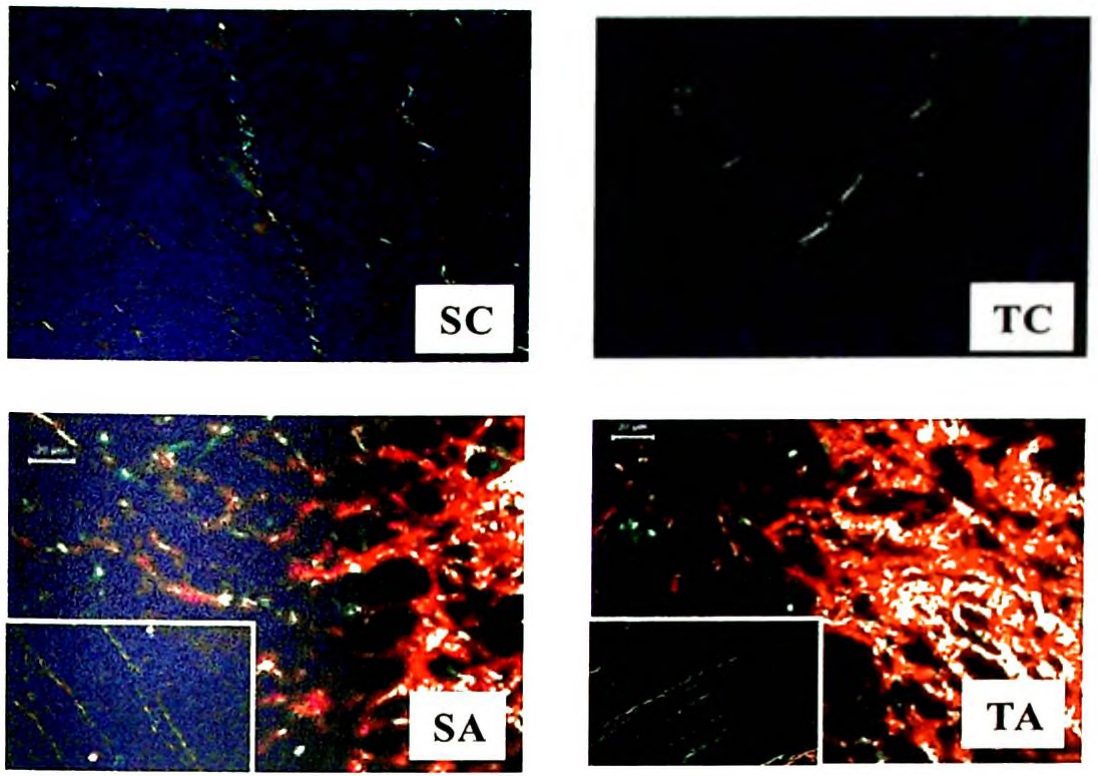

3B

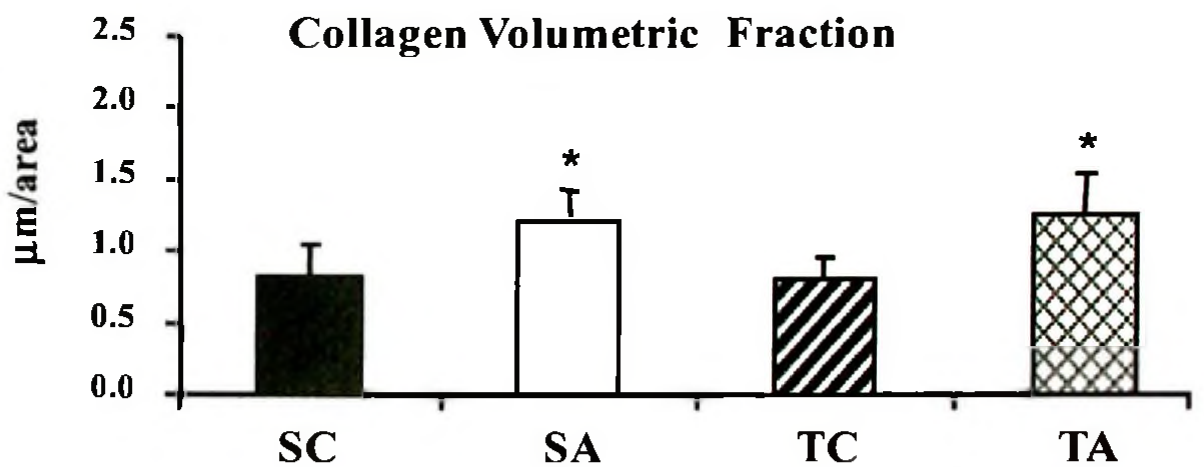

3C

Hydroxyproline

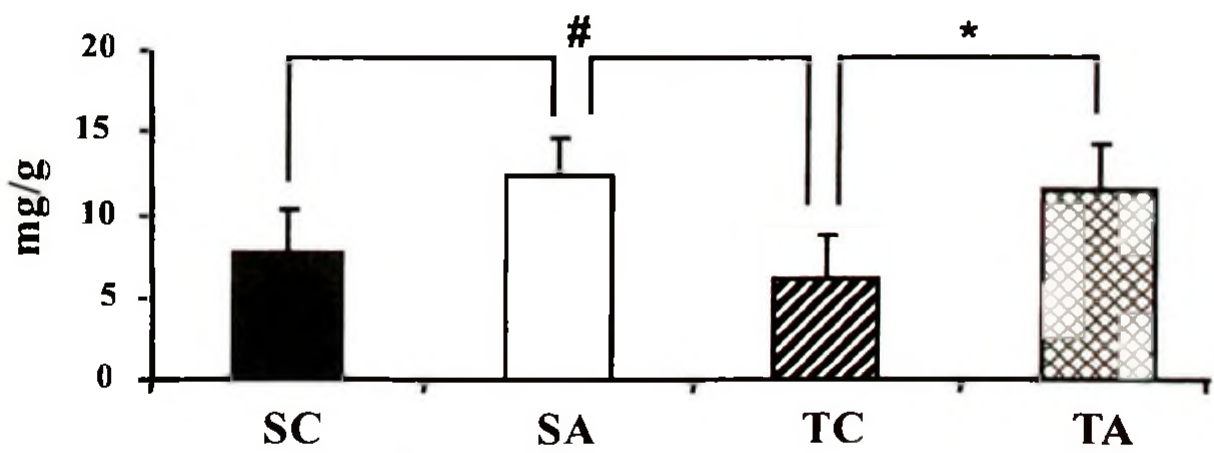

Figure 3. Efeitos do EA, treinamento físico e treinamento físico associado ao tratamento com EA sobre o colágeno cardíaco. 3A: Fotografia de um corte histológico representativo 
do miocárdio na microscopia ótica em luz polarizada. Representação das fibras de colágeno no VE dos grupos (SC) controle e (TC) treinado controle (painel superior). Sedentário controle (SC) e treinado anabolizante (TA) no inset (painel inferior). O painel inferior mostra regiões com Palch cardíaco (fibrose reparativa) no VE do grupo SA (painél da esquerda) e do grupo TA (painél da direita). 3B: Análise quantitative das fibras de colágeno no miocárdio. * vs control (SC) e treinado (T), $P<0.05$. 3C: Concentração de hidroxiprolina no VE dos grupos controle (SC); (SA), grupo tratado com anabolizante; (TC), grupo treinado; e (TA) treinado e tratado com anabolizante. "vs. controle (SC) e treinado (TC), $P<0,05$. *vs. treinado (TC), $P<0,05$. $20 \mu \mathrm{m}$.

Os resultados encontrados na figura $3 \mathrm{~A}$, mostram que a FVC foi aumentado no grupo treinado tratados com anabolizante (TA) em comparação com o grupo treinado controle (TC) $(1,25 \pm 0.30$ vs. $0,80 \pm 0,17 \mu \mathrm{m} /$ área; $\mathrm{P}<0,05)$, estes valores correspondem a um aumento aproximado de $65 \%$.

A concentração de OH-Pro (figura 3A) foi maior no grupo SA, do que nos grupos SC e TC $(12,4 \pm 2,2$ vs. $7,8 \pm 2,5$ e $6,2 \pm 2,5 \mathrm{mg} / \mathrm{g}$, respectivamente; $P<005)$. Ainda, a contração foi maior no grupo TA, quando comparado com o grupo TC $(11,5 \pm 2,8$ vs. $6,2 \pm 2,5 \mathrm{mg} / \mathrm{g}$, respectivamente; $P<0,05)$.

A concentração de colágeno calculado pela concentração de OH-Pro foi $59 \%(92.5 \mathrm{mg} / \mathrm{g}$ PVE) maior no grupo SA, quando comparada com o grupo SC (58.2 mg/g PVE), o que corresponde aproximadamente $8 \%$ da hipertrofia cardíaca do grupo SA comparado com o grupo SC. A concentração de colágeno foi $85 \%(85.8 \mathrm{mg} / \mathrm{g}$ PVE) maior no grupo TA, quando comparado ao grupo TC (46.3 mg/g PVE), o que corresponde aproximadamente $7 \%$ da hipetrofia cardiaca observada no grupo TA comparada ao grupo TC. O grupo SC não foi diferente do grupo TC.

Assim, o grupo TA apresentou aumento significativo do colágeno, pela quantificação da FVC, por aumento da expressão dos gene do colágeno tipo I e do tipo III e aumento da concentração de hidroxiprolina.

Os resultados da Figura 4 mostram os efeitos do tratamento com losartan na prevenção dos efeitos promovidos sobre a FVC, pelo uso do EA isolado ou associado ao treinamento fisico. 
4A
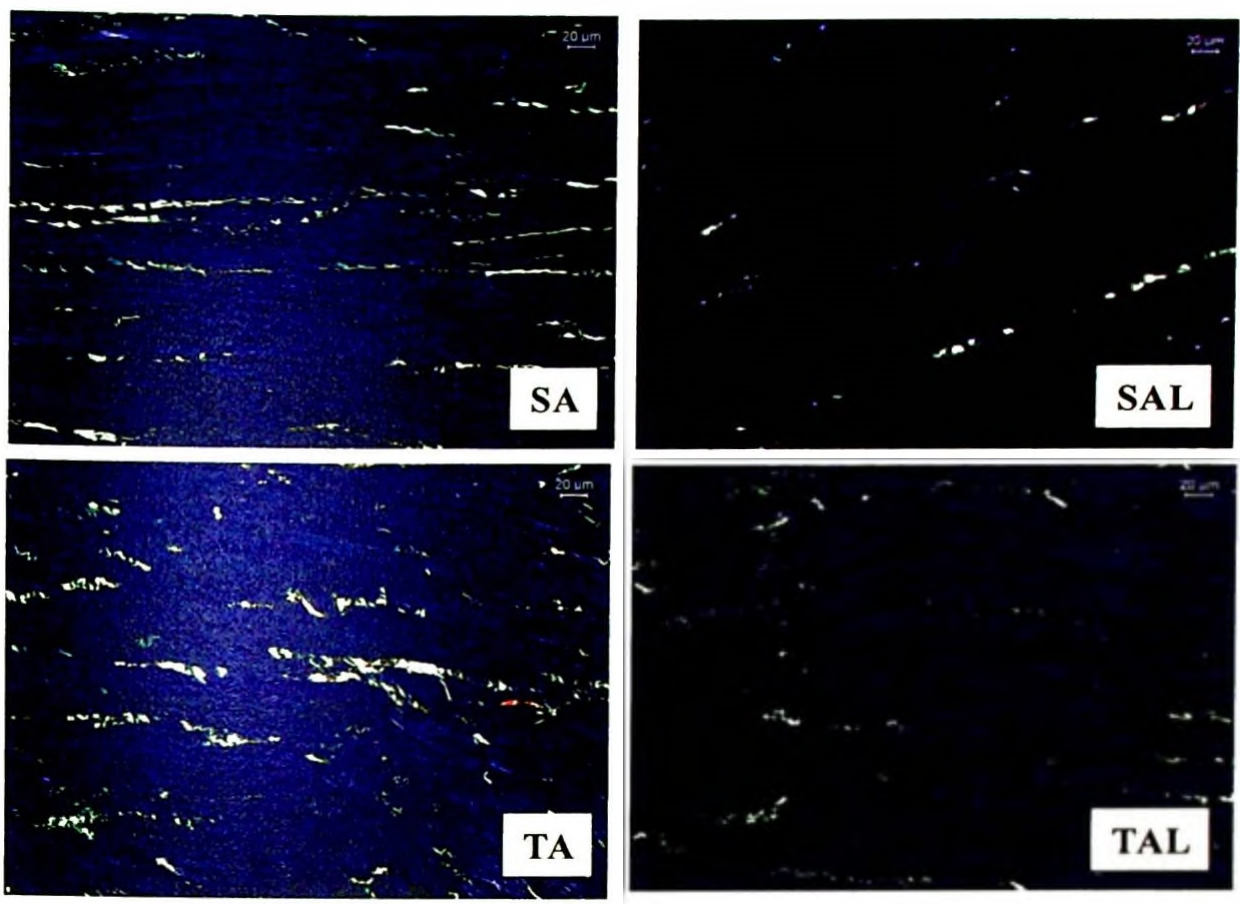

4B

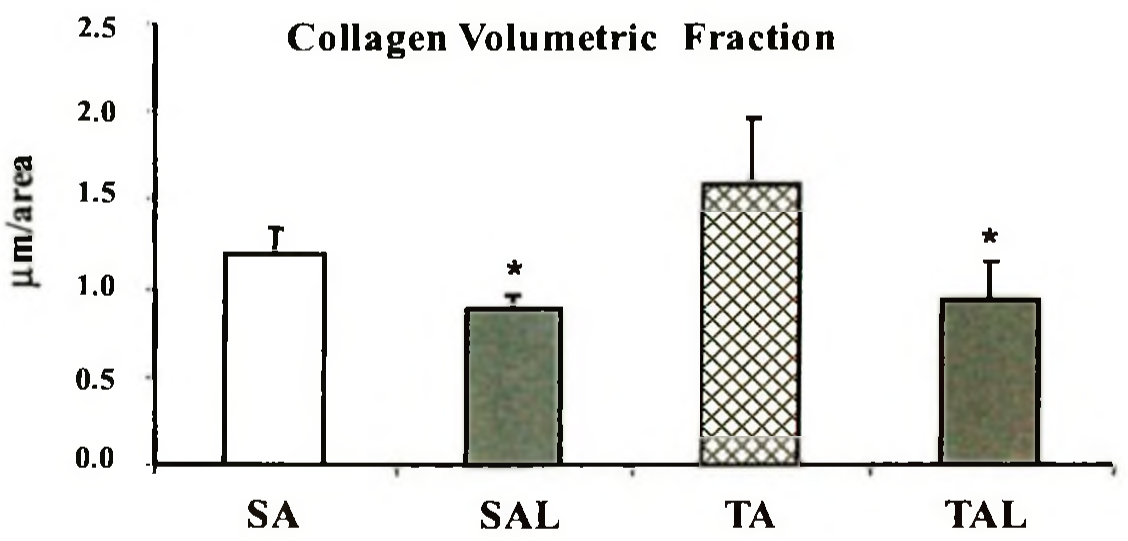

Figure 4. Efeitos do tratamento com losartan sobre o colágeno cardiaco induzido pelo tratamento com esteróide anabolizante. 4A: Fotografia de um corte histológico representativo do miocárdio na microscopia ótica em luz polarizada. Representaçãodas fibras de colágeno no VE dos grupos (SA) esteróide e (SAL) esteróide tratado com losartan (painel superior); e (TA) treinado esteróide (TAL) treinado tratado com esteróide e losartan (painéis inferiores). 4B: Análise quantitative das fibras de colágeno no miocárdio. Grupos esteróide $(\mathrm{SA})$, tratado com esteróide mais losartan (SAL), treinado e tratado com esteróide (TA) e 
treinado e tratado com esteróide mais losartan (TAL). Os resultados estão apresentados como média \pm DP. * vs. esteróide (SA) e treinado e tratado com esteróide (TA), $\mathrm{P}<0,05$. — $20 \mu \mathrm{m}$.

O colágeno do tipo III aumentou $56 \%$ no grupo TA e foi prevenido pelo uso de losartan, ainda o grupo TAL mostrou significante diminuição da FVC $(0,9 \pm 0,2 \mu \mathrm{m} / a$ área $)$ em relação ao grupo TA $(1,6 \pm 0,4 \mu \mathrm{m} /$ área $)$. Um resultado bastante interessante foi a observação de colágeno reparativo em determinadas regiões do miocárdio nos grupos SA e TA (patch cardiaco), conforme pode ser observado na Figura $3 \mathrm{~A}$, painel inferior.

\subsubsection{Sistema Renina Angiotensina}

Uma vez que, o aumento de colágeno pode estar associado a maior atividade do SRA foram estudas a atividade da ECA no VE, expressão gênica do receptor AT1 e da concentração de Ang II. 


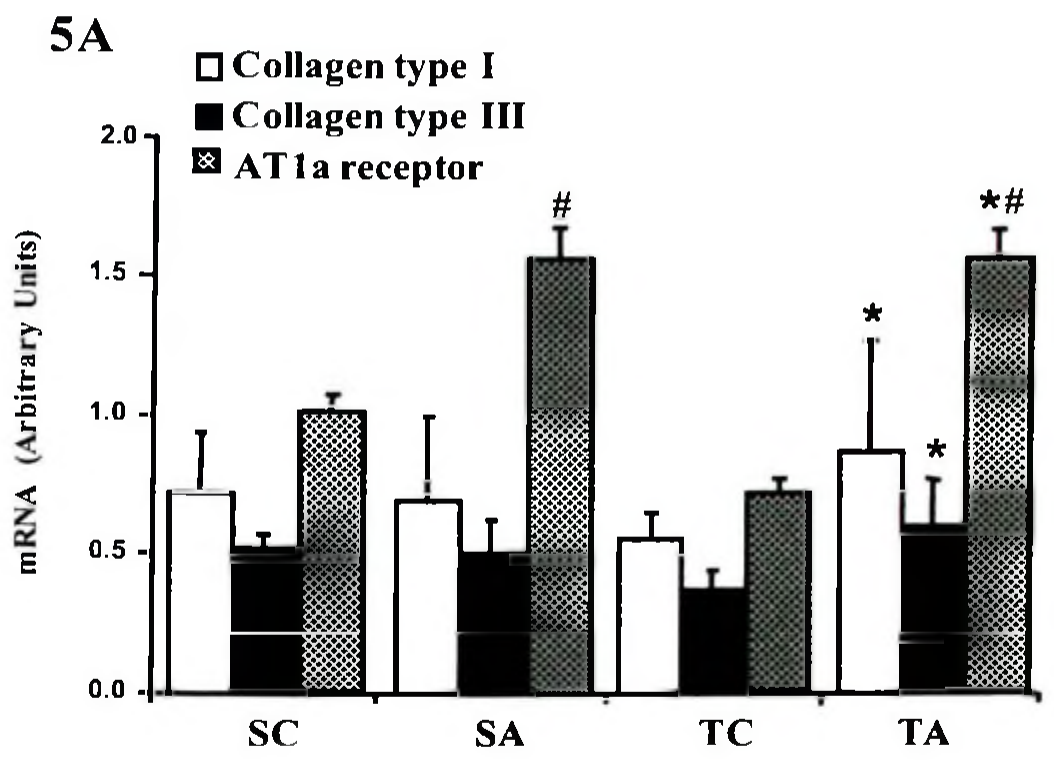

5B

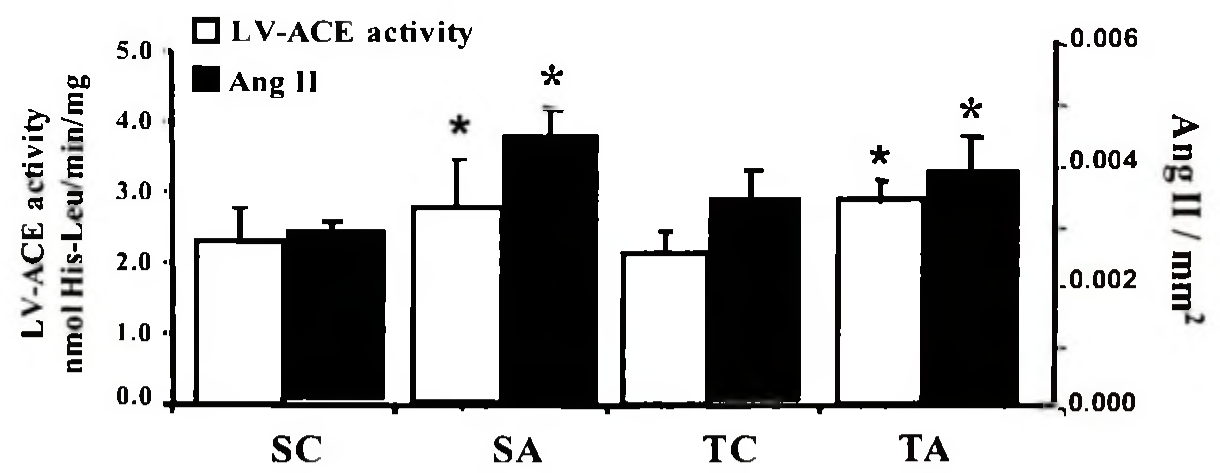

5C

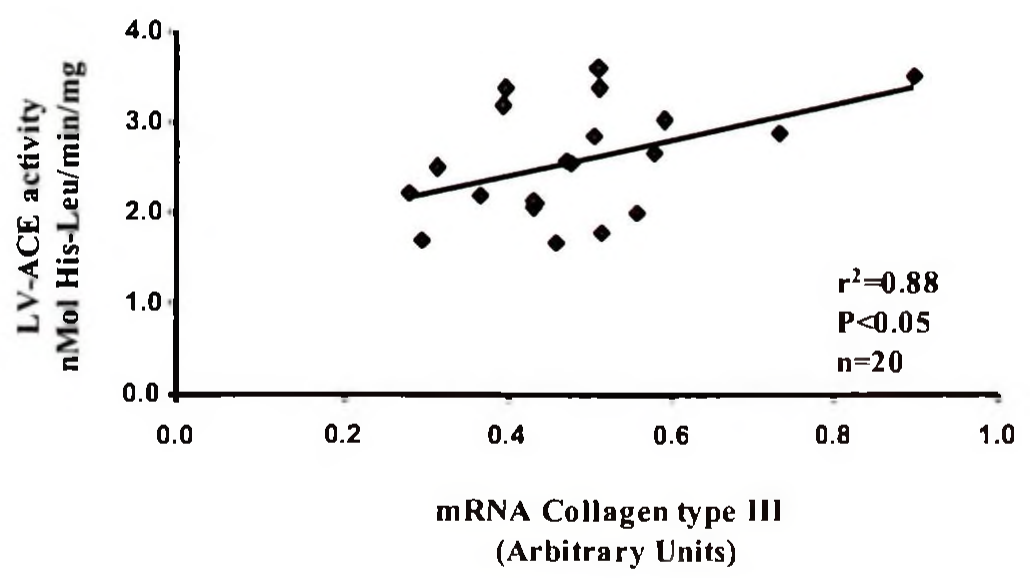


Figure 5. Efeito dos esteróides anabolizantes associados ao treinamento físico sobre a cxpressão de colágeno do tipo II e III, receptores AT1 e ativadade da ECA no VE. 5A: Efeitos da expressão relativa dos genes do colágeno do tipo I e III, e receptores ATla nos grupos controle (SC), tratado com esteróide anabolizante (SA), treinado (TC), treinado tratado com esteróide anabolizante (TA). ${ }^{*} P<0,05$ vs. treinado (TC) para colágeno tipo III e ${ }^{*} P=0,076$ para colágeno tipo I. ${ }^{*} \mathrm{P}<0,05$ vs. treinado (TC) e ${ }^{\sharp} P<0,05$ vs. controle (SC) para receptor AT1a. 5B: Efeitos sobre a atividade da ECA no VE (nmol His-Leu/min/mg) do controle (SC); (SA), esteróide anabolizante; (TC), trainado; e (TA) trainado e tratado com esteróide anabolizante. ${ }^{*} P<0,01$ vs os grupos controle (SC) e treinado (TC). Efeitos sobre a quantificação da Ang II (Ang II $/ \mathrm{mm}^{2} ; \mathrm{n}=4$ /grupo) do grupo controle (SC); (SA), esteróide anabolizante; (SA), treinado anabolizante; (TA) treinado e tratado com anabolizante. ${ }^{*} P<0,05$ vs grupo controle (SC). 5C: Correlação positive entre atividade da ECA no VE e expressão relativa do gene do colágeno tipo III $\left(\mathrm{r}^{2}=0,88 ; P<0,05\right)$. $\mathrm{n}$, no de animais.

A figura 5A mostra a expressão relative do colágeno do tipo I, III e receptor ATla. A expressão relative do colágeno tipo I foi aumentada nos grupo TA, comparado ao grupo $\mathrm{T}$ $(\mathrm{P}<0,076)$. Entretanto, a expressão relative do colágeno tipo II foi aumentada no grupo TA, compare grupo TC, mas não aumentou no grupo TC $(0,60 \pm 0,17$ vs. $0,37 \pm 0,01$, unidades arbitrárias; $P<0,05)$. Além disso, a expressão relative dos receptors ATla foi aumentada nos grupos SA e TA $(1,59 \pm 0,16$ vs. $1,61 \pm 0,1$, inidades arbitrárias; $P<0,05)$, comparados ao grupo controle $(1,0 \pm 0,05$ unidades arbitrárias) e no grupo TA, quando comparado com o grupo T $(0,74 \pm 0,05$, unidades arbitrárias; $P<0,05)$. A expressão relative do AT2 não foi detectada neste experiment, pela metodologia usada. A expressão relative da ECA nos grupos SC, SA, TC e TA $(1,0 \pm 0,19,1,21 \pm 0,34,1,18 \pm 0,2$ e $1,21 \pm 0,13$ unidades arbitrárias, respectivamente) não foi significativa entre os 4 grupos.

De forma interessante, a atividade da ECA cardíaca aumentou $28 \%$ no grupo SA e $33 \%$ no grupo TA e foi encontrada uma correlação positiva entre a atividade da enzima e a expressão do colágeno tipo III $\left(\mathrm{r}^{2}=0,88 ; \mathrm{P}<0,05\right.$, para todos os grupos) (Figura $5 \mathrm{C}$ ). A expressão gênica dos receptores AT1 e a Ang II foram aumentados significantemente nos grupos tratados com EA grupos SA e TA, mas não no grupo TC.

Esta alteração estrutural no miocárdio pode levar a perda funcional, ou seja, a disfunção ventricular. Assim, analizamos também a função ventricular 


\subsubsection{Avaliação da função ventricular}

Em relação aos indices de função ventricular, ao final do protocolo foi possivel observar que o grupo sedentário anabolizante (SA) e o grupo treinado com anabolizante (TA) apresentaram redução significativa da pressão sistólica de ventrículo esquerdo ( $116 \pm 12$ e $111 \pm 7$ $\mathrm{mmHg}$, respectivamente; $\mathrm{P}<0.05)$ quando comparados com o grupo sedentário controle $(\mathrm{SC}) \mathrm{e}$ com o grupo treinado controle (TC) $(127 \pm 10$ e $130 \pm 10 \mathrm{mmHg}$, respectivamente; $\mathrm{P}<0,05)$ (Figura 6).

\section{Pressão Sistólica do VE}

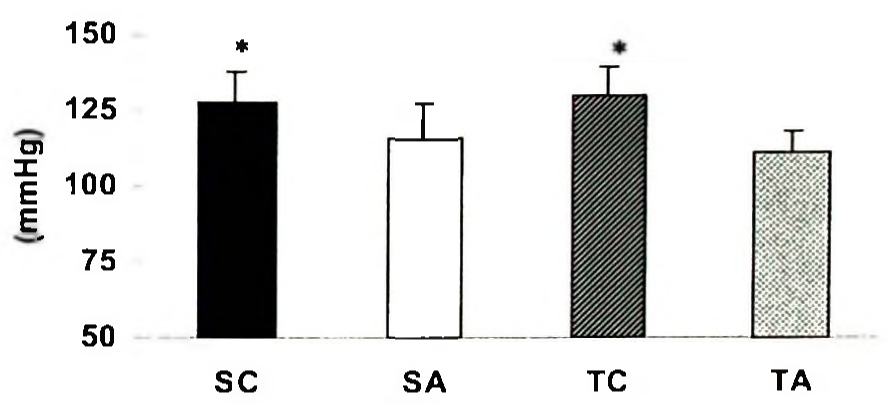

Figura 6. Pressão sistólica do ventrículo esquerdo: Sedentário controle ( $\mathrm{SC}, \mathrm{n}=5)$, sedentário com anabolizante $(S A, n=12)$, treinado controle $(T C, n=6)$ e treinado com anabolizante $(T A, n=9)$. $\left(^{*}\right)$ Diferença significante em relação ao grupo SA e TA, $\mathrm{P}<0,05$. Os resultados estão apresentados como média \pm desvio padrão.

Com relação a pressão diastólica final não houve diferença entre os grupos, porém o grupo treinado controle (TC) apresentou redução significativa da pressão diastólica inicial (PDi) comparado com o grupo sedentário controle (SC) $(-8,9 \pm 2,8$ vs $-5,6 \pm 2,5 \mathrm{mmHg} ; \mathrm{P}<0,05)$ (Figura 7). 


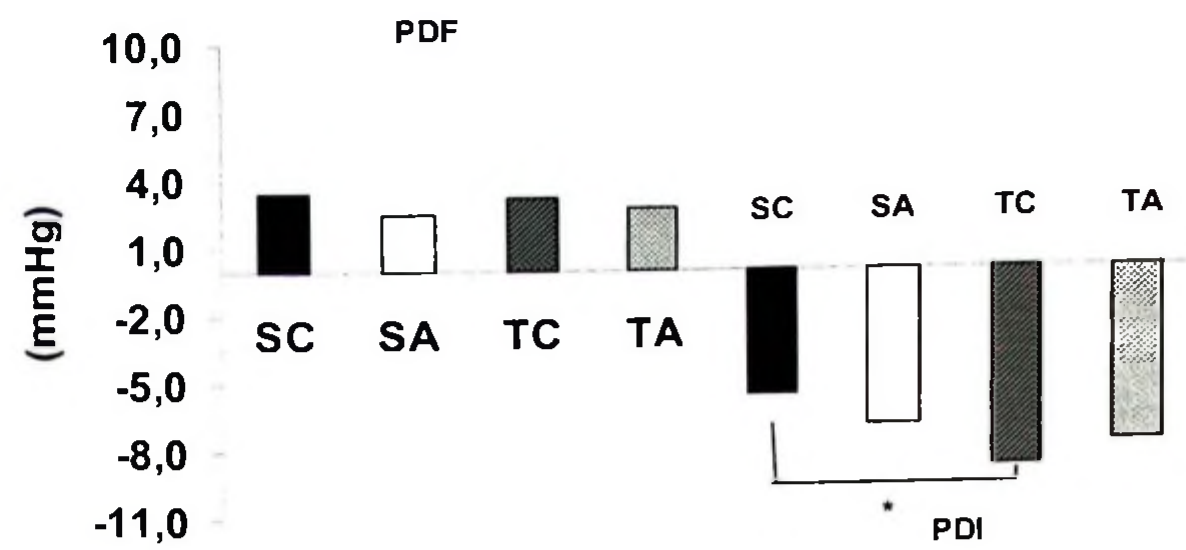

Figura 7. Pressão diastólica final (PDF) e Inicial (PDI) do ventrículo esquerdo: Sedentário controle $(S C, n=5)$, sedentário com anabolizante $(S A, n=12)$, treinado controle (TC, $n=6)$ e treinado com anabolizante $(\mathrm{TC}, \mathrm{n}=9)$. (*) Diferença significante em relação ao grupo $\mathrm{SC}, \mathrm{P}<0,05$. Os resultados estão apresentados como média \pm desvio padrão.

O resultado da derivada de contração ventricular $\left(\mathrm{dPdt}^{+}\right)$, que é um índice de contratilidade cardíaca, demonstrou que ocorreu uma melhora significativa no grupo treinado controle (TC) em comparação com o grupo sedentário controle (SC) (6144t791 vs $4780 \pm 924$ $\mathrm{mmHg} / \mathrm{seg}$ ) em contraste, no grupo treinado com anabolizante (TA) o efeito benéfico do treinamento físico foi perdido e além disso, esta variável estava significantemente reduzida neste grupo $(4289 \pm 932 \mathrm{mmHg} / \mathrm{seg})$ em comparação com o grupo treinado $(6144 \pm 791 \mathrm{mmHg} / \mathrm{seg})$ (Figura 8). A derivada de relaxamento do ventrículo esquerdo ( $\mathrm{dP} / \mathrm{dt}$-) demonstrou também que houve redução significativa no grupo treinado com anabolizante (TA) (3218.945) em comparação com o grupo treinado controle (TC) $(4853 \pm 1173 \mathrm{mmHg} / \mathrm{seg})$ (Figura 9)

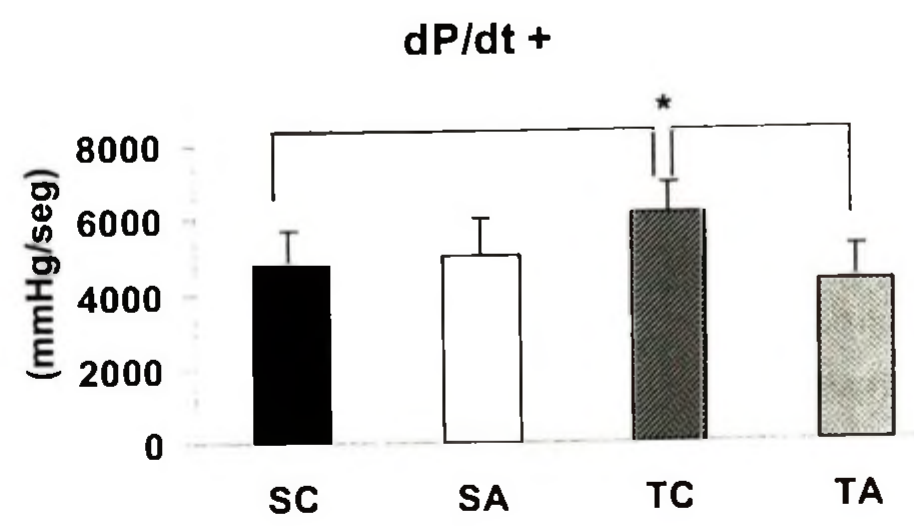

Figura 8. Derivada de contração do ventrículo esquerdo (dP/dt + ): Sedentário controle $(\mathrm{SC}, \mathrm{n}=5)$, sedentário com anabolizante $(\mathrm{SA}, \mathrm{n}=12)$, treinado controle $(\mathrm{TC}, \mathrm{n}=6)$ e treinado com 
anabolizante $(\mathrm{TA}, \mathrm{n}=9)$. (*) Diferença significante em relação ao grupo SC e em relação ao grupo $T A, P<0,05$. Os resultados estão apresentados como média \pm desvio padrão.

\section{dP/dt-}

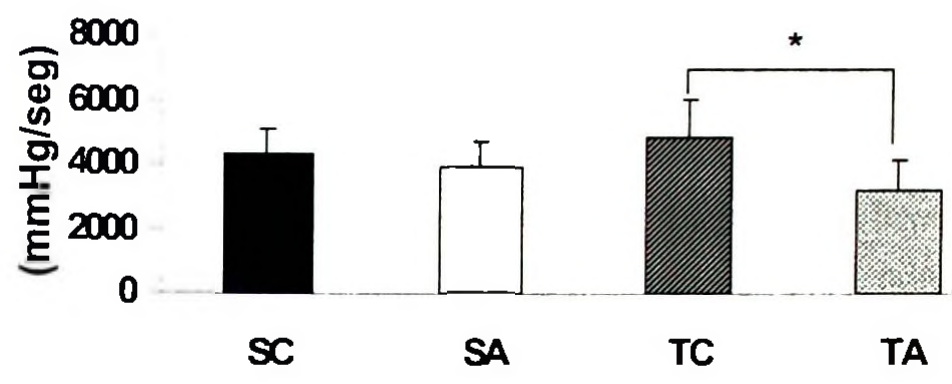

Figura 9. Derivada de relaxamento do ventrículo esquerdo (dP/dt-): Sedentário controle $(S C, n=5)$, sedentário com anabolizante $(S A, n=12)$, treinado controle $(T C, n=6)$ e treinado com anabolizante (TA,n=9). (*) Diferença significativa em relação ao grupo $\mathrm{TA}, \mathrm{P}<0,05$. Os resultados estão apresentados como média \pm desvio padrão.

Estes resultados mostram que o tratamento com EA associado ou não ao treinamento físico aeróbio leva a ativação do SRA e aumento da sintese de colágeno cardíaco. Estes efeitos levam a alterações estruturais no miocárdio, com consequente disfunção ventricular. Por outro lado, enquanto foi observado aumento na contratilidade e no relaxamento cardíaco no grupo TC; nos grupos SA e TA foi observado diminuição da pressão sistólica do VE, e ainda o grupo TA perdeu o efeito de relaxamento ventricular promovido pelo treinamento fisico.

Assim, o uso de EA associado ao treinamento fisico de nataçào leva a hipertrofia cardiaca patológica caracterizada pelo aumento na síntese de colágeno, o qual foi prevenido pelo antagonista dos receptores AT1, mostrando assim a participação do SRA nesse processo. Estes efeitos promovidos pelos EA levam a disfunção ventricular e perda dos efeitos benéficos promovidos pelo treinamento físico aeróbio no coração.

Em conclusão, pela primeira vez foi demostrado que doses suprafisiológicas de esteróides anabolizantes associadas ao treinamento fisico de nataçāo promove um major grau de hipertrofia cardiaca que é caracterizada por um aumento da tibrose intersticial. Estes resultatos mostram que esta associação é deletéria para o mivarartio. uma vez que resultou em queda dos indiess de runcio ventricular e hipertrotia parológica. Estes resulatus ioram publivatos por Rocho et al. $200-[2+0]$. 
No entanto, muito dos efeitos benéficos associados ao bloqueio dos receptores ATl sobre a fibrose cardiaca parecem estar mais relacionados à diminuição na síntese e liberação de aldosterona, do que às ações da Ang II [241], visto que a Ang II, por meio dos receptores AT1, é uma das principais responsáveis pela regulação da secreção de aldosterona, a qual tem importante papel na sintese de colágeno [241, 242].

Além de sua síntese nas glândulas adrenais, a aldosterona também tem sido mostrada ser sintetizada no coração [243]. Atuando de forma parácrina e autócrina em receptores de mineralocorticóides (RM) locais, desencadeia respostas inflamatórias levando à lesão tecidual [244], formação de colágeno, fibrose e remodelamento cardíaco [245]. O bloqueio dos RM tem se mostrado eficiente na redução de colágeno e de marcadores de hipertrofia cardíaca [246].

As ações da aldoterona sobre os RM podem ser moduladas por diferentes fatores, entre eles os glicocorticóides. Os RM apresentam maior afinidade pelos glicocorticóides do que pela aldosterona e em condições fisiológicas as concentrações de glicocorticóides são cerca de 10 vezes maiores do que os de aldosterona, com isso podemos supor que em determinadas situações os RM sejam mais estimulados por glicocorticóides do que pela aldosterona [244]. Tem sido sugerido que glicocorticóides podem atuar como antagonistas dos RM [247], visto que em algumas condições os níveis de aldosterona podem ser altos e mesmo assim não causar efeitos deletérios sobre órgãos e tecidos [248].

As ações dos glicocorticóides ou da aldosterona sobre os RM é regulada pela enzima $11 \beta$ hidroxisteroide dehidrogenase (11 -HSD), que atua como uma oxidase inativando os glicocorticóides [248]. Entre os diferentes subtipos encontrados dessa enzima, a $11 \beta$-HSD tipo 2 vai ser responsável pela conversão do cortisol e da corticosterona em 11-ceto cortisona e 11dehidrocorticosterona que são metabólitos inativos aos RM, o que acaba contribuindo para maior ação da aldosterona sobre esses receptores [249]. Tem sido observada maior HC quando ocorre aumento da expressão da $11 \beta$-HSD2, mostrando que a maior ação da aldosterona nos RM pode ter efeitos prejudiciais ao coração [247]. A atividade e seletividade da $11 \beta$-HSD2 pode ser alterada dependendo do tecido analisado e em alguns tipos de doenças [244].

Assim como o SRA, atualmente também tem sido identificado sítios extra adrenais de sintese de aldosterona, onde a expressão do gene da Aldo-sintase (CYP11B2) foi identificado em tecidos como artéria mesentérica, células musculares lisas endoteliais [250] e coração [251]. 
Foram detectados no tecido cardíaco a expressão de RM, [252] da enzima 11ß-HSD2 [253] e do gene da aldosterona sintase, CYP11B2, apesar de sua concentração ser quase 1000 vezes menores do que na glândula adrenal [254].

A sintese local de aldosterona foi demonstrada, na literatura, baseada em estudos realizados com ratos adrenalectomizados, que não apresentam aldosterona plasmática, entretanto sua concentração e a expressão do gene CYP11B2 foram encontradas aumentadas no coração dos aniamis [255]. Aumentos na expressão cardíaca do gene da aldosterona sintase também foram encontrados na insuficiência cardíaca, onde foi mostrada uma relação direta entre o aumento da expressão com o aumento de aldosterona cardíaca [256]

Em alguns casos a aldosterona tem sido encontrada em níveis até 6 vezes maiores na insuficiência cardíaca, quando comparado a indivíduos saudáveis [257], o dá maior suporte à hipótese de síntese local.

Uma das mais bem descritas ações da aldosterona sobre o coração é a sua ação sobre a matriz extracelular levando ao aumento da fibrose cardiaca [258]. Foi demonstrado em ratos que a fibrose induzida pela administração de aldosterona ocorreu no ventrículo esquerdo e direito, sendo independente de fatores hemodinâmicos [259]. Em outro trabalho muito semelhante ao citado anteriormente, ratos tratados com aldosterona e altas concentrações de sódio também apresentam aumento do colágeno cardíaco, além do aumento da fibronectina e maior espessura da artéria carótida [260]. A ação da aldosterona sobre a fibrose cardíaca também tem sido demonstrada como um importante fator para o remodelamento cardíaco durante o infarto do miocárdio [251], onde o aumento da expressão cardíaca de CYP11B2 foi diretamente relacionado ao aumento fibrose [261].

Apesar das evidências já bem descritas na literatura sobre as ações da aldosterona induzindo a fibrose cardíaca, pouco se sabe sobre os mecanismos pelos quais isso ocorre. Estudos recentes sugerem que o TGF $\beta$ pode participar das ações da aldosterona na fibrose cardáiaca. Nesse estudo, os autores observaram que o aumento do TGF $\beta$ levou a um aumento do cálcio intracelular, o que acabou estimulando a maior expressão do fator de crescimento de tecido conectivo (CTGF), que pode ser responsável pelo aumento da fibrose cardíaca.

Outro fator que tem sido recentemente sugerido, por estar relacionado as ações da aldosterona sobre a fibrose cardiaca, seria a osteopontina, que tem sido mostrada não somente 
como um marcador inflamatório, mas também por apresentar um papel funcional no remodelamento cardíaco. Essa hipótese tem sido confirmada em camundongos geneticamente modificados, que apresentam deficiência para osteopontina, uma vez que nestes animais observou-se que as ações da aldosterona sobre a fibrose cardíaca foram inibidas [262]. As ações da aldosterona sobre a fibrose do miocárdio e o remodelamento cardiaco mediadas pela osteopontina também tem sido mostrada em estudos onde o bloqueio da Ang II e da aldosterona foi eficaz em inibir a expressão de osteopontina no miocárdio de ratos infartados, o que acabou reduzindo o colágeno cardiaco. Assim, estes resultados mostram que o bloqueio das ações da Ang II e da aldosterona sobre seus receptores previnem a hipertrofia cardíaca e o aumento de colágeno, em parte por inibir a expressão de osteopontina [263].

Como demonstrado até o momento, tanto a Ang II como a aldosterona, produzidas no tecido cardíaco, exercem efeitos sobre o sistema cardiovascular, em especial sobre a fibrose e hipertrofia [264], no entanto, ainda não estão claros os efeitos do EA e a sua associação ao treinamento físico, sobre o SRA-Aldosterona.

Assim, o passo seguinte neste estudo foi investigar se a aldosterona também participa destes efeitos deletérios sobre o miocárdio promovidos pelo uso de EA associados ou não ao treinamento físico. Assim, com o objetivo de inibir a liberação e/ou ação da aldosterona usamos um antagonista dos RM, a espironolactona. O fato de termos observado um processo de lesão cardíaca com aumento de síntese de colágeno e deposição de colágeno reparativo investigamos se estes efeitos estavam associados a um processo inflamatório, através da presença de marcadores inflamatórios.

\subsection{Materiais e Métodos}

\subsubsection{Protocolo experimental}

Para este estudo foram utilizados 56 ratos Wistar pesando entre 250-270, os quais foram usados no estudo conforme protocolo abaixo.

Os animais foram divididos em 8 grupos, sendo dois grupos sedentários e dois treinados, conforme descrição abaixo: 


\section{Sedentários: $\mathbf{2 8}$}

Grupo SC- Sedentário controle $(\mathrm{n}=7)$

Grupo SA- Sedentário Anabolizante $(n=7)$

Grupo SAL - SA tratado com Losartan $(n=7)$

Grupo SAE - SA tratado com Espirono-

lactona $(n=7)$

\section{Treinados: $\mathbf{2 8}$}

Grupo TC- Treinado controle $(n=7)$

Grupo TA- Treinado Anabolizante $(n=7)$

Grupo TAL- TA tratado com Los $(n=7)$

Grupo TAE- TA tratado com Espirono-

lactona $(\mathrm{n}=7)$

O grupo tratado com losartan foi repetido neste estudo com o objetivo de compararmos os efeitos da inibição dos receptores AT1 com a inibição dos receptores de aldosterona.

O tratamento com EA foi o mesmo descrito anteriormente, assim com as drogas utilizadas, bem como o protocolo de treinamento físico.

Para avaliarmos a participação da aldosterona os animais foram tratados com um antagonista de RM, a espironolactona, na dose de $10 \mathrm{mg} / \mathrm{Kg} /$ dia [265]. Esta dose bloquea os RM sem interefir na pressão arterial.

Após 10 semanas de treinamento foram realizadas as medidas hemodinâmicas, os animais foram sacrificados e amostras de tecidos, soro e plasma eram adequadamente coletadas e armazenadas em freezer $\left(-80^{\circ} \mathrm{C}\right)$ até serem analisadas. Essas amostras foram utilizadas para o estudo do SRA-Aldosterona.

Resumidamente, foi realizada a seguinte sequência de experimentos:

- Medida da pressão arterial e frequência cardiaca por pletismografia de artéria caudal.

- Função ventricular analisada pelo Ecocardiograma

Função Sistólica: analisada pela fração de ejeção (\%) e fração de encurtamento (\%).

Função Diastólica: analisada pela relação entre o Pico da onda E e Pico da onda A (Relação $\mathrm{E} / \mathrm{A}-\mathrm{m} / \mathrm{s}$ ) e pelo tempo de relaxamento isovolumétrico (TRIV -ms).

- Alterações morfológicas e morfométricas (conforme descrito anteriormente)

a) Análise morfológica - indice de hipertrofia cardiaca

peso úmido (VE+VD)/peso corporal) $(\mathrm{mg} / \mathrm{g})$.

b) Análise morfométrica - técnicas histológicas. 
- Hipertrofia do cardiomiócito - diâmetro de miócitos $(\mu \mathrm{M})$

- Fração Volume de Colágeno Cardíaco -técnica histológica (conforme descrito anteriomente)

- Análises Bioquímicas e Moleculares

- Medida da atividade da ECA cardíaca

- Quantificação proteica dos receptores AT1 e AT2 no coração, por técnica de Western blotting, conforme descrito na Parte 1 desta tese.

- RT-PCR para análise semi-quantitativa da expressão gênica (conforme metodologia descrita anteriormente).

do colágeno do tipo I, do colágeno do tipo III,

da aldosterona sintase (CYP11B2),

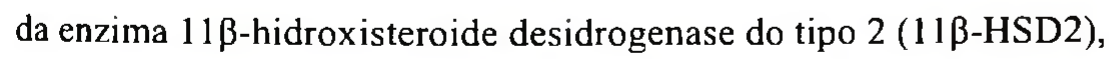

receptores de mineralocorticóides (RM)

dos fatores inflamatórios: fator de crescimento transformador beta (TGF- $\beta$ ) e osteopontina.

gene da gliceraldeído-3-fosfato desidrogenase (GAPDH) como gene normalizador.

\subsubsection{Expressão gênica cardíaca}

Será descrita somente parte da metodologa para quantificação da expressão gênica, pois as demais já foram descritas anteriomente.

A expressão gênica de colágeno tipo I, colágeno tipo III, aldosterona sintase (CYP11B2), receptores de mineralocorticóides (RM), $11 \beta$-hidroxisteroide desidrogenase tipo 2 (11ß-HSD2), fator de crescimento transformador beta (TGF $\beta$ ) e osteopontina, foram determinadas pela técnica de reação de polimerase em cadeia (RT-PCR). Foi utilizado como normalizador o gene da gliceraldeído-3-fosfato desidrogenase (GAPDH), o qual foi alterado com as condições experimentais.

As sequências dos primers utilizados nesse estudo estão descritas na tabela abaixo: 
Tabela 3. Sequência dos oligonucleotídeos para os primers utilizados no RT-PCR.

\begin{tabular}{|l|l|l|c|}
\hline Gene & Tipo & Sequência dos primers $\left(5^{\prime}-3^{\prime}\right)$ & Amplicon \\
\hline Col $1 \alpha 1$ & $\begin{array}{l}\text { Sense } \\
\text { Anti-sense }\end{array}$ & $\begin{array}{l}\text { AGAGAGCATGACCGATGGA } \\
\text { GAGGTTGCCAGTCTGTTGG }\end{array}$ & $172 \mathrm{pb}$ \\
\hline Col $3 \alpha 1$ & $\begin{array}{l}\text { Sense } \\
\text { Anti-sense }\end{array}$ & $\begin{array}{l}\text { AAGGTCCACGAGGTGACAA } \\
\text { AGGGCCTGGACTACCAACT }\end{array}$ & $143 \mathrm{pb}$ \\
\hline CYP11B2 & $\begin{array}{l}\text { Sense } \\
\text { Anti-sense }\end{array}$ & $\begin{array}{l}\text { GGATGTCCAGCAAAGTCTC } \\
\text { ATTAGTGCTGCCACAATGC }\end{array}$ & $324 \mathrm{pb}$ \\
\hline RM & $\begin{array}{l}\text { Sense } \\
\text { Anti-sense }\end{array}$ & $\begin{array}{l}\text { GCTTTGATGGTAGCTGCG } \\
\text { TGAGCACCAATCCGGTAG }\end{array}$ & $154 \mathrm{pb}$ \\
\hline $11 \beta-H S D 2$ & $\begin{array}{l}\text { Sense } \\
\text { Anti-sense }\end{array}$ & $\begin{array}{l}\text { CCGGTTGTGACACTGGTTTTG } \\
\text { GGGGTATGGCATGTCTCCTG }\end{array}$ & $419 \mathrm{pb}$ \\
\hline TGF $\beta$ & $\begin{array}{l}\text { Sense } \\
\text { Anti-sense }\end{array}$ & $\begin{array}{l}\text { GGCGGTGCTCGCTTTGTA } \\
\text { GCGGGTGACTTCTTTGGC }\end{array}$ & $106 \mathrm{pb}$ \\
\hline OTPN & $\begin{array}{l}\text { Sense } \\
\text { Anti-sense }\end{array}$ & $\begin{array}{l}\text { GTCCTTCACTGCCAGCACAC } \\
\text { GAACTCGCCTGACTGTCGAT }\end{array}$ & $450 \mathrm{pb}$ \\
\hline GAPDH & $\begin{array}{l}\text { Sense } \\
\text { Anti-sense }\end{array}$ & $\begin{array}{l}\text { ATGGGTGTGAACCACGAGAA } \\
\text { CGAGTACTGGTGTCAGGTA }\end{array}$ & $141 \mathrm{pb}$ \\
\hline
\end{tabular}

\subsubsection{Transcrição reversa (RT-PCR)}

A amplificação dos segmentos de cDNA foi realizada nas seguintes condições: $5-7 \mu l$ de produto da reação de transcrição reversa (cDNA), 2,5 $\mu$ l do tampão de reação $10 \mathrm{x}$ (Tris-HCl $20 \mathrm{mM}$ (pH 8,4), $\mathrm{KCl} 50 \mathrm{mM}$ ), $0,75 \mu \mathrm{l}$ de $\mathrm{MgCl}_{2} 50 \mathrm{mM}, 2 \mu \mathrm{l}$ da mistura de dNTP 2,5mM (dATP, dTTP, dCTP e dGTP), $0,5 \mu l$ de cada primer (12,5 $\mu \mathrm{M}$ concentração final) e $0,25 \mu 1$ da enzima Taq DNA polimerase Platinum (Gibco) (2,5 unidades da enzima) e $\mathrm{H}_{2} \mathrm{O}$ estéril (q.s.p. $25 \mu \mathrm{l}$ ).

As reações de PCR foram realizadas em termociclador MiniCycler MJ Research, seguindo as condições especificadas para cada par de primers. Os passos da reação de anelamento e amplificação foram os seguintes: 1) reação de denaturação e ativação da Taq, $94^{\circ} \mathrm{C}$, $5 \mathrm{~min}$, um ciclo; 2) reação de denaturação, $94^{\circ} \mathrm{C}, 1 \mathrm{~min}, 35$ ciclos; 3) reação de anelamento, $55^{\circ} \mathrm{C}$, 
1 min, 35 ciclos; 4) reação de extensão, $72^{\circ} \mathrm{C}, 30 \mathrm{~s}, 35$ ciclos; 5) reação de extensão final, $72^{\circ} \mathrm{C}$, 10 min, 35 ciclos; 6) resfriamento, $4^{\circ} \mathrm{C}$, tempo indeterminado.

A extração do RNA total e síntese do cDNA, foram realizados conforem descritos anteriormente

\subsubsection{Avaliação eletroforética dos produtos de amplificação}

Para a análise de formação dos produtos de PCR, alíquotas de $10 \mu 1$ dos produtos de reação foram submetidas à eletroforese em gel de agarose a 3\%, em tampão TAE 1x. O marcador de peso molecular utilizado foi o DNA “Ladder" de $100 \mathrm{pb}$ (Gibco-BRL).

As bandas foram visualizadas por meio da incidência de radiação ultravioleta, em uma câmara escura equipada com um transluminador e as imagens, adquiridas pelo programa Chemilmager 5500 (Alpha Innotech, CA, USA).

As imagens foram salvas, a intensidade das bandas obtidas e analisadas utilizando o programa de análise de densitometria óptica Scion Image, fornecido gratuitamente pela NIH (USA) via internet.

\subsubsection{Análise estatística}

Os dados obtidos neste estudo estão apresentados na forma de média \pm desvio padrão. A análise estatística foi realizada com a utilização do software STATISTIC BASIC por meio de análise de variância de dois fatores (ANOVA two-way). Para melhor compreensão dos resultados, os grupos foram analisados em três etapas, sendo primeiramente comparados os grupos controle com os grupos tratados com EA (treinamento fisico e EA como variáveis independentes). Em um segundo momento, os grupos tratados com EA foram comparados com os grupos tratados com Losartan (treinamento fisico e Losartan como variáveis independentes) e em um terceiro momento, foram comparados os grupos tratados com EA com os grupos tratados com Epironolactona (treinamento físico e Espironolactona como variáveis independentes). Para análise da pressão arterial pré e pós-tratamento experimental foi realizada ANOVA para medidas repetidas. Quando F significante foi aplicado teste post-hoc de Duncan de múltiplas comparações. Para análise da frequência cardíaca pré e pós-tratamento foi realizado Teste t de Student pareado. Foi aceito como valores significantes um $\mathrm{p} \leq 0,05$. 


\subsection{Resultados e Discussão}

\subsubsection{Pressão arterial e fequência cardíaca}

Não foram observadas diferenças na PA entre os grupos estudados nos períodos pré e pós-tratamento, mesmo com o tratamento com losartan ou com espironolactona, para nem um dos grupos estudados. Quando se propõe estudar os efeitos locais de determinados sistemas por meio de intervenções farmacológicas, deve-se ter cuidado para que a PA não seja alterada. Essa precaução deve ser ainda maior quando estes estão diretamente envolvidos com sua regulação, como é o caso do SRA-Aldosterona, uma vez que qualquer alteração poderia ocasionar resultados provenientes de uma alteração pressórica. Por isso, as doses utilizadas do antagonista de receptores ATl, losartan, e do antagonista dos RM, espironolactona, foram já bem demonstradas na literatura, por serem eficazes em inibir os efeitos locais sem consequências hemodinâmicas [265].

Como já esperado, não foram observadas diferenças significantes na FC de repouso entre os grupos sedentários analisados pré e pós-tratamento experimental. Conforme pode ser observado na Figura 10. O treinamento físico de natação utilizado nesse estudo reduziu a FC de repouso no grupo treinado controle, quando comparado pré e pós-treinamento físico. Entretanto, quando a administração de EA foi associada ao treinamento de natação (TA), não foi observada redução da FC repouso, diferente do que haviamos encontrado em estudo prévio. Entretento, foram usada metodologia diferentes, para essa medida, nos dois estudos, sendo nesse utilizada medida indireta por pletismografia caudal.

Como resultados muito interessantes encontrados nesse estudo, destacam-se os diferentes efeitos observados quando o losartan ou espironolactona são associados ao EA. Os animais que realizaram o treinamento físico e foram tratados com EA e losartan (TAL) não apresentaram redução da FC de repouso. Por outro lado, o grupo que recebeu espironolactona apresentou redução da FC de repouso, após o período de tratamento. 


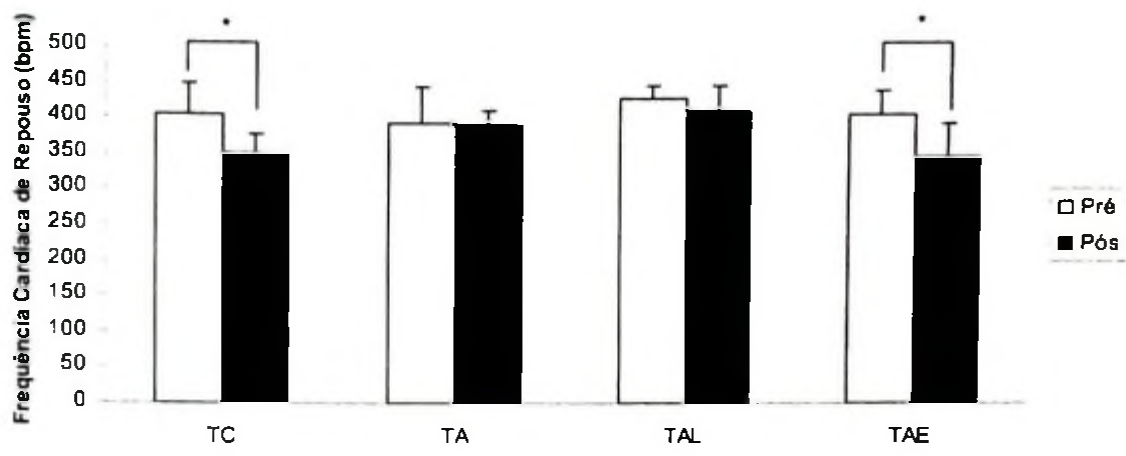

Figura 10. Frequência cardíaca de repouso pré e pós treinamento físico (bpm). Efeitos da administração de EA associado ao treinamento fisico de natação, Losartan ou Espironolactona sobre a frequência cardíaca de repouso pré e pós protocolo experimental. Treinado controle (TC, $\mathrm{n}=7$ ), treinado tratado com anabolizante (TA, $n=7)$, treinado tratado com anabolizante e Losartan (TAL, n=7) e treinado tratado com anabolizante e Espironolactona (TAE, $n=7$ ). Os resultados são apresentados como média \pm DP. $\left({ }^{*}\right)$ Diferença significante entre os períodos pré e pós treinamento de natação no mesmo grupo, $\mathrm{p}<0,05$.

A associação do EA ao treinamento de natação, neste estudo, resultou na perda do efeitos do treinamento sobre a FC de repouso, o que sugere um possivel efeito do EA sobre as adaptações induzidas pelo treinamento. Esses efeitos podem ter ocorrido devido às ações dos EA sobre a modulação autonômica, e de fato alguns estudos têm demonstrado aumento das respostas taquicárdicas e diminuição das bradicárdicas [266, 267].

Outro fator que pode ter contribuído para os efeitos dos EA sobre a FC seria a maior ativação do SRA aldosterona, conforme já demosntramos, no qual a Ang II tem um importante papel sobre a modulação autonômica, aumentando o tônus simpático e diminuindo o parassimpático [268], além de estar associado ao aumento do colágeno intersticial e consequente prejuizo da função diastólica.

Os resultados sobre a FC observados com os tratamentos com as drogas, mostram que os animais treinados que receberam EA, apenas o grupo tratado com a espironolactona apresentou redução da FC de repouso após o periodo de treinamento.

Os antagonistas dos RM têm sido bem descritos na literatura por serem eficientes em reverter os efeitos deletérios induzidos pela aldosterona sobre o sistema cardiovascular em condições patológicas $[239,269]$. No entanto, os efeitos desses antagonistas associados ao EA são desconhecidos, sendo sugerida pela primeira vez, sua eficácia em reverter os efeitos 
induzidos pelo EA sobre a FC de repouso após o treinamento físico. Uma possivel explicação para esses resultados pode ser a ações do EA sobre o aumento da aldosterona cardíaca, que pode ter levado a maior atividade simpática, inibindo os efeitos do treinamento fisico sobre a FC repouso, uma vez que a administração de espironolactona parece ter revertido esses efeitos. Uma segunda hipótese estaria relacionada às alterações estruturais cardiacas induzidas pela aldosterona, em que tem sido mostrado que a aldosterona tem importante papel na fibrose cardiaca e prejuizo da função ventricular, que pode ser revertido por antagonistas dos RM [270].

Por outro lado, o tratamento com losartan não reverteu os efeitos induzidos pelo EA sobre a FC de repouso. Esses resultados podem ter ocorrido devido aos efeitos dos receptores AT1 sobre as adaptações induzidas pelo treinamento, sendo descrito que esses receptores têm importante participação nessas adaptações, exercendo papel fundamental na hipertrofia cardíaca e dos cardiomiócitos [271]. Conforme demonstramos anteriormente, na priemira parte desta tese, o losartan previne a hipertrofia cardíaca observada com o treinamento físico por natação [60]. Com isso, podemos sugerir que o fato de não ser observada diminuição na FC nesse grupo, pode ter ocorrido pela inibição dos efeitos do treinamento fisico sobre a estrutura cardiaca, resultando na falta de adaptações autonômicas sobre a FC.

\subsubsection{Função ventricular}

Conforme descrito na Tabela 3, o tratamento com EA não alterou a função ventricular no guupo sedentário (SA). No entanto, quando a administração de EA foi associada ao treinamento fisico de natação (TA), houve redução do pico de velocidade da onda $E$ e da relação E/A, o que sugere uma possivel disfunção diastólica nesse grupo, em relação aos outros grupos analisados. Estes resultados corroboram os dados encontrados anteriormente com medida direta da função ventricular, com catéter no VE. 
Tabela 4. Índices de função ventricular sistólica e diastólica obtidos pelo exame ecocardiográfico nos grupos Sedentário controle (SC), Sedentário anabolizante (SA), Tremado controle (TC) e Treinado anabolizante (TA).

\begin{tabular}{lcccc}
\hline \multicolumn{1}{c}{ Medida } & SC & SA & TC & TA \\
\hline \multicolumn{2}{l}{ Função Sistólica } & & & \\
FEj (\%) & $81,05 \pm 4,38$ & $79,03 \pm 5,17$ & $78,55 \pm 2,95$ & $79,02 \pm 3,76$ \\
FEn (\%) & $44,30 \pm 3,44$ & $42,39 \pm 4,09$ & $40,23 \pm 2,74$ & $40,77 \pm 3,78$ \\
Função Diastólica & & & \\
Pico E (m/s) & $0,61 \pm 0,07$ & $0,56 \pm 0,06$ & $0,62 \pm 0,06$ & $\mathbf{0 , 4 2 \pm 0 , 1 0 *}$ \\
Pico A (m/s) & $0,43 \pm 0,08$ & $0,40 \pm 0,05$ & $0,40 \pm 0,09$ & $0,38 \pm 0,04$ \\
Relação E/A & $1,53 \pm 0,08$ & $1,34 \pm 0,12$ & $1,68 \pm 0,23$ & $\mathbf{1 , 0 7 \pm 0 , 2 5}$ \\
TRIV (ms) & $25,2 \pm \mathbf{1 , 7}$ & $24,2 \pm 2,5$ & $30,6 \pm 2,8$ & $23,5 \pm 2,3$ \\
& & & & \\
\end{tabular}

Média \pm Desvio Padrão. Dados analisados pela análise de variância de 2-caminhos com post-hoc de Duncan. ${ }^{*} \mathrm{p}<0,05$ vs. SC, SA, e TC.

Quando os animais que receberam EA e realizaram o treinamento fisico foram tratados com Losartan (TAL) ou com Espironolactona (TAE), observou-se que os tratamentos foram eficazes na prevenção dos efeitos deletérios sobre função diastólica, conforme pode ser observado na Tabela 5. 
Tabela 5. Índices de função ventricular sistólica e diastólica obtidos pelo exame ecocardiográfico nos grupos Treinado anabolizante (TA), Treinado anabolizante Losartan (TAL) e Treinado anabolizante Espironolactona (TAE).

$\begin{array}{llll}\text { Medida } & \text { TA } & \text { TAL } & \text { TAE }\end{array}$

\section{Função Sistólica}

$\begin{array}{llll}\text { FEj }(\%) & 79,02 \pm 3,76 & 82,12 \pm 2,74 & 78,66 \pm 3,03 \\ \text { FEn (\%) } & 40,77 \pm 3,78 & 42,08 \pm 2,76 & 40,42 \pm 3,71\end{array}$

\section{Função Diastólica}

$\begin{array}{cccc}\text { Pico E (m/s) } & 0,42 \pm 0,10 & \mathbf{0 , 5 9} \pm \mathbf{0 , 0 7} \ddagger & \mathbf{0 , 5 7} \pm \mathbf{0 , 0 7} \ddagger \\ \text { Pico A (m/s) } & 0,38 \pm 0,04 & 0,404 \pm 0,09 & 0,417 \pm 0,05 \\ \text { Relação E/A } & 1,07 \pm 0,25 & \mathbf{1 , 3 9} \pm \mathbf{0 , 1 2} \ddagger & \mathbf{1 , 4 6} \pm \mathbf{0 , 1 4} \ddagger \\ \text { TRIV (ms) } & 23,5 \pm 2,3 & 30 \pm 1,15 & 31,50 \pm 1\end{array}$

Média \pm Desvio Padrão. Dados analisados pela análise de variância de 2-caminhos com post-hoc de Duncan. $\ddagger \mathrm{p}<0,05$ vs. TA.

O tratamento com EA não alterou a função ventricular no grupo sedentário (SA). No entanto, quando a administração de EA foi associada ao treinamento físico de natação (TA) houve redução do pico de velocidade da onda $E$ e da relação $E / A$, o que sugere uma possível disfunção diastólica nesse grupo, em relação aos outros grupos analisados.

O tratamento com losartan (TAL) ou com espironolactona (TAE) nos grupos tratados com EA preveniu os efeitos deletérios sobre a função diastólica.

KRIEG et al., 2007 [272], observaram por ecocardiograma em usuários de EA a diminuição no pico de velocidade durante a fase inicial de enchimento diastólico. Também foi observado prejuizo da função diastólica em levantadores de peso que utilizavam EA comparados aos que não utilizavam [210]. Prejuízos na função diastólica podem estar relacionados ao aumento do colágeno intersticial, visto que o tecido conectivo é responsável por distribuir as forças de trabalho sobre o coração, exercendo importante influência sobre a complacência ventricular [265]. 


\subsubsection{Hipertrofia cardíaca}

Conforme, já haviamos observado anteriormente somente pelo peso úmido do VE, ocorreu hipertrofia nos grupos SA, TC, TA, que foi observada nesta análise também pelo ecocardiograma $(0,21 \pm 0,02,0,22 \pm 0,03$ e $0,24 \pm 0,02$, respectivamente $v s 0,17 \pm 0,04$ no grupo SC; $P<0,05)$ e confirmado mais uma vez pelo PVE/PC $(0,23 \pm 001,0,22 \pm 0,01$ and $0,24 \pm 0,01$, respectivamente vs $0,20 \pm 0,01$ no grupo $\mathrm{SC} ; P<0,05)$, a qual foi exacerbada no grupo TA comparado aos grupos SA e TC pelo peso úmido.

A figura 11, mostra a hipertrofia cardiaca analisada pelo ecocardiograma e pelo peso das câmaras corrigido pelo peso corporal (PVE/PC mg/g), nos grupos tratados com losartan e com espironolactona.

O tratamento com Losartan, mas não com espironolactona, preveniu a hipetrofia cardiaca no grupo TAL analisada pelo peso úmido.
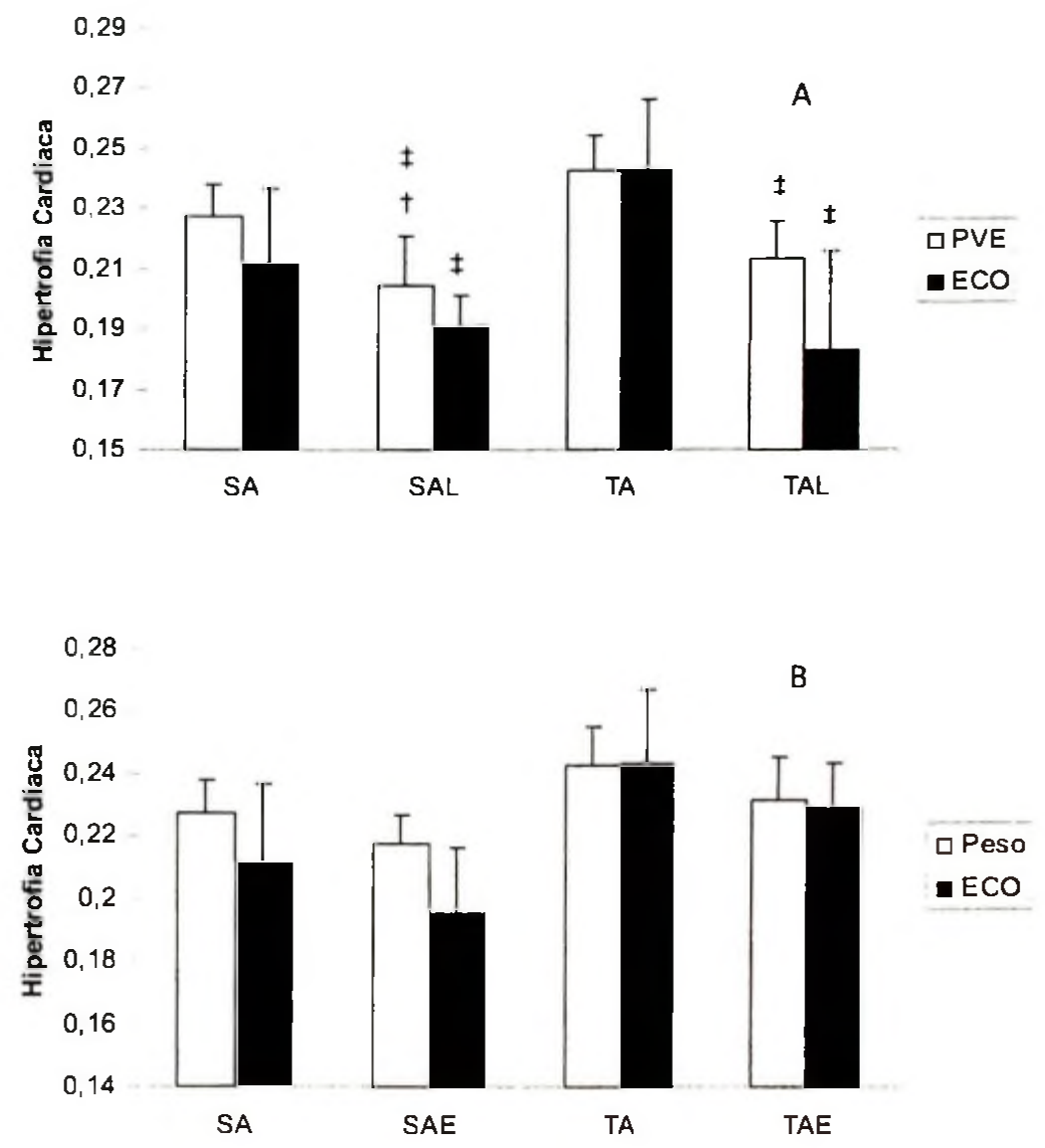
Figura 11. Hipertrofia cardíaca $(\mathrm{mg} / \mathrm{g})$. Efeitos do EA associado ao treinamento físico e ao Losartan (A) ou a Espironolactona (B) sobre a HC avaliada pelo índice de HC (peso do VE/ massa corporal) e por ecocardiograma (LVM $\left.=\left[(D D V E+S I V+P P)^{3}-(D D V E)^{3}\right] \times 1,047\right)$. Sedentário tratado com anabolizante ( $\mathrm{SA}, \mathrm{n}=7$ ), sedentário tratado com anabolizante e Losartan (SAL, $n=7$ ), sedentário tratado com anabolizante e Espironolactona (SAE, $n=7$ ), treinado tratado com anabolizante (TA, $n=7$ ), treinado tratado com anabolizante e Losartan (TAL, $n=7$ ), treinado tratado com anabolizante e Espironolactona (TAE, $n=7)$. Os resultados são apresentados como média \pm DP. $(\dagger)$ Diferença significante em relação ao grupo SA. ( $\ddagger)$ Diferença significante em relação ao grupo $\mathrm{TA}, \mathrm{p}<0,05$.

A figura 11A mostra os efeitos da administração do losartan sobre a hipertrofia cardiaca dos grupos tratados com EA. Como pode ser observado, o tratamento com losartan preveniu a hipertrofia cardíaca nos grupos sedentário (SAL) e treinado (TAL), comparado aos grupos que receberam apenas EA (SA e TA). Por outro lado, quando os animais foram tratados com espironolactona a hipertrofia não foi prevenida em nenhum dos grupos estudados (SAE e TAE), conforme pode ser observado na figura 11B.

\subsubsection{Diâmetro dos cardiomiócitos}

A figura 12 A mostra os efeitos do losartan sobre o diâmetro dos cardiomiócitos. O tratamento com losartan preveniu o aumento no diâmetro dos cardiomiócitos no grupo tratados com EA, tanto sedentários quanto treinados. Por outro lado, a administração da espironolactona nào alterou o diâmetro dos cardimiócitos em nenhum dos grupos analisados (Figura 12B). 

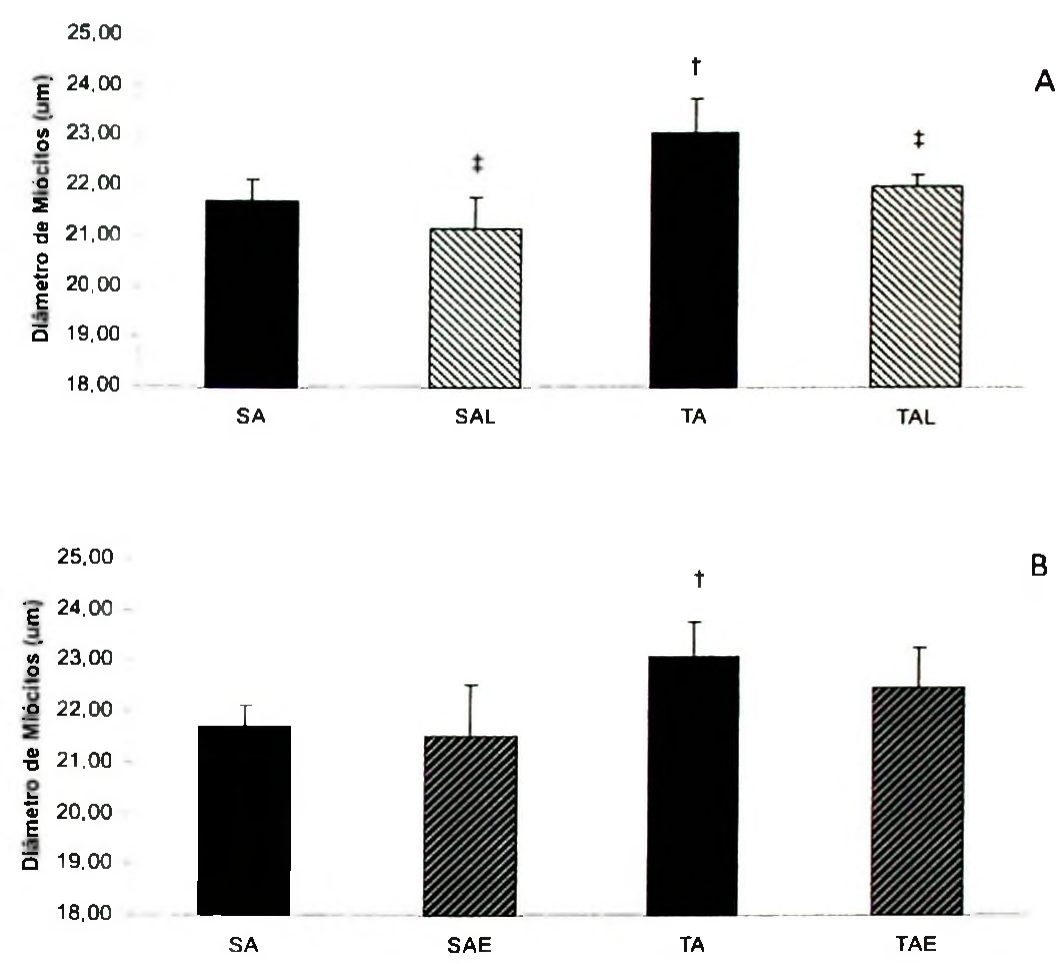

Figura 12. Diâmetro dos cardiomiócitos $(\mu \mathrm{M})$. Efeitos da administração de EA e a associação ao treinamento físico com o tratamento com Losartan (12A) e com Espironolactona (12B) sobre o diâmetro dos cardiomiócitos. Sedentário tratado com anabolizante $(\mathrm{SA}, \mathrm{n}=7)$, sedentário tratado com anabolizante e Losartan ( $\mathrm{SAL}, \mathrm{n}=7$ ), sedentário tratado com anabolizante e Espironolactona (SAE, $n=7$ ), treinado tratado com anabolizante (TA, $n=7$ ), treinado tratado com anabolizante e Losartan (TAL, $n=7$ ) e treinado tratado com anabolizante e Espironolactona (TAE, $n=7$ ). Os resultados são apresentados como média \pm DP. Diferença significante em relação ao grupo SA. ( ) Diferença significante em relação ao grupo TA, $\mathrm{p}<0,05$.

O diâmetro dos cardiomiócitos foi aumentado nos grupos SA, TC e TSA $(21,72 \pm 0,41$, $22,77 \pm 0,93$ and $23,09 \pm 0,66$, respectivamente; $P<0,05)$ comparados ao grupo $C(20,57 \pm 0,28)$. $O$ diâmetro foi maior nos grupos TC e TSA comparado com o grupo SA $(P<0.05)$.

$\mathrm{O}$ aumento no diâmetro dos cardiomiócitos foi prevenido pelo tratamento com losartan nos grupos SAL e TAL $(21,15 \pm 0,62$ e 22,01 $\pm 0,23)$, quando comparados com o grupo TSA $(23,09 \pm 0,66)$. Entretanto, não foi prevenido pelo tratamento com a espironolactona nos grupos SAE e TAE $(21,51 \pm 1,0$ e $22,45 \pm 0,80)$, quando comparados com os grupos SA e TSA $(21,72 \pm 0,41$ e $23,09 \pm 0,66)$. Estes resultados podem ser explicados pelo fato da hipertrofia 
cardíaca ser prevenida com o tratamento com losartan, a droga previne a hipertrofia fisiológica induzida pelo treinamento físico, conforme já havíamos demonstrado anteriormente [60], no primeiro estudo desta tese. Assim, estes resultados corroboram nossos estudos prévios.

A hipertrofia cardíaca induzida pelo treinamento fisico aeróbio é desencadeada por estimulos mecânicos decorrentes da sobrecarga de volume, levando à maior síntese de proteínas contráteis e aumento do sarcoplasma, o que acarreta em aumento no diâmetro dos cardiomiócitos $[101,265]$.

Por outro lado, diferentemente do que ocorre com o treinamento físico, a hipertrofia cardíaca encontrada no grupo sedentário anabolizante parece estar relacionada ao aumento do colágeno cardíaco, sendo observado aumento na fração volume de colágeno e colágeno tipo III, quando comparados ao grupo sedentário controle. Conforme mostramos anteriormente o aumento da OH-Pro implica em aumento de peso no VE. Assim, o tratamento com EA parece também estar associado ao aumento no diâmetro dos cardiomiócitos, apesar desse resulado ser significantemente menor, em relação ao observado nos grupos que realizaram o treinamento fisico de natação. O aumento dos cardiomiócito induzido pelo EA pode ocorrer devido aos seus efeitos diretos sobre a síntese protéica muscular [273], ou ainda, por aumentar vias patológicas, aumentando a expressão de genes usualmente encontrados na vida fetal, como a miosina de cadeia pesada e a $\alpha$ actina esquelética.

\subsubsection{Colágeno cardíaco}

A figura 13, mostra os resultados do colágeno cardíaco, pela $\mathrm{FVC}(\mathrm{A}, \mathrm{B}$ e C) e expressão gênica do colágeno do tipo I e III (D, E e F) nos grupos controle (A e D) e tratados com losartan (B e E) e com espironolactona (C e F).

Conforme já haviamos observado no estudo anterior, a hipetrofia cardiaca no grupo SA foi associada ao aumento da expressão e concentração de colágeno. A FVC foi aumentada nos grupos SA e TSA, comparados aos grupos C e T $(2,32 \pm 0,28$ e $2,0 \pm 0,11$ vs. $1,17 \pm 0,17$ e $1,33 \pm 0,2$ $\mu \mathrm{m} /$ area, respectivamente; $P<0,05)$. A FVC foi prevenida pelo tratamento com losartan, conforme demonstramos anteriormente. Estes resultados foram confirmados, com estes experimentos e também a FVC foi prevenida pelo tratamento com a espironolactona nos grupos 
SAE e TSE $(1,46 \pm 0,53$ e $1,37 \pm 0,05)$, comparados aos grupos SA e TSA $(2,32 \pm 0,28$ e $2,0 \pm 0,11$ $\mu \mathrm{m} ; \mathrm{P}<0,05)$.

Conforme observado anteriormente, a expressão relative do colágeno tipo III foi significativamente aumentada nos grupos SA e TSA comparados aos grupos SC e TC (1,32 $\pm 0,32$ e $1,26 \pm 0,05$ vs $0,73 \pm 0,17$ e $0,88 \pm 0,12 \mathrm{UA}$, respectivamente, $\mathrm{P}<0,05$ ). A expressão relative do colágeno do tipo I não foi diferente para os 4 grupos: C, SA, TC e TSA $(0,86 \pm 0,15,1,02 \pm 0,06$, $0,83 \pm 0,24$ e $1,12 \pm 0,2 \mathrm{UA}$, respectivamente).

A expressão relativa do colágeno do tipo III foi prevenida pelo tratamento com losartan nos grupos SAL e TAL $(0,90 \pm 0,1$ e $0,96 \pm 0,14)$ e também pelo tratamento com a espironolactona nos grupos SAE e TAE $(1,01 \pm 0,07$ e 0,85 $\pm 0,08)$ comparados com os grupos SA e TSA $(1,32 \pm 0,32$ e $1,26 \pm 0,05)$, respectivamente; $\mathrm{P}<0,05$. Além disso, a expressão relative do colágeno tipo I foi prevenida pelo tratamento com losartan no grupo TAL $(0,86 \pm 0,12)$ comparado com o grupo TSA, e também pelo tratamento com a espironolactona nos grupos SAE e TAE $(0,87 \pm 0,09$ e $0,88 \pm 0,05)$ comparados com os grupos SA e TSA $(1,02 \pm 0,06$ e 1,12 $\pm 0,02)$, respectivamente; $\mathrm{P}<0,05$. 

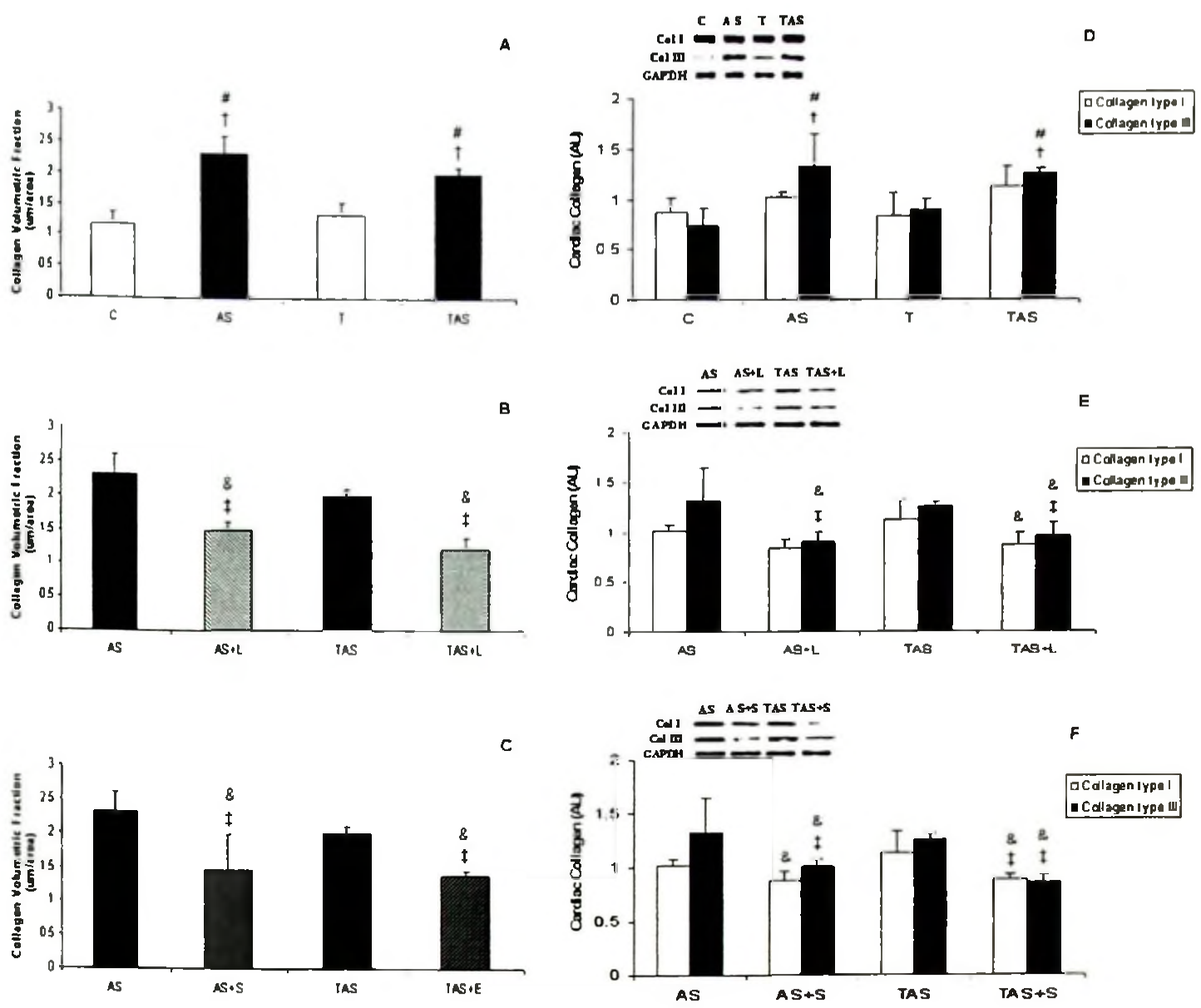

Figura 13. Colágeno cardíaco. Fração de volume de colágeno (CVF) (no esquerdo) e expressão de colágeno cardíaco tipo I ( $\square$ ) e tipo III ( $\square$ ) (no direito) nos grupos sedentário controle (C, n=7), sedentário anabolizante ( $A S, n=7)$, treinado $(T, n=7)$, treinado anabolizante (TAS, $n=7)(A$ e $D)$, sedentário anabolizante tratado com losartan ( $A S+L, n=7)$, treinado anabolizante tratado com losartan (TAS $+\mathrm{L}, \mathrm{n}=7$ ) ( $\mathrm{B}$ e $\mathrm{E}$ ), sedentário anabolizante tratado com espironolactona (AS+S, $n=7)$ e treinado anabolizante tratado com espironolactona (TAS $+S, n=7$ ) (C e $F$ ). Blots representativos da expressão de colágeno tipo I e III (D, E e F). As bandas alvo foram corrigidas pelo GAPDH cardíaco. Resultados expressos como media \pm DP. $\dagger P<0,05$ vs $C, \# P<0,05$ vs $\mathrm{T}, \ddagger$ $P<0,05$ vs $A S, \& P<0,05$ vs TAS. 


\subsubsection{Sistema Renina Angiotensina cardíaco}

A figura 14, mostra os resultados ddo SRA cordíaco. A atividade da ECA é mostrada nas figuras ( $A, B$ e $C$ ) e expressão gênica dos receptore ATla e AT2 são mostrados nas figuras (D, E e F) nos grupos controle (A e D) e tratados com losartan (B e E) e com espironolactona (C e F).
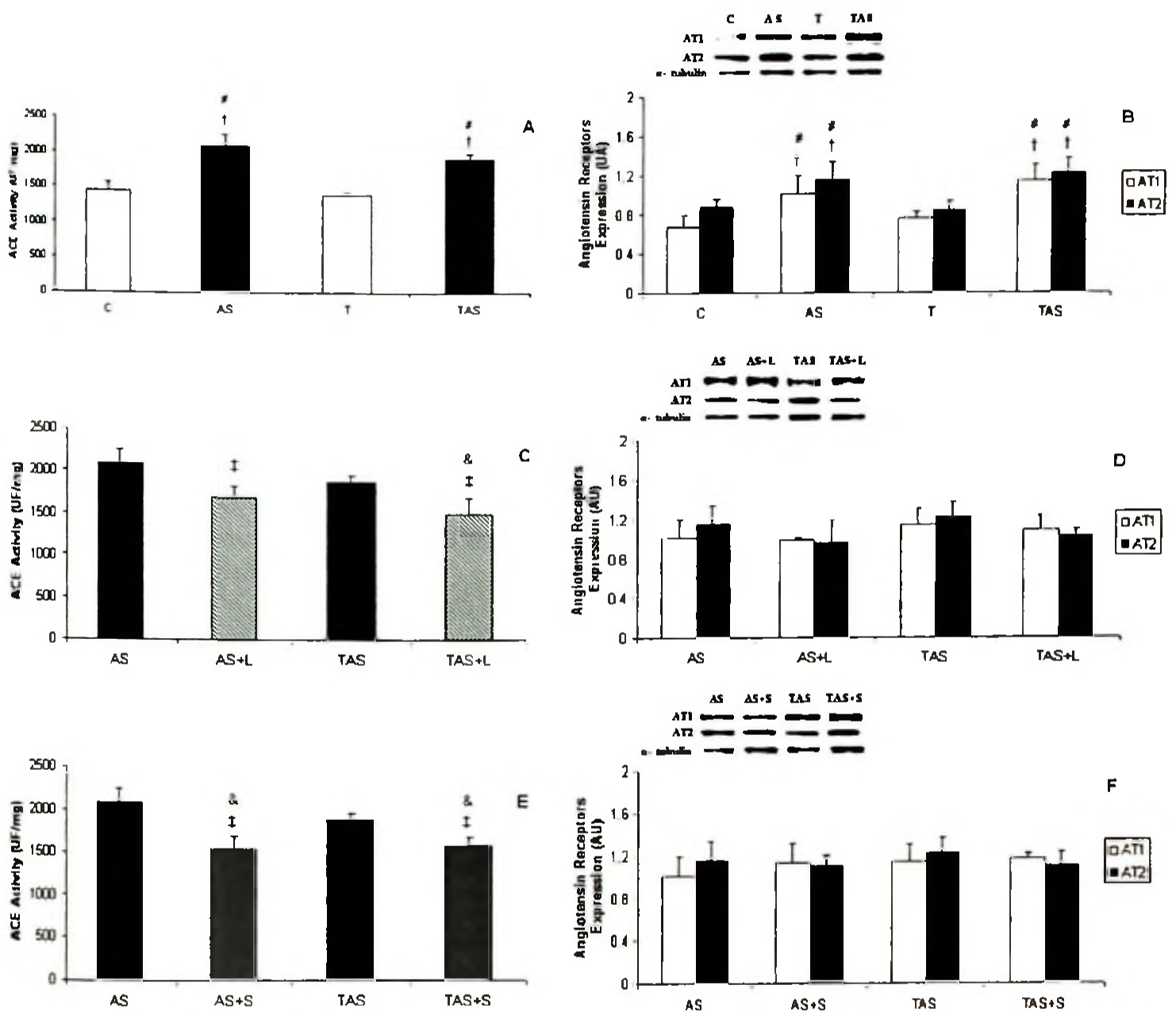

Figura 14. Sistema Renina Angiotensina cardíaco. Atividade da enzima conversora de angiotensina (ACE) (no VE), expressão dos receptores AT1 (ם) e AT2 (匹) (no VD) nos grupos sedentário controle $(C, n=7)$, sedentário anabolizante $(A S, n=7)$, treinado $(T, n=7)$, treinado anabolizante (TAS, $n=7$ ) (A e B), sedentário anabolizante tratado com losartan ( $\mathrm{AS}+\mathrm{L}, \mathrm{n}=7$ ), treinado anabolizante tratado com losartan (TAS $+\mathrm{L}, \mathrm{n}=7)(\mathrm{C}$ e $\mathrm{D})$, sedentário anabolizante tratado com espironolactona $(A S+S, n=7)$ e treinado anabolizante tratado com espironolactona $(T A S+S, n=7)(E$ e F). Blots representativos da expressão dos recptores AT1 e AT2 (B, D e F). 
As bandas alvo foram corrigidas pela $\alpha$-tubulin cardíaca. Resultados expressos como media \pm DP. $\dagger P<0,05$ vs $\mathrm{C}, \# P<0,05$ vs $\mathrm{T}, \ddagger P<0,05$ vs $\mathrm{SA}, \& P<0,05$ vs TAS.

Com relação ao SRA cardíaco foi observado aumento na atividade da ECA no VE nos grupos SA e TSA comparados aos grupos SC e TC $(2083 \pm 161,1879 \pm 75,1445 \pm 115$ and $1377 \pm 44$, respectivamente; $\mathrm{P}<0,001)$. O aumento na atividade da enzima foi prevenido pelo tratamento com losartan nos grupos SAL e TAL (1682 \pm 140 e 1495 \pm 187$)$, e também pelo

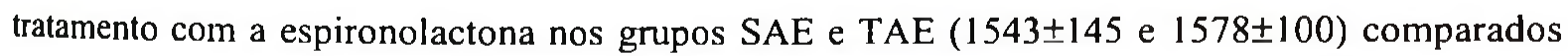
com os grupos SA e TSA $(2083 \pm 161$ e 1879 \pm 75$)$, respectivamente. Houve aumento na expressão protéica do receptorese AT1 e AT2 nos grupos SA e TSA comparados aos grupos SC e TC (AT1: $1,02 \pm 0,2,1,15 \pm 0,16,0,66 \pm 0,12$ e $0,76 \pm 0,06$, respectivamente; $P<0,05$; AT2: $1,16 \pm 0,18$, $1,21 \pm 0,15,0,87 \pm 0,08$ e $0,83 \pm 0,1$, respectivamente; $P<0,05)$.

O aumento na expressão dos receptors foi prevenido pelo tratamento com losartan nos

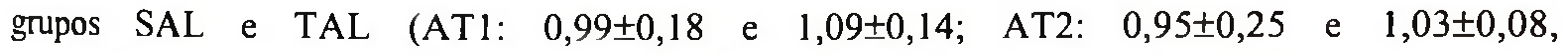
respectivamente), entretando não foi prevenida pelo tratamento com espironolactona nos grupos SAE e TAE (AT1: $1,14 \pm 0,18$ e 1,18 $\pm 0,05$; AT2: $1,10 \pm 0,11$ e $1,11 \pm 0,12$, respectivamente),

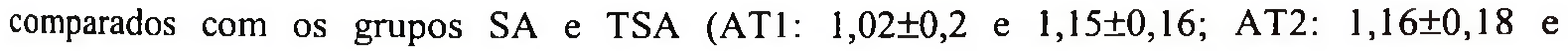
$1,21 \pm 0,15)$, respectivamente.

As ações da Ang II através dos receptores AT1 têm sido consideradas um dos principais estímulos para proliferação de fibroblastos [274], aumento da síntese de proteínas da matriz extracelular [275], liberação de fatores inflamatórios, [276], ou ainda diminuição da expressão das metaloproteinases 1 (MMP-1), as quais são responsáveis pela degradação do colágeno [277].

O bloqueio dos receptores AT1, com Losartan, foi eficaz em restaurar a atividade da colagenase, diminuindo o efeito pró-fibrótico da Ang II [277]. Em condições patológicas, modelos de infarto, sobrecarga de volume e estenose aórtica, o tratamento com Losartan foi eficaz em prevenir a hipertrofia cardiaca [233, 278].

Resultados semelhantes foram encontrados neste estudo, em que o tratamento com Losartan inibiu e/ou preveniu o aumento do colágeno intersticial induzido pelo EA no grupo sedentário. O que pode explicar, em parte, a menor hipertrofia cardíaca encontrada nesse grupo. Uma vez que, mostramos anteriormente que parte da hipetrofia promovida pelos EA pode ser 
decorrente do aumento da concentração de OH-Pro. Isso sugere que os receptores AT 1 apresentam importante papel na fibrose cardíaca induzida pelo EA. No grupo tratado com losartan e EA associados ao treinamento observa-se prevenção da hipertrofia, diminuição da fração volume de colágeno e redução na expressão de colágeno tipo I e III, em relação aos grupos tratados com EA. A redução do colágeno cardíaco observado nesse grupo pode ter sido responsável pelos efeitos benéficos do Losartan sobre a função diastólica, eficaz em reverter os efeitos deletérios induzidos pela associação do EA ao treinamento físico.

Ao contrário do observado com o tratamento com losartan, o tratamento com espironolactona não preveniu a hipertrofia cardíaca nos grupos SAE e TAE, comparados aos grupos que receberam EA. No entanto, foi observada menor fração volume de colágeno e expressão dos colágenos tipos I e III nesses grupos. Estes resultados estão deacordo com dados obtidos para o diâmetro dos miócitos, que também não foi prevenido por esse tratamento, sugerindo assim o importante papel da aldosterona sobre a síntese de colágeno cardíaco, não influenciando os efeitos do treinamento físico. Assim como o tratamento com losartan, a espironolactona também preveniu a disfunção diastólica induzida pela associação do EA ao treinamento físico, que pode ter sido decorrente da diminuição na síntese e deposição de colágeno cardiaco.

Resultados semelhantes foram obtidos em estudos com bloqueio dos RM, com espironolactona, em baixas doses, os quais mostraram que o tratamento foi eficaz em reverter a fibrose cardíaca, sem produzir efeitos sobre a hipertrofia cardíaca [260], e também foi efetivo em reduzir o colágeno do miocárdio em ratos idosos e hipertensos [279].

Recentemente tem sido proposto que algumas das ações atribuídas à Ang II, principalmente sobre a hipertrofia cardíaca e aumento do colágeno intersticial, podem estar diretamente relacionadas à síntese e liberação de aldosterona cardíaca [280], associada a respostas inflamatórias, levando a lesão tecidual [244], síntese de colágeno e remodelamento [12, 258], independentemente de alterações hemodinâmicas, sugerindo os efeitos locais da aldosterona [259].

Embora, nosso resultados mostrem que não houve alteração na expressão dos RM com nenhum tratamento, a Figura 15, mostra que houve aumento na expressão gênica da aldosterona sintase (CYP11B2) e dal 1 $\beta$-hidroxiesteroide desidrogenase do tipo 2 (11 -HSD2) nos grupos SA 
$(45 \%$ e $42 \%)$ e TAS $(73 \%$ e $69 \%)$, comparados com o grupo SC e TC, respectivamente, $\mathrm{P}<0,05$. Ainda, houve diminuição na expressão gênica da $11 \beta$-HSD2 no grupo TC comparado ao grupo $\mathrm{SC}(\mathrm{P}<0,05)$. 

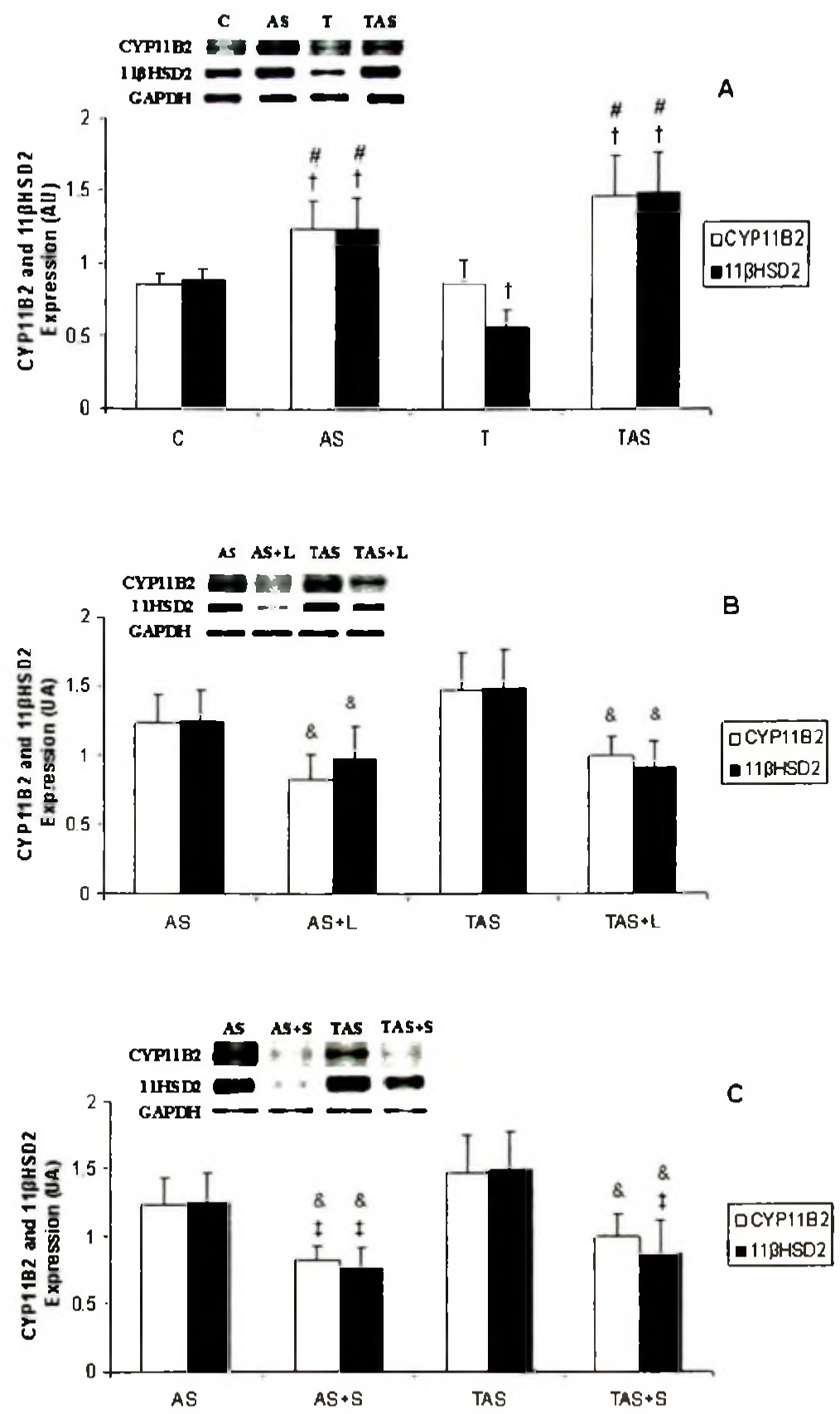

Figure 15. Gene da aldosterona sintase (CYP11B2) e $11 \beta$-hidroxisteroide dehidrogenase tipo 2 (11ß-HSD2). A expressâo cardiaca do CYP11B2 e 11 $\beta$-HSD2 nos grupos sedentário controle $(C, n=7)$, sedentário anabolizante (AS, $\mathrm{n}=7$ ), treinado $(T, n=7)$, treinado anabolizante (TAS, $n=7)(A)$, sedentário anabolizante tratado com losartan ( $A S+L$, $\mathrm{n}=7$ ). treinado anabolizante tratado com losartan $(T A S+L, n=7)(B)$, sedentário anabolizante tratado com 
ispironolactona ( $A S+S, n=7$ ) e treinado anabolizante tratado com espironolactona (TAS+S, $n=7)(C)$. Blots representativos da expressão de CYP11B2 e $11 \beta$-HSD2 na figura acima. As bandas alvo foram corrigidas peia GAPDH cardiaca. Resultados expressos como media \pm DP. $+P<0,05$ vs $\mathrm{C}, \# P<0,05$ vs $\mathrm{T}, \ddagger P<0,05$ vs $\mathrm{AS}$, \& $P<0,05$ vs TAS.

O tratamento com losartan preveniu o aumento na expressão gênica da CYP11B2 e da 11ß-HSD2 nos grupos SAL $(0,83 \pm 0,17$ e $0,97 \pm 0,25)$ e TAL $(0,99 \pm 0,14$ e $0,90 \pm 0,19)$,

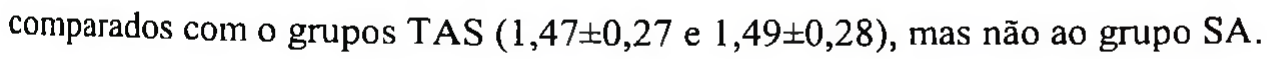

$\mathrm{O}$ tratamento com espironolactona preveniu o aumento da expressão gênica da CYP11B2 e da 11 $\beta$-HSD2 nos grupos SAE $(0,82 \pm 0,11$ e $0,76 \pm 0,16)$ e TAE $(0,99 \pm 0,17$ e $0,86 \pm 0,25)$, comparados com o grupo TAE $(1,47 \pm 0,27$ and $1,49 \pm 0,28)$, respectivamente, e também quando comparado com o grupo SA $(1,23 \pm 0,2$ e 1,24 $\pm 0,22)$, mas não quando comparado ao grupo TAE.

Os grupos tratados com EA apresentaram aumento na expressão do gene CYP11B2 em relação aos grupos controle. $\mathrm{O}$ aumento na expressão desse gene está diretamente relacionado ao aumento nas concentrações de aldosterona cardíaca [256], o que sugere que o tratamento com EA pode aumentar a sintese de aldosterona cardíaca nesses animais, a qual pode ter importante papel na fibrose cardiaca observada nesses grupos [258].

O tratamento dos animais com Losartan ou com Espironolactona preveniu o aumento na expressão do gene CYP11B2, o que consequentemente pode ter reduzido a sintese de aldosterona cardíaca e ser responsável pela menor fibrose observada. Alguns estudos têm descrito os efeitos do bloqueio do SRA aldosterona sobre a expressão do gene CYP11B2, em que animais tratados com inibidores da ECA apresentaram redução da aldosterona cardíaca e menor expressão do gene CYP11B2 [255]. Assim como, o tratamento com losartan reduziu as concentrações da enzima aldo-sintase em animais infartados [251].

A aldosterona age na maioria dos casos por meio dos RM [249]. No entanto, a interação da aldosterona com o RM é modulada por diferentes fatores, entre eles, a enzima $11 \beta$-HSD2, responsável pela inativação da corticosterona, permitindo, desta forma uma maior ação da aldosterona sobre os receptores. Neste estudo não foram observadas diferenças na expressão dos RM cardiacos em nenhum dos grupos analisados. No entanto, os grupos tratados com EA apresentaram um aumento na expressão da $11 \beta-H S D 2$ cardíaca. Assim, demonstramos, pela primeira vez, que o EA pode alterar a seletividade dos RM, aumentando a expressão da enzima 
11ß-HSD2 e permitindo, desta forma, maior ação da aldosterona sobre os RM, que pode ser responsável pelos efeitos deletérios induzidos pelo EA.

Um resultado muito interessante encontrado nesse estudo mostra o efeito do treinamento físico sobre a expressão da 11ß-HSD2. Apenas o grupo TC apresentou diminuição na expressão dessa enzima, sugerindo que o treinamento físico aeróbio pode alterar a seletividade desses receptores à aldosterona, além de permitir a maior interação dos RM com o glicocorticóide, inibindo os efeitos deletérios da aldosterona sobre o coração. Os glicocorticóides podem atuar como antagonistas dos RM [247], mostrando que baixa expressão da 11 $\beta$-HSD2, mesmo com os níveis de aldosterona elevados, pode prevenir seus efeitos colaterais, principalmente pela ligação da corticosterona aos RM [248].

Ambos os tratamentos com antagonistas dos receptores AT1 e dos RM foram eficazes em prevenir o aumento na expressão da $11 \beta$-HSD2 induzido pelo EA. O que pode ter contribuido para a menor fibrose cardiaca nesses grupos, visto que, como discutido anteriormente, a diminuição na expressão da $11 \beta-H S D 2$ está relacionada à menor fibrose cardiaca.

\subsubsection{Fatores inflamatórios cardíacos}

Tanto a Ang II, como a aldosterona, podem exercer efeitos sobre a hipertrofia cardíaca e aumento do colágeno por meio da liberação de fatores inflamatórios. Dentre eles, destacam-se o TGF $\beta$ e a osteopontina. A Figura 16 mostra os resultados observados com o efeitos do EA associados ou não treinamento físico e o tratamento com losartan e espironolactona sobre fatores inflamatórios.

Houve aumento significativo na expressão gênica do TGF $\beta$ e da osteopontina nos grupos SA $(1089,2 \pm 169$ e $1381,6 \pm 147)$ e TSA $(1244,0 \pm 113$ e 1674,3 \pm 326$)$, comparados aos grupos SC $(839,3 \pm 122$ e $777,7 \pm 32)$ e TC $(858,3 \pm 101$ e $1067,1 \pm 247)$, respectivamente, $\mathrm{P}<0,05$. Além disso, a expressão gênica da osteopontina foi exacerbada no grupo TSA comparado com o grupo SA $(\mathrm{P}<0,01)$. 

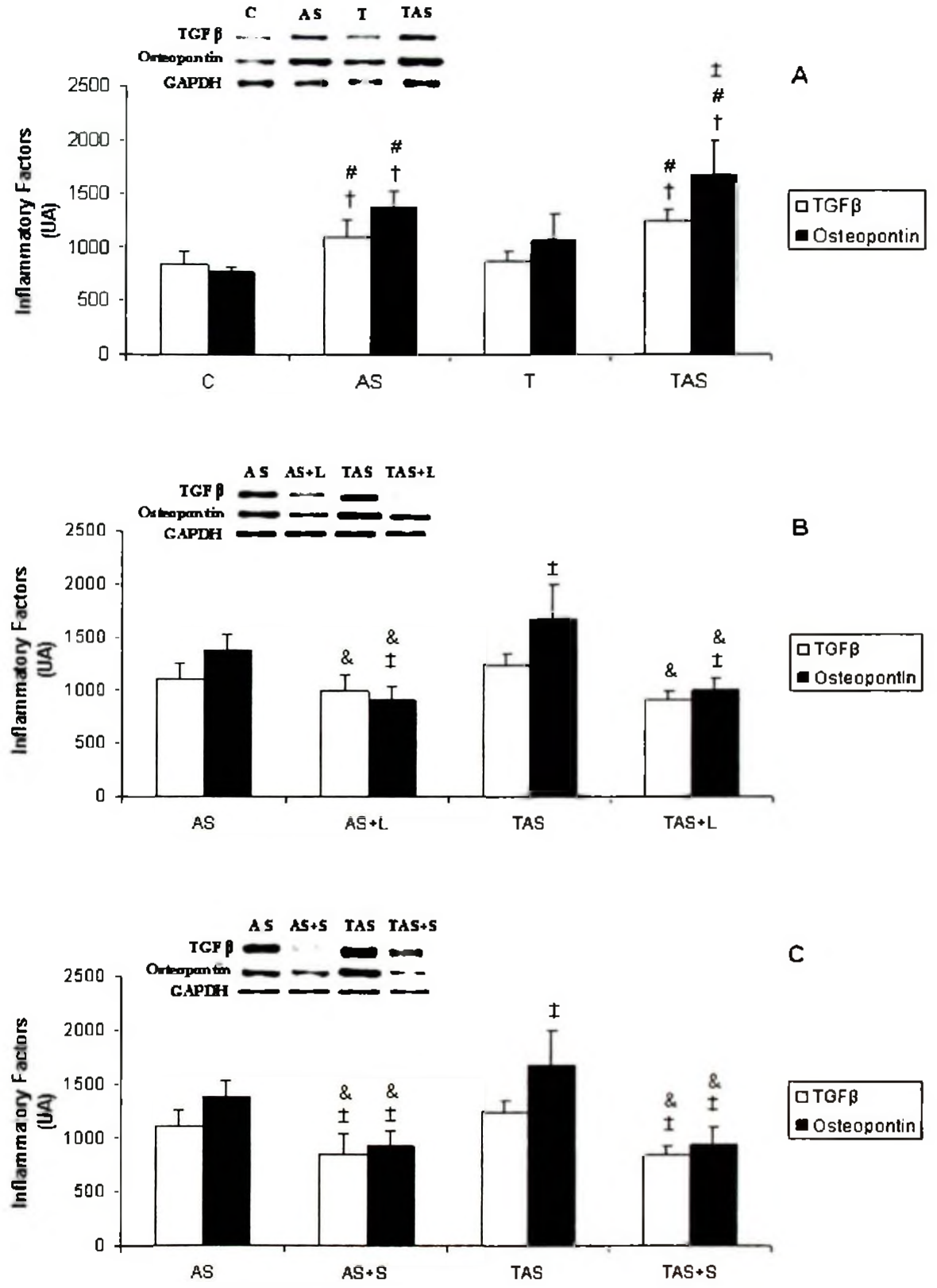

Figura 16. Fatores inflamatórios. Expressão do fator de crescimento transformador beta $\beta$ (TGF $\beta, \square)$ e osteopontina ( $\square$ ) cardiaca nos grupos sedentário controle $(C, n=7)$, sedentário anabolizante (AS, $n=7)$, treinado $(T, n=7)$, treinado anabolizante (TAS, $n=7)(A)$, sedentário anabolizante tratado com losartan ( $A S+L, n=7$ ), treinado anabolizante tratado com losartan (TAS+L, $n=7)(B)$, 
sedentário anabolizante tratado com espironolactona $(\mathrm{AS}+\mathrm{S}, \mathrm{n}=7)$ e treinado anabolizante tratado com espironolactona (TAS $+\mathrm{S}, \mathrm{n}=7$ ) (C). Blots representativos da expressão de TGF $\beta$ and osteopontina na figura acima. As bandas alvo foram corrigidas pela GAPDH cardiaca. Resultados expressos como media \pm DP. $\dagger P<0,05$ vs $\mathrm{C}, \# P<0,05$ vs T, $\ddagger P<0,05$ vs SA, $\& P<0,05$ vs TAS.

O tratamento com losartan preveniu o aumentos da expressão gênica do TGF $\beta$ e da

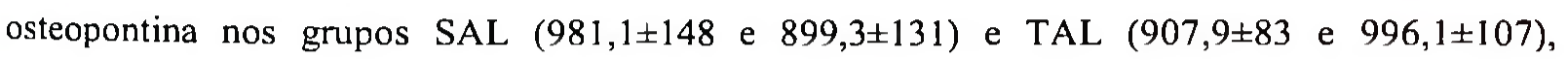
comparados com os grupos SA (1089,2 \pm 169 e $1381,6 \pm 147)$ e TSA $(1244,0 \pm 113$ e $1674,3 \pm 326)$, mas não quando comparados com o grupo SA para o gene do TGF $\beta$.

O tratamento com a espirolactona preveniu o aumento da expressão gênica do TGF $\beta$ e da

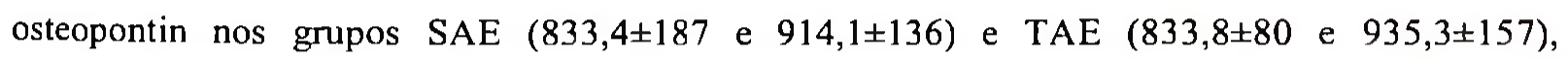
comparados com os grupos SA $(1089,2 \pm 169$ e $1381,6 \pm 147)$ e TSA $(1244,0 \pm 113$ and 1674,3 \pm 326 ), respectively, $\mathrm{P}<0,05$.

A ligação da Ang II nos receptores AT1 desencadeia uma cascata de sinalização intracelular, estimulando a liberação de TGF $\beta$ pelos cardiomiócitos, levando à necrose tecidual, ou sobre os fibroblastos, aumentando a fibrose [276]. O TGF $\beta$ também pode ser liberado pelas ações da aldosterona, induzindo o aumento na expressão de fatores de crescimento do tecido conectivo [261]. Ainda, a aldosterona pode promover uma maior liberação de osteopontina, que tem sido colocada em destaque por ter importante papel sobre a hipertrofia cardíaca e fibrose intersticial. Este resultado tem sido evidenciado em camudongos knockout para o gene da osteopontina, que não apresentam a ação da aldosterona [262].

Os resultados observados mostram que a administração de EA aumenta a atividade do SRA-Aldosterona, o que parece estar diretamente relacionado aos efeitos deletérios produzidos sobre o tecido cardíaco, uma vez que o bloqueio dos receptores ATl e dos RM preveniram esses efeitos. Uma possível hipótese dos mecanismos pelos quais os EA atuam sobre o SRA aldosterona estaria relacionada à afinidade dos EA aos RM, devido à sua estrutura similar a aldosterona [217]. Os EA, por meio dos RM, ativariam o SRA aldosterona, visto que um mecanismo inverso tem sido proposto na modulação desse sistema, em que a maior ativação dos RM parece aumentar a atividade da ECA e a expressão dos receptores AT1 [269].

O EA pode ainda agir sobre os RM por alterar a expressão da enzima 11ßHSD2, influenciando na modulação dos RM, conforme sugerido no presente estudo. Essa alteração permite a maior ação da aldosterona sobre os receptores, o que está relacionada aos efeitos 
deletérios da aldosterona sobre o tecido cardíaco. No entanto, mais estudos são necessários para o melhor entendimento dos mecanismos pelos quais os EA aumentam o SRA-Aldosterona cardíaco, principalmente associados ao treinamento físico aeróbio.

Assim, os resultados deste estudo mostraram que:

1) Doses suprafisiológicas de EA levam ao desenvolvimento de hipertrofia cardíaca, que foi exacerbada quando associada com o treinamento físico com natação.

2) A hipertrofia cardíaca foi prevenida pelo tratamento com losartan, mas não com espironolactana, entretanto sómente o losartan preveniu o aumento no diâmetro dos cardiomiócitos com o treinamento físico.

3) Os antagonistas dos receptors AT1 e dos RM foram efetivos em prevenir o aumento da FVC e da expressão gênica do colágeno do tipo I e III e também preveniram a disfunção diastólica induzida pelo uso de EA associado ao treinamento físico.

4) O aumento da expressão gênica da CYP11B2 e da $11 \beta \mathrm{HSD} 2$ induzida pelo tratamento com EA sugere o importante papel da aldosterona nos efeitos deletérios sobre o miocárdio.

5) Os marcadores inflamatórios (TGF $\beta$ e osteopontina) podem estar envolvidos nos efeitos deletérios promovidos pelo tratamento com EA ou na associação da droga com o treinamento físico.

Estes resultados estão de acordo com o crescente número de evidências de que o remodelamento interticial do miocárdio é o maior determinante da hipertrofia patológica induzido pelo tratamento com EA associado ou não ao treinamento físico, levando à disfunção diastólica.

Estes resultados estão submetidos para publicação por Carmo, EC et al., 2010.

Em contraste com os efeitos benéficos observados como resposta ao treinamento físico aeróbio, estes resultados demonstram que o uso de EA associados ao treinamento promove alterações e/ou adaptações no sistema cardiovascular como hipertrofia cardiaca patológica com aumento de tecido fibrótico e disfunção ventricular. SCHAIBLE e SCHEURER (1979) [84] mostraram que o aumento no fluxo coronário é proporcional ao grau de hipertrofia induzido pelo treinamento físico, resultante de um aumento do leito vascular coronário. 
Assim, na sequência desta linha de investigação estudamos quais seriam esses efeitos sobre o sistema vascular, como o fluxo sanguíneo para o miocárdio e para musculatura esquelética.

Os esteróides anabolizantes podem promover efeitos tróficos através da sua ligação aos receptores de andrógeno promovendo um balanço nitrogenado positivo, ou seja, um aumento na razão de sintese protéica e diminuição na degradação destas proteínas [211, 281], porém os efeitos destas substâncias sob os receptores de andrógenos no músculo esquelético não é uniforme e depende da concentração destes receptores no músculo em questão [282].

Receptores androgênicos são encontrados na musculatura esquelética e cardiaca, os quais possuem a mesma afinidade e caracteristicas bioquímicas daqueles presentes nos órgãos reprodutores [281]. Porém, o número de receptores presentes nos músculos é muito menor do que os encontrados nos órgãos reprodutivos. Desta forma, podem variar de acordo com o músculo, sendo esta característica, em parte, responsável pela menor sensibilidade do músculo esquelético aos andrógenos [282]. Além disso, os esteróides anabólicos sintéticos são de grupos heterogêneos com afinidades diferentes para o receptor de andrógeno. A testosterona tem uma razão anabólica/ androgênica de 1 para 1, enquanto a razão para a nandrolona é de 10 para 1 e o estanozolol apresenta alta razão anabólica, sendo esta de 30 para 1 . Assim, seus efeitos vão depender do músculo e do tipo de droga em estudo.

\section{Perfusão miocárdica}

Para um bom funcionamento do sistema cardiovascular é necessário que o coração esteja recebendo suprimentos adequados. O fornecimento de oxigênio para o músculo cardíaco é dependente do fluxo sangüíneo e da extração de oxigênio. Em condições normais de repouso, o coração extrai aproximadamente $75 \%$ do oxigênio oferecido através do fluxo sangüíneo restando uma margem pequena de aumento nesta extração de oxigênio e durante o exercício físico, para que a necessidade miocárdica de oxigênio seja atendida, o fluxo coronariano precisa aumentar de 4 a 6 vezes [283].

Resultados de estudos recentes têm demonstrado que o treinamento físico provoca melhora na perfusão miocárdica e entre os componentes envolvidos nesta melhora podemos citar a função endotelial. O aumento da pressão transmural do vaso (shear stress) pode aumentar a 
produção de óxido nítrico e, consequentemente, o fluxo sangüíneo vascular. Este mecanismo de vasodilatação, mediada pela ação endotelial, tem sido apontada como uma das principais adaptações vasculares promovidas pelo treinamento físico. Maior disponibilidade de óxido nítrico pode ocorrer devido ao aumento na expressão de enzimas antioxidantes e na expressão da enzima óxido nítrico sintase [284].

Diferentemente dos resultados observados com o treinamento físico, o uso de esteróides anabolizantes pode prejudicar a função vascular. Um estudo realizado por FERRER et al., (1994) [285] demonstrou que os prejuízos observados na função vascular de coelhos tratados com o esteróide anabólico nandrolona ocorreu devido ao menor relaxamento da aorta torácica destes animais, causado pela inibição da guanilato ciclase e conseqüente diminuição da produção de óxido nitrico endotelial. Um estudo de EBENBICHLER et al. (2001) [286] observou que em fisiculturistas, usuários de esteróides anabolizantes, o percentual de alteração no diâmetro da artéria braquial após uma hiperemia reativa estava diminuído quando comparado a atletas controle, caracterizando uma disfunção endotelial. Além disso, maior rigidez aórtica foi demonstrada em atletas que fazem o uso de esteróides anabolizantes [287] e prejuízos na reatividade vascular não dependente do endotélio, também foram observados em fisiculturistas usuários de anabolizantes, sendo este um efeito reversível após a descontinuidade do uso destas substâncias $[153,288]$.

Outro mecanismo que poderia corroborar com uma melhor perfusão miocárdica é a angiogênese. A angiogênese é o processo de formação de novos vasos sangüíneos a partir de vasos preexistentes, primariamente na microvasculatura. No indivíduo adulto saudável, as células endoteliais que revestem o lúmen dos vasos sangüíneos encontram-se quiescentes, isto é, apresentam atividade mitogênica próxima a zero, portanto neoformação vascular é virtualmente ausente. Mais detalhes sobre este tema, será abordado no próximo estudo.

Em estudos com animais experimentais [222], analisando a influência combinada de esteróides anabolizantes e exercício físico em camundongos, sobre o diâmetro dos miócitos, número de capilares em volta de um miócito, densidade capilar e distância intercapilar, observaram que o exercício físico isolado causou aumento da densidade capilar, encurtou a distância intercapilar e induziu aumento do número de capilares em volta de um simples miócito, em contraste, a associação de esteróide anabolizante com exercício físico induziu hipertrofia 
moderada dos miócitos cardíacos e prejudicou a adaptação microvascular cardíaca induzida pelo treinamento físico. Em outro estudo similar, com propionato de testosterona, [289], foi verificado que esta substância é capaz de inibir o aumento da capilarização induzida pelo exercício e induziu moderada hipertrofia dos miócitos. Dessa forma o prejuízo microvascular poderia trazer um desequilíbrio entre a oferta e a demanda de oxigênio ao miocárdio principalmente durante o exercício físico.

Há uma relação estreita entre o consumo de oxigênio pelo miocárdio e o fluxo sangüíneo coronário. Com o aumento do gasto energético pelo coração, ocorre aumento proporcional da produção de substâncias ou metabólitos responsáveis pela vasodilatação coronária. Dois mecanismos podem explicar o controle metabólico do fluxo sangüíneo coronário, o desbalanço entre a demanda e o suprimento de substâncias essenciais para o metabolismo, como exemplo o oxigênio $\left(\mathrm{O}_{2}\right)$, ou ainda, o desbalanço entre a produção e o catabolismo de substâncias derivadas do metabolismo, como exemplo o gás carbônico $\left(\mathrm{CO}_{2}\right)$ e a adenosina. $\mathrm{A}$ adenosina é um potente vasodilatador, sendo considerado um mediador importante para a resposta vasodilatadora durante situações de aumento de demanda energética para o coração.

O papel local da adenosina no sistema cardiovascular se torna evidente devido a demonstração de que a mesma é sintetizada por fibroblastos vasculares [290] e cardíacos [291], cardiomiócitos [292], células endoteliais cardíacas [293] e vascular [294], além de células do músculo liso vascular [291]. A demanda extracelular de adenosina depende da biosíntese e do catabolismo desta substância, além de alterações no seu transporte [295].

A adenosina pode ser sintetizada de quatro maneiras: através de defosforilações seqüenciais intracelulares do ATP (adenosina tri-fosfato) para adenosina [296], através da conversão extracelular do ATP para adenosina mediada por ectoenzimas [297], através da transmetilação mediada pela hidrólise de S-adenosil-L-homocisteína para L-homocisteína e adenosina [298] ou ainda, pela saída do AMPc para a superfície celular, seguido da conversão do AMPc para AMP (adenosina mono-fosfato) por uma ectofosfodiesterase e a conversão de AMP para adenosina por uma ecto-5` nucleotidase [291].

Os nucleotídeos da adenina são liberados no espaço extracelular, a partir de uma variedade de células em resposta a estímulos ativadores e também pelo rompimento de células durante a injúria de tecidos ou morte celular. O ATP e outros nucleotídeos não atravessam 
livremente as membranas celulares, provavelmente para assegurar a conservação desta molécula em processos essenciais às funções intracelulares, porém podem sair ou entrar na célula via um sistema de transporte mediado por carrier. O ATP citoplasmático pode ser liberado em quantidades significativas, sem que haja perda morfofuncional da célula. A concentraçào local destes nucleotídeos dependerá da quantidade liberada, do efeito de diluição no espaço extracelular e da capacidade de enzimas catabólicas, especialmente ectonucleases. Uma vez liberados, estes nucleotídeos podem interagir com receptores purinérgicos (P2) antes de sua rápida degradação até adenosina por um conjunto de ectonucleotidases [291].

Desta forma, pode-se inferir que ocorre a liberação ativa de nucleotídeos no espaço extracelular e estes nucleotídeos são hidrolisados por uma cascata extracelular de enzimas responsáveis pela remoção de nucleotídeos da adenina neste espaço e que são de maneira geral denominadas de ectonucleotidases. Os nucleosídeos podem ser re-utilizados para ressíntese, ou ainda, o produto da hidrólise pode iniciar uma função adicional mediada por receptor. Existe, portanto, uma família de ecto-enzimas capazes de hidrolisar ATP e outros nucleotídeos. As ectonucleotidases incluem membros da familia de E-NTPDase (ecto-nucleosídeo trifosfato difosfoidrolase), E-NPP (ecto-nucleotídeo pirofosfatase fosfodiesterase) e ecto-5'nucleotidase. A atividade catalítica máxima destas enzimas está adaptada ao ambiente extracelular e requer a presença de cátions divalentes tais como o cálcio e o magnésio e um pH alcalino [299].

Os membros da família E-NTPDase podem hidrolisar nucleosideos 5'-trifosfato e nucleosideos 5'-difosfato, enquanto que a Ecto-5'-nucleotidase catalisa o passo final da degradação de nucleotídeos extracelular, através da hidrólise de nucleosídeo 5 '-monofosfato para o respectivo nucleosídeo e fosfato (Pi). A Ecto-5'nucleotidase é a enzima responsável pela maior formação de adenosina extracelular através da liberação dos nucleotídeos de adenina ([300-302].

No coração a ação de uma ATP-difosfoidrolase [303] hidrolisa ATP e ADP até AMP e de uma ecto-5'-nucleotidase [303, 304], que está presente na superficie externa da maioria das células e que metaboliza AMP até adenosina. No músculo esquelético, a liberação de adenosina se dá em resposta a contração [305], através de células musculares [306], endoteliais [294] ou nervosas [307].

Embora o papel da adenosina na regulação do fluxo sangüineo, para o coração ou para o músculo esquelético, seja bem estudado, não se tem conhecimento sobre os efeitos dos EA sobre 
a hidrólise extracelular dos nucleotideos de adenina e a formação de adenosina. Uma vez que, o treinamento fisico aeróbio é capaz de melhorar a perfusão miocárdica devido a diversas adaptações e sendo a adenosina um dos importantes moduladores locais fisiológicos, o qual pode aumentar o fluxo sangüíneo, avaliamos, neste estudo, as vias de formação da adenosina com o uso de esteróides anabolizantes associados ao treinamento fisico.

\subsection{Objetivos}

Assim, a sequência deste estudo teve como objetivos investigar os efeitos do tratamento com EA associado ou não ao treinamento físico por natação, sob ao fluxo sangüíneo coronário de ratos normotensos, verificando a participação da adenosina como um dos possiveis mecanismos regulatórios.

Assim, neste estudo foi analizado:

- O fluxo sangüíneo para o miocárdio:

- em repouso

- após vasodilatação induzida por acetilcolina;

- A atividade das enzimas que levam à formação de adenosina:

- ATP-difosfoidrolase

- 5'-nucleotidase; ;

- As alterações morfológicas e morfométricas:

- hipertrofia cardiaca (metodologia descrita anteriormente)

- densidade capilar cardíaca

- hipertrofia vascular

- colágeno perivascular;

- O comportamento da pressão arterial e freqüência cardiaca em repouso; (metodologia descrita anteriormente).

\subsection{Materiais e Métodos}

\subsubsection{Grupos e seqüência experimental}


Um total de 56 animais foram separados em 4 grupos conforme o protocolo experimental abaixo. Os animais foram divididos em dois grupos (um para análises de fluxo e outro para análises morfológicas):

- Sedentário Controle (SC; $n=14)$;

- Sedentário tratado com esteróide anabolizante (SA; $n=14)$;

- Treinado controle (TC; $\mathrm{n}=14)$;

- Treinado tratado com esteróide anabolizante (TA; $n=14)$.

\subsubsection{Histomorfometria do colágeno perivascular}

Para avaliar o colágeno perivascular o coração foi cortado, fixado em formol e incluso em parafina. Cortes histológicos de $7 \mu \mathrm{m}$ de espessura, montados em lâmina de vidro e coradas pela técnica de Picrosirius red [235] foram realizados. Os cortes foram avaliados no sistema computadorizado de imagens (Leica Q500 iw e Leica DMLS, Leica Imaging Systems, Ltda., Cambridge, UK), utilizando-se lentes de aumento microscópicas.

A fibrose perivascular, área corada positivamente para colágeno ao redor das artérias coronárias, foi quantificada sob luz polarizada em aumento de 20 vezes. O colágeno perivascular (CPV) foi calculado como a razão entre a fibrose perivascular e a área da luz do vaso. Foram selecionados para esta medida apenas artérias com diâmetros entre $50 \mu \mathrm{m}$ e $200 \mu \mathrm{m}$, e que apresentassem um corte histológico com aspecto circular (razão entre os diâmetros menor e maior $>0,50)$.

\subsubsection{Quantificação do número de capilares no músculo esquelético}

Ao final do protocolo experimental os animais foram sacrificados e seus músculos sóleos foram removidos e pesados. Os músculos foram seccionados transversalmente, fixados em formaldeido a $6 \%$ por 24 horas e processados por desidratação, diafanização e banho de parafina a $60^{\circ} \mathrm{C}$. Após foi realizada a inclusão dos mesmos em cassetes contendo parafina fundida, que ao solidificar deu origem a um bloco de parafina para cada sujeito da amostra, dos quais se obteve cortes microtômicos de $3 \mu \mathrm{m}$ de espessura, submetidos à montagem de lâminas para análise histológica, com coloração de PAS (Periodic Acid Schiff), para visualização dos vasos capilares. 
A análise histológica foi realizada com utilização do sistema de análise de imagens Qrantimet Leica ${ }^{\circledR}$, (Leica Cambridge, United. Kingdom) por intermédio de estudo cego. A lâmina foi observada inicialmente em aumentos menores, sendo escolhido um local em que não haja ranhuras ou bolhas e que contenham o maior número de fibras de corte transversal. Escolhido - local, a imagem foi ampliada 400x para realizar as medidas. Para análise do número de capilares, a mesma área foi igualmente delimitada, com o auxilio do cursor para mensurar o diâmetro de cada vaso. Segundo critérios estabelecidos, o diâmetro será o principal parâmetro para identificação dos capilares, sendo considerados capilar, vasos com diâmetro igual ou menor que $12 \mu \mathrm{m}$.

Foram analisados 5 campos de visão das lâminas de cada amostra nas quais foi quantificado o número total de fibras musculares e de capilares por campo de visão e partir destes valores foi calculada a razão Capilar/Fibra (rC/F) de cada animal, como preditor de capilarização no tecido estudado.

\subsubsection{Hipertrofia vascular}

Através das medidas realizadas nas lâminas preparadas para a detecção do colágeno perivascular, uma estimativa da hipertrofia vascular foi realizada calculando-se a razão entre a área da parede e a área da luz de vasos de resistência que apresentavam diâmetros entre $50 \mu \mathrm{m}$ e $150 \mu \mathrm{m}$ e nos quais os cortes histológicos se apresentassem com aspecto circular (razão entre os diâmetros menor e maior $>0,50)$.

\subsubsection{Hipertrofia muscular esquelética}

A hipertrofia foi avaliada através da relação entre o peso de cada músculo (peso úmido) e o peso corporal. Os resultados são expressos como razão peso dos músculos/peso corporal do animal $(\mathrm{mg} / \mathrm{g})$.

\subsubsection{Determinação do fluxo sangüíneo para o coração e músculo esquelético pela} utilização da técnica das microesferas coloridas.

A técnica das microesferas fornece informações detalhadas sobre a perfusão regional [308], sendo as microesferas coloridas um método não radioativo e relativamente simples, o qual tem 
sido bem aplicado em algumas espécies de animais [309-311]. Esta técnica consiste da infusão de microesferas coloridas dentro do ventrículo esquerdo do animal e da retirada de amostras de referência para cálculo dos valores absolutos de fluxo.

\section{Procedimentos cirúrgicos}

Os animais foram anestesiados com pentobarbital sódico (40 $\mathrm{mg} / \mathrm{kg}$, ip) e entubados (Gelko - 14G). Dois cateteres de polietileno (PE-10) preenchidos de salina foram utilizados para a canulação dos animais, sendo um para a artéria femoral direita e outro para a veia femoral direita.

Um terceiro cateter de polietileno (PE-50) foi utilizado para a canulação do ventrículo esquerdo pela artéria carótida direita. O cateter foi inserido até o ventrículo e sua posição foi determinada pela observação da característica onda de pressão ventricular e confirmada por necropsia.

\section{Microesferas coloridas}

Para determinação da distribuição do fluxo cardíaco foram utilizadas microesferas coloridas vermelhas e brancas (Dye-Trak microespheres, Triton Technology, San Diego, CA, USA) segundo o protocolo previamente descrito por HAKKINEN, MILLER, SMITH e KNIGHT (1995). As microesferas são compostas de polietileno (98\%) e divinilbenzeno (2\%) tendo diâmetro de $15,1 \pm 0,2 \mu \mathrm{m}$ e concentração comercial de 3000 esferas $/ \mathrm{mL}$.

A concentração média das esferas foi utilizada como base para o cálculo do número de esferas infundidas. Para a determinação da absorbância média das esferas, amostras das diluições utilizadas (15.000-25.000 esferas) foram colocadas em tubos de $15 \mathrm{~mL}$. Adicionou-se $2 \mathrm{~mL}$ de etanol $(100 \%)$ a $4^{\circ} \mathrm{C}$, centrifugou-se e o sobrenadante foi aspirado. As amostras foram colocadas em estufa $\left(56^{\circ} \mathrm{C}\right)$ overnight para secagem. No dia seguinte foi adicionado dimetilformamida, as amostras foram centrifugadas e a absorbância foi determinada em espectrofotômetro. A solução comercial foi sonicada (Vibra Cell, Sonics \& Materials Inc., Danbury, CT, USA) durante 5 minutos imediatamente antes das diluições em salina contento 0,01\% de Tween 80 (Sigma Chemical Co, St. Louis, MO, USA). Todas as amostras de microesferas já diluídas foram ultrasonicadas durante 1 minuto imediatamente antes da infusão. 


\section{Infusão das microesferas no ventriculo esquerdo}

Uma solução contendo 200.000 esferas vermelhas $/ 180 \mu \mathrm{L}$ foi infundida no ventrículo esquerdo para determinação da distribuição do fluxo no coração. Esta solução foi sonicada durante 1 minuto imediatamente antes da infusão. Um total de $180 \mu \mathrm{L}$ desta solução foram colocados em uma extensão de cateter P50 $(75 \mathrm{~cm})$ o qual foi conectado a uma seringa de $1 \mathrm{~mL}$ com salina pré-aquecida $\left(40^{\circ} \mathrm{C}\right)$ contendo Tween $80(0,01 \%)$. A outra cânula posicionada na artéria femoral foi conectada a outra seringa de $1 \mathrm{~mL}$ pré-heparinizada para retirada de sangue durante a infusão. A retirada de sangue foi iniciada dez segundos antes da infusão das esferas com uma bomba (Infusion and Withdrawl Pump, Harvad Apparatus, South Natick, Mass, USA) a um fluxo contínuo de $0,5 \mathrm{~mL} / \mathrm{min}$, continuando a retirada por mais 75 segundos após o início da infusão. Foram injetadas 200.000 esferas vermelhas no ventrículo esquerdo com um fluxo de $0,36 \mathrm{~mL} / \mathrm{min}$ durante 50 segundos (Infusion Pump 22, Harvard Apparatus, South Natick, Mass, USA). Desta forma, os $180 \mu \mathrm{L}$ de solução contendo as microesferas foram injetados nos primeiros 30 segundos.

$\mathrm{O}$ volume de sangue retirado foi reposto através do volume injetado durante a infusão das esferas e por um pequeno volume de salina $(0,1-0,2 \mathrm{~mL})$ injetado in bolus logo após o término do procedimento.

Em uma segunda etapa o procedimento foi repetido com microesferas na cor branca, porém antecedida pela administração de um vasodilatador (acetilcolina) na dose de $30 \mu \mathrm{g} / \mathrm{kg}$, através da cânula localizada na veia femoral direita. Esta etapa foi realizada para que fosse possivel mimetizar as respostas vasodilatadoras que ocorrem durante o exercício fisico.

Após a infusão das microesferas no ventrículo esquerdo os animais foram sacrificados e o coração retirado para análise.

\section{Digestão e processamento dos tecidos}

\section{Reagentes}

Os reagentes utilizados no processamento dos tecidos com microesferas coloridas foram preparados segundo especificações do fabricante das microesferas (Triton Technology, San Diego, CA, USA). 
Reagente de digestão I (Reagente 10\% Triton X-100): $900 \mathrm{~mL}$ de água destilada foram aquecidas a $50^{\circ} \mathrm{C}$, a seguir, 6,06g de Trizma Base e $0,1 \mathrm{~g}$ de Azida Sódica foram adicionados e o $\mathrm{pH}$ foi ajustado para 8,5. Após o ajuste do $\mathrm{pH}, 100 \mathrm{~mL}$ de Triton X-100 foi acrescentado à solução, a qual foi armazenada em frasco plástico.

$\checkmark$ Reagente de digestão II (Reagente Ácido Deoxicólico Sódico): Em $1 \mathrm{~L}$ de água destilada aquecida foram adicionados $6,06 \mathrm{~g}$ de Trizma Base, $0,5 \mathrm{~mL}$ de Tween 80 e $0,1 \mathrm{~g}$ de Azida Sódica durante agitação, em seguida o $\mathrm{pH}$ foi ajustado para 8,5 e 20,73g de ácido deoxicólico sódico foi acrescentado, sendo realizado um novo ajuste do $\mathrm{pH}$. A solução foi armazenada em frasco plástico.

Reagente de hemólise: $20 \mathrm{ml}$ de etanol absoluto foi adicionado a $100 \mathrm{~mL}$ do reagente de digestão I. Esta solução foi armazenada em frasco plástico.

\section{$\underline{\text { Amostra de Sangue }}$}

A amostra de sangue retirada foi pesada e colocada em tubo de polipropilene de $15 \mathrm{~mL}$ propriamente identificado. Um total de $4 \mathrm{~mL}$ de reagente de hemólise foi adicionado e a amostra foi centrifugada durante 30 minutos a $2000 \mathrm{~g}$. O sobrenadante foi desprezado e $2 \mathrm{~mL}$ de hidróxido de sódio $(2 \mathrm{~N})$ foram acrescentados ao tubo. As amostras foram incubadas em banho maria (BM) a uma temperatura de $70^{\circ} \mathrm{C}$, seguindo a partir deste momento o mesmo procedimento dos demais tecidos.

\section{Tecidos}

Os tecidos foram processados segundo técnica adaptada de HAKKNNEN et al. (1995) [312]. Após a retirada do tecido, o mesmo foi pesado $(0,4-2,0 \mathrm{~g})$ e inserido em um tubo de polipropilene de $15 \mathrm{ml}$, previamente identificado. Após a adição de $4 \mathrm{ml}$ de hidróxido de sódio $(2 \mathrm{~N})$ os tubos foram tampados e colocados em $\mathrm{BM}$ à $70^{\circ} \mathrm{C}$ por aproximadamente 2 horas. As amostras foram agitadas (Vortex Maxi Mix II, Thermolyne, Dubuque, Iowa, USA) a cada 15 minutos até a diluição dos tecidos no reagente. Quando observado esta amostra dissolvida, os tubos foram removidos do banho e $8 \mathrm{~mL}$ de Reagente de Digestão I foram adicionados. A seguir as amostras foram misturadas por inversão manual (3-5 vezes) e centrifugadas por 30 minutos à 2000g. Após a centrifugação, o sobrenadante de cada amostra foi desprezado e $10 \mathrm{~mL}$ de 
Reagente de Digestão II foram adicionados. As amostras foram novamente colocadas em BM $\left(70^{\circ} \mathrm{C}\right)$ por aproximadamente 3 horas. Os tubos foram novamente agitados a cada 20 minutos até 0 momento em que pudesse ser observada visualmente a total digestão das amostras. Neste momento, as amostras foram retiradas do banho e centrifugadas por 30 minutos a $2000 \mathrm{~g}$. O sobrenadante de cada amostra foi aspirado, permanecendo no tubo aproximadamente $100-200 \mu \mathrm{L}$ da amostra, a qual foi adicionada etanol absoluto $\left(4^{\circ} \mathrm{C}\right)$. Os tubos foram agitados para lavagem das amostras e logo após, foram centrifugadas durante 15 minutos a $2000 \mathrm{~g}\left(4^{\circ} \mathrm{C}\right)$. O etanol adicionado foi aspirado, permanecendo $100-200 \mu \mathrm{L}$ no fundo de cada tubo. Estes tubos contendo as amostras foram colocados em estufa $\left(56^{\circ} \mathrm{C}\right)$ durante aproximadamente 12 horas para secagem.

\section{Extração do corante e medidas de absorbância}

Para extração do corante, $250 \mu \mathrm{L}$ de dimetilformamida foi adicionado em cada tubo. As amostras foram agitadas vigorosamente por 30 segundos e centrifugadas durante 10 minutos à $2000 \mathrm{~g}$.

As leituras das absorbâncias no espectrofotômetro (DU-640 Spectrophotometer, Beckmann Instruments, Inc., Fullerton, CA, USA) foram realizadas em cubeta de quartzo de 0,7 $\mathrm{mL}$ (Sigma), onde foram colocados $200 \mu \mathrm{lLdo}$ sobrenadante de cada amostra centrifugada. Os picos dos espectros de absorbância das microesferas brancas e vermelhas foram respectivamente, 370 e $530 \mathrm{~nm}$, utilizando-se uma largura de banda de luz $<1,8 \mathrm{~nm}$. A absorbância mínima aceitável foi de 0,01 AU (absorbância da amostra) para ambas as esferas. Absorbâncias menores que estas foram excluídas da análise.

\subsubsection{Determinação do número de microesferas e do fluxo sangüíneo}

Para determinação do número de microesferas nos tecidos (brancas ou vermelhas), soluções com número conhecido de microesferas foram processadas. A média da absorbância destas amostras permite determinar uma constante de leitura do espectrofotômetro para as microesferas vermelhas e brancas. Desta forma, o número de microesferas nos tecidos foi calculado a partir da seguinte fórmula: 


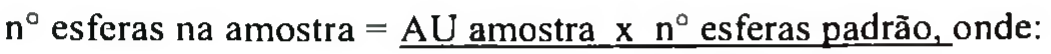

AU padrão

$\checkmark$ AU amostra $=$ absorbância da amostra de tecido

$\checkmark \mathrm{n}^{\circ}$ esferas padrão $=$ número de esferas na solução padrão

$\checkmark \mathrm{AU}$ padrão = média das absorbâncias das soluções padrões.

O tempo de retirada da amostra de sangue $(\mathrm{min})$ foi calculado dividindo o volume de sangue retirado durante a infusão das microesferas vermelhas e brancas pela velocidade da bomba de retirada $(0,5 \mathrm{~mL} / \mathrm{min})$.

A constante de retirada do sangue ( $Q$ sangue, $\mathrm{mL} / \mathrm{min}$ ) foi determinada pela divisão do volume de sangue $(\mathrm{mL})$ pelo tempo de retirada da amostra $(\mathrm{min})$.

\subsubsection{Análises bioquímicas}

\section{Determinação das atividades enzimáticas}

Para determinação de uma das vias de formação de adenosina, a atividade enzimática da ATP-difosfoidrolase e 5'-nucleotidase foram analisadas na fração do soro sangüíneo e na fração sarcolemal do coração. A preparação da fração do soro sangüíneo e da fração sarcolemal cardíaca foi realizada ao final do protocolo experimental ( 24 horas após a última sessão de treinamento).

Para obtenção da fração do soro sangüíneo, os animais foram sacrificados por decapitação e o sangue recolhido e centrifugado a $3000 \mathrm{rpm}$, durante 15 minutos a uma temperatura de $4^{\circ} \mathrm{C}$. O sobrenadante obtido de cada amostra centrifugada representa a fração do soro sangüíneo. Esta fração foi armazenada em tubos eppendorf $(1,5 \mathrm{~mL})$ previamente identificados e mantida em freezer com temperatura de $-20^{\circ} \mathrm{C}$ até sua utilização.

Para obtenção da fração sarcolemal cardíaca, os animais foram sacrificados e o coração retirado. O material enzimático foi obtido essencialmente como descrito por Velema [313]. Cada coração foi cortado em pequenos pedaços e homogeneizado em $80 \mathrm{~mL}$ de um meio constituído de Tris- $\mathrm{HCl} 20 \mathrm{mM}$ e EDTA $1 \mathrm{mM}(\mathrm{pH}=7,0)$, usando um homogeneizador por quatro períodos de $7 \mathrm{~s}$ em velocidade máxima com intervalos de $15 \mathrm{~s}$ de descanso. Após o tecido estar homogeneizado, o mesmo foi submetido a um processo de subfracionamento celular, obtido através de cetrifugação diferencial como observado na TABELA 2. 
O homogeneizado foi centrifugado durante 20 minutos a $8.800 \mathrm{~g}$ e o sobrenadante (S1) obtido foi recentrifugado a $12.500 \mathrm{~g}$ durante 20 minutos. Este procedimento foi repetido com o sobrenadante S2 e o sobrenadante resultante S3 foi centrifugado a $44.000 \mathrm{~g}$ durante 1 hora. O precipitado obtido foi ressuspenso em $15 \mathrm{ml}$ de tampão estoque (Tris-oxalato $20 \mathrm{mM}, \mathrm{KCl} 0,6 \mathrm{M}$ (para extrair miofibrilas), EDTA $1 \mathrm{mM}$ e pH=6,8) e recentrifugado a $44.000 \mathrm{~g}$ durante mais 1 hora. $\mathrm{O}$ precipitado foi ressuspenso em um volume adequado de Tris- $\mathrm{HCl} 20 \mathrm{mM}$ e $\mathrm{pH}=7,2$, na proporção que resulta em concentração de proteína de cerca de 0,4 a $0,5 \mathrm{mg} / \mathrm{ml}$. Esta preparação representa a fração enriquecida em sarcolema.

Todos os procedimentos para a obtenção da fração sarcolemal foram realizados à temperatura $0-4^{\circ} \mathrm{C}$. A fração sarcolemal cardiaca foi armazenada em tubos eppendorf $(1,5 \mathrm{~mL})$ previamente identificados e mantida em freezer a $-20^{\circ} \mathrm{C}$ até sua utilização.

Tabela 6 - Esquema geral de subfracionamento celular obtido através de centrifugação diferencial

\begin{tabular}{c|c|c|c|c|c}
\hline Seqüência & Amostra & $\begin{array}{c}\text { Velocidade } \\
(\mathrm{g})\end{array}$ & $\begin{array}{c}\text { Duraçāo } \\
(\mathrm{min})\end{array}$ & $\begin{array}{c}\text { Temperatura } \\
\left({ }^{\circ} \mathrm{C}\right)\end{array}$ & Desprezado \\
\hline \hline & $\mathrm{HT}$ & 8.800 & 20 & $0-4$ & $\mathrm{P} 1$ \\
$1^{\circ}$ passo & $\mathrm{S} 1$ & 12.500 & 20 & $0-4$ & $\mathrm{P} 2$ \\
$2^{\circ}$ passo & $\mathrm{S} 2$ & 12.500 & 20 & $0-4$ & $\mathrm{P} 3$ \\
$3^{\circ}$ passo & $\mathrm{S} 3$ & 44.000 & 60 & $0-4$ & $\mathrm{~S} 4$ \\
$4^{\circ}$ passo & $\mathrm{P} 4$ & 44.000 & 60 & $0-4$ & $\mathrm{~S} 5$ \\
$5^{\circ}$ passo &
\end{tabular}

$(\mathrm{HT})=$ homogeneizado total $;(\mathrm{S})=$ sobrenadante $(\mathrm{P})=$ precipitado

\section{Medida da atividade enzimática da ATP-difosfoidrolase}

As atividades de hidrólise do ATP e do ADP foram determinadas em um meio de incubação que continha Tris- $\mathrm{HCl} 50,0 \mathrm{mM}^{2} \mathrm{CaCl}_{2}$ 1,5mM $(\mathrm{pH}=7.4)$ para a fração sarcolemal e Tris-HCl 112,5mM (pH=8,0) para o soro como descrito por OSES, (2004), [314] juntamente com a proteína em uma temperatura de $37^{\circ} \mathrm{C}$ por 10 minutos em um volume final de $200 \mathrm{LL}$ para ambos. A reação foi iniciada pela adição de nucleotídeo (ATP, ADP) em uma concentração final de $2 \mathrm{mM}$ para a fração sarcolemal e de ATP $3 \mathrm{mM}$ e ADP $2 \mathrm{mM}$ para o soro. O tempo de incubação e a quantidade de proteína adicionada ao meio de reação foram escolhidos de modo a 
assegurar a linearidade da formação do produto. A reação enzimática foi interrompida pela adição de $200 \mathrm{uL}$ de TCA (concentração final de 10\%).

Após a retirada das amostras do meio de incubação, somente as amostras da fração do soro sangüíneo foram centrifugadas durante 15 minutos por $5000 \mathrm{rpm}$. Ao final do processo, ambas as amostras foram mantidas em gelo, por pelo menos 10 minutos e posteriormente aliquotas foram retiradas para determinação do fosfato inorgânico pelo método de LANZETTA, (1979), [315] sendo que as alíquotas da fração do soro sangüineo foram diluídas 10 vezes (40 $\mu \mathrm{L}$ da amostra para $360 \mu \mathrm{L}$ de água deionizada) e as alíquotas da fração de membrana sarcolemal não sofreram diluição.

Todas as amostras foram ensaiadas em duplicata ou triplicata, sendo que a hidrólise não enzimática foi corrigida através de controles onde o material enzimático foi adicionado ao tubo somente após a reação ter sido interrompida com TCA. A atividade específica foi expressa em nmol de fosfato liberado por minuto e por miligrama de proteína ( $\mathrm{nmol} \mathrm{Pi} / \mathrm{min} / \mathrm{mg}$ ) nas condições de ensaio descritas. A proteína foi determinada pelo método de BRADFORD (1976), [73] utilizando como padrão albumina bovina (BSA).

\section{Medida da atividade enzimática da ecto-5'-nucleotidase}

A atividade de hidrólise do AMP foi determinada de acordo com protocolo de HEYMANN et al, (1984), [316] em um meio contendo Tris- $\mathrm{HCl} 100 \mathrm{mM}(\mathrm{pH} 7,5)$ e $\mathrm{MgCl}_{2}$ 15,0mM para a fração sarcolemal cardiaca e Tris- $\mathrm{HCl} 100 \mathrm{mM}(\mathrm{pH} 8,9)$ para a fração do soro sangüíneo como descrito por OSES et al. (2004) [314]. A este meio foi adicionada a proteína que foi pré-incubada durante 10 minutos a $37^{\circ} \mathrm{C}$. A reação foi iniciada pela adição de AMP $2 \mathrm{mM}$ para a fração sarcolemal cardíaca e para a fração do soro sangüíneo. O tempo de incubação e a quantidade de proteína adicionada ao meio de reação foram escolhidos de modo a assegurar a linearidade da formação do produto. A reação enzimática foi interrompida pela adição de $200 \mathrm{uL}$ de TCA (concentração final de 10\%).

Após a retirada das amostras do meio de incubação, somente as amostras da fração do soro sangüíneo foram centrifugadas durante 15 minutos por $5000 \mathrm{rpm}$. Ao final do processo, ambas as amostras foram mantidas em gelo, por pelo menos 10 minutos e posteriormente aliquotas foram retiradas para determinação do fosfato inorgânico pelo método de LANZETTA 
et al. (1979), [315] sendo que as alíquotas da fração do soro sangüíneo foram diluídas 8 vezes (50 $\mu \mathrm{L}$ da amostra para $350 \mu \mathrm{L}$ de água deionizada) e as alíquotas da fração de membrana sarcolemal não sofreram diluição.

Todas as amostras foram ensaiadas em duplicata ou triplicata, sendo que a hidrólise não enzimática foi corrigida através de controles onde o material enzimático foi adicionado ao tubo somente após a reação ter sido interrompida com TCA. A atividade específica está expressa em nmol de fosfato liberado por minuto e por miligrama de proteína ( $\mathrm{nmol} \mathrm{Pi} / \mathrm{min} / \mathrm{mg}$ ) nas condições de ensaio descritas. A proteína foi determinada pelo método de BRADFORD (1976), [73] utilizando como padrão albumina bovina (BSA).

\subsubsection{Análise estatística}

Os dados obtidos neste estudo estão apresentados na forma de média \pm erro padrão. A análise estatística foi realizada através da análise de variância de dois fatores (ANOVA) e, somente para os dados de evolução do peso corporal e de resposta vasodilatadora à acetilcolina foi utilizada ANOVA de dois fatores para medidas repetidas, seguidas de post-hoc de Tukey para comparações entre as médias quando diferenças significativas foram observadas entre os grupos com ANOVA. Para todas as análises, foi adotado como nível de significância $p<0,05$.

\subsection{Resultados e Discussão}

Neste grupo de estudo os resultados de Pressão arterial, frequência cardíaca e hipertrofica cardiaca foram os mesmos observados nos grupo anteriores.

\subsubsection{Hipertrofia cardíaca}

Figura 17 mostra o percentual de hipertrofia cardiaca (\%) de cada grupo. Estes resultados demonstram que o tratamento com anabolizante (SA) e o treinamento fisico (TC) isoladamente, causaram hipertrofia cardiaca de $8 \%$ e $16 \%$ respectivamente, quando comparados ao grupo controle (SC). A associação do tratamento com anabolizante e do treinamento físico (TA) promoveu um grau de hipertrofia cardíaca ainda maior (24\%), quando comparado ao grupo controle, sendo também significantemente maior em relação aos grupos sedentário tratado com anabolizante (SA) e treinado controles (TC). 


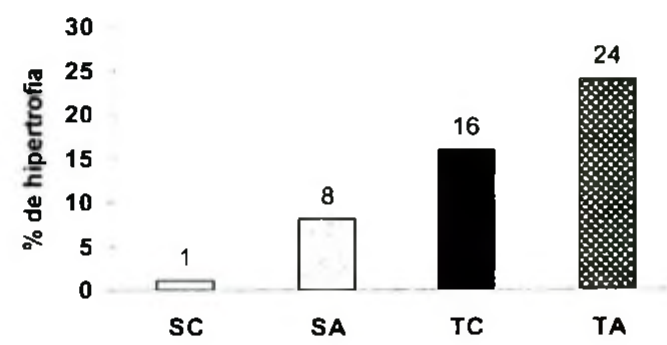

Figura 17. Percentual de hipertrofia cardiaca entre os grupos (\%). Sedentário controle (SC), sedentário tratado com anabolizante (SA), treinado controle (TC) e treinado tratado com anabolizante (TA).

\subsubsection{Fluxo sangüineo coronário}

A técnica das microesferas coloridas foi utilizada para avaliar o fluxo sangüíneo coronário em repouso e após a infusão do vasodilatador acetilcolina, para mimetizar a vasodilatação que ocorre durante o exercício físico. Através da análise do número de microesferas encontradas no tecido podemos inferir o fluxo sangüineo para este tecido. A Figura 18 demonstra em repouso (basal) a distribuição do fluxo sangüíneo para o miocárdio entre os grupos, calculado através da relação entre o $\mathrm{n}^{\circ}$ de esferas encontradas no tecido e o peso do tecido e a Figura 19 demonstra o fluxo sangüíneo para o miocárdio calculado em $\mathrm{mL} / \mathrm{min}$.

Os resultados observados na Figura 8 demonstram que em repouso o fluxo sangüíneo coronário encontra-se aumentado no grupo treinado controle (TC) comparado aos grupos sedentário controle (SC) e tratados com esteróides anabolizantes (SA e TA).

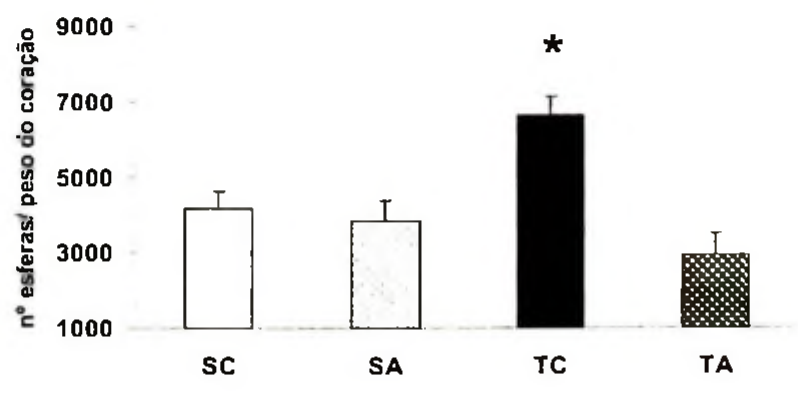

Figura 18. Fluxo sangüíneo coronário basal ( $n^{0}$ de esferas/ peso do tecido). Sedentário controle (SC, $n=7)$, sedentário tratado com anabolizante $(S A, n=9)$, treinado controle $(T C, n=6)$ e treinado tratado com anabolizante (TA, $n=6)$. Os resultados estão apresentados como média \pm erro padrão. (*) Diferença significante do grupo treinado em relação aos outros grupos $(\mathrm{SC}, \mathrm{p}=0,01 ; \mathrm{SA}, \mathrm{p}<0,01$ e TA, $\mathrm{p}<0,001)$. 
Quando analisados os resultados demonstrados na Figura 19 nenhuma diferença significativa foi observada entre os grupos, embora tenha sido observada uma tendência a aumento no fluxo sangüíneo coronário do grupo treinado controle (TC), quando comparado ao grupo treinado tratado com anabolizante $(\mathrm{TA})(\mathrm{p}=0,07)$.

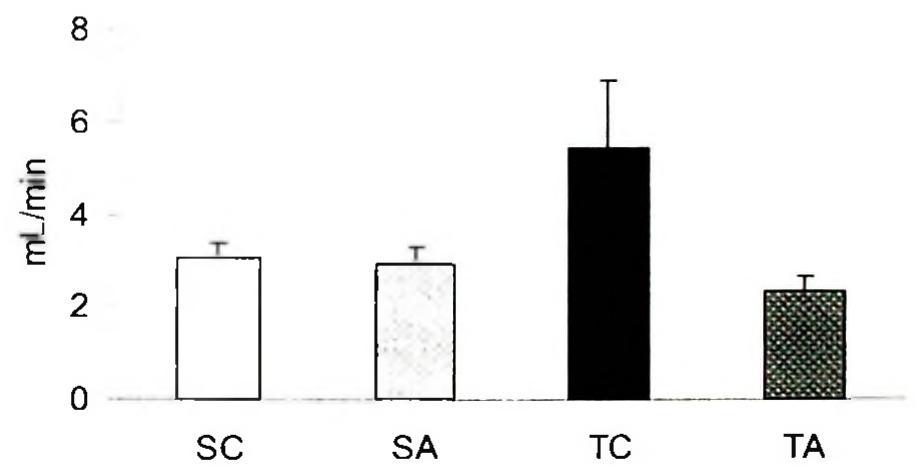

Figura 19. Fluxo sangüíneo coronário basal $(\mathrm{mL} / \mathrm{min})$. Sedentário controle $(\mathrm{SC}, \mathrm{n}=5)$, sedentário tratado com anabolizante $(\mathrm{SA}, \mathrm{n}=6)$, treinado controle $(\mathrm{TC}, \mathrm{n}=5)$ e treinado tratado com anabolizante (TA, $n=4)$. Os resultados estão apresentados como média \pm erro padrão.

As Figura 20 e 21 demonstram, respectivamente, o fluxo sangüíneo calculado através do $n^{0}$ de esferas no tecido e em $\mathrm{mL} / \mathrm{min}$ após a infusão de acetilcolina. Conforme ilustrado na Figura 20, nos grupos tratados com esteróide anabolizante (SA e TA) não foi observada resposta vasodilatadora à acetilcolina, pois o fluxo sangüíneo coronário nestes grupos permaneceu diminuído, quando comparado aos grupos sedentário e treinado controle (SC e TC).

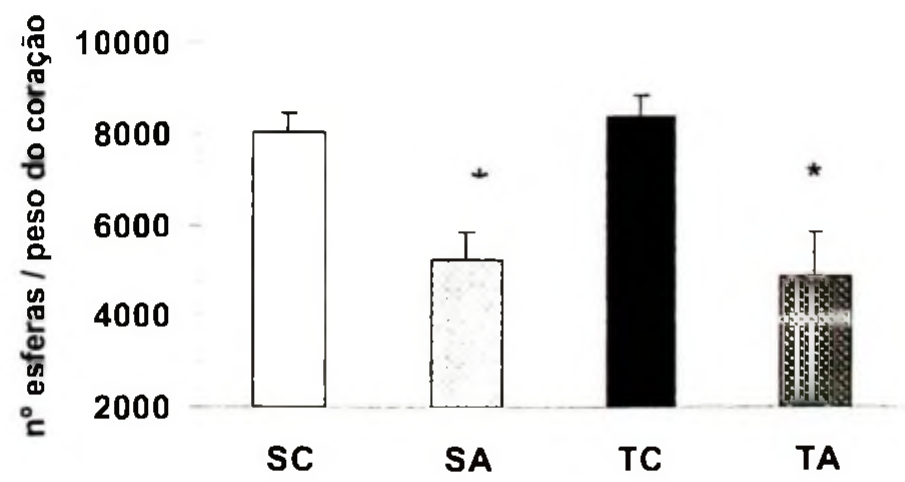

Figura 20. Fluxo sangüíneo coronário após acetilcolina ( $\mathrm{n}^{\mathrm{a}}$ de esferas/ peso do tecido). Sedentário controle $(\mathrm{SC}, \mathrm{n}=7)$, sedentário tratado com anabolizante ( $\mathrm{SA}, \mathrm{n}=8)$, treinado controle $(\mathrm{TC}, \mathrm{n}=6)$ e treinado tratado com anabolizante (TA, $n=8)$. Os resultados estão apresentados como média \pm erro padrão. ( ${ }^{*}$ ) Diferença significante cm relação aos grupos $\mathrm{SC}$ e TC, $\mathrm{p}<0,05$. 
Ao observarmos o fluxo sangüíneo coronário determinado em $\mathrm{mL} / \mathrm{min}$ na Figura 21 , verificamos que no grupo treinado tratado com anabolizante (TA) o resultado é semelhante ao da Figura 20, onde não houve aumento de fluxo após a infusão de acetilcolina, quando comparado aos grupos controles (SC e TC), porém este resultado não foi observado em relação ao grupo sedentário tratado com anabolizante (SA).

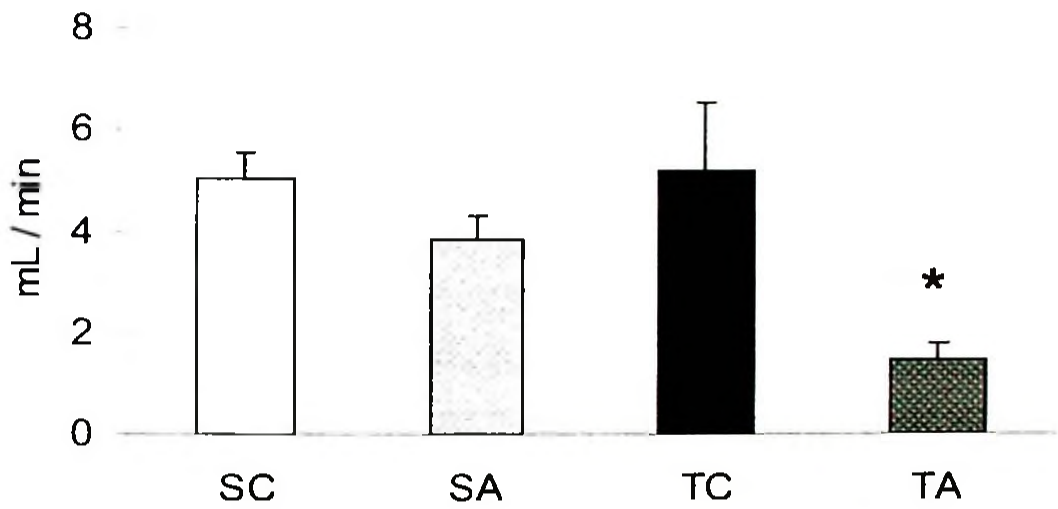

Figura 21. Fluxo sangüíneo coronário após acetilcolina $(\mathrm{mL} / \mathrm{min})$. Sedentário controle $(\mathrm{SC}, \mathrm{n}=5)$, sedentário tratado com anabolizante $(S A, n=6)$, treinado controle $(T C, n=4)$ e treinado tratado com anabolizante (TA, n=3). Os resultados estão apresentados como média \pm erro padrão $(*)$ Diferença significante em relação aos grupos SC e TC, p<0,05.

As Figura 22 e 23 demonstram respectivamente o débito cardíaco (DC) dos grupos experimentais em repouso e após a administração de acetilcolina. Podemos observar na Figura 22 que o DC basal do grupo treinado tratado com esteróide anabolizante (TA) apresentou uma tendência à redução $(\mathrm{p}=0,05)$, quando comparado ao grupo treinado controle (TC).

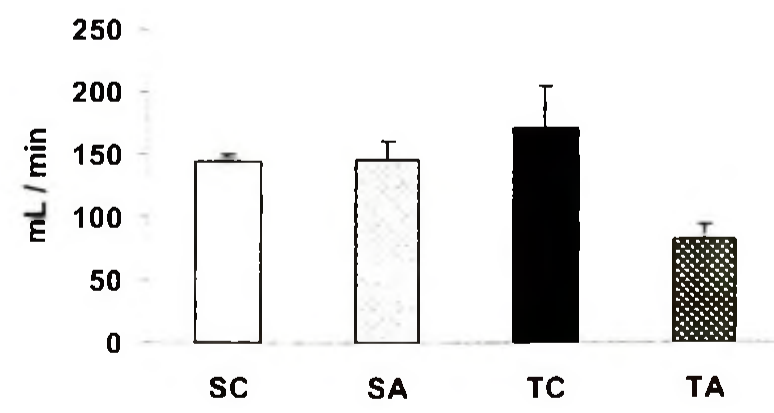

Figura 22. Débito cardíaco basal $(\mathrm{mL} / \mathrm{min})$. Sedentário controle ( $\mathrm{SC}, \mathrm{n}=6)$, sedentário tratado com anabolizante (SA, $n=5)$, treinado controle $(T C, n=4)$ e treinado tratado com anabolizante (TA, $n=4)$. Os resultados estão apresentados como média \pm erro padrão. 
Após a administração de acetilcolina, como demonstrado na Figura 23, o DC dos grupos tratados com anabolizante (SA e TA) permaneceu reduzido, sendo considerado significantemente diferente do grupo treinado controle (TC), porém o menor DC foi observado no grupo treinado tratado com anabolizante (TA), o qual também apresentou diferença significativa em relação ao grupo sedentário controle (SC).

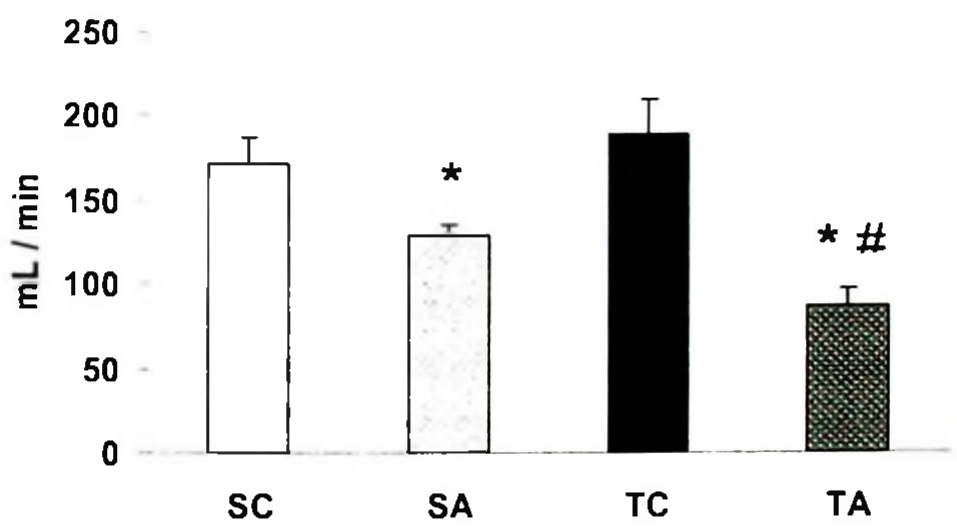

Figura 23. Débito cardíaco após acetilcolina ( $\mathrm{mL} / \mathrm{min})$. Sedentário controle ( $\mathrm{SC}, \mathrm{n}=4)$, sedentário tratado com anabolizante (SA, $n=6)$, treinado controle $(T C, n=4)$ e treinado tratado com anabolizante (TA, $\mathrm{n}=4$ ). Os resultados estão apresentados como média \pm erro padrão. (*) Diferença significante em relação ao grupo treinado controle (SA $\times \mathrm{TC}, \mathrm{p}<0,05$; TA $\times$ TC, $\mathrm{p}<0,005$ ); (\#) diferença significante em relação ao grupo sedentário controle (TA x SC, $\mathrm{p}<0,005$ ).

Para confirmarmos que os resultados observados no fluxo sangüíneo e débito cardiaco se deram devido ao tratamento utilizado e não por diferentes respostas hemodinâmicas a dose de acetilcolina administrada, os valores de queda da pressão arterial e de aumento da freqüência cardiaca de cada grupo antes e após a administração de acetilcolina foram analisados e estes resultados estão demonstrados na Figura 24. Os resultados demonstram que tanto a queda de pressão arterial, quanto o aumento reflexo da freqüência cardiaca foram semelhantes entre os grupos. 


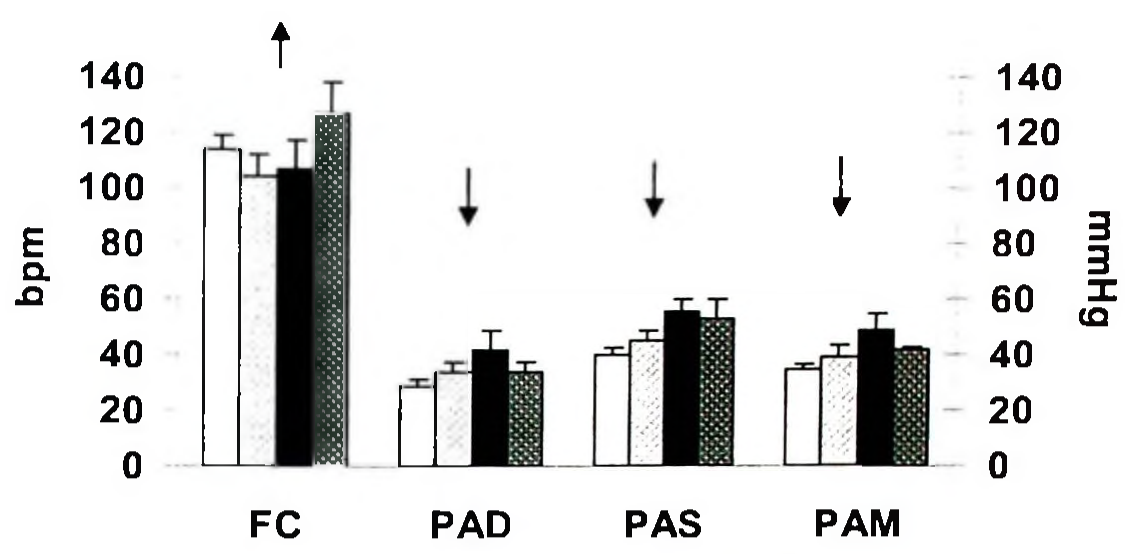

\section{$\square$ SC $\square$ SA $\square$ TC 圆TA}

Figura 24. Delta de pressão arterial e freqüência cardíaca entre período pré e pós administração de acetilcolina ( $\mathbf{m m H g}$ e bpm). Sedentário controle $(\mathrm{SC}, \mathrm{n}=4)$, sedentário tratado com anabolizante $(\mathrm{SA}, \mathrm{n}=4)$, treinado controle $(\mathrm{TC}, \mathrm{n}=4)$ e treinado tratado com anabolizante (TA, n=4). Os resultados estão apresentados como média \pm erro padrão.

Estes resultados mostram no grupo de animais treinados, durante o período basal, um maior fluxo sangüíneo coronário, demonstrado através do número de esferas encontradas no tecido, o que pode ser resultado do maior enchimento ventricular que ocorre durante a diástole cardiaca em resposta ao treinamento físico de endurance [317]. O maior enchimento ventricular nesta situação ocorre devido à redução da freqüência cardíaca, a qual permite um maior tempo de enchimento ventricular. Desta forma, a bradicardia de repouso observada como resposta ao treinamento físico, neste estudo, pode explicar o aumento do fluxo sangüíneo coronário observado no grupo treinado.

Conforme demonstramos anteriormente [240], o treinamento físico promoveu melhora do estado inotrópico cardíaco observado pelo aumento na derivada temporal positiva ( $\mathrm{dP} / \mathrm{dt}$ positiva) e melhora da função diastólica através da redução da pressão diastólica inicial do VE. Assim, o treinamento físico promoveu hipertrofia cardíaca, e proporcional aumento no fluxo sangüíneo coronário, associado a melhor função cardíaca.

Ao avaliarmos a resposta vasodilatadora à acetilcolina, o grupo sedentário controle respondeu com aumento no fluxo sangüíneo coronário, o qual foi alcançado devido a um incremento de $18 \%$ no débito cardíaco em relação ao repouso. Entretanto, um resultado não 
esperado foi observado no grupo TC, onde um pequeno aumento no fluxo sangüíneo coronário ocorreu em resposta a um incremento de $11 \%$ no débito cardíaco em relação ao repouso, não sendo, portanto semelhante à resposta observada no grupo controle. De fato, estudos demonstram que na circulação coronária o treinamento fisico é capaz de aumentar a sensibilidade a agentes vasodilatadores em animais saudáveis [318, 319], portanto nossos resultados divergem dos encontrados na literatura. Talvez, uma maior dose de acetilcolina fosse necessária, para o gnupo treinado, para que uma maior vasodilatação fosse alcançada, já que esse grupo também parte de valores mais altos de fluxo sangüíneo coronário e débito cardíaco basal. No entanto, curvas dose-resposta à acetilcolina não foram realizadas, sendo esta, portanto uma limitação do trabalho.

Ao analisarmos os grupos tratados com EA podemos observar que somente o tratamento com esta droga não modificou o comportamento do fluxo sangüíneo coronário em relação ao gupo controle SC, estes resultados estão de acordo com os encontrados na literatura, onde não foi observada disfunção ventricular em ratos sedentários tratados com EA [227]. Entretanto, o aumento no fluxo sangüineo coronário observado no grupo TC foi diminuido pela associação com o EA. Outro dado importante em relação ao grupo treinado tratado com anabolizante foi observado no débito cardíaco, o qual foi reduzido em relação ao grupo $\mathrm{TC}(p=0,05)$, desta maneira pode contribuir para a redução de $29 \%$ no fluxo sangüineo observada neste grupo em relação ao grupo SC. Assim, estes resultados corroboram com os dados obtidos anteriormente [240], onde foi observada perda dos efeitos benéficos promovidos pelo treinamento físico aeróbio sobre alguns indices de função ventricular no grupo TA, tais como queda da pressão sistólica do VE, um efeito inotropismo negativo e diminuição do relaxamento cardíaco, quando comparados ao grupo TC, desta forma, caracterizando um estado patológico. Estudos realizados em humanos também demonstram prejuizos na função cardíaca. O relaxamento do VE foi prejudicado em fisiculturistas usuários de EA [320], além de uma menor distensibilidade aórtica observada nestes atletas [287].

O menor fluxo sangüíneo coronário observado nos grupos tratados com EA pode ser devido, em parte, ao menor débito cardíaco observado nestes grupos, sendo que o maior prejuizo do débito ocorreu exatamente no grupo TA. Prejuizos na vasodilatação dependente de endotélio 
já foram relatados na literatura tanto em humanos [286], quanto em animais [321], o que vêm de acordo com nossos dados, já que a acetilcolina é um vasodilatador dependente de endotélio.

Assim, estes dados confirmam que o uso de altas doses do EA decanoato de nadrolona associado ao treinamento físico de natação prejudicam o fluxo sangüíneo coronário e o desempenho cardíaco. Desta maneira, também avaliamos algumas possíveis alterações estruturais que poderiam contribuir para o menor fluxo sangüíneo observado neste grupo.

\subsubsection{Morfometria Cardíaca}

\section{- Densidade capilar}

A densidade capilar no músculo cardíaco está demonstrada na Figura 25. Conforme pode ser obsrvado, somente a administração do esteróide anabolizante (SA) e o treinamento físico (TC) não alteraram a densidade capilar cardíaca, enquanto que a associação do treinamento físico com o uso de esteróides anabolizantes (TA) reduziu o número de capilares por área no coração, quando comparado aos outros três grupos (SC, SA e TC).

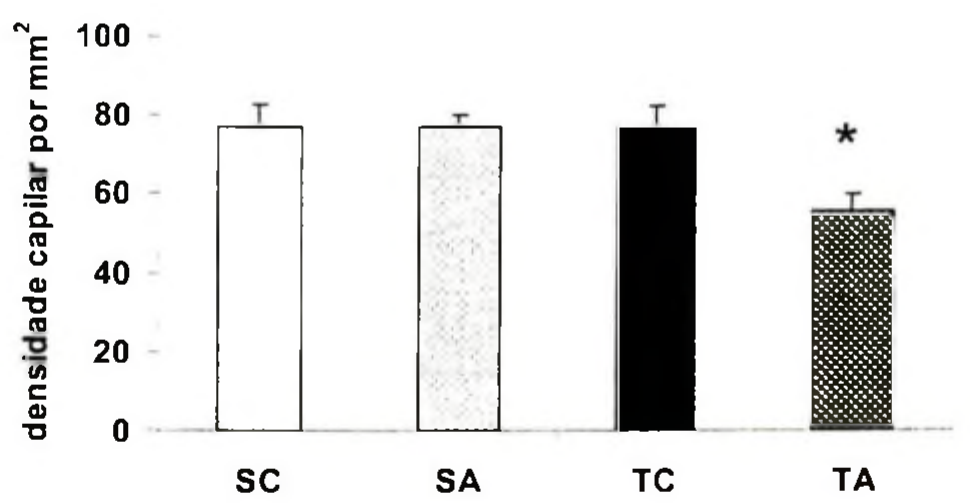

Figura 25. Densidade capilar cardíaca. Sedentário controle ( $S C, n=6)$, sedentário tratado com anabolizante ( $\mathrm{SA}, \mathrm{n}=6)$, treinado controle $(\mathrm{TC}, \mathrm{n}=6)$ e treinado tratado com anabolizante (TA, $\mathrm{n}=5$ ). Os resultados estão apresentados como média \pm erro padrão. $\left({ }^{*}\right)$ Diferença significante em relaçào aos grupos SC, SA e TA, p<0,05.

Na Figura 26 podemos observar fotos ilustrativas demonstrando a contagem de capilares no tecido cardíaco dos quatro grupos estudados (SC, SA, TC e TA). 


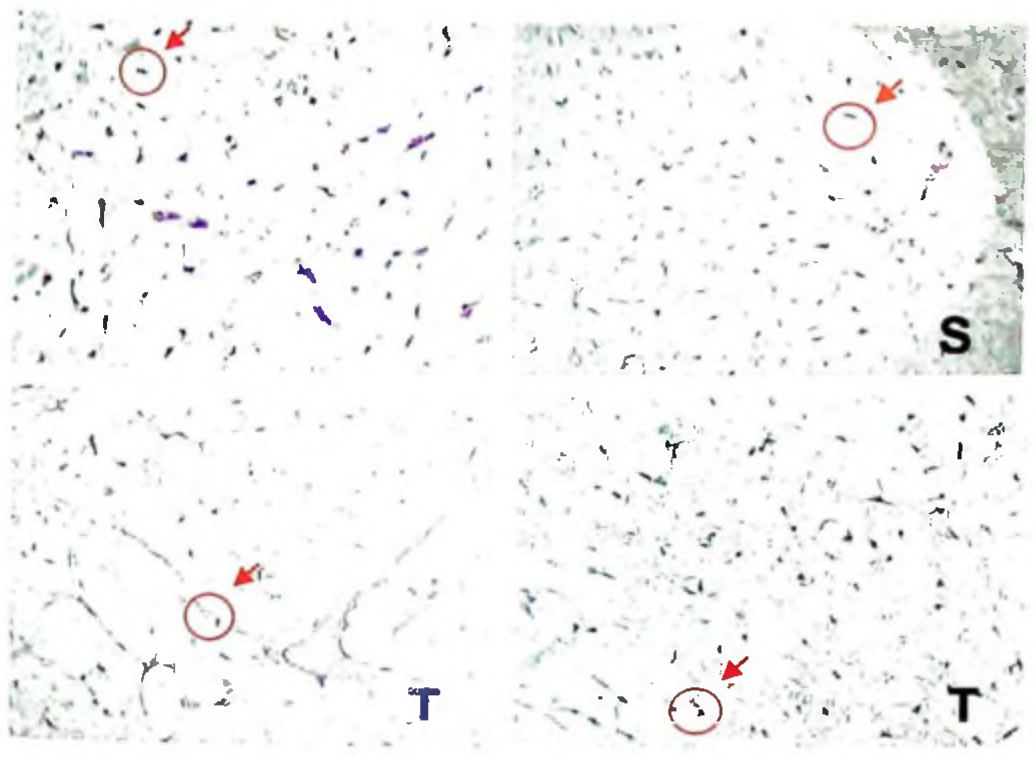

Figura 26. Fotos ilustrativas da densidade capilar cardíaca nos quatro grupos estudados. Visualização em microscópio óptico utilizando objetiva de imersão com aumento de $400 \mathrm{x}$. Scdentário Controle (SC), sedentário tratado com esteróide anabolizante (SA), treinado controle (TC) e treinado tratado com esteróide anabolizante (TA).

\section{- Colágeno perivascular}

A Figura 27 ilustra os resultados referentes ao colágeno perivascular (CPV) calculado através da relação entre a área corada positivamente para colágeno ao redor das artérias coronárias e a área do vaso. Não foram observadas diferenças significantes entre os grupos.

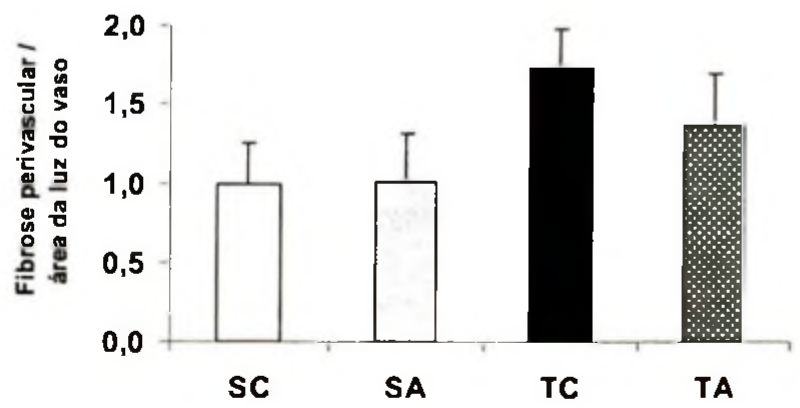

Figura 27. Colágeno Perivascular. Sedentário controle (SC, $n=6)$, sedentário tratado com anabolizante (SA, $n=6$ ), treinado controle $(T C, n=5)$ e treinado tratado com anabolizante (TA, $n=6)$. Os resultados estão apresentados como média \pm erro padrão. 
Na Figura 28 podemos observar fotos ilustrativas do colágeno perivascular depositado ao redor de vasos de resitência no tecido cardíaco dos quatro grupos estudados (SC, SA, TC e TA).
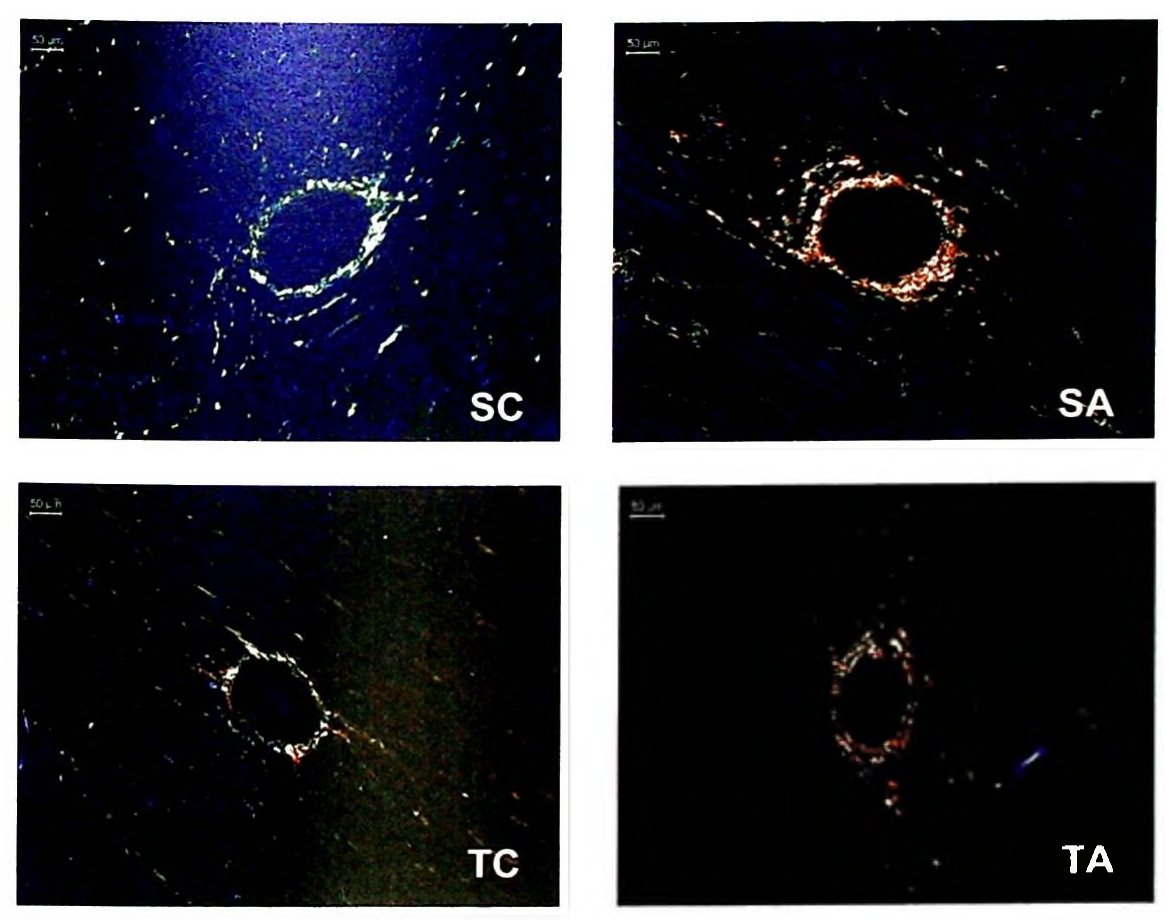

Figura 28. Fotos ilustrativas do colágeno perivascular nos quatro grupos estudados. Colágeno quantificado sob luz polarizada, com a utilização de lentes de aumento de $20 x$. Sedentário Controle (SC), sedentário tratado com esteróide anabolizante (SA), treinado controle (TC) e treinado tratado com esteróide anabolizante (TA). 


\section{- Hipertrofia vascular}

Os resultados apresentados na Figura 29 fazem uma relação entre a área da parede do vaso e a área da luz do vaso, nos apresentando uma estimativa de hipertrofia vascular. Nenhuma diferença significante foi observada entre os grupos.

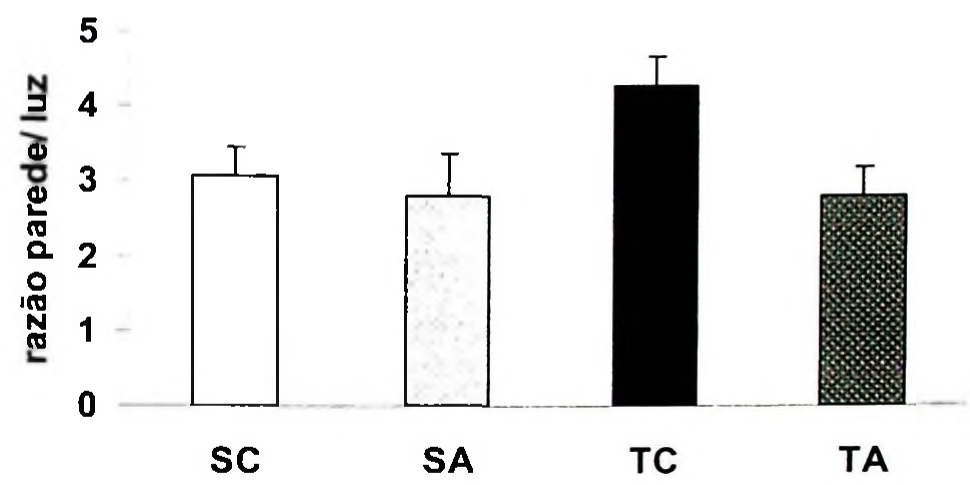

Figura 29. Hipertrofia vascular (razão parede/ luz). Sedentário controle $(S C, n=5)$, sedentário tratado com anabolizante (SA, $n=6)$, treinado controle (TC, $n=5)$ e treinado tratado com anabolizante $(\mathrm{TA}, \mathrm{n}=5)$. Os resultados estão apresentados como média \pm erro padrão.

Uma rede capilar adequada é de vital importância para um aporte sangüíneo cardíaco ideal em condições normais, bem como no coração hipertrofiado, especialmente durante a atividade fisica. Na literatura, ainda existem controvérsias com relação à angiogênese e treinamento físico. Na maioria dos estudos onde animais jovens, como ratos e cobaias, são submetidos ao treinamento fisico de natação ou em esteira é possível observar aumento na densidade capilar cardiaca ou na razão capilar/ fibra, entretanto estes resultados não são registrados em ratos, cães ou porcos adultos submetidos ao mesmo tipo de treinamento [322].

Neste trabalho, uma estimativa da hipertrofia vascular foi utilizada para analisar se o treinamento físico, o uso de esteróide anabolizante e a associação de ambos poderiam atuar sobre o remodelamento de pequenos vasos de resistência $(50-150 \mu \mathrm{m})$ no coração, acarretando desta maneira em alterações no fluxo sangüíneo para este tecido, entretanto, nenhuma modificação ocorreu em resposta a estes tratamentos. De fato, o treinamento físico parece não causar alterações na razão parede/ luz de arteríolas de ratos normotensos, diferente do que pode ser observado em animais hipertensos, onde o treinamento físico é capaz de normalizar a maior razão parede/ luz encontrada tanto em músculos ativos, quanto em músculos não ativos durante o 
Ireinamento, provavelmente sendo este um dos mecanismos responsáveis pela redução da pressão arterial observada nestes animais [323]. Embora alguns estudos demonstrem que o uso de esteróides anabolizantes pode levar ao aumento da pressão arterial, pouco se sabe sobre os possiveis mecanismos de atuação destas substâncias, principalmente sobre a estrutura vascular.

O colágeno é uma proteína que forma uma rede de fibrilas na camada média dos vasos e é 100 vezes mais rígido do que a elastina, sendo o seu papel o de prevenir a superdistenção dos vasos, portanto, alterações significativas na quantidade de colágeno perivascular podem prejudicar a distenção dos vasos, ou ainda, permitir a superdistensão dos mesmos. Neste estudo a quantidade de colágeno depositada em volta de vasos de resistência foi analisada em animais treinados e nenhuma diferença foi observada neste grupo. Alterações no metabolismo de colágeno geralmente são observadas em condições patológicas [324] ou ainda devido ao processo de envelhecimento. Já está bem claro na literatura que o treinamento físico aeróbio é capaz de minimizar os efeitos da idade na maior produção de colágeno [325], no entanto em indivíduos jovens saudáveis nenhum efeito do exercício é observado [326, 327], o que está de acordo com os resultados observados neste estudo.

Neste estudo, nenhuma alteração foi observada nos grupo de animais que foram tratados com EA, entretanto o fato de terem sido estudados vasos com grandes diferenças nos seus diâmetros $(50-200 \mu \mathrm{m})$, sem separá-los em pequenos grupos pode ter sido um fator limitante para a observação de alterações na estrutura vascular.

Neste estudo, nenhuma alteração foi observada nos grupo de animais que foram tratados com esteróides anabolizantes, entretanto o fato de terem sido estudados vasos com grandes diferenças nos seus diâmetros $(50-200 \mu \mathrm{m})$, sem separá-los em pequenos grupos pode ter sido um fator limitante para a observação de alterações na estrutura vascular.

Podemos concluir, portanto, que a hipertrofia cardiaca foi acompanhada por diminuída densidade capilar cardíaca nos animais que realizaram treinamento associado ao uso de altas doses de decanoato de nandrolona, submetendo desta maneira estes animais a um possível prejuizo no suprimento sangüíneo para o miocárdio. Entretanto, nenhuma alteração foi observada em relação ao colágeno perivascular e a hipertrofia vascular, demonstrando que outros fatores, que não somente os estruturais poderiam estar contribuindo para o menor fluxo sangüíneo coronário observado devido ao uso de anabolizante. Desta forma, este estudo avaliou o papel da 
adenosina como um dos possíveis reguladores do fluxo sangüineo coronário, devido a este ser um importante metabólito na regulação local deste fluxo.

\subsubsection{Hidrólise de nucleotídeos}

\section{- Fração do soro sangüíneo}

A hidrólise dos nucleotídeos ATP e ADP através da ação da enzima ATP-difosfoidrolase estão demonstradas na Figura 30. Podemos observar que maior hidrólise de ATP ocorreu nos grupos submetidos ao treinamento em comparação aos grupos sedentários, enquanto que a hidrólise de ADP permaneceu aumentada no grupo treinado controle, porém este mesmo resultado não foi observado no grupo treinado tratado com esteróide anabolizante.

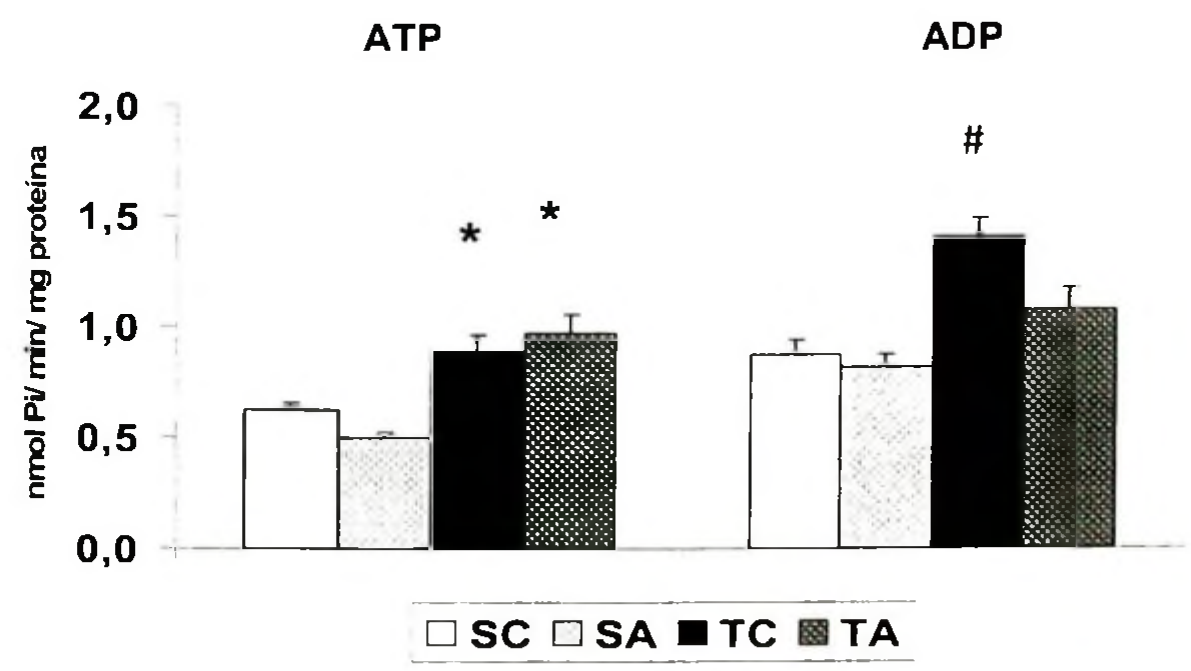

Figura 30. Medida da atividade enzimática da ATP-difosfoidrolase na fração de soro sangüineo através da hidrólise de ATP e ADP ( $\mathrm{nmol} \mathrm{Pi} / \mathrm{min} / \mathrm{mg}$ proteína). Sedentário controle ( $\mathrm{SC}, \mathrm{n}=12)$, sedentário tratado com anabolizante $(\mathrm{SA}, \mathrm{n}=12)$, treinado controle (TC, $\mathrm{n}=10$ ) e treinado tratado com anabolizante (TA, $n=11)$. Os resultados estão apresentados como média \pm erro padrão. $\left({ }^{*}\right)$ Diferença significante para hidrólise de ATP em relação aos grupos sedentários (TC x SC, $p=0,01$; TC x SA, $p<0,001$ e TA x SC e SA, p<0,001). (\#) Diferença significante para hidrólise de ADP em relação aos outros grupos (TC x SC e SA, p<0,001 e TC x $T A, p<0,05)$. 
Ainda na fração de soro sangüíneo podemos observar a atividade da enzima 5' nucleotidase representada através da hidrólise de AMP. A Figura 31 demonstra que a hidrólise de AMP está aumentada somente no grupo treinado controle.

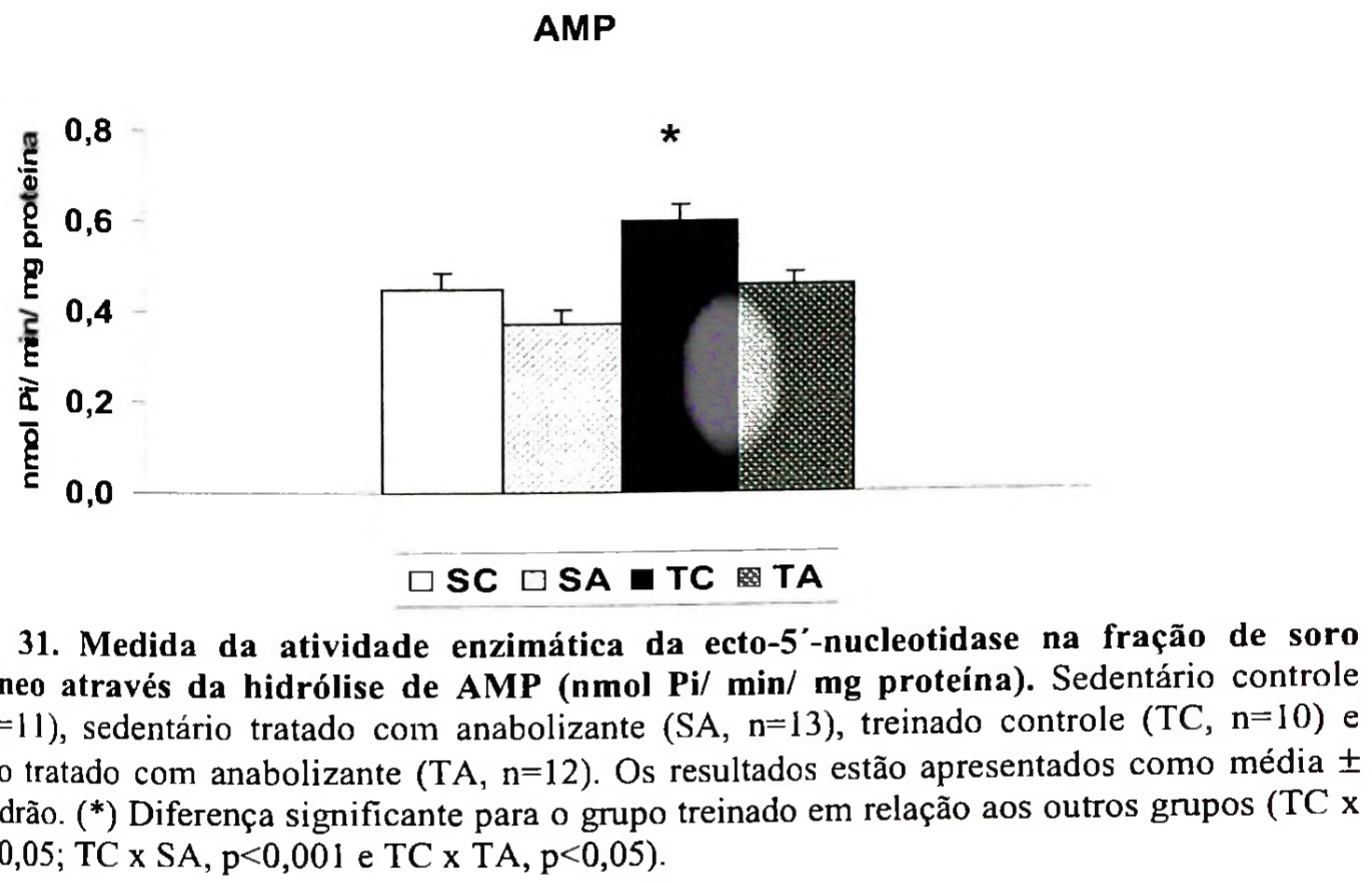

\section{- Fração sarcolemal do coração}

A hidrólise de nucleotídeos na fração sarcolemal do coração representa uma das vias locais de formação de adenosina. A atividade da enzima ATP-difosfoidrolase no coração está demonstrada na Figura 32 através da hidrólise de ATP e ADP. Podemos observar que no coração a hidrólise destes nucleotídeos está aumentada nos grupos que foram submetidos ao treinamento em relação ao grupo sedentário controle. 


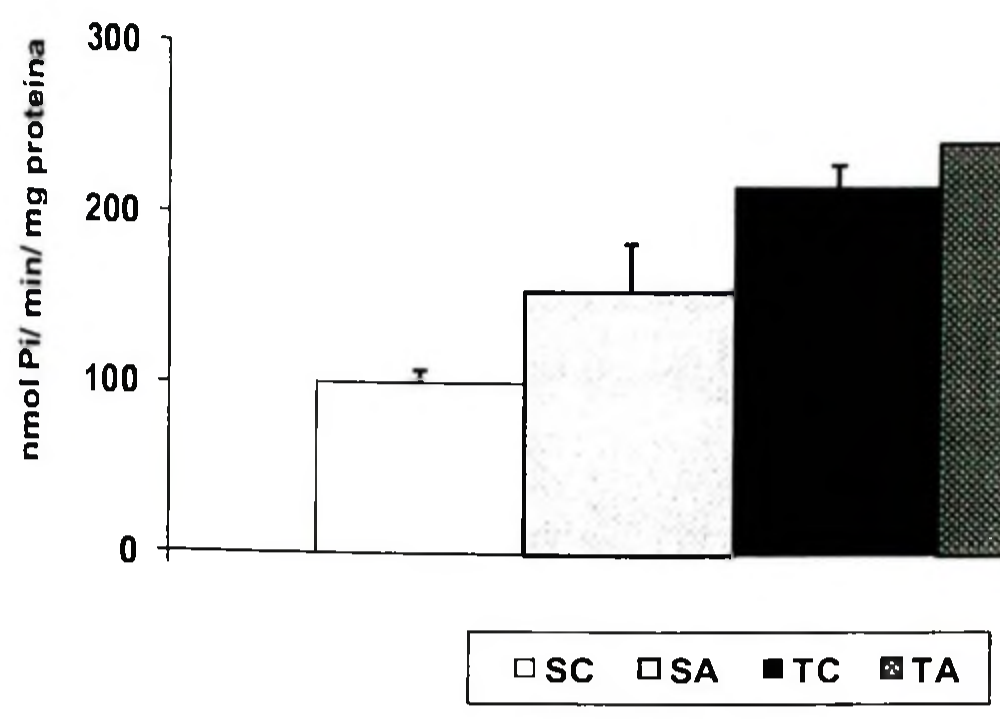

Figura 32. Medida da atividade enzimática da ATP-difosfoidrolase na fração sarcolemal do coração através da hidrólise de ATP e ADP ( $\mathrm{nmol} \mathrm{Pi} / \mathrm{min} / \mathrm{mg}$ proteína). Sedentário controle $(\mathrm{SC}, \mathrm{n}=5)$, sedentário tratado com anabolizante $(\mathrm{SA}, \mathrm{n}=5)$, treinado controle $(T C, \mathrm{n}=5)$ e treinado tratado com anabolizante (TA, $n=5)$. Os resultados estão apresentados como média \pm erro padrão. (*) Diferença significante para hidrólise de ATP em relação ao grupo sedentário controle (TC $\mathrm{x}$ $\mathrm{SC}, \mathrm{p}<0,05 ; \mathrm{TA} \times \mathrm{SC}, \mathrm{p}<0,005$ ). (\#) Diferença significante para hidrólise de ADP em relação ao grupo sedentário controle (TC $\times \mathrm{SC}, \mathrm{p}<0,01$; TA x SC, p<0,05).

Resposta semelhante também foi observada na hidrólise de AMP, ou seja, maior atividade da enzima ecto-5'-nucleotidase nos grupos treinados comparados aos grupos sedentários, a qual pode ser observada na Figura 33. 


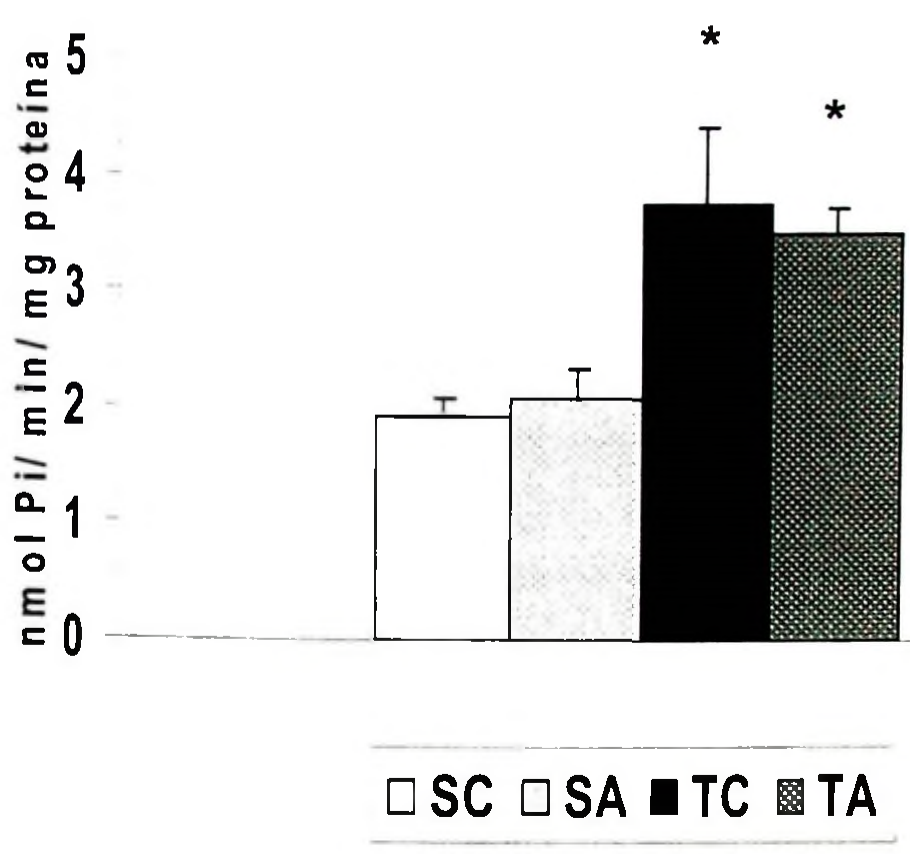

Figura 33. Medida da atividade enzimática da ecto- 5 -nucleotidase na fração sarcolemal do coração através da hidrólise de AMP (nmol Pi/ min/ mg proteína). Sedentário controle (SC, $\mathrm{n}=5)$, sedentário tratado com anabolizante $(\mathrm{SA}, \mathrm{n}=5)$, treinado controle $(\mathrm{TC}, \mathrm{n}=5)$ e treinado tratado com anabolizante (TA, $n=5)$. Os resultados estão apresentados como média \pm erro padrão. $\left(^{*}\right)$ Diferença significante para hidrólise de AMP em relação aos grupos sedentários (TC x SC e $\mathrm{SA}, \mathrm{p}<0,05$; TA $\times \mathrm{SC}$ e $\mathrm{SA}, \mathrm{p} \leq 0,05)$.

Adenosina é liberada pelo coração durante qualquer evento no qual o suprimento de oxigênio é inadequado as necessidades de oxigênio (ex: isquemia, hipóxia e aumento no consumo de oxigênio). Desta maneira, a adenosina tem um papel crucial na regulação local do fluxo sangüíneo [328].

Neste estudo, a adenosina foi avaliada através da atividade de enzimas envolvidas na cascata de hidrólise dos nucleotídeos extracelulares de adenina, os quais têm como produto final a formação de adenosina. Portanto, a atividade das enzimas ATP-difosfoidrolase, que hidrolisa ATP e ADP até AMP, e 5 -nucleotidase, que hidrolisa AMP até adenosina foram medidas na fraçào do soro sangüíneo, que representa a formação de adenosina sistêmica, e na fração sarcolemal do coração, que está envolvida na formação local de adenosina. 
Maior atividade das enzimas ATP-difosfoidrolase e 5'-nucleotidase foi observada no grupo submetido ao treinamento físico, levando desta maneira a uma maior produção de adenosina tanto circulante, quanto local, já que este aumento foi observado na fração solúvel do soro e na fração sarcolemal. Dados da literatura corroboram com estes resultados, demonstrando que a atividade da enzima 5'-nucleotidase encontra-se aumentada no miocárdio de ratos que foram submetidos ao treinamento físico [329]. No entanto, este trabalho demonstra pela primeira vez que toda a cascata de hidrólise dos nucleotídeos de adenina está ativada como efeito do treinamento físico, tanto sistêmico, quanto localmente no coração. Esta maior formação de adenosina pode ser uma das vias que está atuando para manter a maior perfusão sangüínea cardíaca nos animais treinados.

A formação de adenosina pela via de degradação dos nucleotídeos de adenina nunca havia sido estudada em animais submetidos ao tratamento com esteróides anabolizantes. Portanto, este trabalho demonstra pela primeira vez que pode ocorrer um desequilibrio nos níveis extracelulares de adenosina devido ao uso de altas doses do esteróide anabolizante decanoato de nandrolona associados ao treinamento físico. Semelhante desequilíbrio nos níveis extracelulares de adenosina já foi demonstrado em células do músculo liso vascular de artérias de condução (aorta) e de microvasos de resistência (arteríola renal) de ratos espontaneamente hipertensos (SHR) [295].

Ao analisarmos a atividade das enzimas na fração do soro sangüíneo, podemos observar que a hidrólise de nucleotídeos não foi alterada devido ao uso do esteróide anabolizante, quando comparado ao grupo controle, no entanto ocorreram alterações no grupoTA. A hidrólise de ATP no grupo TA foi aumentada igualmente a do grupo TC, entretanto diferente do observado no grupo treinado, no qual a hidrólise de ADP foi diminuída pelo uso do EA, tornando-se semelhante à observada nos grupos sedentários.

Além disso, também foi observada redução na hidrólise de AMP, o qual é degradado para adenosina através da enzima 5'-nucleotidase. Dessa maneira, pode ocorre maior formação de ADP conforme ocorreu no grupo TA, o qual provavelmente foi acumulado devido à redução na hidrólise deste nucleotídeo, levando, portanto a menor formação de AMP e por consequiência de adenosina. Através destes resultados poderiamos sugerir que: 
I-a menor formação de adenosina extracelular circulante pode ser também um mecanismo que influencia no menor fluxo sangüíneo coronário observado no grupo treinado tratado com esteróide anabolizante;

2- o acúmulo de ADP observado neste grupo pode causar aumento da agregação plaquetária, através da ligação deste nucleotídeo a receptores purinérgicos específicos (P2), [330] sendo que já foi demonstrado que o uso prolongado de EA pode estimular a agregação plaquetária, desta forma facilitando a formação de trombos e o processo de aterosclerose [331].

A hidrólise extracelular dos nucleotídeos de adenina na fração sarcolemal do coração, em parte, representa a produção local de adenosina extracelular.

Conforme já mencionado anteriormente o grupo treinado promoveu um aumento na atividade das enzimas envolvidas na via de degradação dos nucleotídeos de adenina, que também foi observado no grupo treinado e tratado com esteróides anabolizantes. Nenhuma alteração foi observada no grupo que foi submetido somente ao tratamento com anabolizante. Portanto, podemos sugerir que o uso de alta dose do EA decanoato de nandrolona, não alterou a formação de adenosina extracelular no coração e diferente do observado na fração do soro, não prejudicou 0 aumento na produção de adenosina em resposta ao treinamento físico, podendo este ser um possivel mecanismo de defesa local do coração para este grupo, no qual foi demonstrado redução de fluxo sangüíneo coronário. Desta forma, a aumentada produção de adenosina observada neste gnupo pode ser um mecanismo compensatório, o qual esteja ocorrendo na tentativa de manter o fluxo sangüíneo para o miocárdio, pois estudos demonstram o aumento na liberação desta substância em situações de disfunção endotelial [332], hipóxia e isquemia cardíaca [328].

Em conclusão, podemos afirmar que doses suprafisiológica do EA decanoato de nandrolona associada ao treinamento físico aeróbio de natação em ratos normotensos atenua as adaptações benéficas promovidas pelo treinamento fisico ao sistema cardiovascular. Além disso, um processo patológico pode ser caracterizado devido à presença de hipertrofia cardíaca patológica e menor densidade capilar cardíaca, com diminuição na produção de adenosina circulante, com redução no fluxo sangüíneo coronário e no débito cardíaco, e ainda com prejuízo na resposta vasodilatadora à acetilcolina. Todos estes fatores sugerem que o suprimento sangüíneo ao músculo cardiaco não está ocorrendo de maneira adequada, levando a um menor fornecimento de 
oxigênio para este músculo, o qual é extremamente dependente do fluxo sangüíneo para um bom desempenho. Estes resultados estão submetidos para publicação por Roque FR et al., 2010.

Investigamos também o fluxo para musculatura esquelética. As adaptações funcionais e morfológicas da musculatura esquelética e outros sistemas decorrentes de treinamento físico de natação são bem descritas, resultando em modificações metabólicas (capacidade oxidativa muscular e otimização nos sistemas de produção de energia) e circulatórias centrais e periféricas (débito cardiaco, fluxo sanguíneo muscular, aumento de capilares). Destas, no músculo esquelético, considera-se a angiogênese uma importante adaptação decorrente do treinamento de resistência aeróbia. O aumento no número de capilares ao redor da fibra pode ser até $50 \%$ maior nos músculos de membros superiores de nadadores em relação aos sedentários, o que permite uma melhor permuta de gases, calor e substratos energéticos entre o sangue e as fibras musculares ativas $[333,334]$. bem como outro.

O treinamento fisico é capaz de induzir o aumento na proliferação de células endoteliais em fibras do tipo I e II no músculo esquelético, mostrando a expressão aumentada de compostos angiogênicos, como o VEGF (Vascular-Endotelial Growth Factor) no músculo e circulação [335-337]. Este fator de crescimento é específico para a microvasculatura, sendo um potente mitógeno de células endoteliais relacionado ao controle da formação de novos capilares, e o principal implicado na resposta angiogênica ao exercício [336, 338].

VEGF e seus receptores atualmente são considerados elementos criticos para a ocorrência da angiogênese in vivo. A interação entre o receptor VEGFR2 e VEGF estimula a proliferação e migração de células endoteliais, através de uma cascata de sinalização e a tirosina quinase, que ativa Fosfoinositol-3-quinase, Fosfolipase-C- $\gamma$ e proteina quinase C- $€$ para estimular expressão de outros genes, incluindo eNOS (sintetase catalisadora da produção de Oxido Nítrico endotelial NO) cuja atividade é crítica para a sinalização do VEGF [336-339].

É bem estabelecido que a associação de dose suprafisiológica de EAA com treinamento físico causa efeitos deletérios para diversos sistemas, dentre eles o cardiovascular, resultando em diminuição da capilarização no músculo cardiaco e esquelético de animais [222], porém não se sabe como os compostos angiogênicos, como o VEGF, se comporta nesta associação.

Embora se conheça vários efeitos benéficos do treinamento físico aeróbio em relação ao músculo esquelético, pouco se sabe sobre sua associação com o uso de EA. A maioria dos 
estudos relaciona o uso destes recursos a atletas de força ou que treinam em alta intensidade. Pouco foi elucidado sobre os efeitos da associação do treinamento físico aeróbio por natação e de doses suprafisiológicas de EA na angiogênese no músculo esquelético. Desta forma, esta parte deste estudo teve como objetivo avaliar os efeitos de dose suprafisiológica de EAA sobre o remodelamento da microvasculatura, expressão protéica do VEGF e fluxo sanguineo no músculo sóleo, o músculo com maior potencial de adaptabilidade ao treinamento de resistência aeróbia, verificando se a droga é capaz de alterar a angiogênese induzida pelo treinamento por natação.

\subsubsection{Fluxo sanguíneo para o músculo esquelético}

A Figura 34 mostra os resultados de perfusão regional do músculo sóleo na condição basal e após a administração de acetilcolina. Não houve diferença significativa entre os grupos na condição basal, entretanto após a administração de acetilcolina houve diminuição nos grupos TA $(0,82 \pm 0,20 \mathrm{ml} / \mathrm{min})$ e SC $(1,20 \pm 0,15 \mathrm{ml} / \mathrm{min})$ em relação ao grupo TC $(2,60 \pm 0,39 \mathrm{ml} / \mathrm{min}$; $\mathrm{P}<0,05)$. Nos animais do grupo TC o fluxo aumentou após administração da acetilcolina em relação a condição basal $(0,79 \pm 0,24 \mathrm{ml} / \mathrm{min} ; \mathrm{P}<0,05)$, o que não ocorreu com os outros grupos.

Este aumento não foi observado nos grupos sedentários, e o grupo TA perdeu o efeito do treinamento sob o fluxo, após administração da acetilcolina.

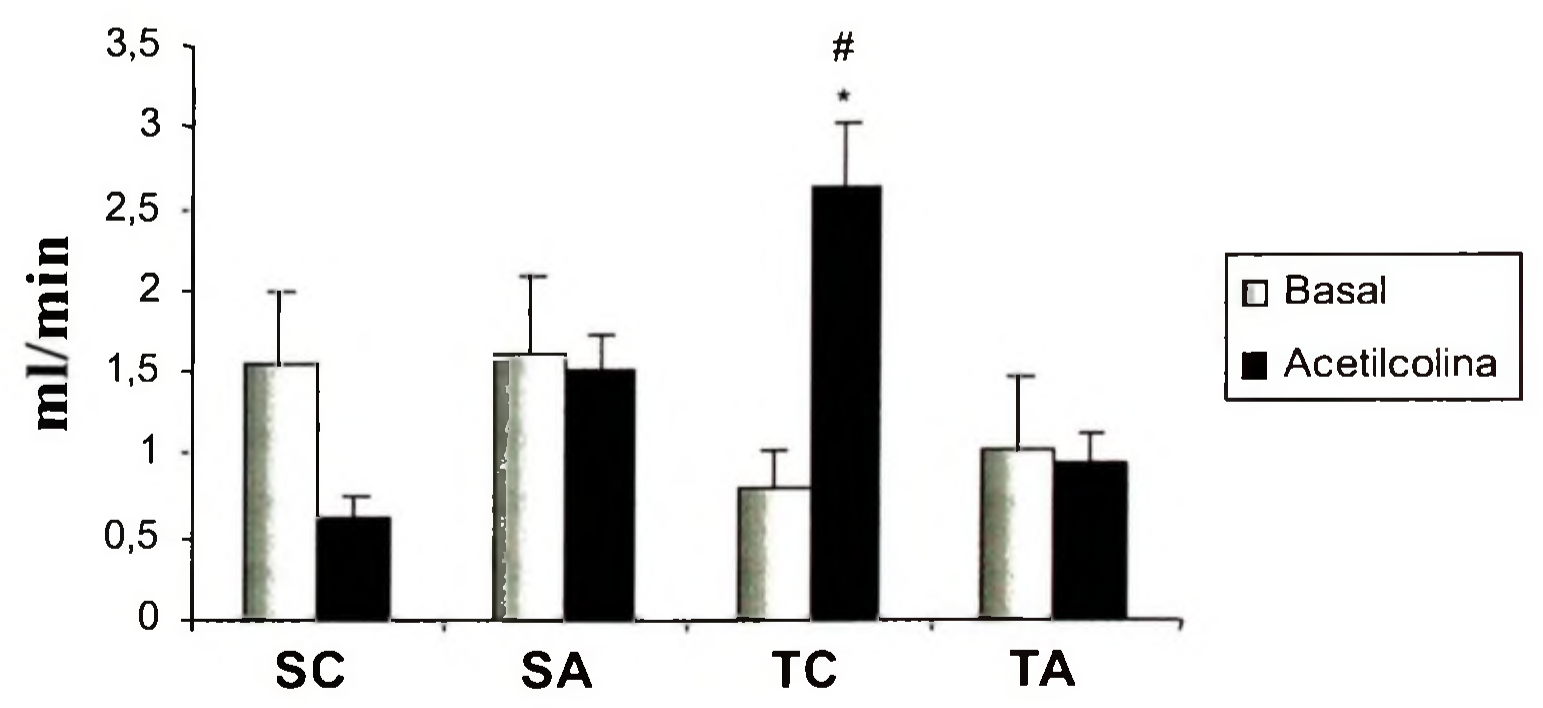

Figura 34. Fluxo sanguíneo basal e sob administração de acetilcolina para músculo sóleo. Resultados expressos como média \pm erro padrão. $\left({ }^{*}\right)$ diferença significativa dos animais TC sob 
administração de acetilcolina em relação aos grupos TA e SC. (\#) diferença significativa do grupo TC em relação à sua condição basal. $(\mathrm{p}<0,05)$.

A resposta vasodilatadora dependente de endotélio, deste grupo foi inibida no músculo sóleo, o que sugere que a associação de EAA com o treinamento aeróbio apresenta resposta diminuída à Ach, com capacidade vasodilatadora dependente de endotélio prejudicada. A capacidade de vasodilatação endotélio dependente é um aspecto importante durante o exercício, permitindo um aporte adequado de sangue e substratos para os músculos ativos e para manter o desempenho fisico [340].

O estímulo físico do aumento de fluxo é capaz de disparar a biossintese de fatores de crescimento angiogênicos, os quais são protetores nas doenças vasculares [339].

Os resultados observados neste estudo estão compativeis com os de [341], que mostraram que o uso EA associado ao treinamento anaeróbio resultou em diminuição na síntese de NO e prejuízo na vasodilatação dependente de endotélio.

\subsubsection{Morfologia muscular esquelética - hipertrofia}

Os resultados da avaliação de hipertrofia da musculatura esquelética obtidos pelo peso do músculo esquelético normalizado pelo peso corporal do animal ( $\mathrm{SC}=0,49 \pm 0,02, \mathrm{SA}=0,48 \pm 0,01$, $\mathrm{TC}=0,44 \pm 0,03, \mathrm{TA}=0,48 \pm 0,01, \mathrm{mg} / \mathrm{g}$ ) mostram que o treinamento físico, assim como o uso de EAA não levou a hipertrofia no músculo estudado.

\subsubsection{Morfometria muscular esquelética - número de capilares por fibra}

Os resultados da análise histológica para o sóleo estão apresentados na Figura 35. Foram encontrados aumentos significativos na razão capilar/fibra $(\mathrm{rC} / \mathrm{F} ; \mu \mathrm{m})$ do grupo TC $(2,29 \pm 0,08)$ comparado aos grupos TA $(1,82 \pm 0,09)$, SC $(1,74 \pm 0,12)$ e SA $(1,58 \pm 0,07 ; \mathrm{P}<0,05)$, ou seja, o número de capilares por fibra muscular esquelética encontra-se aumentado no grupo TC em relação aos outros grupos estudados. 


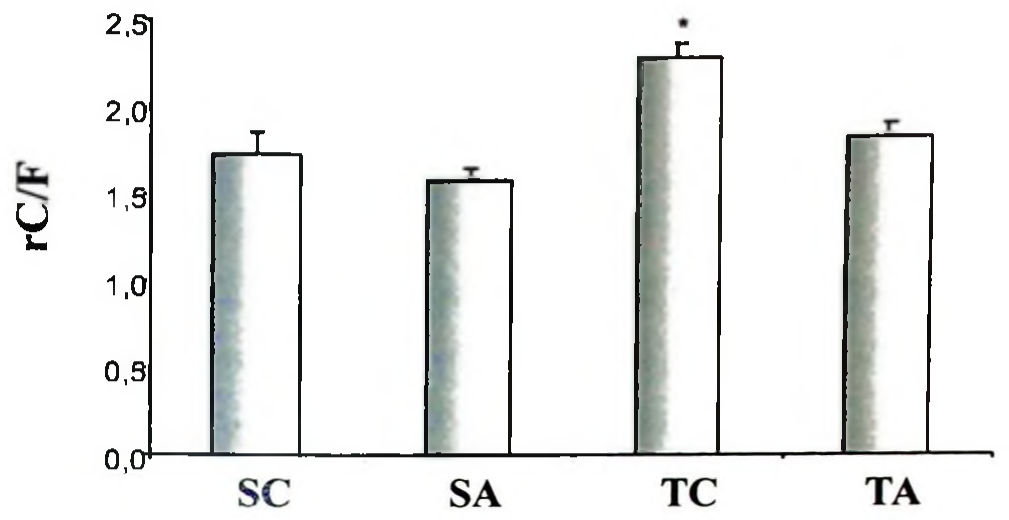

$\mathbf{A}$
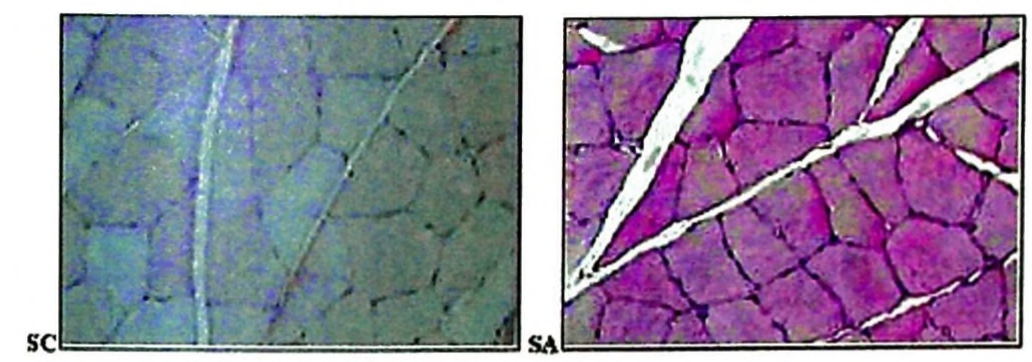

B

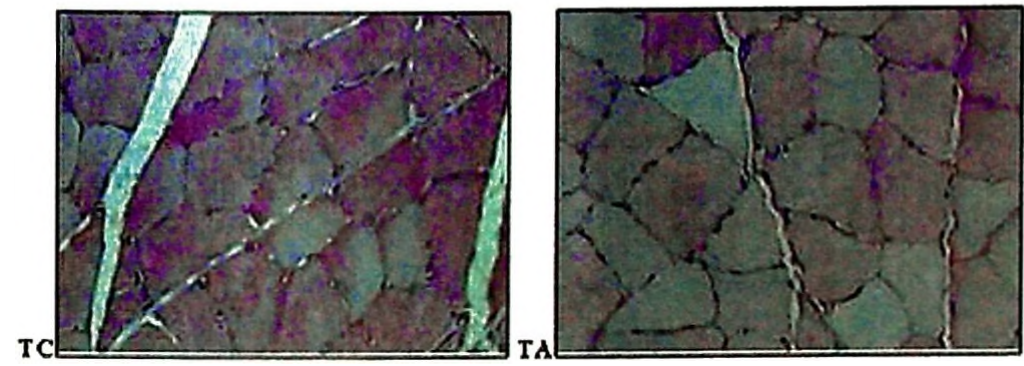

Figura 35. A) Razão Capilar/Fibra para o músculo sóleo. Aumentos significativos para o grupo TC comparado aos grupos TA, SA e SC. Resultados expressos como média \pm erro padrão. $(\mathrm{p}<0,05)$. B) Fotos ilustrativas do músculo sóleo. Microscopia ótica com aumento de $40 \mathrm{X}$, para os quatro grupos. Sedentário Controle (SC), Sedentário Anabolizado (SA), Treinado Controle (TC), Treinado Anabolizado (TA). $-20 \mu \mathrm{m}$.

Estes resultados mostram que o uso de EA associado ao treinamento fisico, impediu o aumento no número de capilares por fibra muscular esquelética, promovendo uma rarefação capilar neste grupo, comparado ao grupo TC. Sendo assim, a angiogênese observada como efeito do treinamento foi inibida no grupo TA. Estas alterações estruturais levaram a alterações 
funcionais com diminuição do fluxo sanguíneo muscular no grupo TA, o que reforça outros resultados já demontrados na literatura [222, 342].

\subsubsection{Expressão de VEGF (Vascular-endotelial Growth Factor)}

A Figura 36 mostra os resultados de expressão gênica do VEGF no sóleo, mostrada pela Razão VEGF/GAPDH. Houve aumento da expressão no grupo TC $(1,75 \pm 0,25)$ comparado aos demais grupos, ou seja, a expressão do VEGF aumentou $31 \%$ neste grupo em relação aos grupos TA $(1,02 \pm 0,08), 58 \%$ em relação ao grupo SC $(0,73 \pm 0,09)$ e $39 \%$ em relação ao grupo SA $(1,07 \pm 0,13)(\mathrm{P}<0,05)$. A expressão gênica do VEGF foi corrigida pelos respectivos resultados de expressão da proteína normalizadora, o GAPDH.

A

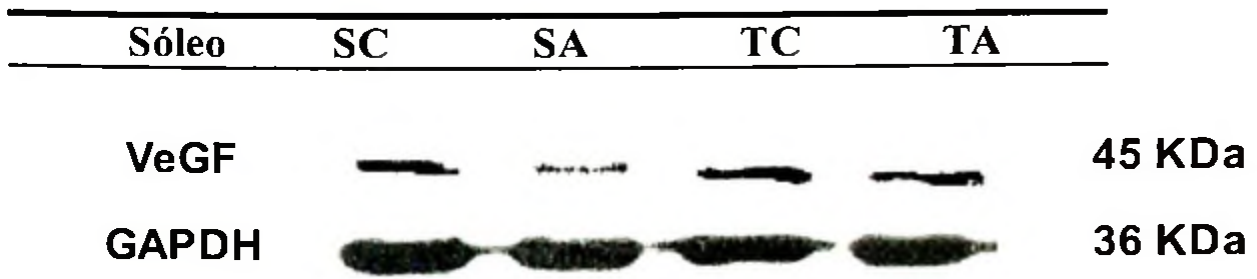

B

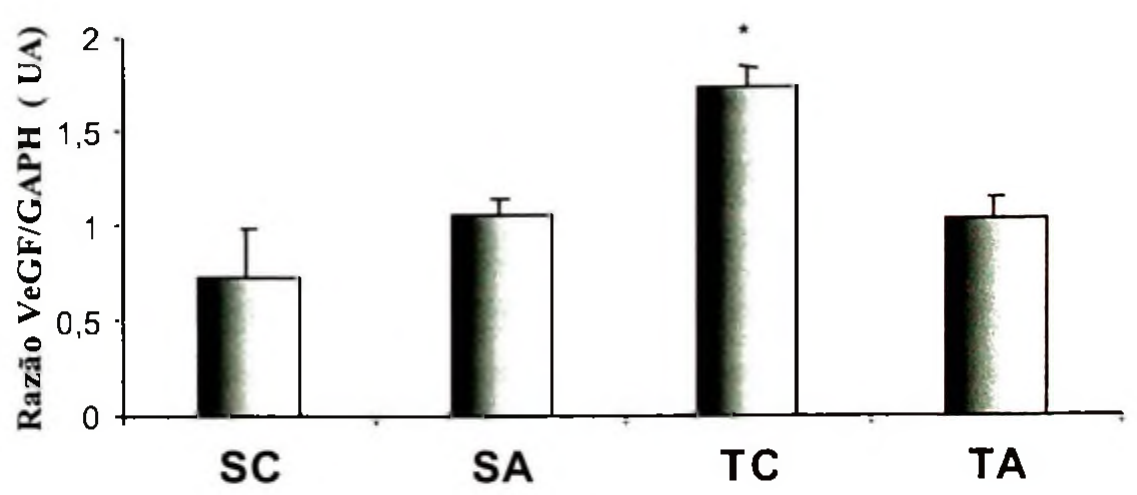

Figura 36. Expressão protéica de VEGF no músculo sóleo A) Representação das bandas da expressão proteica para VEGF e GAPDH. B) Quantificação da razão VEGF/GAPDH para o músculo sóleo. $\left(^{*}\right)$ aumento significativo do grupo TC comparado aos grupos TA, SC e SA. Resultados expressos como média \pm erro padrão. $(\mathrm{p}<0,05)$. 
A análise da expressão protéica do VEGF confirma os resultados de angiogênese no grupo TC, além de explicar a rarefação no grupo TA, comparado ao grupo TC. Assim, estes resultados mostram que mesmo sendo submetido ao treinamento fisico aeróbio o uso de EA leva a prejuizo estrutural e funcional vascular, levando a perda das adaptações microvasculares pomovidas pelo treinamento.

O VEGF é considerado o principal fator de crescimento envolvido na angiogênese e sua expressão é iniciada pela hipóxia e fortemente estimulada pelo estresse de cisalhamento decorrente do aumento do fluxo sanguíneo, nas sessões de exercício, durante o treinamento aeróbio [339]. No grupo TA sua expressão se encontra diminuída em relação ao grupo TC sem diferenças em relação aos grupos sedentários.

A atenuação dos valores de $\mathrm{rC} / \mathrm{F}$ e da expressão de VEGF foi consistente no músculo estudado, indicando que o grupo TA, além de apresentar queda no débito cardíaco e diminuição na vasodilatação endotélio dependente, também apresenta uma menor quantidade de capilares por fibra muscular esquelética, que parece ser uma conseqüência relacionada à diminuição do fluxo, aliada a diminuição na expressão de VEGF e possivelmente de suas vias de sinalização.

Diversos estudos confirmam o papel do VEGF na angiogênese induzida pelo exercício, mostrando aumento nos niveis de mRNA e de expressão protéica de VEGF em ratos, e relacionando estes aumentos a uma quantidade aumentada de capilares funcionais [336, 338, 343], resultados similares aos observados nesse estudo para o grupo TC.

Os estudos de D'ASCENZO et al. (2006) [344] e RAY et al.(2008) [345], mostram in vitro os efeitos deletérios da testosterona e seus derivados em doses suprafisológicas, na produção de VEGF em células tronco mesenquimais colhidas de sangue de cordão umbilical de ratos. Estes resultados reforçam a hipótese de que os EA são capazes de alterar a homeostase das células endoteliais e que podem diminuir a produção de fatores de crescimento que protegem contra doenças vasculares. Esses estudos mostraram que a os EA, nessas células, altera o crescimento das células endoteliais com um forte efeito antiproliferativo, induzindo apoptose e modificando as concentrações intracelulares de cálcio, um marcador para ativação precoce de células endoteliais, ainda, promove a produção e liberação de citocinas e fatores que predispõe ao dano vascular [346]. 
Concluindo, este estudo mostra evidências de que a associação entre EA e treinamento fisico é deletéria para o endotélio e para a microvasculatura no músculo sóleo. Estes efeitos podem estar relacionados com a diminuição na expressão do VEGF, resultando em menor angiogênese e número de capilares por área de fibra, nos animais tratados com EA e treinados, comparados aos treinados. A queda do fluxo sanguineo muscular, neste grupo, provavelmente é uma conseqüência da diminuição do débito cardíaco em repouso e durante o treinamento. Desta forma, esse estudo mostra que mesmo associados ao treinamento físico aeróbio o uso de EA leva a prejuizo da função vascular. Por outro lado, o treinamento físico promove remodelamento microvascular, aumentando o fluxo sanguíneo para a periferia, o que pode contribuir para a uma menor incidência de doenças vasculares em indivíduos treinados. Estes resultados foram publicados por Soci et al., 2009.

Portanto, no estudo 4, mostramos que uso de EA por si só leva a efeitos deletérios sobre o miocárdio e sistema vascular, porém quando associado ao treinamento fisico aeróbio estes efeitos são mais pronunciados. Esta associação leva a ativação do SRA-Aldosterona cardíaco com aumento na síntese de colágeno, com desenvovimento de um processo de fibrose e com ativação de fatores inflamatórios. No sistema vascular cardíaco e periférico diminui a vasodilatação endotélio dependente com diminuição da via de síntese de adenosina e diminuição da expressão do VEGF, respectivamente. Estas alterações moleculares levaram a alterações estruturais, que contribuíram significativamente para a disfunção ventricular observada na associação desta droga com o treinamento físco e levando a perda dos efeitos benéficos promovidos pelo treinamento fisico no Sitema Cardiovascular.

Estes resultados observados sobre o fluxo sanguíneo com o treinamento, nos levaram a investigar quais seriam os mecanismos envolvidos na mobilização das células progenitoras endoteliais para a circulação sanguínea com o treinamento fisico. Ainda, para entendermos melhor esses mecanismos, o estudo foi realizado em ratos espontaneamente hipertensos (SHR), numa doença em que a rarefação capilar é bem demonstrada e contribiu com o aumento dos níveis pressórico. Assim, investigamos se o número e a capacidade funcional das células progenitoras endoteliais (CPE) derivadas da medula óssea e circulantes, sabidamente diminuídas na hipertensão arterial (HA), melhoram pós treinamento físico, corroborando para o processo de revascularização muscular. 


\section{Estudo 5: Efeitos do treinamento físico aeróbio sobre a angiogênese na hipertensão arterial.}

A descoberta das células progenitoras endoteliais (CPE) derivadas da medula óssea no sangue periférico, publicada pela revista Science em 1997, mudou o conceito dos mecanismos reparatórios voltados para o dano vascular e fortaleceu a possibilidade de que elas podem ser uma ferramenta poderosa na terapia vascular $[347,348]$.

As CPE, originárias do hemangioblasto, são células tronco caracterizadas por ter a capacidade de se diferenciar em uma célula endotelial madura dando origem a novos vasos. Sabese ainda que elas são identificadas por marcadores superficiais de membrana específicos, tais como, o CD34+ e o VEGFR2+ [349]; e que o número e a capacidade funcional das CPE são regulados, não somente, por vários fatores de crescimento angiogênicos e citocinas em resposta ao dano vascular e a fatores de risco cardiovascular, mas também a modificações no estilo de vida, como a prática de exercício fisico aeróbio [350].

Alguns estudos evidenciam que as CPE derivadas da medula óssea circulam no sangue periférico [351] migram e se incorporam para exercer uma de suas principais funções, a neovascularização [352]. Mais recentemente, outros estudos mostraram que elas aumentam de número em resposta a isquemia tecidual [353] e participam do desenvolvimento de vasos colaterais após expansão ex vivo e transplante de órgãos [354, 355], o que contribuiu sobremaneira para quebrar o paradigma de que a neovascularização em adultos não está restrita a angiogênese, envolvendo também o mecanismo de vasculogênese no período pós-natal.

Na busca de novos conhecimentos envolvendo as CPE, alguns investigadores verificaram que fatores de risco para doenças cardiovasculares, como, diabetes, hiperlipidemia, fumo e hipertensão arterial afetam consideravelmente o número e a atividade funcional dessas células, tanto em indivíduos saudáveis quanto em pacientes com doença da artéria coronária, reportando uma correlação inversa entre o número de CPE e a quantidade de fatores de risco. [356]. Além disso, outros estudos sugerem que, entre os fatores de risco, a hipertensão arterial (HA) aparece como a principal causa da diminuição migratória das CPE para circulação, provavelmente 
repercutindo no desenvolvimento da rarefação vascular [357]. De fato, estes autores foram os primeiros a demonstrar que o número e a função das CPE estavam reduzidos na circulação de pacientes com HA. Posteriormente, o grupo do Imanishi $[358,359]$ descreveram que a HA reduz os niveis de CPE na medula óssea e provoca um acelerado processo de envelhecimento celular.

Recentemente, Werner e colaboradores (2005) [360] demonstraram que a redução do número de CPE é um preditor independente de morbidade e mortalidade de doenças cardiovasculares. Estes achados sugerem que a regulação do número e função das CPE influenciam diretamente na manutenção e no desenvolvimento de doenças cardiovasculares.

Por outro lado, evidências acumuladas mostram que o treinamento fisico aeróbio reduz os niveis de pressão arterial e melhora a função endotelial e a rarefação capilar na HA [338, 361 365]. Apesar desse importante papel do exercicio na prevenção e no tratamento da HA, os mecanismos envolvidos nas mudanças vasculares provocadas por essa conduta não medicamentosa, especialmente na HA, não são totalmente compreendidos. Uma possibilidade atraente é o aumento na produção e função das CPE.

Investigações recentes mostram que o treinamento fisico aeróbio aumenta a liberação e a funçào das CPE derivadas da medula óssea promovendo angiogênese $[120,121,123,142,366$ 368], o que sugere que o treinamento físico pode melhorar a saúde vascular por meio das CPE. Portanto, a proposta para essa investigação foi verificar: 1) o possível prejuízo nos números e função das CPE associados ao dano vascular na $\mathrm{HA}$ em modelo de ratos espontaneamente hipertensos (SHR), e 2) o efeito do treinamento físico aeróbio sobre a rarefação vascular associada à HA, particularmente sobre os niveis e as propriedades funcionais das CPE em SHR.

\subsection{Objetivos}

Assim, tivemos como objetivos estudar o efeito do treinamento físico aeróbio sobre a modulação das CPE derivadas da medula óssea e investigar qual a participação destas células na revascularização decorrentes deste treinamento em modelo de ratos espontaneamente hipertensos.

Mais especificamente, avaliar o efeito do treinamento fisico aeróbio em ratos WKY e 
SHR sobre:

- a evolução da massa corporal;

- o comportamento da pressão arterial e da freqüência cardíaca no repouso;

- a capacidade de tolerância ao esforço físico;

- o consumo de oxigênio;

- a quantificação das CPE medulares e circulantes;

- a capacidade funcional, por ensaio clonogênico e formação de vasos das CPE;

- o envelhecimento das CPE;

- a revascularização, pela análise da razão capilar por fibra no músculo sóleo;

- área de secção transversa do músculo sóleo;

- porcentagem dos tipos de fibras por histoquímica no músculo sóleo;

- a expressão protéica de eNOS, iNOS, VEGF, VEGFR1 e 2 no músculo sóleo.

\subsection{Materiais e Métodos}

\subsubsection{Animais de experimentação}

Foram utilizados 28 ratos machos espontaneamente hipertensos (SHR), com 12 semanas de vida em que o quadro de hipertensão arterial já está estabelecido e 28 ratos machos Wistar Kyoto (WKY), como controles do SHR. Os animais foram provenientes do Biotério Central do Instituto de Ciências Biomédicas da Universidade de São Paulo. Os ratos estavam pesando entre 240 e 270 g no início do protocolo. Eles foram mantidos em gaiolas com 3 a 4 ratos, em local com temperatura ambiente entre $22-24^{\circ} \mathrm{C}$ e luz controlada em ciclo invertido de 12 horas (claroescuro), alimentados com ração e água à vontade.

Os animais foram aleatoriamente divididos em 4 grupos experimentais com 7 animais em cada grupo, conforme descrito abaixo:

- ratos Wistar Kyoto (WKY);

- ratos Wistar Kyoto treinado (WKY-T);

- ratos espontaneamente hipertensos (SHR); 
- ratos espontaneamente hipertensos treinado (SHR-T).

Foram utilizados 2 lotes de animais conforme subdivisão acima.

\subsubsection{Protocolo de treinamento físico aeróbio}

O treinamento físico de natação foi realizado segundo protocolo de Medeiros et al. (2004) [67], conforme descrito anteriormente como P1. Os animais foram treinados durante 10 semanas, sessões de $60 \mathrm{~min}, 1$ vez ao dia, 5 vezes por semana, com aumento gradual da sobrecarga de trabalho (peso na cauda em porcentagem do peso corporal) até atingir $4 \%$ do peso corporal.

Pré e pós o período de treinamento físico os animais foram submetidos a análises hemodinâmicas, ao teste de tolerância ao esforço máximo e a medidas do $\mathrm{VO}_{2}$ máximo; e posteriormente foram sacrificados por decapitação, e as amostras necessárias foram coletadas e armazenadas adequadamente para análises histológicas, bioquímicas, celulares e moleculares.

\subsubsection{Avaliação da pressão arterial e frequiência cardíaca de repouso}

A pressão arterial foi realizada pré e pós período de treinamento físico por pletismografia de cauda (sistema da KENT SCIENTIFIC RTBP1001 para ratos e camundongos, Litchfield, USA), nos 4 grupos de animais. Conforme descrito anteriormente. Os animais estavam acordados, em repouso e mantidos sob restrição de movimentos para que as medidas fossem realizadas.

\subsubsection{Protocolo de avaliação da tolerância ao esforço físico máximo}

Para realização do protocolo de avaliação do esforço físico máximo, os animais dos 4 grupos WKY, WKYT, SHR e SHRT foram posicionados individualmente sobre a esteira rolante. Imediatamente após o posicionamento do animal foi iniciado o teste de esforço. A velocidade inicial foi de $6 \mathrm{~m} / \mathrm{min}$ (sem inclinação), que constitui em um protocolo escalonado com incrementos de velocidade de $3 \mathrm{~m} / \mathrm{min}$ a cada $3 \mathrm{~min}$, até que fosse atingida a velocidade máxima suportada pelos animais. O critério para a determinação da exaustão do animal e interrupção do 
leste foi o momento em que o rato não foi mais capaz de correr dentro da caixa metabólica mediante o incremento de velocidade da esteira.

Esta avaliação foi feita pré e pós o período de treinamento, para comparar a resposta de desempenho do animal entre os grupos. Embora o teste em esteira não seja específico ao Ireinamento físico realizado no presente estudo, utilizaremos esse teste para auxiliar na verificação da eficácia do treinamento físico como predição de uma melhora na capacidade de realização de esforço. Foram comparados o tempo ( $\mathrm{min})$, a velocidade $(\mathrm{m} / \mathrm{min})$ e a distância $(\mathrm{m})$ percorrida por cada rato.

\subsubsection{Protocolo de medida do consumo máximo de oxigênio.}

Após a semana de adaptação à caixa metabólica, os ratos foram submetidos a um teste progressivo de esforço máximo em esteira rolante adaptado de Brooks \& White (1978) [146], com incremento de carga de $3 \mathrm{~m} / \mathrm{min}$ a cada $3 \mathrm{~min}$, até a exaustão, para a obtenção do $\mathrm{VO}_{2}$ pico.

O consumo máximo de oxigênio e a produção de dióxido de carbono, foram mensurados por detenminação da fração expirada de oxigênio $\left(\mathrm{FeO}_{2}\right)$ e de dióxido de carbono $\left(\mathrm{FeCO}_{2}\right)$ durante o teste de exercício progressivo até exaustão.

Neste protocolo os ratos foram colocados numa caixa metabólica sobre a esteira rolante, que serviu como câmara de mistura dos gazes expirados. Esta câmara é conectada a um tubo na forma de "T", para a retirada de amostras de ar $(1000 \mathrm{ml} / \mathrm{min})$ para serem analisadas as $\mathrm{FeO}_{2}$ e $\mathrm{FeCO}_{2}$ em um analisador de gazes. A outra via do tubo em " $T$ " é utilizada para a aspiração do ar em fluxo contínuo $(2500 \mathrm{ml} / \mathrm{min})$, regulável por bomba aspiradora. A parte da frente da caixa metabólica possui uma abertura de $2 \mathrm{~mm}$ da superficie, que permite a entrada de ar ambiente unidirecional sugado pela bomba aspiradora. O fluxo de ar na caixa metabólica é de $3500 \mathrm{ml} / \mathrm{min}$.

O rato foi colocado dentro da caixa metabólica por um período de repouso de 30 minutos para o registro do estado basal e, em seguida, o teste foi iniciado com velocidade de $3 \mathrm{~m} / \mathrm{min}$. Durante cada estágio ( $3 \mathrm{~min}$ ) de exercício realizado, foram analisadas as $\mathrm{FeO}_{2}$ e $\mathrm{FeCO}_{2}$ dos gazes contidos no ar da caixa metabólica. Foram consideradas as frações expiradas dos trinta últimos segundos de cada estágio para a determinação do $\mathrm{VO}_{2}$ pico de cada estágio. 
Ao atingir a exaustão o rato foi mantido na caixa metabólica por aproximadamente 3 min e as fraçōes expiradas foram registradas para verificar a recuperação do animal e o funcionamento dos analisadores.

O consumo de oxigênio foi calculado através da seguinte fórmula matemática:

$$
\mathrm{VO}_{2}=\text { fluxo de ar } \mathrm{X}\left(\mathrm{FiO}_{2}-\mathrm{FeO}_{2}\right) / \text { peso corporal }
$$

Onde:

$\mathrm{VO}_{2}=\mathrm{ml} \cdot \mathrm{Kg}^{-1} \cdot \mathrm{min}^{-1}$

Fluxo de ar $=1000 \mathrm{ml} / \mathrm{min}$ (analisador) $+2500 \mathrm{ml} / \mathrm{min}$ (bomba de aspiração) $=3500 \mathrm{ml} / \mathrm{min}$.

$\mathrm{FiO}_{2}=$ fração de oxigênio inspirada (ar ambiente).

$\mathrm{FeO}_{2}=$ fração de oxigênio expirada (caixa de mistura).

Peso corporal $=\mathrm{Kg}$.

Para a análise dos dados foi utilizado o maior valor do $\mathrm{VO}_{2}$.

\subsubsection{Avaliação da caracterização histoquímica do músculo esquelético}

O músculo esquelético sóleo foi extraído cuidadosamente e fixado em uma massa de montagem a base de tissue tek (para manter o tecido na posição correta pré-congelamento) pela região tendinosa (Figura 1). 


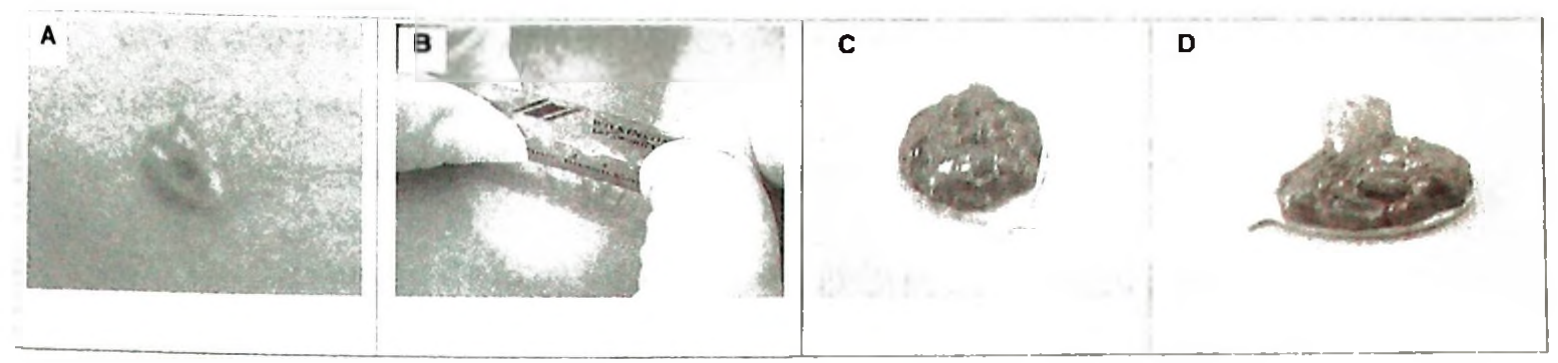

Figura 1. Extração do tecido muscular esquelético. (A) Retirada do músculo sóleo. (B) Corte transversal com lâmina nova sob̉e base rígida. (C) Massa de montagem a base de tissue tek sobre a placa onde será identificada a amostra. (D) O tecido sobre a massa de montagem que servirá como apoio para a permanência na posição correta pré congelamento.

Posteriormente à fixação na massa de montagem a base de tissue tek, o sóleo foi mergulhado em isopentano (crioprotetor que evita artefatos nas amostras) e em seguida em nitrogênio líquido para o congelamento, onde serão mantidos até que os cortes sejam realizados (Figura 2).

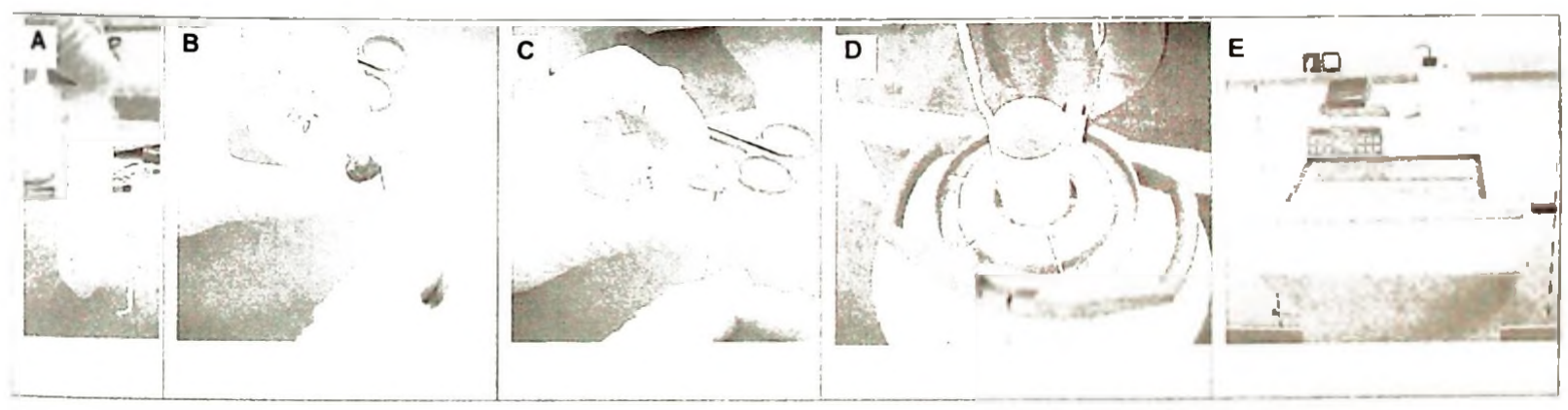

Figura 2. Congelamento e cortes do tecido. (A) Isopentano refrigerado em nitrogênio líquido. Quando o isopentano fica com a base congelada é o ponto ótimo para imersão do tecido. (B) Tecido é introduzido no isopentano durante 10 segundos $(C)$ e posteriormente transferido para tubo de $50 \mathrm{ml}$ contendo nitrogênio líquido. (D) Conservação em nitrogênio líquido a aproximadamente $-196^{\circ} \mathrm{C}$ (E) Criostato Mícron HM505E, onde foram realizados os cortes do tecido. 
Após a obtenção dos cortes de $10 \mu \mathrm{m}$ foram realizadas reações adaptadas de Brooke \& Kaiser (1970), que permitiram a avaliação da atividade da enzima miosina ATPase por meio de soluções com diferentes pHs $(4,3$ e 10,3), com o intuito de realizar a tipagem das fibras.

\subsubsection{Determinação da área de secção transversa e tipos de fibras musculares}

A captura das imagens foi realizada com amplificação de $200 x$ em objetiva de $20 x$. A aquisição das imagens foi processada em computador acoplado a um sistema de vídeo por meio de um programa de imagens (Leica Qwin). Foram analisados 10 campos de cada corte histológico, na tentativa de avaliar o tecido por inteiro. Foi calculada a área de secção transversa por cada tipo de fibra muscular em $\mu \mathrm{m}^{2}$.

Para a identificação dos tipos de fibras pela técnica ATPase miosínica em pH 10.3 (alcalino) (Figura 3A), as fibras escuras foram caracterizadas de tipo II, as claras de tipo I e cinza as intermediárias. Já no pH 4.3 (ácido) (Figura 3B), as fibras escuras são do tipo I, as claras do tipo II e as cinzas do tipo intermediárias.
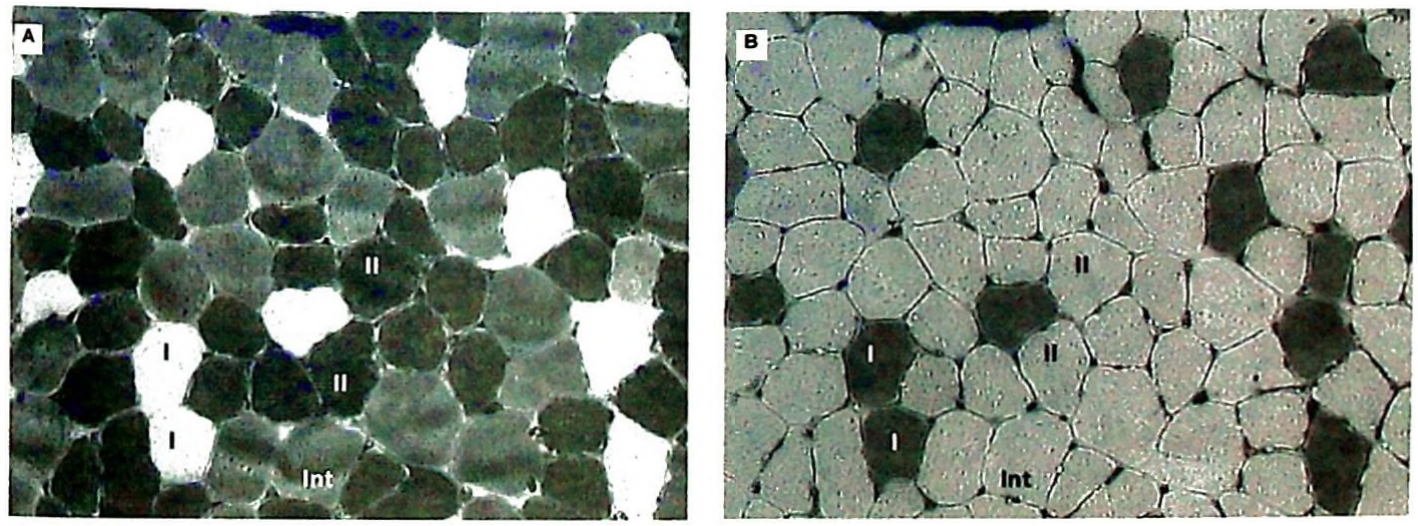

Figura 3. Corte histológico do músculos sóleo em diferentes pHs: 10.3 (A) e 4.3 (B) de um animal controle. 


\subsubsection{Análise da razão capilar por fibra}

A razão capilar por fibra do músculo sóleo foi avaliada por meio da reação histoquímica para miosina ATPase no pH 10.3, como descrito anteriormente [369] e quantificada pela análise de 10 campos não sobrepostos, com uma amplificação de $200 x$, distribuídos de uma maneira randômica usando um sistema computacional morfométrico (Leica Quantimet 500, Cambridge, UK) (Figura 4). Para calcular a razão capilar por fibra, o número total de capilares foi dividido pelo número total de fibras contabilizadas no mesmo campo. Somente vasos com um diâmetro menor que $10 \mu \mathrm{m}$ foram contabilizados.

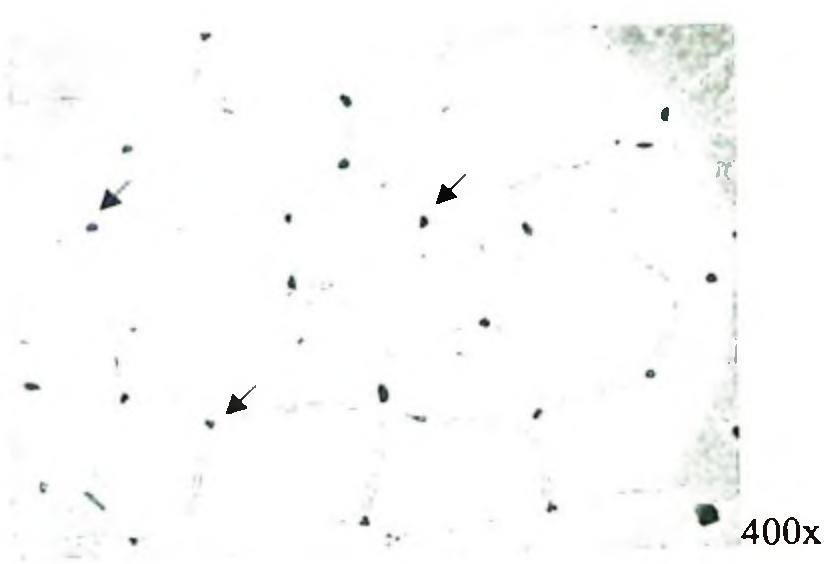

Figura 3: Capilarização no músculo sóleo em rato controle, pH 10.3.

\subsubsection{Extração das células mononucleadas da medula óssea}

Após o período de treinamento os animais foram sacrificados e as células da medula óssea foram obtidas do fêmur e tíbia dos 4 grupos de animais. Após tricotomia dos membros inferiores, foi realizada uma incisão para a visualização da articulação coxo-femural. Após ruptura dos ligamentos e divulsão para a retirada do tecido muscular adjacente, o fêmur foi imerso em tubo falcon contendo PBS (phosphate-buffered saline) e penicilina G $(100 \mathrm{U} / \mathrm{mL})$ e estreptomicina $(100 \mu \mathrm{g} / \mathrm{mL})$. O mesmo procedimento foi repetido para a retirada da tíbia. 
Sob condições estéreis, a medula óssea foi extraída do osso através da lavagem da cavidade com meio de cultura Dulbecco's Modified Eagle's Médium (DMEM) através de seringa e agulha. Após sucessivas lavagens e homogeneização do meio contendo células, foi feito um gradiente de separação com Ficoll (Ficoll-Paque, GE Healthcare, Canada) para separação da porção de células mononucleadas (CMN). O material foi centrifugado por 25 minutos a $2000 \mathrm{rpm}$ $\left( \pm 23^{\circ} \mathrm{C}\right)$ para a separação das células. Depois de separadas as células foram lavadas com PBS e novamente submetidas à centrifugação por 5 minutos a $1000 \mathrm{rpm}$, e em seguida ressuspendidas em pequeno volume de PBS IX para posterior contagem. Em seguida, foram encaminhadas para análise de proliferação, senescência e ensaios funcionais de unidades formadoras de colônia em matrigel, conforme metodologias descritas posteriormente.

\subsubsection{Extração das células mononucleadas do sangue periférico}

Concomitante a retirada dos fêmures e tíbias para separação das CMN da medula óssea, foram retirados $10 \mathrm{ml}$ de sangue periférico de cada animal para separação da porção de CMN circulantes. Com uma seringa estéril usando um anti-coagulante (heparina sódica), os $10 \mathrm{ml}$ de sangue foram coletados via veia cava inferior.

Após coleta, o sangue foi transferido para um tubo tipo falcon de $50 \mathrm{ml}$ em que foi adicionado um volume igual de PBS $1 \mathrm{X}$, portanto $10 \mathrm{ml}$. Em seguida, adicionamos em um tubo tipo falcon novo, $15 \mathrm{ml}$ de Ficoll (Ficoll-Paque, GE Healthcare, Canada) e cuidadosamente depositamos o sangue periférico diluído para que fosse realizado um gradiente de separação por densidade para obtenção da porção de $\mathrm{CMN}$ circulantes. O material foi centrifugado por 25 minutos a $2000 \mathrm{rpm}\left( \pm 23^{\circ} \mathrm{C}\right)$ para a separação das células. Depois de separadas as células foram lavadas com PBS $1 \mathrm{X}$ e novamente submetidas à centrifugação por 5 minutos a $1000 \mathrm{rpm}$, e em seguida ressuspendidas em pequeno volume de PBS $1 \mathrm{X}$ para posterior contagem. Em seguida, foram destinadas a análise no citometro de fluxo e ensaio funcional de unidades formadoras de colônia, conforme metodologias descritas posteriormente. 


\subsubsection{Quantificação das células progenitoras endoteliais na medula óssea.}

Após a obtenção das células mononucleadas derivadas da medula óssea dos grupos WKY, IVKT, SHR e SHRT como descrito acima, foram cultivadas em cultura celular sendo plaqueadas aproximadamente $5 \times 10^{6}$ de $\mathrm{CMN}$ de cada grupo em placas de cultura 6 wells contendo fibronectina (BD BioCoat, USA). As células foram cultivadas em meio endotelial basal (EndoCult Basal Medium, StemCell Technologies Inc, Canada) com suplementação (EndoCult Supplements, StemCell Technologies Inc, Canada), incubadas por 2 dias a $37^{\circ} \mathrm{C}, 5 \%$ de $\mathrm{CO}_{2}$ com $95 \%$ de umidade.

Após 2 dias de cultura, as células não aderentes contendo a população de células progenitoras endoteliais foram coletadas e plaqueadas novamente em placas de cultura 24 poços contendo fibronectina (BD BioCoat, USA) com meio endotelial basal suplementado. As células aderidas na primeira placa continham células endoteliais maduras e alguns monócitos, as quais foram descartadas.

Após adesão das células, aproximadamente 4 horas, as mesmas foram lavadas com meio e as CPE foram identificadas pela incubação com $2,4 \mu \mathrm{g} / \mathrm{mL}$ de 1,1 - dioctadecyl-3,3,3,3tetramethylindocarbocyanine-labelled acetilado LDL (DiLDL; CellSystems, coloração vermelha) por 1 hora. Em seguida, as células foram fixadas em $2 \%$ de paraformaldeído e contracoradas com isotiocianato de fluresceína (FITC, coloração verde) conjugado a Ulex europaeus aglutinina I (lectina, $10 \mu \mathrm{g} / \mathrm{mL}$, Sigma). A coloração positiva para DiLDL acetilado e lectina foram caracterizadas como $\mathrm{CPE}$. Dois investigadores analisaram o número de CPE por placa, pela contagem de 3 campos aleatórios em microscópio invertido para fluorescência (Zeiss, Germany).

\subsubsection{Ensaio de envelhecimento celular associado à atividade da $\beta$-galactosidase}

A atividade da $\beta$-galactosidase (SA- $\beta$-gal) será medida, conforme descrito por Dimri et al. (1995) [370], para analisar o efeito do treinamento fisico sobre o acelerado processo de envelhecimento das CPE da medula óssea na hipertensão arterial. Concisamente, as CPE derivadas da medula óssea serão lavadas em PBS, fixadas por 3 min (temperatura ambiente) em $2 \%$ de paraformaldeído e lavadas e incubadas por $24 \mathrm{~h}$ a $37^{\circ} \mathrm{C}$ com a solução de coloração SA- $\beta$ gal [5-bromo-4-cloro-3 indyl $\beta$-D-galactopylanoside (X-Gal) $1 \mathrm{mg} / \mathrm{mL}$, ferrocianeto de potássio 5 
mmol/L, ferricianeto de potássio $5 \mathrm{mmol} / \mathrm{L}, \mathrm{NaCl} 150 \mathrm{mmol} / \mathrm{L}, \mathrm{MgCl} 22 \mathrm{mmol} / \mathrm{L}$, deoxicolato de sódio $0,01 \%$ e Nonidet-40 0,02\%]. Após a coloração, as mesmas serão analisadas em 5 campos, para contagem das células marcadas em microscópio invertido (Nikon, USA), e captura das respectivas imagens ilustrativas.

\subsubsection{Citometria de fluxo}

As CPE circulantes foram submetidas à marcação com anticorpos de membrana específicos para identificação destas células através do CD34+ (Santa Cruz, USA) e flk-1+ (VEGFR2) (BD Pharmingen, USA), com intuito de averiguar a quantidade de CPE mobilizadas para circulação. Após a marcação as CPE foram analisadas em citometria de fluxo para determinação do grau de pureza celular. Foi realizado o protocolo de seleção positiva através da presença dos marcadores de membrana $\mathrm{CD} 34+$ e flk-1, por meio de separação de célula ativada por fluorescência (FACS, Becton-Dickinson). Durante o processamento no citômetro de fluxo, há a passagem de células individualmente por uma câmara de fluxo que gera um fluxo laminar de células, onde incide um raio de luz (laser). A dispersão do mesmo e dos corantes fluorescentes emite luzes de freqüências variadas que são captadas por filtros e detectores fotomultiplicadores, os quais convertem a luz em pulsos eletrônicos e que serão captados pelo software. A dispersão luminosa fornece os primeiros dados sobre a caracterização da amostra celular. Assim, os corantes fluorescentes permitem a identificação do fenótipo celular. Deste modo, o conjunto dessas informações permite a quantificação das células e análise da pureza celular. Os devidos controles isotípicos para cada um dos fluorocromos (BD Pharmingen, USA) e da condição de células sem marcação serão utilizados para a padronização das fluorescências.

\subsubsection{Avaliação funcional de formação de unidade formadora de colônia.}

O ensaio clonogênico representa uma tecnologia valiosa para a avaliação da atividade funcional das CPE. Esta técnica será empregada nas CPE medulares e circulantes. Basicamente o ensaio clonogênico envolve três etapas: 1) a primeira etapa consiste na separação e quantificação das $\mathrm{CMN}$, como mencionados acima 2) a segunda etapa envolve a cultura celular destas células em que serão então colocadas $5 \times 10^{6} \mathrm{CMN}$ em placas de cultura de 6 poços contendo fibronectina (BD BioCoat, USA). As células serão cultivadas em meio endotelial específico para análise de função destas células tronco (EndoCult- StemCell Technologies, Canada). Após 2 dias de 
incubaçào para seleção da população de CPE, as células não aderentes são novamente plaqueadas com meio especifio EndoCult 3). Finalmente, após 3 dias de cultura, a terceira etapa inclui a contagem em microscópio invertido (Nikon, USA) do número de unidades formadoras de colònia (UFC), após 7 dias a $37^{\circ} \mathrm{C}$ em câmara úmida. Esta técnica demonstra o potencial destas células de formarem vasos sanguíneos.

\subsubsection{Avaliação funcional de formação de tubos como capilares sobre matrigel.}

O efeito do treinamento físico sobre a formação de tubos em CPE medular na HA foi examinada pelo ensaio de formação de tubos como capilares sobre matrigel. Sucintamente, placas de cultura de 96 poços foram cobertas com $100 \mu \mathrm{l}$ de Matrigel (13 mg/ml, BD Biosciences), os quais foram solidificados por $30 \mathrm{~min}$ a $37^{\circ} \mathrm{C}$. $2 \times 10^{4} \mathrm{CPE}$ foram plaqueadas sobre a superficie de matrigel com meio endotelial basal já suplementado (EndoCult, StemCell Technologies Inc, Vancouver, Canada) e cultivadas a $37^{\circ} \mathrm{C}, 5 \%$ de $\mathrm{CO}_{2}$ com $95 \%$ de umidade. As imagens dos poços com matrigel foram capturas com microscópio invertido (Nikon, USA) em objetivas de $4 \mathrm{x}$, para análise qualitativa das CPE em forma de tubos como capilares e analisadas em 3 campos aleatórios.

\subsubsection{Western Blotting}

O músculo sóleo foi homogeneizado em tampão de lise hipotônico contendo tampão

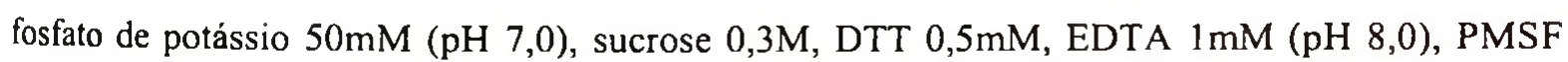
$0,3 \mathrm{mM}, \mathrm{NaF} 10 \mathrm{mM}$ e coquetel de inibidor de fosfatase (1:100). O sobrenadante foi transferido para tubos de $1,5 \mathrm{ml}$ e a concentração de proteina, das amostras, analisada por meio do método de Bradford (Bio-Rad - EUA). Alíquotas foram armazenadas em freezer $-80^{\circ} \mathrm{C}$ até o momento de serem utilizadas. A metodologia foi a mesma descrita anteriormente.

Foram utilizados como anticorpos primários anti-VEGF (Santa Cruz, EUA), VEGFR1 (Santa Cruz, EUA), VEGFR2 (Santa Cruz, EUA), eNOS (Santa Cruz, EUA) e iNOS (Santa Cruz, EUA). Em seguida as mesmas foram lavadas $3 \times 10$ min com TBS-T, incubadas por 2 horas com os respectivos anticorpos secundários (IgG anti-rabbit, anti-rabbit, anti-rabbit, anti-rabbit e anti-mouse, Amersham Biosciences, EUA) conjugados à peroxidase. Posteriormente visualizadas e quantificadas (número de pixels) pelo sistema Image, fornecido gratuitamente pela NIH (EUA) 
via internet. Essas análises foram realizadas em nosso laboratório. O gliceroldeído-3-fosfato desidrogenase (GAPDH) foi utilizado como normalizador.

\subsubsection{Análise estatística}

Os dados foram analisados utilizando a análise de variância ANOVA de duas vias (treinamento físico e HA como fatores independentes), para comparar os valores dos grupos e teste de Tukey como pos-hoc (Statistica software, StatSoft, Inc., Tulsa, OK, USA). Foi adotado para todos os experimentos um $\mathrm{p}<0,05$ de significância. Todos os resultados foram apresentados na forma de média \pm erro padrão da média (EPM).

\subsection{RESULTADOS E DISCUSSÃO}

Primeiramente foi investigado o comportamento da massa corporal (MC) dos 4 grupos estudados, com objetivo de verificar se o treinamento fisico (TF) aeróbio interfere na mesma.

A Figura 5A mostra a MC dos grupos: WKY, WKY-T, SHR, SHR-T pré e pós período de 10 semanas com protocolo de TF aeróbio. Não houve diferença da MC no início do protocolo entre os grupos, e foi observada uma manutenção da MC nos grupos treinados (WKY-T e SHRT) ao final do protocolo em comparação aos grupos sedentários (WKY e SHR).

Os dados encontrados na literatura com relação à alteração na $\mathrm{MC}$ em resposta ao $\mathrm{TF}$ aeróbio são em sua maioria realizados com humanos e animais de experimentação e mostram resultados bem diversos, devido aos diferentes protocolos de treinamento que são utilizados com modificações em freqüência, intensidade, duração e tipo de exercício. Porém, estudos que utilizaram o mesmo modelo de animal genético, SHR e WKY, vão de encontro com os dados obtidos neste estudo, em que os grupos treinados chegam ao final do protocolo com um menor ganho de MC comparado aos grupos sedentários [323, 371].

Os estudos que mostram diminuição da $\mathrm{MC}$ ou menor ganho pós TF aeróbio atribuem esses resultados ao fato do exercício elevar o metabolismo basal devido a um aumento do gasto calórico com uso predominante do metabolismo oxidativo. Esse aumento do gasto calórico somado ao longo de semanas ou meses pode explicar essa diferença em relação aos indivíduos 
sedentários, principalmente por uma redução do tecido adiposo. Portanto, após o sacrificio foi leita a remoção da gordura reto peritoneal dos animais, conforme ilustrado na Figura 5B, e foi observada uma reduzida quantidade de tecido adiposo nos animais treinados comparados aos sedentários, explicando em partes esse menor ganho da MC ao final do periodo experimental.

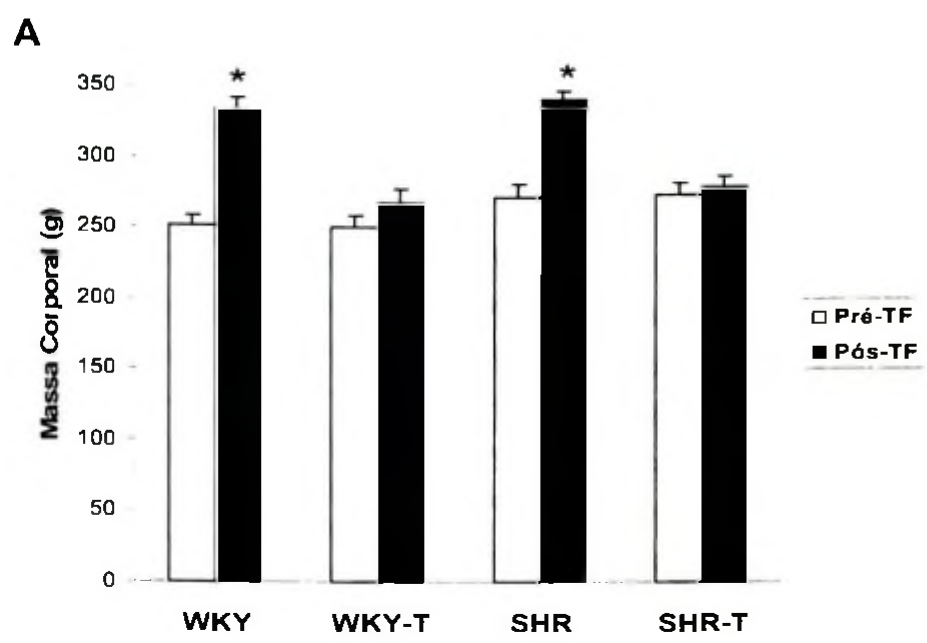

B

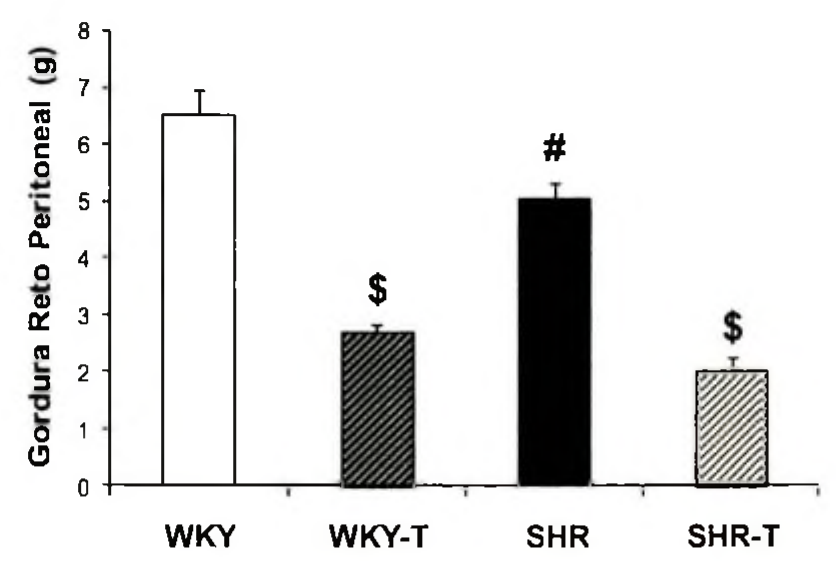

Figura 5. Massa corporal pré e pós TF de natação (A) e medida da gordura reto peritoneal pós periodo de TF (B). Os dados estão representados na forma de média \pm EPM. * vs. Pré-TF e WKY-T e SHR-T Pós-TF, $p<0,05 ; \$$ vs. WKY e SHR, $p<0,01$ e \# vs. WKY, $p<0,05$. 
Conforme previamente descrito, o propósito da primeira parte do estudo foi verificar se há alterações nos níveis e na capacidade funcional das CPE medulares em SHR, e se esta modulação ocorreria em sinergia com o prejuizo vascular associado à $\mathrm{HA}$.

Como se pode observar na Figura 6, os animais SHR comparados aos controles WKY apresentam uma elevada pressão arterial, acompanhada de rarefação capilar na musculatura esquelética e mudanças na proporção do tipo de fibras dessa musculatura; porém sem afetar a área de secção transversa, a tolerância ao esforço e o consumo máximo de oxigênio. De fato, esses dados sugerem que similar ao que ocorre na HA no homem, os SHR apresentam um aumento progressivo da PA. Este desajuste crônico no controle da PA na HA repercute num aumento da resistência vascular periférica, culminando na oclusão capilar na microcirculação [372]. A rarefação vascular é um dos primeiros sinais que promove o rearranjo nas proporções dos tipos de fibra, mudando proporcionalmente o metabolismo requerido para a região. Embora exista estas alterações morfofuncionais, não houve intolerância ao esforço e atrofia, conforme ocorre em individuos com insuficiência cardíaca [373]. 
A

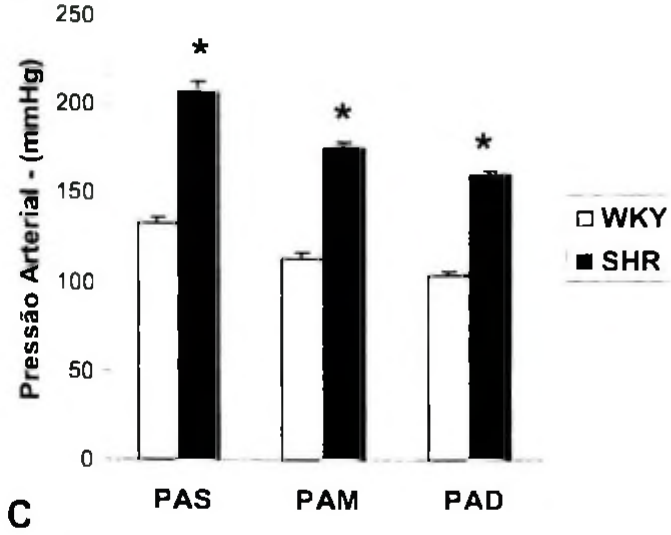

C

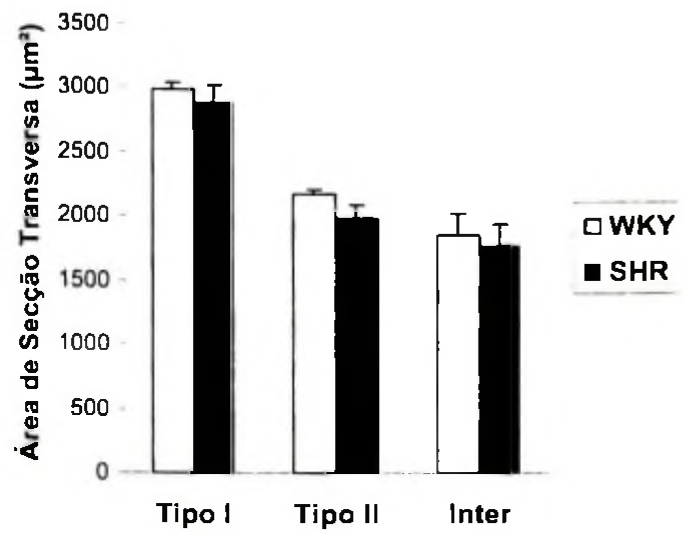

$\mathbf{E}$

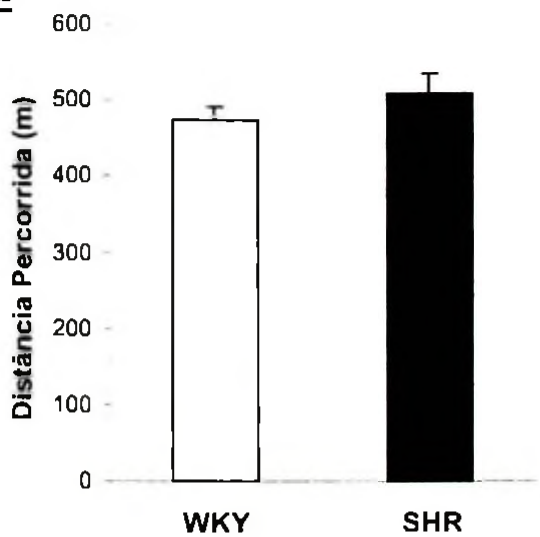

B
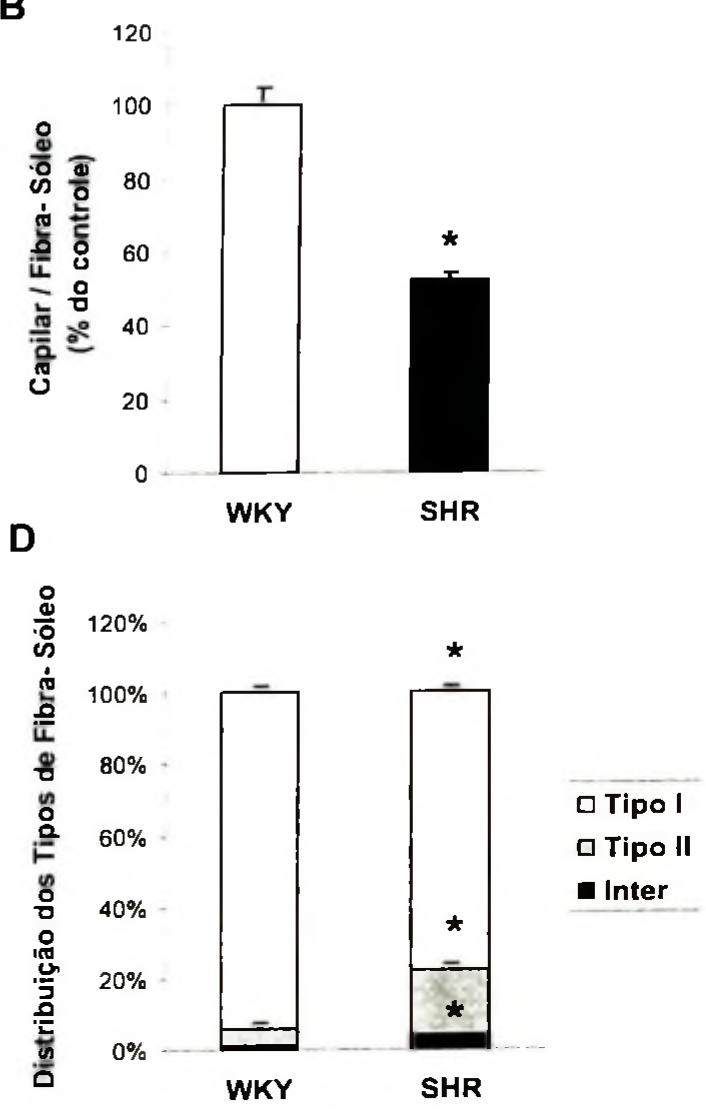

$\mathbf{F}$

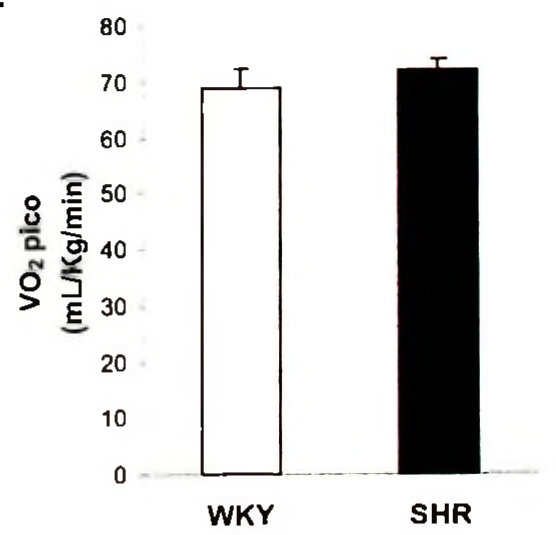

Figura 6. Pressão Arterial Sistólica (PAS), Média (PAM) e Diastólica (PAD) (A); razão capilar por fibra no músculo sóleo (B); área de secção transversa do sóleo (C); proporção de tipos de fibra no sóleo (D); tolcrância à realização de esforços fisicos $(\mathrm{E})$ e consumo máximo de oxigênio (F) em ratos WKY e SHR. Os dados estão representados na forma de média \pm EPM. ${ }^{*}$ vs. WKY, $\mathrm{p}<0,001$. Inter $=$ Intermediária. 
Para verificar se há disfunção das CPE na medula óssea de SHR e se estas ocorrem simultaneamente com o dano vascular periférico mostrado anteriormente, em um primeiro experimento, analisou-se a proliferação das CPE através do número de células duplamente marcadas para DiLDL acetilado e Lectina, em seguida foi avaliada a senescência destas pela atividade da $\beta$-galactosidase e por último avaliou-se a capacidade funcional das CPE através dos ensaios de unidades formadoras de colônia e formação de tubos como capilares sobre matrigel.

Como observado na Figura 7, os níveis (A) e a capacidade funcional (C e D) das CPE estava significantemente reduzida nos SHR, quando comparados aos do grupo WKY, enquanto foi observado um aumento significante no número de células senescentes (B) no grupo SHR comparado ao controle.

Os resultados do prejuízo nos números e função das CPE na medula óssea, embora não determinantes, auxiliam na idéia de que esta população celular corrobora para o início ou manutenção do dano vascular induzido por fatores de risco cardiovascular, no caso, o que demonstra que as CPE podem estar envolvidas no estabelecimento da rarefação vascular na HA, como sugerido em modelos induzidos pelos fatores de risco cardiovascular [358, 359, 374-376].

De consenso na literatura, a hipótese mais aceita é que o prejuizo das CPE circulantes é um preditor independente de morbi-mortalidade para DCV, levando ao remodelamento vascular, consequentemente falha no processo de neovascularização $[356,357,360]$. Dessa forma, investigaremos futuramente o perfil das CPE no sangue periférico para comprovar tal fenômeno, porém, como a medula óssea é o maior reservatório dessas células tronco adultas, pode ser observado que este prejuízo ocorre desde sua origem. 
A

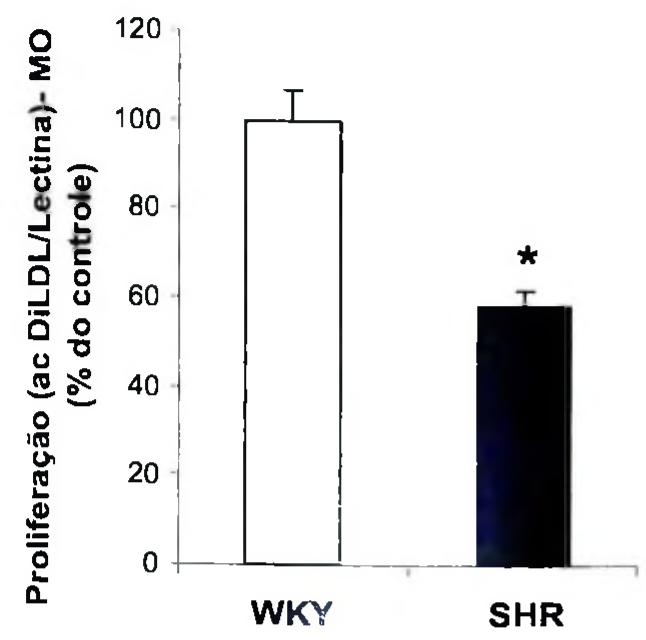

C

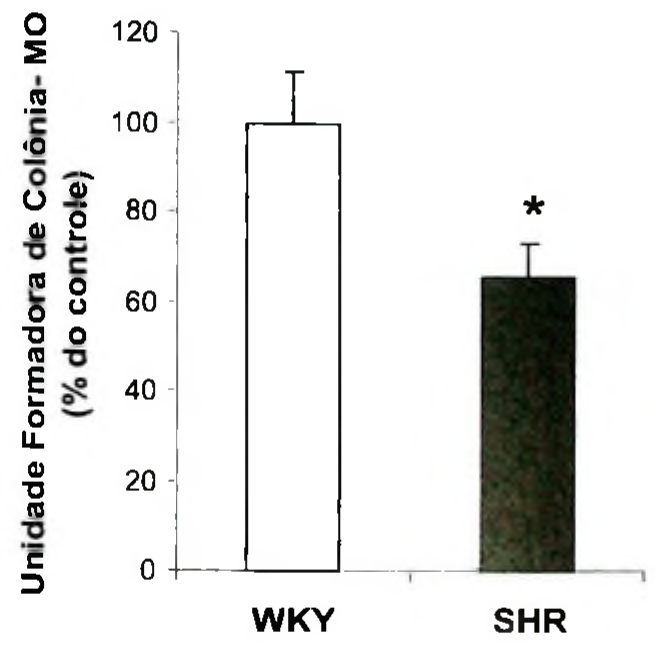

B

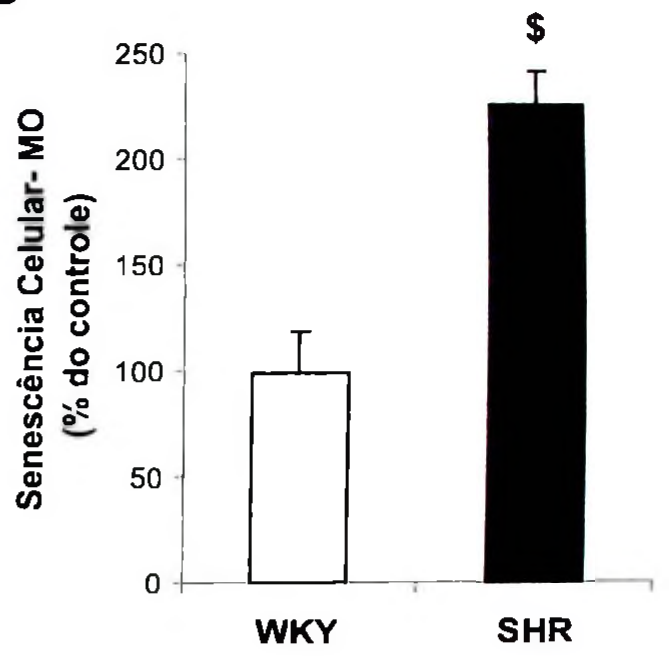

D

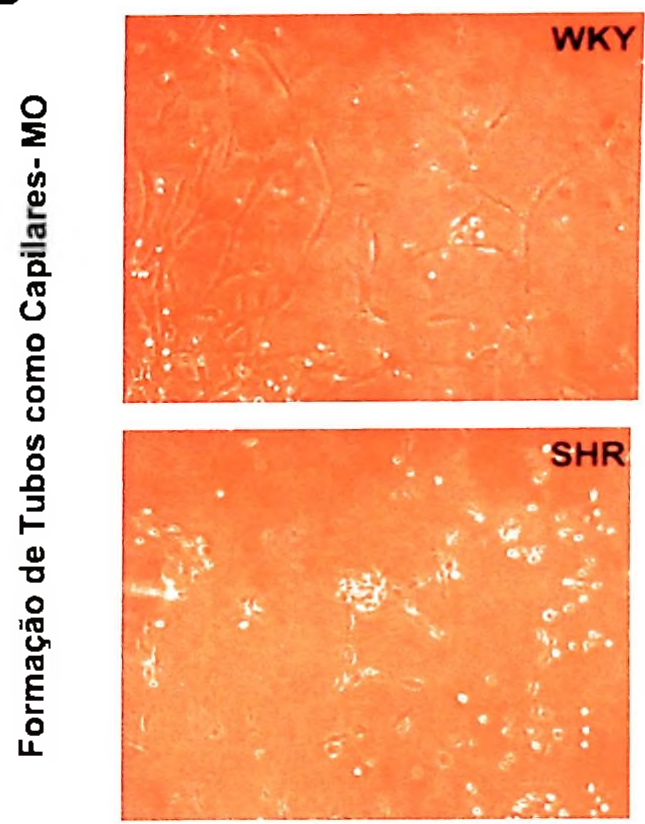

Figura 7. Proliferação das CPE na medula óssea (MO) através da dupla marcação para acDiLDL e Lectina (A), senescência celular na MO (B), unidade formadora de colônia na MO (C), e formação de tubos como capilares sobre matrigel na MO (D) em WKY e SHR. Os dados estão representados na forma de média \pm EPM. * $p<0,01$ e $\$ p<0,001$. 
Como o treinamento fisico aeróbio se apresenta como importante ferramenta nãofarmacológica na reversão das alterações desencadeadas pela HA, optou-se em utilizá-lo na ientativa de controle da PA, consequentemente na correção da rarefação vascular e modulação da bioatividade das CPE. Segue os resultados mediante efeito do TF aeróbio, uma vez que foi caracterizado o perfil das CPE na HA.

Estudos epidemiológicos vêm demonstrando nas últimas décadas a relação inversa existente entre o nivel de condição física e o desenvolvimento de doenças cardiovasculares [377]. Assim, a inatividade física está associada com maior risco de desenvolvimento de hipertensão arterial, sendo considerado o exercício físico regular um componente chave na prevenção e tratamento da HA, contribuindo, contudo, para melhoria de outros fatores de risco cardiovascular.

Foram realizados na década de 60 os primeiros estudos que constataram o potencial efeito preventivo do treinamento físico aeróbio no controle e tratamento da PA, surgindo às primeiras evidências de redução na PA em indivíduos hipertensos que faziam exercício físico regular [378$380]$.

Na Figura 8A, Pré TF, observa-se que os grupos SHR e SHR-T apresentavam niveis elevados de PA comparados aos grupos controle, WKY e WKY-T; sem diferença da FC entre os quatro grupos. Entretanto, Pós TF, representado pela Figura 8B, observa-se que o treinamento fisico de natação de baixa intensidade e longa duração foi eficaz em reduzir a Pressão Arterial Sistólica (PAS), Pressão Arterial Diastólica (PAD), Pressão Arterial Média (PAM) do grupo SHR-T comparado ao grupo SHR, sem nenhuma alteração de pressão nos grupos de animais controle, WKY e WKY-T. Porém, observa-se uma redução da FC de repouso nos grupos de animais treinado, WKY-T e SHR-T, em comparação aos sedentários.

Estes resultados estão de acordo com os encontrados na literatura, confirmando a eficácia do treinamento físico aeróbio em reduzir a PA em ratos espontaneamente hipertensos, sem mudanças significantes em ratos normotensos. Além disso, a redução da PA foi acompanhada pela bradicardia de repouso nos animais treinados, usada como um dos principais marcadores de treinamento físico aeróbio $[323,338,361,365,371,381]$. 
A

\section{Pré TF}

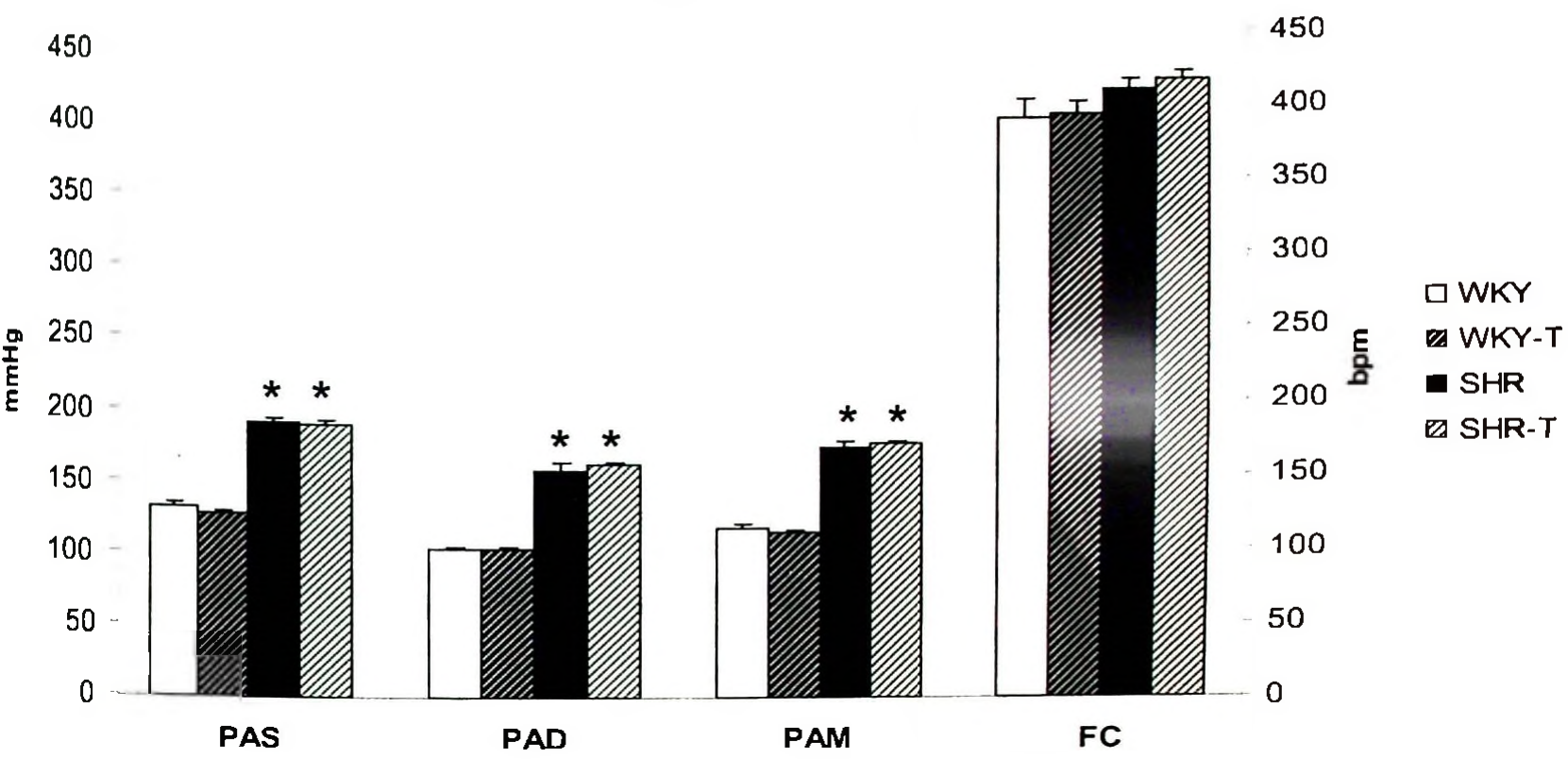

B

\section{Pós TF}

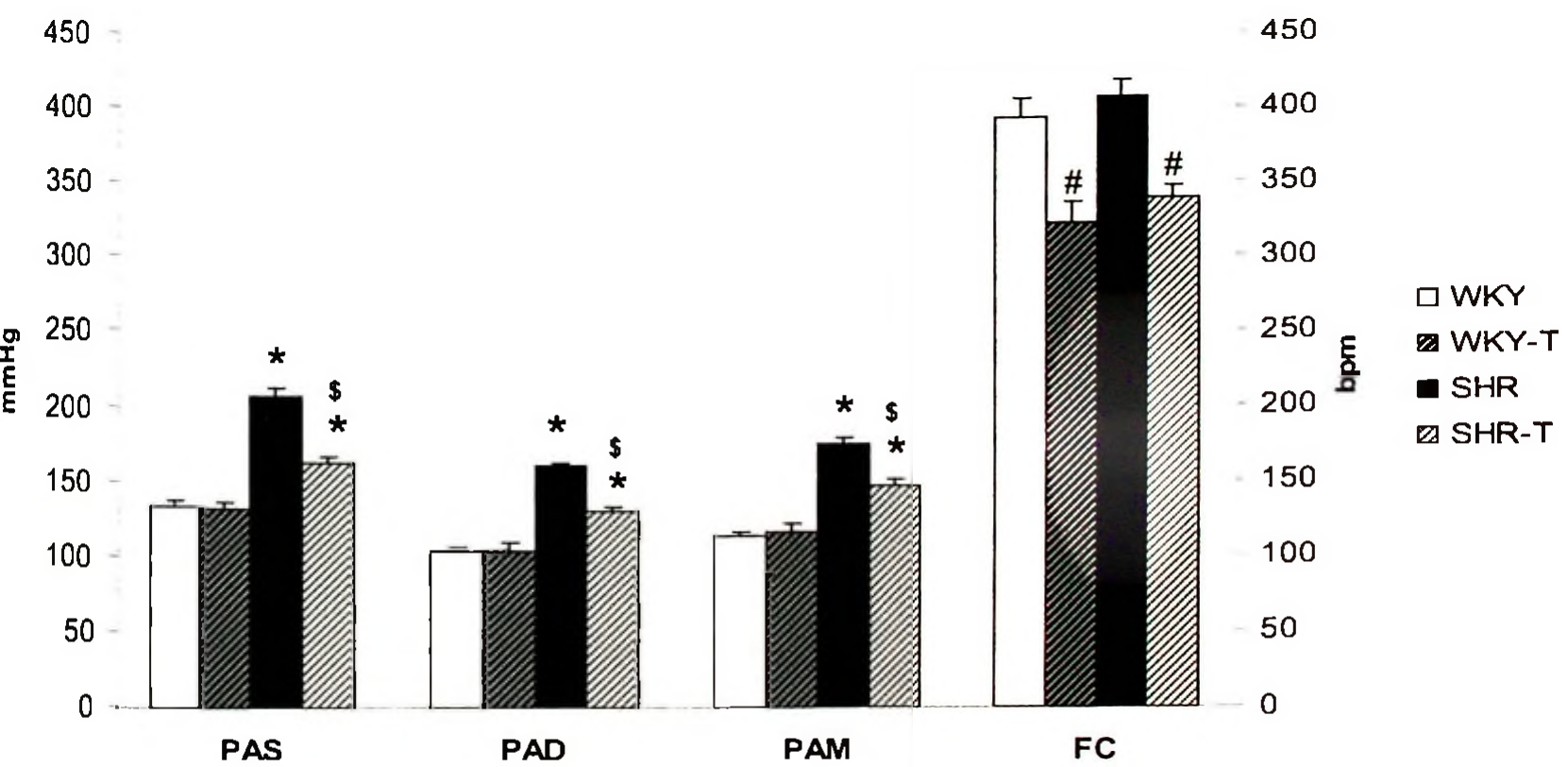

Figura 8. Pressão Arterial Sistólica (PAS), Pressão Arterial Diastólica (PAD), Pressão Arterial Média (PAM) e Freqüência Cardiaca (FC) de repouso Pré TF (FIGURA A) e Pós TF (FIGURA 
B) de ratos WKY e SHR submetidos ao protocolo experimental; sedentários (S) e treinados (T). Os resultados estão expressos como média \pm EPM. ${ }^{*} \mathrm{p}<0,05$ vs. WKY e WKY-T; \# $\mathrm{p}<0,05$ vs. IVKY e SHR; $\$ p<0,05$ vs. SHR.

Após analisar o efeito hipotensor do TF sobre a HA, foi realizado o teste de tolerância ao esforço. O teste de esforço máximo é utilizado como uma ferramenta para avaliar o desempenho fisico após um período de treinamento físico aeróbio. Sendo assim, visando testar a eficácia do treinamento, conseqüentemente, uma maior tolerância a realização de um exercício aeróbio. Os animais foram submetidos ao teste em esteira rolante até a exaustão pré e pós o período de treinamento fisico de natação. Foram avaliadas as variáveis distância percorrida, tempo e velocidade.

É importante ressaltar que embora o teste não tenha sido modalidade específica ao tipo de treinamento realizado, o mesmo pode proporcionar bons indícios da melhora da capacidade máxima de realização de esforço físico aeróbio, tais como, melhora do metabolismo oxidativo e cardiopulmonar.

As Figuras 9A, 9B e 9C mostram que os valores de velocidade, tempo e distância percorrida, respectivamente, foram semelhantes entre os grupos Pré TF. Entretanto, os animais treinados aumentaram significativamente a velocidade, tempo e distância percorrida no teste Pós TF. Assim, estudos vêm demonstrando uma relação direta entre o treinamento físico e uma melhora na capacidade de tolerância ao esforço através da mensuração das variáveis acima apontadas. Desta forma, o teste em esteira até a exaustão vem sendo bastante utilizado para a verificação da capacidade aeróbia em animais de experimentação [105, 323, 382]. 

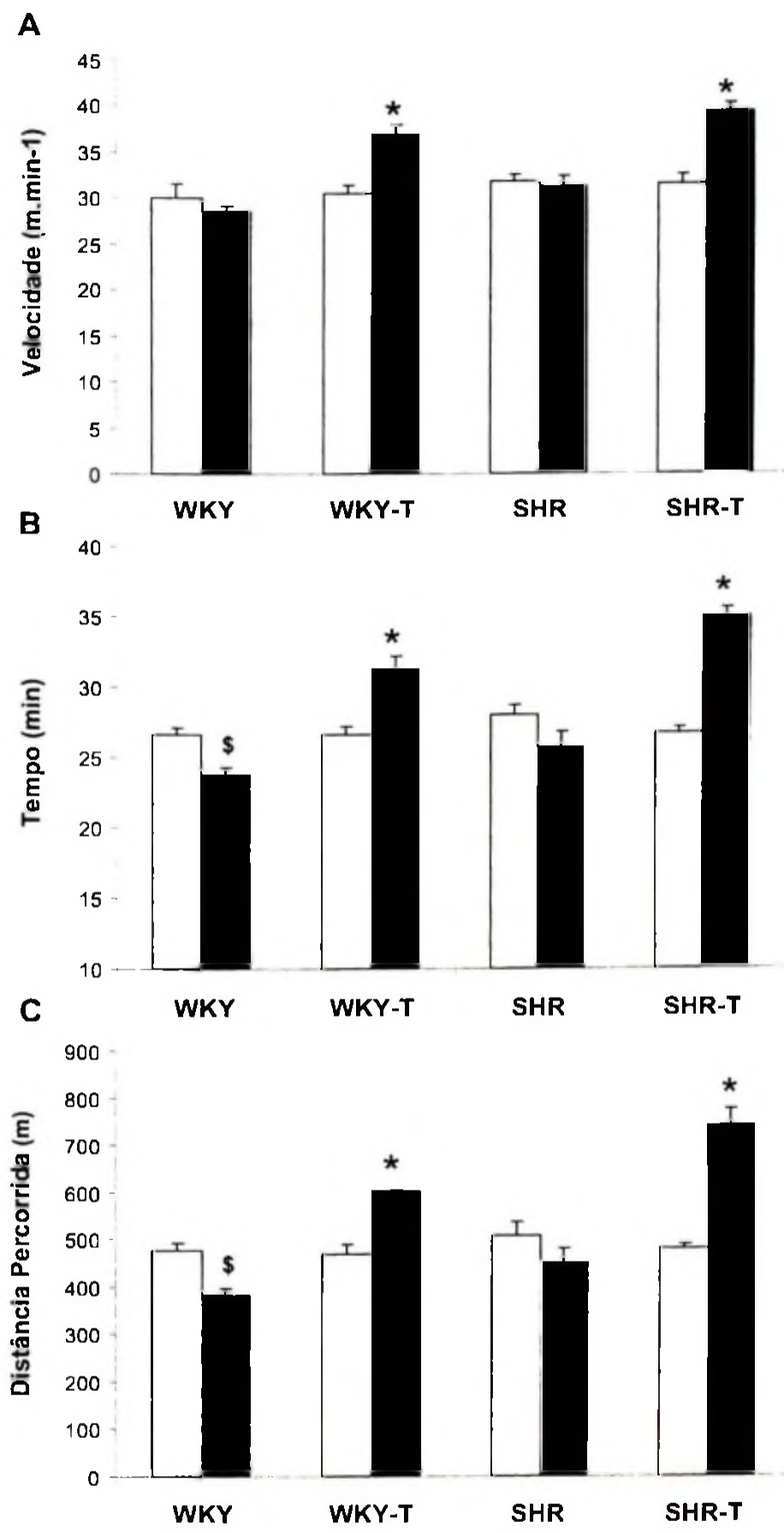

Figura 9: Teste de esforço físico máximo. Velocidade (Figura A), Tempo (Figura B) e Distância Percorrida (Figura C) Pré e Pós TF. Os resultados estão expressos como média \pm EPM. ${ }^{*} \mathrm{p}<0,05$ comparado com o Pré TF e WKY e SHR Pós TF; $\$ \mathrm{p}<0,05$ comparado ao Pré TF e WKY-T e SHR-T Pós TF. 
Depois da análise do teste de tolerância ao esforço realizamos a medida do $\mathrm{VO}_{2}$ pico dos animais pré e pós TF. O consumo máximo de oxigênio retrata a capacidade máxima do organismo de extrair oxigênio. Esta é a medida que melhor avalia a potência aeróbia, ou seja, a quantidade máxima de energia que pode ser transformada em trabalho aeróbio das fibras musculares por unidade de tempo.

A Figura 10 mostra o $\mathrm{VO}_{2}$ pico dos animais pré e pós o protocolo experimental. No período Pré TF observa-se que todos os grupos tinham o mesmo nível médio de $\mathrm{VO}_{2}$ pico, entretanto Pós TF observa-se a eficácia do treinamento com uma resposta maior de consumo de oxigênio para os grupos que treinaram (WKY-T e SHR-T) e uma redução para os grupos controle (WKY e SHR). Isto pode ser explicado pelo fato do consumo de oxigênio máximo/ pico reduzir com o avançar da idade, além de ser influenciado pelo sedentarismo [383]. Assim, resultado está compatível ao encontrado na literatura, em que ratos treinados aerobicamente apresentaram uma manutenção e/ou aumento dos valores do consumo de oxigênio e redução nos animais controle Pós TF, quando comparados ao início do protocolo [323, 384].

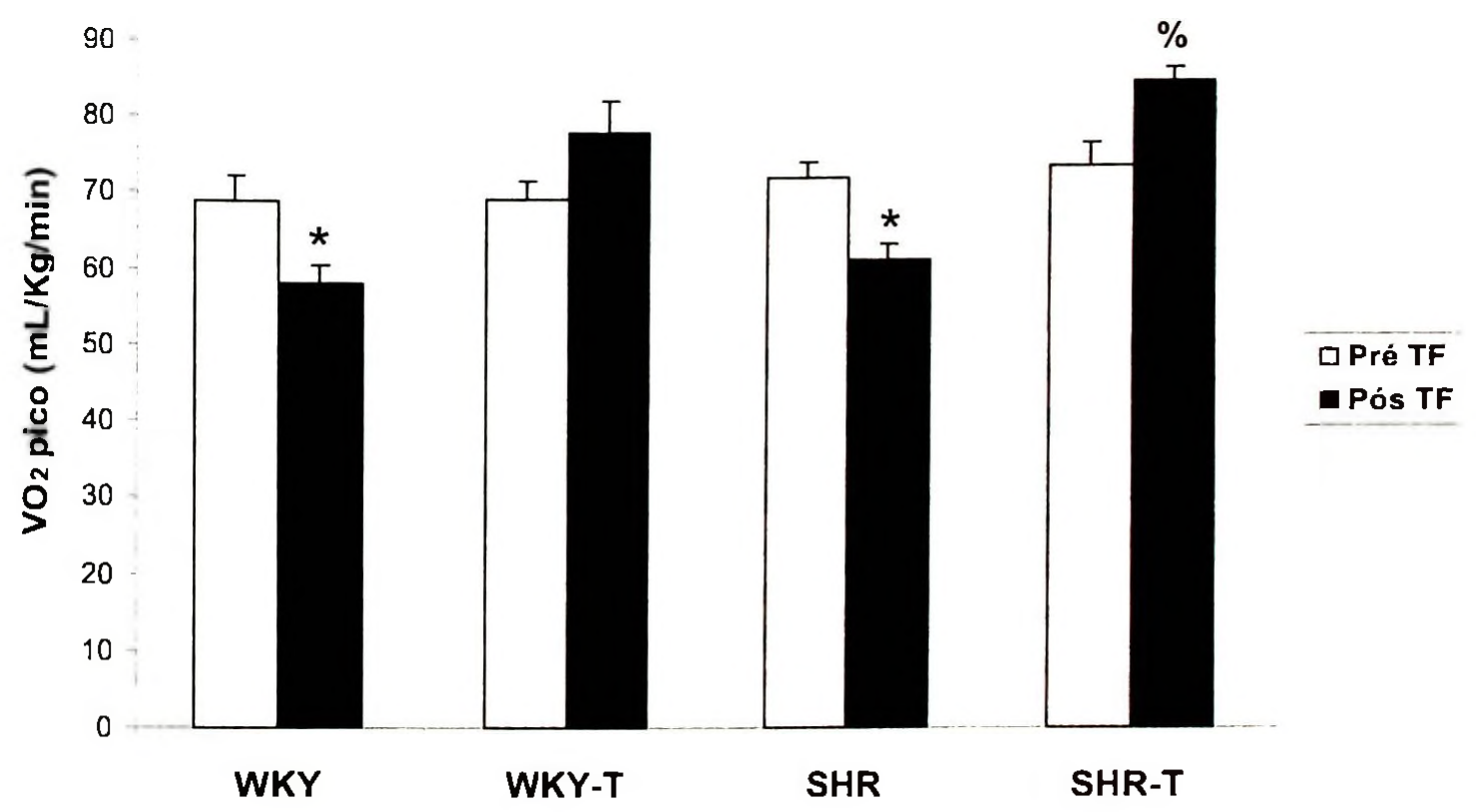

Figura 10. Consumo de oxigênio pico pré e pós TF. Os resultados estão expressos como média \pm EPM. ${ }^{*} \mathrm{p}<0,05$ comparado Pré TF e WKY-T e SHR-T Pós TF; $\%$ p $<0,05$ comparado Pré TF e WKY e SHR Pós TF. 
Foi investigado também o efeito do TF sobre a rarefação capilar e as mudanças nos tipos de fibras associados a HA, conforme demonstrado anteriormente. Na Figura 11, observa-se que o TF corrigiu a rarefação capilar no grupo SHR-T (A), sem modificar a área de secção transversa do músculo sóleo dos 4 grupos estudos $(C)$. Entretanto, o TF foi efetivo em recuperar a proporção na distribuição dos tipos de fibras equiparando ao animal controle (D). É possivel observar na Figura $11 \mathrm{~B}$ essas alterações pela imagem representativa dos cortes histológicos do músculo sóleo para cada grupo estudado, pela caracterização histoquímica da atividade da ATPase miosínica.

A

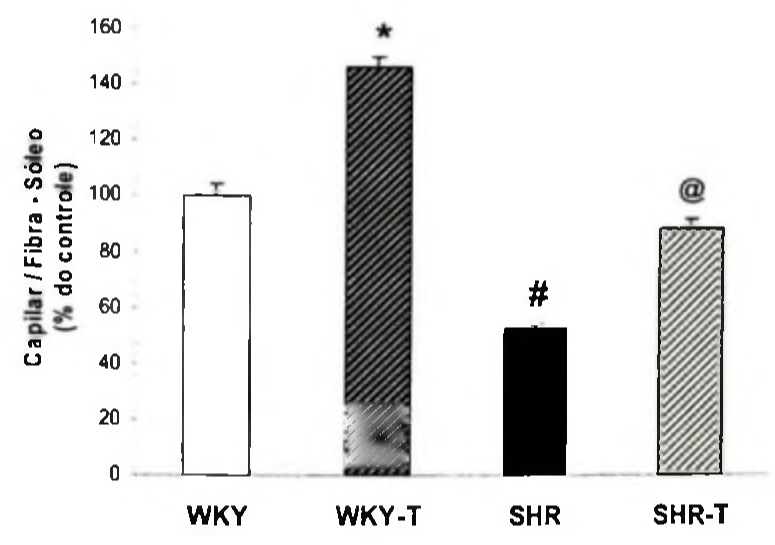

$\mathbf{B}$

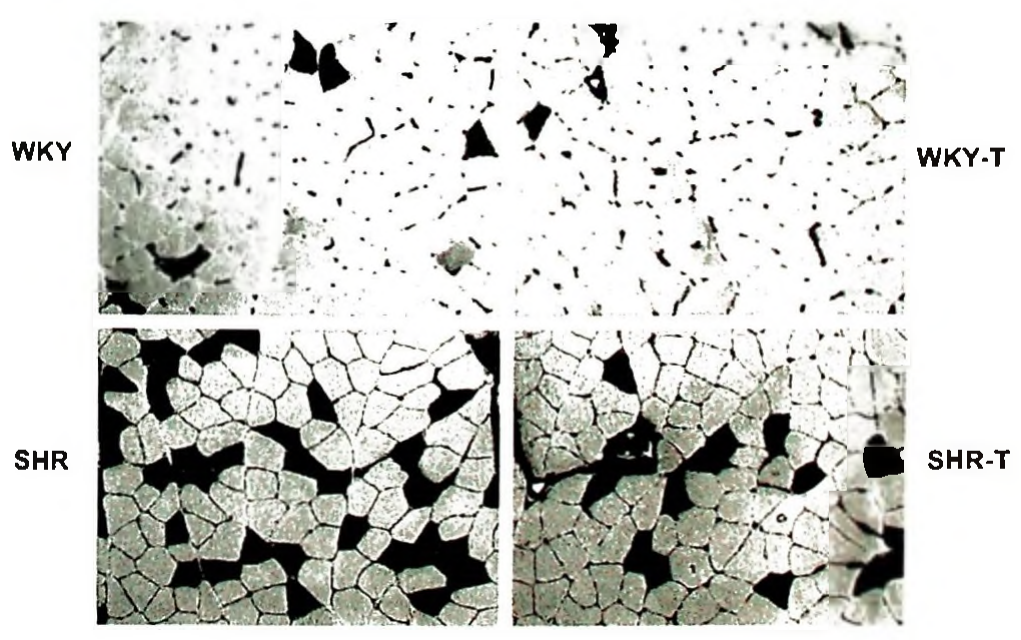




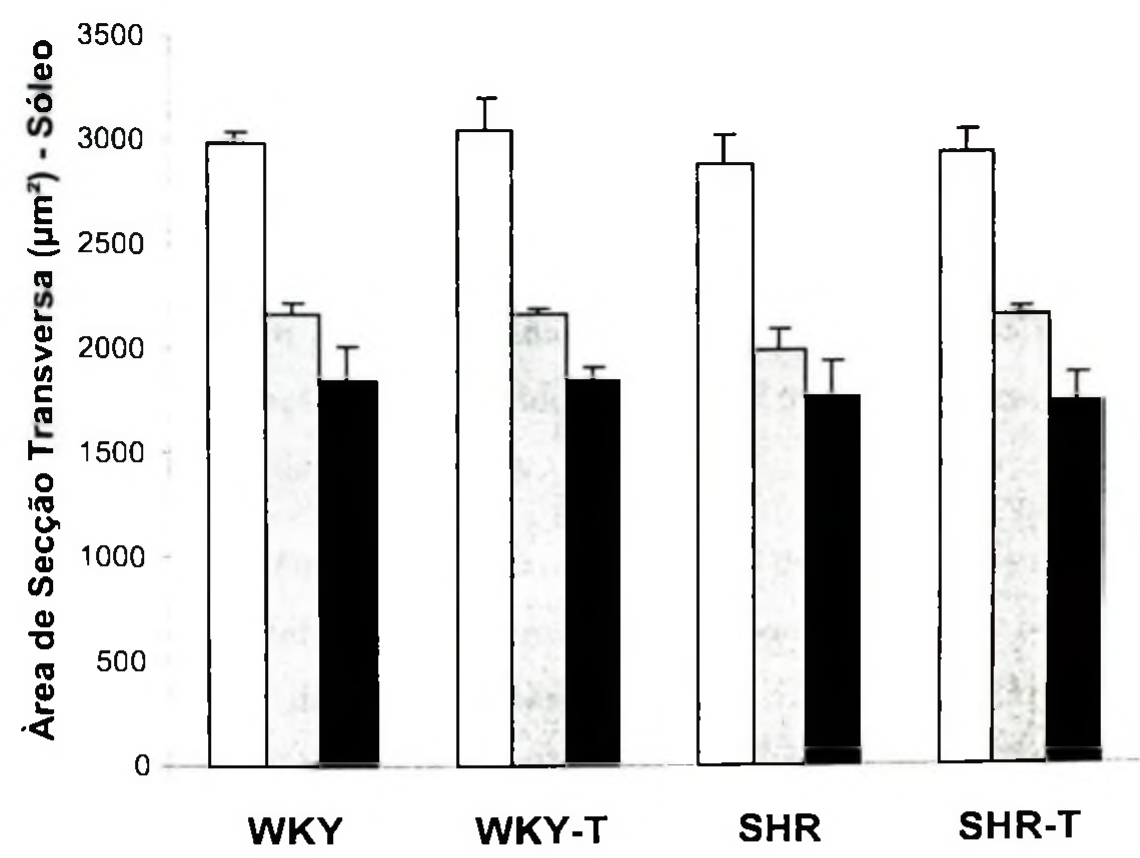

D

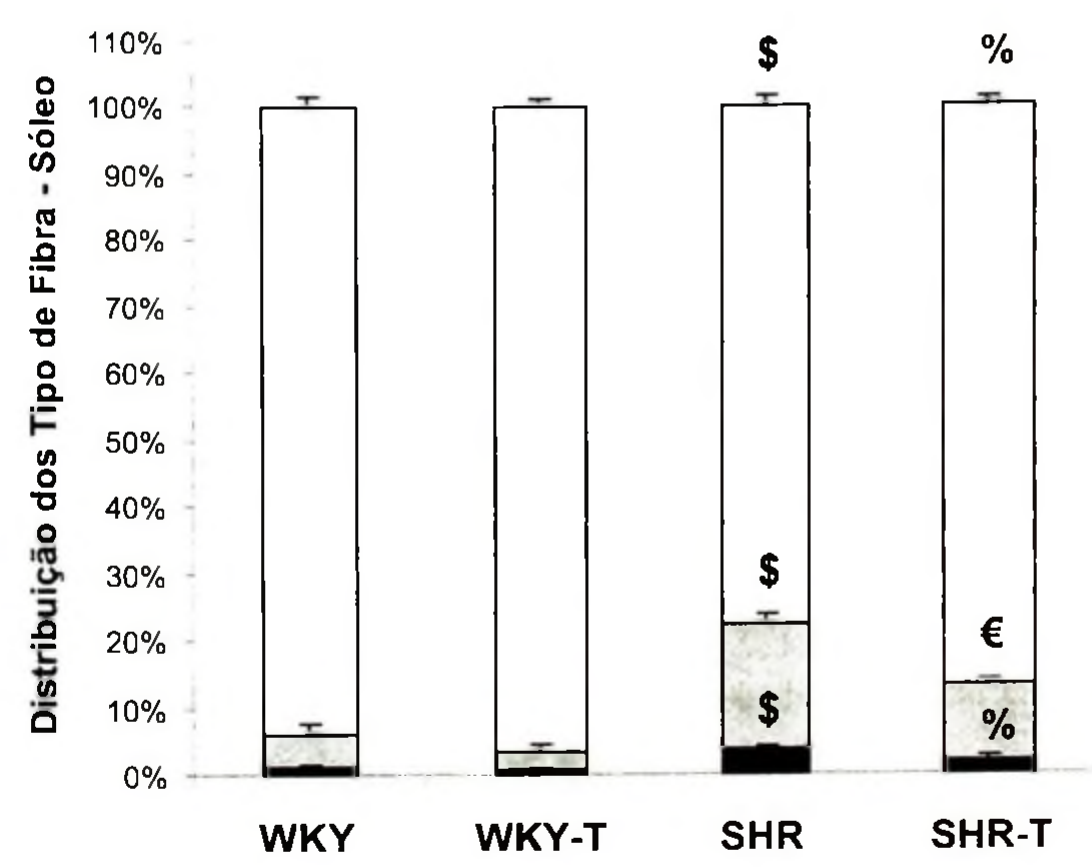

Figura 11. Efeito do TF sobre: razão capilar por fibra (A), caracterização histoquímica pela da reação ATPase miosínica (B), área de seç̧ão transversa (C), e distribuição dos tipos de fibra (D). Os dados estão representados na forma de média $\pm E P M .{ }^{*} p<0,05$ vs. WKY, SHR e SHR-T; \# $\mathrm{p}<0,05$ vs. WKY, WKY-T e SHR-T, @ $\mathrm{p}<0,05$ vs. WKY-T e SHR; $\$ \mathrm{p}<0,001$ vs. WKT, WKY-T e SHR-T; $\% \mathrm{p}<0,01$ vs. WKY-T, $€ \mathrm{p}<0,01$ vs. WKY, WKY-T, SHR. 
Depois de confirmado os benefícios do TF aeróbio sobre a redução da PA, correção da rarefação capilar e recuperação do perfil de tipos de fibra na HA, além de comprovar a eficácia do treinamento físico através de marcadores como a bradicardia de repouso e aumento da tolerância ao esforço e $\mathrm{VO}_{2}$ pico, o próximo passo foi investigar se esta melhora é acompanhada também por uma recuperação na bioatividade das CPE medulares, uma vez que demonstramos anteriormente a disfunção das CPE na HA.

Diversos estudos têm demonstrado um aumento das CPE em sangue periférico e medula óssea em resposta ao TF aeróbio, tanto em indivíduos saudáveis [121, 142, 366, 367, 385, 386], quanto em portadores de doença da artéria coronária $[120,122,123]$, insuficiência cardíaca [387], doença arterial periférica [368], hemodiálise [388] e obesidade [376].

Os estudos de Imanishi [358, 359] foram os primeiros a relatarem uma diminuição na proliferação das CPE na medula óssea tanto em animais geneticamente hipertensos (SHR) quanto em pacientes hipertensos, acompanhada também de um aumento na senescência celular, e falha na formação de unidades formadores de colônia, sendo essa, uma importante medida da capacidade funcional, considerada, portanto, um preditor de formação de vasos. Entretanto, nenhum estudo até o momento reportou este potencial efeito benéfico do TF aeróbio sobre as CPE na HA.

Interessantemente, a Figura 12, 13, 14 e 15, respectivamente, pela primeira vez, mostram que o TF aeróbio foi eficaz em restaurar o número de CPE da medula óssea de SHR, acompanhada pela recuperação da formação de unidades formadoras de colônia e uma melhor fornação de tubos como capilar, além de reduzir a porcentagem de células senescentes.

Estes dados são de grande importância, pois esta disfunção das CPE medular pode refletir uma diminuição sistêmicas dessas células, prejudicando sua atuação no processo de reparação e revascularização tão pertinentes para o indivíduo hipertenso que apresenta quadro de dano vascular concatenado com a elevação dos níveis de PA; contudo através da intervenção não medicamentosa, o TF foi promissor em recuperar esta perda, além de normalizar as propriedades funcionais das $\mathrm{CPE}$, corroborando possivelmente para restauração da rede microvascular repercutindo na redução da PA. 
A

Ac DildL
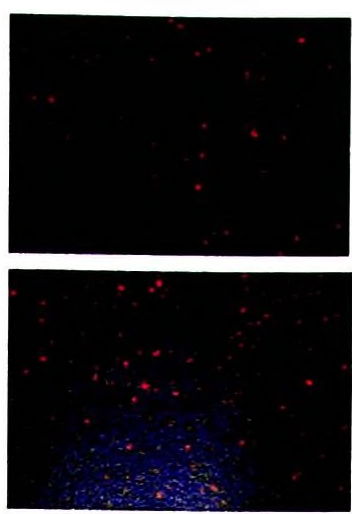

WKY-T

SHR-S

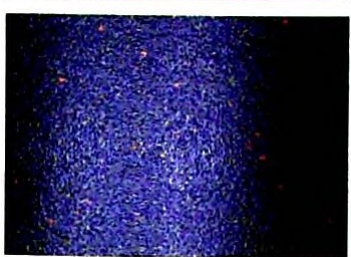

SHR-T

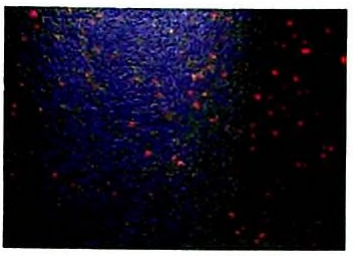

B

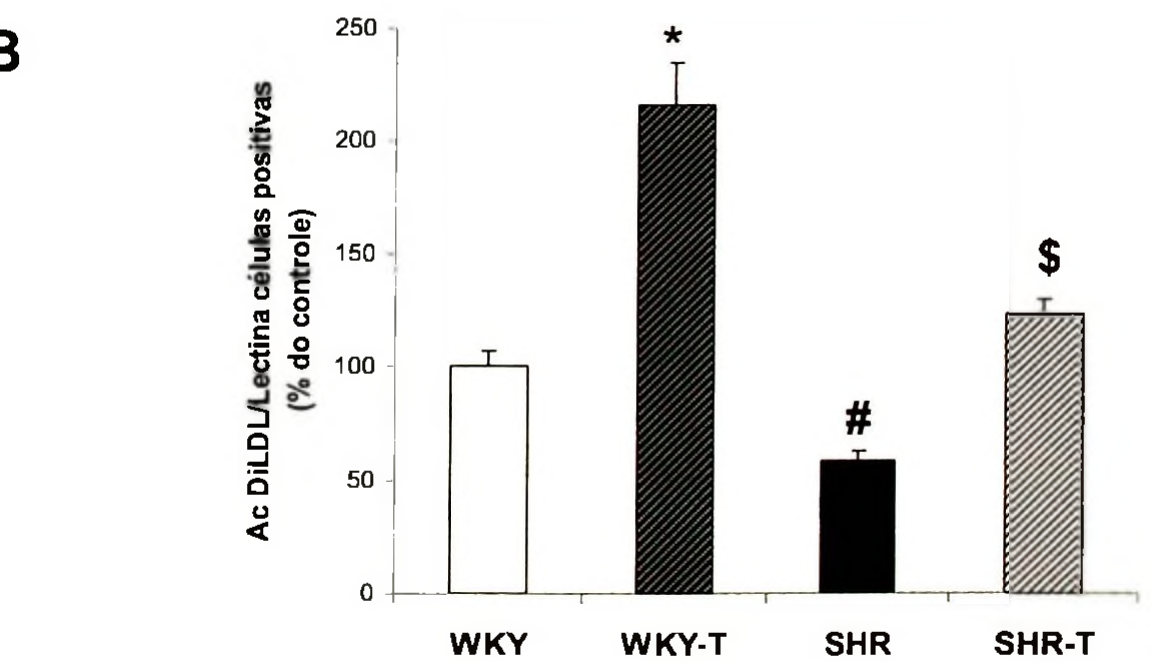

Figura 12. Efeito do TF aeróbio na proliferação das CPE da medula óssea. A Figura $12 \mathrm{~A}$ mostra fotos representativas da fluorescência para DiLDL acetilado e Lectina e as células duplamente positivas identificando as CPE da medula óssea. A Figura 12B mostra a análise quantitativa das CPE. Os resultados estão expressos como média $\pm \mathrm{EPM}{ }^{*} \mathrm{p}<0,05$ vs. WKY, SHR e SHR-T; \# $p<0,05$ vs. WKY, WKY-T e SHR-T; $\$ p<0,05$ vs. WKY-T e SHR.
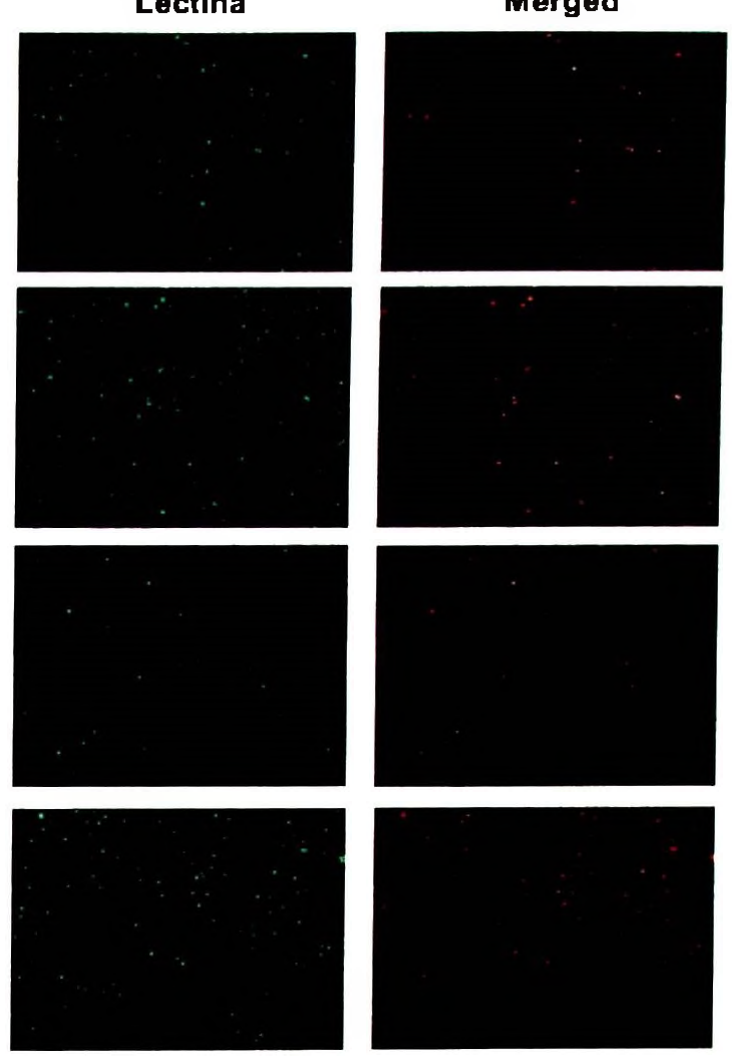
A

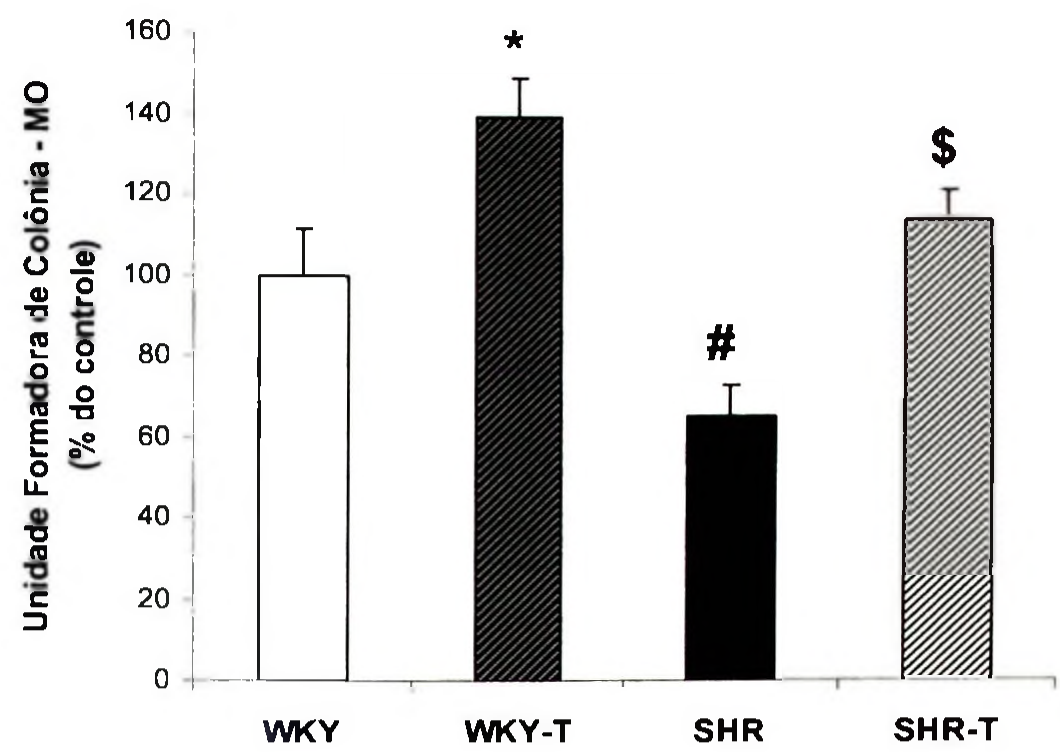

B

$2^{\circ}$ dia
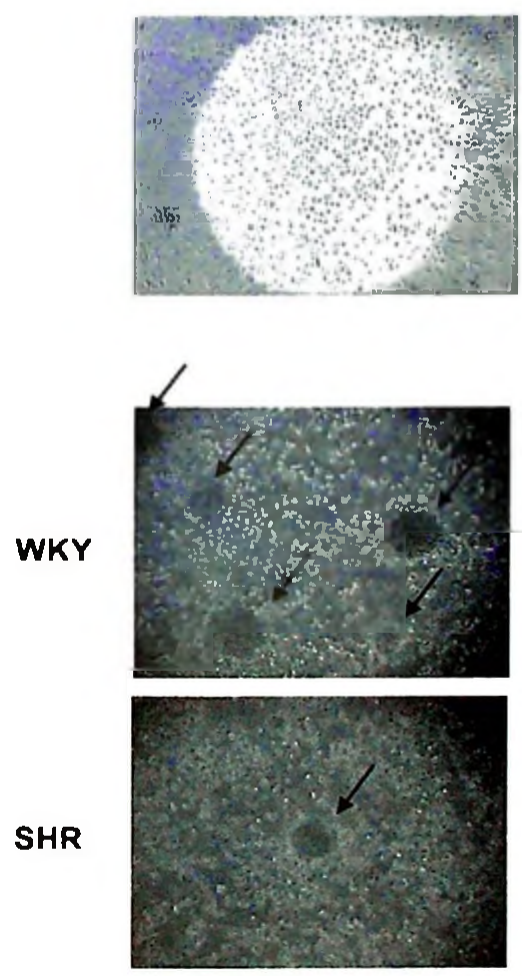

$5^{\circ}$ dia
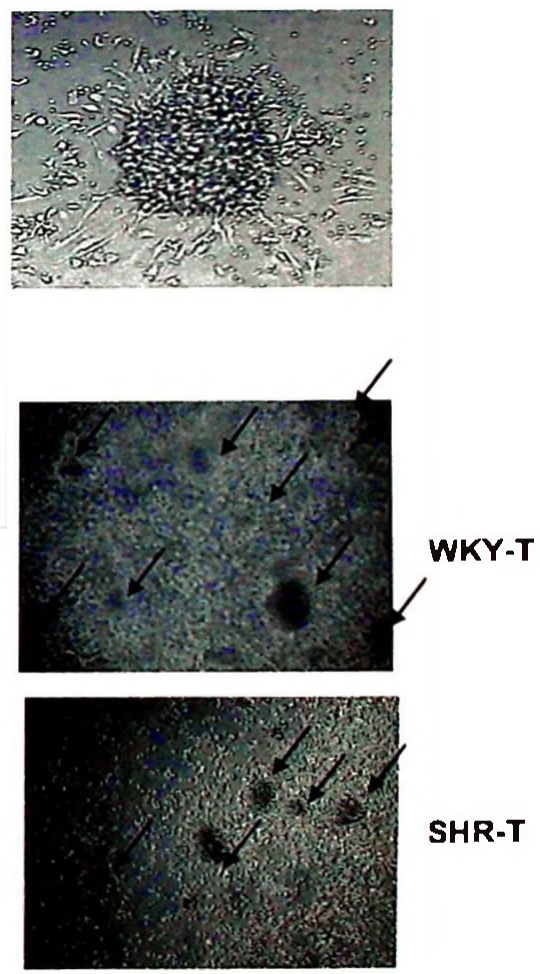

SHR-T

Figura 13. Efeito do TF aeróbio sobre as unidades formadoras de colônia da medula óssea. A Figura 13A mostra a quantificação das UFC. A Figura $13 \mathrm{~B}$ mostra foto representativa do $2^{\circ}$ dia do plaqueamento das $\mathrm{CPE}$ e ao $5^{\circ}$ dia já contendo a colônia de células, além das fotos da formação de colônias de cada grupo estudado. Os resultados estão expressos como média \pm EPM. ${ }^{*} \mathrm{p}<0,05$ vs. WKY e SHR; \# p<0,05 vs. WKY, WKY-T e SHR-T; $\$ \mathrm{p}<0,05$ vs. SHR. 
A
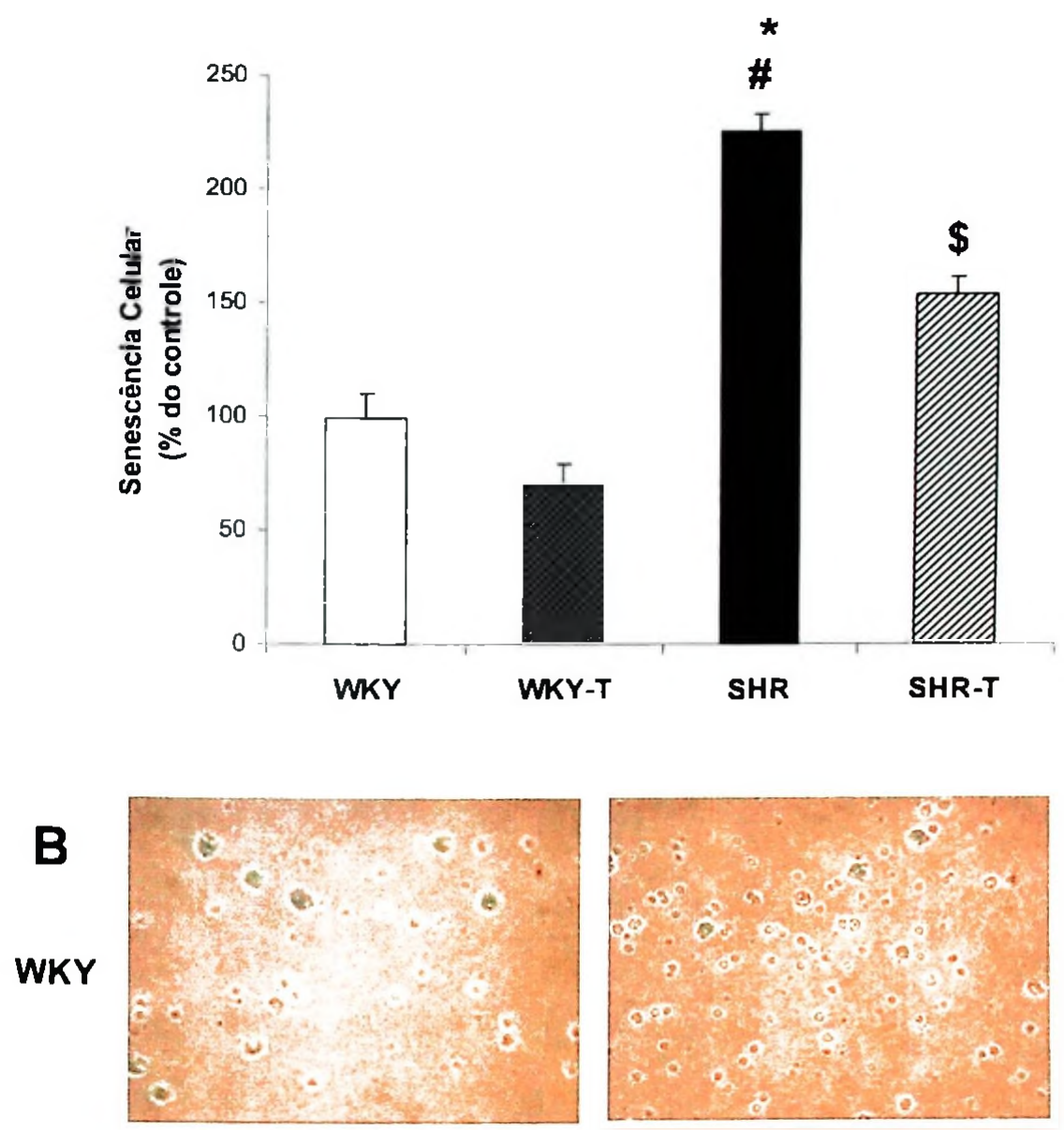

WKY-T
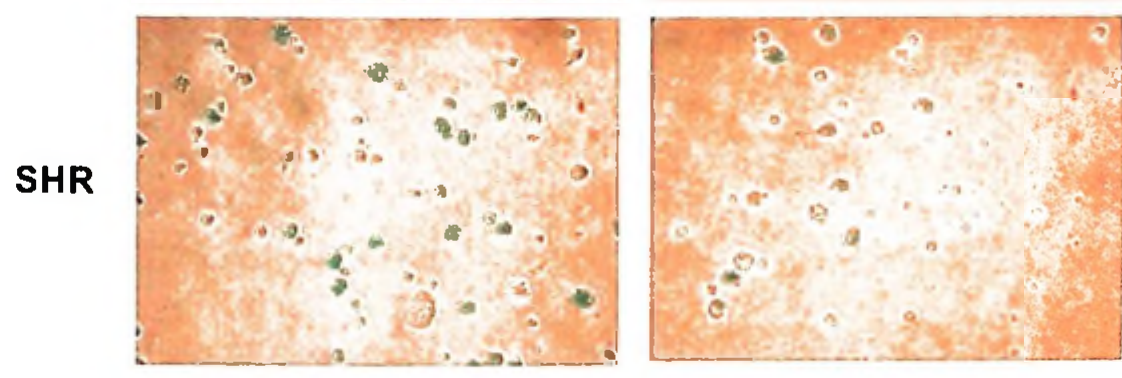

SHR-T

Figura 14. Efeito do TF aeróbio sobre a senescência das CPE da medula óssea. A Figura 14A mostra a quantificação das CPE senescentes. A Figura 14B mostra as fotos representativas do ensaio de senescência associada à atividade da $\beta$ - galactosidase de cada grupo estudado. Os resultados estão expressos como média \pm EPM. ${ }^{*} \mathrm{p}<0,01$ vs. WKY e WKY-T, \# $\mathrm{p}<0,05$ vs. SHR-T; $\$ p<0,05$ vs. WKY, WKY-T e SHR. 


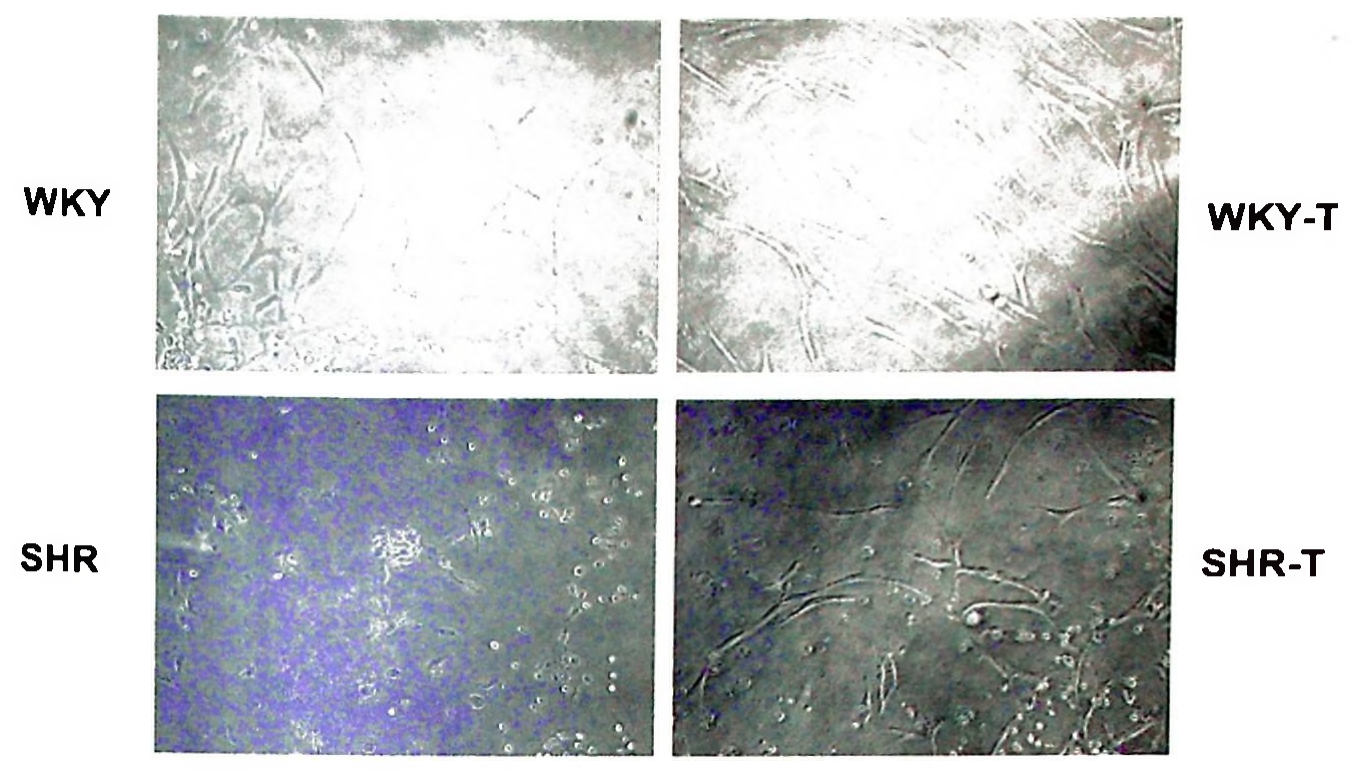

Figura 15. Efeito do TF aeróbio sobre a formação de tubos como capilares em matrigel das CPE da medula óssea. A figura mostra as fotos representativas da formação de tubos como capilares de cada grupo estudado, possibilitando análise qualitativa das mesmas.

É sabido que e o perfil das CPE circulantes e a liberação de fatores de crescimento são cruciais para o entendimento da atuação das mesmas, uma vez que elas recrutadas da medula óssea para circulação irão promover a neovascularização. Nesse sentido, foi investigado alguns fatores mobilizadores na microcirculação e a modulação sistêmica das CPE, na tentativa de melhor elucidar sua participação na HA e sobre os efeitos do TF.

Uma vez analisado a bioatividade das CPE na medula óssea de SHR e o efeito benéfico do TF aeróbio sobre a modulação das mesmas, foi investigado este perfil na circulação.

Similar ao que aconteceu na medula óssea, a Figura 16 mostra uma redução nos níveis sistêmicos de CPE medidas agora por citometria de fluxo através da dupla marcação positiva por CD34 e Flk1 (VEGFR2). Além disso, a Figura 17 mostra uma redução na capacidade funcional das CPE circulantes medida através na quantificação de unidades formadoras de colônia. O TF foi eficiente em recuperar estas perdas, normalizando os valores para niveis semelhantes aos normotensos WKY. 
Estudos revelam que os fatores de risco para DCV são cruciais para disfunção das CPE circulantes. Este prejuízo engloba desde os níveis até a capacidade funcional das mesmas e a redução dessas na circulação reflete diretamente uma falha no processo de reparo vascular e revascularização a favor do desenvolvimento de doenças cardiovasculares mediante ao dano do vaso $[348,350,356,357,360,374]$.

Como descrito anteriormente, o TF vem sendo utilizado como uma importante ferramenta no controle e prevenção de DCV. Nesse sentido, sabe-se que o TF aeróbio é efetivo em recuperar a disfunção endotelial em DCV e promover revascularização, embora o seu papel sobre a modulação das CPE na HA seja pouco conhecido, seu emprego em outras patologias e fatores de risco já foram bem demonstradas. Em analogia ao encontrado em outros fatores de risco, o TF restaurou os níveis e as propriedades funcionais das CPE na HA em SHR.

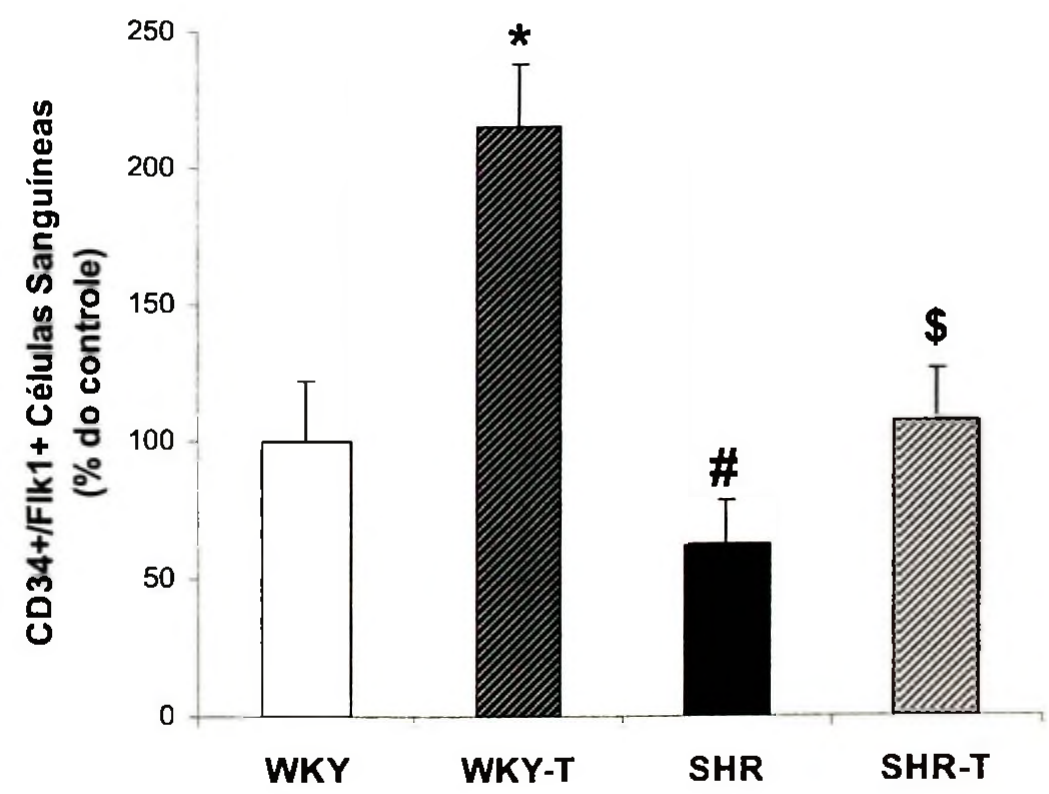

Figura 16. Efeito do TF aeróbio na mobilização das CPE. O gráfico mostra a análise quantitativa dos níveis das CPE circulantes medida por citometria de fluxo através da dupla marcação positiva para CD34 e Flkl. Os resultados estão expressos como média \pm EPM. ${ }^{*}$ p< 0,05 vs. WKY, SHR e SHR-T; \# p<0,05 vs. WKY, WKY-T e SHR-T; $\$ p<0,05$ vs. WKY-T e SHR. 


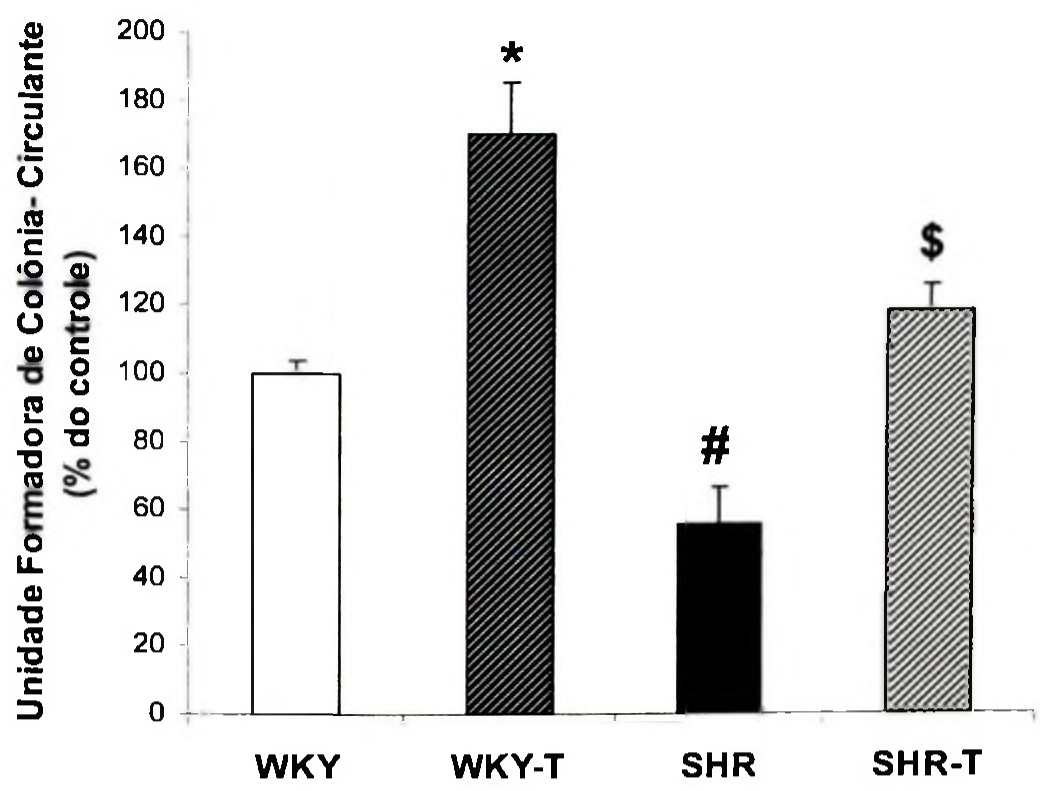

Figura 17. Efeito do TF aeróbio sobre as unidades formadoras de colônia de CPE circulantes. $O$ gráfico mostra a quantificação das UFC. Os resultados estão expressos como média \pm EPM. ${ }^{*}$ p $<0,05$ vs. WKY e SHR; \# p<0,05 vs. WKY, WKY-T e SHR-T; $\$ p<0,05$ vs. SHR.

Uma vez comprovada à eficácia do TF na correção da disfunção das CPE em SHR, foi investigado localmente alguns dos principais fatores mobilizadores das CPE da medula óssea para periferia, como o VEGF e a eNOS.

Como pode ser observado na Figura 18B a hipertensão arterial reduziu $47 \%$ os níveis de VEGF na microcirculação, porém o TF foi responsável por aumentar $47 \%$ no grupo normotenso treinado e normalizar no grupo SHR-T. Não foi observado diferenças entre os grupo na expressão protéica do VEGFR1 como demonstrado na Figura 18C, entretanto foi visualizado um aumento na expressão do VEGFR2 somente nos grupos treinados, WKY-T e SHR-T (Figura 18D).

Estudos prévios provaram que o VEGF, SDF-1 e o G-CSF têm um importante papel na indução da MMP-9, precursor da biosíntese, secreção e posterior mobilização das CPE medulares para o sangue periférico [389]. 
De fato, diversos estudos vêm demonstrando que o VEGF tem sido considerado crucial na diferenciação e migração das CPE para circulação. Em situações fisiológicas, a isquemia ou hipóxia é acreditada ser o sinal predominante para induzir a mobilização de CPE da medula óssea por meio de aumento nos níveis de VEGF circulante [352, 389-391].

A hipóxia gerada na musculatura esquelética pelo TF aeróbio é um dos mais potentes estimulos fisiológicos conhecidos por desencadear a sintese de fatores de crescimento, principalmente de VEGF, e consequentemente aumentar o número de CPE circulantes promovendo angiogênese [120]. A hipóxia altera o endotélio microvascular causando a mobilização de CPE para estas regiões. A adesão dessas são significativamente elevadas no endotélio nesta condição e a exposição das CPE nesses sítios gera a proliferação e a organização de clusters celulares, os quais se alinham em direção ao gradiente isquêmico e formam cordões como vasos. Dessa forma, tanto o aumento do $\mathrm{VO}_{2}$ máximo como do fluxo sanguíneo induzido pelo TF aeróbio são capazes de gerar maior hipóxia e estresse de cisalhamento, respectivamente, conduzindo ambos para uma elevada produção de VEGF, o qual vem sendo intitulado como o principal responsável pela atividade migratória, adesão $e$ incorporação de CPE na microcirculação, promovendo a formação de novos vasos [366]. Além disso, sabe-se que a ligação do VEGF ao seu receptor 2 é determinante na indução de formação de vasos, principalmente quando induzidos pelo TF aeróbio, promovendo angiogênese.

A Figura 19B mostra uma redução de $33 \%$ nos níveis de eNOS na HA, enzima essa responsável pela formação de NO. O TF foi eficiente em recuperar esta perda, normalizando para valores iguais aos normotensos. Em contraste, a HA aumentou $46 \%$ os níveis de iNOS, e o TF reduziu este valor para concentrações inferiores aos normotensos (Figura 19C).

Interessantemente, estudo de Laufs et al. (2004) [123] mostraram que o treinamento físico é capaz de influenciar no número de $\mathrm{CPE}$, em que camundongos treinados comparado aos sedentários apresentaram um significante aumento de CPE na circulação e na medula óssea a partir do $7^{\circ}$ dia de treinamento, sendo sustentado por mais de um mês mediante a prática regular de exercício. Os pesquisadores também mostraram pela primeira vez que camundongos tratados com bloqueador da NO sintase e knockout para este gene tiveram inibidos estes aumentos, indicando o importante papel do NO na mobilização de CPE [392], sugerindo um aumento NO 
dependente das CPE na resposta ao exercício [123]. Posteriormente, Steiner et al. (2005) [122], investigaram pacientes com doença arterial coronariana e com fatores de risco cardiovascular e observaram depois de 12 semanas de treinamento aeróbio um aumento no número de CPE e que estavam correlacionados com os aumentos de óxido nítrico (NO).

Aumento nos niveis de iNOS e redução de eNOS, tem sido encontrados em situações de estresse oxidativo, já bem demonstrados em SHR. Sabe-se que o aumento de espécies reativas de oxigênio mediadas por estas situações inflamatórias, como aumento de iNOS, corroboram para a disfunção das CPE, conduzindo posteriormente ao dano do vaso e a DCV [350]. Pela primeira vez demonstramos que o TF foi eficiente em reverter este processo no controle da formação de vasos concomitante com restauração da bioatividade das CPE mediada pela recuperação dos níveis de VEGF e eNOS. 
A

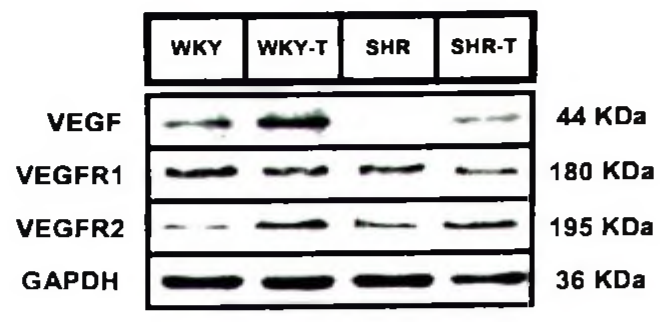

B

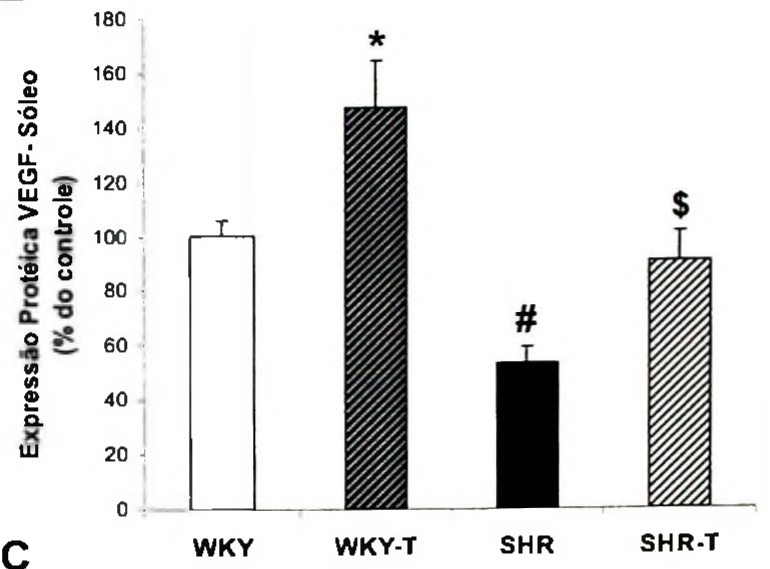

C
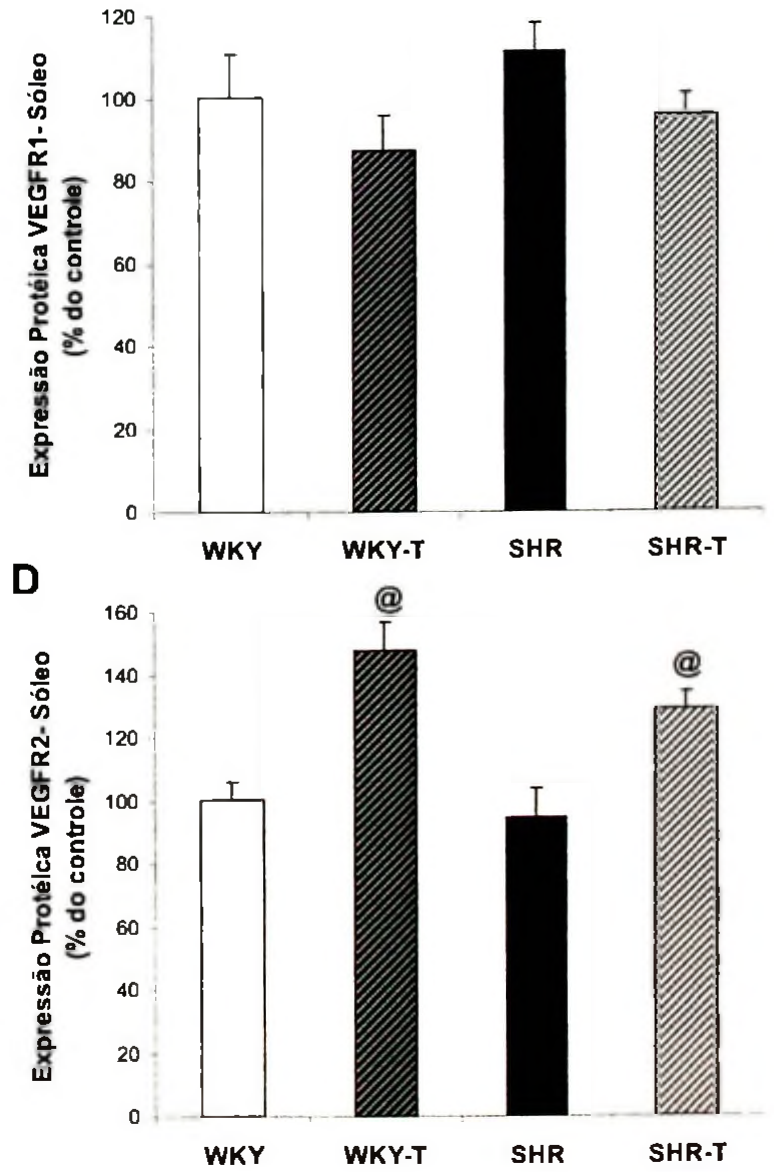
FIGURA 18 - Efeito do TF aeróbio sobre a expressão protéica de fator de crescimento vascular endotelial (VEGF, B), fator de crescimento vascular endotelial receptor 1 (VEGFR1, C) e fator de crescimento vascular endotelial receptor 2 (VEGFR2, D). A figura A mostra imagens representativas dos blots para VEGF, VEGFR1, VEGFR2 e GAPDH. O GAPDH foi usado como proteina normalizadora para as proteínas estudas. Os resultados estão expressos como média \pm EPM. * $\mathrm{p}<0,05$ vs. WKY, SHR e SHR-T; \# $<<0,05$ vs. WKY, WKY-T e SHR-T; $\$$ p $<0,05$ vs. WKY-T e SHR; @ p $<0,05$ vs. WKY e SHR. 
A
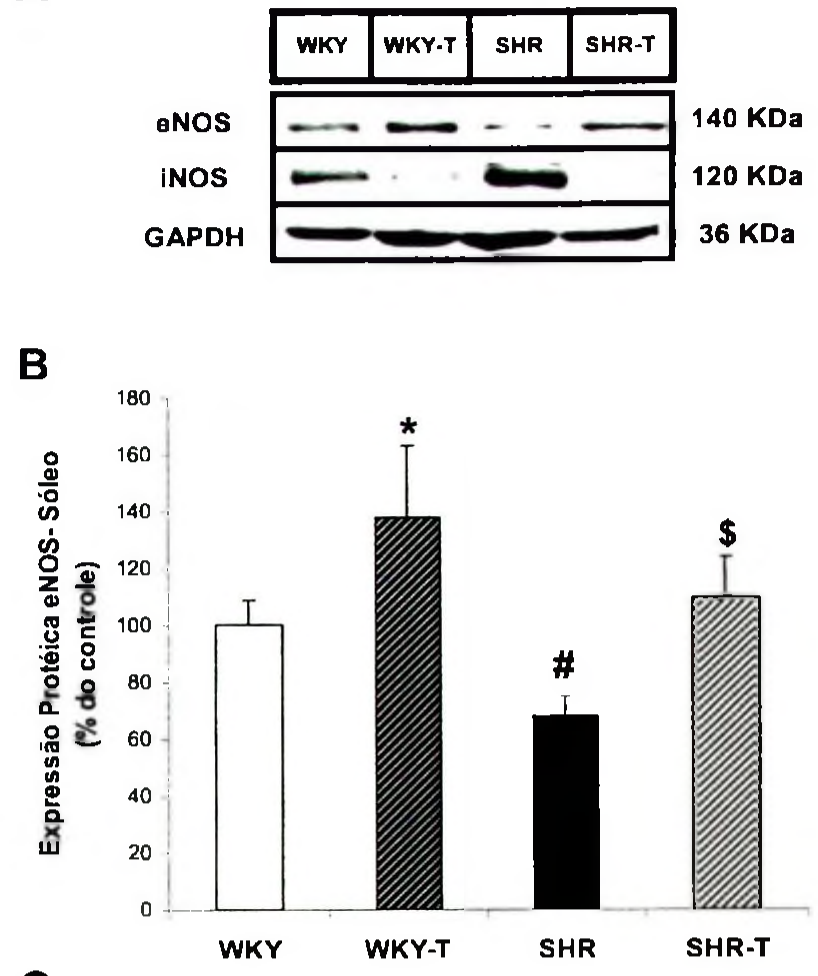

C

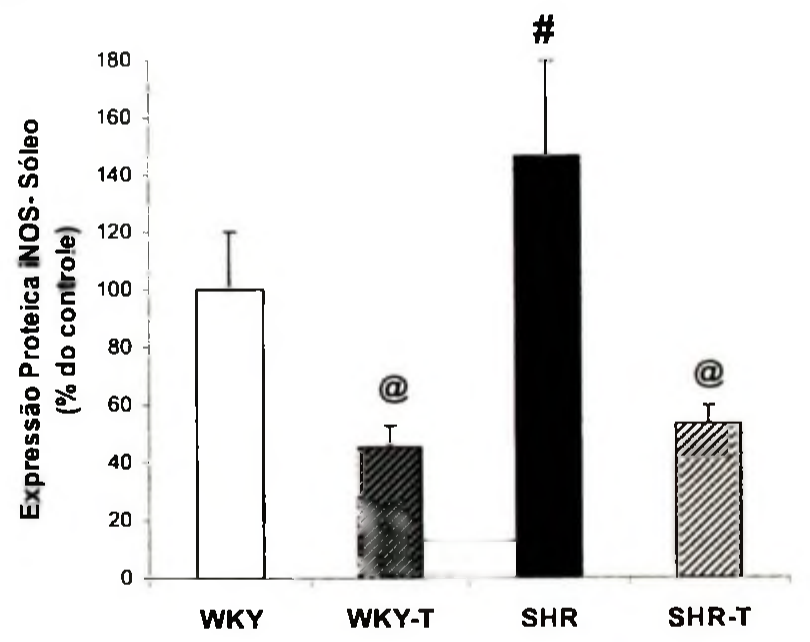

Figura 19. Efeito do TF aeróbio sobre a expressão protéica da óxido nitrido sintase endotelial (eNOS, B) e óxido nitrido sintase induzível (iNOS, C). A figura A mostra imagens representativas dos blots para eNOS, iNOS e GAPDH. O GAPDH foi usado como proteína normalizadora para as proteinas estudas. Os resultados estão expressos como média \pm EPM. ${ }^{*}$ p $<$ 0,05 vs. WKY, SHR e SHR-T; \# p<0,05 vs. WKY, WKY-T e SHR-T; $\$ p<0,05$ vs. SHR; @ p $<$ 0,05 vs. WKY e SHR. 
O desequilíbrio entre o reparo e o dano vascular promove a progressão de DCV. Um possivel mecanismo pelo qual os fatores de risco cardiovascular, particularmente a HA, causam o início, a manutenção e a progressão dessas DCV é a inativação da bioatividade das CPE. A análise dos números e função das CPE pode ser um excelente biomarcador para condições clínicas não favoráveis responsáveis por desenvolver DVC, como já demonstrado por estudos prévios em revistas de grande impacto. Várias intervenções têm sido propostas para recuperação deste quadro de disfunção das CPE, tais como, a terapia farmacológica, a terapia celular e a modificação no estilo de vida, através da prática regular de exercício físico. Portanto, de uma perspectiva clínica, é importante a adoção de uma apropriada intervenção que seja efetiva em melhorar este perfil das CPE em indivíduos que apresentam desde fatores de risco cardiovascular até a presença de DCV. A escolha pela utilização do TF aeróbio no presente estudo foi efetiva em corrigir a rarefação capilar e reduzir a pressão arterial em SHR, prevenindo o dano vascular. Esta melhora vascular ocorre em sinergia com a restauração dos niveis e propriedades funcionais das CPE medulares e circulantes, acompanhada também pela normalização dos fatores mobilizadores, determinantes no recrutamento de CPE para periferia e na formação de novos vasos. Estes resultados sugerem que o TF pode recuperar o dano vascular por meio das CPE, promovendo a revascularização periférica. Assim, há perspectiva do potencial terapêutica destas células no tratamento da HA pós TF.

Desta forma, podemos concluir neste estudo 5, que o TF foi efetivo em corrigir a rarefação capilar e reduzir a pressão arterial em SHR. Esta melhora vascular ocorre em sinergia com a restauração dos níveis e propriedades funcionais das CPE medulares e circulantes, acompanhada também pela normalização dos fatores mobilizadores VEGF e eNOS. Estes resultados sugerem que o TF pode restaurar o dano vascular por meio das CPE, promovendo a revascularização periférica. Assim, mais uma vez o TF pode ser um potencial terapêutico não farmacológico na hipertensão, ativando estas células e promovendo reparo e restaurando a função celular.

\section{Parte 3. Perspectivas Futuras}




\section{Identificar miRNAs diferencialmente expressos na hipertrofia cardíaca} cardíaca fisiológica, que possam ser potencialmente alvos para terapia gênica com sense e/ou antisense para miRNAs em patologias cardíacas.

Minha experiência com estudo de miRNAs foi iniciada com um estudo realizado comparando o perfil de miRNA expresso em stem cells cardíacas e cardiomiócitos de camundongos, com objetivo de identificarmos os miRNAs que estavam envolvidos nos passos de diferenciação de stem cells cardíacas para cardiomiócitos. Este estudo foi um dos projetos que realizei no meu Estágio de Pós-doutoramento nos Estados Unidos, no Laboratório de Stem Cells do Keck Graduate Institute, Claremont, Califórnia, com supervisão do Dr Ian Phillips.

Nós estudamos 569 miRNAs, baseados no sistema Sanger miRBase Release 10.1 e os resultados foram confirmados por Real Time PCR (Oliveira et al., 2008). Na sequência deste estudo, miRNAs altamente expressos em stem cells foram selecionados e inibidos com antisenses para miRNAs em cultura de stem cells cardíacas. Desta forma, as stem cells cardíacas foram diferenciadas em cardiomiócitos por ativação da via de sinalização do TGF- $\beta$ III e Activina A. Com isso, nosso trabalho também mostrou a via de sinalização envolvida na diferenciação (Oliveira et al., 2009). Com minha experiência obtida durante meu estágio de Pós-doutoramento tenho como objetivo estudar miRNAs que são expresso na hipertrofia cardíaca físiológica excêntrica por treinamento físico e usamos essa informação para terapia gênica nos processos de hipertrofia patológica.

\subsection{0 que são os microRNAs?}

Os miRNAs são RNAs de fita simples de 17-25 nucleotídeos, não codificadores de proteinas, que agem como potentes reguladores pós-transcricionais da expressão gênica em plantas e animais [393]. O Lin4 (do inglês lineage-deficient-4) foi o primeiro miRNA descoberto em 1993, sendo nesta época associado à regulação do desenvolvimento larval em Caenorhabditis elegans [394]. Até o momento, mais de 5000 seqüências de miRNAs, de mais de 50 tipos de organismos diferentes foram catalogados no banco de dados MirBase, sendo que mais 500 miRNAs diferentes foram identificados em humanos, e estudos bioinformáticos estimam que este 
número supere 1000 miRNAs, constituindo uma das maiores classes de reguladores gênicos [395].

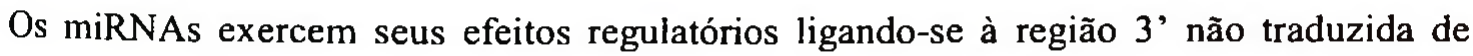
RNAs mensageiros (RNAm)-alvo. Este mecanismo de atuação permite a redução dos níveis protéicos de seus genes-alvo, raramente afetando o nível de expressão transcricional [393].

A regulação pós-transcricional exercida pelos miRNAs na região 3' não traduzida depende do grau de complementaridade com o RNAm-alvo, podendo ocorrer por inibição da tradução ou degradação do RNAm. O pareamento de modo imperfeito com o RNAm acarreta a inibição da tradução do RNAm alvo, sendo o mecanismo principal de atuação dos miRNAs em mamíferos. Em função de os miRNAs possuírem seqüências pequenas e agirem sem a necessidade de pareamento completo, um único miRNA pode regular muitos RNAm-alvo, além de cooperarem no controle de um único RNAm [396]. Alguns estudos indicam que um miRNA pode regular até 200 RNAs, os quais podem apresentar funções totalmente diversas. Desta forma, os miRNAs constituem uma enorme e complexa rede regulatória da sinalização celular.

Em plantas, a regulação dos miRNAs ocorre principalmente através de sua interação perfeita com o RNAm, levando-o à sua degradação (mecanismo de iRNA-RNA de interferência). No entanto, já se têm exemplos da ocorrência deste silenciamento gênico também em mamíferos [397, 398].

Na última década, houve um grande avanço na área da biologia. A descoberta de pequenos RNAs, incluindo miRNAs e pequenos RNA de interferência (siRNA), com destaque na edição de dezembro de 2002 da revista Science. Desde a descoberta do RNA de interferência em nematóides, siRNA proporcionou um avanço técnico para a genética em sistemas biológicos de mamíferos. O grande impacto dos pequenos RNAs foi bem comemorado em 2006 pelo Prêmio Nobel atribuído a dois cientistas que descobriram RNAi [399].

Até o momento, há diversas ferramentas disponíveis para modular a ação de miRNAs em seus alvos. Oligonucleodídeos quimicamente modificados, complementares à seqüência de miRNA maduro (anti-miR), podem reduzir os niveis de miRNAs com expressão alterada. lnversamente, sequências análogas ao miRNA (miR-mímico) podem servir para elevar os níveis 
de miRNAs com expressão reduzida. É importante notar que, devido aos miRNAs atuarem como inibidores da expressão gênica, o efeito do acréscimo de miR-mímicos específicos para um sistema promove a diminuição da expressão dos mRNAs-alvos. Inversamente, o efeito de antimiR atenua a inibição dos genes alvos. Deste modo, o principal efeito de um inibidor de miRNA é a ativação da expressão gênica e um miR-mímico é a supressão do gene [96]. Devido a capacidade de interação de um único miRNA com diversos alvos, relacionados a um determinado fenótipo, sua modulação pode exercer efeitos mais potentes, quando comparado aos tratamentos atuais com atuação em um único alvo.

Apesar de não terem suas funções totalmente esclarecidas, a descoberta dos miRNAs atraiu a comunidade científica pelas evidências sugestivas, de que estes pequenos RNAs apresentam papel fundamental em diversos processos biológicos. Em mamíferos, os miRNAs foram associados à regulação da proliferação, apoptose, diferenciação celular, hematopoiese, secreção de insulina e outros hormônios, além de atuarem no desenvolvimento e funcionamento muscular esquelético e cardíaco [400, 401]. Estudos recentes enfatizam a importância dos miRNAs nos processo biológicos ao relatar alterações na expressão dos mesmos em diferentes patologias humanas.

Algumas questões tem sido levantadas a respeito da participação dos miRNAs no processo de HC patológica e fisiológica. Evidências mostram que alterações na expressão de miRNAs no coração estão diretamente ligadas ao remodelamento cardíaco. Vários estudos tem demonstrado um padrão de "assinatura" de miRNAs que são superexpressos ou apresentam expressão diminuída no remodelamento cardíaco hipertrófico patológico, em humanos e em animais experimentais [96, 402]. O miR-1, miR-29, miR-30, miR133 e miR-150 apresentam, freqüentemente, expressão diminuída, enquanto o miR-21, miR-23a, miR-125, miR-195, miR199 e miR-214 são superexpressos na hipertrofia patológica. Rooij et al. (2006) [402], mostraram em um modelo de HC patológica através de constrição transversa da aorta, onde mais de 180 mRNAs foram analisados, um aumento na expressão de um grupo específico de miRNAs na HC. Observações in vitro mostraram que o miR-23a, miR-23b, miR-24, miR-195, miR-199a e miR214 são suficientes para induzir a HC em cardiomiócitos. Em contraste, o miR-150 e miR-181b, que se estavam diminuídos no modelo de $\mathrm{HC}$, quando aumentados in vitro promovem diminuição do tamanho dos cardiomiócitos. 
Outro fato importante foi observado com o miR-208, esse microRNA é codificado no intron 27 do gene da miosina de cadeia pesada do tipo alfa ( $\alpha$-MCP), estudos mostram uma relação direta na expressão de $\alpha-\mathrm{MCP}$ com o miR-208 e inversamente proporcional a $\beta$-MCP. A deleçào do gene do miR-208 em camundongos mostrou que este microRNA atua diretamente no bloqueio pós-transcricional da $\beta$-MCP e foram resistentes ao desenvolvimento de fibrose, desta forma exercendo papel fundamental na manutenção da função cardíaca [97, 403]. Assim, miRNAs localizados em genes de proteinas sarcoméricas, como miR-208a, miR-208b e miR-499, hospedados nos genes da $\alpha$-MCP, $\beta-\mathrm{MCP}$ e MCP-7b, respectivamente, podem ser importantes alvos de estudo na HC induzida pelo TF.

Atualmente, segundo nosso conhecimento, somente um estudo foi realizado com $\mathrm{HC}$ fisiológica, entretanto os autores estudaram somente o miR-1 e miR-133 e o protocolo usado foi de treinamento de força, com uma sobrecarga de $85 \%$ do peso corporal [404] e animais transgênicos para a via AKT-PI3K-mTOR. O treinamento resistido promove sobrecarga pressórica sobre o a parede do miocárdio levando ao desenvolvimento de HC concêntrica. Ainda, com este treinamento não são observados os efeitos benéficos promovidos pelo TF aeróbio sobre o sistema cardiovascular [176]. Sendo assim, estudos com treinamento aeróbio ainda não foram realizados.

Apesar de promissores, poucos estudos foram publicados sobre o papel dos miRNAs na HC patológica. Estudos mais recentes investigaram a expressão de miRNAs em resposta ao exercício fisico, porém se limitaram à musculatura esquelética [405].

\subsection{Objetivos futuros}

Assim, temos como objetivo traçar o perfil de microRNAs expressos no coração de ratos normotensos, submetidos a dois protocolos de treinamento fisico para obter graus diferentes de hipertrofia cardíaca fisiológica. O dois protocolos que descrevemos na Parte 1, desta Tese de Livre-docência (T1 e T2), e também na hipertrofia patológica do SHR. Serão selecionados os microRNAs diferencialmente expressos (que aumentem ou diminuam proporcionalmente ao grau de $\mathrm{HC}$ ) para pesquisa dos genes alvos destes microRNAs. 
$\mathrm{Na}$ seqüência temos como objetivo testar a hipótese de que microRNAs diferencialmente expressos, como efeito do TF no animal normotenso, possam ser silenciados ou superexpressos no coração do animal SRH na tentativa de reverter, pelo menos em parte, a hipertrofia patológica independente do treinamento físico, promovendo melhora da função ventricular. Esta pode ser uma estratégia para uso futuro em diferentes patologias cardiacas como terapia gênica.

As metodologias utilizadas para obtermos os resultados preliminares já foram descritas anteriormente, portanto não serão descritas aqui novamente.

\subsection{Resultados preliminares}

Os resultados preliminares para esse estudo são bastante promissores. Foram isoladas amostras de RNA mensageiros do tecido cardíaco de ratos Wistar treinados com os protocolos P1 e P2, de natação. Um pool de RNA de dois animais foi usado para o microRNA microArray. Neste experimento, 349 microRNAs foram analisados com uma plataforma Agilent (LC Science LLC, Houston, TX), baseado no Sistema Sanger miRBase Release 13.0.

Uma representação esquemática com o resultado dos miRNAs diferencialmente expressos está apresentada na Figura 1. 

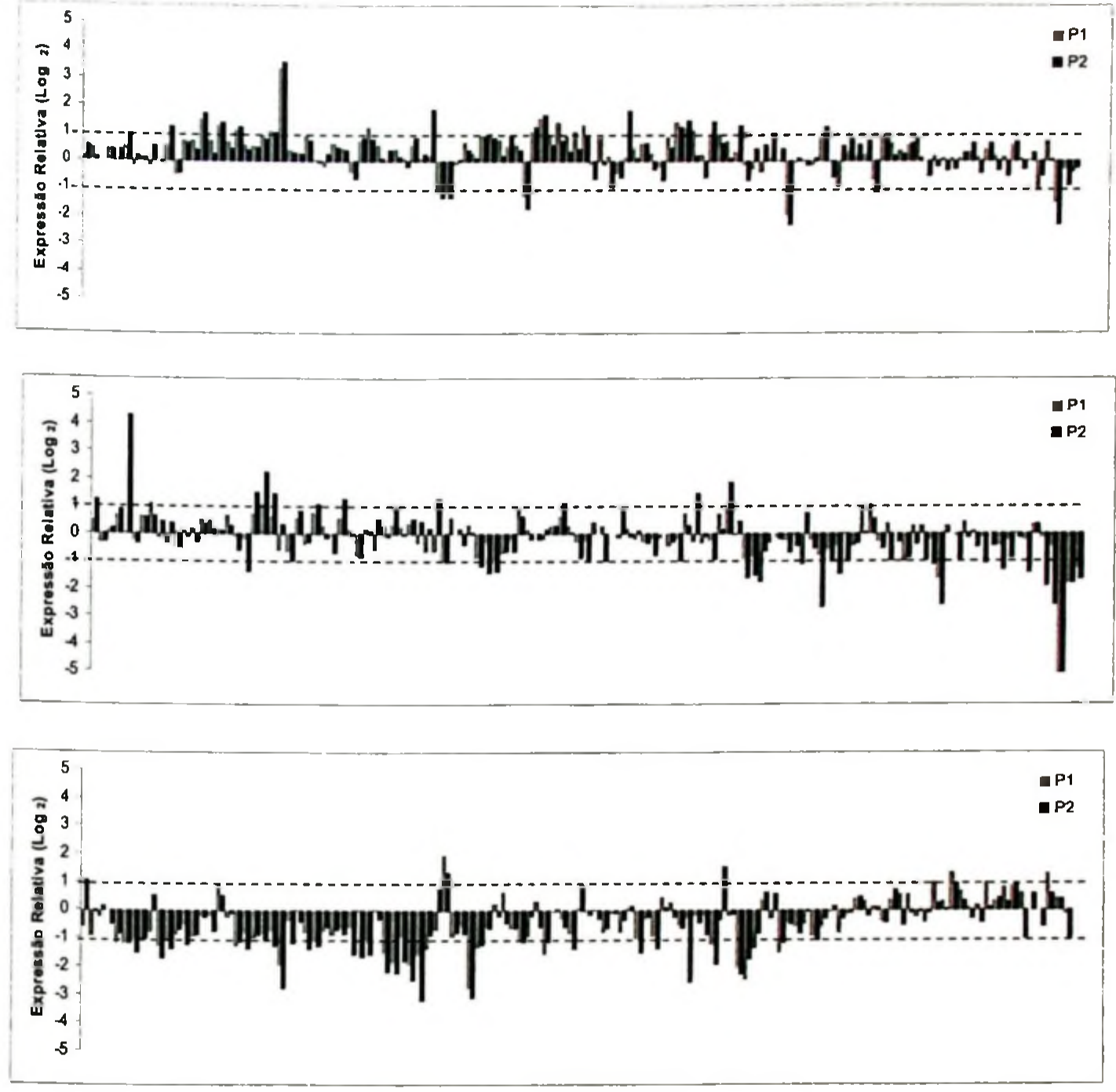

Figura 1. Representação dos miRNAs diferencialmente expressos no coração de ratos treinados com os Protocolos P1 e P2 em relação ao grupo controle. Foram considerados como diferencialmente expressos aqueles que apresentaram expressão relativa superior a um ou inferior a menos um $\left(\log _{2}>1\right.$ ou $\left.<-1\right)$ e com valor de $p<0,05$.

Deste total de 349 miRNAs analisados no coração dos animas treinados, 63 estavam diferencialmente expresso no animais treinados com o protocolo P1 e 98 com o Protocolo P2. Desta análise encontramos 44 microRNAs alterados em ambos os protocolos, conforme mostrado na Figura 2. 


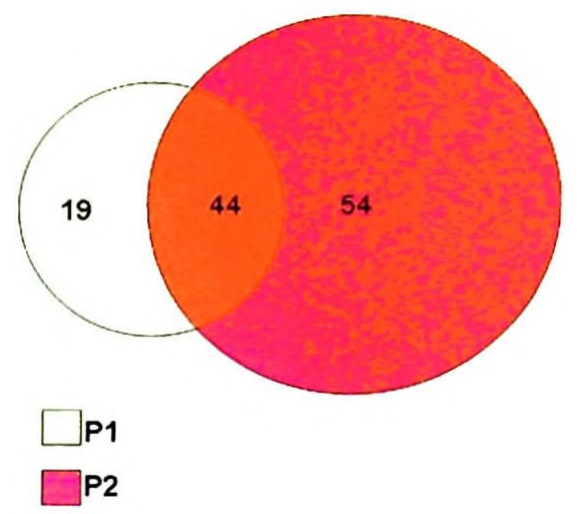

Figura 2. Total de miRNAs diferencialmente expressos no coração dos animais treinados com o Protocolo P1 e P2.

Para analisar o efeito do volume de treinamento sobre a expressão dos microRNAs, isolamos os diferencialmente expressos em P1 $(>1$ ou $<-1)$. Em seguida, selecionamos os microRNAs que apresentavam maior diferença de expressão no P2 ( $\geq 15 \%)$ em relação ao P1. Assim temos que, dos 349 microRNAs analisados, 24 estavam aumentados (vermelho) no P1 e destes 5 também aumentaram sua expressão com o P2. Por outro lado, 39 microRNAs estavam diminuidos (verde) no P1 e 19 diminuíram ainda mais sua expressão em P2, conforme representado na Figura 3. 


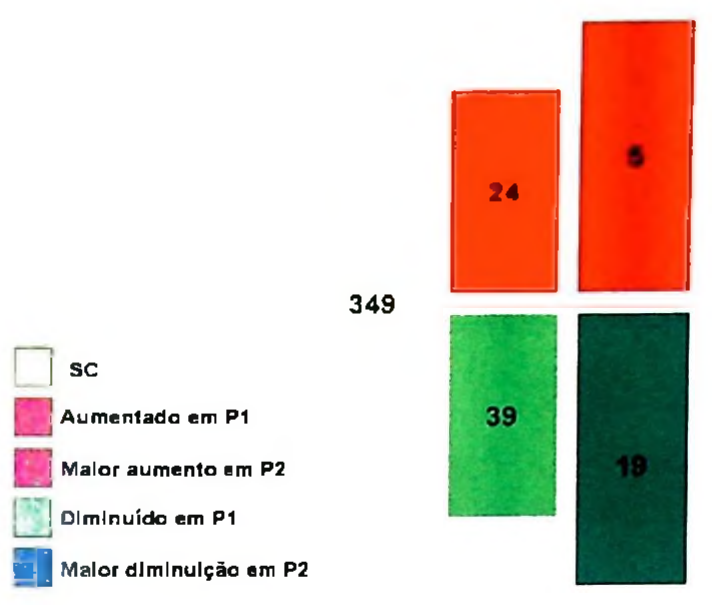

Figura 3. Representação da seleção dos miRNAs diferencialmente expressos no coração dos ratos treinados com o protocolo P1 e P2.

Os valores obtidos para HC, pela medida direta do peso úmido do VE corrigido pelo peso corporal (VE/PC) mostram que o TF induziu $\mathrm{HC}$ nos dois grupos ( $\mathrm{Pl}$ e P2), conforme observamos na Parte 1 desta Tese de Livredocência. A hipertrofia do VE do grupo treinado com o protocolo P1 foi de $13 \%$ e com o P2 de $28 \%$, em relação ao grupo sedentário. Ainda, investigamos os marcadores de hipertrofia patológica ANF, $\alpha$-actina esquelética e a relação $\alpha / \beta$ MHC. Nós observamos que não ocorreram alterações na expressão gênica do ANF e da $\boldsymbol{\alpha}$-actina esquelética, enquanto ocorreu aumento da expressão da relação $\alpha / \beta-\mathrm{MHC}$, portanto com aumento relativo da expressão da $\alpha$-MHC e diminuição da $\beta$-MHC. Assim, esses resultados mostram que a hipertrofia promovida pelo treinamento, nos dois grupos experimentais, é fisiológica, sem a presença de marcadores patológicos.

Conforme descrito na literatura para hipertrofias patológicas, o TF também diminuiu a expressão do miR-1, miR-133a e miR-133b (Figura 4). 


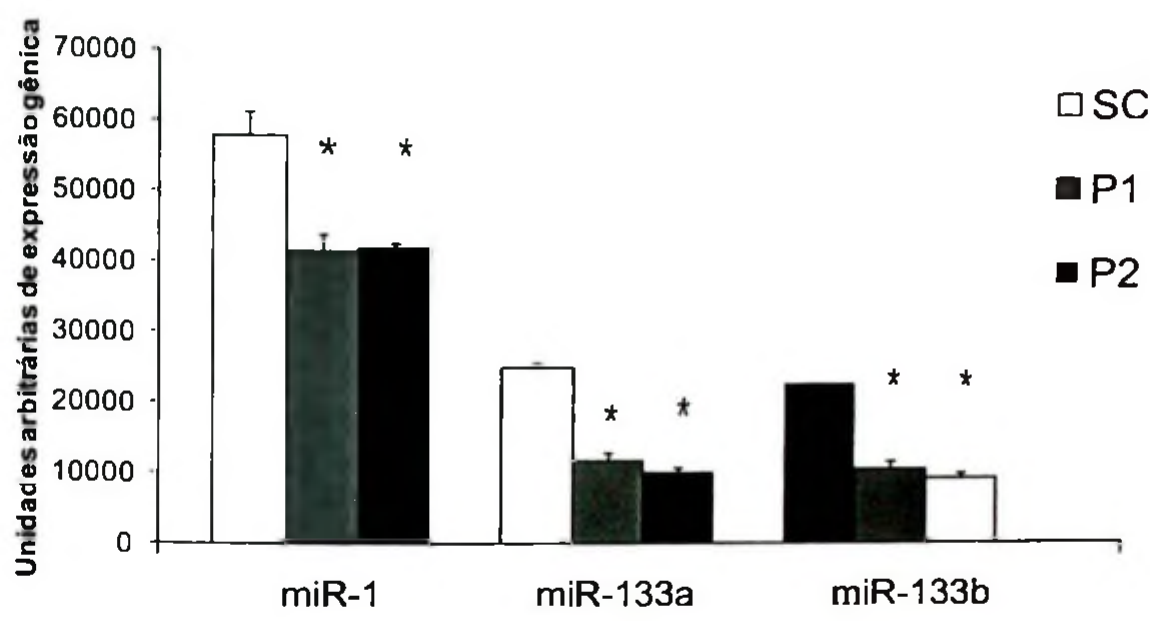

Figura 4. Expressão gênica dos miRNAs-1, 133a e 133b. $\mathrm{P}<0,01$ vs. Controle.

Assim, estes resultados mostram que miR-1, miR-133a e miR-133b apresentam downregulation não somente na hipertrofia patológica (Rooij et al., 2006), mas também na fisiológica induzida pelo TF aeróbio.

Baseados nos resultados apresentados na Figura 3, selecionamos os miRNAs com maior expressão, e com o uso de ferramentas de bioinformática (programa TargetScan e miRBase), buscamos os genes alvo para esse miRNAs. Entre estes genes alvo foram encontrados genes para o Colágeno I e Colágeno III, os quais são alvos para a familia do miR-29, o qual era uma dos selecionados.

Os resultados apresentados na Figura 5 mostram aumento na expressão dos miR-29a, miR-29c. É importante observar neste resultado e nos resultados do micro RNA microArray, que as alterações na expressão dos microRNAs são mais expressivas nos animais treinados com o P2, quando comparados ao $\mathrm{P} 1$, de acordo com a $\mathrm{HC}$, que é mais pronunciada no grupo treinado com o P2, do que o P1. 


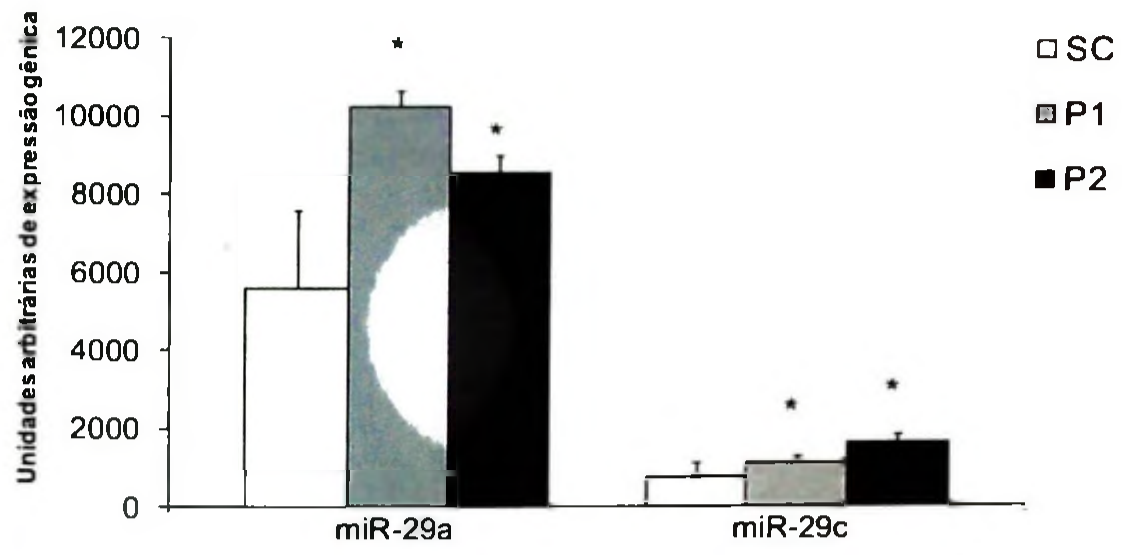

Figura 5. Expressão gênica dos miRNAs-29a e 29c.

Os miR-29a,b,c pertencem a uma família de miRNAs que apresentam como genes alvo diferentes tipos de Colágeno. Este miRNAs apresentam sequências bem conservadas em genes para diferentes tipos de colágeno

A figura 6, mostra uma representados esquemática das sequências de miR-29a,b,c bem conservadas e as posições ao longo do gene do colágeno 1A-1, 1A-2 e 3A-1, do rato. No genoma humano também são encontradas 3 sequências conservadas para miR-29a,b,c no Colágeno 1A-1; 2 sequências conservadas para mir-29a,b,c no Colágeno 1A-2 e para o Colágeno 3A-1, conforme pesquisa feita pelos programas de bioinformática TargetScan e miRBase. Assim, esses resultados também abrem perpectivas para investigação clínica.

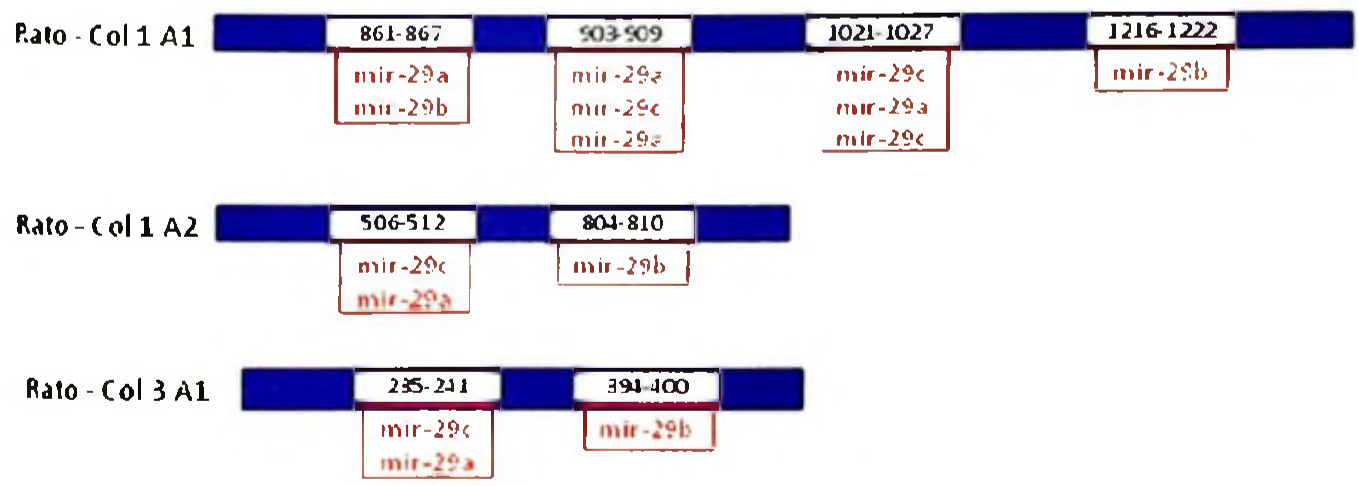

Figura 6. Resentação esquemática da localização dos miR29a, 29b e 29c na sequência dos genes do Col do tipo I e do tipo III. 
O aumento da expressão dos mir-29a e mir-29c na HC induzida pelo TF pode estar relacionado com a diminuição dos tipos de colágeno alvo, no coração do rato. A figura 7A e 7B, mostram a expressão gênica do Col I e do Col III, respectivamente no coração dos animais treinados com os protocolos P1 e P2.

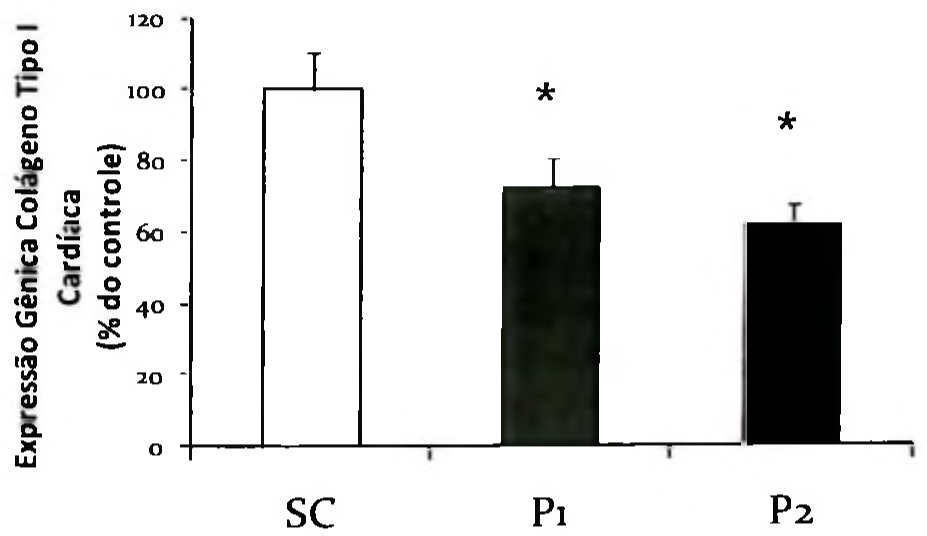

Figura 7A. Expressão gênica do Colágeno do tipo I no coração dos animais treinados com os protocolos P1 e P2.

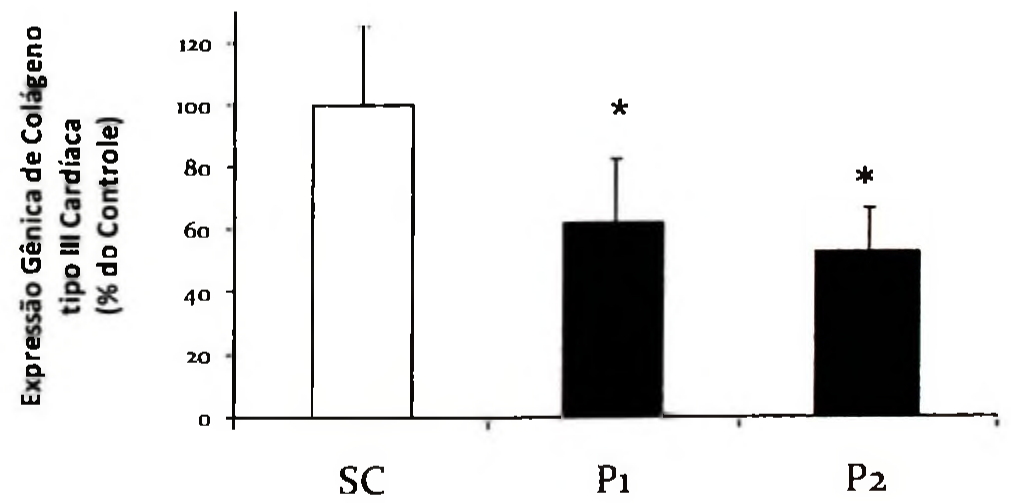

Figura 7B. Expressão gênica do Colágeno do tipo III no coração dos animais treinados com os protocolos P1 e P2

Os resultados mostraram diminuição na expressão do Col I de $27 \%$ e $33 \%$ e do Col III de $38 \%$ e $48 \%$ no $\mathrm{P} 1$ e $\mathrm{P} 2$ respectivamente, vs $\mathrm{S} \quad(\mathrm{P}<0,05)$, que foram acompanhados 
proporcionalmente pela diminuição na concentração da OH-Prolina, a principal proteína componente da estrutura do colágeno.

A Tabela 1. Mostra os reultados obtidos pelo ecocardiograma para função sistólica e diastólica dos animais treinados com os dois protocolos de treinamento. Os resultados mostram uma melhora de função diastólica, pelo aumento da relação da ondaE/onda $\mathrm{A}$, nos animais treinados com o protocolo P2.

Estes resultados sugerem que a diminuição na síntese de colágeno pode levar a diminuição da complacência ventricular e conseqüentemente, melhora de função ventricular.

Tabela 1. Função sistólica e diastólica analisadas pelo Ecocardiograma em animais treinados pelos protocolos P1 e P2.

\begin{tabular}{|c|c|c|c|}
\hline & $\operatorname{SC}(n=7)$ & $P 1(n=6)$ & $P 2(n=6)$ \\
\hline \multicolumn{4}{|c|}{ Função Sistólica } \\
\hline $\mathrm{FEj}(\%)$ & $77 \pm 5$ & $75 \pm 2$ & $73 \pm 2$ \\
\hline FEn $(\%)$ & $39 \pm 4$ & $38 \pm 3$ & $36 \pm 2$ \\
\hline $\mathrm{VME}(\mathrm{m} / \mathrm{s})$ & $0,204 \pm 0,02$ & $0,211 \pm 0,2$ & $0,222 \pm 0,04$ \\
\hline \multicolumn{4}{|c|}{ Função Diastólica } \\
\hline Pico E (m/s) & $0,451 \pm 0,05$ & $0,499 \pm 0,05$ & $0,458 \pm 0,03$ \\
\hline $\operatorname{Pico} A(\mathrm{~m} / \mathrm{s})$ & $0,328 \pm 0,06$ & $0,333 \pm 0,03$ & $0,279 \pm 0,01$ \\
\hline Relação E/A & $1,396 \pm 0,16$ & $1,504 \pm 0,19$ & $1,644 \pm 0,11^{\star}$ \\
\hline $\operatorname{TRIV}(\mathrm{ms})$ & $27,6 \pm 1,9$ & $30,7 \pm 1,5$ & $30,7 \pm 2,0$ \\
\hline
\end{tabular}

Resultados são expressos como média $\pm \mathrm{SD}$. ${ }^{*} \mathrm{P}<0,05$.

Estes resultados são bastante promissores, entretanto ainda necessitamos mostrar se realmente estes efeitos são dependente da diminuição da expressão da família dos miR-29. Assim, serão utilizados antisense para esse miRNAs para confirmarmos essa hipótese. Inicialmente, essa hipótese será testada em cultura celular de cardiomiócitos e fibroblastos separadamente, para depois ser testado no animal associados ao treinamento físico. 
Essa será uma das linhas de investigação a ser iniciada como perspectivas futuras, para determinarmos os mecanismos moleculares envolvidos na melhora de função ventricular observada como resposta ao TF. Ainda, poderá ser usada a terapia gênica com sense e/ou antisense para microRNAs para tratamento de patologias como hipertrofia patológica do animal hipertenso. Estes resultados em conjunto abrem perspectivas para o potencial terapêutico do tratamento com sense e/ou antisense de miRNAs.

- Oliveira EM, Tang YL, Qian K, Shen L, Ong L, Phillips IM. Different microRNA In Mouse Heart, Cardiac Stem Cells And Cardiac Stem Cells With GATA4, Indicate Different Sets Of microRNA Involved In Stem Cell Differentiation By Gene Repression. Circulation. s. 491 p. 118, 2008.

- Oliveira EM, Ahmad A, Ibrani D, Tang YL, Phillips MI. Inhibition of microRNAas762, 762+ 21, and microRNAs762+31, differentiates Cardiac Stem Cells into cardiomyocytes by activation of TGFBIII and Activin A receptors pathways. Circulation, 2009 (abstract). Poster session AHA 3225. (manuscrito em fase final de preparação)

\section{CONSIDERAÇÕES FINAIS}

Nesta tese de Livre-Docência mostramos que a hipertrofia cardiaca físiológica induzida pelo treinamento físico, tanto excêntrica, quanto concêntrica tem a participação de um mecanismo local de ativação dos receptores AT1, dependente possivelmente do estresse mecânico sobre os cardiomiócitos, que ativa uma via de sinalização dependente de Akt-mTor.

Enquanto, na hipertrofia patológica decorrente da associação de drogas anabólicas com o treinamento, leva a ativação do SRA sistêmico e local com aumento de Ang II e aldosterona. Esses efeitos levam ao aumento da sintese de colágeno promovendo alterações estruturais e disfunção ventricular, que é exacerbada pelo treinamento. Ocorre, ainda diminuição do fluxo sanguíneo cardiaco e periférico com rarefação capilar. A rarefação vascular pode estar associada a diminuição no número das CEPs. 
A identificação de microRNA envovidos nesses processos físiológicos e patológicos poderá fomecer informações para um tratamento terapêutico com sense e/ou antisense para microRNAs reventendo o quadro patológicos.

\section{REFERÊNCIAS}

1. Menard, J., Anthology of the renin-angiotensin system: a one hundred reference approach to angiotensin II antagonists. J Hypertens Suppl, 1993. 11(3): p. S3-11.

2. Fleming, I., K. Kohlstedt, and R. Busse, New fACEs to the renin-angiotensin system. Physiology (Bethesda), 2005. 20: p. 91-5.

3. Danser, A.H. and M.A. Schalekamp, Is there an internal cardiac renin-angiotensin system? Heart, 1996. 76(3 Suppl 3): p. 28-32.

4. Griendling, K.K., B. Lassegue, and R.W. Alexander, The vascular angiotensin (AT1) receptor. Thromb Haemost, 1993. 70(1): p. 188-92.

5. Donoghue, M., et al., A novel angiotensin-converting enzyme-related carboxypeptidase (ACE2) converts angiotensin I to angiotensin 1-9. Circ Res, 2000. 87(5): p. E1-9.

6. Tipnis, S.R., et al., $A$ human homolog of angiotensin-converting enzyme. Cloning and functional expression as a captopril-insensitive carboxypeptidase. J Biol Chem, 2000. 275(43): p. 33238-43.

7. Ferrario, C.M., et al., Angiotensin-(1-7): a new hormone of the angiotensin system. Hypertension, 1991. 18(5 Suppl): p. III126-33.

8. Iwai, M. and M. Horiuchi, Devil and angel in the renin-angiotensin system: $A C E-$ angiotensin II-AT1 receptor axis vs. ACE2-angiotensin-(1-7)-Mas receptor axis. Hypertens Res, 2009. 32(7): p. 533-6.

9. Crackower, M.A., et al., Angiotensin-converting enzyme 2 is an essential regulator of heart function. Nature, 2002. 417(6891): p. 822-8.

10. Vickers, C., et al., Hydrolysis of biological peptides by human angiotensin-converting enzyme-related carboxypeptidase. J Biol Chem, 2002. 277(17): p. 14838-43.

11. Ferrario, C.M., Contribution of angiotensin-(1-7) to cardiovascular physiology and pathology. Curr Hypertens Rep, 2003. 5(2): p. 129-34.

12. Santos, R.A., M.J. Campagnole-Santos, and S.P. Andrade, Angiotensin-(1-7): an update. Regul Pept, 2000. 91(1-3): p. 45-62.

13. Iyer, S.N., C.M. Ferrario, and M.C. Chappell, Angiotensin-(1-7) contributes to the antihypertensive effects of blockade of the renin-angiotensin system. Hypertension, 1998. 31(1 Pt 2): p. 356-61.

14. Unger, T., et al., Angiotensin receptors. J Hypertens Suppl, 1996. 14(5): p. S95-103.

15. Santos, R.A., et al., Angiotensin-(1-7) is an endogenous ligand for the G protein-coupled receptor Mas. Proc Natl Acad Sci U S A, 2003. 100(14): p. 8258-63.

16. Ichihara, A., et al., Renin, prorenin and the kidney: a new chapter in an old saga. J Nephrol, 2009. 22(3): p. 306-11.

17. Fleming, I., Signaling by the angiotensin-converting enzyme. Circ Res, 2006. 98(7): p. 887-96. 
18. Urata, H. and D. Ganten, Cardiac angiotensin II formation: the angiotensin-I converting enzyme and human chymase. European Heart Journal, 1993. 14 Suppl I: p. 177-82.

19. Liao, Y. and A. Husain, The chymase-angiotensin system in humans: biochemistry, molecular biology and potential role in cardiovascular diseases. Canadian Journal of Cardiology, 1995. 11 Suppl F: p. 13F-19F.

20. Boucher, R., et al., Tonin, angiotensin II system. A review. Circulation Research, 1977. 41(4 Suppl 2): p. 26-9.

21. Santos, C.F., et al., Conversion of renin substrate tetradecapeptide to angiotensin II by rat MAB elastase-2. Canadian Journal of Physiology and Pharmacology, 2004. 82(11): p. 1000-5.

22. Atlas, S.A., The renin-angiotensin aldosterone system: pathophysiological role and pharmacologic inhibition. J Manag Care Pharm, 2007. 13(8 Suppl B): p. 9-20.

23. Cohen, M.L. and K.D. Kurz, Angiotensin converting enzyme inhibition in tissues from spontaneously hypertensive rats after treatment with captopril or MK-421. J Pharmacol Exp Ther, 1982. 220(1): p. 63-9.

24. Lindpaintner, K., et al., Tissue renin-angiotensin systems: focus on the heart. J Hypertens Suppl, 1987. 5(2): p. S33-8.

25. Dzau, V.J. and R.N. Re, Evidence for the existence of renin in the heart. Circulation, 1987. 75(1 Pt 2): p. I134-6.

26. Dzau, V.J., et al., $A$ comparative study of the distributions of renin and angiotensinogen messenger ribonucleic acids in rat and mouse tissues. Endocrinology, 1987. 120(6): p. 2334-8.

27. Dostal, D.E., et al., Detection of angiotensin I and II in cultured rat cardiac myocytes and fibroblasts. Am J Physiol, 1992. 263(4 Pt 1): p. C851-63.

28. Okamura, T., et al., Vascular renin-angiotensin system in two-kidney, one clip hypertensive rats. Hypertension, 1986. 8(7): p. 560-5.

29. Schunkert, H., et al., Increased rat cardiac angiotensin converting enzyme activity and $m R N A$ expression in pressure overload left ventricular hypertrophy. Effects on coronary resistance, contractility, and relaxation. J Clin Invest, 1990. 86(6): p. 1913-20.

30. Schorb, W., et al., Angiotensin II is mitogenic in neonatal rat cardiac fibroblasts. Circ Res, 1993. 72(6): p. 1245-54.

31. Matsubara, H., et al., Differential gene expression and regulation of angiotensin II receptor subtypes in rat cardiac fibroblasts and cardiomyocytes in culture. J Clin Invest, 1994. 93(4): p. 1592-601.

32. Yamazaki, T., et al., The renin-angiotensin system and cardiac hypertrophy. Heart, 1996. 76(3 Suppl 3): p. 33-5.

33. Miyata, S. and T. Haneda, Hypertrophic growth of cultured neonatal rat heart cells mediated by type 1 angiotensin II receptor. Am J Physiol, 1994. 266(6 Pt 2): p. H244351.

34. Baker, K.M. and J.F. Aceto, Angiotensin II stimulation of protein synthesis and cell growth in chick heart cells. Am J Physiol, 1990. 259(2 Pt 2): p. H610-8.

35. Sadoshima, J. and S. Izumo, Molecular characterization of angiotensin II--induced hypertrophy of cardiac myocytes and hyperplasia of cardiac fibroblasts. Critical role of the ATl receptor subtype. Circ Res, 1993. 73(3): p. 413-23. 
36. Crabos, M., et al., Characterization of angiotensin II receptors in cultured adult rat cardiac fibroblasts. Coupling to signaling systems and gene expression. J Clin Invest, 1994. 93(6): p. 2372-8.

37. Weber, J.R., Left ventricular hypertrophy: its prime importance as a controllable risk factor. Am Heart J, 1988. 116(1 Pt 2): p. 272-9.

38. Panidis, I.P., et al., Development and regression of left ventricular hypertrophy. J Am Coll Cardiol, 1984. 3(5): p. 1309-20.

39. Morganroth, J., et al., Comparative left ventricular dimensions in trained athletes. Ann Intern Med, 1975. 82(4): p. 521-4.

40. Alpert, M.A., et al., Effect of exercise and cavity size on right ventricular function in morbid obesity. Am J Cardiol, 1989. 64(19): p. 1361-5.

41. Richey, P.A. and S.P. Brown, Pathological versus physiological left ventricular hypertrophy: a review. J Sports Sci, 1998. 16(2): p. 129-41.

42. Perrault, H. and R.A. Turcotte, Exercise-induced cardiac hypertrophy. Fact or fallacy? Sports Med, 1994. 17(5): p. 288-308.

43. Fleck, S.J., Cardiovascular adaptations to resistance training. Med Sci Sports Exerc, 1988. 20(5 Suppl): p. S146-51.

44. Urhausen, A. and W. Kindermann, Echocardiographic findings in strength- and endurance-trained athletes. Sports Med, 1992. 13(4): p. 270-84.

45. Haykowsky, M.J., et al., Effects of long term resistance training on left ventricular morphology. Can J Cardiol, 2000. 16(1): p. 35-8.

46. Wolfe, L.A., D.A. Cunningham, and D.R. Boughner, Physical conditioning effects on cardiac dimensions: a review of echocardiographic studies. Can J Appl Sport Sci, 1986. 11(2): p. 66-79.

47. Morgan, H.E. and K.M. Baker, Cardiac hypertrophy. Mechanical, neural, and endocrine dependence. Circulation, 1991. 83(1): p. 13-25.

48. Rigat, B., et al., An insertion/deletion polymorphism in the angiotensin I-converting enzyme gene accounting for half the variance of serum enzyme levels. J Clin Invest, 1990. 86(4): p. 1343-6.

49. Montgomery, H.E., et al., Association of angiotensin-converting enzyme gene I/D polymorphism with change in left ventricular mass in response to physical training. Circulation, 1997. 96(3): p. 741-7.

50. Williams, A.G., et al., The ACE gene and muscle performance. Nature, 2000. 403(6770): p. 614 .

51. Schunkert, H., et al., Association between a deletion polymorphism of the angiotensinconverting-enzyme gene and left ventricular hypertrophy. N Engl J Med, 1994. 330(23): p. 1634-8.

52. Benigni, A., et al., Disruption of the Ang II type 1 receptor promotes longevity in mice. J Clin Invest, 2009. 119(3): p. 524-30.

53. Haznedaroglu, I.C., A local renin--angiotensin system in the bone marrow: hypothesis and clues. Exp Hematol, 1999. 27(1): p. 186-7.

54. Vlahakos, D.V., K.P. Marathias, and N.E. Madias, The Role of the Renin-Angiotensin System in the Regulation of Erythropoiesis. Am J Kidney Dis.

55. Mrug, M., et al., Angiotensin II stimulates proliferation of normal early erythroid progenitors. J Clin Invest, 1997. 100(9): p. 2310-4. 
56. Rodgers, K.E., et al., Effect of angiotensin II on hematopoietic progenitor cell proliferation. Stem Cells, 2000. 18(4): p. 287-94.

57. Azizi, M., et al., Acute angiotensin-converting enzyme inhibition increases the plasma level of the natural stem cell regulator $N$-acetyl-seryl-aspartyl-lysyl-proline. J Clin Invest, 1996. 97(3): p. 839-44.

58. Cashman, J.D., A.C. Eaves, and C.J. Eaves, The tetrapeptide AcSDKP specifically blocks the cycling of primitive normal but not leukemic progenitors in long-term culture: evidence for an indirect mechanism. Blood, 1994. 84(5): p. 1534-42.

59. Kanasaki, K., et al., $N$-acetyl-seryl-aspartyl-lysyl-proline inhibits DNA synthesis in human mesangial cells via up-regulation of cell cycle modulators. Biochem Biophys Res Commun, 2006. 342(3): p. 758-65.

60. Oliveira, E.M., et al., Local renin-angiotensin system regulates left ventricular hypertrophy induced by swimming training independent of circulating renin: $a$ pharmacological study. J Renin Angiotensin Aldosterone Syst, 2009. 10(1): p. 15-23.

61. Esther, C.R., Jr., et al., Mice lacking angiotensin-converting enzyme have low blood pressure, renal pathology, and reduced male fertility. Lab Invest, 1996. 74(5): p. 953-65.

62. Cheng, D.Y. and C.A. Gruetter, Chronic estrogen alters contractile responsiveness to angiotensin II and norepinephrine in female rat aorta. Eur J Pharmacol, 1992. 215(2-3): p. 171-6.

63. Brosnihan, K.B., et al., Bi-directional actions of estrogen on the renin-angiotensin system. Braz J Med Biol Res, 1999. 32(4): p. 373-81.

64. Seltzer, A., et al., Estrogens regulate angiotensin-converting enzyme and angiotensin receptors in female rat anterior pituitary. Neuroendocrinology, 1992. 55(4): p. 460-7.

65. Fisher, M., et al., [Hormonal replacement therapy summer 2002--much ado about what?]. Harefuah, 2002. 141(10): p. 888-90, 930.

66. Chung, S.C., et al., Effect of exercise during the follicular and luteal phases on indices of oxidative stress in healthy women. Med Sci Sports Exerc, 1999. 31(3): p. 409-13.

67. Medeiros, A., et al., Swimming training increases cardiac vagal activity and induces cardiac hypertrophy in rats. Braz J Med Biol Res, 2004. 37(12): p. 1909-17.

68. Oliveira, E.M., Bases Moleculares da Ativação da Enzima Conversora de Angiotensina na Hipertrofia Cardiaca no rato, in Ciencias Biológicas: Bioquimica. 1999, Universidade Federal do Rio Grande do Sul: Porto Alegre.

69. Oliveira, E.M. and J.E. Krieger, Cronic B-adrenoreceptor stimulation and cardiac hypertrophy with no induction of circulating renin. European Journal of Pharmacology, 2005.

70. Li, J.S., A.M. Sharifi, and E.L. Schiffrin, Effect of AT1 angiotensin-receptor blockade on structure and function of small arteries in SHR. Journal of Cardiovascular Pharmacology, 1997. 30(1): p. 75-83.

71. Oliveira, E.M. and J.E. Krieger, Chronic beta-adrenoceptor stimulation and cardiac hypertrophy with no induction of circulating renin. Eur J Pharmacol, 2005. 520(1-3): p. 135-41.

72. Srere, P.A. and G.C. Brooks, The circular dichroism of glucagon solutions. Arch Biochem Biophys, 1969. 129(2): p. 708-10. 
73. Bradford, M.M., A rapid and sensitive method for the quantitation of microgram quantities of protein utilizing the principle of protein-dye binding. Anal Biochem, 1976. 72: p. 248-54.

74. Lewis, S.F., et al., Non-autonomic component in bradycardia of endurance trained men at rest and during exercise. Acta Physiol Scand, 1980. 109(3): p. 297-305.

75. Keul, J., et al., The athlete's heart-haemodynamics and structure. Int J Sports Med, 1982. 3 Suppl 1: p. 33-43.

76. Stone, M.H., et al., Health-and performance-related potential of resistance training. Sports Med, 1991. 11(4): p. 210-31.

77. Stratton, J.R., et al., Cardiovascular responses to exercise. Effects of aging and exercise training in healthy men. Circulation, 1994. 89(4): p. 1648-55.

78. Kanakis, C. and R.C. Hickson, Left ventricular responses to a program of lower-limb strength training. Chest, 1980. 78(4): p. 618-21.

79. Holloszy, J.O. and F.W. Booth, Biochemical adaptations to endurance exercise in muscle. Annu Rev Physiol, 1976. 38: p. 273-91.

80. Forjaz, C.L., et al., Post-exercise changes in blood pressure, heart rate and rate pressure product at different exercise intensities in normotensive humans. Braz J Med Biol Res, 1998. 31(10): p. 1247-55.

81. Lampman, R.M. and D.E. Schteingart, Effects of exercise training on glucose control, lipid metabolism, and insulin sensitivity in hypertriglyceridemia and non-insulin dependent diabetes mellitus. Med Sci Sports Exerc, 1991. 23(6): p. 703-12.

82. Blomqvist, C.G. and B. Saltin, Cardiovascular adaptations to physical training. Annu Rev Physiol, 1983. 45: p. 169-89.

83. Holloszy, J.O. and E.F. Coyle, Adaptations of skeletal muscle to endurance exercise and their metabolic consequences. J Appl Physiol, 1984. 56(4): p. 831-8.

84. Schaible, T.F. and J. Scheuer, Effects of physical training by running or swimming on ventricular performance of rat hearts. J Appl Physiol, 1979. 46(4): p. 854-60.

85. Bjomstad, H., et al., Electrocardiographic findings of left, right and septal hypertrophy in athletic students and sedentary controls. Cardiology, 1993. 82(1): p. 56-65.

86. Wei, C.C., et al., Differential ANG II generation in plasma and tissue of mice with decreased expression of the ACE gene. Am J Physiol Heart Circ Physiol, 2002. 282(6): p. H2254-8.

87. Huston, T.P., J.C. Puffer, and W.M. Rodney, The athletic heart syndrome. N Engl J Med, 1985. 313(1): p. 24-32.

88. Zou, Y., et al., Mechanical stress activates angiotensin II type I receptor without the involvement of angiotensin II. Nat Cell Biol, 2004. 6(6): p. 499-506.

89. Convertino, V.A., L.C. Keil, and J.E. Greenleaf, Plasma volume, renin, and vasopressin responses to graded exercise after training. J Appl Physiol, 1983. 54(2): p. 508-14.

90. Leenen, F.H., Left ventricular hypertrophy in hypertensive patients. Am J Med, 1989. 86(1B): p. 63-5.

91. Yuan, B.X. and F.H. Leenen, Dietary sodium intake and left ventricular hypertrophy in normotensive rats. Am J Physiol, 1991. 261(5 Pt 2): p. H1397-401.

92. Nagano, M., et al., Role of cardiac angiotensin II in isoproterenol-induced left ventricular hypertrophy. Hypertension, 1992. 19(6 Pt 2): p. 708-12. 
93. Huentelman, M.J., et al., Protection from angiotensin II-induced cardiac hypertrophy and fibrosis by systemic lentiviral delivery of ACE2 in rats. Exp Physiol, 2005. 90(5): p. 78390.

94. Diez-Freire, C., et al., ACE2 gene transfer attenuates hypertension-linked pathophysiological changes in the SHR. Physiol Genomics, 2006. 27(1): p. 12-9.

95. Raizada, M.K. and A.J. Ferreira, ACE2: a new target for cardiovascular disease therapeutics. J Cardiovasc Pharmacol, 2007. 50(2): p. 112-9.

96. van Rooij, E., et al., Dysregulation of microRNAs after myocardial infarction reveals a role of miR-29 in cardiac fibrosis. Proc Natl Acad Sci U S A, 2008. 105(35): p. 13027-32.

97. van Rooij, E. and E.N. Olson, MicroRNAs: powerful new regulators of heart disease and provocative therapeutic targets. J Clin Invest, 2007. 117(9): p. 2369-76.

98. Barauna, V.G., et al., AT1 receptor participates in the cardiac hypertrophy induced by resistance training in rats. Am J Physiol Regul Integr Comp Physiol, 2008. 295(2): p. R381-7.

99. Alves, M.F., et al., A continuous fluorescent assay for the determination of plasma and tissue angiotensin I-converting enzyme activity. Braz J Med Biol Res, 2005. 38(6): p. 861 8.

100. Chomczynski, P. and N. Sacchi, Single-step method of RNA isolation by acid guanidinium thiocyanate-phenol-chloroform extraction. Anal Biochem, 1987. 162(1): p. 156-9.

101. Heineke, J. and J.D. Molkentin, Regulation of cardiac hypertrophy by intracellular signalling pathways. Nat Rev Mol Cell Biol, 2006. 7(8): p. 589-600.

102. Reudelhuber, T.L., K.E. Bernstein, and P. Delafontaine, Is angiotensin II a direct mediator of left ventricular hypertrophy? Time for another look. Hypertension, 2007. 49(6): p. 1196-201.

103. Xiao, H.D., et al., Mice with cardiac-restricted angiotensin-converting enzyme (ACE) have atrial enlargement, cardiac arrhythmia, and sudden death. Am J Pathol, 2004. 165(3): p. 1019-32.

104. Xiao, H.D., et al., Mice expressing $A C E$ only in the heart show that increased cardiac angiotensin II is not associated with cardiac hypertrophy. Am J Physiol Heart Circ Physiol, 2008. 294(2): p. H659-67.

105. Evangelista, F.S. and J.E. Krieger, Small gene effect and exercise training-induced cardiac hypertrophy in mice: an Ace gene dosage study. Physiol Genomics, 2006. 27(3): p. 231-6.

106. Kagiyama, S., et al., Angiotensin II-induced cardiac hypertrophy and hypertension are attenuated by epidermal growth factor receptor antisense. Circulation, 2002. 106(8): p. 909-12.

107. Kagiyama, S., et al., Antisense to epidermal growth factor receptor prevents the development of left ventricular hypertrophy. Hypertension, 2003. 41(3 Pt 2): p. 824-9.

108. Dostal, D.E., The cardiac renin-angiotensin system: novel signaling mechanisms related to cardiac growth and function. Regul Pept, 2000. 91(1-3): p. 1-11.

109. Tsutsumi, Y., et al., Angiotensin II type 2 receptor overexpression activates the vascular kinin system and causes vasodilation. J Clin Invest, 1999. 104(7): p. 925-35.

110. Ferrario, C.M., New physiological concepts of the renin-angiotensin system from the investigation of precursors and products of angiotensin 1 metabolism. Hypertension. 55(2): p. 445-52. 
111. Chappell, M.C., Emerging evidence for a functional angiotensin-converting enzyme 2angiotensin-(1-7)-MAS receptor axis: more than regulation of blood pressure? Hypertension, 2007. 50(4): p. 596-9.

112. Grobe, J.L., et al., Prevention of angiotensin II-induced cardiac remodeling by angiotensin-(1-7). Am J Physiol Heart Circ Physiol, 2007. 292(2): p. H736-42.

113. Ferrario, C.M., et al., Effect of angiotensin-converting enzyme inhibition and angiotensin II receptor blockers on cardiac angiotensin-converting enzyme 2. Circulation, 2005. 111(20): p. 2605-10.

114. Ferrario, C.M., Angiotensin-converting enzyme 2 and angiotensin-(1-7): an evolving story in cardiovascular regulation. Hypertension, 2006. 47(3): p. 515-21.

115. Ishiyama, Y., et al., Upregulation of angiotensin-converting enzyme 2 after myocardial infarction by blockade of angiotensin II receptors. Hypertension, 2004. 43(5): p. 970-6.

116. Carvalho, M.B., et al., Evidence for Mas-mediated bradykinin potentiation by the angiotensin-(1-7) nonpeptide mimic AVE 0991 in normotensive rats. Hypertension, 2007. 50(4): p. 762-7.

117. Bellantuono, I., Haemopoietic stem cells. Int J Biochem Cell Biol, 2004. 36(4): p. 607-20.

118. Morici, G., et al., Supramaximal exercise mobilizes hematopoietic progenitors and reticulocytes in athletes. Am J Physiol Regul Integr Comp Physiol, 2005. 289(5): p. R1496-503.

119. Rehman, J., et al., Exercise acutely increases circulating endothelial progenitor cells and monocyte-/macrophage-derived angiogenic cells. J Am Coll Cardiol, 2004. 43(12): p. 2314-8.

120. Adams, V., et al., Increase of circulating endothelial progenitor cells in patients with coronary artery disease after exercise-induced ischemia. Arterioscler Thromb Vasc Biol, 2004. 24(4): p. 684-90.

121. Hoetzer, G.L., et al., Aging, exercise, and endothelial progenitor cell clonogenic and migratory capacity in men. J Appl Physiol, 2007. 102(3): p. 847-52.

122. Steiner, S., et al., Endurance training increases the number of endothelial progenitor cells in patients with cardiovascular risk and coronary artery disease. Atherosclerosis, 2005. 181(2): p. 305-10.

123. Laufs, U., et al., Physical training increases endothelial progenitor cells, inhibits neointima formation, and enhances angiogenesis. Circulation, 2004. 109(2): p. 220-6.

124. Bonsignore, M.R., et al., Circulating hematopoietic progenitor cells in runners. J Appl Physiol, 2002. 93(5): p. 1691-7.

125. Thijssen, D.H., et al., Haematopoietic stem cells and endothelial progenitor cells in healthy men: effect of aging and training. Aging Cell, 2006. 5(6): p. 495-503.

126. Wardyn, G.G., et al., Effects of exercise on hematological parameters, circulating side population cells, and cytokines. Exp Hematol, 2008. 36(2): p. 216-23.

127. Paul, M., A. Poyan Mehr, and R. Kreutz, Physiology of local renin-angiotensin systems. Physiol Rev, 2006. 86(3): p. 747-803.

128. Koike, G., et al., Angiotensin converting enzyme and genetic hypertension: cloning of rat cDNAs and characterization of the enzyme. Biochem Biophys Res Commun, 1994. 198(1): p. 380-6.

129. Erdos, E.G. and R.A. Skidgel, The angiotensin I-converting enzyme. Lab Invest, 1987. 56(4): p. 345-8. 
130. Hooper, N.M. and A.J. Turner, Isolation of two differentially glycosylated forms of peptidyl-dipeptidase A (angiotensin converting enzyme) from pig brain: a re-evaluation of their role in neuropeptide metabolism. Biochem J, 1987. 241(3): p. 625-33.

131. Soubrier, F., et al., Two putative active centers in human angiotensin I-converting enzyme revealed by molecular cloning. Proc Natl Acad Sci U S A, 1988. 85(24): p. 9386-90.

132. Lattion, A.L., et al., The testicular transcript of the angiotensin I-converting enzyme encodes for the ancestral, non-duplicated form of the enzyme. FEBS Lett, 1989. 252(1-2): p. 99-104.

133. Hubert, C., et al., Structure of the angiotensin I-converting enzyme gene. Two alternate promoters correspond to evolutionary steps of a duplicated gene. J Biol Chem, 1991. 266(23): p. 15377-83.

134. Ondetti, M.A. and D.W. Cushman, Enzymes of the renin-angiotensin system and their inhibitors. Annu Rev Biochem, 1982. 51: p. 283-308.

135. Shapiro, R., B. Holmquist, and J.F. Riordan, Anion activation of angiotensin converting enzyme: dependence on nature of substrate. Biochemistry, 1983. 22(16): p. 3850-7.

136. Wei, L., et al., The two homologous domains of human angiotensin I-converting enzyme are both catalytically active. J Biol Chem, 1991. 266(14): p. 9002-8.

137. Beldent, V., et al., Cell surface localization of proteolysis of human endothelial angiotensin I-converting enzyme. Effect of the amino-terminal domain in the solubilization process. J Biol Chem, 1995. 270(48): p. 28962-9.

138. Ramchandran, R., et al., Metalloprotease-mediated cleavage secretion of pulmonary ACE by vascular endothelial and kidney epithelial cells. Am J Physiol, 1996. 271(2 Pt 2): p. H744-51.

139. Hubert, C., et al., The hematopoietic system: a new niche for the renin-angiotensin system. Nat Clin Pract Cardiovasc Med, 2006. 3(2): p. 80-5.

140. Chisi, J.E., J. Wdzieczak-Bakala, and A.C. Riches, Inhibitory action of the peptide AcSDKP on the proliferative state of hematopoietic stem cells in the presence of captopril but not lisinopril. Stem Cells, 1997. 15(6): p. 455-60.

141. Strawn, W.B., et al., Renin-angiotensin system expression in rat bone marrow haematopoietic and stromal cells. Br J Haematol, 2004. 126(1): p. 120-6.

142. Witkowski, S. and J.M. Hagberg, Progenitor cells and age: can we fight aging with exercise? J Appl Physiol, 2007. 102(3): p. 834-5.

143. Junot, C., et al., Effect of angiotensin-converting enzyme inhibition on plasma, urine, and tissue concentrations of hemoregulatory peptide acetyl-Ser-Asp-Lys-Pro in rats. J Pharmacol Exp Ther, 1999. 291(3): p. 982-7.

144. Carmona, A.K., et al., A continuous fluorescence resonance energy transfer angiotensin Iconverting enzyme assay. Nat Protoc, 2006. 1(4): p. 1971-6.

145. Oliveira, E.M., R.A. Santos, and J.E. Krieger, Standardization of a fluorimetric assay for the determination of tissue angiotensin-converting enzyme activity in rats. Braz $\mathrm{J}$ Med Biol Res, 2000. 33(7): p. 755-64.

146. Brooks, G.A. and T.P. White, Determination of metabolic and heart rate responses of rats to treadmill exercise. J Appl Physiol, 1978. 45(6): p. 1009-15.

147. Mairbaurl, H., et al., Training-dependent changes of red cell density and erythrocytic oxygen transport. J Appl Physiol, 1983. 55(5): p. 1403-7. 
148. Tamaki, T., S. Uchiyama, and S. Nakano, $A$ weight-lifting exercise model for inducing hypertrophy in the hindlimb muscles of rats. Med Sci Sports Exerc, 1992. 24(8): p. 881-6.

149. Notomi, T., et al., A comparison of resistance and aerobic training for mass, strength and turnover of bone in growing rats. Eur J Appl Physiol, 2000. 83(6): p. 469-74.

150. Notomi, T., et al., Effects of resistance exercise training on mass, strength, and turnover of bone in growing rats. Eur J Appl Physiol, 2000. 82(4): p. 268-74.

151. Yaspelkis, B.B., 3rd, et al., Resistance training increases glucose uptake and transport in rat skeletal muscle. Acta Physiol Scand, 2002. 175(4): p. 315-23.

152. Viitasalo, J.T., P.V. Komi, and M.J. Karvonen, Muscle strength and body composition as determinants of blood pressure in young men. Eur J Appl Physiol Occup Physiol, 1979. 42(3): p. 165-73.

153. Alves, M.J., et al., Abnormal neurovascular control in anabolic androgenic steroids users. Med Sci Sports Exerc. 42(5): p. 865-71.

154. Smith, M.L. and P.B. Raven, Cardiovascular responses to lower body negative pressure in endurance and static exercise-trained men. Med Sci Sports Exerc, 1986. 18(5): p. 54550.

155. Harris, K.A. and R.G. Holly, Physiological response to circuit weight training in borderline hypertensive subjects. Med Sci Sports Exerc, 1987. 19(3): p. 246-52.

156. Kelley, G.A. and K.S. Kelley, Progressive resistance exercise and resting blood pressure $\therefore$ A meta-analysis of randomized controlled trials. Hypertension, 2000. 35(3): p. 838-43.

157. Kelley, G., Dynamic resistance exercise and resting blood pressure in adults: a metaanalysis. J Appl Physiol, 1997. 82(5): p. 1559-65.

158. Goldberg, A.P., Aerobic and resistive exercise modify risk factors for coronary heart disease. Med Sci Sports Exerc, 1989. 21(6): p. 669-74.

159. Ray, C.A. and D.I. Carrasco, Isometric handgrip training reduces arterial pressure at rest without changes in sympathetic nerve activity. Am J Physiol Heart Circ Physiol, 2000. 279(1): p. H245-9.

160. Carter, J.R., et al., Strength training reduces arterial blood pressure but not sympathetic neural activity in young normotensive subjects. J Appl Physiol, 2003. 94(6): p. 2212-6.

161. Delp, M.D. and M.H. Laughlin, Time course of enhanced endothelium-mediated dilation in aorta of trained rats. Med Sci Sports Exerc, 1997. 29(11): p. 1454-61.

162. Lizardo, J.H., et al., Post-resistance exercise hypotension in spontaneously hypertensive rats is mediated by nitric oxide. Clin Exp Pharmacol Physiol, 2008. 35(7): p. 782-7.

163. Ricci, G., et al., Left ventricular size following endurance, sprint, and strength training. Med Sci Sports Exerc, 1982. 14(5): p. 344-7.

164. Stone, M.H., et al., Cardiovascular responses to short-term olympic style weight-training in young men. Can J Appl Sport Sci, 1983. 8(3): p. 134-9.

165. Lusiani, L., et al., Echocardiographic evaluation of the dimensions and systolic properties of the left ventricle in freshman athletes during physical training. Eur Heart J, 1986. 7(3): p. 196-203.

166. Goldstein, D.S., Stress-induced activation of the sympathetic nervous system. Baillieres Clin Endocrinol Metab, 1987. 1(2): p. 253-78.

167. Barauna, V.G., et al., Cardiovascular adaptations in rats submitted to a resistancetraining model. Clin Exp Pharmacol Physiol, 2005. 32(4): p. 249-54. 
168. Sahn, D.J., et al., Recommendations regarding quantitation in M-mode echocardiography: results of a survey of echocardiographic measurements. Circulation, 1978. 58(6): p. 1072-83.

169. Schiller, N.B., et al., Recommendations for quantitation of the left ventricle by twodimensional echocardiography. American Society of Echocardiography Committee on Standards, Subcommittee on Quantitation of Two-Dimensional Echocardiograms. Joumal of the American Society of Echocardiography, 1989. 2(5): p. 358-67.

170. Litwin, S.E., et al., Serial echocardiographic assessment of left ventricular geometry and function after large myocardial infarction in the rat. Circulation, 1994. 89(1): p. 345-54.

171. Queiroz, A.C., et al., Clinic and ambulatory blood pressure responses after resistance exercise. J Strength Cond Res, 2009. 23(2): p. 571-8.

172. Effron, M.B., Effects of resistive training on left ventricular function. Med Sci Sports Exerc, 1989. 21(6): p. 694-7.

173. Fagard, R.H., Athlete's heart: a meta-analysis of the echocardiographic experience. Int $\mathbf{J}$ Sports Med, 1996. 17 Suppl 3: p. S140-4.

174. Pluim, B.M., et al., The athlete's heart. A meta-analysis of cardiac structure and function. Circulation, 2000. 101(3): p. 336-44.

175. Pluim, B.M., et al., Correlation of heart rate variability with cardiac functional and metabolic variables in cyclists with training induced left ventricular hypertrophy. Heart, 1999. 81(6): p. 612-7.

176. Barauna, V.G., et al., Effects of resistance training on ventricular function and hypertrophy in a rat model. Clin Med Res, 2007. 5(2): p. 114-20.

177. Sadoshima, J. and S. Izumo, Molecular characterization of angiotensin II-induced hypertrophy of cardiac myocytes and hyperplasia of cardiac fibroblasts. Critical role of the AT1 receptor subtype. Circulation Research, 1993. 73(3): p. 413-23.

178. Fields, N.G., B.X. Yuan, and F.H. Leenen, Sodium-induced cardiac hypertrophy. Cardiac sympathetic activity versus volume load. Circulation Research, 1991. 68(3): p. 745-55.

179. Kyselovic, J., et al., Prevention of salt-dependent cardiac remodeling and enhanced gene expression in stroke-prone hypertensive rats by the long-acting calcium channel blocker lacidipine. Journal of Hypertension, 1998. 16(10): p. 1515-22.

180. Ahn, J., et al., Cardiac structural and functional responses to salt loading in SHR. American Journal of Physiology. Heart and Circulatory Physiology, 2004. 287(2): p. H767-72.

181. Brilla, C.G., J.S. Janicki, and K.T. Weber, Impaired diastolic function and coronary reserve in genetic hypertension. Role of interstitial fibrosis and medial thickening of intramyocardial coronary arteries. Circulation Research, 1991. 69(1): p. 107-15.

182. Urhausen, A. and W. Kindermann, Echocardiographic findings in strength- and endurance-trained athletes. Sports Medicine, 1992. 13(4): p. 270-84.

183. Kaplan, N.M., New perspectives in the treatment of hypertension with arterial disease. J Cardiovasc Pharmacol, 1985. 7 Suppl 2: p. S131-4.

184. Kromer, E.P. and G.A. Riegger, Effects of long-term angiotensin converting enzyme inhibition on myocardial hypertrophy in experimental aortic stenosis in the rat. Am J Cardiol, 1988. 62(1): p. 161-3. 
185. Linz, W., B.A. Scholkens, and D. Ganten, Converting enzyme inhibition specifically prevents the development and induces regression of cardiac hypertrophy in rats. Clin Exp Hypertens A, 1989. 11(7): p. 1325-50.

186. Nagano, M., et al., Converting enzyme inhibitors regressed cardiac hypertrophy and reduced tissue angiotensin II in spontaneously hypertensive rats. J Hypertens, 1991. 9(7): p. 595-9.

187. Bohm, M., et al., Reduction of cardiac hypertrophy in TGR(mREN2)27 by angiotensin II receptor blockade. Mol Cell Biochem, 1996. 163-164: p. 217-21.

188. Belova, L.A., Angiotensin II-generating enzymes. Biochemistry (Mosc), 2000. 65(12): p. 1337-45.

189. Re, R. and S.E. Bryan, Functional intracellular renin-angiotensin systems may exist in multiple tissues. Clin Exp Hypertens A, 1984. 6(10-11): p. 1739-42.

190. Sadoshima, J., et al., Autocrine release of angiotensin II mediates stretch-induced hypertrophy of cardiac myocytes in vitro. Cell, 1993. 75(5): p. 977-84.

191. Leri, A., et al., Stretch-mediated release of angiotensin II induces myocyte apoptosis by activating $p 53$ that enhances the local renin-angiotensin system and decreases the Bcl-2to-Bax protein ratio in the cell. $\mathrm{J}$ Clin Invest, 1998. 101(7): p. 1326-42.

192. Zou, Y., et al., Mechanical stress activates angiotensin II type I receptor without the involvement of angiotensin II. Nature Cell Biology, 2004. 6(6): p. 499-506.

193. Dinh, D.T., et al., Angiotensin receptors: distribution, signalling and function. Clin Sci (Lond), 2001. 100(5): p. 481-92.

194. Clerk, A., et al., Signaling pathways mediating cardiac myocyte gene expression in physiological and stress responses. J Cell Physiol, 2007. 212(2): p. 311-22.

195. McMullen, J.R. and G.L. Jennings, Differences between pathological and physiological cardiac hypertrophy: novel therapeutic strategies to treat heart failure. Clin Exp Pharmacol Physiol, 2007. 34(4): p. 255-62.

196. DeBosch, B., et al., Aktl is required for physiological cardiac growth. Circulation, 2006. 113(17): p. 2097-104.

197. Kemi, O.J., et al., Activation or inactivation of cardiac Akt/mTOR signaling diverges physiological from pathological hypertrophy. J Cell Physiol, 2008. 214(2): p. 316-21.

198. McMullen, J.R., et al., Phosphoinositide 3-kinase(p110alpha) plays a critical role for the induction of physiological, but not pathological, cardiac hypertrophy. Proc Natl Acad Sci U S A, 2003. 100(21): p. 12355-60.

199. Liu, H.W., et al., Angiotensin II regulates phosphoinositide 3 kinase/Akt cascade via a negative crosstalk between $A T 1$ and AT2 receptors in skin fibroblasts of human hypertrophic scars. Life Sci, 2006. 79(5): p. 475-83.

200. Moschella, P.C., et al., Regulation of mTOR and S6K1 activation by the nPKC isoforms, PKCepsilon and PKCdelta, in adult cardiac muscle cells. J Mol Cell Cardiol, 2007. 43(6): p. 754-66.

201. Martineau, L.C. and P.F. Gardiner, Insight into skeletal muscle mechanotransduction: MAPK activation is quantitatively related to tension. J Appl Physiol, 2001. 91(2): p. 693702.

202. Atherton, P.J., et al., Selective activation of AMPK-PGC-lalpha or PKB-TSC2-mTOR signaling can explain specific adaptive responses to endurance or resistance training-like electrical muscle stimulation. FASEB J, 2005. 19(7): p. 786-8. 
203. Laemmli, U.K., Cleavage of structural proteins during the assembly of the head of bacteriophage T4. Nature, 1970. 227(5259): p. 680-5.

204. Towbin, H., O. Ozbey, and O. Zingel, An immunoblotting method for high-resolution isoelectric focusing of protein isoforms on immobilized $\mathrm{pH}$ gradients. Electrophoresis, 2001. 22(10): p. 1887-93.

205. Haupt, H.A. and G.D. Rovere, Anabolic steroids: a review of the literature. Am J Sports Med, 1984. 12(6): p. 469-84.

206. Kuhn, C.M., Anabolic steroids. Recent Prog Horm Res, 2002. 57: p. 411-34.

207. Gardner, F.H., Anabolic steroids in aplastic anemia. Acta Endocrinol Suppl (Copenh), 1985. 271: p. 87-96.

208. Sheffield-Moore, M., et al., Androgen therapy induces muscle protein anabolism in older women. J Clin Endocrinol Metab, 2006. 91(10): p. 3844-9.

209. Snyder, P.J., et al., Secretion of uncombined subunits of luteinizing hormone by gonadotroph cell adenomas. J Clin Endocrinol Metab, 1984. 59(6): p. 1169-75.

210. De Piccoli, B., et al., Anabolic steroid use in body builders: an echocardiographic study of left ventricle morphology and function. Int J Sports Med, 1991. 12(4): p. 408-12.

211. Griggs, R.C., et al., Effect of testosterone on muscle mass and muscle protein synthesis. J Appl Physiol, 1989. 66(1): p. 498-503.

212. Ariel, G. and W. Saville, Effect of anabolic steroids on reflex components. J Appl Physiol, 1972. 32(6): p. 795-7.

213. Hickson, R.C., et al., Glucocorticoid antagonism by exercise and androgenic-anabolic steroids. Med Sci Sports Exerc, 1990. 22(3): p. 331-40.

214. Sheffield-Moore, M., et al., Short-term oxandrolone administration stimulates net muscle protein synthesis in young men. J Clin Endocrinol Metab, 1999. 84(8): p. 2705-11.

215. Ferry, A., et al., Effects of anabolic/androgenic steroids on regenerating skeletal muscles in the rat. Acta Physiol Scand, 1999. 166(2): p. 105-10.

216. Saborido, A., F. Molano, and A. Megias, Effect of training and anabolic-androgenic steroids on drug metabolism in rat liver. Med Sci Sports Exerc, 1993. 25(7): p. 815-22.

217. Melchert, R.B. and A.A. Welder, Cardiovascular effects of androgenic-anabolic steroids. Med Sci Sports Exerc, 1995. 27(9): p. 1252-62.

218. Nieminen, M.S., et al., Serious cardiovascular side effects of large doses of anabolic steroids in weight lifters. Eur Heart J, 1996. 17(10): p. 1576-83.

219. Wilson, D.M., et al., Effects of testosterone therapy for pubertal delay. Am J Dis Child, 1988. 142(1): p. 96-9.

220. LeGros, T., et al., The effects of 17 alpha-methyltestosterone on myocardial function in vitro. Med Sci Sports Exerc, 2000. 32(5): p. 897-903.

221. Trifunovic, B., et al., An androgenic steroid decreases left ventricular compliance in rats. Am J Physiol, 1995. 268(3 Pt 2): p. H1096-105.

222. Tagarakis, C.V., et al., Anabolic steroids impair the exercise-induced growth of the cardiac capillary bed. Int J Sports Med, 2000. 21(6): p. 412-8.

223. Thompson, P.D., et al., Left ventricular function is not impaired in weight-lifters who use anabolic steroids. J Am Coll Cardiol, 1992. 19(2): p. 278-82.

224. Van Zyl, C.G., T.D. Noakes, and M.I. Lambert, Anabolic-androgenic steroid increases running endurance in rats. Med Sci Sports Exerc, 1995. 27(10): p. 1385-9. 
225. Smith, D.M. and D.Y. Tenney, Effects of steroids on mouse oocyte maturation in vitro. J Reprod Fertil, 1980. 60(2): p. 331-8.

226. Martini, L., The Salpha-reduction of testosterone in the neuroendocrine structures. Biochemical and physiological implications. Endocr Rev, 1982. 3(1): p. 1-25.

227. Liang, M.T., et al., Effects of anabolic steroids and endurance exercise on cardiac performance. Int J Sports Med, 1993. 14(6): p. 324-9.

228. Trifunovic, B., et al., Novel attributes of an androgenic steroid-mediated increase in cardiac end diastolic stiffness in rats. Can J Physiol Pharmacol, 1998. 76(6): p. 657-64.

229. Brown, B.S. and A.H. Pilch, The effects of exercise and dianabol upon selected performances and physiological parameters in the male rat. Med Sci Sports, 1972. 4(3): p. $159-65$.

230. Viru, A. and P. Korge, Role of anabolic steroids in the hormonal regulation of skeletal muscle adaptation. J Steroid Biochem, 1979. 11(1C): p. 931-2.

231. Di Bello, V., et al., Effects of anabolic-androgenic steroids on weight-lifters' myocardium: an ultrasonic videodensitometric study. Med Sci Sports Exerc, 1999. 31(4): p. 514-21.

232. Rost, R., The athlete's heart. Historical perspectives--solved and unsolved problems. Cardiol Clin, 1997. 15(3): p. 493-512.

233. Ferreira, J.C., et al., The role of local and systemic renin angiotensin system activation in a genetic model of sympathetic hyperactivity-induced heart failure in mice. Am J Physiol Regul Integr Comp Physiol, 2008. 294(1): p. R26-32.

234. Pope, H.G., Jr. and D.L. Katz, Affective and psychotic symptoms associated with anabolic steroid use. Am J Psychiatry, 1988. 145(4): p. 487-90.

235. Junqueira, L.C., G. Bignolas, and R.R. Brentani, Picrosirius staining plus polarization microscopy, a specific method for collagen detection in tissue sections. Histochem $\mathrm{J}$, 1979. 11(4): p. 447-55.

236. Bergman, I. and R. Loxley, New spectrophotometric method for the determination of proline in tissue hydrolyzates. Anal Chem, 1970. 42(7): p. 702-6.

237. Gunja-Smith, Z., J. Lin, and J.F. Woessner, Jr., Changes in desmosine and pyridinoline crosslinks during rapid synthesis and degradation of elastin and collagen in the rat uterus. Matrix, 1989. 9(1): p. 21-7.

238. Kochakian, C.D. and B.R. Endahl, Changes in body weight of normal and castrated rats by different doses of testosterone propionate. Proc Soc Exp Biol Med, 1959. 100(3): p. 520-2.

239. Brilla, C.G., et al., Collagen metabolism in cultured adult rat cardiac fibroblasts: response to angiotensin II and aldosterone. J Mol Cell Cardiol, 1994. 26(7): p. 809-20.

240. Rocha, F.L., et al., Anabolic steroids induce cardiac renin-angiotensin system and impair the beneficial effects of aerobic training in rats. Am J Physiol Heart Circ Physiol, 2007. 293(6): p. H3575-83.

241. Kawano, H., et al., Valsartan decreases type I collagen synthesis in patients with hypertrophic cardiomyopathy. Circ J, 2005. 69(10): p. 1244-8.

242. Iglarz, M., et al., Involvement of oxidative stress in the profibrotic action of aldosterone. Interaction wtih the renin-angiotension system. Am J Hypertens, 2004. 17(7): p. 597-603.

243. Bonvalet, J.P., et al., Aldosterone: intracellular receptors in human heart. Eur Heart J, 1995. 16 Suppl N: p. 92-7. 
244. Struthers, A.D., Aldosterone blockade in cardiovascular disease. Heart, 2004. 90(10): p. 1229-34.

245. Wharton, J., et al., Differential distribution of angiotensin AT2 receptors in the normal and failing human heart. J Pharmacol Exp Ther, 1998. 284(1): p. 323-36.

246. Zannad, F., et al., Limitation of excessive extracellular matrix turnover may contribute to survival benefit of spironolactone therapy in patients with congestive heart failure: insights from the randomized aldactone evaluation study (RALES). Rales Investigators. Circulation, 2000. 102(22): p. 2700-6.

247. Qin, W., et al., Transgenic model of aldosterone-driven cardiac hypertrophy and heart failure. Circ Res, 2003. 93(1): p. 69-76.

248. Nagata, K., et al., Mineralocorticoid receptor antagonism attenuates cardiac hypertrophy and failure in low-aldosterone hypertensive rats. Hypertension, 2006. 47(4): p. 656-64.

249. de Carvalho Frimm, C., M.K. Koike, and M. Curi, Subendocardial fibrosis in remote myocardium results from reduction of coronary driving pressure during acute infarction in rats. Arq Bras Cardiol, 2003. 80(5): p. 509-20.

250. Takeda, Y., et al., Production of aldosterone in isolated rat blood vessels. Hypertension, 1995. 25(2): p. 170-3.

251. Silvestre, J.S., et al., Activation of cardiac aldosterone production in rat myocardial infarction: effect of angiotensin II receptor blockade and role in cardiac fibrosis. Circulation, 1999. 99(20): p. 2694-701.

252. Lombes, M., et al., Immunohistochemical and biochemical evidence for a cardiovascular mineralocorticoid receptor. Circ Res, 1992. 71(3): p. 503-10.

253. Funder, J.W., et al., Mineralocorticoid action: target tissue specificity is enzyme, not receptor, mediated. Science, 1988. 242(4878): p. 583-5.

254. Silvestre, J.S., et al., [The cardiovascular steroid system]. Therapie, 1998. 53(3): p. $217-$ 26.

255. Wehling, M., Rapid effects of aldosterone: relevant in cardiac ischemia? Hypertension, 2005. 46(1): p. 27-8.

256. Yoshimura, M., et al., Expression of aldosterone synthase gene in failing human heart: quantitative analysis using modified real-time polymerase chain reaction. $\mathrm{J}$ Clin Endocrinol Metab, 2002. 87(8): p. 3936-40.

257. Hatakeyama, H., et al., Vascular aldosterone. Biosynthesis and a link to angiotensin IIinduced hypertrophy of vascular smooth muscle cells. J Biol Chem, 1994. 269(39): p. 24316-20.

258. Robert, V., et al., Biological determinants of aldosterone-induced cardiac fibrosis in rats. Hypertension, 1995. 26(6 Pt 1): p. 971-8.

259. Brilla, C.G., et al., Remodeling of the rat right and left ventricles in experimental hypertension. Circ Res, 1990. 67(6): p. 1355-64.

260. Nehme, J., et al., Differences between cardiac and arterial fibrosis and stiffness in aldosterone-salt rats: effect of eplerenone. J Renin Angiotensin Aldosterone Syst, 2006. 7(1): p. 31-9.

261. Satoh, M., et al., Aldosterone synthase (CYPI1B2) expression and myocardial fibrosis in the failing human heart. Clin Sci (Lond), 2002. 102(4): p. 381-6.

262. Sam, F., et al., Mice lacking osteopontin exhibit increased left ventricular dilation and reduced fibrosis after aldosterone infusion. Am J Hypertens, 2004. 17(2): p. 188-93. 
263. Zhang, Y.L., et al., Blockades of angiotensin and aldosterone reduce osteopontin expression and interstitial fibrosis infiltration in rats with myocardial infarction. Chin Med J (Engl), 2008. 121(21): p. 2192-6.

264. Ye, P., et al., Regulation of aldosterone synthase gene expression in the rat adrenal gland and central nervous system by sodium and angiotensin II. Endocrinology, 2003. 144(8): p. 3321-8.

265. Weber, K.T. and C.G. Brilla, Pathological hypertrophy and cardiac interstitium. Fibrosis and renin-angiotensin-aldosterone system. Circulation, 1991. 83(6): p. 1849-65.

266. Beutel, A., C.T. Bergamaschi, and R.R. Campos, Effects of chronic anabolic steroid treatment on tonic and reflex cardiovascular control in male rats. J Steroid Biochem Mol Biol, 2005. 93(1): p. 43-8.

267. Pereira-Junior, P.P., et al., Cardiac autonomic dysfunction in rats chronically treated with anabolic steroid. Eur J Appl Physiol, 2006. 96(5): p. 487-94.

268. Phillips, M.I., Functions of angiotensin in the central nervous system. Annu Rev Physiol, 1987. 49: p. 413-35.

269. Fraccarollo, D., et al., Additive amelioration of left ventricular remodeling and molecular alterations by combined aldosterone and angiotensin receptor blockade after myocardial infarction. Cardiovasc Res, 2005. 67(1): p. 97-105.

270. Lijnen, P. and V. Petrov, Antagonism of the renin-angiotensin system, hypertrophy and gene expression in cardiac myocytes. Methods Find Exp Clin Pharmacol, 1999. 21(5): p. 363-74.

271. Zhu, Y.C., et al., Role of angiotensin AT1 and AT2 receptors in cardiac hypertrophy and cardiac remodelling. Clin Exp Pharmacol Physiol, 2003. 30(12): p. 911-8.

272. Krieg, A., et al., Cardiac tissue Doppler in steroid users. Int J Sports Med, 2007. 28(8): p. 638-43.

273. Kochakian, C.D. and A.A. Welder, Anabolic-androgenic steroids: in cell culture. In Vitro Cell Dev Biol Anim, 1993. 29A(6): p. 433-8.

274. Burlew, B.S. and K.T. Weber, Connective tissue and the heart. Functional significance and regulatory mechanisms. Cardiol Clin, 2000. 18(3): p. 435-42.

275. Komuro, I., Molecular mechanism of cardiac hypertrophy and development. Jpn Circ J, 2001. 65(5): p. 353-8.

276. Booz, G.W. and K.M. Baker, Molecular signalling mechanisms controlling growth and function of cardiac fibroblasts. Cardiovasc Res, 1995. 30(4): p. 537-43.

277. Chen, K., et al., Angiotensin II regulation of collagen type I expression in cardiac fibroblasts: modulation by PPAR-gamma ligand pioglitazone. Hypertension, 2004. 44(5): p. 655-61.

278. Dent, M.R., et al., Losartan attenuates phospholipase $C$ isozyme gene expression in hypertrophied hearts due to volume overload. J Cell Mol Med, 2006. 10(2): p. 470-9.

279. Young, M. and J.W. Funder, Eplerenone, but not steroid withdrawal, reverses cardiac fibrosis in deoxycorticosterone/salt-treated rats. Endocrinology, 2004. 145(7): p. 3153-7.

280. Burla, A.K., et al., Eplerenone offsets cardiac and aortic adverse remodeling in spontaneously hypertensive rats. Int J Cardiol, 2007. 114(1): p. 64-70.

281. Celotti, F. and P. Negri Cesi, Anabolic steroids: a review of their effects on the muscles, of their possible mechanisms of action and of their use in athletics. J Steroid Biochem Mol Biol, 1992. 43(5): p. 469-77. 
282. Janssen, P.J., et al., Immunohistochemical detection of the androgen receptor with monoclonal antibody F39.4 in routinely processed, paraffin-embedded human tissues after microwave pre-treatment. J Histochem Cytochem, 1994. 42(8): p. 1169-75.

283. Tune, J.D., et al., Control of coronary blood flow during exercise. Exp Biol Med (Maywood), 2002. 227(4): p. 238-50.

284. Fukai, T., et al., Regulation of the vascular extracellular superoxide dismutase by nitric oxide and exercise training. J Clin Invest, 2000. 105(11): p. 1631-9.

285. Ferrer, M., et al., Treatment with the anabolic steroid, nandrolone, reduces vasoconstrictor responses in rabbit arteries. Eur J Pharmacol, 1994. 258(1-2): p. 103-10.

286. Ebenbichler, C.F., et al., Flow-mediated, endothelium-dependent vasodilatation is impaired in male body builders taking anabolic-androgenic steroids. Atherosclerosis, 2001. 158(2): p. 483-90.

287. Kasikcioglu, E., et al., Aortic elastic properties in athletes using anabolic-androgenic steroids. Int J Cardiol, 2007. 114(1): p. 132-4.

288. Lane, H.A., et al., Impaired vasoreactivity in bodybuilders using androgenic anabolic steroids. Eur J Clin Invest, 2006. 36(7): p. 483-8.

289. Tagarakis, C.V., et al., Testosterone-propionate impairs the response of the cardiac capillary bed to exercise. Med Sci Sports Exerc, 2000. 32(5): p. 946-53.

290. Jackson, E.K., et al., Possible role of adenosine deaminase in vaso-occlusive diseases. J Hypertens, 1996. 14(1): p. 19-29.

291. Dubey, R.K., et al., Exogenous and endogenous adenosine inhibits fetal calf seruminduced growth of rat cardiac fibroblasts: role of A2B receptors. Circulation, 1997. 96(8): p. 2656-66.

292. Meghji, P., C.A. Holmquist, and A.C. Newby, Adenosine formation and release from neonatal-rat heart cells in culture. Biochem J, 1985. 229(3): p. 799-805.

293. Mullane, K. and D. Bullough, Harnessing an endogenous cardioprotective mechanism: cellular sources and sites of action of adenosine. J Mol Cell Cardiol, 1995. 27(4): p. 1041-54.

294. Deussen, A., G. Moser, and J. Schrader, Contribution of coronary endothelial cells to cardiac adenosine production. Pflugers Arch, 1986. 406(6): p. 608-14.

295. Dubey, R., et al., Dysregulation of extracellular adenosine levels by vascular smooth muscle cells from spontaneously hypertensive rats. Arterioscler Thromb Vasc Biol, 2001. 21(2): p. 249-54.

296. Deussen, A. and J. Schrader, Cardiac adenosine production is linked to myocardial pO2. J Mol Cell Cardiol, 1991. 23(4): p. 495-504.

297. Gordon, E.L., J.D. Pearson, and L.L. Slakey, The hydrolysis of extracellular adenine nucleotides by cultured endothelial cells from pig aorta. Feed-forward inhibition of adenosine production at the cell surface. J Biol Chem, 1986. 261(33): p. 15496-507.

298. Lloyd, H.G., et al., The transmethylation pathway as a source for adenosine in the isolated guinea-pig heart. Biochem J, 1988. 252(2): p. 489-94.

299. Zimmermann, C., D. Kohler, and B. Schonhofer, /Value of retrospective assessment of the Epworth Sleepiness Scale after long-term CPAP therapy in obstructive sleep apnea disorder]]. Pneumologie, 2000. 54(12): p. 572-4.

300. Hellsten, Y., The effect of muscle contraction on the regulation of adenosine formation in rat skeletal muscle cells. J Physiol, 1999. 518 ( Pt 3): p. 761-8. 
301. Jacobs, A.E., A. Oosterhof, and J.H. Veerkamp, Purine and pyrimidine metabolism in human muscle and cultured muscle cells. Biochim Biophys Acta, 1988. 970(2): p. 130-6.

302. Zimmermann, N., et al., Inotropic effects of diadenosine monophosphate (APIA) in isolated human cardiac preparations. J Cardiovasc Pharmacol, 2000. 35(6): p. 881-6.

303. Menezes de Oliveira, E., et al., Characterization and localization of an ATP diphosphohydrolase activity (EC 3.6.1.5) in sarcolemmal membrane from rat heart. Mol Cell Biochem, 1997. 170(1-2): p. 115-23.

304. Naito, Y. and J.M. Lowenstein, 5'-Nucleotidase from rat heart membranes. Inhibition by adenine nucleotides and related compounds. Biochem J, 1985. 226(3): p. 645-51.

305. Hellsten, Y., et al., Adenosine concentrations in the interstitium of resting and contracting human skeletal muscle. Circulation, 1998. 98(1): p. 6-8.

306. Hellsten, Y. and U. Frandsen, Adenosine formation in contracting primary rat skeletal muscle cells and endothelial cells in culture. J Physiol, 1997. 504 ( Pt 3): p. 695-704.

307. Cunha, R.A. and A.M. Sebastiao, Adenosine and adenine nucleotides are independently released from both the nerve terminals and the muscle fibres upon electrical stimulation of the innervated skeletal muscle of the frog. Pflugers Arch, 1993. 424(5-6): p. 503-10.

308. De Angelis, K., et al., Blood flow measurements in rats using four color microspheres during blockade of different vasopressor systems. Braz J Med Biol Res, 2005. 38(1): p. 119-25.

309. De Angelis, K., et al., Impairment on cardiac output and blood flow adjustments to exercise in L-NAME-induced hypertensive rats. J Cardiovasc Pharmacol, 2006. 47(3): p. 371-6.

310. Hale, S.L., K.J. Alker, and R.A. Kloner, Evaluation of nonradioactive, colored microspheres for measurement of regional myocardial blood flow in dogs. Circulation, 1988. 78(2): p. 428-34.

311. Shimada, K., et al., Adenosine-induced coronary flow reserve in Watanabe heritable hyperlipidemic rabbits. Jpn Circ J, 2000. 64(12): p. 971-6.

312. Hakkinen, J.P., et al., Measurement of organ blood flow with coloured microspheres in the rat. Cardiovasc Res, 1995. 29(1): p. 74-9.

313. Velema, J. and J. Zaagsma, Purification and characterization of cardiac sarcolemma and sarcoplasmic reticulum from rat ventricle muscle. Arch Biochem Biophys, 1981. 212(2): p. 678-88.

314. Oses, J.P., et al., Soluble NTPDase: An additional system of nucleotide hydrolysis in rat blood serum. Life Sci, 2004. 74(26): p. 3275-84.

315. Lanzetta, P.A., et al., An improved assay for nanomole amounts of inorganic phosphate. Anal Biochem, 1979. 100(1): p. 95-7.

316. Heymann, D., M. Reddington, and G.W. Kreutzberg, Subcellular localization of 5'nucleotidase in rat brain. J Neurochem, 1984. 43(4): p. 971-8.

317. Levy, W.C., et al., Endurance exercise training augments diastolic filling at rest and during exercise in healthy young and older men. Circulation, 1993. 88(1): p. 116-26.

318. Muller, J.M., P.R. Myers, and M.H. Laughlin, Vasodilator responses of coronary resistance arteries of exercise-trained pigs. Circulation, 1994. 89(5): p. 2308-14.

319. Oltman, C.L., et al., Effects of exercise training on vasomotor reactivity of porcine coronary arteries. Am J Physiol, 1992. 263(2 Pt 2): p. H372-82. 
320. Nottin, S., et al., Cardiovascular effects of androgenic anabolic steroids in male bodybuilders determined by tissue Doppler imaging. Am J Cardiol, 2006. 97(6): p. 912-5.

321. Ammar, E.M., S.A. Said, and M.S. Hassan, Enhanced vasoconstriction and reduced vasorelaxation induced by testosterone and nandrolone in hypercholesterolemic rabbits. Pharmacol Res, 2004. 50(3): p. 253-9.

322. Brown, M.D., Exercise and coronary vascular remodelling in the healthy heart. Exp Physiol, 2003. 88(5): p. 645-58.

323. Melo, R.M., E. Martinho, Jr., and L.C. Michelini, Training-induced, pressure-lowering effect in SHR: wide effects on circulatory profile of exercised and nonexercised muscles. Hypertension, 2003. 42(4): p. 851-7.

324. Isoyama, S., et al., Collagen deposition and the reversal of coronary reserve in cardiac hypertrophy. Hypertension, 1992. 20(4): p. 491-500.

325. Eghbali, M., et al., Collagen accumulation in heart ventricles as a function of growth and aging. Cardiovasc Res, 1989. 23(8): p. 723-9.

326. Thomas, D.P., et al., Collagen gene expression in rat left ventricle: interactive effect of age and exercise training. J Appl Physiol, 2000. 89(4): p. 1462-8.

327. Thomas, D.P., et al., Exercise training attenuates aging-associated increases in collagen and collagen crosslinking of the left but not the right ventricle in the rat. Eur $\mathrm{J}$ Appl Physiol, 2001. 85(1-2): p. 164-9.

328. Hori, M. and M. Kitakaze, Adenosine, the heart, and coronary circulation. Hypertension, 1991. 18(5): p. 565-74.

329. Langfort, J., et al., Effect of various types of exercise training on 5'-nucleotidase and adenosine deaminase activities in rat heart: influence of a single bout of endurance exercise. Biochem Mol Med, 1996. 59(1): p. 28-32.

330. Burnstock, G., Purinergic P2 receptors as targets for novel analgesics. Pharmacol Ther, 2006. 110(3): p. 433-54.

331. Ferenchick, G.S., Anabolic/androgenic steroid abuse and thrombosis: is there a connection? Med Hypotheses, 1991. 35(1): p. 27-31.

332. Minamino, T., et al., Impact of coronary risk factors on contribution of nitric oxide and adenosine to metabolic coronary vasodilation in humans. J Am Coll Cardiol, 1998. 31(6): p. 1274-9.

333. Ingjer, F. and P. Brodal, Capillary supply of skeletal muscle fibers in untrained and endurance-trained women. Eur J Appl Physiol Occup Physiol, 1978. 38(4): p. 291-9.

334. Saltin, B. and L.B. Rowell, Functional adaptations to physical activity and inactivity. Fed Proc, 1980. 39(5): p. 1506-13.

335. Jensen, L., J. Bangsbo, and Y. Hellsten, Effect of high intensity training on capillarization and presence of angiogenic factors in human skeletal muscle. J Physiol, 2004. 557(Pt 2): p. 571-82.

336. Kraus, R.M., et al., Circulating plasma VEGF response to exercise in sedentary and endurance-trained men. J Appl Physiol, 2004. 96(4): p. 1445-50.

337. Waters, R.E., et al., Voluntary running induces fiber type-specific angiogenesis in mouse skeletal muscle. Am J Physiol Cell Physiol, 2004. 287(5): p. C1342-8.

338. Amaral, S.L., P.E. Papanek, and A.S. Greene, Angiotensin II and VEGF are involved in angiogenesis induced by short-term exercise training. Am J Physiol Heart Circ Physiol, 2001. 281(3): p. H1163-9. 
339. Prior, B.M., H.T. Yang, and R.L. Terjung, What makes vessels grow with exercise training? J Appl Physiol, 2004. 97(3): p. 1119-28.

340. Green, D.J., et al., Effect of exercise training on endothelium-derived nitric oxide function in humans. J Physiol, 2004. 561(Pt 1): p. 1-25.

341. Cunha, T.S., et al., Influence of high-intensity exercise training and anabolic androgenic steroid treatment on rat tissue glycogen content. Life Sci, 2005. 77(9): p. 1030-43.

342. Soares, J.M. and J.A. Duarte, Effects of training and an anabolic steroid on murine red skeletal muscle. A stereological analysis. Acta Anat (Basel), 1991. 142(2): p. 183-7.

343. Amaral, S.L., et al., Exercise training causes skeletal muscle venular growth and alters hemodynamic responses in spontaneously hypertensive rats. J Hypertens, 2001. 19(5): p. 931-40.

344. D'Ascenzo, M., et al., Role of L-type Ca2+ channels in neural stem/progenitor cell differentiation. Eur J Neurosci, 2006. 23(4): p. 935-44.

345. Ray, R., et al., Sex steroids and stem cell function. Mol Med, 2008. 14(7-8): p. 493-501

346. Watanabe, O., et al., Greatly raised vascular endothelial growth factor (VEGF) in POEMS syndrome. Lancet, 1996. 347(9002): p. 702.

347. Asahara, T., et al., Isolation of putative progenitor endothelial cells for angiogenesis. Science, 1997. 275(5302): p. 964-7.

348. Miller-Kasprzak, E. and P.P. Jagodzinski, Endothelial progenitor cells as a new agent contributing to vascular repair. Arch Immunol Ther Exp (Warsz), 2007. 55(4): p. 247-59.

349. Eguchi, M., H. Masuda, and T. Asahara, Endothelial progenitor cells for postnatal vasculogenesis. Clin Exp Nephrol, 2007. 11(1): p. 18-25.

350. Umemura, T. and Y. Higashi, Endothelial progenitor cells: therapeutic target for cardiovascular diseases. J Pharmacol Sci, 2008. 108(1): p. 1-6.

351. Taylor, D.A., et al., Regenerating functional myocardium: improved performance after skeletal myoblast transplantation. Nat Med, 1998. 4(8): p. 929-33.

352. Asahara, T., et al., Bone marrow origin of endothelial progenitor cells responsible for postnatal vasculogenesis in physiological and pathological neovascularization. Circ Res, 1999. 85(3): p. 221-8.

353. Kocher, A.A., et al., Neovascularization of ischemic myocardium by human bonemarrow-derived angioblasts prevents cardiomyocyte apoptosis, reduces remodeling and improves cardiac function. Nat Med, 2001. 7(4): p. 430-6.

354. Kalka, C., et al., Transplantation of ex vivo expanded endothelial progenitor cells for therapeutic neovascularization. Proc Natl Acad Sci U S A, 2000. 97(7): p. 3422-7.

355. Murohara, T., et al., Transplanted cord blood-derived endothelial precursor cells augment postnatal neovascularization. J Clin Invest, 2000. 105(11): p. 1527-36.

356. Hill, J.M., et al., Circulating endothelial progenitor cells, vascular function, and cardiovascular risk. N Engl J Med, 2003. 348(7): p. 593-600.

357. Vasa, M., et al., Number and migratory activity of circulating endothelial progenitor cells inversely correlate with risk factors for coronary artery disease. Circ Res, 2001. 89(1): p. E1-7.

358. Imanishi, T., et al., Effect of estrogen on differentiation and senescence in endothelial progenitor cells derived from bone marrow in spontaneously hypertensive rats. Hypertens Res, 2005. 28(9): p. 763-72. 
359. Imanishi, T., et al., Endothelial progenitor cell senescence is accelerated in both experimental hypertensive rats and patients with essential hypertension. J Hypertens, 2005. 23(10): p. 1831-7.

360. Werner, N., et al., Circulating endothelial progenitor cells and cardiovascular outcomes. N Engl J Med, 2005. 353(10): p. 999-1007.

361. Amaral, S.L., T.M. Zorn, and L.C. Michelini, Exercise training normalizes wall-to-lumen ratio of the gracilis muscle arterioles and reduces pressure in spontaneously hypertensive rats. J Hypertens, 2000. 18(11): p. 1563-72.

362. Hagberg, J.M., J.J. Park, and M.D. Brown, The role of exercise training in the treatment of hypertension: an update. Sports Med, 2000. 30(3): p. 193-206.

363. Whelton, S.P., et al., Effect of aerobic exercise on blood pressure: a meta-analysis of randomized, controlled trials. Ann Intern Med, 2002. 136(7): p. 493-503.

364. Pescatello, L.S., et al., American College of Sports Medicine position stand. Exercise and hypertension. Med Sci Sports Exerc, 2004. 36(3): p. 533-53.

365. Fagard, R.H., Physical activity, physical fitness and the incidence of hypertension. J Hypertens, 2005. 23(2): p. 265-7.

366. Wahl, P., W. Bloch, and A. Schmidt, Exercise has a positive effect on endothelial progenitor cells, which could be necessary for vascular adaptation processes. Int J Sports Med, 2007. 28(5): p. 374-80.

367. Yang, Z., et al., Acute exercise-induced nitric oxide production contributes to upregulation of circulating endothelial progenitor cells in healthy subjects. J Hum Hypertens, 2007. 21(6): p. 452-60.

368. Shaffer, R.G., et al., Effect of acute exercise on endothelial progenitor cells in patients with peripheral arterial disease. Vasc Med, 2006. 11(4): p. 219-26.

369. Sillau, A.H. and N. Banchero, Visualization of capillaries in skeletal muscle by the ATPase reaction. Pflugers Arch, 1977. 369(3): p. 269-71.

370. Dimri, G.P., et al., A biomarker that identifies senescent human cells in culture and in aging skin in vivo. Proc Natl Acad Sci U S A, 1995. 92(20): p. 9363-7.

371. Silva, G.J., et al., Acute and chronic effects of exercise on baroreflexes in spontaneously hypertensive rats. Hypertension, 1997. 30(3 Pt 2): p. 714-9.

372. Feihl, F., et al., Hypertension: a disease of the microcirculation? Hypertension, 2006. 48(6): p. 1012-7.

373. Bacurau, A.V., et al., Sympathetic hyperactivity differentially affects skeletal muscle mass in developing heart failure: role of exercise training. J Appl Physiol, 2009. 106(5): p. $1631-40$.

374. van Zonneveld, A.J. and T.J. Rabelink, Endothelial progenitor cells: biology and therapeutic potential in hypertension. Curr Opin Nephrol Hypertens, 2006. 15(2): p. 16772.

375. Kalka, C., et al., Vascular endothelial growth factor(165) gene transfer augments circulating endothelial progenitor cells in human subjects. Circ Res, 2000. 86(12): p. 1198-202.

376. Walther, C., et al., Effect of increased exercise in school children on physical fitness and endothelial progenitor cells: a prospective randomized trial. Circulation, 2009. 120(22): p. 2251-9. 
377. Paffenbarger, R.S., Jr., et al., The association of changes in physical-activity level and other lifestyle characteristics with mortality among men. N Engl J Med, 1993. 328(8): p. 538-45.

378. Hamer, J., J. Fleming, and E. Shinebourne, Effect of walking on blood-pressure in systemic hypertension. Lancet, 1967. 2(7507): p. 114-8.

379. Hanson, J.S. and W.H. Nedde, Preliminary observations on physical training for hypertensive males. Circ Res, 1970. 27(1 Suppl 1): p. 49-53.

380. Boyer, J.L., Exercise therapy in hypertensive men. JAMA, 1970. 213(1): p. 131.

381. Veras-Silva, A.S., et al., Low-intensity exercise training decreases cardiac output and hypertension in spontaneously hypertensive rats. Am J Physiol, 1997. 273(6 Pt 2): p. H2627-31.

382. Koch, L.G. and S.L. Britton, Artificial selection for intrinsic aerobic endurance running capacity in rats. Physiol Genomics, 2001. 5(1): p. 45-52.

383. Hepple, R.T., et al., Aerobic power declines with aging in rat skeletal muscles perfused at matched convective O2 delivery. J Appl Physiol, 2003. 94(2): p. 744-51.

384. Evangelista, F.S., et al., Loss of resting bradycardia with detraining is associated with intrinsic heart rate changes. Braz J Med Biol Res, 2005. 38(7): p. 1141-6.

385. Mobius-Winkler, S., et al., Time-dependent mobilization of circulating progenitor cells during strenuous exercise in healthy individuals. J Appl Physiol, 2009. 107(6): p. 194350 .

386. Shantsila, E. and G.Y. Lip, Endothelial function and endothelial progenitors: possible mediators of the benefits from physical exercise? Eur J Cardiovasc Prev Rehabil, 2009. 16(4): p. 401-3.

387. Sarto, P., et al., Effects of exercise training on endothelial progenitor cells in patients with chronic heart failure. J Card Fail, 2007. 13(9): p. 701-8.

388. Manfredini, F., et al., Exercise capacity and circulating endothelial progenitor cells in hemodialysis patients. Int J Sports Med, 2007. 28(5): p. 368-73.

389. Hristov, M. and C. Weber, Endothelial progenitor cells: characterization, pathophysiology, and possible clinical relevance. J Cell Mol Med, 2004. 8(4): p. 498-508.

390. Yamaguchi, J., et al., Stromal cell-derived factor-I effects on ex vivo expanded endothelial progenitor cell recruitment for ischemic neovascularization. Circulation, 2003. 107(9): p. 1322-8.

391. Urbich, C. and S. Dimmeler, Endothelial progenitor cells: characterization and role in vascular biology. Circ Res, 2004. 95(4): p. 343-53.

392. Aicher, A., et al., Essential role of endothelial nitric oxide synthase for mobilization of stem and progenitor cells. Nat Med, 2003. 9(11): p. 1370-6.

393. Kim, V.N., MicroRNA biogenesis: coordinated cropping and dicing. Nat Rev Mol Cell Biol, 2005. 6(5): p. 376-85.

394. Lee, R.C., R.L. Feinbaum, and V. Ambros, The C. elegans heterochronic gene lin-4 encodes small RNAs with antisense complementarity to lin-14. Cell, 1993. 75(5): p. 84354.

395. Lee, E.J., et al., Systematic evaluation of microRNA processing patterns in tissues, cell lines, and tumors. RNA, 2008. 14(1): p. 35-42.

396. Brennecke, J., et al., Principles of microRNA-target recognition. PLoS Biol, 2005. 3(3): p. e85. 
397. Hammond, S.M., Dicing and slicing: the core machinery of the RNA interference pathway. FEBS Lett, 2005. 579(26): p. 5822-9.

398. Valencia-Sanchez, M.A., et al., Control of translation and $m R N A$ degradation by miRNAs and siRNAs. Genes Dev, 2006. 20(5): p. 515-24.

399. Lee, Y.S. and A. Dutta, MicroRNAs in cancer. Annu Rev Pathol, 2009. 4: p. 199-227.

400. Thum, T., D. Catalucci, and J. Bauersachs, MicroRNAs: novel regulators in cardiac development and disease. Cardiovasc Res, 2008. 79(4): p. 562-70.

401. Esau, C., et al., MicroRNA-143 regulates adipocyte differentiation. J Biol Chem, 2004. 279(50): p. 52361-5.

402. van Rooij, E., et al., A signature pattern of stress-responsive microRNAs that can evoke cardiac hypertrophy and heart failure. Proc Natl Acad Sci U S A, 2006. 103(48): p. 18255-60.

403. van Rooij, E. and E.N. Olson, microRNAs put their signatures on the heart. Physiol Genomics, 2007. 31(3): p. 365-6.

404. Care, A., et al., MicroRNA-133 controls cardiac hypertrophy. Nat Med, 2007. 13(5): p. 613-8.

405. Drummond, M.J., et al., Aging differentially affects human skeletal muscle microRNA expression at rest and after an anabolic stimulus of resistance exercise and essential amino acids. Am J Physiol Endocrinol Metab, 2008. 295(6): p. E1333-40. 


\title{
Local renin-angiotensin system regulates left ventricular hypertrophy induced by swimming training independent of circulating renin: a pharmacological study
}

\author{
Edilamar M. Olivetra," Maurício S. Sasaki," Marcela Cerêncio," Valério G. Baraúna," José E. Krieger"
}

\section{Xey wonds: \\ ondap-11 \\ nederte, \\ exerdse \\ trining. \\ lesartan. \\ phrslologica \\ contac \\ ippertophy. \\ renbn- \\ uglotens'n \\ ystem}

Laboratoy of

Buchemistry. School of Atracal Education and Spoot. Universily of Sao Prob. Sáa Paulo, SP. बैद्या]

'Laboratory of Genetics and Moleculat

(ardology, Hear

rstulule (nCor).

Liriversily of Sdo Paulo

Sconool of Medicine, Sáo

fzzio. SP. Brazil

Correspondence to

Edlamar M. Oliveira

Laboralony of

Bochemustry.

school of Physical

Ederation and Sporl

Av. Prol Mello Moraes.

65. Butants.

Cudade Universitária,

cos50a.900. Sa Paulo. Exast

The +551130913136

far +5S 1138135921

Errad ediamarausp.br

\section{Jouraal of}

the Realn

Angloteesle-

Adosterone

system

Including other

Pcplidergk systems)

March 2009

Volume 10

lumber 1

\begin{abstract}
Introduction. This study addressed the role of the local renin-angiotensin system (RAS) in the left ventricular hypertrophy (LVH) induced by swimming training using pharmacological blockade.

Materials and methods. Fenule Wistar rats treated with enalapril maleate (60 mg. $\mathrm{kg}^{-1} \cdot \mathrm{d}^{-1}$, $\mathrm{n}=38$ ), losartan (20 mg.kg ${ }^{-1} \cdot \mathrm{d}^{-1}, \mathrm{n}=36$ ) or high salt diet $(1 \% \mathrm{NaCl}, \mathrm{n}=38)$ were trained by two protocols (T1: 60-min swinuming session, 5 days per week for 10 weeks and T2: the same T1 protocol until the $8^{\text {th }}$ week, then $9^{\text {th }}$ week they trained twice a day and $10^{\text {th }}$ week they trained three times a day). Salt loading prevented activation of the systemic RAS. Haemodynamic parameters, soleus citrate synthase (SCS) activity and LVH (left ventricular/body weight ratio, $\mathrm{mg} / \mathrm{g}$ ) were evaluated.

Results. Resting heart rate decreased in all trained groups. SCS activity increased $41 \%$ and $106 \%$ in T1 and T2 groups, respectively. LVH was $20 \%$ and $30 \%$ in T 1 and T 2 groups, respectively. Enalapril prevented $39 \%$ of the LVH in T2 group ( $p<0.05$ ). Losartan prevented $41 \%$ in $\mathrm{T} 1$ and $50 \%$ in T2 $(p<0.05)$ of the LVH in trained groups. Plasma renin activity (PRA) was inhibited in all salt groups and it was increased in $\mathrm{T} 2$ group. Conclusions. These data provide evidence that the physiological LVH induced by swiniming training is regulated by local RAS independent from the systemic, because the hypertrophic response was maintained even when PRA was inhibited by chronic salt loading. However, other systems can contribute to this process.
\end{abstract}

\section{Introduction}

The renin-angiotensin system (RAS) is recognised as an imponant systemic homonal regulator of cardiovascular homeostatic mechanism. However, this idea has been modified because several components of the RAS and their mRNAs have been found in different tissues leading to the concept of local tissue RAS.' All components of the RAS have been identified in the heart (angiotensinogen, renin, angiotensin-converting enzyme (ACE) and angiotensin II (Ang II) receptors), both at mRNA and at protein level. ${ }^{1}$ Previous reports suggested that the cardiac RAS is activated by several hypertrophic stimuli such as pressure overload, sympathetic stimulation or heart failure, ${ }^{2}$ and that subpressor doses of ACE inhibitors or Ang II type 1 (AT $_{1}$ )-receptor blockers can cause regression of cardiac hypertrophy independently of the reduced systolic blood pressure ${ }^{3,4}$ Also, biomechanical stress can be transduced to intracellular signalling and induces cardiac hypertrophy by $\mathrm{AT}_{1}$-receptors." These findings suggest that the local RAS may play an important role in the genesis of the cardiac hypertrophy.

Under pathological conditions, such as arterial hypertension and aortic stenosis, the chronic left ventricular pressure overload is an imporant stimulus for left ventricular hypertrophy (LVH). The tissue RAS, mainly Ang II, plays an important role in the ventricular remodelling process promoting cardiomyocyte hypertrophy, myocardial fibrosis" and consequently ventricular dysfunction. Conversely, in endurance athletes, an increased cardiac wall tension due to the combined increased pressure and volume during physical exercise seems to be an important stimulus for physiological LVH $^{7}$ However, athletes usually show normal diastolic filling patterns, suggesting no changes in the myocardial (compliance) connective tissuc.

Regarding the $\triangle C E$ gene, the insertion (1) or deletion (D) polymorphism in the gene encoding ACE has been associated with differences in the plasma levels of ACE as well as cardiac ACE activity." The absence (D) of a 287-base pair marker in the ACE gene is associated with higher 
ACE levels than its presence (I). Results from athletes show that exercise-related left ventricle (LV) growth might be influenced by ACE genotype. Montgomery et al." reported that LV mass increases more in DD athletes versus Il after 10 weeks of endurance training. The role of RAS in the physiolngical hypertrophy development has also been confirmed by other groups. ${ }^{11,12}$ These data suggest that cardiac RAS might be an important regulator of myocardial growth in response to a physiological hypertrophic stimulus such as the physical training.

The present study was designed to address the role of the RAS in the cardiac hypertrophy induced by physical training by investigating the local and systemic RAS participation in the physiological hypertrophy induced by swimming training, using two very well-controlled training protocols.

\section{Materials and methods Animal care}

Female normotensive Wistar rats (190 to $220 \mathrm{~g}$, $\mathrm{n}=112$ ) were used and handled according to approved institutional guidelines. The animals were housed 3-5 per cage in a controlled room temperature $\left(22^{\circ} \mathrm{C}\right)$ with a 12 -h dark-light cycle and fed standard rat chow having access to water or drug treatment ad libitum. All protocols and surgical procedures used were in accordance with the guidelines of the Brazilian College for Animal Experimentation and were approved by the Ethics Committee of the School of Physical Education and Sport of the Universiry of Sảo Paulo.

The rats were randomly assigned into three experimental groups. Group 1 (ACE inhibitor (ACE-I), $\mathrm{n}=38$ ): treated with enalapril maleate, $60 \mathrm{mg} \cdot \mathrm{kg}^{-1}$. $\mathrm{d}^{-1}$ as drinking water. Group 2 (AT,-receptor blocker Los, $n=36$ ): treated with losartan, $20 \mathrm{mg}$. $\mathrm{kg}^{-1} \cdot \mathrm{d}^{-1}$ as drinking water. Group 3 (Salt, $\mathrm{n}=38$ ): chronic salt loading treatment $(1 \% \mathrm{NaCl}$ was added to drinking water). These oral doses of ACE-I and AT,-receptor blocker were chosen because they do not lower blood pressure in normotensive rats, ${ }^{13.14}$ while high salt diet was used to inhibit the systemic RAS due to decrease in the renin release. ${ }^{14}$ The treatments began on the same day as the exercise training and continued thereafter.

Swimming training was performed according to two protocols described below, designated Tl and $\mathrm{T} 2$.

\section{Exercise training protocols and experimental groups}

Protocol 1 ('r1): Swimming sessions of 60-min duration, 5 days a week, for 10 weeks.

Protocol 2 (T2): This protocol began two weeks before T1. Animals assigned to T2 performed a swimming training protocol similar to protocol T1 until the end of the $8^{\text {th }}$ week. On the $9^{\text {th }}$ week, they trained twice a day, swimming sessions of 60-min duration with a 6-h interval between each session. On the $10^{\text {th }}$ week, they trained three times a day, having swimming sessions of $60-\mathrm{min}$ duration with a 4 -h interval between each session. The aim of increasing training frequency (protocol T2) was to induce robust cardiac hypertrophy.

Group 1 ( $n=38)$ was sulxdivided into six subgroups: sedentary ( $S, n=6)$, sedentary treated with enalapril (S-ACE-I, $n=6$ ), swimming trained following protocol $1(T 1, n=7)$, swimming trained following protocol 1 and treated with enalapril (T1-ACE-I, $\mathrm{n}=6)$, swimming trained following protocol 2 (T2, $\mathrm{n}=7$ ), swimming trained following protocol 2 and treated with enalapril (T2-ACE-I, $n-6$ ).

Group $2(n=36)$ was subdivided into six subgroups: sedentary ( $S, n=6)$, sedentary treated with losartan ( $S$-Los, $n=6$ ), swimming trained following protocol $1(T 1, n=6)$, swimming trained following protocol 1 and treated with losartan (T1-Los, $n=6$ ), swimming trained following protocol 2 (T2, $n=6$ ), swimming trained following protocol 2 and treated with losartan (T2-Los, $n=6$ ).

Group $3(n=38)$ was subdivided into six subgroups: sedentary $(S, n=7)$, sedentary treated with high salt diet ( $S$-Salt, $n=7$ ), swimming trained following protocol 1 ( $11, \mathrm{n}=6)$, swimming trained following protocol 1 and treated with high salt diet (T1-Salt, $n=6$ ), swimming trained following protocol 2 (T2, $\mathrm{n}=6)$, swimming trained following protocol 2 and treated with high salt diet (T2-Salt, $\mathrm{n}=6$ ). This protocol with chronic salt loading was used only to uncouple local versus systemic activation of the RAS due to plasma renin activity (PRA) inhibition. ${ }^{1415}$ It should be noted that each experimental group had a different sedentary group. This was necessary because, due to the high number of animals used, not all training groups could be performed at the same time.

Animals were trained in a swimming apparatus specially designed to allow individual exercise training of rats similar to the one described and illustrated for mice. ${ }^{16}$ The apparatus consisted of 
two coupled 700 I water glass tanks of different dimensions. The outer tank measured $60 \mathrm{~cm}$ in diameter, $1.60 \mathrm{~cm}$ in width and $90 \mathrm{~cm}$ in height. The inner tank was divided into 14 lanes with a surface area of $20 \times 20 \mathrm{~cm}$ per lane and a depth of $60 \mathrm{~cm}$. A heating system kept the water temperature between $30-32^{\circ} \mathrm{C}$ and a water filter with a flow capacity of $4201 . \mathrm{h}^{-1}$ was used to clean the swimming apparatus.

Exercise duration and workload were increased gradually until rats could swim for 60 min wearing caudal dumbbells weighing $5 \%$ of their body weight. Thereafter, duration and dumbbells were kept constant. It has been estimated that a rat swimming alone consumes $\mathrm{O}_{2}$ at $50-65 \%$ of its maximum capacity. ${ }^{17}$ All animals were weighed once a week and the workload adjusted to $5 \%$ of body weight. This swimming protocol has been characterised previously as low to moderate intensity and long duration due to improvement in muscle oxidative capacity. ${ }^{14}$ Sedentary groups were placed in the swimming apparatus for 10 min twice a week without workload to mimic the water stress associated with the experimental protocol.

\section{Haemodynamic parameters}

Tail-cuff systolic blood pressure was measured in the three experimental groups twice a week during the first two weeks, using a tail-cuff plethysmograph (Kent Scientific). Systolic blood pressure did not reduce among the treated groups of animals compared to the non-treated groups (data not shown).

Twenty-four hours after the last training session, under anaesthesia (ketamine $90 \mathrm{mg} \cdot \mathrm{kg}^{-1}$ and xylasine $10 \mathrm{mg} \cdot \mathrm{kg}^{-1}$, i.p.) a cannula (PE-50) was inserted into the carotid artery and emerged through the back of the rat's neck. Twenty-four hours after implantation, the cannula was connected to a strain-gauge transducer (P23 Db; Gould-Statham) and systolic, diastolic and mean arterial pressure were recorded on a beat to beat basis (AT/CODAS) at a frequency of $1,000 \mathrm{~Hz}$ for $30 \mathrm{~min}$ in quiet, conscious, unrestrained rats. Heart rate was obtained from arterial blood pressure pulses.

At the end of the experimental period, the rats were killed by quick decapitation without prior anaesthesia and blood and soleus muscle samples were harvested, frozen and stored at $-80^{\circ} \mathrm{C}$. To determine PRA, the first $3 \mathrm{ml}$ of trunk blood (a mixture of venous and arterial blood) was rapidly collected in chilled glass tubes containing a mixture of potassium EDTA (25 $\mathrm{mmol}$ ), $o$-phenanthroline $(0.44 \mathrm{mmol})$, pepstatin A $(0.12$ $\mathrm{mmol}$ ), and 4-(chloromercuribenzoic acid) (1 mmol). This mixture of protease inhibitors prevented the in vitro production and degradation of angiotensin peptides. ${ }^{19}$ The blood was centrifuged, the plasma was separated and stored at $-20^{\circ} \mathrm{C}$. In addition, the heart was harvested and weighed

\section{Measurement of cardiac hypertrophy}

To measure cardiac mass, the LV was dissected corresponding to the remaining tissue upon removal of both atria (AT) and the free wall of the right ventricle (RV). The interventricular septum remained as part of the $L V$. The cardiac hypertrophy was assessed by the measurement of the ratio of $L V, R V$ and $A T$ weight $(W)$ in milligrams to animal body weight (BW) in grams ( $\mathrm{LWW} / \mathrm{BW}, \mathrm{RVW} / \mathrm{BW}$ and ATW/BW in mg.g $\mathrm{g}^{-1}$ ).

\section{PRA assay}

The PRA was measured by angiotensin I radioimmunoassay, using a commercially available kit (REN-CT2, CIS Bio International, Gif-sur-Yvette, France). This assay permits direct measurement of PRA. Results were quantified in a gamma counter, and the enzyme activity was expressed as $\mathrm{ng} \mathrm{AI} \cdot \mathrm{ml}^{-1} \cdot \mathrm{h}^{-1}$. This assay was only performed in $\mathrm{T} 1$ and $\mathrm{T} 2$ training protocols to observe the PRA modulation by the exercise training, and in salt loading groups to confirm the inhibition of PRA.

\section{Citrate synthase activity measurement}

Citrate synthase activity was determined spectrophotometrically in mixed right soleus according to the method of Srere ${ }^{20}$ and used as a marker of muscle oxidative activity. The enzyme activity was measured in whole muscle homogenates of sedentary $(n=7), T 1(n=8)$ and $T 2(n=8)$ groups, and the amount of the complex resulting from acetyl-CoA and oxaloacetate was determined at $412 \mathrm{~nm}$ and $25^{\circ} \mathrm{C}$, at an interval of $10 \mathrm{~min}$. Citrate synthase activity was expressed as $\mu \mathrm{mol} . \mathrm{ml}^{-1} . \mathrm{mg}^{-1}$ of protein and was only measured in these groups to show the effectiveness of the swimming training protocols and show that the increased frequency of swimming training leads to significant endurance conditioning

\section{Protein determination}

Protein was measured by the method of Bradford $^{21}$ using bovine serum albumin as a standard. 


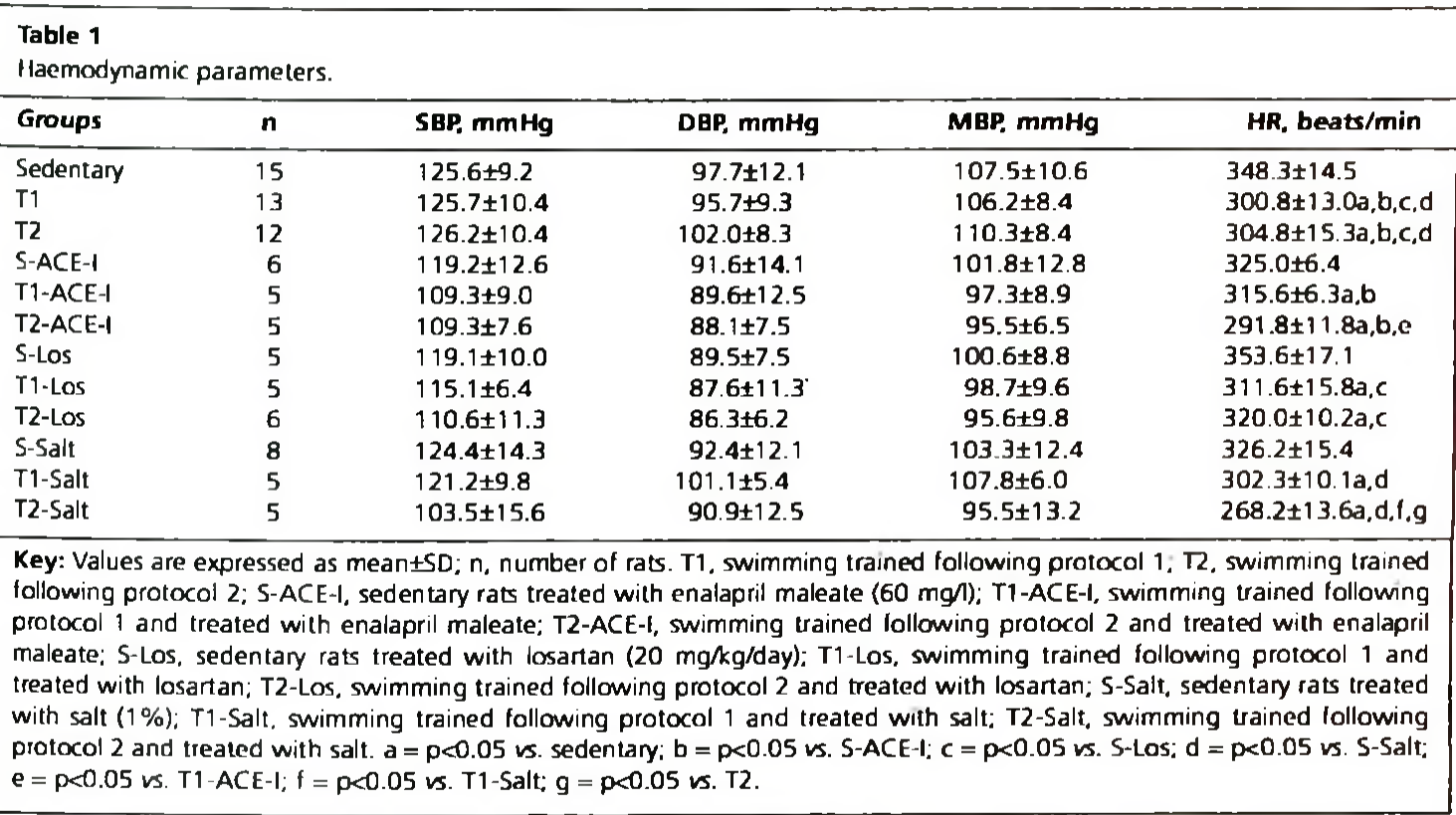

\section{Statistical analysis}

Results are represented as meantstandard deviation (SD). Statistical analysis was performed using randomised (wo- way ANOVA, except for citrate synthase activity when one-way ANOVA was used. P values $<0.05$ were accepted as statistically significant. Tukey's post hoc test was used for individual comparisons between means when a significant change was observed with ANOVA.

\section{Results \\ Haemodynamic parameters}

Table 1 summarises systolic blood pressure (SBP), diastolic blood pressure ( $\mathrm{DBP}^{\mathrm{P}}$ ), mean blood pressure (MBP) and heart rate (HR) measured at the time prior to sacrifice, $48 \mathrm{~h}$ after the last session of swimming training of groups 1,2 and 3. There was no difference of blood pressure among sub-groups that were treated with different inhibitors. However, HR decreased significantly after 10 weeks of swimming training in T1 and T2 groups compared to their respective controls. In addition, the T2-ACE-1 and T2-Salt showed a larger reduction in HR. The HR in T2-ACE-I was reduced compared to sedentary, S-ACE-I and T1-ACE-I groups. The HR in T2-Salt was reduced compared to sedentary, S-Salt, T1-Salt and T2 groups. Neither enalapril, losartan nor salt alone altered HR. The development of resting bradycardia in the trained animals indicates that aerobic conditioning was achieved with these two training protocols.

\section{Citrate synthase activity}

One of the hallmarks of skeletal muscle adaptation to aerobic conditioning is the increase in muscle oxidative activity concomitant with an increase in aerobic work capacity. Citrate synthase, an enzyme that catalyses a condensation between oxalacetate and acetyl-CoA to form citrate in the citric acid cylcle, has been shown to undergo adaptive increases due to exercise in skeletal muscle fibres. Citrate synthase activity in the soleus muscle of rats was significantly higher in both $\mathrm{T} 1$ and $\mathrm{T} 2(275.7 \pm 62.7$ and $385.4 \pm 48.8$ $\mu \mathrm{mol} . \mathrm{ml}^{-1} . \mathrm{mg}^{-1}$, respectively; $\left.\quad p<0.05\right)$ trained groups compared to sedentary (188.0 $166.3 \mu \mathrm{mol}$. $\left.\mathrm{ml}^{-1} \cdot \mathrm{mg}^{-1}\right)$.

\section{Cardiac hypertrophy}

$\mathrm{BW}$ before and after swimming training was similar among all the studied groups (table 2). LVW/BW ratio was used as an inclex of hypertrophy. The absolute values referring to $\mathrm{BW}, \mathrm{LVW} /$ $\mathrm{BW}, \mathrm{RVW} / \mathrm{BW}$ and $\mathrm{ATW} / \mathrm{BW}$ in all groups of rats are summarised in table 2 . Right ventricular hypertrophy (RVH) obtained by $\mathrm{T} 1$ and $\mathrm{T} 2$ training protocols was $10 \%$ and $22 \%$, respectively. Neither enalapril nor losartan treatment decreased RVH in trained groups. As expected, the LVH was obtained by $\mathrm{T} 1$ and $\mathrm{T} 2$ (20\% and $30 \%$, respectively; $p<0.05)$ trained groups compared to their respective controls. The results were similar in the 1, 2 and 3 trained groups. The LVH induced by $\mathrm{T} 2$ training protocol was $50 \%$ higher than that produced by the T1 training protocol in all three trained groups $(p<0.05)$. Nthough the weight 


\begin{tabular}{|c|c|c|c|c|c|}
\hline & $n$ & BW $g$ & LVW/BW, $\mathrm{mg} / \mathrm{g}$ & RVW/BW, $\mathrm{mg} / \mathrm{g}$ & ATW/BW, $\mathrm{mg} / \mathrm{g}$ \\
\hline \multicolumn{6}{|l|}{ Group 1: } \\
\hline Sedentary & 6 & $223.2 \pm 7.5$ & $1.99 \pm 0.153$ & $0.532 \pm 0.058$ & $0.130 \pm 0.032$ \\
\hline S-ACE-I & 5 & $227.9 \pm 14.7$ & $2.05 \pm 0.039$ & $0.489 \pm 0.026$ & $0.134 \pm 0.015$ \\
\hline & 7 & $229.2 \pm 15.9$ & $2.39 \pm 0.081 a$ & $0.584 \pm 0.039$ & $0.166 \pm 0.022$ \\
\hline T1-ACE-I & 6 & $217.0 \pm 23.5$ & $2.22 \pm 0.061$ & $0.578 \pm 0.033$ & $0.161 \pm 0.020$ \\
\hline$\sqrt{2}$ & 7 & $205.6 \pm 15.0$ & $2.60 \pm 0.126 a, b$ & $0.636 \pm 0.065 d$ & $0.182 \pm 0.023 d$ \\
\hline T2-ACE-I & 6 & $204.7 \pm 13.9$ & $2.44 \pm 0.118 a, c$ & $0.633 \pm 0.023 d$ & $0.159 \pm 0.023$ \\
\hline \multicolumn{6}{|l|}{ Group 2: } \\
\hline Sedentary & 5 & $228.6 \pm 17.7$ & $1.93 \pm 0.090$ & $0.513 \pm 0.081$ & $0.137 \pm 0.008$ \\
\hline S-Los & 5 & $238.1 \pm 11.4$ & $1.84 \pm 0.090$ & $0.499 \pm 0.035$ & $0.132 \pm 0.020$ \\
\hline $\mathrm{T} 1$ & 6 & $222.0 \pm 7.2$ & $2.25 \pm 0.130 \mathrm{e}$ & $0.565 \pm 0.021$ & $0.139 \pm 0.026$ \\
\hline T1-Los & 6 & $235.3 \pm 9.8$ & $2.03 \pm 0.100 t$ & $0.543 \pm 0.070$ & $0.137 \pm 0.030$ \\
\hline $\mathrm{T} 2$ & 6 & $223.7 \pm 12.4$ & $2.47 \pm 0.072 \mathrm{e}, \mathrm{f}$ & $0.631 \pm 0.050 \mathrm{e}$ & $0.167 \pm 0.023$ \\
\hline T2-Los & 6 & $206.6 \pm 9.4$ & $2.09 \pm 0.055 \mathrm{~g}$ & $0.621 \pm 0.063 e$ & $0.167 \pm 0.015$ \\
\hline \multicolumn{6}{|l|}{ Group 3: } \\
\hline Sedentary & 7 & $247.0 \pm 22.3$ & $2.16 \pm 0.060$ & $0.540 \pm 0.060$ & $0.130 \pm 0.030$ \\
\hline S-Salt & 7 & $258.1 \pm 22.9$ & $2.33 \pm 0.122 \mathrm{~h}$ & $0.572 \pm 0.066$ & $0.127 \pm 0.016$ \\
\hline $\mathrm{T} 1$ & 5 & $240.3 \pm 10.8$ & $2.64 \pm 0.088 i$ & $0.594 \pm 0.063$ & $0.176 \pm 0.015$ \\
\hline T1-Salt & 6 & $229.2 \pm 17.3$ & $2.82 \pm 0.144 i$ & $0.719 \pm 0.043 k .1$ & $0.204 \pm 0.015 \mathrm{~m}$ \\
\hline $\mathrm{T} 2$ & 6 & $238.8 \pm 10.0$ & $2.85 \pm 0.089 i, j$ & $0.677 \pm 0.071 k$ & $0.208 \pm 0.018 m$ \\
\hline T2-Salt & 6 & $245.1 \pm 17.5$ & $2.94 \pm 0.201 \mathrm{i}, j$ & $0.729 \pm 0.073 k$ 。I & $0.201 \pm 0.027 m$ \\
\hline \multicolumn{6}{|c|}{ 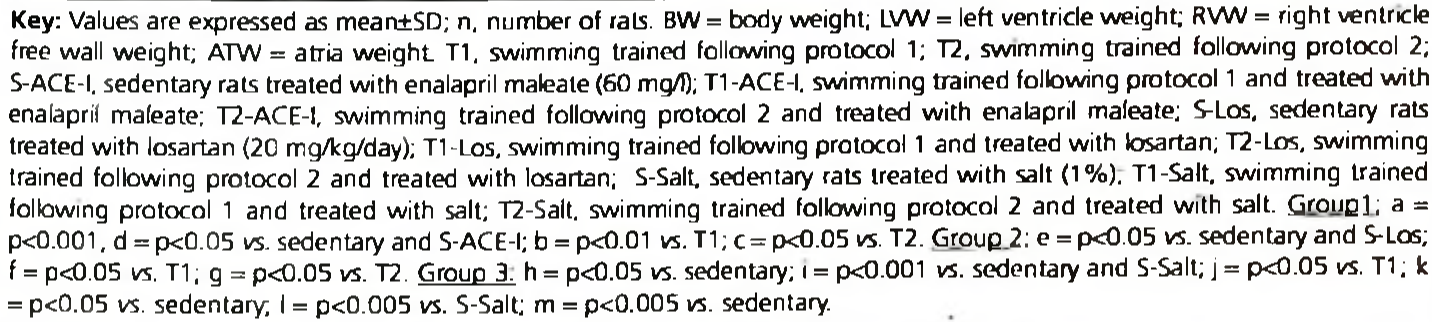 } \\
\hline
\end{tabular}

gain of RV was less pronounced than that of the $\mathrm{LV}$ in both $\mathrm{T} 1$ and $\mathrm{T} 2$ training protocols, the percentage of weight gain in the $L V$ and the RV was proportional to both ventricles, suggesting that hypertrophy was developing symmetrically.

Figure 1A shows the effects of the specific ACE-I (enalapril) in LVH induced by swimming training and its association to the different training protocols. Both T1 and T2 training protocols induced significant LVH (20\% and $31 \%$, respectively; $\mathrm{p}<0.001)$ compared with the sedentary. The LVH for both T1-ACE-I and T2-ACE-I was 10\% ( $>0.05$ ) and $22 \%(p<0.05)$, respectively, compared with sedentary. Collectively, these results indicate that the drug was able to prevent, at least partially, swimming training-induced cardiac hypertophy in T1-ACE-1 group (because T1-ACE-I group was not different when compared with $\mathrm{T} 1$ group) and in T2-ACE-I group (because T2-ACE-1 group was different compared with the S-ACE-I group) There was no significant difference between S-ACE-I and sedentary groups.
Figure 1B shows the effects of the $\mathrm{AT}_{1}$-receptor blocker (losartan) on the LVH induced by swimming training and its association to the $\mathrm{LVH}$ induced by the different training protocols. Both $\mathrm{T} 1$ and $\mathrm{T} 2$ training protocols induced significant LVH similar to that observed in the enalapriltreated group ( $17 \%$ and $28 \%$, respectively; $p<0.05$ ) compared with the sedentary. The LVH at both T1-Los and T2-Los was maintained at $5 \%$ and $8 \%$ (both $\mathrm{p}>0.05$ ), respectively, compared with S-Los. The results indicate that the treatment was able to prevent totally, in T1-Los and T2-Los groups, the swimming training-induced LVH (figure $1 B_{\text {; }}$ table 2). There was no difference between S-Los and sedentary.

Chronic salt loading was used only to uncouple local versus systemic activation of the RAS. The swimming training resulted in activation of PRA only in the $T 2$ training protocol $(4.33 \pm 1.10 \mathrm{ng}$

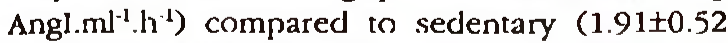
$\mathrm{ng}$ Angl.ml ${ }^{-1} \cdot \mathrm{h}^{-1}$ ) group. The activation of PRA was totally inhibited by salt treatment in the S-Salt

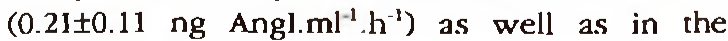




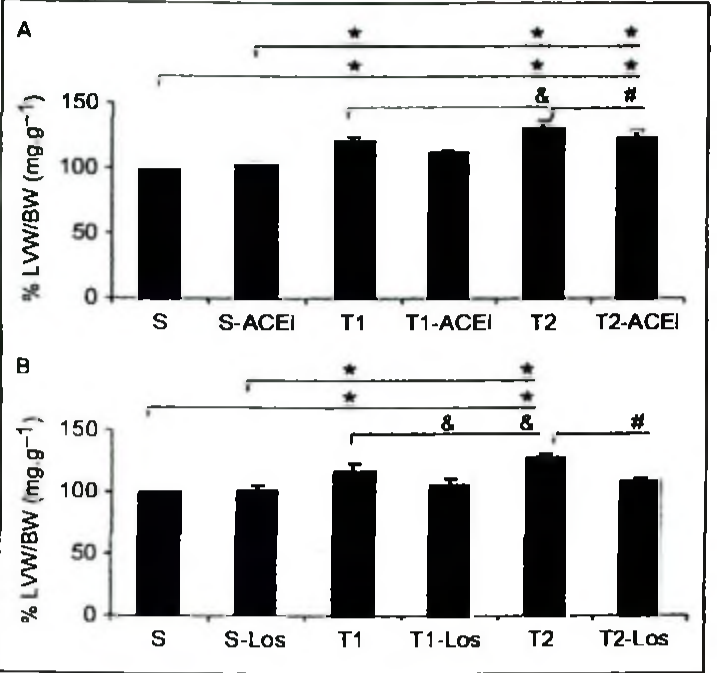

Figure 1

(A) Effects on left ventricle weight normalised by total body weight (\% LVW/OW, mg. $\mathrm{g}^{-1}$ ) of two swimming training protocols and treatment with ACE-I (enalapril maleate), combined or not with training. in Wistar rats. Results are expressed as mean \pm SD. S. sedentary; S-ACE-I, sedentary rats treated with enalapril maleate $\left(60 \mathrm{mg} \cdot \mathrm{kg}^{-1} \cdot \mathrm{d}^{-1}\right)$ : $\mathrm{T1}$, swimming trained following protocol 1; T1-ACE-I, swimming trained following protocol 1 and treated with enalapril maleate; T2, swimming trained following protocol 2; T2-ACE-I, swimming trained following protocol 2 and treated with enalapril maleate. ${ }^{*}=p<0.001$ vs. S and S-ACE-l; $\#=p<0.01$ vs. T1; $\&=p<0.05$ vs. T2. (B) Effects on left ventricle weight normalised by total body weight (\% LWW/BW, mg. $\mathrm{g}^{-1}$ ) of two swimming training protocols and treatment with AT,-receptor blocker (losartan (LOS)), combined or nol with training, in Wistar rats. Results are expressed as mean \pm SD. S, sedentary; S-Los, sedentary rats treated with losartan $\left(20 \mathrm{mg} \cdot \mathrm{kg}^{-1} \cdot \mathrm{d}^{-1}\right) ; \mathrm{T} 1$, swimming trained following protocol 1; T1-Los، swimming trained following protocol 1 and treated with losartan; T2, swimming trained following protocol 2; T2-Los, swimming trained following protocol 2 and treated with losartan. " $=p<0.05$ vs. S and S-ACE-1; \# = p $<0.05$ vs. T2; $\&=p<0.05$ vs. T1.

T1-Salt (0.31 $\pm 0.16 \mathrm{ng}$ AngI. $\left.\mathrm{ml}^{-1} \cdot \mathrm{h}^{-1}\right)$ and T2-Salt

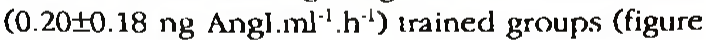
$2 \mathrm{~A}$ ). Figure $2 \mathrm{~B}$ shows the effects of the swimming training on LVH and the association of chronic salt loading on cardiac hypertroplyy induced by $\mathrm{T} 1$ and $\mathrm{T} 2$ training protocols. Both T1 and $\mathrm{T} 2$ training protocols induced significant $\mathbf{L V H}$, similar to that observed in the enalapril- and losartan-treated groups ( $22 \%$ and $32 \%$, respectively; $\mathrm{p}<0.001$ ) compared with the sedentary. The high salt diet in both T1 and T2 trained groups increased LVH significantly $(21 \%$ and $26 \%$, respectively; $p<0.001)$ compared with the S-Salt, indicating that the plasma RAS inhibition was not able to prevent the cardiac hypertrophy induced by swimming training. Salt loading produced a slight, but significant, hypertrophy when compared to the sedentary group $(8 \% ; p<0.05)$

\section{Discussion}

Our results, demonstrating that LVH was not decreased when the systemic RAS was inhibited by chronic salt treatment, show that the LVH induced by swimming training depends on the local RAS activity (as shown by losartan and enalapril treatment) instead of the systemic RAS. This is the first report of a detailed study that has been performed to investigate the paricipation of the local versus systemic RAS in the cardiac hypenrophy induced by aerobic exercise training.

There are many data in the literature that support the role of the RAS in the development of cardiac hypertrophy in many pathological states. We have also provided here evidence for a role for RAS in the physiological hypertrophy. Our resuits are in agreement with those of Iemitsu et al., ${ }^{22}$ which show that both forms of cardiac hypertrophy may share some of the same molecular mechanisms.

\section{Physical conditioning markers}

The training protocols were designed to obtain different magnitudes of cardiac hypertrophy to study the systemic and local RAS participation in the mechanisms of swimming-induced physiological hypertrophy. In this study, two training markers were used to show that the animals were trained. Concerning the cardiovascular effects, resting bradycardia has Iseen considered the hallmark of the aerobic exercise training adaptation. ${ }^{16,1 H}$ The swimming trained groups showed a lower resting HR when compared to the sedentary. The magnitude of resting bradycardia was even larger in the T2 groups.

Also, the increase in skeletal muscle oxidative capacity by exercise training is a well-established adaptation, ${ }^{16,14}$ and is also considered a good metalolic marker for exercise training efficiency. Citrate synthase activity was measured in mixed soleus muscle of rats. The enzyme activity increased significantly, $41 \%$ and $106 \%$ in $\mathrm{T} 1$ and $\mathrm{T} 2$ groups, respectively, compared with the sedentary. These results show the effectiveness of the swimming training protocols and show that the increased frequency swimming training leads to significant endurance conditioning.

In addition, there were no differences in SBP, DBP and MBP among groups, after swimming training. This finding is in accordance with previous reports from our group ${ }^{16,1423}$ and others, ${ }^{10,24}$ showing that arterial pressure remains unchanged in exercisetrained nonnotensive animals and humans. 


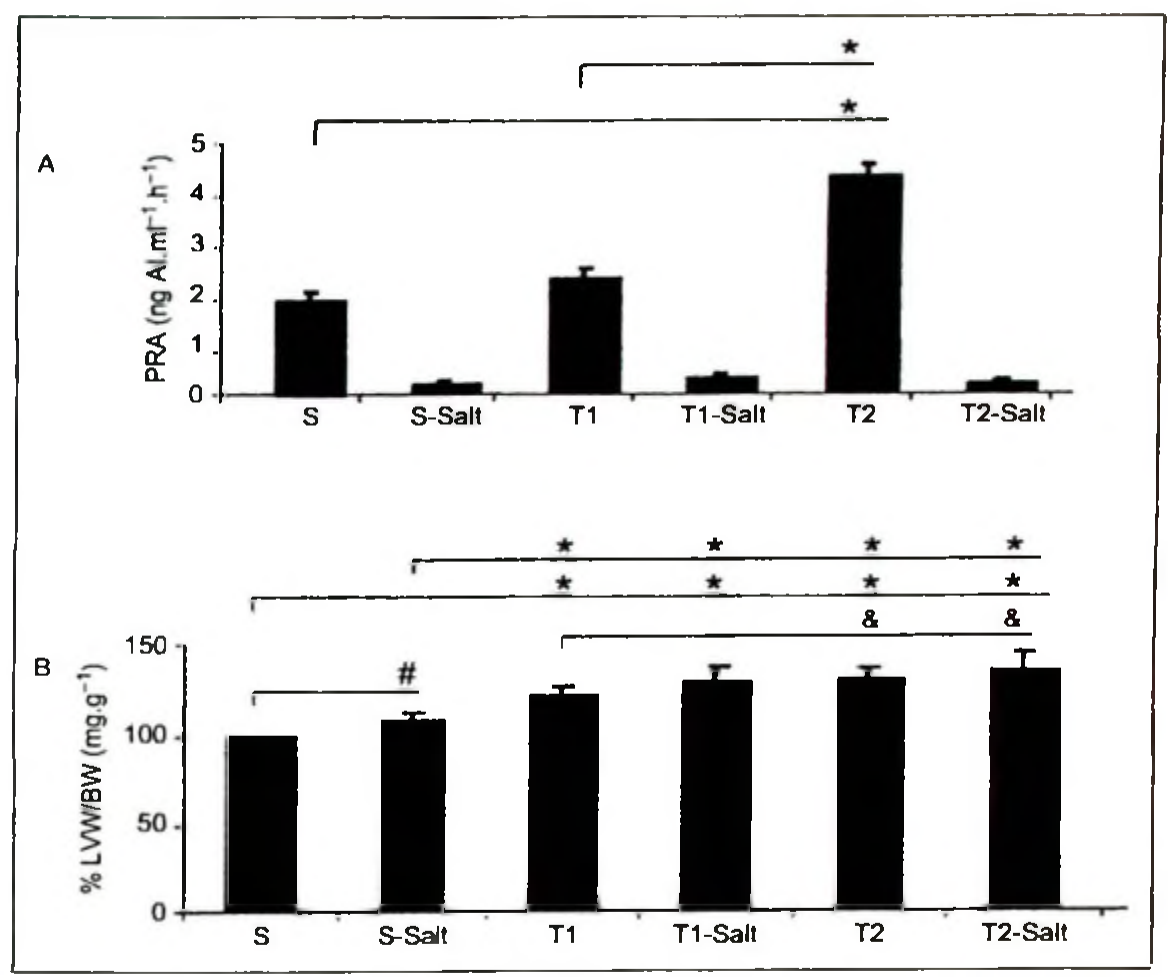

Figure 2

(A) Effects on PRA of two swimming training protocok and chronic salt loading treatment (Salt). combined or not with training, in Wistar rats. Results are expressed as mean+SD. S, sedentary. S-Salt, sedentary rats treated with salt $(1 \%)$ : T1, swimming trained following protocol 1; T1-Salt, swimming trained following protocol 1 and treated with salt; $R$. swimming trained following protocol 2; T2-Salt, swimming trained following protocol 2 and treated with salt. ${ }^{*}=p<0.01$ ws. S and T1. (B) Effects on left ventricle

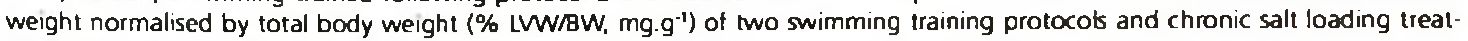
ment (Salt), combined or not with training. in Wistar rats. Results are expressed as meantSD. S. sedentary: S-Salt. sedentary rats treated with salt (1\%); T1, swimming trained following protocol 1; T1-Salt, swimming trained following protocol 1 and treated with salt: T2, swimming trained following protocol 2; T2-Salt, swimming trained following protocol 2 and treated with salt. ${ }^{*}=p<0.001$ vs. S and S-Salt; $\#=p<0.05$ vs. S; $\&=p<0.05$ vs. T1.

\section{Cardiac hypertrophy and RAS}

Although physiological stimulus, such as exercise training, results in cardiac hypertrophy, only a few reports have investigated the role of RAS in this process., 43,25 Previous results and the ones presented here clearly demonstrate that stwimming training leads to cardiac hypertrophy, ${ }^{1+25,26}$ and the magnitude is influenced by endurance conditioning. ${ }^{16,27}$ LVH increased by $20 \%$ in the T'1; however, T2 group increased 50\% more than olsserved by $\mathrm{T} 1$ group. RVH increased by $10 \%$ to $23 \%$ in the $T 1$ to ' $I 2$ group. The results confirm what Bjomstad et al ${ }^{2 x}$ described with athletic students and sedentary controls, that RVH is a normal characteristic in the heart of trained healthy subjects.

\section{RAS blockade by ACE inhibition}

Enalapril is a well-known ACE-1 used for the treatment of hypertension and heart failure. Our findings show that the treatment with enalapril at a dose that did not decrease blood pressure, partially, attenuated cardiac hypertrophy estimated by the ratio of $\mathrm{LVW}$ to $\mathrm{BW}$. Regarding the percentage of LVH in each group, the enalapril treatment did not completely prevent cardiac hypertophy in $\mathrm{T} 1$. but attenuated it by $39 \%$ in T2 trained groups. However, the hyperrophy of T2-ACE-I group was still increased when compared with the S-ACE-1 group. Since the cardiac hypertrophy was not completely blocked by ACE-I, we cannot discard the hypohesis that cardiac hypermphy might be infuenced by other alternative enzymatic pathways of Ang Il formation independent of ACE activity, such as chymase. ${ }^{2 y}$ Besides, the $\mathrm{AT}_{1}$-receptor can be activated by mechanical suress through an Ang II-independent mechanism. ${ }^{5}$

There are also other non-Ang II mechanisms of physiological hypertrophy that could still be activated even with RAS blockade to explain the residual cardiac hypertrophy observed, such as intracellular phosphoinositide-3-kinase pathway through the insulin-like growth factor 1 receptor ${ }^{\text {* }}$ and kinin $\mathbf{B}_{2}$ receptor. ${ }^{31}$ 
RAS blockade by Ang II receptor antagonism Several studies have focused on the effect of Ang II receptor blockers on the development of pressure-overload hyperiophy. It prevents LVH and reduces the stretch-induced hypertrophic response in cardiac myocytes. ${ }^{6,32}$ In the present study, the losartan treatment was able to prevent $41 \%$ of the cardiac hypertrophy in T1 and 50\% in T2 trained groups. Therefore, the T1-Los and T2-Los groups were not different when compared with sedentary and S-Los groups.

These results show that the AT,-receptor blocker was more effective than the specific ACE-I to prevent the cardiac hypertrophy induced by swimming training. These data are not in agreement with those previously reported in the literature. Greenen et al. ${ }^{25}$ showed that L-158,809, a non-peptide $\mathrm{AT}_{1}$-receptor selective blocker, does not prevent physiological cardiac hypentophy induced by swimming training in adult rats. However, the drug was administered as a subcutaneous bolus of $10 \mathrm{mg} / \mathrm{kg}$ twice per week with an interval of 72 and $96 \mathrm{~h}$ berween each injection. As the half-life of this drug in rats' plasma is $7.6 \pm 3.1 \mathrm{~h}^{33}$ there is the possibility that the local system was not totally inhilited

Dissociation of RAS local versus systemic by chronic salt loading

Different from what has been previously shown, y.25 we were able to demonstrate the association of LVH induced by swimming training and local activation of RAS, even when PRA was suppressed by chronic salt loading. This manoeuvre led to the inhibition of the systemic RAS and prevented exercise training from causing the expected induction of renin release. Swimming training resulted in activation of PRA. Nevertheless, it was only significant for the T2 training protocol, where the frequency of swimming training was increased. Our observations are consistent with those reported in the literature that show PRA significantly increased after graded workload. ${ }^{34,35}$

On the other hand, the concentration of sodium may modulate cardiac mass. ${ }^{36,37} \mathrm{LV}$ mass increased $8 \%$ when the sodium salt diet was administrated alone compared to sedentary controls. These findings are also consistent with those reported in the literature that show that dietary salt is able to increase heart weight despite the lack of an increase in blood pressure, ${ }^{34,3 y}$ however, upregulate the $\mathrm{AT}_{1}$-receptor, ${ }^{37}$ and thus this might be the mechanism of the induced cardiac hypertrophy. Our findings show that $\mathbf{L V H}$ increased by $22 \%$ to $31 \%$ in the T1 to T1-Salt and increased by $32 \%$ to
$36 \%$ in the T2 to T2-Salt groups when the hypertrophy was initially compared to sedentary group. Therefore, cardiac hypertrophy observed in the T1 and T2-Salt groups added approximately the same value observed for the sodium salt diet alone. The effects of these two procedures were additive. Similar results were observed to RV. Swimming training induced $\mathrm{LVH}$ even when the PRA was suppressed by chronic salt loading diet (T1 and T2 plus salt groups), suggesting the dissociation between systemic and local activation of the RAS by exercise training. $\Lambda$ previous report, using bilateral nephrectomy, has also suggested that the local RAS can be regulated independently from the systemic RAS and may contribute to the cardiac hypertrophic response. ${ }^{\text {to }}$

\section{Conclusions}

Taken together, our results demonstrate that the two aerobic swimming training protocols used induce different magnitudes of cardiac hypertrophy. Using the specific inhibitors enalapril and losartan, we demonstrated that the RAS has a key role in exercise-induced cardiac hypertrophy. Using chronic salt loading treatment, we demonstrated that swimming-induced physiological hypertrophy is locally regulated and independent from the systemic RAS.

\section{Acknowledgements}

We are grateful to Marcele de Almeida Coelho for technical assistance. M.S. Sasaki (No. 01/13636-3) and V.G. Baraúna (No. 01/14451-7) were recipients of FAPESP Scientific Initiation Fellowship. M. Cerêncio was the recipient of CNPq (PIBIC) Scientific Initiation Fellowship.

\section{References}

1. Paul M, Poyan Mchr A, Kreutz R. Physiology of lexal renin-angiexcensin systemes. Physird Rez, 2006:86:747-803.

2. Unger T. The role of the renin-angiotensin sysem in the development of cardiovasczlar dixcasce. $\Lambda \mathrm{m} /$ Cardiol 2002;893A-9A, discusision 10A

3. Levy 1), Gartixan IRJ, Silvage 1)1), Kinned WU, Cisaclli WP.

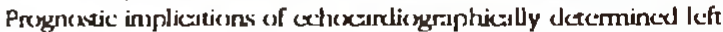
ventricular mass in the Framingham Heare Snady. N EuglJ Mod $19 \times 0 ; 322: 1561-6$

4. Turner AJ, Hexper NM. The angientensin-crenverting enzyne gene family: genenuics and pharnatedogy. Trerseds Pharnacol Sci 2002;23:177-83.

5. Zou Y, Akazawa H, Qin I ef al. Moxhanical strexsi activales angicxensin II typ: 1 recepecor withesut the involvenxent of angiexc:nsin II. Nat Cell Biol 2001;6:499-506

6. Siadeshima J, Izumo s. Molecular characactization of angiotensin II-inducer hypertophy of cardiac myexytes and hyperplasia of Erdiac filoreblasts. Critical role of the AT1 receptur sutxyp:. Circ Res 1993;73:413-23. 
7. Rest R. The athlese's heart. Historical perspextives wherd and unsolved problems. Cardiol Clin 1997;15:493-512. 8. Danxer $\Lambda \mathrm{H}$, Schalekjmp MA, Bax WA al angiexensincrenverting enzyme in the human heart effect of the deletion itwertion polynxorphism. Circtalation 1995;92:1387-8.

9. Myersion SG, Montgomery HE, Whittingham $M$ et al laft ventricular hypertrophy with excrcise and ACE gone insertion/daletion polymorphism: a randomized controlled vial ruith kexartin. Circulation 2001;103:226-30.

10. Montgomery $\mathrm{HE}$, Clarkwon $\mathrm{P}$, Dosllery $\mathrm{CM}$ et at Axwxiation of angioxensin-converting enzyme gene $\mathrm{V} / \mathrm{D}$ polymorphism with change in left ventricular mass in response: to physical training. Circulation 1997;96:741-7.

11. Fatini C, Guazzelli R, Mancti $P$ et al. RAS gencs influence exercise-induced left ventricular hypertrophy: an elitce athlctes study. Med Sc1 Sports Exerc 2000;32:1868-72.

12. Dict F, Graf C, Mahnke $\mathrm{N}$ et al. ACE and angicuensinesgen gene generypes and left ventricular miss in athletes. Eur J Clin liuest $2001 ; 31: 836-42$

13. Li JS, Sharifi AM, Schiffrin EL. Effect of ATl angiotensinreceptor blexckade: on structure and function of small arteric: in SHR. J Cardiouasc Pharmacol 1997;30:75-83.

14. Oliveira EM, Kricager JE. Chronic beta-adrenexceptor stimulation and cardiac hypertrophy with no induction of circulating renin. Eur / Pharmacol 2005;520:135-41.

15. Barauna VG, Magalhaes PC, Kricger JE, Oliveira EM. AT1 receptor paricipates in the cardiac: hypertrophy induexd by resistance training in rats. Am J Physiol Regul hutegr Comp Physiol 2008;295:R381-7.

16. Evangclista FS, Brum PC, Kricger JE. Duration-cxontrelled stvimming excrcise training induces curdiac hypertophy in nuice BrazJ Med Biol Res 2003;36:1751-9.

17. Laker MA, Horrath SM. Influcrnce of water temperature on oxygen uptakc by stvimming rats. I Appl Pbjosiol $1964 ; 19: 1215-8$.

18. Medeiros A, Oliveira EM, Gianolla $R$ Casarini DE Negrad $C E$, Brum PC. Sivimning training increascs cardiac: vagulatavity and induces cardiac hypertophy in rats. Braz J Med Biol Rex 2004:37:1909-17.

19. Kohira $K$, Tabuchi $Y$, Senanayake $P$, Brexinitan $K B$, Ferrario CM. Reasisessroxt of plasrna angikxensins measurement: cfferss of proceasc inhibitors and semple: handling proxedures. Peptides 19$) 1 ; 12: 1135-41$

20. Srerc PA. Studies on purified citrate-enzymes: metaIxolic interpretutions. Biochem Soc Symp 1968;27:11-21.

21. Bradford MM. A rapid and sensitive methex for the cuantitition of microgram quantitics of prexcein uilizing the principle: of prexcin-dyc binding. Anal Biochem 1976;72:248-54.

22. Icmitsu $M$, Macda S, Miyauchi T, Matsuda $M$, Tanaka H. Gence expression profiling of excrcice-induced cardiac hypenrophy in rats. Acla Physiol Scand 2005;185:259-70.

23. Evangelisea FS, Kricger JE. Small gence effect and excrcise training-induced cardiac hypertophy in mice: an Acx genc dosage study. Phystol Cienomics 2006;27:231-6.
24. Suacsen J, Pagard $R$, Hesipel P, Lijnen P, Vanheci L Amery A. Plasma renin sysecm during excreixc in normal men. I Appl Phyiol 1987;63:188-94.

25. Gecencen DI, Malhexra A, Butrick PM. Angicxensin recuptor 1 blexdade doss not prevent physicological cardiac hypertremhy in the adult rat. J App/ Physiol 1996;81:816-21

26. Pelliceia A, Mars in 13. Outer limits of the adjlece's heart, the cffect of gender, and relevance to the differcntial diagnexsis with primary esrdiac disceases. Cardiol Clin 1997;15:381-96.

27. Kaplan ML, Chcsilow Y, Vikstrom K et al. Cardiac adaptetions to chronic excreise in mice. $1 \mathrm{~m} J$ Physiol 1994;267:H1167-73.

28. Bjomstad $H$, Storstein L, Mexen H1), Hals $O$. Electrocardiongraphic findings of left, right and septal hypererephy in athletic students and sedentary conterols. Cardiology 1993;82:56-65.

29. Balcells $\mathrm{E}$, Meng $Q \mathrm{C}$, Johnsen WH, Jr., Oparil Si, 1)ell'Italia LJ. Angiotensin II formition from ACE and chymasse: in human and animal hearts: methoxls and specics comsideraticons. Am J Pbystol 1997;273:H1769-74.

30. McMullen JR, Shicsi T, Huang WY et al. The insulin-like grownh factor 1 recepur induces physiological heart growth via the phosphoinositicle 3-kinase(p1 10alpha) pathrvaly. J Biol Chem 2004;279:4782-93.

31. Butista EC, Ramalho ת), Reis PC et al. Swimming training exaceatates pathological cardic hyperterphy in kinin 132 receptor-deficjent micx. Int Immusuphamacol 2008;8:271-5.

32. Bruckschlegel G, Holmer $S R$, Jandeleit $K$ et al. Bleckade of the renin-angioxensin system in eardiac pressure-everload hypertrophy in rats. Hypertersston 1995;25:250-9.

33. Colleti AE, Kricter PA. Dispxsition of the angiotensin II receptor antagonist L-158,809 in rats and rhestsi monkcys. Drug Melab Dispas 1994;22:183-8.

34. Convertino VA, Keil LC, Grecenlesf JE. Plasinia volume, renin, and vasespressin responsics to graded cxercise after training. J Appl Physiol 1983;54:508-14.

35. Kexchen TA, Hartley LH, Rice TW, Mougcy EH, Jones LG, Masun JW. Renin, norepincphrine, and epinephrine responses to gradexl excrcixe. J Appl Phystol 1971;31:178-84.

36. Mergan $T$, Aubert JF, Brunner $H$. Interaction bxerveen scxlium intake, angiexcensin $\Pi$, and blexd pressurce as a causc: of cardiac hypertrophy. Am J Hyperents 2001;14:914-20.

37. Zhu $Z$, Zhu $S$, Wu $Z$ el al. Effect of sexlium on hlexxd pressurc, Grdiac hypereruphy, and angiexensin receptor expression in racs. Am J Hyperterss 2004;17:21-1.

38. Lil A, Veinot JP, Lex:nen FH. Prevention of high silt dictinduced cardiac hypertrophy and fibroxis by spironolactonc: $\Lambda \mathrm{m} /$ Hypertens 2003;16:319-23.

39. Yuan BX, Lecnen FH. Dictary sexdium intake and left ventricular hypertophy in normotensive rats. $1 \mathrm{~m} /$ Pbjsiol 1991;261:H1397-401.

40. Nagano M, Higaki J, Nakamura fi et al. Role of cirdiac: angiotensin 11 in isesprexerenol-induced left ventricular hyperurophy. Hypertension 1992;19:708-12. 


\section{American Heart Association.

\author{
Learn and Live.
}

\section{JOURNAL OF THE ANIERICAN HEART ASSOCIATION}

\section{Hypertension}

Aerobic exercise training induced LVH involves regulatory microRNAs, decreases ACE- ANG II with synergistic regulation of ACE2-ANG (1-7).

Tiago Fernandes, Nara Hashimoto, Flavio C Magalhaes, Adriana K Carmona, Jose Eduardo Krieger, Michael lan Phillips, and Edilamar M Oliveira

HYPERTENSION/2010/153577

You might find this additional information useful.

Topic Callections Articles on similar topics can be found in the following collections:

http://hypcr.ahajoumals.org/cgi/colleclion

Reviews You can subrnit your review by logging in at

hup://submit-hyper ahajoumals.org and entering the

Reviewer Area

Information about Hypertension can be found at:

http://hyper.ahajournals.org

To subscribe to Hypertension, pleasc go to hetp://hyper.ahajournals.org/subseriptions/

Disclaimer: The manuscript and its contents are confidential, intended for journal review purposes only, and not to be further disclosed. 
Acrobic exercise training induced LVH involves regulatory microRNAs, decreases ACEANG II with synergistic regulation of ACE2-ANG (1-7).

T. Fernandes ${ }^{1}$, N.Y. Hashimoto' ${ }^{1}$, F.C. Magalhães ${ }^{1}$, A.K. Carmona ${ }^{3}$, J.E. Krieger ${ }^{4}$, M.I. Phillips ${ }^{2}$, E.M. Oliveira ${ }^{1,2}$.

'Laboratory of Biochemistry, School of Physical Education and Sports, University of São Paulo, Brazil. ${ }^{2}$ Keck Graduate Institute, Claremont, CA, USA. ${ }^{3}$ Department of Biophysics, Paulista Medicine School, Federal University of São Paulo and ${ }^{4}$ Heart Institute (InCor), Medical School, University of São Paulo, São Paulo, Brazil.

Running head: Effect of aerobic exercise training on cardiac RAS.

Author for correspondence:

E.M. Oliveira

School of Physical Education and Sport, University of São Paulo.

Laboratory of Biochemistry of the Motor Activity.

Av. Professor Mello Moraes, 65-Cidade Universitária- São Paulo- SP

05508-900-Brazil

Phone: (5511) 3091-2118 FAX: (5511) 3813-5921

e-mail: edilamar@usp.br 


\section{Abstract}

Acrobic exercise training leads to a physiological, non pathological left ventricular hypertrophy. The biochemical and molecular mechanisms that underlie physiological cardiac hypertrophy versus pathological cardiac hypertrophy are unknown. We studied the role of microRNAs (miR 27a, 27b, 145 and 150) regulating the classic RAS and the novel cardiac RAS that includes ACE2 and Ang (1-7) in trained rats. Three groups, control (sedentary), swimming trained with protocol 1 (T1: low intensity, long duration training) and protocol 2 (T2: low intensity, high long duration aerobic training) were studied. Cardiac ACE activity (32\%) and protein expression (31\%), Ang II levels (46\%) were lower in T2, however AT1 mRNA levels (69\% in T1 and 99\% in T2) and protein expression (240\% in T1 and 300\% in T2) increase after training. A novel finding was the increase in AT2 receptors mRNA levels (220\%) and protein expression (332\%), ACE2 activity $(41 \%)$ and protein expression ( $91 \%)$, and Ang (1-7) levels (81\%) in the heart by T2. Changes in specific microRNAs by exercise targeted the genes of these RAS components. LVH induced by acrobic training involves microRNAs regulation, increased cardiac AT1 receptor without Ang II participating in the cardiac hypertrophy. The discovery that ACE2, Ang (1-7) and AT2 receptors are increased in the heart by exercise suggests that this non classic cardiac RAS counteracts the classic cardiac RAS. The counterbalance effect increases vasodilatation and cardiac hypertrophy in response to the demands of aerobic capacity for greater transport of blood and oxygen supply to the exercising cardiac muscle.

Key words: aerobic exercise training, cardiac hypertrophy, Renin Angiotensin System, microRNAs, Angiotensin II receptors, ACE2, Ang (1-7). 


\section{INTRODUCTION}

Left ventricular hypertrophy (LVH) induced by aerobic exercise training is physiological and an important compensatory mechanism in response to chronic increases in hemodynamic overload. This phenotype is associated with sarcomeres added in series to lengthen the cardiac cell, as well as in parallel. The increased cross sectional area contributes to increased ventricular stroke volume and cardiac output which improves aerobic capacity. In contrast, pathological LVH in cardiovascular diseases (CVD) is associated with increased fibrosis, and lowered aerobic capacity leading to high mortality (1-3).

Several studies have demonstrated that the Renin Angiotensin System (RAS) plays an important role in the progression of LVH (4-6). However, there are only limited data about the mechanisms of exercise training on RAS and LVH. The aim of this study was to elucidate these mechanisms of exercise training on physiological LVH.

Under pathological conditions such as, arterial hypertension $(7,8)$, myocardial infarction $(9,10)$ and heart failure $(11)$ increased local cardiac RAS levels, represented by augmented angiotensinogen (AGT), angiotensin converting enzyme I (ACE) and angiotensin II (Ang II), producing pathological LVH. Blockade of the classical RAS promotes therapeutic benefits to patients with essential hypertension and CVD (8). Cardiac Ang $\Pi$ is implicated in fibrosis induction, but is not required for LVH (12). In transgenic animal's models for RAS components (13-15) and AT1R activation by mechanical stress (16-18), LVH is produced without the participation of Ang II. A novel cardiac RAS which includes angiotensin converting enzyme 2 (ACE2) and has a pivotal role in the Angiotensin-(1-7) formation and may oppose the classical RAS. ACE2 is an essential regulator of heart function (19) and is implicated in vasodilatation and control of fibrosis (20-23). Previous findings suggest that ACE2 maintains the important balance 
between the Ang II and Ang (1-7), favoring the cardiovascular homeostasis. However, the role of exercise training on cardiac ACE2-Ang (1-7) axis is unknown.

The gene expression are regulated by a new class of RNAs called microRNAs (miRNAs), recently discovered. MiRNAs are endogenous, small and noncoding RNA, that often act as negative regulators of gene expression by inhibition the translation or promoting the degradation of target mRNAs. Recent studies have shown roles for miRNAs in numerous forms of CVD and pathological cardiac hypertrophy $(24,25)$, however miRNAs may be important for normal development and physiological process as cardiac hypertrophy induced by aerobic exercise training.

Interestingly, our group has recently shown that ATIR blockade prevents physiological LVH induced by resistance training (18) as well as by aerobic exercise training (26). Moreover, aerobic exercise training promoted LVH by cardiac RAS stimulation independent of the systemic RAS (26). However, the biochemical and molecular adaptations of aerobic exercise training on cardiac RAS were not investigated. We hypothesize that exercise training alters specific microRNAs that regulate their target cardiac RAS genes and the balance of classic RAS genes and novel RAS genes (ACE2) contribute to physiological LVH.

\section{MATERIAL AND METHODS}

\section{Animal Care}

Female normotensive Wistar rats (190 to $220 \mathrm{~g}, \mathrm{n}=42$ ) were used and handled according to approved Institutional guidelines. The animals were housed 3-5 per cage in a controlled room temperature $\left(22^{\circ} \mathrm{C}\right)$ with a 12 -h dark-light cycle and fed standard rat chow having access to water ad libitum. All protocols and surgical procedures used were in accordance with the National Institutes of Health (NIH) Guide for the Care and Use of Laboratory Animals and were approved 
by the Ethics Committee of the School of Physical Education and Sport of the University of São Paulo.

The rats were divided randomly into three experimental groups, each with 14 rats: sedentary control $(S, n=7)$, swimming trained with protocol $1(T 1, n=7)$ and swimming trained with protocol 2 (T2, n=7), as described below. Each group was subdivided into 2 groups, one for hemodynamic, biochemical, and molecular studies, and the other for morphological and histological studies.

\section{Exercise Training Protocols}

Protocol 1 (T1) low intensity, long duration exercise: training consisted of swimming sessions of 60-min duration, 5 days a week, for 10 weeks, which were carried out between 11:30 AM and 1:30 PM. Protocol 2 (T2) low intensity, high long duration exercise: Animals assigned to $\mathrm{T} 2$ performed the same swimming training protocol as T1 until the end of the $8^{\text {th }}$ week. On the $9^{\text {th }}$ week rats trained twice a day, swimming sessions of sixty-minute duration with four hours interval between sessions. In that week swimming sessions were carried on from 07:30 to 08:30 $\mathrm{AM}$ and from 12:30 $\mathrm{AM}$ to 1:30 PM. On the $10^{\text {th }}$ week rats trained three times a day, with sessions of sixty-minute duration with four hours interval between sessions. In that week swimming sessions were carried on from 07:30 to 08:30 AM, from 12:30 AM to 1:30 PM, and from 5:30 to 6:30 PM. The aim of increasing training frequency (protocol 2) was to induce the magnitude of cardiac hypertrophy. This protocol has already been used previously in our laboratory (26).

\section{MicroRNA Microarray}

RNA from two animals in each group was pooled and used for miRNA expression analysis (LC Science, Houston, TX) with the Agilent platform. Data are expressed in arbitrary units of intensity (u.a) 
For detailed Material and Methods, please see the online data supplement, available at http://hyper.ahajournals.org.

\section{Statistical analysis}

Results are represented as mean \pm SD. Statistical analysis was performed using one-way ANOVA. $P$ values $<0.05$ were accepted as statistically significant. Tukey's post hoc test was used for individual comparisons between means when a significant change was observed with ANOVA.

\section{RESULTS}

\section{Hemodynamic Parameters}

Table 1 summarizes systolic blood pressure (SBP), diastolic blood pressure (DBP), mean blood pressure (MBP) and heart rate (HR) results of the groups S, T1 and T2. There was no difference of blood pressure among three groups. However, HR decreased significantly after 10 weeks of swimming training in $\mathrm{T} 1(301.2 \pm 15.3$ beats $/ \mathrm{min})$ and $\mathrm{T} 2(309 \pm 14$ beats $/ \mathrm{min})$ groups compared to $\mathrm{S}$ group $(344.8 \pm 12.1$ beats $/ \mathrm{min}, \mathrm{P}<0.05)$. The development of resting bradycardia in the trained animals indicates that aerobic conditioning was achieved with these two aerobic exercise training protocols.

\section{Cardiac Hypertrophy}

Body weight $(\mathrm{BW})$ before and after swimming training was similar among all the studied groups. LV and RV/BW ratio was used as an index of hypertrophy. The absolute values referring to $\mathrm{BW}, \mathrm{LV} / \mathrm{BW}$ and $\mathrm{RV} / \mathrm{BW}$ in all groups of rats are summarized in the Table 2. Left ventricle hypertrophy (LVH) obtained by T1 and T2 training protocol was $13 \%(2.8 \pm 0.14 \mathrm{mg} / \mathrm{g} ; \mathrm{P}<0.05)$ and $27 \%$ (3.2 $\pm 0.12 \mathrm{mg} / \mathrm{g} ; \mathbf{P}<0.01)$, respectively, compared to $\mathrm{S}$ group $(2.5 \pm 0.06 \mathrm{mg} / \mathrm{g})$. Right ventricle hypertrophy (RVH) obtained by $\mathrm{T} 1$ and $\mathrm{T} 2$ training protocol was $15 \%(0.68 \pm 0.06 \mathrm{mg} / \mathrm{g}$; 
$\mathrm{P}<0.05)$ and $35 \%(0.80 \pm 0.08 \mathrm{mg} / \mathrm{g} ; \mathbf{P}<0.01)$, respectively, compared to $\mathrm{S}$ group $(0.59 \pm 0.04$

$\mathrm{mg} / \mathrm{g}$ ). The increase in LV/BW ratio observed with swimming training was further confirmed by the increase of $\mathrm{LV}$ myocytes diameter in $\mathrm{T} 1(13.2 \pm 1.3 \mu \mathrm{g})$ and $\mathrm{T} 2(14.4 \pm 1.3 \mu \mathrm{g})$ group compared to $S$ group $(11 \pm 1.1 \mu \mathrm{g}), \mathrm{P}<0.05$ (Table 2).

\section{Molecular Markers of Pathological LVH}

It is well known that pathological cardiac hypertrophy is characterized by the induction of genes normally expressed during fetal development, such as, atrial natriuretic factor (ANF), skeletal muscle $\alpha$ - actin and decreased the ratio of $\alpha / \beta$-myosin heavy chain (MHC). The mRNA levels of these 4 genes were assessed in the LV of sedentary (S) and trained groups (T1 and T2) by real time RT-PCR. Figure 1 shows that swimming training not modified the gene expression of ANF. Similar, T1 not changed the gene levels of skeletal $\alpha$ - actin and $\alpha / \beta$ - MHC, however the T2 significantly lowered $53 \%$ the LV levels of skeletal $\alpha$ - actin and it increased $98 \%$ the LV levels of $\alpha / \beta-\mathrm{MHC}$.

\section{RAS Biochemical Analysis}

To evaluate the role of swimming exercise training on systemic RAS, we measured the serum ACE activity and plasma renin activity, two important enzymes involved in the systemic Ang II synthesis. Figure $2 \mathrm{~A}$ shows that serum ACE activity was increased $3.8 \%$ in $\mathrm{T} 1(\mathrm{P}=\mathrm{NS})$ and $23.5 \%$ in $\mathrm{T} 2(\mathrm{P}<0.05)$ compared to $\mathrm{S}$ group. In parallel, as shown in Figure $2 \mathrm{~A}$, plasma renin activity also was increased $20 \%$ in $\mathrm{Tl}(\mathrm{P}=\mathrm{NS})$ and $126 \%$ in T2 $(\mathrm{P}<0.01)$ compared to $\mathrm{S}$ group. Note that systemic RAS was not modified in TI group; this effect was only observed with increased exercise frequency, represented by $\mathrm{T} 2$ group.

In contrast, Figure 2B shows that local cardiac ACE activity was reduced $11 \%(\mathrm{P}=\mathrm{NS})$ and $15 \%(\mathrm{P}=\mathrm{NS})$ in RV and LV, respectively, in $\mathrm{T} 1$ group and $40 \%(\mathrm{P}<0.05)$ and $32 \%(\mathrm{P}<0.05)$ in RV and LV, respectively, in T2 group compared to S group. Interestingly, Figure 2B also 
shows that LV ACE2 activity was increased $12 \%$ in T1 $(1,708 \pm 354 \mathrm{uF} / \mathrm{min} / \mathrm{mg}, \mathrm{P}=\mathrm{NS})$ and $41 \%$ in T2 $(2,160 \pm 218 \mathrm{uF} / \mathrm{min} / \mathrm{mg}, \mathrm{P}<0.01)$ when compared with $\mathrm{S}$ group $(1,531 \pm 174 \mathrm{uFmin} / \mathrm{mg})$.

\section{RAS Molecular Analysis}

In order, to test whether swimming exercise training modulates cardiac RAS gene expression, we assessed by real time RT-PCR of ACE, ACE2, ATIR and AT2R gene expression in the heart. Although not significant, mRNA levels of ACE showed a small decrease and ACE2 mRNA a small increase in both trained groups (data not shown). AT2 receptor gene expression was increased $26 \%(\mathrm{P}=\mathrm{NS})$ in $\mathrm{T} 1$ and $332 \%$ in $\mathrm{T} 2(\mathrm{P}<0.001)$, $\mathrm{T} 1$ was different from $\mathrm{T} 2$ $(\mathrm{P}<0.001)$ (Figure 5E). Also, AT1 receptor gene expression increased in T1 $(69 \%, \mathrm{P}<0.05)$ and T2 $(99 \%, \mathrm{P}<0.01)$ when compared with $\mathrm{S}$ group (Figure 5D).

Similar results were obtained for RAS protein expression determined by Western blotting. Figure 3B, shows swimming exercise training decreased cardiac ACE protein expression $22 \%$ ( $\mathrm{P}=\mathrm{NS})$ in $\mathrm{T} 1$ and $31 \%$ in $\mathrm{T} 2(\mathrm{P}<0.05)$ compared to $\mathrm{S}$ group. As ACE is responsible for Ang II generation, this reduction was followed by decreased of Ang $\amalg$ levels $26 \%(\mathrm{P}=\mathrm{NS})$ in $\mathrm{T} 1$ and $44 \%$ in T2 $(\mathrm{P}<0.05)$ compared to $\mathrm{S}$ group (Figure 3C). Furthermore, Ang II concentration evaluated by ELISA confirmed this reduction with $26 \%$ in $\mathrm{T} 1(2.32 \pm 0.55 \mathrm{pg} / \mathrm{mg}, \mathrm{P}=\mathrm{NS})$ and $46 \%$ in $\mathrm{T} 2(1.71 \pm 0.40 \mathrm{pg} / \mathrm{mg}, \mathrm{P}<0.05)$ when compared to $\mathrm{S}$ group $(3.15 \pm 1.35 \mathrm{pg} / \mathrm{mg})$ (Figure 3D), indicating an attenuation of the ACE-Ang II axis induced by swimming exercise training.

Swimming exercise training also had an effect on the protein expression of the novel RAS, ACE2 and Ang (1-7) in the heart. As shown in Figure 4B, swimming training increased ACE2 protein expression in both trained groups ( $68 \%$ in $\mathrm{T} 1$ and $91 \%$ in $\mathrm{T} 2, \mathrm{P}<0.05)$, compared with the S group. Ang (1-7) formation was increased (55\% in $\mathrm{T} 1, \mathrm{P}=\mathrm{NS}$ and $81 \%$ in $\mathrm{T} 2, \mathrm{P}<0.05$; Figure 4C) compared to S group. Figure 4D shows the increase of the Ang (1-7)/ Ang II ratio in 
both trained groups $(80 \%$ in $\mathrm{T} 1, \mathrm{P}<0.05$ and $190 \% \mathrm{~T} 2, \mathrm{P}<0.01)$ compared with the $\mathrm{S}$ group, suggesting increased Ang (1-7) formation from Ang II mediated by aerobic training.

Protein expression of ATI receptor, in concert with the increase in ATI mRNA levels, was 2.4 fold greater in $\mathrm{Tl}(\mathrm{P}<0.05)$ and 3.0 fold greater in $\mathrm{T} 2(\mathrm{P}<0.05)$ compared to the $\mathrm{S}$ group (Figure 5B). The AT2 receptor also was increased 1.6 fold in $\mathrm{T} 1(\mathrm{P}=\mathrm{NS})$ and 2.2 fold $(\mathrm{P}<0.05)$ in T2 (Figure 5C), which is in concert with the increase in AT2 mRNA in the heart.

\section{MicroRNA Analysis}

MicroRNA array analysis was restricted to those miRNAs that had a significant change from baseline. MicroRNAs that targeted RAS genes were studied for their expression in each training group. Figure 6A shows microRNAs targeting ACE: miR27a in S group the relative expression value was $1,760 \pm 108$. In $\mathrm{T} 1$ group the value was $2,225 \pm 78,(26 \%$ increase from $\mathrm{S}$; $\mathrm{P}>0.05)$ and in $\mathrm{T} 2$ group the expression was $3,218 \pm 30,(83 \%$ increase from $\mathrm{S} ; \mathrm{P}<0.01)$. Also, T1 was different from $\mathrm{T} 2(\mathrm{P}<0.01)$. Similarly, miR27b in $\mathrm{S}$ group the relative expression values was $3,409 \pm 89$. In $\mathrm{T} 1$ group the value was $4,341 \pm 124,(27 \%$ increase from $\mathrm{S} ; \mathrm{P}<0.05)$ and in $\mathrm{T} 2$ group the expression was $4,939 \pm 59$, $(45 \%$ increase from $\mathrm{S} ; \mathrm{P}<0.01)$. Also, $\mathrm{Tl}$ was different from $\mathrm{T} 2$ $(\mathrm{P}<0.01)$. Figure 6B shows microRNA targeting ACE2: miR 150 in $\mathrm{S}$ group the relative expression value was $4,078 \pm 170, T 1=3,591 \pm 103$ was not significant compare to $S$, however in T2 group the expression was $2,512 \pm 28$, (38\% decrease from $\mathrm{S} ; \mathrm{P}<0.01)$. Also, T1 was different from $\mathrm{T} 2(\mathrm{P}<0.01)$. MiR145 in $\mathrm{S}$ group the relative expression value was $8,806 \pm 220$. In $\mathrm{T} 1$ group the value was $10,138 \pm 198,(15 \%$ increase from $\mathrm{S} ; \mathrm{P}<0.05)$, and in $\mathrm{T} 2$ group the expression was 4,627 $\pm 61,(47 \%$ decrease from $\mathrm{S} ; \mathrm{P}<0.001)$. Also, $\mathrm{T} 1$ was different from $\mathrm{T} 2(\mathrm{P}<0.01)$.

Figure 6C shows microRNA targeting AT1 receptor: miR350 in S group the relative expression value was $195 \pm 24$. In Tlgroup the values was $89 \pm 7$, (55\% decrease from $S ; P<0.05)$, and in T2group the expression was $69 \pm 7$, (64\% decrease from $\mathrm{S} ; \mathrm{P}<0.05)$. 


\section{DISCUSSION}

Our results show that swimming exercise training 1) induced physiological LVH 2) is not correlated with pathological cardiac hypertrophy markers, 3) decreased cardiac ACE and Ang I levels, 4) enhanced AT 1 receptor expression, 5) increased AT2 receptors expression, 6) increased ACE2 activity and protein expression in the left ventricle augmenting Ang (1-7) formation, 7) alterations of specific microRNAs targeted to RAS genes.

In contrast to markers for pathological hypertrophy (31), physiological hypertrophy reported here is not associated with activation of fetal genes, such as, atrial natriuretic factor (ANF), skeletal muscle $\alpha$ - actin and $\beta$-myosin heavy chain ( $\beta$-MHC). Even in the T2 group there were no pathological hypertrophy markers.

Furthermore, the study confirmed the exercise-associated adaptations like resting bradycardia indicating that aerobic condition was achieved $(26,27)$.

Ang II has been proposed as a direct cardiac hypertrophic factor, however, recent evidence suggest that several transgenic animal models with increased formation of local Ang II in the heart do not develop hypertrophy, but show increased fibrosis and present hypertrophy only when excess of cardiac Ang II enters the circulation and causes increase in blood pressure (12-14). Xiao et al. (15) reported that mice expressing ACE only in the heart showed that increased cardiac angiotensin $I I$ is not associated with cardiac hypertrophy. In addition, our group also demonstrated in transgenic mice harboring one, two, three or four ACE gene copies that the magnitude of physiological LVH induced by swimming training was not associated with ACE levels (17). Taken together, these results and ours suggest that Ang II is not a direct hypertrophic factor in the cardiac tissue.

Swimming exercise training increased AT1 receptor levels and promotes physiological LVH without participation of Ang II. The results in the present study, supports a similar AT1 
receptor increase we reported with resistance training (18) and our previous findings of losartan treatment blocking the LVH in this two swimming training protocols (26). Therefore, there is cvidence to demonstrate that cardiac RAS changes are critical for the development of physiological LVH in the models. The mechanism for overexpressing AT1 receptor and causing cardiac hypertrophy may be because AT1 receptor has a transactivating effect on the epidermal growth factor receptor (EGFR) (32). Inhibiting the EFGR prevents Ang II induced LVH in rats (33). Zou et al. (16) showed in vitro and in vivo that AT1 receptor is a mechanical sensor and converts mechanical stress into a biochemical signal inducing LVH without involvement of Ang II. Further, Yasuda et al. (34) showed that mechanical stress activates an anticlockwise rotation of transmembrane 7 domain of AT1 receptor causing a conformational change of the receptor independently of Ang II. We report here for first time, that aerobic exercise training increased AT2 receptor genes and protein expression in the left ventricle. Studies suggest that AT1 and AT2 receptor may serve opposing functions in the heart, although exhibiting the same ligand binding affinity $(4,12)$. In spite of the function of AT1 receptors being well documented, the role of AT2 receptors in cardiac regulation is not fully investigated. AT2 receptor has been associated with dephosphorylation and inactivation of growth factor-activated MAPK and inactivation of ERK $1 / 2$ providing a protective role in the heart (35). Furthermore, AT2 receptor increases generation of nitric oxide and bradykinin, inducing vasodilation (36). Yang et al. (37) demonstrated that transgenic animals overexpressing AT2 receptors preserve left ventricle function after myocardial infarction. Our results suggest that AT2 receptor has a cardioprotective role opposing deleterious cardiac remodeling in CVD. In contrast to pathological condition, the present study showed an increased AT2 receptor expression in the heart that could be involved in the vasodilatation induced by aerobic exercise training. This modulation would increases transport of blood and oxygen to the exercising cardiac muscle conducing to high performance. 
To our knowledge, the present study is the first to demonstrate the effect of aerobic exercise training on ACE2 and Ang (1-7) in the heart of normotensive rats. The present study shows that compared with sedentary control animals, trained groups increased ACE2 activity and protein expression in the left ventricle augmenting Ang (1-7) formation. The discovery of ACE2 helped understand that classical RAS has a reciprocal side, the novel RAS. ACE2 cleaves Ang I to generate the inactive Ang (1-9) peptide, but the preferred pathway with 500 fold greater efficiency is Ang $\Pi$ to generate the vasodilator Ang (1-7) $(6,38,39)$. In hypertension, a decrease in ACE2 mRNA and protein expression, leads to increases in local Ang II levels and might reduce myocardial blood flow preferentially via coronary vasoconstriction or microcirculatory dysfunction. However, with the use of ACE1 inhibitor or AT1R blocker, the ACE2 level is enhanced (38-40). Transgenic animal models overexpressing cardiac ACE2 by systemic lentiviral delivery resulted in a regression of pathological LVH in hypertensive rats (21). Ishiyama et al. (20) showed that the use of AT1 receptor blocker augmented plasma Ang (1-7)/Ang II ratio suggesting increased generation of Ang (1-7) from Ang II. In addition, Crackower et al. (19) showed that deletion of ACE2 in mice resulted in elevated cardiac and plasma Ang $\amalg$, together with impaired cardiac contractility and exhibited left ventricle dilatation. Therefore, ACE2 might protect against LVH by reduction of Ang II concentration and increase of Ang (1-7) generation $(6,20-23)$. The vasodilator effects of the ACE2-Ang (1-7) axis are mediated through different vasoactive release, probably nitric oxide, prostaglandins and bradykinin $(41,42)$.

Thus the mechanism of aerobic exercise training to prevent or treatment $\mathrm{LVH}$ is by diminished vascular resistance and consequently increased cardiac flow, in part, due to the reduction ACE and Ang II levels and an increase in Ang (1-7) by elevated ACE2 expression. In fact, the swimming training promoted increased Ang (1-7)/Ang II ratio in the heart demonstrating augmented of the vasodilator by decreased vasoconstrictor. 
This study also reveals potential molecular mechanisms for the results. MicroRNAs target multiple genes but targeted genes are controlled by specific miRNAs $(24,25)$. In rats, ACE is targeted by miR27a and miR27b, which were significantly expressed in the training groups. Both miRNAs had more expression with more exercise volume. Increased expression indicates inhibition of the target gene by miRNA. This appears to be the case with miR27a and miR27b as ACE decreased in $22 \%(\mathrm{~T} 1)$ and $31 \%$ (T2) compared to control, while miR27a increased $26 \%$ (T1) and $88 \%$ (T2) compared to control and miR2 $7 \mathrm{~b}$ increased $27 \%(\mathrm{~T} 1)$ and $44 \%(\mathrm{~T} 2)$. By the same principle, decreased expression of miRNAs reflects increased expression of genes and this appears to be the case for the AT1 receptor genes where training decrease miR350, which target AT1 receptor. The ACE2 gene is targeted by miR150 and miR 145 and, in the T2 group, where the expression of ACE2 was highest, both microRNAs were at their lowest level of expression compared to control or $\mathrm{T} 1$, indicating that more aerobic exercise frequency affected miR 150 and miR145.

Exercise is widely recognized as an important lifestyle factor in improving cardiac health. This study reveals some of the biochemical and molecular mechanisms of aerobic exercise training on physiological, non pathological, cardiac hypertrophy. These include increased cardiac ATl receptor activation and a cascade of events, including a decrease in classical ACE-Ang II axis counterbalanced by an increase in the novel ACE2-Ang (1-7) axis. Exercise influences these changes, by altering the expression of specific microRNAs targeting RAS genes. Together these effects provide more aerobic capacity needed for the exercised heart.

\section{PERSPECTIVES}

It has long been recognized that there is a difference in outcomes between physiological and pathological LVH. This study shows that aerobic exercise induced LVH is associated with 
changes in specific microRNA. These microRNA target the RAS and interestingly are inversely associated in this study with decreased ACE and increased ACE2. While further studies need to be down on inhibiting these microRNA the results suggest that a difference between physiological and pathological LVH may be due to the role of microRNA releasing ACE2 and that the ACE2 -(Ang 1-7) axis could be developed for reducing pathological LVH.

\section{SOURCES OF FUNDING}

Oliveira EM was the recipient of a CNPq-PDE Fellowship (No.200994/2007-7).

Fernandes T was the recipient of a FAPESP Fellowship (No.07/56771-4) and Hashimoto NY was the recipient of a CAPES Fellowship. Dr MI Phillips was supported by grant from NIH 1 R0 I HL 077602 .

\section{DISCLOUSERS}

None.

\section{REFERENCES}

1. Dorn II GW. The fuzzy logic of physiological cardiac hypertrophy. Hyperiension. 2007; 49: 962-970.

2. Heineke J, Molkentin JD. Regulation of cardiac hypertrophy by intracellular signaling pathways. Nat Rev Mol Cell Biol. 2006; 7: 589-600.

3. McMullen JR, Jennings GL. Differences between pathological and physiological cardiac hypertrophy: novel therapeutic strategies to treat heart failure. Clin Exp Pharmacol Physiol. $2007 ; 34: 255-262$. 
4. Dostal DE. The cardiac renin-angiotensin system: novel signaling mechanisms related to cardiac growth and function. Regulatory Peptides. 2000; 91:1-11.

5. Shikata C, Takeda A, Takeda N. Effect of an ACE inhibitor and an AT1 receptor antagonist on cardiac hypertrophy. Mol Cell Biochem. 2003; 248: 197-202.

6. Grobe JL, Mecca AP, Lingis M, Shenoy V, Bolton TA, Machado JM, Speth RC, Raizada MK, Katovich MJ. Prevention of angiotensin II-induced cardiac remodeling by angiotensin-(1-7). Am J Physiol Heart Circ Physiol. 2007; 292: 736-742.

7. Kang N, Walther T, Tian XL, Bohlender J, Fukamizu A, Ganten D, Bader M. Reduced hypertension-induced end-organ damage in mice lacking cardiac and renal angiotensinogen synthesis. J Mol Med. 2002; 80: 359-366.

8. Dahlof B, Zanchetti A, Diez J, Nicholls MG, Yu CM, Barrios V, Aurup P, Smith RD, Johansson M; For the REGAAL Study Investigators. Effects of losartan and atenolol on left ventricular mass and neurohormonal profile in patients with essential hypertension and left ventricular hypertrophy. J Hypertension. 2002; 20: 1855-1864.

9. Fraccarollo D, Galuppo P, Schmidt I, Ertl G, Bauersachs J. Additive amelioration of left ventricular remodeling and molecular alterations by combined aldosterone and angiotensin receptor blockade after myocardial infarction. Cardiovasc Res. 2005; 67: 97-105.

10. Lal A, Veinot JP, Ganten D, Leenen FHH. Prevention of cardiac remodeling after myocardial infarction in transgenic rats deficient in brain angiotensinogen. $J$ Mol Cell Cardiol. 2005; 39: 521-529.

11. Ferreira JC, Bacurau AV, Evangelista FS, Coelho MA, Oliveira EM, Casarini DE, Krieger JE, Brum PC. The role of local and systemic renin angiotensin system activation in a genetic model of sympathetic hyperactivity-induced heart failure in mice. Am J Physiol Regul Integr Comp Physiol. 2008; 294: 26-32. 
12. Reudelhuber TL, Bernstein KE, Delafontaine P. Is angiotensin II a director mediator of left ventricular hypertrophy? Time for another look. Hypertension. 2007; 49: 1196-1201.

13. Van Kats JP, Methot D, Paradis P, Silversides DW, Reudelhuber TL. Use of a biological peptide pump to study chronic peptide hormone action in transgenic mice. Direct and indirect effects of angiotensin II on the heart. J Biol Chem. 2001; 276: 44012-44017.

14. Xiao HD, Fuchs S, Campbell DJ, Lewis W, Dudley SC Jr, Kasi VS, Hoit BD, Keshelava G, Zhao H, Capecchi Mr, Bernstein KE. Mice with cardiac-restricted angiotensin-converting enzyme (ACE) have atrial enlargement, cardiac arrhythmia, and sudden death. Am J Pathol. 2004; 165: 1019-1032.

15. Xiao HD, Fuchs S, Bernstein EA, Li P, Campbell DJ, and Bernstein KE. Mice expressing ACE only in the heart show that increased cardiac angiotensin II is not associated with cardiac hypertrophy. Am J Physiol Heart Circ Physiol. 2008; 294: 659-667.

16. Zou Y, Akazawa H, Qin Y, Sano M, Takano H, Minamino T, Makita N, Iwanaga K, Zhu W, Kudoh S, Toko H, Tamura K, Kihara M, Nagai T, Fukamizu A, Umemura S, Iiri T, Fujita T, and Komuro I. Mechanical stress activates angiotensin II type 1 receptor without the involvement of angiotensin II. Nat Cell Biol. 2004; 6:499-506.

17. Evangelista FS, Krieger JE. Small gene effect and exercise training-induced cardiac hypertrophy in mice: an Ace gene dosage study. Physiol Genomics. 2006; 27: 231-236.

18. Barauna VG, Magalhaes FC, Krieger JE, Oliveira EM. ATI receptor participates in the cardiac hypertrophy induced by resistance training in rats. Am J Physiol Regul Integr Comp Physiol. 2008; 295: R381-387.

19. Crackower MA, Sarao R, Oudit GY, Yagil C, Kozieradzki I, Scanga SE, Oliveira-dosSantos JA, Da Costa J, Zhang L, Pei Y, Scholey J, Ferrario CM, Manoukian AS, Chappell MC, 
Backx PH, Yagil Y, Penninger JM. Angiotensin-converting enzyme 2 is an essential regulator of hcart function. Nature. 2002; 417: 822-828.

20. Ishiyama Y, Gallagher PE, Averill DB, Tallant EA, Brosnihan KB, Ferrario CM. Upregulation of angiotensin converting enzyme-2 after myocardial infarction by blockade of angiotensin II receptors. Hypertension. 2004; 43: 970-976.

21. Huentelman MJ, Grobe Jl, Vasquez J, Stewart JM, Mecca AP, Katovich MJ, Ferrario CM, Raizada MK. Protection from angiotensin $\Pi$-induced cardiac hypertrophy and fibrosis by systemic lentiviral delivery of ACE2 in rats. Exp Physiol. 2005; 90: 783-790.

22. Díez-Freire C, Vasquez J, Correa de Adjounian MF; Ferrari MF; Yuan L, Silver X, Torres R, Raizada MK. ACE2 gene transfer attenuates hypertension-linked pathophysiological changes in the SHR. Physiol Genomics. 2006; 27: 12-19.

23. Raizada MK and Ferreira AJ. ACE2: A New Target for Cardiovascular Disease Therapeutics. J Cardiovasc Pharmacol. 2007; 50: 112-119.

24. Van Rooij E, Olson EN. Micro RNAs: powerful new regulators of heart disease and provocative therapeutic agents. J Clin Invest. 2007; 117: 2369-2376

25. Van Rooij E, Marshall WS, Olson EN. Toward microRNA-based therapeutics for heart disease. The sense in antisense. Circ Res. 2008; 103:919-928.

26. Oliveira EM, Sasaki MS, Cerêncio M, Baraúna VG, Krieger JE. Local renin-angiotensin system regulates left ventricular hypertrophy induced by swimming training independent of circulating renin: a pharmacological study. J Renin Angiotensin Aldosterone Syst. 2009; 10:1527. Medeiros A, Oliveira EM, Gianolla R, Casarini DE, Negrão CE, Brum PC. Swimming training increases cardiac vagal activity and induces cardiac hypertrophy in rats. Braz J Med Biol Res. 2004; 37: 1909-1917. 
28. Kohara K, Tabuchi Y, Senanayake P, Brosnihan KB, Ferrario CM. Reassessment of plasma angiotensins measurement: effects of protease inhibitors and sample handling procedures. Peptides. 1991; 12: 1135-1141.

29. Alves MF, Araujo MC, Juliano MA, Oliveira EM, Krieger JE, Casarini DE, Juliano L, and Carmona AK. A continuous fluorescent assay for the determination of plasma and tissue angiotensin I-converting enzyme activity. Braz J Med Biol Res. 2005; 38: 861-868.

30. Bradford MM. A rapid and sensitive method for the quantitation of microgram quantities of protein utilizing the principle of protein-dye binding. Anal Biochem. 1976; 72: 248-254.

31. Izumo S, Nadal-Ginard BE, Mahdavi V. Protooncogene induction and reprogramming of ( $a r d i a c$ gene expression produced by pressure overload. Proc Natl Acad Sci U S A. 1988; 85: 339-343.

32. Kagiyama S, Eguchi S, Frank G, Inagami T, Zhang CL, Phillips MI Angiotensin II induced cardiac hypertrophy and hypertension are attenuated by epidermal growth factor receptor antisense. Circulation. 2002; 106:909-912.

33. Kagiyama S, Qian K, Kagiyama T, Phillips MI. Antisense to epidermal growth factor receptor prevents the development of left ventricular hypertrophy. Hypertension. 2003; $41: 824$ 829.

34. Yasuda N, Miura S, Akazawa H, Tanaka T, Qin Y, Kiya Y, Imaizumi S, Fujino M, Ito K, Zou Y, Fukuhara S, Kunimoto S, Fukuzaki K, Sato T, Ge J, Mochizuki N, Nakaya H, Saku K, and Komuro I. Conformational switch of angiotensin $I I$ type 1 receptor underlying mechanical stress-induced activation. EMBO Rep. 2008; 9:179-186.

35. Horiuchi M, Akishita M, Dzau VJ. Recent progress in angiotensin II type 2 receptor research in the cardiovascular system. Hypertension. 1999; 33: 613-621. 
36. Tsutsumi Y, Matsubara H, Masaki H, Kurihara H, Murasawa S, Takai S, Miyazaki M, Nozawa Y, Ozono R, Nakagawa K, Miwa T, Kawada N, Mori Y, Shibasaki Y, Tanaka Y, Fujiyama S, Koyama Y, Fujiyama A, Takahashi H, Iwasaka T. Angiotensin II type 2 receptor overexpression activates the vascular kinin system and causes vasodilation. $J$ Clin Invest. 1999; 104:925-935.

37. Yang Z, Bove CM, French BA, Epstein FH, Berr SS, DiMaria JM, Gibson JJ, Carey RM, Kramer CM. Angiotensin II type 2 receptor overexpression preserves left ventricular function after myocardial infarction. Circulation. 2002; 106: 106-111.

38. Ferrario CM, Jessup J, Chappell MC, Averill DB, Brosnihan KB, Tallant EA, Diz DI, Gallagher PE. Effect of angiotensin-converting enzyme inhibition and angiotensin II receptor blockers on cardiac angiotensin-converting enzyme 2. Circulation. 2005; 111 : 2605-2610.

39. Chappell MC. Emerging Evidence for a Functional Angiotensin-Converting Enzyme 2Angiotensin-(1-7)-Mas Receptor Axis: More Than Regulation of Blood Pressure? Hypertension. 2007; 50: 596-599.

40. Ferrario CM. Angiotensin-Converting Enzyme 2 and Angiotensin-(1-7): An Evolving Story in Cardiovascular Regulation. Hypertension. 2006; 47: 515-521.

41. Li P, Chappell MC, Ferrario CM, Brosnihan KB. Angiotensin-(1-7) augments bradykinininduced vasodilation by competing with ACE and realizing nitric oxide. Hypertension. 1997; 29: $394-400$.

42. Carvalho MB, Duarte FV, Faria-Silva R, Fauler B, da Mata Machado LT, de Paula RD, Campagnole-Santos MJ, Santos RA. Evidence for Mas-mediated bradykinin potentiation by the angiotensin-(1-7) nonpeptide mimic AVE 0991 in normotensive rats. Hypertension. 2007; 50: $762-767$. 


\section{FIGURE LEGEND}

Figure 1. Effect of swimming exercise training on gene expression of molecular markers of pathological cardiac hypertrophy evaluated by real time RT-PCR. Targeted genes were normalized by cyclophilin mRNA. Groups: S- sedentary, T1-swimming training protocol I group and T2-swimming training protocol 2. Data are reported as means $\pm S D$. Significant difference vs. "S, ${ }^{\dagger} \mathrm{T} 2, \mathrm{P}<0.05$. LV: Left Ventricle; ANF: atrial natriuretic factor; MHC: myosin heavy chain.

Figure 2. Effect of swimming exercise training on systemic and cardiac RAS activity. A: Serum ACE activity and Plasma Renin activity. B: Right Ventricle (RV) ACE activity, Left Ventricle (LV) ACE activity and Left Ventricle (LV) ACE2 activity. Groups: S- sedentary, T1- swimming training protocol 1 and T2- swimming training protocol 2 . Data are reported as means \pm SD. Significant difference vs. ${ }^{\star} \mathrm{S},{ }^{\dagger} \mathrm{T} 2, \mathrm{P}<0.05$.

Figure 3. Effect of swimming exercise training on classical ACE-Ang $\Pi$ axis in the heart. Data are presented as means \pm SD. A: representative blots of ACE, Ang $\Pi$ and $\alpha$-tubulin from sedentary (S) and trained groups (T1 and T2). B-C: cardiac ACE and Ang II protein expression analyzed by western blotting, respectively. Targeted bands were normalized to cardiac $\alpha$-tubulin. D: Angiotensin II peptide concentration in the heart analysed by ELISA. Significant difference vs. 'S, $\mathrm{P}<0.05$.

Figure 4. Effect of swimming exercise training on novel ACE2- Ang (1-7) axis in the heart. Data are presented as means \pm SD. A: representative blots of ACE2, Ang (1-7) and $\alpha$-tubulin 
from sedentary (S) and trained groups (T1 and T2). B-C: cardiac ACE2 and Ang-(1-7) protein expression analyzed by western blotting, respectively. Targeted bands were normalized to cardiac Q-tubulin. D: Angiotensin (1-7) generation from Angiotensin II represented by Ang (1-7)/Ang II ratio. Significant difference vs. ${ }^{\mathrm{S}} \mathrm{S},{ }^{\dagger} \mathrm{T} 2, \mathrm{P}<0.05 ;{ }^{\dagger} \mathrm{S}, \mathrm{P}<0.01$.

Figure 5. Effect of swimming exercise training on AT1 and AT2 receptor gene and protein expression in the heart. Data are presented as means \pm SD. A: representative blots of AT1, AT2 and $\alpha$-tubulin from sedentary (S) and trained groups (T1 and T2). B-C: cardiac AT1 and AT2 protein expression analyzed by western blotting, respectively. Targeted bands were normalized to cardiac $\alpha$-tubulin. D-E: cardiac AT1 and AT2 gene expression analyzed by real time RT-PCR, respectively. Targeted genes was normalized by cyclophilin mRNA. Significant difference vs. "S, $\mathrm{P}<0.05 ;{ }^{\ddagger} \mathrm{S}, \mathrm{P}<0.01 ;{ }^{\S} \mathrm{S}, \mathrm{P}<0.001$ and ${ }^{\|} \mathrm{T} 2, \mathrm{P}<0.001$.

Figure 6. Effect of swimming exercise training on specific microRNAs target to RAS genes. A: microRNAs associated with ACE: miR27a and miR27b. B: microRNAs associated with ACE2: miR150 and miR145. C: microRNA associated with ATl receptor: miR350. Significant difference vs. "S, ${ }^{\dagger} \mathrm{T} 2, \mathrm{P}<0.05 ;{ }^{\ddagger} \mathrm{S}, \mathrm{P}<0.01 ;{ }^{\S} \mathrm{S}, \mathrm{P}<0.001$ and ${ }^{\mathrm{I}} \mathrm{T} 2, \mathrm{P}<0.001$ and ${ }^{\mathrm{I}} \mathrm{T} 2, \mathrm{P}<0.01$. 
Table 1. Hemodynamic parameters.

\begin{tabular}{ccccc}
\hline & SBP, mmHg & DBP, mmHg & MBP, mmHg & HR, bcats/min \\
\hline S & $1276 \pm 3.9$ & $97.6 \pm 10.3$ & $113.5 \pm 7.3$ & $344.8 \pm 12.1$ \\
T 1 & $123.3 \pm 8.5$ & $96.4 \pm 5.2$ & $110.7 \pm 6.7$ & $301.2 \pm 15.3^{*}$ \\
T 2 & $123.0 \pm 8.4$ & $94.3 \pm 8.9$ & $108.3 \pm 9.0$ & $309.0 \pm 14.0 *$ \\
\hline
\end{tabular}

Values are means \pm SD; SBP, systolic blood pressure; DBP, diastolic blood pressure; MBP, mean blood pressure. Significant difference vs. ${ }^{*}$ control $\mathrm{P}<0.05$.

Table 2. Cardiac Hypertrophy.

\begin{tabular}{ccccc}
\hline & BW, g & LV/BW, mg/g & RV/BW, mg/g & Myocyte Diameter, $\mu \mathrm{m}$ \\
\hline S & $245.8 \pm 9.4$ & $2.5 \pm 0.06$ & $0.59 \pm 0.04$ & $11 \pm 1.1$ \\
T 1 & $232.2 \pm 6.4$ & $2.8 \pm 0.14^{*} \dagger$ & $0.68 \pm 0.06^{*} \dagger$ & $13.2 \pm 1.3^{*}$ \\
T 2 & $234.7 \pm 17.3$ & $3.2 \pm 0.12 \ddagger$ & $0.80 \pm 0.08 \ddagger$ & $14.4 \pm 1.3^{*}$
\end{tabular}

Values are means $\pm \mathrm{SD}$; $\mathrm{BW}$, body weight; $\mathrm{LV}$, left ventricular weight; $\mathrm{RW}$, right ventricular weight. Significant difference vs. ${ }^{*}$ control, $†$ T2. $\mathrm{P}<0.05 ; \ddagger \mathrm{S}, \mathrm{P}<0.01$. 


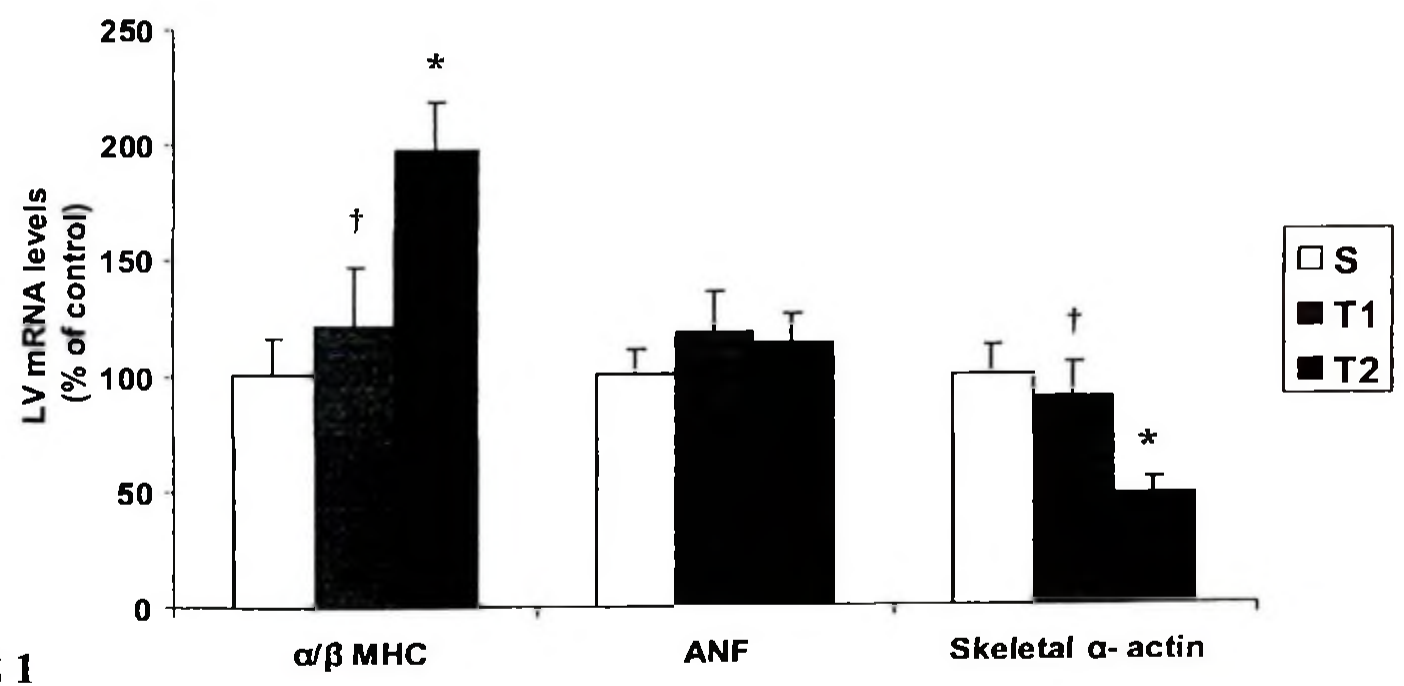


A

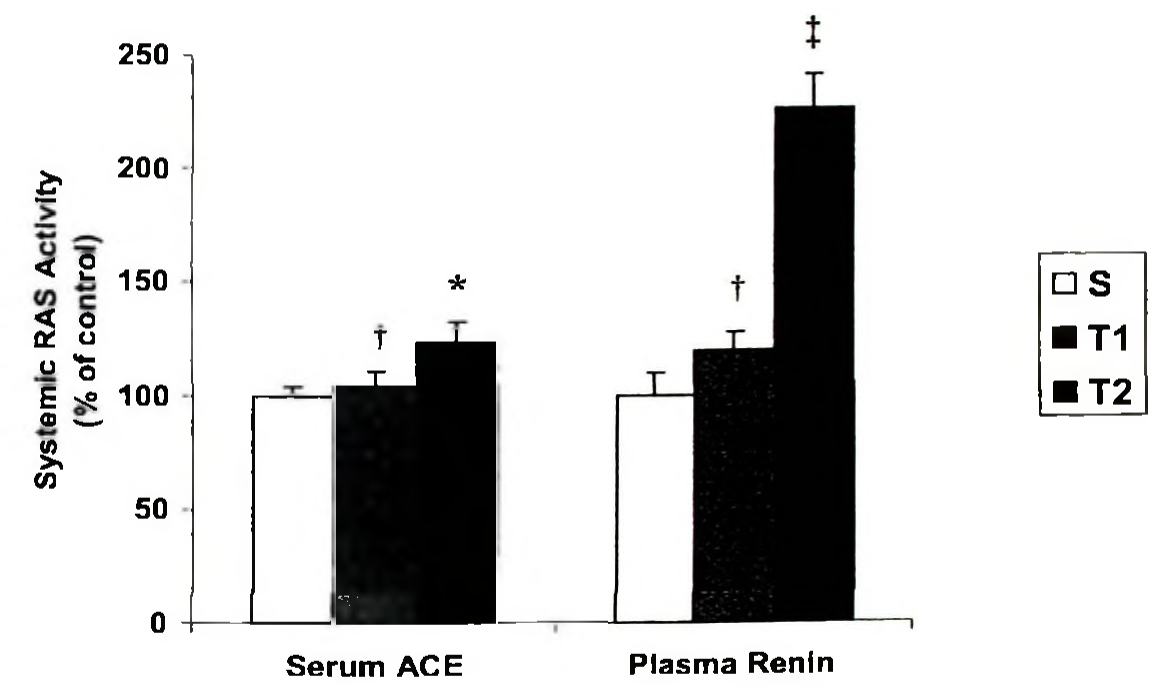

FIGURE 2

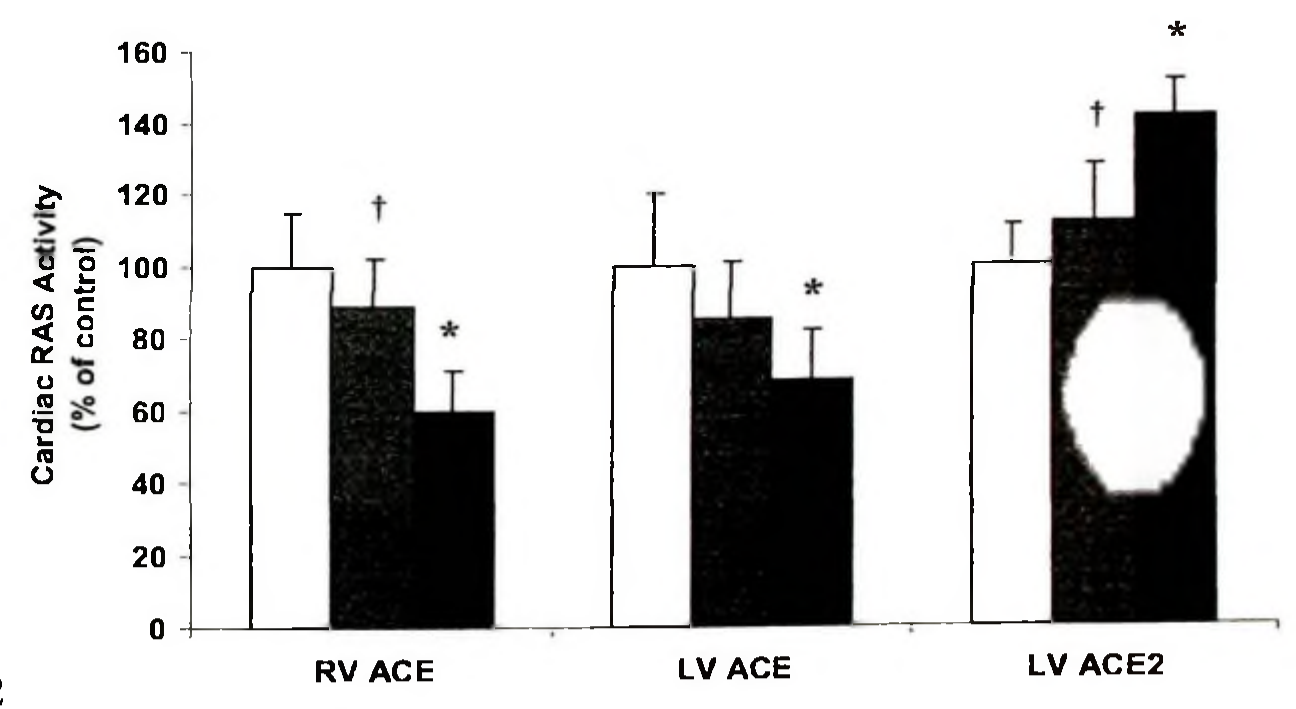


A

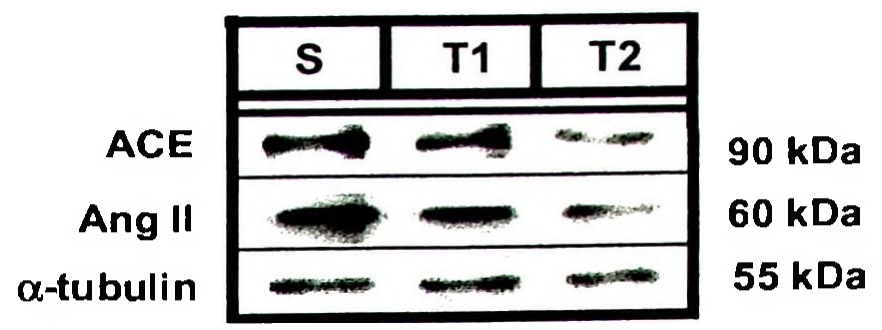

B

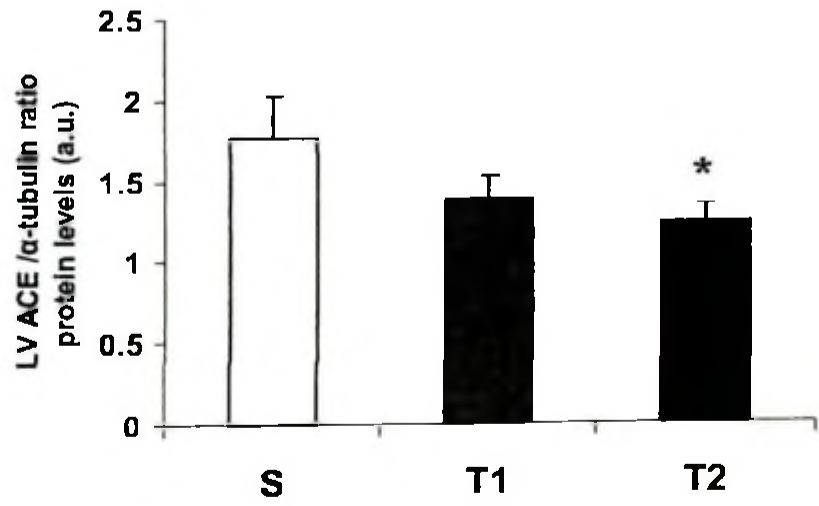

C

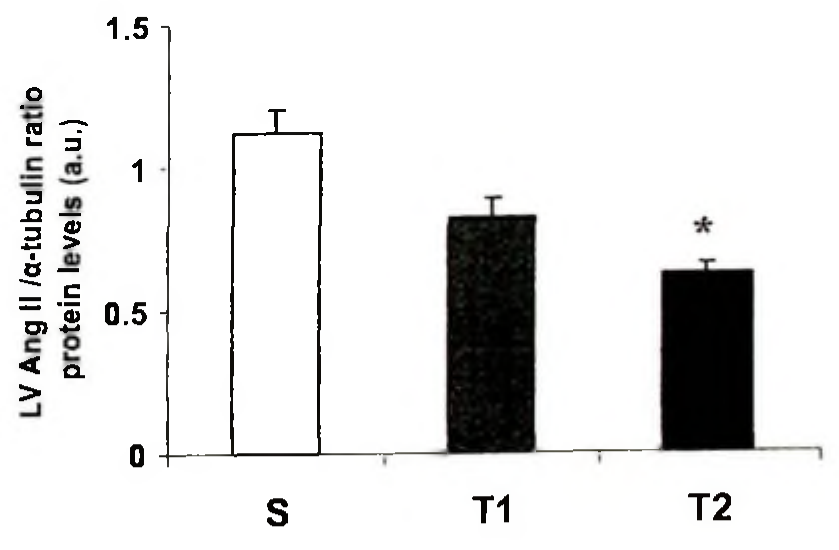

FIGURE 3

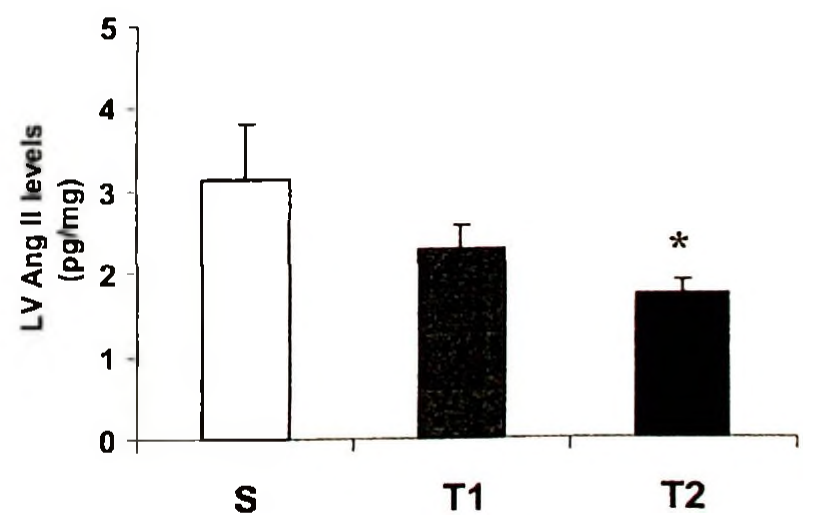


A

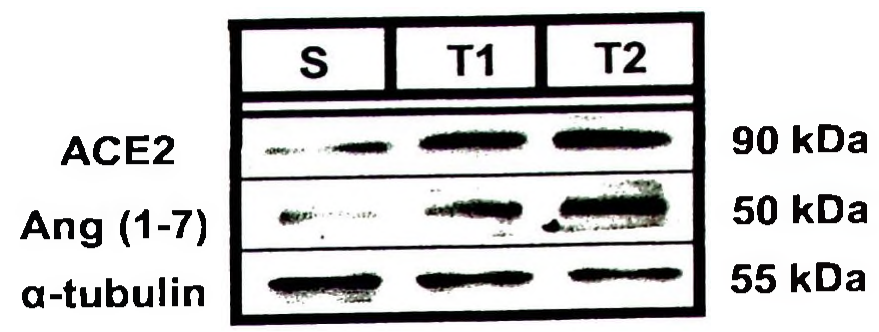

B

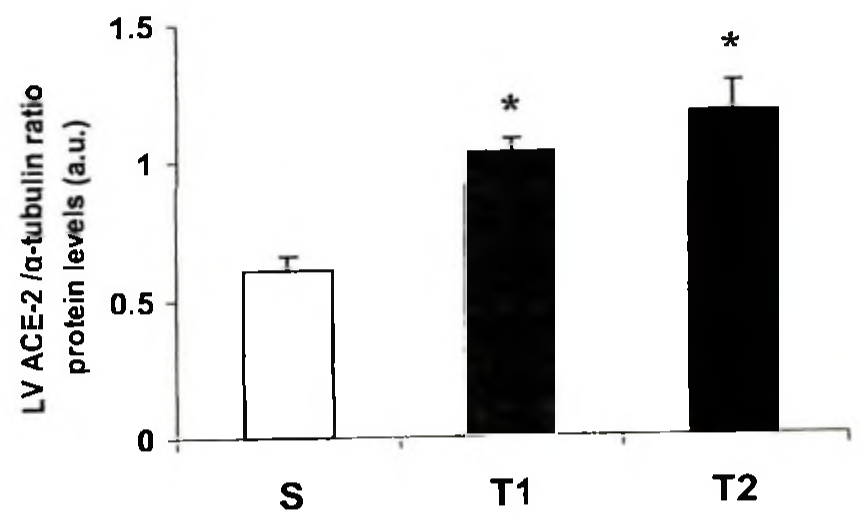

C

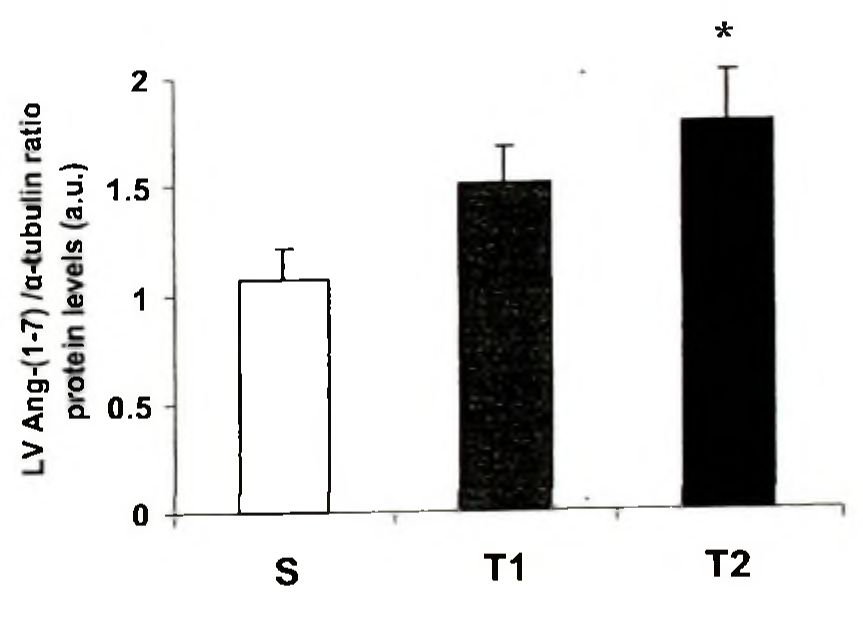

D

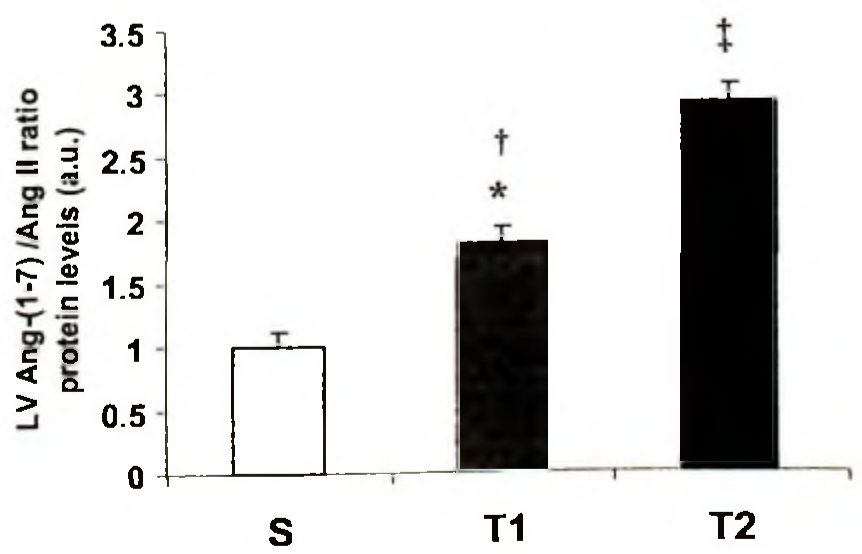

FIGURE 4

S 
A

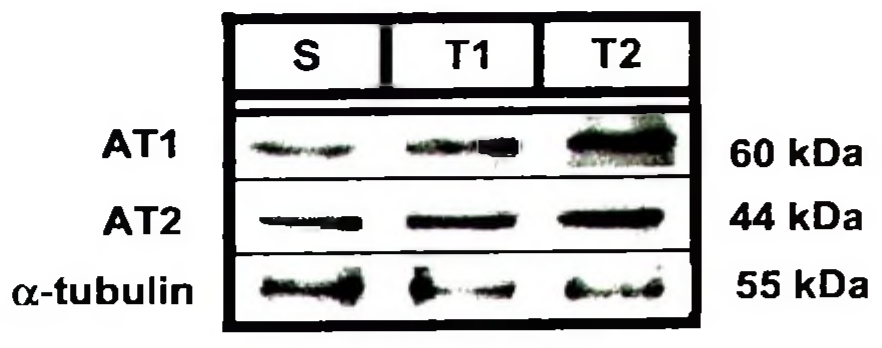

D
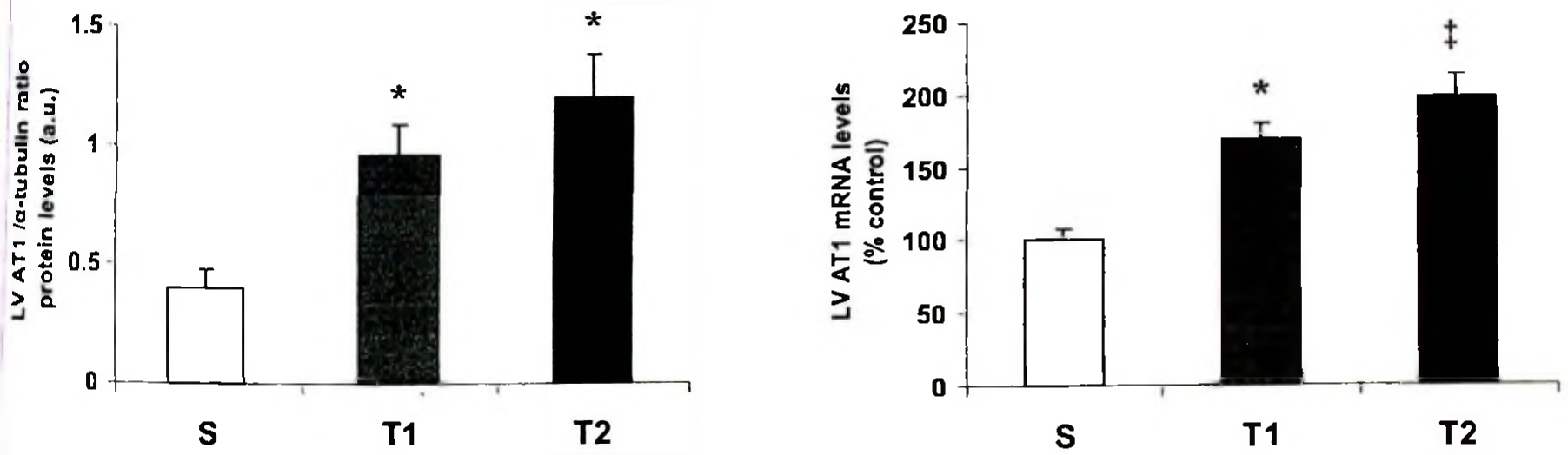

E
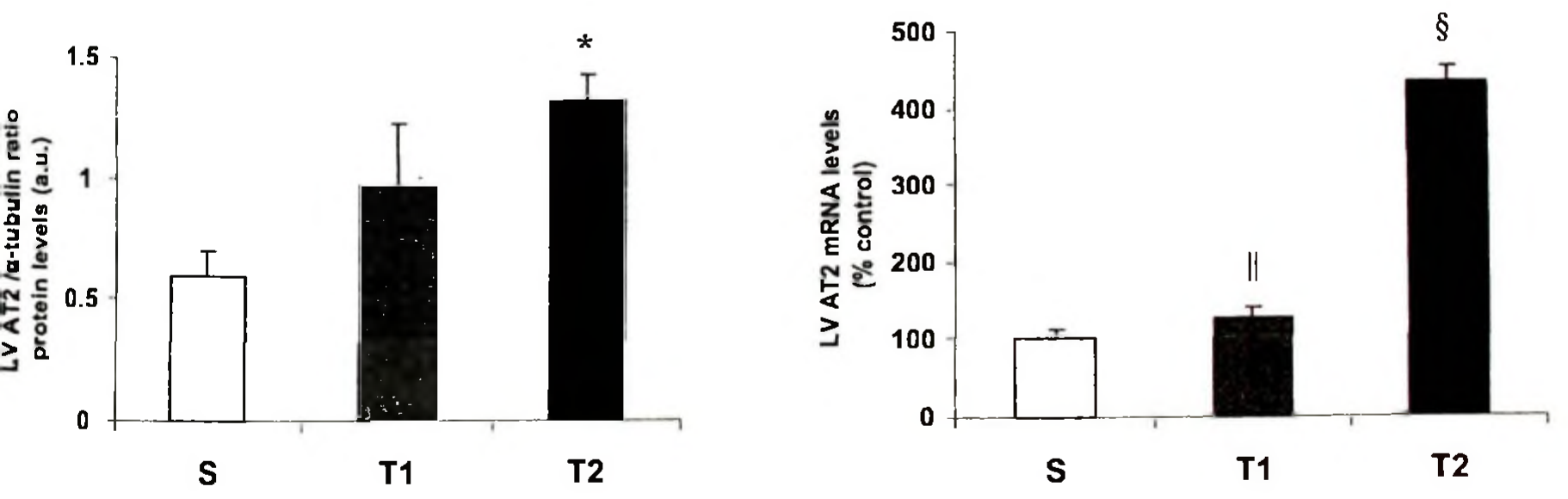

URE 5 
A

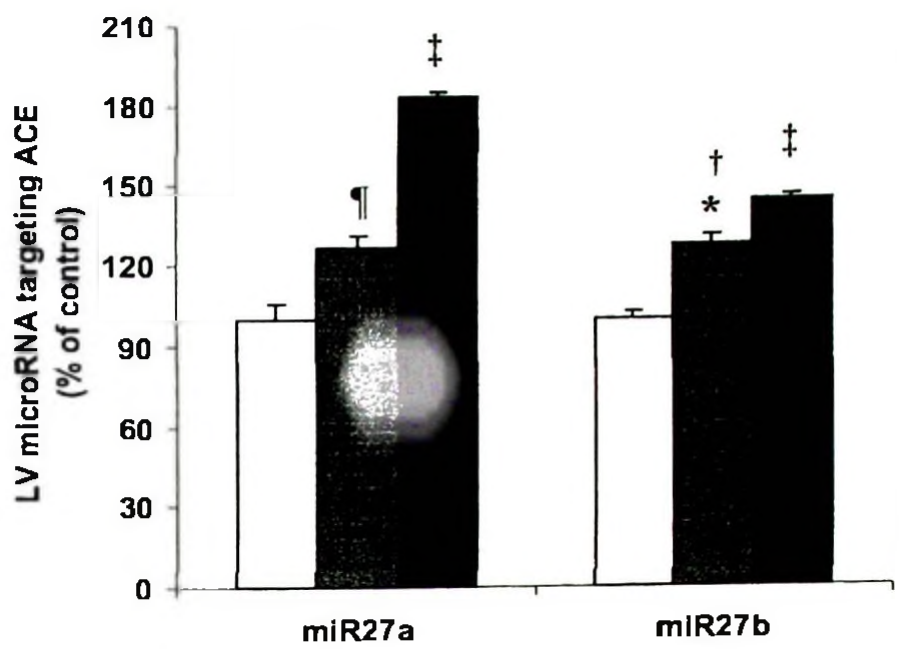

B

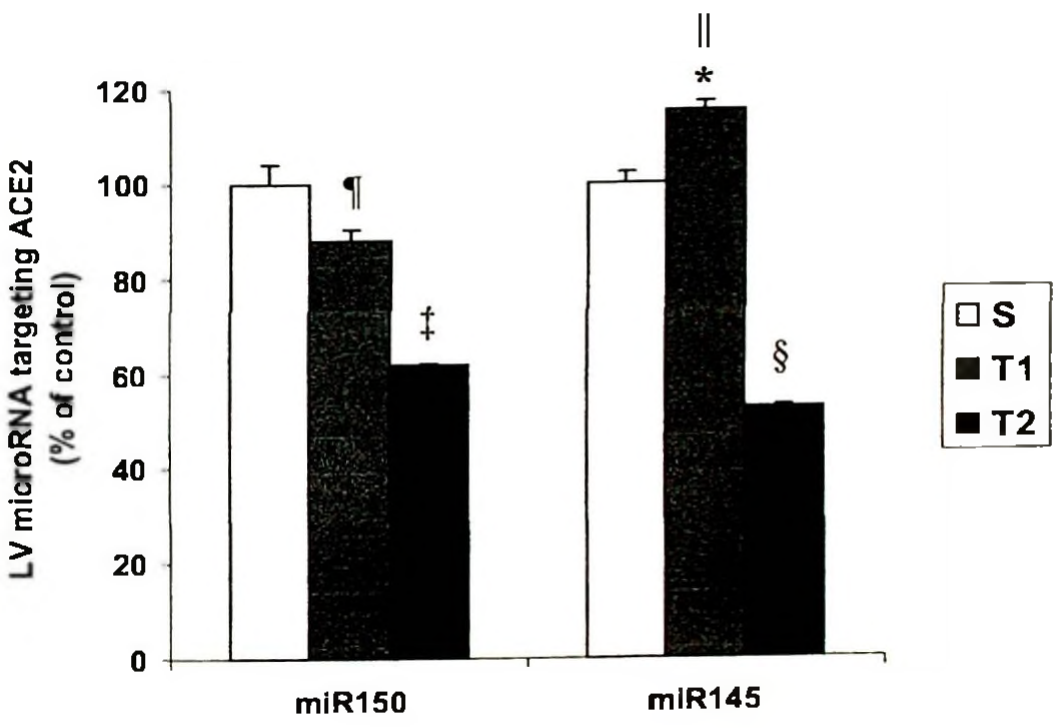

C

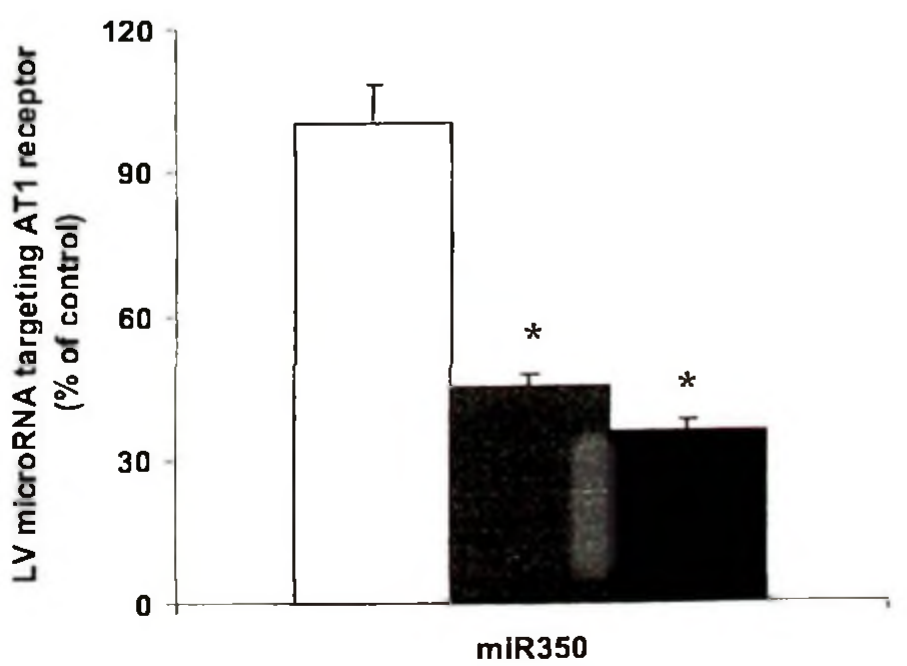




\title{
CARDIOVASCULAR ADAPTATIONS IN RATS SUBMITTED TO A RESISTANCE-TRAINING MODEL
}

\author{
Valerio G Barauna,* Miguel Luis B Junior, ${ }^{\ddagger}$ Luis Fernando BP Costa Rosa, ${ }^{\ddagger}$ Dulce E Casarini, \\ José Eduardo Krieger ${ }^{\dagger}$ and Edilamar M Oliveira* ${ }^{\dagger}$ \\ *Laboratory of Biochemistry, School of Physical Education and Sport, University of São Paulo, São Paulo, \\ 'Laboratory of Genetics and Molecular Cardiology and Unit of Applied Physiology, Heart Institute (InCor), \\ University of São Paulo School of Medicine, Sâo Paulo, 'Laboratory of Metabolism, Institute of Biomedical Science, \\ University of São Paulo, São Paulo, and ${ }^{\S}$ Nephrology Division, Kidney and Hypertension Hospital, UNIFESP, \\ São Paulo, Brazil
}

\section{SUMMARY}

1. The present study sought to evaluate cardiovascular adaptations, such as blood pressure (BP), heart rate (HR) and cardiac hypertrophy, to resistance training (RT) in a rat model.

2. The training protocol consisted of four sets of 10-12 repetitions of the squat exercise performed at $65-75 \%$ of one repetition maximum (1RM) over 4 wceks. Aninals were randomly divided into three groups: control $(n=8, C O)$, electrically stimulated $(n=8, \mathrm{ES})$ and trained $(n=8$, TR; also electrically stimulated). Blood pressure and $H R$ were measured by a direct method in conscious rats after the training period.

3. All groups began with similar 1 RM and $1 \mathrm{RM} /$ bodyweight (BW) ratio, however, at the end of the protocol only the TR group was different from the beginning ( $56 \%$ and $50 \%$, respectively; both $P<0.01$ ). The $\mathrm{CO}$ and ES groups had similar alues for cardiac chambers weight/BW ratio, $\mathrm{HR}$ and diastolic, systolic and mean BP. Left ventricular hypertrophy $(\mathrm{LVH})$ determined by the left ventricle $(\mathrm{LV})$ weight $/ \mathrm{BW}$ ratio was increased in the TR group (12\%) when compared to CO $(P<0.01)$ or ES groups $(P<0.01)$. No changes were found in the wcights of the atrium or right ventricle. Diastolic $(14 \%)$ and mean BP $(13 \%)$ were lower in the TR group $(P<0.05)$, whereas systolic BP and HR remained unchanged.

4. Collectively these results demonstrate that the rat RT model used is associated with significant development of cardiac hypertrophy and lowering of resting BP. These cardiovascular adaptations seem to a result of the training exercise and not influenced by stress since circulating calecholamine levels and adrenal gland weights remained unchanged in all groups.

Key words: cardiovascular system, myocardial hypertrophy, resistance training, weight lifting.

Correspondence: Dr Edilamar M Oliveira, Laborntory of Biochenustry. School of Physical Education and Spor,. Ave. Prof. Mello Moracs, 65, Butantā, Cidade Universitária, 05508-9000, São Paulo, Brazil. Email: cdilamar@usp.br

Reccived 31 May 2004; revision 28 Novenber 2004; accepred I December 2004.

\section{INTRODUCTION}

In contrast to aerobic training, the cardiovascular adaptations induced by resistance training (RT) are not as well documented in published medical reports. For example, there is agreement in published reports that acrobic training elicits small reductions of arterial blood pressure (BP), but less is known about RT. Some studies in hurnans have suggested that the RT may also reduce anerial $\mathrm{BP}^{1-7}$ however, inconsistent results have been found and possible mechanisms remain unclear. Also described in some published reports, RT may lead the heart to develop concentric hypertrophy; however, molecular and cellular stirnuli are still unclear- ${ }^{8}$ One of the main problems is the lack of models using laboratory animals. There are, in fach, some models described in the literature, but none of them have focused on the cardiovascular system.-16 The great majority of the studies have focused on skcletal muscle adaptations such as the cellular and molecular mechanisms of skeletal muscle hypertophy. ${ }^{17}$ One of the rajor advantages of using animal models is the capability of precisely control environmental and food intake condicions for all animals. Furthermore, the animals can be killed and tissue samples harvested and used for physiological, histological, biochemical and molecular analysis.

Acrobic excrcise has becn one of the modifiable interventions indicated for preventing or controlling hypertension, but only recendy has RT been similarly prescribed. ${ }^{18}$ Since then several studies using humans as subjects have demonstrated the benefits of this type of exercise including: therapeutic intervention in osteoporosis, ${ }^{19}$ as well as muscular and metabolic diseases. ${ }^{21}$

The purpose of the present study was to determine the effects of chronic RT on BP, heart rate (HR) and cardiac hypertrophy in an animal model and to investigate potential limitations of the model associated with the electrical stimulation used. A well-documented squat-training apparatus for RT in rats ${ }^{12}$ and an adapted training protocol for humans following American College of Spors Medicine guidelines were used. This raining emphasizes moderate loads and a high number of repctitions, as practiced by bodybuilders. ${ }^{21}$ This apparatus was chosen because it mimics the traditional squat excrcises performed by humans and the results obtained in skeletal muscle are similar to those seen in humans. ${ }^{17}$ 


\section{METHODS}

Animials

Twenty-four Wistar rats $(360-400 \mathrm{~g}$ and 14 weeks old) were randomly divided into three groups: control (CO; $n=8$ ), electrically stimulated (RS; $n=8)$ and trained (TR: $n=8$ ). Animals were housed in standard cages and frod and waler were provided ad libitum. The environmental temperature mas kiept at $23 \pm 1^{\circ} \mathrm{C}$ and a 12:12 dark-light cycle was maintained throughout the experiment. Animals were weighed every week. The measurements vere undertiken on the first day of the first week following the 2 weeks indaptation period and on the last day of the fourth week All protocols and surgical procedures used were in accordance with the guidelines of the Brazilian College for Animal Experimentation and were approved by the Ehics Committee of the Institute of Biomedical Science of the University of Säo Paulo.

\section{Excrcise protocol}

Animals were exercised following a model adapted from Tamaki et al. ${ }^{12}$ (Fig. 1) Rats fitted with a canvas jacket were able to regulate the twisting and flexion of their torsos and were suspended in a standard position on theis hind limbs. An electrical stimulation $(20 \mathrm{~V}, 0.3 \mathrm{~s}$ duration at $3 \mathrm{~s}$ intervals) was applied to the rat's tail through a surface electrode. As a result, the rats flexed their legs repeatedly, which lifted the weight-arm of

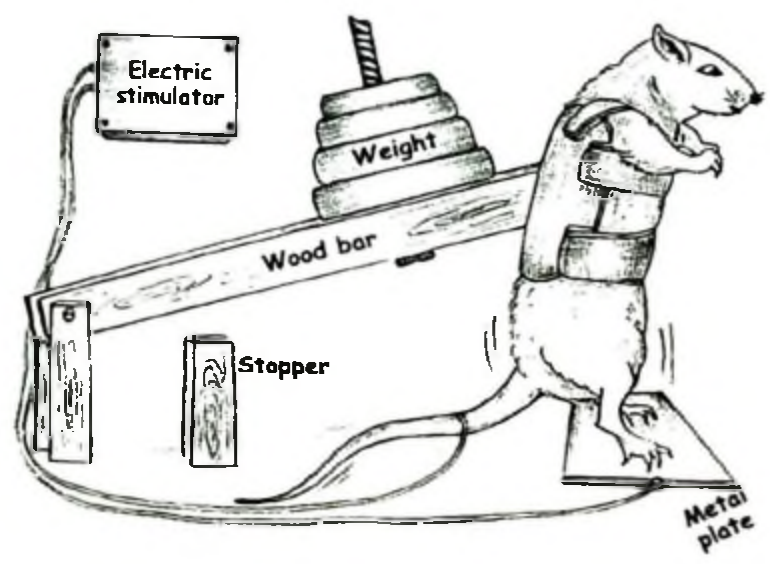

Fig. 1 Apparatus used to perform resistance training in the rats adapted from Tamaki es al. 1992. the training apparatus. The TR and ES groups were exercised by four sets of 12 repetitions with a $90 \mathrm{~s}$ resi period between each set, five times per week for 4 weeks. This exercise regimen was staried after 2 weeks of adapation. After measurement of the maximum weight lifted (IRM) with the squat-training apparatus, the training load was set at 65-75\% of IRM only for the TR groups. The ES group received the came slimulus intensity and the same number of sets and repetitions as the TR group but without a training load. The ES group was used as a control to study the effects of the electrical stimulation. All training sessions were performed in a dark rnom. The IRM was defined as the minimum load that the rats were unable to jump following electrical stimulation. The IRM was measured biweekly.

Placement of arterial cathelers was made under anaesthesia $4 \mathrm{~h}$ after the end of the exereise protocol as described below. On the day following BP and IIR was recorded as described below. rats were killed by decapitation and trunk blood was collected into prechilled tubes and stored at $-80^{\circ} \mathrm{C}$ for measurements of plasma catecholamines (CA) concentrations. In addition. plantaris muscle, adrenal glands and heart were harvestod and weighted.

\section{Cardiac morphology}

After removal from the thoracic cavily, the heart was trimmed of excess of non-cardiac tissues. The heart was dissected to obtain the left ventricle (LV; free wall plus septum), atrium and right ventricle (RV) weights separately. Hypertrophy was expressed as increase in LV weight nomalized for bodyweight (LV/BW).

\section{Mcasurement of plasma CA}

Catecholamines such as noradrenaline (NE), adrenaline (EPI) and dopamine (DA) were measured by HPLC using ion-pair reverse phase chromatography coupled with eletrochemical detection $(0.5 \mathrm{~V})$, as described by Naffah-Mazzacoratti ef al." Fast isocratic separation was obtained using an RP 18 Brownlee column $(4.6 \times 250 \mathrm{~mm}, 5 \mu$. Applied Biosysicms, San Jose, CA, USA) eluted with the following mobile phase: $20 \mathrm{mmol} / \mathrm{L}$ sodium dibasic phosphate. $20 \mathrm{mmol} / \mathrm{L}$ citric acid. $\mathrm{pH} 2.64$ containing $10 \%$ methanol. $0.12 \mathrm{mmol} / \mathrm{L} \quad \mathrm{Na}_{2} \mathrm{EDTA}$ and $566 \mathrm{mg} / \mathrm{t}$ heptanesulphonic acid. The total time for sample analysis was $30 \mathrm{~min}$ Concentrations were directly deternined using the following equation

\section{$\mathrm{pg} \mathrm{A} / \mathrm{mL}=$ PsA/PsDHBA $\times$ Standard quantity 3 Dilution factor PstAMstDHBA}

where: $\mathbf{A}=$ amine; $P s$ = peak area of amine in the cumple; PstA = peak ares of amine in the standard; PsDHBA $=$ peak area of dihydroxybenzylamine (DHBA) in the sample; and PsWHBA = peak area of DIBA in the standard. The intemal standard of extraction is DHBA. Results were expressed as $\mathrm{pg} / \mathrm{mg}$ protein

Table 1 Bodyweight and absolute IRM in the first and the fourth week of training, adrenals glands and heart chambers weight normalized for the bodyweight and hear rate

\begin{tabular}{|c|c|c|c|c|}
\hline & & $\mathrm{CO}$ & ES & TR \\
\hline \multirow[t]{2}{*}{ Bodyweight (g) } & First week & $379 \pm 6.9$ & $374 \pm 11.5$ & $385 \pm 4.1$ \\
\hline & Fourth week & $413 \pm 5.3^{*}$ & $394 \pm 8.6$ & $402 \pm 4.2$ \\
\hline Atrium (mg/g) & Fourth week & $0.15 \pm 0.013$ & $0.15 \pm 0.011$ & $0.14 \pm 0.013$ \\
\hline Righı ventricle $(\mathrm{mg} / \mathrm{g})$ & Fourth week & $0.53 \pm 0.02$ & $0.59 \pm 0.03$ & $0.55 \pm 0.04$ \\
\hline Left ventricle (mg/g) & Fourth week & $2.05 \pm 0.05$ & $2.05 \pm 0.02$ & $2.30 \pm 0.03^{*}$ \\
\hline Planıaris we $\mathrm{ghh}(\mathrm{mg} / \mathrm{g})$ & Fourth week & $0.40 \pm 0.013$ & $0.41 \pm 0.02$ & $0.44 \pm 0.01 * *$ \\
\hline \multirow[t]{2}{*}{ IRM (g) } & First wcek & $531 \pm 63.3$ & $491 \pm 53.7$ & $519 \pm 47.2$ \\
\hline & Fourth week & $619 \pm 44$ & $625 \pm 61.2$ & $833 \pm 49.5$ \\
\hline Hean rale (b.p.m.) & Fourth weck & $364 \pm 6.3$ & $357 \pm 10.6$ & $333 \pm 8.8$ \\
\hline Adrenal wcight (mg/g) & Fourth week & $0.17 \pm 0.04$ & $0.17 \pm 0.03$ & $0.17 \pm 0.01$ \\
\hline
\end{tabular}

CO, control; ES, electrically stimulated; TR, trained; IRM. repetition maximum; BW, bodyweight: LV, left ventricle. Data are reportod as means \pm SEM $n=8$ each group. The BW and RM/BW ratio showed were oblained in the first and fourth week after the adaptation period. " $P<0.05$ comparing $B W$ of the $\mathrm{CO}$ group in the fourth versus the first week and the CO versus TR and ES at the end of the protocol. " $P<0.01$ comparing LV/BW of the TR group versus $\mathrm{CO}$ and ES. $* P<0.05$ comparing plantaris muscles weight of the TR group versus $C O$ and ES. $\$ P<0.05$ comparing the IRM of the TR group in the fourth versus the first week and the TR versus CO and ES at the end of the protocol. All others comparisons were not statislically significant. 
Pasma ( $0.5 \mathrm{~mL}$ ) was previously submitted to the following purification rgime: $50 \mathrm{mg} \mathrm{Al} \mathrm{O}_{3}$ was weighed out in centrifuge tubes and the samples were alded in Tris-buffer, plI 8.8, plus $40 \mu \mathrm{L}$ ( $8 \mathrm{ng}$ ) of DHIBA (internal uandard). The suspension was vortex-mixed for $10 \mathrm{~min}$. The precipitated alumina was washed three times and vortex-mixed with $1 \mathrm{~mL}$ of water and the $\mathrm{CA}$ were subsequently eluted with $400 \mu \mathrm{L}$ of $100 \mathrm{mmol} / \mathrm{L}$ perchloric acid afler $3 \mathrm{~min}$ of vortex mixing. After centrifugation for $3 \mathrm{~min}$ at $2500 \mathrm{~g}$. the supernatant was filtered and $100 \mu \mathrm{L}$ was injected into the reverse phase column. The concentration of L-dopa was expressed as $\mathrm{pg} / \mathrm{mg}$ protein.

\section{Arterial BP and HR}

Thenty-four hours after the last training session and under pentobarbital anaesthesia ( $40 \mathrm{mg} / \mathrm{kg}$ IP), a cannula (PE-50) was inserted into the carotid whery, emerging through the back of the rat's neck. During the experimental session, this cannula was connected to a strain-gauge transducer (P23 Db; Gould-Statham). Twenty-four hours after the surgery, arterial BP was recorded on a beat-to-beat basis (AT/CODAS) at a trequency of $100 \mathrm{~Hz}$ for $30 \mathrm{~min}$ in quiet, conscious, unrestrained rats. The data reported indicales the average of al] values of systolic, diastolic and mean arterial pressure over the entire recording period of $30 \mathrm{~min}$; HR was taken from BP pulse records.

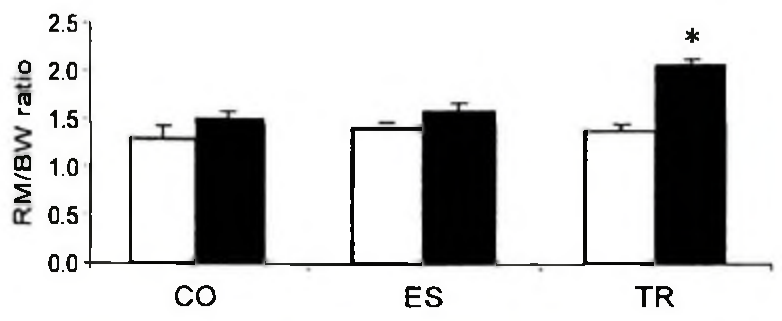

Fig. 2 Repetition maximum relative to bodyweigh! ( $B W$ ) of all groups before and after of resistance trajning. The measurements were undertaken on the firsl day of the first week following the 2 weeks adaplation period and on the last day of the fourth week CO, control; ES, electrically stimulated; TR. urained Data are reported as means \pm SEM. $n=8$ each group. - $P<0.01$ comparing the RM/BW of the TR group in the fourth week ( $\square$ ) versus the first week ( $\square$ ) and the TR versus $C O$ and ES at the end of the prolocol.

\section{Statistical analysis}

Results are reported as means \pm standard errors of the means (SEM). The BW, RM and RM/BW were analysed by (wo-way ANOVA repeated measure. All others statistical analyses were made by one-way ANova. Values were considered to be statistically significant when $P<0.05$. Tukey's post-hoc test was used for individual comparisons between means when a significant change was observed with ANOVA.

\section{RESULTS}

\section{Bodyweight}

The BW of the animals at the beginning of the study was similar among the thrce groups (Table 1). Following the training protocol BW showed non-significant increase of $4 \%$ in the TR group $(P>0.05), 5 \%$ in the ES group $(P=0.058)$ and a significant increase of $8 \%$ in the $\mathrm{CO}$ group $(P<0.01)$.

\section{Maximal strength}

One repetition maximum is expressed in two ways: absolute and relative to $\mathrm{BW}$. Table 1 shows the values of the absolute IRM before (first week) and after craining (fourth week). All groups began the training protocol with similar IRM $(515 \mathrm{~g} \pm 128 \mathrm{~g})$. However, IRM after training increased significantly only in the TR group (CO, 26\%; ES, 20\% both $P>0.05$; TR, 56\% $P<0.01$ ). As $B W$ can influence this variable, the strength was also expressed as IRM/BW (g lifted/g BW) (Fig. 2). All groups began the training protocol with similas $1 \mathrm{RM} / \mathrm{BW}$. The results show that only the relative 1RM of the TR group increased at the end of the training period as compared to the beginning valucs $(\mathrm{CO}, 1.30 \pm 0.36-$ $1.50 \pm 0.23 P>0.05 ; \mathrm{ES}, 1.41 \pm 0.20-1.59 \pm 0.27 P>0.05$; TR, $1.38 \pm 0.22-2.07 \pm 0.18 P<0.01)$

\section{Skeletal muscle weight}

Table 1 also shows the values of the plantaris muscles weight normalized by the BW. As expected, the plantaris muscles raised $6.5 \%$ and $9.2 \%$ more wcight in comparison to $\mathrm{CO}$ and ES groups, respectively (both $P<0.05$ ). No difference was observed between $\mathrm{CO}$ and ES group.

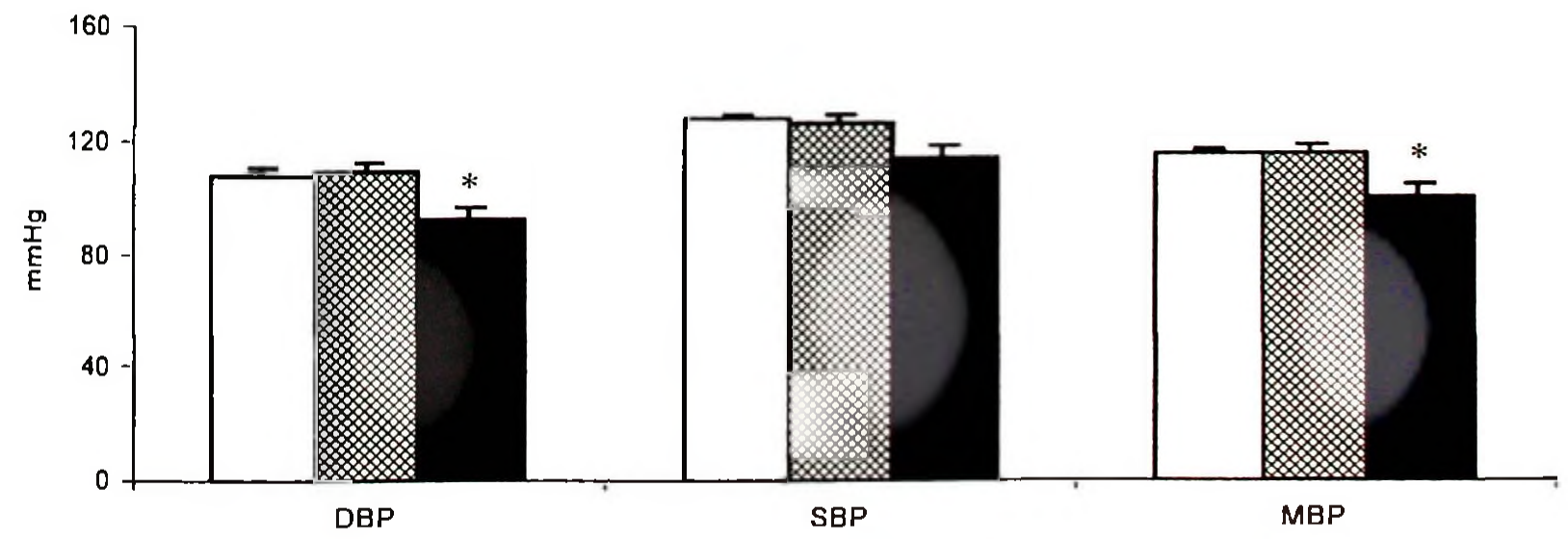

Fig. 3 Systolic, diastolic and mean resting blood pressure after 4 weeks of training. Dath are reported as means \pm SEM. $P<0.05$. $n=8$ each group

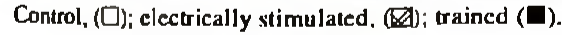




\section{Heart weight}

Right ventricle/BW (Table 1, $P>0.05$ ) and atrium/BW (Table 1, $P>0.05$ ) remained unchanged among the groups, whereas LV ueigh/BW ratio was approximately $12 \%$ greater in the TR group compared to both $\mathrm{CO}$ and ES groups $(P<0.01)$ (Table I).

\section{Blood pressure}

Fony-eight hours after the last training session, the resting BP and HR were measured directly using an intra-anterial cannula. Figure 3 shows the resting values of diastolic blond pressure (DBP), systolic blood pressure (SBP) and mean blood pressure (MBP). For all comparisons, the values from the $\mathrm{CO}$ and ES groups were similar. A non-significant reduction of $10 \%$ was found in the SBP for the TR group compared to the CO and ES groups $(P>0.05)$. The DBP and MBP were, respectively, $14 \%$ and $13 \%$ lower in the TR compared to $\mathrm{CO}$ and ES groups $(P<0.05)$. While not statistically significant, resting HR (Table 1 ) was $8 \%$ lower in the TR compared to $\mathrm{CO}(P=0.062)$ group and $6 \%$ lower coropared to ES group $(P=0.075)$.

\section{Catecholamines and adrenal glands}

To determine whether the electrical stimulation could be influencing the results obtained, the concentrations of CA (and its precursors) were measured as an index of stress. No statistical differences were found among the three groups $(P>0.05)$ (Fig. 4). Similarly, the weight of the adrenal glands when normalized for BW showed no significant differences among the groups (Table 1).

\section{DISCUSSION}

The main effects observed after 4 weeks of RT in a rat model were development of cardiac hypertrophy accompanied by significant reduction in resting $\mathrm{BP}$, which are similar to the cardiovascular adaptations observed in humans submitted to squatting exercises.
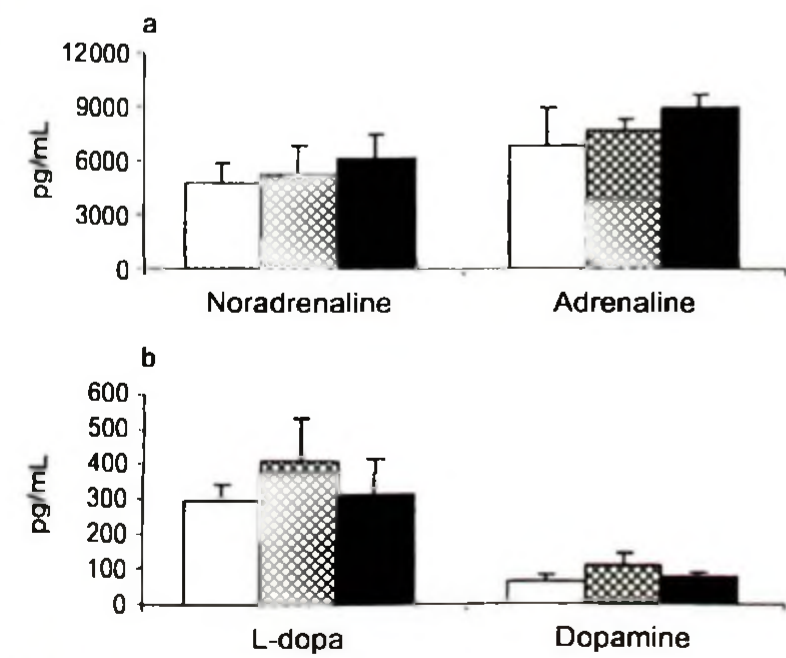

Fig. 4 (a) Adrenaline and nor arrenaline, (b) L-Dopa and dopamine. Dala are reported as means \pm SEM. Not significant. Control, (口); electrically slimulaied, (घ); trained (ם).
The current study showed, for the first time to our knowledge, that this model can be used to investigate the effects of RT on the cardiovascular system of rats and that the clectrical stimulation used did not induce detoctable changes in the ES group, suggesting that the effects observed were directly related to the exercise training.

The BW changes associated with this type of training protocol appear to be discrete. The TR and the ES groups in the current study tended to increase but only the $\mathrm{CO}$ group showed a significant $12 \%$ increase compared with the values at the beginning of the training sessions. Tamaki et al. using the same training apparatus but with a different training protocol (15 sets of 15 repetitions), found similar findings. ${ }^{12}$ The $\mathrm{CO}$ group was heavier than the TR group after the fourth week of training and, the difference increased to $22 \%$ by the 12 th wcek, whereas other authors using similar protocol have found no differences between the TR and CO groups. ${ }^{10,11,15,16}$

The IRM was used as an index of training efficiency. Additionally, the maximal strength achieved by the rats was used to determine the training load and to demonstrate training adaptation. Similar to aerobic training, where maximal $\mathrm{HR}$ or $\mathrm{VO}_{2 \max }$ are used to prescribe exercise, ${ }^{23} 1 \mathrm{RM}$ is used in RT for prescription..$^{24}$ In the present research, ES animals were considered as the true controls as the $\mathrm{CO}$ group did not receive electrical stimulation. This allowed us to investigate the independent effects of electrical stimulation on stress. Similar results for absolute 1RM have been found by others but none of them have used an electrically stimulated plus a nonstimulated group as controls. ${ }^{10-12,15.16}$ The plantaris muscle mass increased $6.5 \%$ and $9.2 \%$ in the TR group compared to CO and ES groups, respectively $(P<0.05)$. These findings are consistent with the fact that the plantaris muscle has predominance of white fibres, glycolytic metabolism and thus is more susceptible to muscle hypertrophy after RT program. ${ }^{25}$

Another common adaptation induced by exercise is the left venuricular hypertrophy (LVH), alchough characteristics differ depending on the type of exercise involved. Eccentric LVH is very well described as a response to aerobic training in both humans and animals, ${ }^{2 x, 27}$ while concentric LHV is associated with RT. ${ }^{8}$ The results from the current sudy demonstrated LVH in rats in response to RT. The extent of LVH found in the TR group (12\%) was similar to that reported in some human studies involving weight lifters training for no longer than 3 months, ${ }^{28.29}$ but smaller than that seen in other studies investigating athletes engaged in this type of exercise for more than 1 year. ${ }^{830}$

In addition, we have observed in rats that, similarty to humans, RT leads to lower BP while HR remains unchanged. Reduced resting $H R$ is normally observed as a positive effect of training and is frequently viewed as a chronic adaptation to endurance exercise. Longitudinal studies involving resistance shor-term training ( $<20$ weeks) demonstrated significant reductions of up to $13 \%, 31,32$ and non-significant reductions that varied from 6 to $8 \% .^{33.34}$ Similar to these latter results, the protocol used in the present study produced a non-significant decrease of $6 \%$ (TR $v . s$ ES, $P=0.075$ ) and $8 \%$ (TR vs CO, $P=0.062$ ) in resting $\mathrm{HR}$. The mechanism involved in this adaptation during $R T$ requires further investigation.

Another haernodynamic parameter that has been investigated is resting BP. It has been suggested that intermittent increases in BP during RT could cause vascular wall hyperurophy and thus decrease luminal diameter, resulting in increased vascular resistance and 
BP. ${ }^{19}$ However, only limited research has been conducted in this area. Hypertension observed in resistance-trained athletes can be atrituted to a variety of factors including androgen abuse, over training, or a large increase in muscle mass. ${ }^{36,37}$ In contrast, some cross-sectional studies have reported reductions, ${ }^{38}$ or lack of change ${ }^{39.4}$ in BP. Also longitudinal studies have reported reductions ${ }^{1-7}$ or similar arterial $\mathrm{BP}, 5,21,41$ as a chronic adaptation to RT. Although some scudies have reported that $R T$ can reduce $B P$, only (wo studies (from the same group) have atrempted to clarify the mechanisms underlying this adaptation. ${ }^{27}$ Both studies used isometric handgrip training and measured muscle sympachetic nerve activity (MSNA). No decreases in MSNA as a result of chronic isometric training were observed. Evidence from aerobic training suggests that exercise may decrease both systemic sympathetic activity and arterial $\mathrm{BP}^{42}$ Also from aerobic training, its efficacy for cardiovascular risk reduction appears, at least in part, derived from modifications of arterial properties, such as increase in arterial compliance. ${ }^{43}$ Regarding RT, the issue is even less clear. The studies have found that this type of exercise may be associated 10 a decrease in arterial compliance, ${ }^{43}$ but none of the studies have demonstrated decreases in BP which lead us to hypothesize that a higher training intensity may have been used compared to the ones that found decreases in BP. ${ }^{43.44}$ Another mechanism that may help to explain the decrease in BP is peripheral vascular adaptations. It has been postulated that this training regimen may lead to increased exposure of shear stress and release of vasoactive substances that may contribute to functional or structural changes in the resistance vessels. ${ }^{45}$ Although not investigated directly in the present work, these events may also take place in this model and are consistent with our findings of lower DBP and MBP in the TR groups.

Furthermore, although our resules showed non-significant reductions in $\mathrm{SBP}$ and $\mathrm{HR}$, the double-product (SBP $\times \mathrm{HR}$ ) was $18 \%$ lower in the TR versus CO group (data not showed). The double-product is an index of cardiac workload, we might conclude that RT is a mode of exercise that can improve cardiovascular funcion and might be used as a non-pharmacological treatment, or prevention protocol, for cardiovascular disease.

We have also attempted to investigate the effects of the electrical stimulation as a confounding variable, since previously published studies using this training apparatus have not addressed this issue. In this context, we were able to demonstrate that two stress indices remained unchanged at the end of the training period. Namely, electrical stimulation was not associated with changes in CA plasma levels, a marker of sympathetic activity ${ }^{46}$ and adrenal hypertrophy. These two parameters are the second and third adapeations (of four) to chronic biological stress stimuli as defined by Selye, ${ }^{47}$ who observed that prolonged stress ultimately forces organisms to adapt to maintain the organic capacity to face continued challenges. In addition, all the ES group results werc similar to the $\mathrm{CO}$ group.

Collectively these results demonstrate that the rat RT model used is associated with significant development of cardiac hyperurophy and lowering of resting BP. These cardiovascular adaptations seem to be a result of the uraining exercise and probably not influenced by stress since circulating CA levels and adrenal gland weights remained unchanged in all groups. Although these responses have boen well documented in humans, it is the first time that these cardiovascular adaptations have been observed in the rat model. This may enable the development of cellular and molecular studies aimed at uncovering the mechanisms associated to the cardiac hypertrophy and lower BP in response to chronic RT. Furthermore, understanding the mochanisms leading to reductions of arterial $\mathrm{BP}$ associatod to RT may be of value to be explored in humans. ${ }^{\text {th }}$

\section{ACKNOWLEDGEMENTS}

The authors thank Marcele de Almeida Coelho for technical assistance. VG Barauna was the recipient of a FAPESP scholarship (No.01/14451-7). JEK is supported by grant FAPESP 01/00009-0.

\section{REFERENCES}

1. Kelley GA, Kelley KS. Progressive resistance exercise and resting blood pressure: A meta-analysis of randomized controlled trials. Hyperiension 2000; 35: 838-43.

2. Carter IR, Ray CA. Downs EM. Cooke WH. Strength training reduces arterial blood pressure but not sympathetic neural activity in young normotensive subjects. J. Appl. PhysinL 2003; 94: 2212-16.

3. Stone MH, Wilson GD, Blessing D. Rozenek R. Cardiovascular responses to short-term olympic style weight-training in young men. Can. J. Appl Spon Sci. 1983; 8: 134-9.

4. Wiley RL, Dunn CL, Cox RH, Hucppehen NA, Scoa MS. Lsometric exercise training lowers resting blood prexsure. Med. Sci. Sports Exenc. 1992; 24: 749-54.

5. Hurley BF. Hagberg $M$. Goldberg AP ef al. Resistive training can reduce coronary risk factors without altering VO2max or percent body fat. Med. Sci. Sports Exerc. 1988; 20: 150-4

6. Harris KA, Holly RG. Physiological response to circuit weight training in borderline hypertensive subjects. Med. Sci. Sports Exerc. 1987; 19: 246-52.

7. Ray CA, Carrasco DI. Isometric handgrip training reduces arterial pressure at rest without changes in sympathetic nerve activity. Am. $J$. Physiol. Hean Cinc. Physiol. 2000; 279: H245-9.

8. Pluim BM, Zwinderman AH, van der Laarse A, van der Wall EE. The athlele's heart. A meta-analysis of cardiac structure and funclion. Circulation 2000; 101 : 336-44.

9. Klitgaard H. A model for quantitative strength training of hindlimb muscles of the rat. J. Appl. Physiol 1988; 64: 1740-5.

10. Notomi $T$, Lee SJ, Obimoto $\mathrm{N}$ et al. Effocts of resistance exercise training on mass, strength, and turnover of bone in growing rats. Eur. J. Appl. Physiol 2000; 82: 268-74.

11. Notomi T, Okazaki Y, Okimoto N. Saitoh S, Nakamura T, Suzuki M. A comparison of resistance and acrobic trining for mass, strength and turnover of bone in growing rats. Eur. J. Appl. Physiol. 2000; 83: 469-74.

12. Tamaki T, Uchiyama S, Nakano S. A weight-lifting exercise model for inducing hypertrophy in the hindlimb muscles of rats. Med. Sci. Sports Exenc. 1992; $24: 881-6$.

13. Tamaki T, Akatsuka A, Tokunaga $M$, Ishige $K$, Uchiyamn $S$, Shiraishi T. Morphological and hiochemical evidence of muscle hyperplasia following weight-lifting exercise in rats. Am. J. Physiol. 1997; 273: C246-56

14. Wong TS, Booth FW. Skeletal muscle enlargement with weight-lifing exercise by rats. J. Appl. Physiol. 1988; 65: 950-4.

15. Yaspelkis 3rd BB, Singh MK. Trevino B. Krisan AD. Collins DE. Resistance training increases glucose uptake and transport in rat skeletal muscle. Acta Physiol. Scand. 2002; 175: 315-23.

16. Krisan AD, Collims DE. Crain AM et al. Resistance training enhances components of the insulin signaling cascade in normal and high faf-fed rodent skeletal muscle. J. Appl. Physiol 2004; 96: 1691-700.

17. Lowe DA. Alway SE. Animal models for inducing muscle hypertrophy: Are they relevant for clinical applications in humans? J. Orthon. Sports Phys. Ther. 2002; 32: 36-43. 
I8 American College of Sporls Medicine. Position Stand. Physical aclivity, physical fitness, and hypertension. Med. Sci. Sports Exerr. 1993; 25: i-x.

19. Layne JE, Nelson ME. The effects of progressive resistance training on bone density: A review. Ated. Sci. Spons Exerc. 1999; 31: 25-30.

20. Tollback $A$, Eriks son S. Wredenberg A ef al. Effects of high resistance training in patients with myotonic dystrophy. Scand. J. Rehab. Med. 1999; 31: 9-16.

21. Deschenes MR. Kraemer WJ. Performance and physiologic adaptations to resistance training. Am. J. Phys. Med. Rehab. 2002; 81: S3-16.

22 Naffah-Mazzacoratti MG, Cassarini DE, Femandes MIS, Cavalheiro EA. Serum catecholamine levels delermined by high performance liquid chromatography coupled with electrochemical detection. Arq. Bras. Endocrinol Metah. 1992; 36: 119-22.

23. Zavorsky GS. Evidence and possible mechanisms of altered maximum heart rate with endurance training and tapering. Sports Med. 2000; 29: 13-26.

24. Fernandez R. One repetition maximum clarified. J. Onthop. Sports Phys. Ther. 2001; $31: 264$.

25. Tesch TA, Larsson L. Muscle hypertophy in bodybuilders. Eur. J. Appl Physiol. 1982: 49: 304-6.

26. Shapiro LM. Physiological left ventricular hypertrophy. Br. Hean J. 1984: 52: 130-5.

27. Wisloff U, Helgerud J, Kemi OJ, Ellingsen O. Intensity-controlled treadmill running in rats: VO ( 2 max) and cardiac hypertrophy. Am. J. Physiol. Hear Circ. Physiol. 2001; 280: H1301-10.

28. Brown SP. Thompson WR. Standardization indices of cardiac hypentrophy in weight lifters. J. Sports Sci. 1987; 5: 147-53.

29. Van den Broeke $C$. Fagard $R$. Left ventricular structure and function, assessed by imaging and Doppler echocardiography, in athletes engaged in throwing events. Int. J. Sponts Med. 1988; 9: 407-11. .

30. Fagard RH. Athlete's heart: A meta-analysis of the echocardiographic experience. Int. J. Sports Med. 1996; 17 (Suppl. 3): S140-4.

31. Goldberg L, Ellior DL, Kuehl KS. A comparison of the cardiovascular effects of running and weight training. J. Strength Cond. Res. 1994; 8: 219-24

32 Kanakis C, Hickson RC. Left ventricular responses to a program of lower-lintb strength training. Chest 1980; 78: 618-21.

33. Lusiani L, Ronsisvalle G. Bonanome A et al. Echocandiographic evaluation of the dimensions and systolic properties of the left ventricle in freshman athletes during physical training. Eur. Heart $J$. 1986; 7: 196-203.
34. Ricci G, Lajoie D. Petitclere R et al. Left ventricular size following endurance, sprint, and strength training. Med. Sci. Sports Exerc. 1982; 14: 344-7.

35. Folkow B. Physiological axpecis of primary hyperiension. Physiol. Rev. 1982: 62: 347-504.

36. Riebe D. Fernhall B. Thompson PD. The blood pressure response to exercise in anabolic steroid users. Med. Sci. Sports Exere. 1992; 24: 633-7.

37. Viitasalo JT, Komi PV, Karvonen MU. Muscle strength and body composition as determinants of blood pressure in young men. Eur. $J$. Appl Physiol. Occup. Physiol. 1979; 42: 165-73.

38. Smith ML, Raven PB. Cardiovascular responses to lower body negative pressure in endurance and static exercise-trained men. Med. Sci Sports Exerc. 1986; 18: 545-50.

39. Longhurst JC, Kelly AR, Gonyea WJ, Mitchell JH. Cardiovascular responses to static exercise in distance nunnes and weight lifters. J. Appl. Physiol 1980; 49: 676-83.

40. Fleck SJ, Dean LS. Resistance-training experience and the pressor response during resistance excrcise. J. Appl Physiol. 1987; 63: 1 i6-20.

41. Van Hoof R, Macor F, Lijnen $P$ et al. Effect of strength training on blood pressure measured in various conditions in sedentary men. Int. J. Sports Med. 1996; 17: 415-22.

42. O'Sullivan SE, Bell C. The effects of exercise and training on human cardiovascular reficx control. J. Aufon. Nerv. Syst. 2000; 81: 16-24.

43. Kingwell BA. Large artery stiffness: Implications for exercise capacity and cardiovascular risk. Clin. Exp. Phamacol Physiol. 2002; 29: 214-17.

44. Bertovic DA, Waddell TK, Gatzka CD, Cameron JD, Dart AM, Kingwell BA. Muscular strength training is associated with low arterial compliance and high pulse pressure. Hyperiension 1999; 33: $1385-91$.

45. Delp MD, Laughlin MH. Time course of enhanced endotheliummedialed dilation in aorta of trained rats. Med. Sci. Sports Exerc. 1997; 29: $1454-61$.

46. Goldstein DS. Stress-induced activation of the sympathetic nervous sysiem. Baillieres Clin. Endocrinol. Metab. 1987; 1: 253-78.

47. Selye $\mathrm{H}$. The evolution of the stress concept Stress and cardiovascular discase. Am. J. Candiol. 1970; 26: 289-99.

48. Cook NR, Cohen J, Herbert PR, Taylor-JR, Hennekens CH. Implication of small reduction in diastolic blood pressure for primary prevention. Arch Intem Med. 1995; 155: 701-9. 


\title{
Effects of Resistance Training on Ventricular Function and Hypertrophy in a Rat Model
}

\author{
Valério Garrone Barouna, MSc; Koleizu Teodoro Rosa, MSc; \\ Maria Cláudia Irigoyen, PhD; and Edilamar Menezes de Oliveira, PhD
}

\begin{abstract}
Objective: The purpose of this study was to follow the ventricular function and cardiac hypertrophy in rats undergoing a resistance-training program for a period of 3 months.

Design: Forty animals were divided into two major groups: control $(n=16)$ and resistance trained $(n=24)$. From the resistance-trained group, 12 animals were resistance trained for 1 month and another 12 for 3 months. The resistance-training protocol was performed with 4 sets of 12 repetitions using $65 \%$ to $75 \%$ of one repetition maximum (maximum lifted weight with the exercise apparatus).
\end{abstract}

Methods: Echocardiographic analysis was performed at the beginning of the resistance-training period and at the end of each month. The repetition maximum was measured every 2 weeks. Cardiac hypertrophy was determined by echocardiography, by the absolute weight of the cardiac chambers and by histology of the left ventricle.

Results: Before resistance training, both groups had similar repetition maximums, ranging from 1.8-fold to 2-fold the body weight; however, at the end of the resistance-training period, the repetition maximum of the resistance-trained group was 6-fold greater than the body weight The left ventricular mass as assessed by echocardiography was $8 \%, 12 \%$ and $16 \%$ larger in the resistance-trained group than in the control group in the first, second and third months, respectively. This hypertrophy showed a similar increase in the interventricular septum and in the free posterior wall mass. There was no reduction in the end-diastolic left ventricular internal diameter during the 3-month resistance-training period. Systolic function did not differ between the groups throughout the resistance-training period.

Conclusion: Resistance training induces the development of concentric cardiac hypertrophy without ventricular dysfunction or cavity reduction. Although diastolic function was not completely investigated, we cannot exclude the possibility that resistance training results in diastolic dysfunction.

Keywords: Cardiac hypertrophy: Echocardiography: Resistance training

R training is a spccialin, also known as weight or strength increase muscle strength, muscle endurance and muscle power. In response to this kind of training, both skeletal and cardiac muscle adapts. The main muscle adaptation of the athlcte's body is the increase in size or mass (hypertrophy) of lype II skelctal muscle cells ${ }^{1}$ and cardiac hypertrophy. However, different from hypertensive conditions when pressurc overload is continuous, the cardiovascular response to this exercise model is characterized by the intermittent increase in blood pressure during exercise. ${ }^{2}$

Due to the pressure overload during exercise, practitioners of modalities such as weight training develop a cardiac hypertrophy different from those practitioners of sports with a high dynamic component (e.g., running). This hypertrophy is charactcrized by increases in the left ventricular (LV) wall and no changes in the diameter of the LV cavity in diastole. Thus, these athletes are presumed to develop concentric LV
Reprint Requesta: Edilamar Menezes de Ollveira. PhD. Laboratory of Biochemistry. School of Physlcal Education and Sport, Av. Prof. Mello Moraes. 65. 05508-900. Butanta. Cidade Unlversitárla, Sio Paulo. SP-Brazil. Tel: 55-11-3091-3136. Fax: 55-I1-3813-5921, Emall: cdllamar@usp.br

$\begin{array}{ll}\text { Received: June 12. } 2006 & \text { Grant Suppore: Recipient of FAPESP } \\ \text { Revlsed: December 10.2006 } & \text { Fellowship N03/10302-2 (Barauna) } \\ \text { Accepted: January 18. } 2007 & \text { Supported by FAPESP grant OA/11624-6 } \\ & \text { (Olveira) and 01/00009-0) (Irigoyen) } \\ \text { dol: } 10.3121 / \mathrm{cm} .2007 .707 & \end{array}$


hypertrophy charactcrized by an increased ratio of wall thickness to radius. ${ }^{3.4}$ The increase in wall thickness induced by pressure-overload is mainly due to an increase in the myocyte cross-sectional area. ${ }^{5}$

Cardiac hypertrophy might also result from pressure overload observed in many pathologic conditions such as hypertension. However, this kind of hypertrophy is followed by diastolic or systolic dysfunction and a disproportionate increase in the thickness of the LV posterior wall and interventricular septum.6,7 Moreover, similar adaptations are usually found in athletes who use anabolic steroids associated with resistance training. 7,8

Athough several authors ${ }^{3-5}$ have studied the impact of different sports on cardiac structure, a follow-up study using an animal model has not been used yet to study adaptive changes in resistance training. We chose to focus on the resistance-trained heart to investigate echocardiographic data, such as the association of LV mass with myocyte thickness and heart weight, and to investigate changes in ventricular function in rats undergoing resistance training for a period of $I$ and 3 months.

\section{Methods}

Animal Care and Resistance-Training Protocol

Forly male Wistar rats $(250-300 \mathrm{~g}, 10$ weeks old) were randomly divided into two groups: control $(n=16)$ and resistance trained (trained) $(n=24)$. Half the animals were sacrificed after 1 month of training ( 8 controls and 12 trained) and the others after 3 months. Animals were housed in standard cages, and food and water were provided ad libitum. Animals were weighed every week. The environmental temperature was kept at $23 \pm 1{ }^{\circ} \mathrm{C}$, and a dark:light cycle of 12 hours each was maintained throughout the experiment. All protocols were in accordance with the guidelines of the Brazilian College for Animal Experimentation and were approved by the Biomedical Sciences Institute/USP-Ethical Committee for Animal Research.

Animals were exercised following a model described by Tamaki et al. ${ }^{9}$ Rats fitted with a canvas jacket were able to regulatc the twisting and flexing of their torsos and were suspended in a standard position on their hind limbs. An electrical stimulation ( $20 \mathrm{~V}, 0.3 \mathrm{sec}$ duration at $3 \mathrm{sec}$ intervals) was applied to the rat's tail through a surface electrode. As a result, the rats flexed their legs repeatedly, which lifted the weight-arm of the training apparatus. Twelve animals from the trained group were exercised with 4 sets of 12 repetitions each with a $90 \mathrm{sec}$ rest period between each set, 5 times per weck for 4 weeks, and the remaining animals in the group werc exercised for 12 weeks. This excrcise program started after 2 wceks of adaptation. After measurement of the maximum weight lifted ( 1 repetition maximum) with the squat-training apparatus, the training load was set at $65 \%$ to $75 \%$ of 1 repetition maximum. All training sessions were performed in a dark room. The maximum power generated for jumping in rats ( 1 repetition maximum) was defined as the maximum load that the rats were able to jump following electrical stimulation, and was measured biweekly.

\section{Echocardiography}

Echocardiographic features were obtained under the recommendations of the American Society of Echocardiography. 10 Transthoracic echocardiography was performed before the training and every 30 days until the end of the third month, and by only one observer using Sequoia 512 equipment (ACUSON Corporation, Mountain View, CA) and a 10 to $14 \mathrm{MHz}$ multifrequency linear transducer. Images were obtained with the transducer placed on the animal's shaved chest (lateral recumbence). To optimize the image, a transmission gel was used between the transducer and the animal's chest (general imaging gel, ATL Inc., Reedsville, PA). Animals were scanned from below at a depth of $2 \mathrm{~cm}$ with the focus optimized at $1 \mathrm{~cm}$. All measurements were performed by the same observer based on the average of 3 consecutive cardiac cycles. Rats were anesthetized with halothane $(0.75 \%$ to $1.25 \%, 1 \mathrm{~L} / \mathrm{min})$. Wall thickness and $\mathrm{LV}$ dimensions were obtained from a short-axis view at the level of the papillary muscles. LV mass was calculated by the use of the following formula, assuming a spherical LV geometry and validated in rats: $L V$ mass $=1,047 x\left[\left(\mathrm{LVd}+\mathrm{PWd}+[\mathrm{Wd})^{3}-\mathrm{LVd}^{3}\right]\right.$, where 1,047 is the specific gravity of muscle, LVd is LV end-diastolic diameter and PWd and IWd are end-diastolic posterior and interseptum wall thickness, respectively. LV shortening was calculated as (LVd-LVs)/LVdx 100, where LVs is LV end-systolic diameter. LV ejection fraction was calculated according to the Teichholz formula. Two-dimensionally guided pulsed Doppler recordings of LV transmitral flow were obtained from the apical 4-chamber view. Isovolumic relaxation time was taken as the time from aortic valve closure to the onset of mitral flow. Velocity of circumferential shortening was measured using the formula (LVd-LVs)/(LvdxET), where ET is the ejection time.

\section{Morphological Analysis}

The hearts were excised and perfused through the aortic stump from a reservoir located $70 \mathrm{~cm}$ above the heart and kept at room temperature. All hearts were initially perfused with $10 \mathrm{ml}$ of phosphate buffered saline to wash out the blood, and after the hearts were stopped at diastole by perfusion with $14 \mathrm{mM} \mathrm{KCl}$. The left ventricle was obtained as that remaining after removal of both atria and the free wall of the right ventricle. Afterwards, the cardiac chamber was weighed.

For histological analysis, the left ventricle was fixed in $6 \%$ formaldehyde and embedded in paraffin, cut into $5 \mu \mathrm{m}$ sections at the level of the papillary muscle and subsequently stained with hematoxylin and cosin. Two randomly selected sections from each animal were visualized by light microscopy using an oil immersion objective with a calibrated magnification $(400 X)$. Myocytes with visible nuclei and intact cellular membranes were chosen for diameter determination. The width of individually isolated 
isrdiomyocytes displayed on a viewing screen was manually raced across the middle of the nuclei with a digitizing pad and determined by a computer-assisted image analysis system (Quantimet 520, Cambridge Instruments, Cambridge, UK). For each animal, approximately 20 visual fields were analyzed.

\section{Sioristical Analysis}

All data are expressed as mean \pm standard deviation (SD). Differences among groups (icft ventricle, right ventricle and atrium weight) were assessed by the Student $t$ tcst. All other statistical comparisons wcre performed by a randomized repeated measure 1-way analysis of variance (ANOVA). When a significant difference was detected, comparisons were carried out by Tukey's post-hoc test. $P<0.05$ was considered statistically significant.

\section{Results}

No difference was observed between groups for body weight or heart rate during the 3 month study period (table 1).

\section{One Reperition Maximum}

Figure I shows a progressive increase in the absolute weight lifted by the trained group obtained during the repetition maximum test. Both the control and the trained group had similar values for repetition maximum at the beginning (day 0 ) of the protocol. After 15 days, the load lifted by the trained group was already higher than that of the control group and also $76 \%$ higher than that lifted in the first test. At the end of the first month, the trained group lifted $1488 \pm 83 \mathrm{~g}$, and 2350 $\pm 108 \mathrm{~g}$ at the end of the third month, which represents 4.7 -fold and 6.7-fold the body weight for 1 and 3 months, respectively.

\section{Cardiac Function}

Echocardiographic results from cardiac function in control and trained animals are summarized in table 1. Neither diastolic function analyzed by isovolumic relaxation time, nor systolic

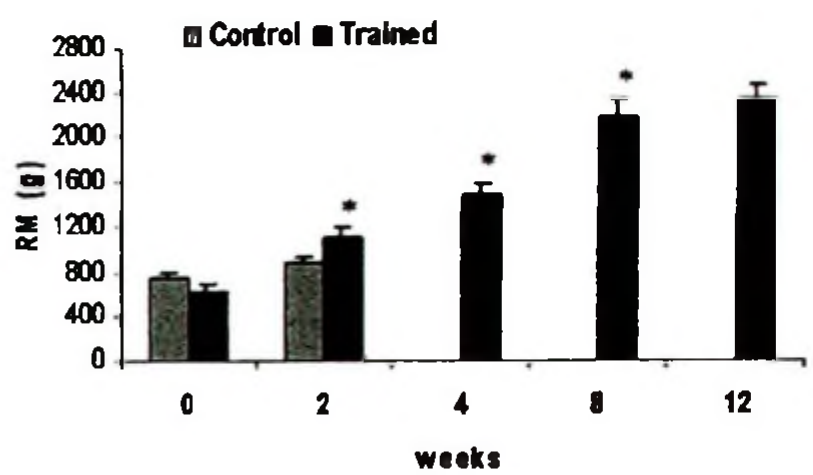

Figure 1. Absolute values for 1 repetition maximum test. Results are presented as mean \pm standard deviation. $P<0.05$ when compared with the previous test. Randomized one-way ANOVA.

function analyzed by both LV ejection fraction and fractional shortening, and by velocity or circumferential fiber shortening were significantly different between the control and trained group during the 3 month training period.

\section{Cardiac Structure by Echocardiography}

The mean relative LV wall thickness of the control group was significantly smaller than that of the trained group in the second and third month. This may indicate the development of concentric hypertrophy. Results from the echocardiography studies are summarized in table 2 .

LV internal diameter, interventricular septum and LV posterior wall thickness were measured during the diastolic phase. No significant difference in LV internal diameter was observed when the control and trained groups were compared in each of the 3 months of the protocol. LV hypertrophy was similar in both walls $(1.4 \%, 7.1 \%$ and $8.3 \%$ in the first, second and third month, respectively). The difference between the control and

Table 1. Body weight, heart rate and cardiac function of control and trained rats during the 3-month training period. Results are presented as mean \pm SD.

\begin{tabular}{|c|c|c|c|c|c|c|c|c|}
\hline & \multicolumn{4}{|c|}{ Control $(n=8)$} & \multicolumn{4}{|c|}{ Trained $(n=12)$} \\
\hline & \multicolumn{4}{|c|}{ Month } & \multicolumn{4}{|c|}{ Month } \\
\hline & 0 & 1 & 2 & 3 & 0 & 1 & 2 & 3 \\
\hline$B W, g$ & $306 \pm 24$ & $326 \pm 23$ & $368 \pm 28$ & $370 \pm 21$ & $302 \pm 19$ & $321 \pm 24$ & $347 \pm 23$ & $350 \pm 37$ \\
\hline HA, bpm & $408 \pm 33$ & $420 \pm 15$ & $400 \pm 36$ & $423 \pm 21$ & $420 \pm 13$ & $410 \pm 17$ & $422 \pm 14$ & $417 \pm 19$ \\
\hline LVEF, \% & $54.8 \pm 1.9$ & $55.1 \pm 1.8$ & $53.7 \pm 1.6$ & $52.3 \pm 0.9$ & $52.6 \pm 1.8$ & $54.9 \pm 1.9$ & $54.5 \pm 1.9$ & $52.7 \pm 0.9$ \\
\hline LVFS, \% & $24.8 \pm 1.1$ & $24.9 \pm 1$ & $24.1 \pm 1$ & $23.3 \pm 0.4$ & $23.3 \pm 1.1$ & $24.8 \pm 1.1$ & $24.5 \pm 1.2$ & $23.5 \pm 0.5$ \\
\hline$V C F$, circ/sec & $19.7 \pm 1.7$ & $20.2 \pm 0.8$ & $20.8 \pm 1.7$ & $17.4 \pm 0.5$ & $18.5 \pm 0.6$ & $21.1 \pm 0.5$ & $17.5 \pm 1.8$ & $17.6 \pm 0.8$ \\
\hline IVAT, ms & $20.8 \pm 3.1$ & $21 \pm 1.2$ & $20.4 \pm 1.5$ & $21 \pm 1$ & $19.7 \pm 2.1$ & $20.3 \pm 1$ & $22.4 \pm 1.6$ & $22 \pm 1.6$ \\
\hline
\end{tabular}

BW, body weight; HR, heart rate; IVRT, isovolumetric relaxation time; LVEF, left ventricular ejection fraction; LVFS. left ventricular fractional shortening; VCF, velocity of circumterential fiber shortening.

116 Ventricular function and resistance training 
Table 2. Cardiac structure of the control and trained rats during the 3 month training period. Results are presented as mean \pm SD.

$\frac{\text { Contral }(n=8)}{\text { Month }}$

\begin{tabular}{cccc}
\multicolumn{5}{c}{ Tralned $(n=12)$} \\
\hline 0 & 1 & 2 & 3 \\
\hline $0.71 \pm 0.03$ & $0.72 \pm 0.04$ & $0.72 \pm 0.02$ & $0.75 \pm 0.03$ \\
$0.138 \pm 0.005$ & $0.140 \pm 0.002$ & $0.155 \pm 0.005^{*}$ & $0.155 \pm 0.004^{\circ}$ \\
$0.138 \pm 0.004$ & $0.140 \pm 0.002$ & $0.155 \pm 0.004^{*}$ & $0.155 \pm 0.005^{\circ}$ \\
$0.61 \pm 0.02$ & $0.67 \pm 0.06$ & $0.76 \pm 0.02^{*}$ & $0.84 \pm 0.06^{*}$ \\
$0.39 \pm 0.021$ & $0.39 \pm 0.022$ & $0.43 \pm 0.024^{\circ}$ & $0.42 \pm 0.022^{\circ}$ \\
\hline
\end{tabular}

0

\begin{tabular}{llllll}
\hline LVId, cm & $0.73 \pm 0.06$ & $0.72 \pm 0.05$ & $0.75 \pm 0.04$ & $0.77 \pm 0.03$ \\
PWTd, cm & $0.138 \pm 0.008$ & $0.138 \pm 0.004$ & $0.140 \pm 0.002$ & $0.143 \pm 0.005$ \\
IVSTd, cm & $0.138 \pm 0.007$ & $0.138 \pm 0.004$ & $0.140 \pm 0.001$ & $0.143 \pm 0.006$ \\
LVM. g & $0.59 \pm 0.04$ & $0.62 \pm 0.07$ & $0.68 \pm 0.06$ & $0.72 \pm 0.03$ \\
RWT & $0.38 \pm 0.023$ & $0.38 \pm 0.022$ & $0.37 \pm 0.022$ & $0.37 \pm 0.024$
\end{tabular}

IVSTd, diastolic interventricular septum thickness: LVIDd, left ventricular end-diastolic internal diameter; LVM, left ventricular mass; PWTd, diastolic posterior wall thickness; RWT, relative wall thickness. $* P<0.05, \mathrm{TR} \times \mathrm{CO}$ group at the same age.

trained groups began in the second month and was maintained in the third month (table 2).

LV mass of the control rats was significantly smaller than the mean LV mass of the trained rats starting in the second month $(11.7 \%$ and $16.7 \%$ in the second and third month, respectively, both $P<0.05$ ) (table 2). However, in the first month, no significant difference was found; the LV mass only showed a slight increase $(8 \%)$.

Cardiac Morphology by Absolute Weight and Histology A similar percentage of cardiac hypertrophy was found in the absolute LV weight (figure 2$)(7.6 \%$ in the first month, $P>0.05$; and $13.9 \%, P<0.05$ in the third month). No difference was found in the right ventricle or in the atrium weights. The increase in LV weight was further confirmed by increases of $8.3 \%$ and $14.1 \%$ in the LV myocyte width in the first and the third month, respectively, when control rats were compared with trained rats (figure 3 ).

\section{Discussion}

This is the first follow-up study using echocardiography in rats undergoing resistance training. The LV hypertrophy was

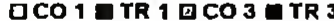

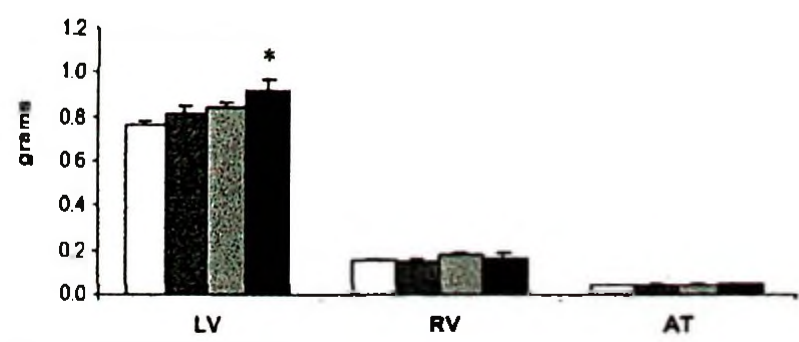

Figure 2. Absolute cardiac chamber weights. LV indicates lett ventricle; RV, right ventricle; $A T$, atrium; $C O 1$ and $C O 3$, 1 -month and 3-month control groups; TR 1 and TR 3,1-month and 3-month trained groups. * $P<0.05$, TR $1 \times$ CO 1 and TR $3 \times$ CO 3. Randomized Student $t$-test. similar when evaluated by echocardiography or absolute weight and cardiomyocyte width. This study showed a similar increase in the septum and free posterior wall mass but no reduction in the end-diastolic LV internal diameter during the 3 month training period, thus resulting in an increase in relative $\mathrm{LV}$ wall thickness. Also, diastolic function assessed by isovolumetric relaxation time, and systolic function assessed by ejection fraction, shortening fraction and velocity of circumferential fiber shortening did not differ between control and trained groups during the training period. These results suggest that resistance training induces concentric cardiac hypertrophy without any trace of ventricular dysfunction or reduction in the size of the ventricular cavity. Furthermore, echocardiography is a well-founded approach to evaluate cardiovascular adaptations in an experimental model that mimics squatting exercises performed by humans.

\section{Repetition Maximum}

To characterize training efficiency, repetition maximum was used as an index. Additionally, the maximum strength achieved by the rats was used to determine the training load and to demonstrate training development. As in aerobic training, where maximum heart rate or $\mathrm{VO}_{2 \max }$ are used to prescribe

\section{口CO1ロTR $1 \boxminus \operatorname{CO} 3 \backsim \operatorname{TR} 3$}

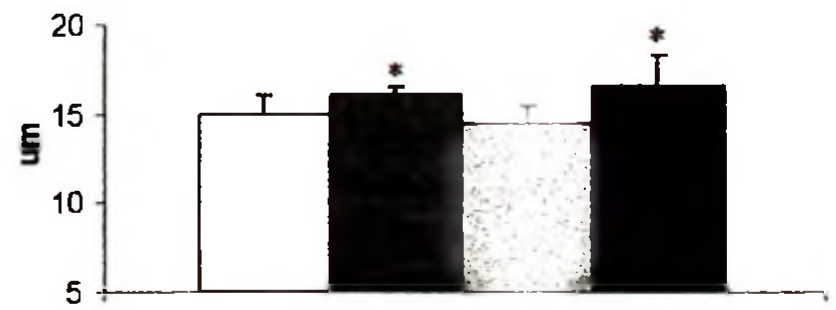

Figure 3. Left ventricular myocyte width. $\mathrm{CO} 1$ and $\mathrm{CO} 3$, 1-month and 3-month control groups; TR 1 and TR 3,1-month and 3-month trained groups. $P<0.05$, TR $1 \times$ CO 1 and TR 3 x CO 3. Randomized Student t-test. 
exercisc, " repetition maximum is used in resistance training fur prescription. ${ }^{12}$ Also, as previously demonstrated, results frum our laboratory showed that this protocol is unaffected by the electrical stimulation. ${ }^{13}$

The results shown here are similar to results from other studies that used the same training apparatus. ${ }^{14}$ The increase in strength may have two origins, neural and muscular, as proposed by Moritani and deVries. 15 They proposed that neural adaptations dominate early in the training program. Later, as meural adaptations reach a plateau, muscular adaptations (hypertrophy) dominate.

\section{Cardiac Structure and LV Mass}

Concerning cardiac structure of the athlete's heart two different morphological forms may be distinguished. In sports with high dynamic and low static demand, eccentric hypertrophy predominates, while in strength training concentric hypertrophy is predominant. ${ }^{3}$ Fagard ${ }^{16,17}$ observed that athletes engaged in static training had LV dimension increased $2.5 \%$ and LV wall thickness increased $12 \%$ compared with that in non-athletes. In addition, Dickerman et al18 demonstrated that LV wall thickness $>13 \mathrm{~mm}$ can be found routinely in elite resistance-trained athletes, and the use of anabolic steroids concomitant with resistance training does appear to augment LV mass. Normal or a slight increase in LV internal diameter and a large increasc in LV wall thickness are commonly explained on the basis of the acute increase in blood pressure during resistance training. 19,20

Also resistance-trained individuals have both the posterior LV wall thickness and intraventricular septum wall thickness greater than average. ${ }^{17,21}$ However, these values do not exceed the limits of normal values, different from those observed in pathologic conditions, such as aortic stenosis, obstructive cardiomyopathy and hypertension. 7,20 Therefore, the increase in the wall thickness is not a required result of all resistance training programs, and the conflicting results in the literature are probably due to differences in sex, age or in the training protocols used, including muscle mass involved, exercise intensity, rest periods between sets and training volume. ${ }^{22}$ Haykowsky et $\mathrm{al}^{21}$ have recently attributed this disparity between studies of whether resistance training consistently results in cardiac hypertrophy to three reasons: (1) acute cardiopulmonary mechanisms that minimize the increase in transmural pressure and LV wall stress during exercise, (2) the underlying use of anabolic steroids by the athlctes, or (3) the specific type of resistance training performed. $\mathrm{H}_{\mathrm{c}}$ believe that this exercise model may be a useful tool to uravcl this discrepancy in an animal model, where the use of anabolic stcroids and the type of resistance training may be preciscly controlled and the cardiac ultra-structure further investigated.

Changes in the LV internal diameter in most cases are not significantly different from normal.3,4,7,16,23,24 Although resistance training may have some effect on LV internal diameter, it is not reduced due to the pressure overload as in hypertension or other forms of induced cardiomyopathy pressure-overload.?

As observed above, LV mass can increase due to an increase in either ventricular wall thickness or internal dimensions. The latter is frequently observed when the primary stimulus is the volume overload. Increased end-diastolic wall stress leads to series replication of sarcomeres, fiber elongations, chamber enlargement and eccentric hypertrophy. Acute increase in peak systolic wall stress (pressure overload) leads to parallel replication of sarcomercs, wall thickening and concentric hypertrophy. 5.25 .26 Both cross-sectional studies and short-term longitudinal studies ${ }^{3,17,21}$ indicate that the absolute LV mass increases significantly due to resistance training. The similarities in the results among the threc different methods of analysis of LV hypertrophy demonstrate that echocardiography is a reliable method to evaluate it also in the animal model.

\section{Cardiac Function}

LV systolic function is gencrally assessed in echocardiographic studies by measuring the extent of fiber shortening, ejection fraction and velocity of circumferential fiber shortening, 27 while diastolic function is assessed by studying the pattern of ventricular filling through the mitral valve. ${ }^{28}$ Abnormalities in systolic and diastolic function are generally associated with cardiac hypertrophy induced by pathological conditions, such as hypertension and valvular disease.7.29 Our results of systolic function are in agreement with those in the literature where reports demonstrate that cardiac function is not altered in resistance-trained individuals. ${ }^{3.4 .7}$ However, to the best of our knowledge, only two studies indicate an enhanced systolic function. ${ }^{30,31}$ One study indicated enhanced diastolic function, reporting that atrial peak-filling rate is greater in power lifters than in non-power lifters. ${ }^{32}$

\section{Clinical Implications of the Study}

Physical activity can potentially be an effective treatment for various clinical conditions, such as cardiovascular disease and osteoarthritis. In recent years, an increasing number of clinical and research experiments have been conducted on resistance exercise in congestive heart failure. Patients with congestive heart failure have a poor clinical status and impaired exercise capacity due to both cardiac limitations and peripheral maladaptations of the skeletal musculature. Levinger et $\mathrm{al}^{33}$ investigated the effects of 8 weeks of resistance training on the $L V$ structure and function of patients with congestive heart failure. They reported that resistance training is a suitable method of exercise for congestive heart failure patients since it does not cause a reduction of LV contractility function or enhance myocardial deterioration as measured by ejection fraction and fractional shortening.

Recent studies ${ }^{34,35}$ indicate that endothelial dysfunction in coronary and also peripheral arterics predicts cardiovascular 
events; however, the mechanisms responsible for the benefits of resistance training on cndothelial function are controversial. It is not clear, however, whether the beneficial effects of resistance training on endothelial function are a consequence of improvements in risk factors (scrum lipid concentration, blood pressure, obesity or glycemic control) induced by resistance training or to some other mechanisms. However, Green et $a^{36}$ show that the benefits of resistance training on vascular function are not solely mediated by the effects of exercise on cardiovascular risk factors. An explanation for the effect of exercise training on vasculature function is that exercise exerts direct effects on the vasculature by increasing shear stress that increases vascular nitric oxide production. Vascular function might be considered a useful independent measure of atherosclerotic disease risk ${ }^{34,35}$ According to recent studies, combined endurance and resistance training or resistance training alone should be recommended as a safe and effective alternative training mode in order to counteract peripheral maladaptation and improve muscle strength necessary for daily activities, and thus improve the quality of life of congestive heart failure patients.

\section{Study Limitations}

Although it is well established that the anesthetic regimen modifies cardiac parameters, such as heart rate and ejection fraction, performing an echocardiogram in awake animals is challenging. We chose to do the echocardiographic examination by using halothane anesthesia in an attempt to keep the heart rate as close as possible to the physiologic state. However, high heart rates, common in rats, are used to unite $\mathbf{E}$ and $A$ peaks and make isovolumic relaxation time too short, which makes diastolic function measurements unavailable. However, having all animals undergo the same anesthetic regimen makes the differences observed trustworthy. Also, as we have followed the animals for only 3 months, we cannot exclude changes occurring over a long period.

\section{Conclusion}

The main findings in this study indicate that resistance training in rats, which mimics squatting exercises performed by humans, induces chronic adaptations, such as cardiac hypertrophy, in the first second and third month of training. It also indicates that cchocardiography is a well-founded approach to evaluate these cardiovascular adaptations in this experimental model

In conclusion, our results suggest that resistance training induces concentric cardiac hypertrophy without systolic dysfunction or reduction in the ventricular cavity. The similarities between previous reports having humans as subjects and our findings indicate that the model may be used for further studics concerning the development of physiological and pathological concentric cardiac hypertrophy.

\section{Acknowledgments}

We are grateful to Dr. J.G. Mill for review of this manuscript.

\section{References}

I. Komi PV. Strength and power in sports. 2nd ed. New York, NY: Blackwell Science, 2003

2. Effron MB. Effocts of resistive training on left ventricular function. Med Sci Sports Exerc 1989;21:694-697.

3. Pluim $B M, Z$ winderman $A H$, van der Laarse $A$, van der Wall EE. The athlete's heart. A meta-analysis of cardiac structure and function. Circulation 2000;101:336-344.

4. Longhurst JC, Kelly AR, Gonyea WJ, Mitchell JH. Echocardiographic left ventricular masses in distance runners and weight lifters. J Appl Physiol 1980;48:154-162.

5. Grossman W, Jones D, McLaurin LP. Wall stress and patterns of hypertrophy in the human left ventricle. J Clin Invest 1975;56:56-64.

6. Shapiro LM, Gibson DG. Patterns of diastolic dysfunction in left ventricular hypertrophy. Br Heart J 1988;59:438-445.

7. Hildick-Smith DJ, Shapiro LM. Echocardiographic differentiation of pathological and physiological left ventricular hypertrophy. Heart 2001;85:615-619.

8. Grace F, Sculthorpe N, Baker J, Davies B. Blood pressure and rate pressure product response in males using high-dose anabolic androgenic steroids (AAS). J Sci Med Sport $2003 ; 6: 307-312$

9. Tamaki $T$, Uchiyama $S$, Nakano $S$. A wcight-lifting exercise model for inducing hypertrophy in the hindlimb muscles of rats. Med Sci Sports Exerc 1992;24:88 I-886

10. Sahn DJ, DeMaria A, Kisslo J, Weyman A. Recommendations regarding quantitation in $\mathbf{M}$-mode echocardiography: results of a survey of echocardiographic measurements. Circulation 1978;58:1072-1083.

11. Zavorsky GS. Evidence and possible mechanisms of altered maximum heart rate with endurance training and tapering. Sports Med 2000;29:13-26.

12. Fernandez R. Onc repetition maximum clarified. J Orthop Sports Phys Ther 2001;31:264.

13. Barauna VG, Junior ML, Costa Rosa LF, Casarini DE, Krieger JE, Oliveira EM. Cardiovascular adaptations in rats submitted to a resistance-training model. Clin Exp Pharmacol Physiol 2005;32:249-254

14. Yaspelkis BB 3rd, Singh MK, Trevino B, Krisan AD, Collins DE. Resistance training increases glucose uptake and transport in rat skeletal muscle. Acta Physiol Scand 2002;175:315-323.

15. Moritani $T$, deVries HA. Neural factors versus hypertrophy in the time course of muscle strength gain. Am J Phys Med 1979;58:115-130.

16. Fagard RH. Athlete's heart: a meta-analysis of the echocardiographic experience. Int J Sports Med 1996; 17:S1 40-S144

17. Fagard RH. Impact of different sports and training on cardiac structure and function. Cardiol Clin 1997;15:397-412.

18. Dickerman RD, Schaller F, McConathy WJ. Left ventricular wall thickening does occur in elite power athletes with or without anabolic steroid use. Cardiology 1998;90:145-148.

19. Fleck SJ. Cardiovascular adaptations to resistance training. Med Sci Sports Exerc 1988;20:S146-S151.

20. MacDougall JD, McKelvic RS, Moroz DE, Sale DG, McCartncy N, Buick F. Factors affecting blood pressure during heavy weight lifting and static contractions. J Appl Physiol 1992;73:1590-1597.

21. Haykowsky MU, Quinney HA, Gillis R, Thompson CR. Left ventricular morphology in junior and master resistance trained athletes. Med Sci Sports Exerc 2000;32:349-352. 
22. Urhuusen A, Kindermann W. Echocardiographic findings in strength-and endurance-trained athletes. Sports Med $1992 ; 13: 270-284$

23. Wolfe LA, Cunningham DA, Boughner DR. Physical conditioning effects on cardiac dimensions: a review of echocardiographic studics. Can J Appl Sport Sci 1986;1 1:66-79.

24. George KP, Wolfe LA, Burggraf GW, Noman R

Electrocardiographic and echocardiographic characteristics of femalc athletes. Med Sci Sports Exerc 1995;27:1362-1370.

25. Perraull $\mathrm{H}$, Turcotte RA. Exercise-induced cardiac hypertrophy. Fact or fallacy? Sports Med 1994;17:288-308.

26. Shapiro LM. Physiological left ventricular hypertrophy. Br Heart J 1984;52:130-135

27. Spirito P, Pelliccia A, Proschan MA, Granata M, Spataro A, Bellone P, Caselli G, Biffi A, Vecchio C, Maron BJ. Morphology of the "athlete's heart" assessed by echocardiography in 947 elite athletes representing 27 sports. Am J Cardiol 1994;74:802-806.

28. Shimizu G, Hirota Y, Kita Y, Kawamura K, Saito T, Gaasch WH. Left ventricular midwall mechanics in systemic arterial hypertension. Myocardial function is depressed in pressure-overload hypertrophy. Circulation 1991;83:1676-1684

29. Nishimura RA, Housmans PR, Hatle LK, Tajik AJ. Assessment of diastolic function of the heart: background and current applications of Doppler echocardiography. Part I. Physiologic and pathophysiologic features. Mayo Clin Proc 1989;64:71-81.

30. Colan SD, Sanders SP, Borow KM. Physiologic hypertrophy: effects on left ventricular systolic mechanics in athletes. J Am Coll Cardiol 1987;9:776-783.

31. Maron BJ. Hypertrophic cardiomyopathy: a systematic review. JAMA 2002;287:1308-1320.

32. MacDougall JD, Tuxen D, Sale DG, Moroz JR, Sution JR. Arterial blood pressure response to heavy resistance exercise. J Appl Physiol 1985;58:785-790.

33. Levinger I, Bronks R, Cody DV, Linton I, Davie A. The effect of resistance training on left ventricular function and structure of patients with chronic heart failure. Int J Cardiol 2005;105:159-163

34. Suwaidi JA, Hamasaki S, Higano ST, Nishimura RA, Holmes DR Jr, Lerman A. Long-term follow-up of patients with mild coronary artery discase and endothelial dysfunction. Circulation 2000; 101:948-954.

35. Vila JA, Keaney JF Jr. Endothelial function: a barometer for cardiovascular risk? Circulation 2002;106:640-642.

36. Green DJ, Walsh JH, Maiorana A, Best MJ, Taylor RR, O'Driscoll JG. Exercise-induced improvernent in endothelial dysfunction is not mediated by changes in CV risk factors: pooled analysis of diverse patient populations. Am J Physiol Heart Circ Physiol 2003;285:H2679-H2687.

\section{Author Affiliations}

Valério Garrone Barauna. MS

School of Physical Education and Sports

University of São Paulo

São Paulo, Brazil

Kaleizu Teodoro Rosa, MSc

Heart Institute (InCor)

University of São Paulo, Medical School

São Paulo, Brazil

Maria Cláudia Irigoyen, PhD

Heart Institute (InCor)

University of São Paulo, Medical School

São Paulo, Brazil

Edilamar Menezes de Oliveira, PhD

School of Physical Education and Sports

University of São Paulo

São Paulo, Brazil 


\title{
CARDIOVASCULAR ADAPTATIONS IN RATS SUBMITTED TO A RESISTANCE-TRAINING MODEL
}

\author{
Valerio G Barauna, ${ }^{*}$ Miguel Luis B Junior, ${ }^{\ddagger}$ Luis Fernando BP Costa Rosa, ${ }^{\ddagger}$ Dulce E Casarini, ${ }^{\natural}$ \\ José Eduardo Kricger ${ }^{\dagger}$ and Edilamar M Oliveira*t \\ "Laboratory of Biochemistry, School of Physical Education and Sport, University of São Paulo, São Paulo. \\ 'Laboratory of Genetics and Molecular Cardiology and Unit of Applied Physiology, Heart Institute (InCor), \\ University of São Paulo School of Medicine, São Paulo, ${ }^{\ddagger}$ Laboratory of Metabolism, Institute of Biomedical Science, \\ University of São Paulo, São Paulo, and ${ }^{\$}$ Nephrology Division, Kidney and Hypertension Hospital, UNIFESP, \\ São Paulo, Brazil
}

\section{SUMMARY}

1. The present study sought to evaluate cardiovascular adaptations, such as blood pressure (BP), heart rate (HR) and cardiac hypertrophy, to resistance training (RT) in a rat model.

2. The training protocol consisted of four sets of 10-12 repetitions of the squat exercise performed at $65-75 \%$ of one repetition maximum (1RM) over 4 weeks. Animals were randomly divided into three groups: control $(n=8, C O)$, electrically stimulated $(n=8, \mathrm{ES})$ and trained $(n=8, \mathrm{TR}$; also electrically stimulated). Blood pressure and HR were measured by a direct method in conscious rats after the training period

3. All groups began with similar $1 \mathrm{RM}$ and $1 \mathrm{RM} / \mathrm{hody}$ weight (BW) ratio, however, at the end of the protocol only the TR group was different from the heginning ( $56 \%$ and $50 \%$, respectively; both $P<0.01$ ). The CO and ES groups had similar values for cardiac chambers weight/BW ratio, $\mathrm{HR}$ and diastolic, systolic and mean BP. Left ventricular hypertmoph (L'H) determined by the left ventricle $(\mathrm{LV})$ weight/BW ratio наs increased in the TR group (12\%) when compared to CO $(P<0.01)$ or ES groups $(P<0.01)$. No changes were found in the ueights of the atrium or right ventricle. Diastolic $(14 \%)$ and mean BP $(13 \%)$ were lower in the TR group $(P<0.05)$, whereas systolic BP and HR remained unchanged.

4. Collectively these results demonstrate that the rat RT model used is associated with significant development of cardiac hypertrophy and lowering of resting BP. These cardiovascular adaptations seem to a result of the training exercise and not influenced by stress since circulating calecholamine levels and adrenal gland weights remained unchanged in all groups.

Key words: cardiovascular system, myocardial hypertrophy, resistance training, weight lifting.

Comespondence: Dr Edilamar M Oliveira, Laboralory of Biochemistry, School of Physical Education and Sporr, Ave. Prof. Mello Moracs, 65, Butanıã, Cidade Universitária, 05508-9000, São Paulo, Brazil. Email: edilamar@usp.br

Reccived 31 May 2004; revision 28 November 2004; accepted I December 2004.

\section{INTRODUCTION}

In contrast to aerobic training, the cardiovascular adaptations induced by resistance training (RT) are not as well documented in published modical reports. For example, there is agreement in published reports that aerobic training elicits small reductions of arterial blood pressure (BP), but less is known about RT. Sorae studies in humans have suggested that the RT may also reduce anerial BP: $:^{1-7}$ however, inconsistent results have been found and possible mechanisms remain unclear. Also described in some published reports, RT may lead the heart to develop concentric hypertrophy; however, molecular and cellular stimuli are still unclear. "One of the main problems is the lack of models using laboratory animals. There are, in fact, some models described in the literature, but none of them have focused on the cardiovascular system ${ }^{9-16}$ The great majority of the srudies have focused on skeletal muscle adaptations such as the cellular and molecular mechanisms of skeletal muscle hyperurophy. ${ }^{17}$ One of the major advantages of using animal models is the capability of precisely control environmental and food intake conditions for all animals. Furthermore, the animals can be killed and tissue samples harvested and used for physiological, histological, biochemical and molecular analysis.

Aerobic exercise has been one of the modifiable interventions indicated for preventing or controlling hypertension, but only recently has RT been similarly prescribed. ${ }^{18}$ Since then several studies using humans as subjects have demonstrated the benefits of this type of exercise including: therapeutic intervention in osteoporosis, ${ }^{19}$ as well as muscular and mctabolic diseases. ${ }^{20}$

The purpose of the present study was to determine the effects of chronic RT on BP, hear rate (HR) and cardiac hypertrophy in an animal model and to investigate potential limitations of the model associated with the electrical stimulation used. A well-documented squat-training apparatus for $\mathrm{RT}$ in rats ${ }^{12}$ and an adapted training protacol for humans following American College of Sports Medicine guidelines were used. This training emphasizes moderate loads and a high number of repetitions, as practiced by bodybuilders." This apparatus was chosen because it mimics the traditional squat exercises performed by humans and the results obtained in skeletal muscle are similar to those seen in humans. ${ }^{17}$ 


\section{METHODS}

Animals

Tuenly-four Wistar rats $(360-400 \mathrm{~g}$ and 14 weeks old) were randomly divided into three groups: control $(\mathrm{CO} ; n=8)$, electrically stimulated (ES; $n=8)$ and Irained (TR; $n=8)$. Animals were housed in standand cages and lood and water were provided ad libitum. The environmental temperature was kept at $23 \pm 11^{\circ} \mathrm{C}$ and a 12:12 dark-light cycle was maintained through out the experiment. Animals were weighed every week. The measurements were underaken on the first day of the first week following the $\mathbf{2}$ weeks adapation period and on the last day of the fourth week All protocols and surgical procedures used were in accordance with the guidelines of the Brailian College for Animal Experimentation and were approved by the Estics Committee of the Institute of Biomedical Science of the University of Sjo Paulo.

\section{Exercise protocol}

Animals were exercised following a model adapted from Tamaki et al. ${ }^{n}$ (Fig. 1). Rats fitted with a canvas jacket were able to regulate the Iwisting and flexion of their torsos and were suspended in a standard position on their hind limbs. An electrical stimulation $(20 \mathrm{~V}, 0.3 \mathrm{~s}$ duration, at $3 \mathrm{~s}$ inernals) was applied to the rat's tail through a surface electrode. As a resule, the rats flexed their legs repeatedly, which lifted the weight-arm of

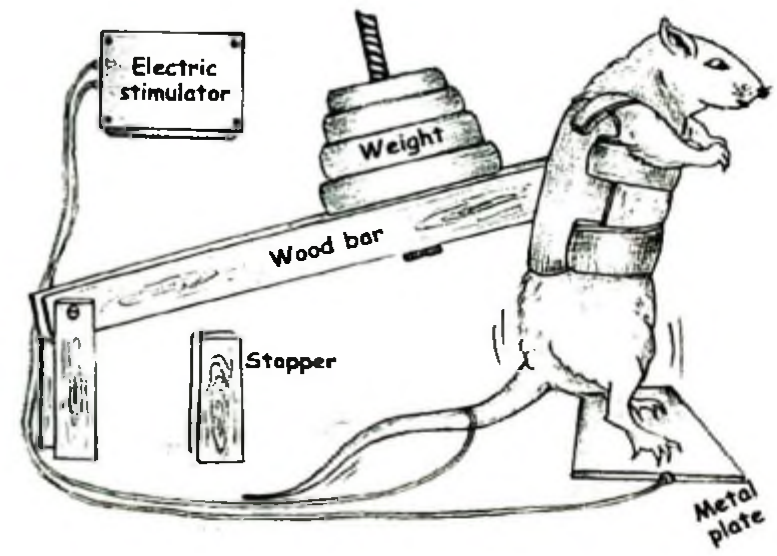

Fig. 1 Apparatus used to perform resistance training in the rats adapted from Tamaki el al. 1992 the training apparatus. The TR and ES groups were exercised by four sets of 12 repetitions with a $90 \mathrm{~s}$ rest period between each sel, five times per week for 4 weeks. This exercise regimen was started after 2 weeks of adaptation. After measurement of the maximum weight lifted (IRM) with the squal-training apparatus, the training load was set at 65-75\% of IRM only for the TR groups. The ES group received the same stimulus intensity and the same number of sets and repetitions as the TR group but without a training load. The ES group was used as a control to study the effects of the electrical stimulation. All training sessions were performed in a dark room. The IRM was defined as the minimum load that the rats were unable to jump following electrical stimulation. The IRM was measured biweekly.

Placement of arterial calheters was made under anaesthesia $4 \mathrm{~h}$ after the end of the exercise protocol as described below. On the day following BP and HR was reconded as described below, rats were killed by decapitation and trunk blood was collected into prechilied tubes and stored at $-80^{\circ} \mathrm{C}$ for measurements of plasma catecholamines (CA) concentrations. In addition, plantaris muscle, adrenal glands and heart were harvestod and weighted.

\section{Cardiac morphology}

After removal from the thoracic cavity, the heart was trimmed of excess of non-cardiac tissues. The heart was dissected to obtain the left ventricle (LV; free wall plus septum), atrium and right ventricle (RV) weights separately. Hypertrophy was expressed as increase in LV weight normalized for bodyweight (LV/BW)

\section{Measurcment of plasma CA}

Catecholamines such as noradrenaline (NE), adrenaline (EPI) and dopamine (DA) were measured by HPLC using ion-pair reverie phave chromatography coupled with eletrochemical detection $(0.5 \mathrm{~V})$, as described by Naffah-Mazzacoratti et al." - Fast isocratic separation was obtained using an RP 18 Brownlee column $(4.6 \times 250 \mathrm{~mm}, 5 \mu$. Applied Biosystems, San Jose, CA, USA) eluted with the following mobile phase: $20 \mathrm{mmol} / \mathrm{L}$ sodium dibasic phosphate, $20 \mathrm{mmol} / \mathrm{L}$ citric acid, pH 2.64, containing 10\% methanol, $0.12 \mathrm{mmol} / \mathrm{L} \quad \mathrm{Na}_{2} E D T A$ and $566 \mathrm{mg} / \mathrm{L}$ heptanesulphonic acid. The total lime for sample analysis was 30 min. Concentrations were directly determined using the following equation:

\section{pg $\mathrm{A} / \mathrm{mL}=$ PsA/PsDHBA $\times$ Standard quantity 3 Dilution factor} PstA PstDHBA

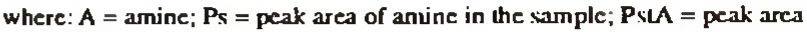
of amine in the standard; P.DHBA = peak area of dihydroxybenzylamine (DHBA) in the sample; and PsWHBA = peil area of DHBA in the standard. The intemal standard of extraction is DHBA. Resuls were expressed as $\mathrm{pg} / \mathrm{mg}$ protein.

Table 1 Bodyweight and absolute IRM in the first and the fourth week of training. adrenals glands and heart chambers weight normalized for the bodyweight and heart rate

\begin{tabular}{lllll}
\hline & & CO & ES & TR \\
\hline Bodyweight (g) & First week & $379 \pm 6.9$ & $374 \pm 11.5$ & $385 \pm 4.1$ \\
& Fourth wcek & $413 \pm 5.3$ & $394 \pm 8.6$ & $402 \pm 4.2$ \\
Atriurn (mg/g) & Fourth week & $0.15 \pm 0.013$ & $0.15 \pm 0.011$ & $0.14 \pm 0.013$ \\
Right ventricle (mg/g) & Fourth week & $0.53 \pm 0.02$ & $0.59 \pm 0.03$ & $0.55 \pm 0.04$ \\
Lefl ventricle (mg/g) & Fourth week & $2.05 \pm 0.05$ & $2.05 \pm 0.02$ & $2.30 \pm 0.03^{*}$ \\
Planlaris weight (mg/g) & Fourth week & $0.40 \pm 0.013$ & $0.41 \pm 0.02$ & $0.44 \pm 0.01^{* *}$ \\
IRM (g) & First week & $531 \pm 63.3$ & $491 \pm 53.7$ & $519 \pm 47.2$ \\
& Fourth wcek & $619 \pm 44$ & $625 \pm 61.2$ & $833 \pm 49.5$ \\
Hicart rasc (b.p.m.) & Fourth week & $364 \pm 6.3$ & $357 \pm 10.6$ & $333 \pm 8.8$ \\
Adrenal weighl (mg/g) & Fourth week & $0.17 \pm 0.04$ & $0.17 \pm 0.03$ & $0.17 \pm 0.01$ \\
\hline
\end{tabular}

CO, control; ES, electrically stimulated; TR, trained; IRM, repetition maximum; BW, bodyweight; LV, left ventricle. Data are reportod as means \pm SEM. $n=8$ each group. The BW and RM/BW ratio showed were obtained in the first and fourth week after the adaptation period. " $P<0.05$ comparing BW of the $\mathrm{CO}$ group in the fourth versus the first week and the CO versus TR and ES at the end of the protocol. ${ }^{*} P<0.01$ comparing LV/BW of the TR group versus $\mathrm{CO}$ and ES. "P $P<0.05$ comparing plantaris muscles weight of the TR group versus $C O$ and $E S$. $P<0.05$ comparing the IRM of the TR group in the fourth versus the first weck and the TR versus CO and ES at the end of the protocol. All others comparisons were not statistically significant 
Pasma (0.5 mL) was previously submitted to the following purification regime: $50 \mathrm{mg} \mathrm{Al}_{2} \mathrm{O}_{5}$ was weighed out in centrifuge tubes and the samples were added in Tris-buffer, pH 8.8, plus $40 \mu \mathrm{L}$ (8 $\mathrm{ng}$ ) of DHBA (internal tandard). The suspension was vortex-mixed for 10 min. The precipitated alumina was washed three times and vortex-mixed with $1 \mathrm{~mL}$ of water and the $C A$ were subsequently eluted with $400 \mu \mathrm{L}$ of $100 \mathrm{mmol} / \mathrm{L}$ perchloric acid afler 3 min of vortex mixing. After centrifugation for $3 \mathrm{~min}$ at $2500 \mathrm{~g}$. the supernatant was filtered and $100 \mu \mathrm{L}$ was injected into the reverse phase column. The concentration of $\mathrm{L}$-dopa was expressed as $\mathrm{pg} / \mathrm{mg}$ protein.

\section{Artcrial BP and HR}

Tuenty-four hours after the last training session and under pentobarbital anaesthesia (40 mg/kg IP), a cannula (PE-50) was inserted into the carotid artery. emerging through the back of the rat's neck. During the experimental session, this cannula was connected to a strain-gauge transducer (P23 Db; Gould-Statham). Twenty-four hours after the surgery, arterial BP was recorded on a beat-to-beat basis (AT/CODAS) at a frequency of $100 \mathrm{~Hz}$ for $30 \mathrm{~min}$ in quiet, conscious, unrestrained rats. The data reported indicates the average of all values of systolic, diastolic and mean arterial pressure over the entire recording period of $30 \mathrm{~min}$; HR was taken from BP pulse records.

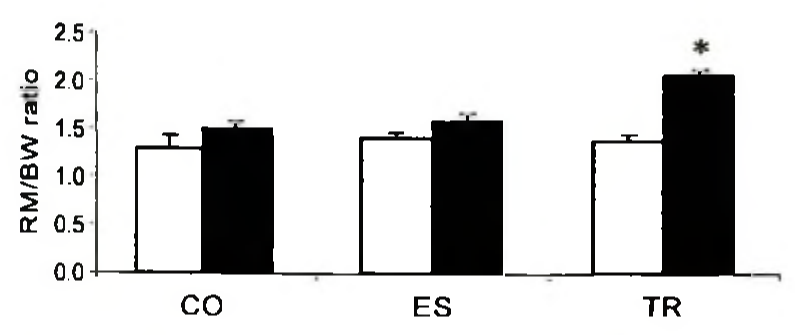

Fig. 2 Repesition maximum relative to bodyweight (BW) of all groups before and after of resistance training. The measurements were undertaken on the first day of the firsi week following the 2 weeks adaptation period and on the last day of the fourth week. CO, control; ES, electrically stimulated; TR. trained Dala are reported as means \pm SEM. $n=8$ each group. $-P<0.01$ comparing the RM/BW of the TR group in the fourth week ( $\square$ ) versus the first weck ( $\square$ ) and the TR versus CO and ES at the end of the protocol

\section{Statistical analysis}

Results are reported as means \pm standard errors of the means (SEM). The BW, RM and RM/HW were analysed by iwo-way ANOVA repeated measure. All others siatistical analyses were made by one-way ANOVA. Values were considered to be statistically significant when $P<0$.05. Tukey's posi-hoc tese was used for individual comparisons between means when a significant change was observed with ANOVA.

\section{RESULTS}

\section{Bodywcight}

The BW of the animals at the beginning of the study was similar among the three groups (Table 1). Following the training protocol BW showed non-significant increase of $4 \%$ in the TR group $(P>0.05), 5 \%$ in the ES group $(P=0.058)$ and a significant increase of $8 \%$ in the $\mathrm{CO}$ group $(P<0.01)$.

\section{Maximal strength}

One repetition maximum is expressed in two ways: absolute and relative to $\mathrm{BW}$. Table 1 shows the values of the absolute IRM before (first week) and after training (fourth week). All groups began the training protocol with similar IRM (515 $\mathrm{g} \pm 128 \mathrm{~g}$ ). However, IRM after craining increased significantly only in the TR group (CO, 26\%; ES, 20\% both $P>0.05$; TR, 56\% $P<0.0$ l). As $B W$ can influence this variable, the strength was also expressed as IRM/BW (g lifted/g BW) (Fig. 2). All groups began the training protocol with similar IRM/BW. The results show that only the relative IRM of the TR group increased at the end of the training period as compared to the beginning values (CO, $1.30 \pm 0.36$ $1.50 \pm 0.23 P>0.05 ; \mathrm{ES}, 1.41 \pm 0.20-1.59 \pm 0.27 P>0.05$; TR, $1.38 \pm 0.22-2.07 \pm 0.18 P<0.01$ ).

\section{Skeletal muscle weight}

Table 1 also shows the values of the plantaris rouscles weight normalized by the BW. As expected, the plantaris muscles raised $6.5 \%$ and $9.2 \%$ more weight in comparison to CO and ES groups, respectively (both $P<0.05$ ). No difference was observed between $\mathrm{CO}$ and $\mathrm{ES}$ group.

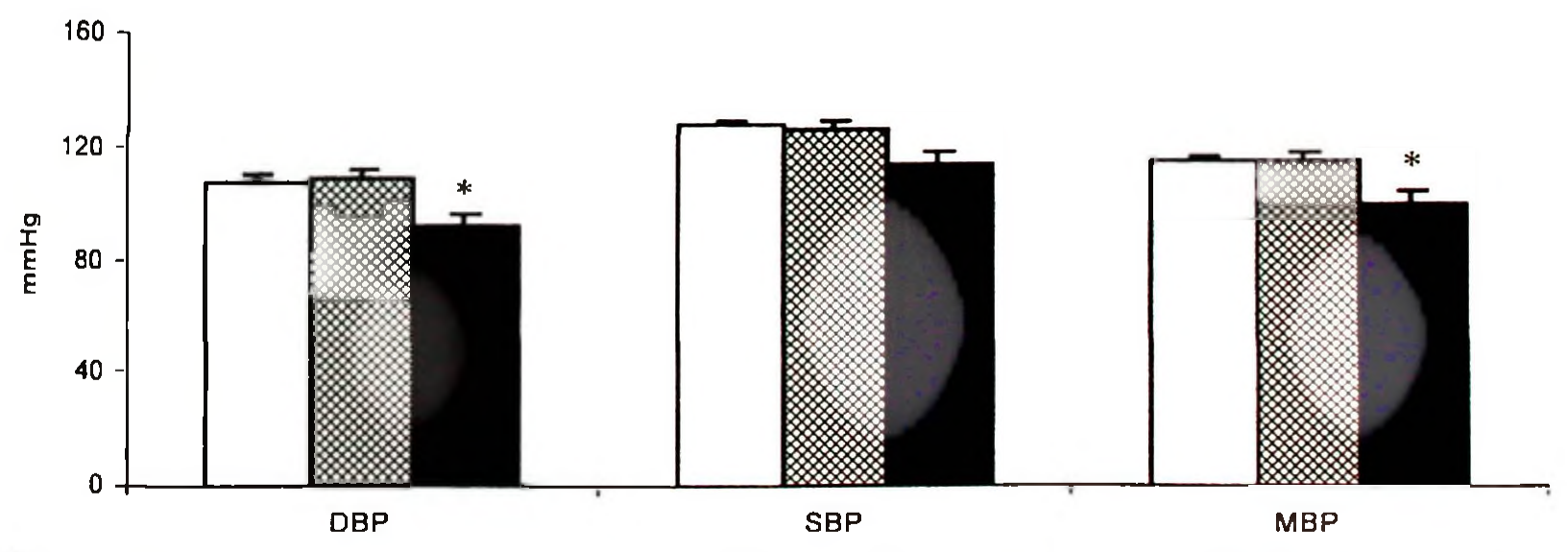

Fig. 3 Systolic, diastolic and mean resting blood pressure after 4 weeks of training. Data are reported as means $\pm S E M$. $P<0.05$. $n=8$ each group-

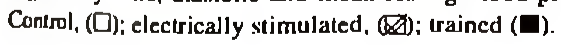




\section{Heart weight}

Right venuricle/BW (Table $1, P>0.05$ ) and aurium/BW (Table 1, $P>0.05$ ) remained unchanged among the groups, whereas $L V$ meigh/BW ratio was approximately $12 \%$ greater in the TR group compared to both CO and ES groups $(P<0.01)$ (Table 1 ).

\section{Blood pressure}

Forty-cight hours after the last training session, the resting BP and HR were measured directly using an intra-arterial cannula. Figure 3 shows the resting values of diastolic blood pressure (DBP), systolic blood pressure (SBP) and mean blood pressure (MBP). For all comparisons, the values from the $\mathrm{CO}$ and ES groups were similar. A non-significant reduction of $10 \%$ was found in the SBP for the TR group compared to the CO and ES groups $(P>0.05)$. The DBP and MBP were, respectively, $14 \%$ and $13 \%$ lower in the TR compared to CO and ES groups $(P<0.05)$. While not statistically significant, resting HR (Table 1) was $8 \%$ lower in the TR compared to $\mathrm{CO}(P=0.062)$ group and $6 \%$ lower compared to ES group $(P=0.075)$.

\section{Catecholamines and adrenal glands}

To determine whether the electrical stimulation could be influencing the results obtained, the concentrations of CA (and its precursors) were measured as an index of stress. No statistical differences were found among the three groups $(P>0.05)$ (Fig. 4). Similarly, the weight of the adrenal glands when normalized for BW showed no significant differences among the groups (Table I).

\section{DISCUSSION}

The main effects observed after 4 weeks of $\mathrm{RT}$ in a rat model were devclopment of cardiac hyperurophy accompanied by significant reduction in resting $\mathrm{BP}$, which are sirnilar to the cardiovascular adaptations observed in humans submitted to squatting exercises.
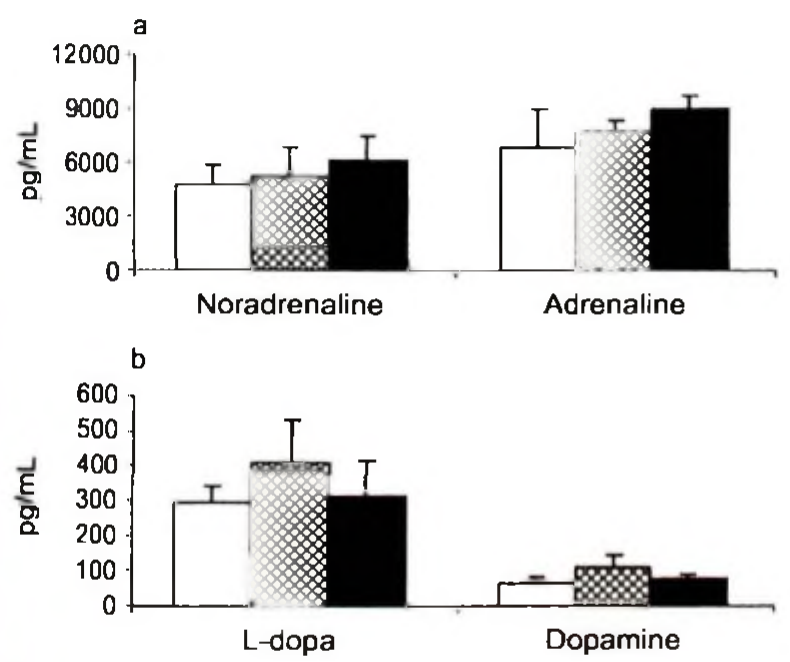

Fig. 4 (a) Adrenaline and noradrenaline, (b) L-Dopa and dopamine. Data are reponed as means \pm SEM. Nol significant. Control, ( $\square)$; electrically slimulaled, (区); trained ( $\square$ )
The current study showed, for the first time to our knowledge, that this model can be used to investigate the effects of RT on the cardiovascular system of rats and that the electrical stimulation used did not induce detectable changes in the ES group, suggesting that the effects observed were directly related to the exercise training.

The BW changes associated with this type of training protocol appear to be discrete. The TR and the ES groups in the current saudy tended to increase but only the $\mathrm{CO}$ group showed a signifcant $12 \%$ increase compared with the values at the beginning of the training sessions. Tamaki et al. using the same training apparatus but with a different training protocol (15 sets of 15 repetitions), found similar findings. ${ }^{12}$ The $\mathrm{CO}$ group was heavier than the TR group after the fourth week of training and, the difference increased to $22 \%$ by the 12 th week, whereas other authors using similar protocol have found no differences between the TR and CO groups. ${ }^{10,11,15.16}$

The $1 R M$ was used as an index of training efficiency. Additionally, the maximal strength achieved by the rats was used to determine the training load and to demonstratc training adaptation. Similar to aerobic training, where maximal $\mathrm{HR}$ or $\mathrm{VO}_{2 \max }$ are used to prescribe exercise, ${ }^{21} 1 \mathrm{RM}$ is used in RT for prescription. ${ }^{24}$ In the present research, ES animals were considered as the true controls as the $\mathrm{CO}$ group did not receive electrical stimulation. This allowed us to investigate the independent effects of electrical stimulation on stress. Similar results for absolute IRM have been found by others but none of them have used an electrically stimulated plus a nonstimulated group as controls. ${ }^{10-12,15.16}$ The plantaris muscle mass increased $6.5 \%$ and $9.2 \%$ in the TR group compared to CO and ES groups, respectively $(P<0.05)$. These findings are consistent with the fact that the plantaris muscle has predominance of white fibres, glycolytic metabolism and thus is more susceptible to muscle hypertrophy after RT program. ${ }^{25}$

Another common adaptation induced by exercise is the left ventricular hypertrophy (LVH), although characteristics differ depending on the type of exercise involved Eccentric LVH is very well described as a response to aerobic training in both hurnans and animals, ${ }^{26,27}$ whilc concentric $\mathrm{LHV}$ is associated with RT. "The results from the current study demonstrated LVH in rats in response to RT. The extent of LVH found in the TR group (12\%) was similar to that reported in some human studies involving weight lifters training for no longer than 3 months, ${ }^{28}$, but smaller than that seen in other studies investigating athletes engaged in this type of exercise for more than 1 year. 8.30

In addition, we have observed in rats that, similarly to humans, RT leads to lower BP while HR remains unchanged. Reduced resting $H R$ is normally observed as a positive effect of training and is frequently viewed as a chronic adaptation to endurance exercise. Longirudinal studies involving resistance short-term training ( $<20$ weeks) demonstrated significant reductions of up to $13 \%,{ }^{31,32}$ and non-significant reductions that varied from 6 to $8 \% .33 .45$ Similar to these latter results, the protocol used in the present study produced a non-significant decrease of $6 \%$ (TR vs ES, $P=0.075$ ) and $8 \%$ (TR vs CO, $P=0.062$ ) in resting HR. The mechanism involved in this adaptation during $R T$ requires further investigation.

Another haemodynamic parameter that has boen investigated is resting BP. It has been suggesicd that intermittent increases in BP during RT could cause vascular wall hypertrophy and thus decrease luminal diameter, resulting in increased vascular resistance and 
BP." However, only limited research has been conducted in this area. Hypenension observed in resistance-trained athletes can be atributed to a variety of factors including androgen abuse, over training, or a large increase in muscle mass. ${ }^{36,37}$ In contrast, some cross-sectional studies have reported reductions, ${ }^{38}$ or lack of change $\mathrm{e}^{39.40}$ in BP. Also longitudinal studies have reported reductions $^{1-7}$ or similar arterial BP, , $^{5,21,41}$ as a chronic adaptation to RT. Although some studies have reported that $R T$ can reduce BP, only two studies (from the same group) have attempted to clarify the mechanisms underlying this adaptation. ${ }^{27}$ Both studies used isometric handgrip training and measured muscle sympathetic nerve activity (MSNA). No decreases in MSNA as a result of chronic isometric training were observed. Evidence from aerobic training suggests that exercise may decrease both systemic sympatheric activity and arterial BP. ${ }^{42}$ Also from aerobic training, its efficacy for cardiovascular risk reduction appears, at least in part, derived from modifications of arterial properties, such as increase in arerial compliance. ${ }^{43}$ Regarding RT, the issue is even less clear. The studies have found that this type of exercise may be associated to a decrease in arterial compliance, ${ }^{43}$ but none of the studics have demonserated decreases in BP which lead us to hypothesize that a higher training intensity may have been used compared to the ones that found decreases in BP. ${ }^{43.44}$ Another mechanism that may help to explain the decrease in BP is peripheral vascular adaptations. It has been postulated that this training regimen may lead to increased exposure of shear stress and release of vasoactive substances that may contribute to functional or structural changes in the resistance vessels. ${ }^{45}$ Although not investigated directly in the present work, these events may also take place in this model and are consistent with our findings of lower DBP and MBP in the TR groups.

Furhermorc, although our results showed non-significant reductions in SBP and HR, the double-product (SBP $\times$ HR) was 18\% lower in the TR versus CO group (data not showed). The double-product is an index of cardiac workload, we might conclude that RT is a mode of exercise that can improve cardiovascular function and might be used as a non-pharmacological treatment, or prevention protocol, for cardiovascular disease.

We have also attempted to investigate the effects of the elecurical sumulation as a confounding variable, since previously published studies using this training apparatus have not addressed this issue. In this context, we were able to demonstrate that two stress indices remained unchanged at the end of the training period. Namely, clectrical stimulation was not associated with changes in CA plasma levels, a marker of sympathetic activity ${ }^{\text {th }}$ and adrenal hypentophy. These two parameters are the second and third adaptations (of four) to chronic biological stress stimuli as defined by Selye, ${ }^{47}$ who observed that prolonged stress ultimately forces organisms to adapt to maintain the organic capacity to face continued chaltenges. In addition, all the ES group results were similar to the $\mathrm{CO}$ group.

Collectively these results demonstrate that the rat RT model used is associatod with significant development of cardiac hypertrophy and lowering of resting BP. These cardiovascular adaptations seem to be a result of the training exercise and probably not influenced by stress since circulating CA levels and adrenal gland weights remained unchanged in all groups. Although these responses have been well documented in humans, it is the first cime that these cardiovascular adaptations have been observed in the rat model. This may enable the development of cellular and molecular studies aimed at uncovering the mechanisms associated to the cardiac hypertrophy and lower BP in response to chronic RT. Furthermore, understanding the mechanisms leading to reductions of arterial BP associated to RT may be of value to be explored in humans. ${ }^{\text {*n }}$

\section{ACKNOWLEDGEMENTS}

The authors thank Marcele de Almeida Coclho for technical assistance. VG Barauna was the recipient of a FAPESP scholarship (No.01/14451-7). JEK is supported by grant FAPESP 01/00009-0.

\section{REFERENCES}

1. Kelley GA. Kelley KS. Progressive resistance exercise and resting blood pressure: A meta-analysis of randomized controlled trials. Hyperiension 2000; 35: 838-43.

2. Carter JR, Ray CA, Downs EM, Cooke WH. Strength training reduces arterial blood pressure but not sympathetic neural activity in young normotensive subjects. J. Appl. Physiol. 2003; 94: 2212-16.

3. Sione $\mathbf{M H}$, Wilson GD, Blessing D. Rozenek R. Candiovascular responses to shon-term olympic style weight-training in young men. Can J. AppL Sport Sci. 1983; 8: 134-9.

4. Wiley RL, Dunn CL, Cox RH, Hueppchen NA, Scou MS. Isometric exercise training lowers resting blood pressure. Med. Sci Spons Exerc. 1992; 24: 749-54.

5. Hurley BF, Hagberg M. Goldberg AP ef al. Resistive training can reduce coronary risk factors without altering VO2max or percent body fat. Med. Sci. Sports Exenc. 1988; 20: 150-4.

6. Harris KA, Holly RG. Physiological response to circuit weight training in borderline hypertensive subjects. Med. Sci. Sports Exert. 1987; 19: 246-52.

7. Ray CA, Carrasco DI. Isometric handgrip training reduces arteria] pressure at rest without changes in sympathetic nerve acrivity. Am. $J$. Physiol. Hean Circ. Physiol. 2000; 279: H245-9.

8. Pluim BM, Z winderman AH, van der Larse $\Lambda$, van der Wall EE. The athlete's heart. A meta-analysis of cardiac sinucture and function. Circulation 2000: 101 : 336-44.

9. Klitgaard H. A model for quantitative strength training of hindlimb muscles of the ral. J. Appl. Physiol 1988; 64: 1740-5

10. Notomi T. Lee SJ. Odimoto $\mathrm{N}$ ef al. Effects of resistance exercise training on mass, strength, and turnover of bone in growing rats. Eur. J. Appl. Physiol. 2000; 82: 268-74.

11. Notomi T. Okazaki Y, Okimoto N, Saitoh S, Nakamura T, Suzuki M. A comparison of resistance and aerobic training for mass, sirength and turnover of bonc in growing rats. Eur. J. AppL Physiol. 2000; 83: 469-74.

12 Tanaki T, Uchiyama $S$, Nalano $S$. A weight-lifting exercise model for inducing hypertrophy in the hindlimb muscles of rats. Mfed. Sci. Sports Exerc. 1992; 24: 881-6.

13. Tamaki $T$, Akatsuka A, Tokunaga $M$, Ishige $K$, Uchiyana $S$, Shirashi T. Morphological and biochemical evidence of muscle hyperplasia following wcight-lifting exercise in rats. Am. J. PhysioL 1997; 273 : C246-56.

14. Wong TS, Booth FW. Skelctal muscle enlargement with weight-lifting exercisc by rats. J. Appl. Phy:siol. 1988; 65: 950-4.

15. Yaspelkis 3rd BB. Singh MK. Trevino B, Krisan AD, Collins DE. Resistance trajning increases glucose uptake and transport in rat skeletal muscle. Acıa PhysinL Scand. 2002; 175: 315-23.

16. Krisan $\mathrm{AD}$, Collins DE, Crain $\mathrm{AM}$ ef al. Resislance training enhances components of the insulin signaling cascade in normal and high fat-fed rodent skeletal muscle. J. Appl. Physiol 2004; 96: 1691-700.

17. Lowe DA, Alway SE Animal models for inducing muscle hypertrophy: Are they relevant for clinical applications in humans? J. Orthop. Sports Phys. Ther. 2002: 32: 36-43. 
18. American College of Sporls Medicine. Position Stand. Physical activity. physical filness, and hypertension. Med. Sci. Sports Exerc. 1993; 25: i-x.

19. Layne JE, Nelson ME. The effects of progressive resistance training on bone density: A revicw. Med. Sci. Sports Exerc. 1999; 31: 25-30.

20 Tollbuck A. Eriksson S, Wredenberg A ef al. Effects of high resistance traning in patients with myotonic dystrophy. Scand. J. Rehab. Med. 1999: $31:$ 9-16

21. Deschenes MR, Kraemer WJ. Performance and physiologic adapxations to resistance training. Am. J. Phys. Med. Rehah. 2002; 81 : S3-16

22 Naflah-Mazzacoratti MG, Cassarini DE, Fernandes MJS, Cavalheiro EA. Serum catecholamine levels desermined by high performance liquid chromatography coupled with electrochemical detection. Arq. Bras. Endocrinol Metab. 1992; 36: 119-22

23. Zavorsky GS. Evidence and possible mechanisms of altered maximum hear rate with endurance training and tapering. Sports Med. 2000; 29: 13-26.

24. Femandez R. One repetition maximum clarified. J. Orthop. Sports Phys. Ther. 2001; $31: 264$.

25. Tesch TA, Larsson L. Muscle hypertophy in bodybuilders. Eur. J. Appl Physiol. 1982; 49: 304-6.

26. Shapiro LM. Physiological left ventricular hypertrophy. Br. Hear J. 1984: 52: 130-5.

27. Wislofi U, Heigerud J, Kemi OJ, Ellingsen O. Intensity-controlled treadmill running in rats: VO (2 max) and candiac hypertrophy. Am. J. Physiol. Hean Circ. Physiol. 2001; 280: H1301-10.

28. Brown SP, Thompson WR. Standardization indices of cardiac hypertrophy in weight lifters. J. Sports Sci. 1987; 5: 147-53.

29. Van den Brocke C. Fagard $\mathbf{R}$. Left ventricular structure and function, assessed by imaging and Doppler echocardiography, in athletes engaged in throwing events. Int. J. Sports Med. 1988; 9: 407-11.

30. Fagard RH. Athlete's heart: A meta-analysis of the echocardiographic experience. Int. J. Sport.s Med. 1996; 17 (Suppl. 3): S 140-4.

31. Goldberg L, Elliot DL, Kuehl KS. A comparison of the cardiovascular effects of running and wcight training. J. Strength Cond. Res. 1994; 8: 219-24.

32. Kanakis C, Hickson RC. Left ventricular responses to a program of lower-limb strength training. Chest 1980; 78: 618-21.

33. Lusiani L. Ronsisvalle G, Bonanome A ef al. Echocardiographic evaluation of the dimensions and systolic properties of the left ventricle in freshman athletes during physical training. Eur. Heart $J$. 1986; 7: 196-203
34. Ricei G. Lajoie D. Petitclerc $R$ et al. Lefı ventricular size following endurance, sprint, and strength training. Med. Sci. Sports Exerc. 1982; 14: 344-7.

35. Folkow B. Physiological aspects of primary hypertension. Physiol. Rev. 1982; 62: 347-504

36. Riebe D. Femhall B. Thompson PD. The blood pressure response to exercise in anabolic steroid users. Med. Sci. Spons Exerc. 1992; 24: 633-7.

37. Vitasalo IT, Komi PV, Karvonen MJ. Muscle strength and body composition as determinants of blood pressure in young men. Eur. $J$. Appl Physiol. Occup. Physiol. 1979; 42: 165-73.

38. Smith ML. Raven PB. Cardiovascular responses to lower body negative pressure in endurance and static excrcise-trained men. Med. Sci. Sports Exerc. 1986; 18: 545-50.

39. Longhurst JC, Kelly AR. Gonyea WJ, Mitchell JH. Cardiovascular responses to stajic exercise in distance nunners and weight liffers. J. Appl. Physiol 1980; 49: 676-83.

40. Fleck SJ, Dean LS. Resistance-training experience and the pressor response during resistance exercise. J. Appl. Physiol. 1987; 63: $116-20$.

41. Van Hoof R, Macor F, Lijnen P et al. Effect of strength training on blood pressure measured in various conditions in sedentary men. Int. J. Sports Med. 1996; 17: 415-22.

42. O'Sullivan SE Bell C. The effects of exercise and training on human candiovascular reflex control. J. Auton. Nery. Syst. 2000; 81: 16-24.

43. Kingwell BA. Large artery stiffness: Implications for exercise capacity and cardiovascular risk. Clin. Exp. Phamacol Physiol. 2002; 29: 214-17.

44. Bertovic DA Waddell TK, Gatzka CD, Cameron JD, Dart AM, Kingwell BA. Muscular strength training is associated with low arterial compliance and high pulse pressure. Hypertension 1999; 33: $1385-91$.

45. Delp MD, Laughlin MH. Time course of enhanced endotheliummediated dilation in aorta of trained rats. Med. Sci. Sports Exerc. 1997; 29: $1454-61$.

46. Goldstein DS. Stress-induced activation of the symparbetic nervous system. Baillieres Clin. Endocrinol. Metab. 1987; 1: 253-78.

47. Selye $\mathbf{H}$. The evolution of the stress concept Stress and cardioviscular discase. Am. J. Cardiol. 1970; 26: 289-99.

48. Cook NR, Cohen J, Herbert PR, Taylor JR. Hennekens CH. Implication of small reduction in diastolic blood pressure for primary prevention. Arch. Intem. Med. 1995; 155: 701-9. 
Valerio G. Barauna, Flávio C. Magalhaes, Jose E. Krieger and Edilamar M.

Oliveira

Am J Physiol Regulatory Integrative Comp Physiol 295:381-387, 2008. First published May 21, 2008;

doi:10.1152/ajpregu.00933.2007

You might find this additional information useful...

This article cites 37 articles, 16 of which you can access free at:

http://ajpregu.physiology.org/cgi/contenUfull/295/2/R381\#BIBL

This article has been cited by 1 other HighWire hosted article:

Local renin-angiotensin system regulates left ventricular hypertrophy induced by

swimming training independent of circulating renin: a pharmacological study

E. M. Oliveira, M. S. Sasaki, M. Cerencio, V. G. Barauna and J. E. Kricger

Journal of Renin-Angiotensin-Aldosterone System, March 1, 2009; 10 (1): 15-23.

[Abstract] [PDF]

Updated information and services including high-resolution figures, can be found at:

http://ajpregu.physiology.org/cgi/content/full/295/2/R381

Additional material and information about American Journal of Physiology - Regulatory, Integrative and Comparative Physiology can be found at:

http://www.the-aps.org/publications/ajpregu

This information is current as of March 22, 2010 .

The American Joumal of Physiology - Regulatory, Integrative and Comparative Phyxiology publishes original investigations that illuminate normal or abnormal regulation and integration of physiological mechanisms at all levels of biological organization, ranging from molecules to humans, including clinical investigations. It is published 12 times a year (monthly) by the American Pbysiological Society, 9650 Rockville Pike, Bethesda MD 20814-3991. Copyright 2005 by the Anerican Physiological Sociely. ISSN: 0363-6119, ESSN: 1522-1490. Visit our website at http://www.thc-aps.ong/. 


\title{
CALL, FOR PAPERS | Control Mechanisms of Renin Synthesis and Release: A 21st
}

\section{Century Perspective}

\section{$\mathrm{AT}_{1}$ receptor participates in the cardiac hypertrophy induced by resistance training in rats}

\author{
Valerio G. Barauna, ${ }^{1,2}$ Flávio C. Magalhaes, ${ }^{1}$ Jose E. Krieger, ${ }^{2}$ and Edilamar M. Oliveira' \\ 'Laboratory of Biochemistry. Schonl of Physical Education and Sports, University of São Paulo. Säo Paulo, ${ }^{2}$ Laboratony \\ of Genetics and Molecular Cardiology and Unit of Applied Physiology, Heart Institute (InCor). University of São Paulo \\ School of Medicine. Säo Paulo, Brazil
}

Submitted 31 December 2007; accepted in final form 19 May 2008

\begin{abstract}
Baraun VG, Magalhaes FC, Krieger JE, Oliveira EM. AT, receptor participates in the cardiac hypertrophy induced by resistance raining in rats. Am J Physiol Regul Integr Comp Physiol 295: R381-R387, 2008. Tirst published May 21, 2008; doi:10.1152/ajpregu.00933.2007.Resistance training is accompanied by cardiac hypertrophy, but the role of the renin-angiolensin system (RAS) in this response is elusive. We evaluated this question in 36 male Wistar rats divided into six groups: control $(n=6)$; trained $(n=6)$; control + losartan $(10$ $m g \cdot k g^{-1} \cdot$ day $\left.^{-1}, n=6\right)$; trained + losartan $(n=6)$; control + kigh salt diel $(1 \%, n=6)$; and trained + high-salt diet $(1 \%, n=6)$. High salt was used to inhibit the systemic RAS and losartan to block the $A T_{1}$ receptor. The exercise protocol consistod of: $4 \times 12$ bouts, $5 \times / w k$ during $8 w k$, with $65-75 \%$ of one repetition maximum. Left reatricle weight-to-body weight ratio increased only in trained and traned t high-salt diet groups $(8.5 \%$ and $10.6 \%, P<0.05)$ compared with control. Also, none of the pathological cardiac hypertrophy markers, atrial natriuretic peptide, and $\alpha \mathrm{MHC}$ ( $\alpha$-myosin heavy chain)Lo- $\beta M H C$ ratio, were changed. ACE activity was analyzed by fluorometric assay (systemic and cardiac) and plasma renin aclivity (PRA) by RIA and remained unchanged upon resistance training, whereas PRA decreased significantly with the high-salt diet. Interestingly, using Western blot analysis and RT-PRC, no changes were observed in cardjac $\mathrm{AT}_{2}$ receptor levels, whereas the $\mathrm{AT}_{1}$ receptor gene $(56 \%$. $P<0.05)$ and protein $(31 \%, P<0.05)$ expressions were upregulated in the trained group. Also, cardiac ANG II concentration evaluated by EliSA remained unchanged $(23.27 \pm 2.4$ vs. $22.01 \pm 0.8 \mathrm{pg} / \mathrm{mg}, P>$ 0.05 ). Administration of a subhypotensive dose of losartan prevented left ventricle hypertrophy in response to the resistance training. Alogether, we provide evidence that resistance training-induced cardiac hypertrophy is accompanied by induction of $\mathbf{A T} \mathbf{T}_{1}$ receptor expression with no changes in cardiac ANG II, which suggests a local activation of the RAS consistent with the hypertrophic response.
\end{abstract}

$A T_{1}$ receptor; renin-angiotensin system; cardiac hypertrophy; resisunsec training

CARDIAC HYPERTROPHY is THE adaptation of the heart to altered mechanical or hormonal stimuli. Exercise training, such as resistance training, is a known hypertrophic stimulus for cardiac enlargement due to pressure overload imposed on the hean during training when the blood pressure may reach peaks of $480 / 350 \mathrm{mml} / \mathrm{lg}(19,21)$. Many studies have demonstrated

Address for reprint requests and other correspondence: Edjlamar Menezes de Oliveira. Laboratory of Biochemistry, School of Physical Education and Spart. Av. Prof. Mello Moraes, 65, Butanta, Cidade Universitária, 05508-9000, Sto Paulo, SP, Brazil (e-mail: cdilamar@ usp.br). that hemodynamic overload activates the renin-angiotensin system (RAS) in the heart $(8,15)$.

The RAS is a cascade of enzymatic action that plays an important role in cardiovascular homoeostasis by influencing vascular tone, fluid, and electrolyte balance. Classical RAS is viewed by cleavage of angiotensinogen (AGT) by renin to produce ANG 1, which is then converted to ANG II by ANG converting enzyme (ACE). The actions of the RAS are mediated mainly by the peptide ANG II through two types of receptors, $\mathrm{AT}_{1}$ and $\mathrm{AT}_{2}$, which are both seven transmembrane, $G$ protein-coupled receptors, and can act either as a systemic hormone (endocrine) or as a locally generated cytokine (paracrine or autocrine). The $A T$, receptor accounts for the majority of the known functions of ANG 11 in various tissues. ANG 11 also acts as a potent growth factor and cytokine for vascular smooth muscle cells, cardiac myocytes, and cardiac fibroblasts $(4,12)$.

The presence of various components of the RAS in cardiac tissue has already been reported (18). Although the origin of each component of this cardiac RAS is not completely known, mRNA expression for some of the RAS components provides support for the local generation of ANG II $(9,27)$.

There are many evidences of the role of the $A T$, receptor in the development of cardiac hypertrophy in many pathologic or experimental states. It has already been demonstrated that AT, mRNA expression increases in response to aortic coartation or acute myocardial infarction (6). Also, long-term treatment of stroke-prone spontaneously hypertensive rats with AT, blocker candesartan significantly reduced left ventricular mass (34). In addition, beneficial effects of $A T_{1}$ receptor blocker on left ventricular hypertrophy also extend to patients with mild-tomoderate hypertension (10). In spite of that, there are only a few studies about the role of the RAS in models of cardiac hypertrophy induced by exercise training. In this regard, we studicd the rat cardiac hypertrophy in response to a resistance training program in the presence and absence of an $\mathrm{AT}_{1}$ blocker (losartan) and diet of $1 \%$ salt to inhibit release. This model of exercise training has been well established in our laboratory $(2,3)$.

\footnotetext{
The costs of publication of this article were defrayed in part by the payment of page charges. The article must therefore be hereby marked "advertisement" in accondance with 18 U.S.C. Section 1734 solely to indicate this fact
} 


\section{MBTHODS}

Animals. Thirly-six Wistar rats were assigned into six groups $(n=$ (6 each): control (CO), control treated with losartan (CO+LOS), iontrol plus high-salt diet (CO+SALT), trained (TR), trained treated with locinan (TR+LOS), and trained plus high-salt dict (TR+SALT) l.oxarlan $\left(10 \mathrm{mg} \cdot \mathrm{kg}^{-1} \cdot \mathrm{day}^{-1}\right)$ was administered in the drinking water at a known dose that blocks the $\mathrm{AT}$, receptor but does not decrease the blood pressure of normotensive rats (20). Salt (1\%) was also admin islend in the drinking water at a known dose to inhibit the renin release but not to alter the blood pressure (24). Salt loading was used only to uncouple local vs. systemic activation of the RAS. Animals wer housed in standard cages and food and water were provided ad libitum The environmental temperature was kept at $23 \pm 1^{\circ} \mathrm{C}$, and : 12:12-h dark-light cycle was maintained throughout the experiment. Animals were weighed every week. All protocols and surgical proredures used were in accordance with the guidelines of the Brazilian College for Animal Experimentation and were approved by the Ethics Commillce of the Institute of Biomedical Science of the University of Siso Paulo.

Exercise protocol. Animals were exercised following a model silapled from Tamaki et al. (29). Rats filted with canvas jackets were able to regulate the twisting and flexion of their torsos and were suspended in a standard position on their hind limbs. An eloctrical samulation ( $20 \mathrm{~V}, 0.3-\mathrm{s}$ duration, at $3-\mathrm{s}$ intervals) was applied to the at's tijl through a surface electrode. As a result, the rats flexed their legs repealedly, which lifted the weight arm of the training apparatus. The TR groups were exercised by four sets of 12 repetitions with a 90-s rest period between each set, five times per week for 4 wk. This etercise regimen was started after 2 wk of adaptation. All training sessions were performed in a dark room. After measurement of the maximum weight lifted [one repetition maximum (IRM)] with the squal-1raining apparalus, the training load was set at 65-75\% of IRM The IRM was defined as the minimum load that the rats were unable in jump following electrical stimulation. On the day following, blood pressure and heart rate were recorded as described below, rats were tilled by quick decapitation without prior anesthesia, and blood and tissue samples were harvested, frozen, and slored at $-80^{\circ} \mathrm{C}$. To determine plasma renin activity the first $3 \mathrm{ml}$ of trunk blood were rapidly collected in chilled glass tubes containing a mixture of protease inhibitors (potassium EDTA $(25 \mathrm{mmol})$, ophenanthroline (0.14 mmol), pepstatin A $(0.12 \mathrm{mmol})$, and 4-(chloromercuribenzoic acid) (1 mmol)] to prevent the in vitro production and degradation of angiotensin peptides (17). The blood was centrifuged, and the plasma a as separated and stored at $-20^{\circ} \mathrm{C}$. In addition, the heart was harvested and weighed. The weight of the left ventricles and the tibia $k n g t h$ were determined, and the hypertrophy index of each animal (weight of left ventricles in milligrams per body weightt in grams and weight of left ventricles in milligrams per tibia length in millimeters) was calculated. The ventricles, lung, kidney, and serum were frozen at $-80^{\circ} \mathrm{C}$ and used within 1 mo for enzyme assay and mRNA and protein preparation.

Arterial blood pressure and heart rate. Twenty-four hours after the last training session and under pentobarbital anesthesia ( $40 \mathrm{mg} / \mathrm{kg}$ ip), a polyethylene cannula (PE-50) was inserted into the carotid artery and emerged through the back of the rat's neck. During the experimental session, this cannula was connected to a strain-gauge transducer (923 Db; Gould-Statham). Twenty-four hours after the surgery, ancrial blood pressure was recorded on a beal-to-beat basis (AT/ CODAS) at a frequency of $100 \mathrm{~Hz}$ for $30 \mathrm{~min}$ in quiet, conscious, unrestrained rats. The data reported indicales the average of all values of systolic, diastolic, and mean arterial pressure over the entire recording period of $30 \mathrm{~min}$; heart rale was taken from blood pressure pulse records.

Plasma renin activity assay. The plasma renin aclivity assay was measured by angiotensin radioimmunoassay, using a commerciaj kit (REN-CT2; CIS Bio International, Gif-sur-Yvelte, France). This assay permits direct measurement of plasma renin activity. Results were quantified in a gamma counter, and the enzyme aclivity was expressed as nanograms ANG I per milliliter per hour.

ACE activity assay. ACE activity in rat serum and tissue extracts were determined using Abz-FRK(Dnp)P-OH derivatives as substrates by continuously measuring the fluorescence according to Alves et al. (1). Tissue samples were quickly harvested, homogenized in Tris $\cdot \mathrm{HCl}$ buffer, $\mathrm{pH} 7.0$, containing $50 \mathrm{mM} \mathrm{NaCl}$ and centrifuged at $1,000 \mathrm{~g}$ for $10 \mathrm{~min}$. The assays were performed at $37^{\circ} \mathrm{C}$ in $0.1 \mathrm{M}$ Tris $\cdot \mathrm{HCl}$ buffer, $\mathrm{pH} 7.0$, containing $50 \mathrm{mM} \mathrm{NaCl}$ and $10 \mu \mathrm{M} \mathrm{ZnCl}_{2}$. Hydrolysis rate of the intramoleculary quenched fluorogenic substrate Abz-YRK-(Dnp)p $(10 \mathrm{mM})$ incubated with aliquots of tissues homogenate and scrum for $30 \mathrm{~min}$ at $37^{\circ} \mathrm{C}$ was assessed to obtain ACE cnzymatic activity. Fuorescence increments along the time were read at $420 \mathrm{~nm}$ cmission:320 nm excitation. Tissues and serum ACE activity were expressed as arbitrary fluorescence units (AFU) $\mathrm{min}^{-1} \cdot \mathrm{mg}^{-1}$ of protein $\times 1,000$. The protein content was determined by the Bradford method (5) by using bovine serum albumin as the standard (Bio-Rad protein assay)

Westem blot analysis. The frozen ventricles were thawed and minced into small pieces and homogenized in cell lysis buffer containing $100 \mathrm{mM}$ Tris, $50 \mathrm{mM} \mathrm{NaCl}, 10 \mathrm{mM}$ EDT A, $1 \%$ Triton $\mathrm{X}-100$, and a mixture of protease inhibitors. Insoluble heart tissues were removed by centrifugation at $3,000 \mathrm{~g}, 4^{\circ} \mathrm{C}, 10 \mathrm{~min}$. Samples were loaded and subjected to SDS-PAGE in $10 \%$ polyacrylamide gels. After electrophoresis, proteins were electrotransferred to nitrocellulose membrane (Amersham Biosciences; Piscalaway, NJ). Equal loading of samples $(60 \mu \mathrm{g})$ and even transfer efficiency were monitored with the use of $0.5 \%$ Ponceau $S$ staining of the blot membrane. The blot membrane was then incubated in a blocking buffer ( $5 \%$ nonfat dry milk, $10 \mathrm{mM}$ Tris $\cdot \mathrm{HCl}, \mathrm{pH} 7.6,150 \mathrm{mM} \mathrm{NaCl}$, and $0.1 \%$ Tween 20) for $2 \mathrm{~h}$ at room temperalure and then probed with a polyclonal anlibody directed against $A T_{1}, \mathrm{AT}_{2}$, or ANG $\mathrm{LII}(1: 1,000 ; 1: 1,000$ or 1:100, respectively; Santa Cruz Biotechnology, Santa Cruz, CA) at room temperature. Binding of the primary antibody was detected with the use of peroxidase-conjugated secondary antibodies, and enhanced chemiluminescence reagents (Amersham Biosciences; Piscataway, NI) were used to visualize the autoradiogram, which was later exposed to pholographic film. The film was developed, and the bands were analyzed using Scion Image software (Scion based on NIH image). GAPDH expression levels were used to normalize the results.

Real-time RT-PCR. The relative gene expression of AGT, ACE, $\mathrm{AT}_{1 \mathrm{a}}$ receplor, ANP (atrial natriuretic peptide), $\alpha \mathrm{MHC}$ ( $\alpha$-myosin heavy chain) and $\beta M H C$ were analyzed by real-time PCR.

Total RNA was isolated from heart tissue with Trizol reagent (GIBCO Invitrogen). Total RNA concentration and integrity were assessed and real-time PCR was performed. The mRNA expression of RAS components were assessed by oligonucleotides primers as follows: for AGT, 5' $5^{-} \mathrm{gC} \mathrm{ACg} g A C$ AgC ACC ATA TT-3' and 5' $-\mathrm{AgA}$ ACT CAT ggA gCC CAg TCA-3'; for ACE, 5'-CAg gAA CgT ggA ACT Tgg A-3' and $5^{\prime}-C T T$ TgA Cgg AAg CAT CAC C-3'; for AT $1 .$. $5^{\prime}-C A C$ AAC CCT CCC AgA AAg Tg-3' and $5^{\prime}$ - Agg gCC ATT TTg TTT TTC Tg-3'; for $\alpha M H C, 5^{\prime}-\mathrm{CgA}_{\mathrm{g}} \mathrm{TC}$ CCA ggT CAA CAA g-3' and $5^{\prime}$-Agg CTC TTT CTg CTg gAC C-3'; for BMHC, 5'-CAT CCC CAA TgA gAC gAA g- $3^{\prime}$, and $5^{\prime}$-Agg CTC TTT CTg CTg gAC A-3'; for ANP, 5'-CTT Cgg ggg TAg gAT TgA C-3', and $5^{\prime}-$ CTT $^{\prime}$ ggg ATC T7T TgC gAT CT- $3^{\prime}$. The expression of cyclophilin $A$ (5'-AAT gCT ggA CCA AAC ACA AA-3' and 5'-CCT TCT TTC ACC TTC CCA AA-3') was measured as an internal control for sample variation in RT reaction. Real-time PCR amplifications were performed with an ABI Prism 770 Sequence Detection System (Appliod Biosystems) by using SYBR Green PCR Master Mix (Applied Biosystems). The results were quantified as $\mathrm{Ct}$ values, where $\mathrm{Ct}$ is defined as the threshold cycle of the PCR at which the amplified product is first detected. Values for the control gene (cyclofilin) were used to standardize the results to compensate for differences in RNA content among the samples. To compare the level of gene expression 
in the trained group to the level in the control group, the following formula was applied $e=2-\Delta \Delta C$

Measurement of ANG $\|$ in heart tissue. Hearts were homogenized in lysis buffer ( $0.1 \mathrm{M}$ sodium phospliate, $0.34 \mathrm{M}$ sucrose, $0.3 \mathrm{M} \mathrm{NaCl}$ ) containing a mixture of protease inhibitors and centrifuged at 10,000 s. $4^{\circ} \mathrm{C}, 10$ min. The supematant was collected, and it was passed through phenylsilica cartidges (Sep-Pak C18 columns; Waters), and the absorbed angiotensin was eluted with methanol. Eluate was dried in a vacuum centrifuge and the pellet was resuspended in EIA buffer, mixed, and centrifuged at $3,000 \mathrm{~g}$ for $10 \mathrm{~min}$ at $4^{\circ} \mathrm{C}$. ANG II levels were detcruined by ELISA, according to the manufacturer's instructions (SPI-BIO). The protein content was determined by the Bradford method (5) by using bovine serum albumin as the standard (Bio-Rad Protein Assay).

\section{RESULTS}

Body weight. Table 1 shows the body weight of the animals at the beginning and at the end of the study. There were no differences in the body weight among all groups neither before Dor after the training protocol. Furthermore, all groups had the body weight increased over the period except the TR+SALT group, whose increase was not significant $(P>0.05)$.

Maximal strength. Table 1 also shows the values of the absolute IRM before (week 1 ) and after training (week 4). It $c$ an be observed that all groups began the training protocol with similar IRM. However, this value increased similarly in all groups (TR, 113\%; TR+LOS, 212\%; TR+SAL, 131\%). Anayzing the IRM load normalized by the body weight, it can be observed that the animals began lifting approximately threefold of their body weight and finished the training period lifting $\sim 5.5$ fold of their body weight $(P<0.05)$.

Hemodynamics parameters. To confirm that the doses of losartan and salt used in this study would not influence the results, some hemodynamic parameters, such as blood pressure and heart rate, were measured directly using an intra-arterial cannula. Table 1 shows the resting values of mean blood pressure and heart rate. Both blood pressure and heart rate remained the same in all groups, regardless of the treatment. Although resting blood pressure was unchanged, we have also measured the blood pressure achieved during one session of exercise training. As already shown by many human studies, one resistance training session induces increase in blood pressure. We have also found in this animal model that systolic blood pressure peaks around $180 \mathrm{mmHg}$, and these peaks were also similar apart from the administration of losartan or salt (data not shown).
Cardiac hypertrophy. Left ventricular weight-to-body weight ratio was $\sim 8.5 \%$ and $10.6 \%$ greater in TR $(2.15 \pm 0.05 \mathrm{mg} / \mathrm{g})$ and TR+SALT $(2.19 \pm 0.06 \mathrm{mg} / \mathrm{g})$ groups, respectively, compared with the $\mathrm{CO}$ group $(1.98 \pm 0.04 \mathrm{mg} / \mathrm{g}$ ) (Fig. $1 A$, $P<0.01$ ). Among trained groups, left ventricular hypertrophy was not observed in the animals that received the $\mathrm{AT}_{1}$ blocker losartan (TR + LOS, $1.99 \pm 0.03 \mathrm{mg} / \mathrm{g}$, Fig. 1A), which suggests a role for local RAS in exercise-induced cardiac hypertrophy. Also, there were no differences among the control groups, regardless of the treatment (CO vs. CO+LOS, $1.97 \pm$ $0.05 \mathrm{mg} / \mathrm{g}$, vs. CO+SALT, $2.00 \pm 0.04 \mathrm{mg} / \mathrm{g}$ ). To confirm these findings, heart weight was also normalized to tibia length (Fig. 1B). An increase of $9.6 \%$ in cardiac hypertrophy in the $\mathrm{TR}(22.8 \pm 0.9 \mathrm{mg} / \mathrm{mm})$ compared with $\mathrm{CO}(20.8 \pm 1.8$ $\mathrm{mg} / \mathrm{mm}$ ) was found.

To better understand whether hypertrophy is physiological or pathological, two markers of pathological hypertrophy, ANP expression and $\alpha$ MHC-to-BMHC ratio, were analyzed and both were not altered after the resistance training (Fig. 3A).

$R A S$. Renin and ACE are the two main enzymes that regulate the formation of the peptide ANG II. Table 2 (ACE) and Fig. 2 (renin) show the activities of these enzymes. ACE activity was decreased by losartan treatment, while no effect could be observed due to the resistance training. ACE activity was assessed in serum and locally in lung, kidney, and heart but has been lowered only by losartan treatment in the serum. Furthermore, no influence could be observed in the renin activity in response to resistance training. However, as expected, losartan treatment increased renin activity possibly due to the blockage of the negative feedback on renal juxtaglomerular cell production and increased release of renin $(P<0.01)$; whereas salt diet almost abolished its activity, as has already been demonstrated by our group (24) $(P<0.01)$. The lower $A C E$ activity by losartan treatment in the serum suggests a compensatory mechanism to increased renin activity in this group.

Figure $3 A$ shows the RT-PCR results of the gene expression of $A G T, A C E$, and $A T_{1}$ receptor in the heart between $C O$ and TR groups. mRNA level of ACE was not altered as already suggested by ACE activity, but AGT decreased $30 \%(P=$ $0.066)$ and $\mathrm{AT}_{1 \mathrm{a}}$ receptor increased $56 \%(P<0.05)$.

In regard to the protein expression, it can be observed that resistance training has no effect on the protein expression of both the $\mathrm{AT}_{2}$ receptor and ANG II (Fig. 3, B and $C$ ). Furthermore, the ANG 11 concentration evaluated by ELISA confirms this result $(\mathrm{CO}, 23.27 \pm 2.4 \mathrm{pg} / \mathrm{mg}$; $\mathrm{TR}, 22.01 \pm 0.8 \mathrm{pg} / \mathrm{mg}$,

Table 1. Body weight, absolute IRM, mean blood pressure, and heart rate

\begin{tabular}{|c|c|c|c|c|c|c|}
\hline Dac & $\mathrm{CO}$ & $\mathrm{CO}+\mathrm{LOS}$ & $\mathrm{CO}+\mathrm{SALT}$ & TR & $T R+L O S$ & TR+SALT \\
\hline \multicolumn{7}{|l|}{ Bod, wh. $g$} \\
\hline lowk & $344 \pm 7.4$ & $334 \pm 5.2$ & $354 \pm 6.8$ & $345 \pm 5.7$ & $342 \pm 6.3$ & $356 \pm 7.9$ \\
\hline \&in wk & $415 \pm 8.7$ & $403 \pm 8.9^{\circ}$ & $379 \pm 14.3^{*}$ & $388 \pm 5.7^{\star}$ & $382 \pm 6.9 *$ & $374 \pm 11.2$ \\
\hline \multicolumn{7}{|l|}{ JRM, $g$} \\
\hline $\mid w w k$ & & & & $960 \pm 26$ & $983 \pm 36$ & $818 \pm 23$ \\
\hline 8th wk & & & & $2046 \pm 130$ & $2085 \pm 28^{*}$ & $1892 \pm 40^{*}$ \\
\hline \multicolumn{7}{|l|}{ Mean blood pressure, mmHg } \\
\hline 8th wk & $108 \pm 2$ & $109 \pm 4$ & $108 \pm 1$ & $106 \pm 1$ & $109 \pm 3$ & $104 \pm 3$ \\
\hline \multicolumn{7}{|l|}{ Ilear ratc, beats/min } \\
\hline 8 th wk & $341 \pm 8$ & $387 \pm 11$ & $344 \pm 10$ & $325 \pm 11$ & $377 \pm 28$ & $326 \pm 9$ \\
\hline
\end{tabular}

Das are reponed as means \pm SE of 6 animal in each group. IRM, I repitition maximum; CO, control; CO+LOS, control treated with losaran; CO+SALT, control + I\% salt diet; TR, trained; TR + LOS, trained treated with losartan; TR +SALT, trained $+1 \%$ salt dieL $P<0.058$ th wk vs. Ist wk. 
Fig. I. Lefi venuricle (LV) hypertrophy. Data are reporiod as means $\pm S E$. $n=6$ each group. A: LV weight relative to body weight (LVW/ budy $w 1 ; \mathrm{mg} / \mathrm{g}$ ) of all groups after resistance triming protacol. CO, control: $\mathrm{CO}+\mathrm{LOS}$, con trod treated with losaran; CO+SAL, control plus 1\% salt diet; TR, trained: TR +LOS, trained treated with losartan; TR + SAL unined $+1 \%$ salt dict. "P $<0.05$ vs. CO, $\mathrm{CO}+\mathrm{LOS}, \mathrm{CO}+\mathrm{SALT}$, or TR+LOS groups. $-P<0.05$ vs. CO groups. $B$ : LVW relative to this lengh ( $\mathrm{mg} / \mathrm{mm}$ ) of groups after resistance taining prorocol. $" P<0.05$ vs. CO group.

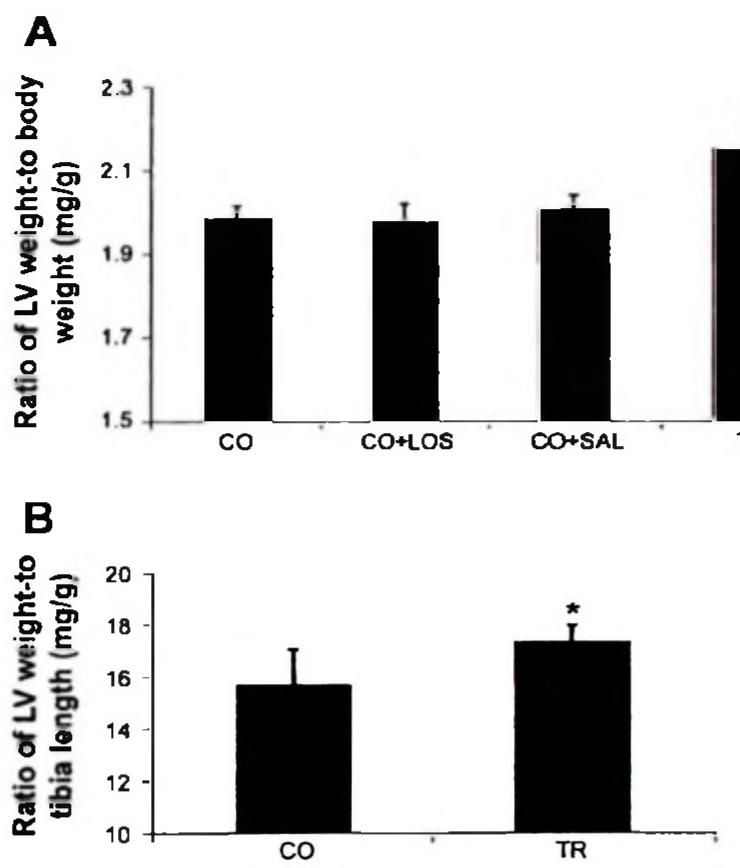

Fig. 3C). However, there was an overexpression of the $\mathrm{AT}_{1}$ receptor protein ( $31 \%$, Fig. $3 B$ ), which is in agreement with the increase in the $\mathrm{AT}_{1 \text { a }}$ mRNA.

\section{DISCUSSION}

In this study, we have focused on the role of RAS in the cardiac hypertrophy induced by resistance training in rats. It a'as observed that $\mathrm{AT}_{1}$ receptor expression increases in response to training without any alterations in other components of the RAS. Furthermore, the treatment with an $\mathrm{AT}_{1}$ receptor blocker losartan prevented this adaptive hypertropby. The implications of the results are twofold: first, $\mathrm{AT}_{\mathbf{1}}$ stimulation is Decessary for the development of cardiac hypertrophy in response to resistance training even in the absence of increased ANG 11; second, the mechanical stretch due to resistance training increases $\mathrm{AT}_{1}$ expression. Other cardiovascular adaptations in this animal model have already been described by our group in previously publications $(2,3)$. Using this animal model of resistance training, we have recently shown that resistance training induces the development of concentric cardiac hypertrophy without ventricular dysfunction or cavity

Table 2. Local and systemic angiotensin-converting encyme activity

\begin{tabular}{lcccc}
\hline \hline \multicolumn{1}{c}{ Group } & \multicolumn{1}{c}{ Lung } & Kidney & Heart & Serum \\
\hline CO & $176.4 \pm 7.8$ & $45.1 \pm 3.2$ & $15.0 \pm 1.1$ & $1793.2 \pm 50.8$ \\
CO+LOS & $214.7 \pm 27.5$ & $31.1 \pm 4.5$ & $15.5 \pm 1.4$ & $1350.2 \pm 35.7$ \\
CO+SALT & $148.1 \pm 14.9$ & $52.9 \pm 3.3$ & $15.5 \pm 0.3$ & $1745.7 \pm 105.1$ \\
$T R$ & $170.3 \pm 15.6$ & $42.3 \pm 3.3$ & $15.2 \pm 0.6$ & $1748.5 \pm 69.7$ \\
IR+LOS & $196.6 \pm 15.6$ & $49.5 \pm 8.4$ & $14.0 \pm 1.1$ & $1379.3 \pm 85.4$ \\
$1 \mathrm{R}+$ SALT & $159.2 \pm 23.0^{4}$ & $55.0 \pm 7.2^{\circ}$ & $15.3 \pm 0.5$ & $1748.2 \pm 89.2$ \\
\hline
\end{tabular}

Dala are reported as means $\pm \mathrm{SE}\left(\mathrm{UF} \cdot \mathrm{min}^{-1} \cdot \mathrm{mg}^{-1} \times 1,000\right)$ of 6 animals in each group. $P<0.01$ vs. $\mathrm{CO}$ group. reduction, analyzed by echocardiography, showing that this stimulus leads to physiological cardiac hypertrophy. In this study, we have also analyzed markers of pathological hypertrophy. ANP expression and the $\alpha \mathrm{MHC}$-to- $\beta$ MHC ratio are both increased during cardiac hypertrophy (16). Hypertension and other forms of cardiac stress are important regulators of higher expression of these markers. However, although the resistance training is also a cardiac stressor, these markers were not altered, which agree with our previous results of ventricular function (3).

The resistance training due to increased cardiac workload during the exercise sessions is a good in vivo model for studying pressure overload on cardiac cells. It has become clear that external load is sensed by cardiac cells, and this stimulus is converted into intracellular signals, which ultimately leads to cardiac hypertrophy; however, the mechanisms involved are less understood (35). It has been observed in vitro that stretch of cultured neonatal rat myocyte induces hypertrophy that is inhibited by $A C E$ inhibitors or $\Lambda T_{1}$ receptor blockers (23). In addition, it has been suggested that mechanical stretch causes a direct release of humoral factors, such as

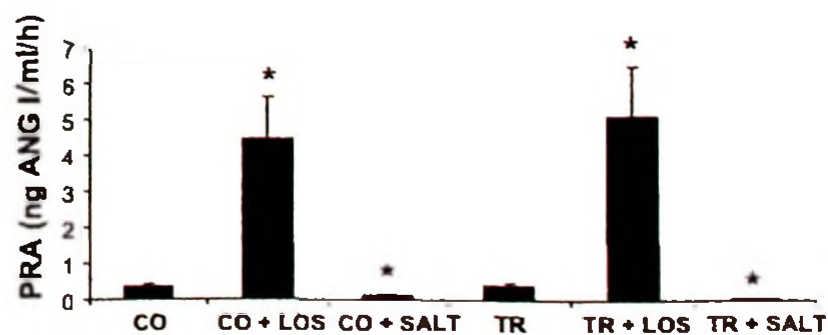

Fig. 2. Effect of resistance training on plasma renin activity (PRA; ng $\mathrm{Al} \cdot \mathrm{ml}^{-1} \cdot \mathrm{h}^{-1}$ ). Data are reported as means $\pm \mathrm{SE} n=6$ each group. ${ }^{\star} P<0.05$ vs. CO or TR groups. 
A

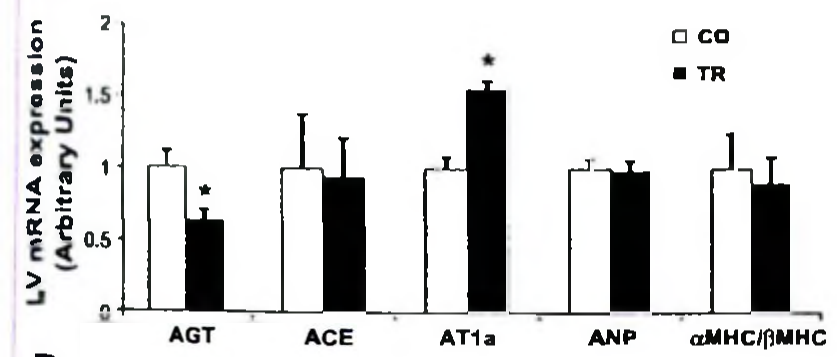

B
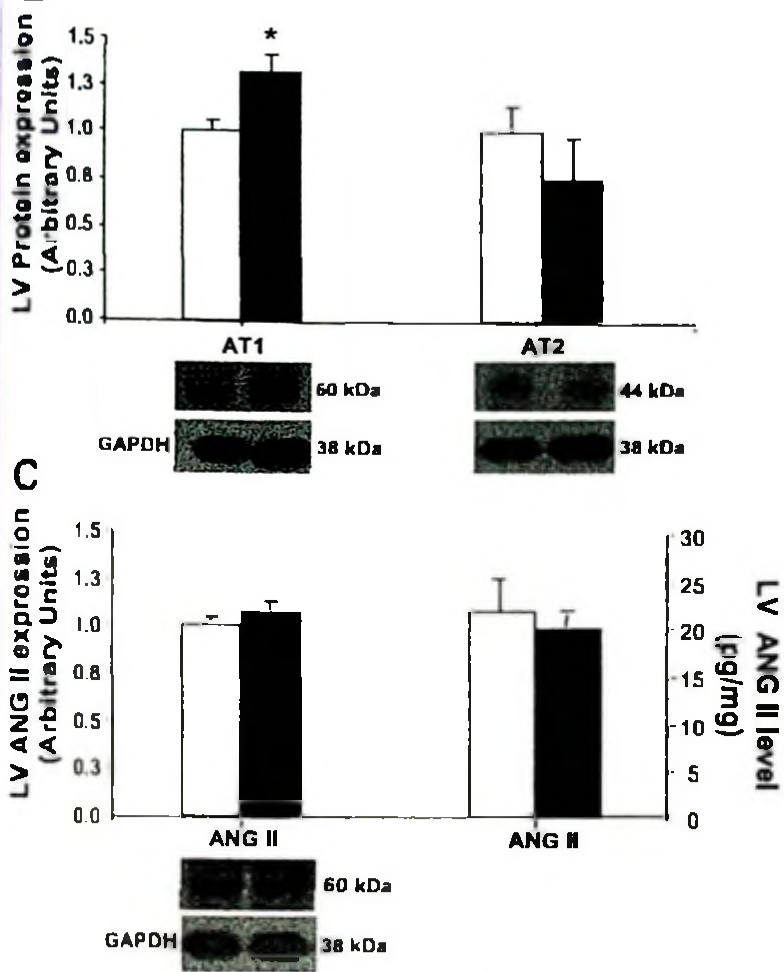

Fig 3. Elfects of resistance training on the gene expression and protein level. A. eflect of resistance training on the mRNA expression of AT, receptor. angiotensinogen ( $A G T$ ), angiotensin converting enzyme (ACE), atrial natriurevic peptide (ANP), $\alpha / \beta$ myosin heavy chain (MHC) in rat ventricles. Quan titation of $A G T, A C E, A N P, \alpha M H C, \beta M H C$ and $A T_{1}$, respectively (normal ired against ciclofitin mRNA). $B$ : effect of resistance training on the protein e spression of $A \mathrm{~T}_{1}$ and $\mathrm{AT}_{2}$ receptor in rat ventricles. Top blor: quantitation of $A T_{1}$ and $\mathrm{AT}_{2}$ protein expression, respectively (normalized against GAPDH). Botsom blot: representative Westem blot of $\mathrm{AT}_{1}$ and $\mathrm{AT}_{2}$. C: ANG Il peptide caxcentuation in the heart analyzed by Western bloting (lefi) and immunore ative (right). Data are reported as means \pm . SE of 6 animals each group. ${ }^{*} P<$ 0.05 vs. CO groups

ANG II and endothelin-1, from cardiac myocytes and that these factors act as initial mediators of the stretch-induced hypertrophic response (28). However, other authors have failed to find considerable amounts of ANG 11 in the medium after mechanical stretch (31), and others, even when finding ANG II in the medium, observe that its amount is far below the amount needed to induce near-maximal hypertrophic effects (25). Recently, in a elegant study, Zou et al. (37) directly demonstrated that the medium from cardiomyocytes conditioned to mechan- ical stretch did not activate intracellular $A T_{1}$ receptor-dependent pathway, which also demonstrated that even if the cells had releasod ANG $\mathrm{II}$, it would not be capable of activating $\mathrm{AT}_{\text {, }}$ receptors. In the present study, we did not observe any alteration in local cardiac $\mathbf{A N G} \mathbf{I I}$ concentration after resistance training, which is in agreement with the lack of alteration in ACE and renin activity and decreased AGT gene expression $(P=0.066)$. Interestingly, in a very recent study, Xiao et al. (33) observed that mice expressing $\mathrm{ACE}$ only in the heart showed local heart ANG 11 concentration twice that of wildtype mice but that cardiac hypertrophy induced by aortic banding did not differ between the genotypes. Altogether, these findings and the ones of the present study suggest that it is very unlikely that ANG 11 plays a role in the cardiac hypertrophy after resistance training.

Our findings might be explained by recent studies suggesting that mechanical load can directly activate the $A T$, receptor even in the absence of ANG 11. A number of studies have addressed the role of the AT, receptor in cardiac hypertrophy, using genetically modified mice models overexpressing AT, receptor in the heart $(14,26,32)$. Van Kats et al. (30) used transgenic mice that had cardiac levels of ANG $I 20$ - to 50 -fold greater than those seen in control groups with no detectable increase in circulating ANG $\mathrm{H}$. These transgenic mice showed no evidence of cardiac hypertrophy at 3 mo of age. In the same study, using another type of transgenic mice that overexpressed a degradation-resistant form of ANG II, the hormone levels reached 100 times the normal levels and began to spill into the circulation. In spite of this, the animals again did not developed cardiac hypertrophy, which was only observed when the blood pressure began to increase in response to the increased circulating ANG II. Recent results by Crowley et al. (7) have demonstrated that cardiac remodeling correlates with increases in blood pressure and that in the absence of an increase in blood pressurc, hearts did not undergo remodeling even under ANG II administration for $4 \mathrm{wk}$. These studies suggest different mechanisms for pressure-mediated and ANG ll-mediated effects through $A T_{1}$ in vivo.

Frank et al, in 2008 (13), demonstrated that a stretch-specific gene program exists and is mediated, at least in part, by the $A T_{1}$ receptor, but that is different from that induced by pharmacological intervention, such as phenylephrine, endothelin, or even ANG 11 induction. Earlier, Malhotra et al. (22) had already described that mechanical stretch and ANG II differentially regulate the RAS in cardiac myocytes in vitro. These differences in the intracellular program induced by stretch or by ANG II might be duc to the fact that the $A T_{1}$ receptor does not only couple to the $G$ protein family, but also to unconventional intracellular signaling, such as JAK2-STAT $1 / 2$ and ATIR-associated proteins. These different effects mediated by pressure and ANG 11 may have important clinical implications since they imply that the RAS may be important in conditions that $\mathrm{AT}_{1}$ receptor levels are increased.

In concert with the findings described above, our results demonstrated that although resistance training did not significantly modify ANG II concenuration, protein and mRNA expression of $A T_{1}$ receptor increased. Furthermore, when the

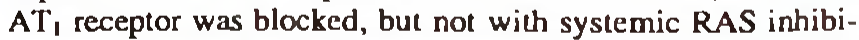
tion, cardiac hypertrophy was prevented, suggesting a key role to the local RAS in this adaptation. The cardiac hypertrophy observed in the present study might be explained by the 
silivation of the $\Lambda T_{1}$ receptor caused by repeated chronic nicchanical stretch due to the resistance training. This finding rigarding physiological cardiac remodeling independent of ING Il concentration is in agreement with another study of our group that did not observe differences in cardiac hypertrophy heturen mice harboring one to four copies of the ACE gene when submitted to physical training (11).

During the revision of this manuscript, Yasuda et al. (36) described the molecular mechanisms of $\mathrm{AT}_{1}$ receptor activation by mechanical stress. Using substituted cysteine accessibility mapping technique, they have observed that the $\mathrm{AT}_{1}$ neceptor might be disrupted by mechanical stretch independently of ANG II and that the counterclockwise rotation of the transmembrane 7 domain might cause activation of intracellular signaling pathways.

\section{Perspeclives and Significance}

This sludy shows for the first time in the literature that local RAS contributes to the development of physiological cardiac bypertrophy in response to resistance training and that the $\mathrm{AT}_{1}$ receptor plays a key role on this adaptation. It allows future studies to investigate the mechanisms and the intracellular si gnaling by which different exercise training leads to different cardjac hypertrophy patterns, such as concentric and eccentric bypertrophy. Furthermore, this study suggests that the activavion of RAS can also be observed even in physiological adaptations induced by resistance training in addition to the well-known action of the RAS in the development of many cardiovascular diseases.

\section{GRANTS}

This work was supported by Fundaçăo de Amparo a Pesquisa do Estado de Sİo Paulo Grant no. 04/11624-6. V. G. Barauna was the recipient of a FAPESP Fellowship no. B3/10302-2.

\section{REFERENCES}

1. Alves MF, A raujo MC, Juliano MA, Oliveira EM, Kricger IE, Casarinl DF, Juliano L, Carmona AK. A continuous fluorescent assay for the determination of plasma and tissue angiotensin I-converting enzyme activity. Braz J Med Biol Res 38: 86I-868, 2005.

2. Bamuna VG, Junior ML, Costa Rosa LF, Casarini DE, Krieger JE, Olivelra EM. Cardiovascular adaptations in rats submitted to a resistancetraining model. Clin Exp Pharmacol Physiol 32: 249-254, 2005.

3. Banuma VG, Rosa KT, Irigoyen MC, de Oliveira EM. Effects of resistance training on ventricular function and hypertrophy in a rat model. Clin Med Res 5: 114-120, 2007.

4. Bernstein KE. Views of the renin-angiotensin system: brilling, mimsy, and slithy tove. Hypertension 47: 509-514, 2006.

5. Bradtord MM. A rapid and sensitive method for the quantitation of microgram quantitics of protein utilizing the principle of protcin-dyc binding. Anal Biochem 72: 248-254, 1976.

6. Chen WS, Sim MK. Effects of des-aspantate-angiotensin I on the expression of angiotensin $A T_{1}$ and $A T_{2}$ receptors in ventricles of hypertrophic rat hearts. Regul Pept 117: 207-212, 2004.

7. Crowley SD, Gurley SB, Herrera MJ, Ruiz P, Grifiths R, Kumar AP, KIm HS, Smithies O, Le TH, Coffman TM. Angiotensin II causes hypertension and cardjac hypertrophy through its receptors in the kidney. Proc Nall Acad Sci USA 103: 17985-17990, 2006.

8. Dahbof B, Herlitz H, Aurell M, Hansson L Reversal of candiovascular uructural changes when treating essential hypertension. The importance of the renin-angiouensin-aldosterone system. Am J Hyperiens 5: 900-911, 1992.

9. Drau VJ. Local expression and pathophysiological role of renin-angiotensin in the blood vessels and hear. Basic Res Cardiol 88, Suppl 1: 1-14. 1993.
10. Elmfeldt D, Olotsson B, Merodith P. The relationships between dose and antihypertensive effect of four $A T_{1}$-receptor blockers. Differences in potency and efficacy. Blond Press II: 293-301, 2002.

11. Evangellsta FS, Kricger JE. Small gene effect and exercise traininginduced cardiac hypertrophy in mice: an Ace gene dosage study. Physiol Genomics 27: 231-236, 2006.

12. Femlng I, Kohlstedt $K$, Busse $R$. The tissue renin-angiotensin system and intracellular signalling. Curr Opin Nephrol Hyperiens 15: 8-13, 2006.

13. Frank D, Kuhn C, Brors B, Hanselmann C, Ludde M, Katus HA, Frey N. Gene expression pattem in biomechanically stretched cardiomyocytes: evidence for a stretch-specific gene program Hyperiension 51 : 309-318. 2008.

14. Hein Ln Stevens ME, Barsh GS, Prate RE, Kobilka BK, Dzau VJ. Overexpression of angiotensin $A T$, receptor transgene in the mouse myocandium produces a lethal phenotype associated with myocyte hyperplasia and heart block Proc Natl Acad Sci USA 94: 6391-6396, 1997.

15. Julius S. Blood pressure lowering only or more? Has the jury reached its verdict? Am J Cardiol 100: 32J-37J, 2007.

16. Klein RM, MacGilivray BK, MeKenzie JC. Markers of cardiac hypertrophy. Ann NY Acad Sci 752: 210-217, 1995.

17. Kohan $K$, Tabuch $Y$, Senanayake P, Brosnihan KR, Ferrario CM. Reassessment of plasma angiotensins measurement: effects of protease inhibitors and sample handling procedures. Peptides 12: 1135-1141. 1991.

18. Knrdi M, De Mello WC, Booz GW. Working outside the system: an update on the unconventional behavior of the renin-angionensin system components. Int J Biochem Cell Biol 37: 1357-1367, 2005.

19. Lentinl AC, McKelvie RS, MeCartney N, Tomlinson CW, MacDougall JD. Left ventricular response in healthy young men during heavyintensity weight-lifuing exercise. J Appl Physiol 75: 2703-2710. 1993.

20. Li JS, Sharifi AM, Schiffrin EL. Effect of AT, angiotensin-receptor blockade on structure and function of small arteries in SHR. J Cardiovare Pharmacol 30: 75-83, 1997.

21. MacDougall JD, Tuxen D, Sale DG, Moroz JR, Sutton JR. Arterial blood pressure response to heavy resistance exercise. J Appl Physiol 58: 785-790, 1985 .

22. Malhotre R, Sadoshima J, Brosius FC 3rd, Izumo S. Mechanical stretch and angiotensin II differentially upregulate the renin-angiotensin system in cardiac myocytes in vitro. Circ Res 85: 137-146, 1999.

23. Miyata S, Hancda T, Osaki J, Kikuchi K. Renin-angioensin system in stretch-induced hypertrophy of cultured neonatal rat heart cells. Eur J Pharmacol 307: 81-88, 1996.

24. Oliveira EM, Krteger JE-Chronic $\beta$-adrenoceptor stimulation and cardiac hypertrophy with no induction of circulating renin. Eur $J$ Pharmacol 520: 135-141. 2005.

25. Pan J, Fukuda K, Salto M, Matsuzaki J, Kodama H, Sano M, Takahashi T, Kato T, Ogawa S. Mechanical stretch activates the JAKJ STAT pathway in rat candiomyocytes. Circ Res 84: $1127-1136,1999$.

26. Paradis P, Dali-Youcef N, Paradis FW, Thibaule G, Nemer M. Overexpression of angiotensin UI type I receptor in cardiomyocytes induces cardiac hypertrophy and remodeling. Proc Natl Acad Sci USA 97: 931936, 2000 .

27. Paul M, Poyan Mehr A, Kreutz R. Physiology of local renin-angiotensin systerns. Physiol Rev 86: 747-803, 2006.

28. Sodoshirna J, Xu Y, Shyter HS, Izumo S. Autocrine release of angiotensin U mediates stretch-induced hypertrophy of cardiac myocytes in vitro. Cell 75: 977-984, 1993.

29. Tamakj T, Sekine T, Akatsuka A, Uchiyama S, Nakano S. Detection of neuromuscular junctions on isolated branched muscle fibers: application of nitric acid fiber digestion method for scanning electron inicroscopy. J Electron Microsc (Tohyo) 41: 76-81, 1992.

30. van Kats JP, Methot D, Paradk P, Silversides DW, Reudelhuber TL. Use of a biological peptide pump w study chronic peptide homone action in transgenic mice. Direct and indirect effects of angiotensin II on the hear J Biol Chem 276: 44012-44017, 2001.

31. van Kesteren CA, Saris JJ, Dekkers DH, Lamers JM, Saxema PR, Schalekamp MA, Danser AH. Cultured neonatal rat candiac myocytes and fibroblasts do not synthesize renin or angiotensinogen: evidence for stretch-induced cardiomyocyte hypertrophy independent of angiotensin IL Cardiovasc Res 43: 148-156, 1999.

32. Wettschureck N, Rutten H, Zywietz A, Gehring D, Wilkle TM, Chen J, Chien KR, Offermanis $S$. Absence of pressure overload induced myocardial hypertrophy after conditional inactivation of $G_{a, r} / G_{a 11}$ in cardiomyocytes. Nat Med 7: 1236-1240, 2001. 
11. Xian III), Fuchs S, Bernsteln EA, IU P, Cumphell DJ, Bernsieln KE. Mice expressing ACE only in the heart show that increased cardiac angiotensin II is not associaled with cardiac hypertrophy. Am J Physiol Heart Cinc Physiol 294: 11659-II667, 2008

34. Xie HH, Chen YY, Mian CY, Shen FM, Su DF. Effects of long-term treatment with candesartan on hemodynamics and organ damage in spontaneously hyperiensive rats. Cardiovasc Drugs Ther 19: 391-397. 2005 .

35. Yamazakı T, Komuro I, Yazakl Y. Signalling pathways for cardiac hypertrophy. Cell Signal 10: 693-698, 1998.
36. Yasuda N, Miura S, Akazawa II, Tanaka T, Qin Y, Klya Y, Imaizuml $S$, Fujlino M, Ito K, Zou $Y$, Fukuhara $S$, Kunimoto $S$, Fukuzak! $K$, Sato T, Ge J, Mochizuki N, Nakaya H, Saku K, Komuro I. Conformational switch of angiocensin II type I receptor underlying mechanical stress-induced activation. FMBO Rep 9: 179-186, 2008.

7. Zou $Y$, N, Iwanage K, Zhu W, Kudoh S, Toko $H$, Tamura $K$, Kithara $M$, Nagal T, Fukmizu A, Umemura S, IirI T, Fulita T, Komuro I. Mechanical stress activates angiotensin II type 1 receptor without the involvement of angiotensin 1I. Nat Cell Biol 6: 499-506, 2004.

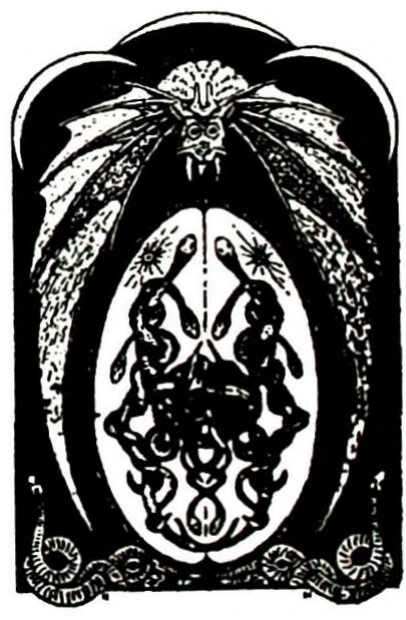




\section{AT1 receptor-AKT-mTOR signaling pathway is activated by a session of strength exercise}

Stéphano Freitas Soares Melo

Marco Aurélio Amadeu

Flávio de Castro Magalhães

Tiago Femandes

Everton Crivoi do Carmo

Diego Lopes Mendes Barretti

Patricia Chakur Brum

Edilamar Menezes de Oliveira

Laboratory of Biochemistry, School of Physical Education and Sports, University of São Paulo, São Paulo, Brazil

ATl Receptor and Resistance Training

Address for reprint requests and other correspondence: Edilamar Menezes de Oliveira, Laboratory of Byochemistry, School of Physical Education and Sport. Av Prof. Mello Moraes, 65, Butantã, Cidade Universitária, 05508-9000, São Paulo, SP, Brazil (e-mail: edilamar@usp.br). 


\begin{abstract}
The angiotensin II type I receptor (AT1R) receptor has an important participation in the development of the cardiac hypertrophy. Previously, we showed that AT1 receptor participates in the cardiac hypertrophy induced by resistance training in rats (2). Here, we studied AT1 receptor signaling pathways related to the cardiac hypertrophy in rats submitted to a session of strength exercise. Male Wistar rats were divided into six groups: control (CO; $n=6)$; control treated with losartan (CO Los; $n=6$ ); exercised and killed 5 minutes after exercise (Ex $5 ; n=6)$; treated with losartan, exercised and killed 5 minutes after the exercise (Ex Los $5 ; n=6)$; exercised and killed 30 minutes after exercise (Ex $30 ; n=6)$ and treated with losartan, exercised and killed 30 minutes after training (Ex Los 30;n=6). The results show that phosphorylation of AKT in Ex 5 and Ex 30 groups increased 63\% $(P<0.05)$ and 62\% $(P<0.05)$, respectively, compared to the group CO. However, only in the Ex 30 group, phosphorylation of mTOR and ERK $1 / 2$ was increased $65 \%(P<0.05)$ and $59 \%(P<0.05)$, respectively, compared to CO. Furthermore, these effects were blocked by losartan treatment in groups Ex Los 5 and Ex Los 30 . However, activation of JNK1/2, p38 and $\mathrm{p} 70^{\text {s6K }}$ proteins were not different between the groups. These results, together with ours previous data show that the AT1R receptor has a role in the activation of AKT/mTOR pathway and ERK $1 / 2$ after a session of strength exercise.
\end{abstract}

Keywords

AT1 receptor; cardiac hypertrophy; resistance training 


\section{INTRODUCTION}

Myocardial hypertrophy is an adaptative response of the heart to increased work load that involves enhanced protein synthesis and an increase in size of individual cardiomyocytes (16). Pathological and physiological cardiac hypertrophies can be induced by a variety of factors such as mechanical stress and neurohumoral factors, functionally different, and are associated with distinct structural and molecular phenotypes $(7,9,26)$.

Angiotensin II (Ang II) or mechanical stress activates a wide spectrum of signaling responses via the angiotensin II type I receptor (AT1R) that mediate blood pressure control, thirst, and sodium balance and diverse pathological actions in cardiovascular, renal, and other cells systems (17). Evidences suggests that AT1R plays an important role in the development of cardiac hypertrophy in pathological conditions such as hypertension or after myocardial infarction maladaptive cardiac hypertrophy result in tissue fibrosis and it is associated with a high risk of mortality due to heart failure and arrhythmia $(23,37)$.

It is generally accepted that activation of $G$ protein-coupled receptors as the AT1R pathway are necessary for inducing pathological hypertrophy, whereas receptor of tirosin kinase coupled to the phosphatidylinositol 3-kinase (PI3K)-AktmTor pathway has been associated with physiological growth of the heart in aerobic training by volume overload $(6,9,10,24)$. Exercise training, such as strength training, is a known hypertrophic stimulus for cardiac enlargement due to blood pressure overload imposed on the heart during exercise training $(13,19)$. It has been 
recognized that these two types of hemodynamic overload results in distinct myocardial remodeling.

Previously, Barauna et al. (2) showed, for the first time in the literature, that local RAS contributes to the development of physiological cardiac hypertrophy in response to resistance training and that AT1R plays a key role on this adaptation. AT1R is considered a pleiotropic receptor able to activate specific pathways through protein $\mathrm{Gq} / 11$ or $\mathrm{Gi} / \mathrm{o}$ and $\mathrm{G} 11 / 12$, and independent of $\mathrm{G}$ protein by inducing signaling pathway in tissues particular $(15,17,38)$. Then, our objective was to study the role of the AT1 receptor in the activation of intracellular signaling pathways PI3K and MAPKs related to increased protein synthesis in rats submitted to a session of strength exercise. 


\section{METHODS}

Animals. Thirty-six male Wistar rats (body weight between 250-300g) were randomly divided into six groups $(n=6$ each): control $(C O, n=6)$, control treated with losartan (Los CO, $n=6$ ), exercised and killed 5 min after exercise (Exe $5, n=6$ ), treated with losartan, exercised and killed 5 min after exercise (Exe 5 Los, $n=6$ ), exercised and killed 30 min after exercise (Exe 30, $n=6$ ), treat with losartan, exercised and killed 30 min after exercise (Exe 30 Los, $n=6)$. Losartan $\left(20 \mathrm{mg} \cdot \mathrm{kg}^{-1}\right)$ was administered in the drinking water at a known dose that blocks the AT1 receptor but does not decrease the blood pressure of normotensive rats (23), and the losartan treatment begun one week before the exercise protocol. Animals were housed in standard cages and food and water were provided ad libitum. The environmental temperature was kept at 23 $\pm 1^{\circ} \mathrm{C}$, and a $12: 12-h$ dark-light cycle was maintained throughout the experiment. All protocols and surgical procedures used were in accordance with the guidelines of the Brazilian College for Animal Experimentation and were approved by the Ethics Committee of the Institute of Biomedical Science of the University of Sāo Paulo.

Exercise protocol. Animals were exercised following a model adapted from Tamaki et al. (36). Rats fitted with canvas jackets were able to regulate the twisting and flexion of their torsos and were suspended in a standard position on their hind limbs. An electrical stimulation ( $20 \mathrm{~V}, 0.3-\mathrm{s}$ duration, at 3-s intervals) was applied to the rat's tail through a surface electrode. As a result, the rats flexed their legs repeatedly, which lifted the weight arm of the training apparatus. The trained groups were exercised by four sets of 12 repetitions with a 90-s rest period between each set. This exercise regimen was started after 1 wk of adaptation. The last day of adaptation was 
measurement of the maximum weight lifted [one repetition maximum (1RM)] with the squat-training apparatus, the training load was set at $75 \%$ of $1 \mathrm{RM}$. The $1 \mathrm{RM}$ was defined as the minimum load that the rats were unable to jump following electrical stimulation. Forty-eight hours after the 1RM test the animals performed a session of strength exercise was done with an overload of $80 \%$ of $1 \mathrm{RM}$. All training sessions were performed in a dark room. After the session, each animal was anesthetized with ether and decapitated, the heart removed and the chambers separate in the left ventricle (LV) and right ventricle (RV) and weighted, however only the LV was placed in buffer, homogenized and adequately stored in freezer $\left(-20^{\circ} \mathrm{C}\right)$ for later analysis.

Westem blot analysis. The frozen ventricles were thawed and minced into small pieces and homogenized in cell lysis buffer containing $100 \mathrm{mM}$ Tris, $50 \mathrm{mM} \mathrm{NaCl}, 10$ $\mathrm{mM}$ EDTA, $1 \%$ Triton $\mathrm{X}-100$, and a mixture of protease inhibitors [phenylmethanesulfonylfluoride $(1 \mathrm{mM})$ o- henanthroline $(30 \mathrm{mmol})$, pepstatin $\mathrm{A}$ $(1 \mathrm{mM})$, and 4-(chloromercuribenzoic acid) $(1 \mathrm{mmol})]$ to prevent the in vitro production and degradation of angiotensin peptides (22). Insoluble heart tissues were removed by centrifugation at $3,000 \mathrm{~g}, 4^{\circ} \mathrm{C}, 10 \mathrm{~min}$. Samples were loaded and subjected to SDS-PAGE in $10 \%$ polyacrylamide gels. After electrophoresis, proteins were electrotransferred to nitrocellulose membrane (Amersham Biosciences; Piscataway, $\mathrm{NJ})$. Equal loading of samples $(60 \mathrm{~g})$ and even transfer efficiency were monitored with the use of $0.5 \%$ Ponceau S staining of the blot membrane. The blot membrane was then incubated in a blocking buffer ( $5 \%$ nonfat dry milk, $10 \mathrm{mM}$ Tris $\mathrm{HCl}, \mathrm{pH} 7.6,150$ $\mathrm{mM} \mathrm{NaCl}$, and $0.1 \%$ Tween 20 ) for $2 \mathrm{~h}$ at room temperature and then probed with a polyclonal antibody directed against total AKT, mTOR, ERK, P38, JNK, P70 ${ }^{\text {s6k }}$ and 
theirs phosphorylated proteins ( $p-A K T, p-m T O R, p-E R K, p-P 38, p-J N K, p-P 70^{S 6 k}$ ) (1:1000; Abcam) at room temperature. Binding of the primary antibody was detected with the use of peroxidase-conjugated secondary antibodies, and enhanced chemiluminescence reagents (Amersham Biosciences; Piscataway, NJ) were used to visualize the autoradiogram, which was later exposed to photographic film. The film was developed, and the bands were analyzed using Scion Image software (Scion based on NIH image). Total protein expression was used to normalize the results. 


\section{STATISTICAL ANALYSIS}

The comparison between groups was made by two-way ANOVA, post hoc test of Duncan was used for comparison between mean when significant changes were observed with ANOVA. P values $<0.05$ were accepted as statistically significant. All results are presented as mean \pm standard deviation (SD). 


\section{RESULTS}

Body weight. There was no difference in body weight between the groups (Table 1). Maximal strength. 1RM was similar among all groups before the exercise protocol. Analyzing the 1RM load normalized by body weight, it was found that animals raised about three times their body weight and no difference was found among the groups (Table 1).

Cardiac weight. There were no changes in the ratio of LV weight and body weight among the groups (Table 1).

\section{TABLE 1}

Figure 1 shows the western blot results of the AKT $\left(\mathrm{Ser}^{473}\right)$ protein and the AKT $\left(\mathrm{Ser}^{473}\right)$ phosphorylation in rat LV. In the groups Exe 5 and Exe 30 the phosphorylation of AKT protein increase $46 \%$ and $47 \%$ respectively, when compared to control group. The effect was blocked by losartan in the group Exe 5 los (61\%) and Exe 30 los (79\%). These results show that the AT1R receptor plays an important role in the activation of AKT after a session of strength exercise (Fig. $1-A$ and $B, P<0.05$ ). The protein mTOR, which is a target protein AKT phosphorylation was increased $65 \%$ in group Exe 30 when compared with to control group. Although, the difference was observed only in the phosphorylation of mTOR between group Exe 30 and group Exe Los 30 $(68 \%)$, these results indicate that the AT1R receptor plays an important role in the activation of the AKT-mTOR pathway after a session of strength exercise (Fig. 1-C and $D, P<0.05$ ). Phosphorylation of mTOR did not occur in group Exe 5 as it did for 
the AKT. This was probably because 5 min might be a short time for its activation. For the $\mathrm{p} 70^{\mathrm{s} 6 \mathrm{~K}}$ protein phosphorylation was not different in any groups compared to control (Fig. 1-E and F, P < 0.05).

FIGURE 1

Figure 2 shows the western blot results of the protein phosphorylation of ERK 1/2, P38 and JNK in rat LV. The protein phosphorylation ERK $1 / 2$ was increased 59\%, only in the group Exe 30 when compared with the control group and it was blocked $66 \%$ in this group compared with the group Los Exe 30 , indicating that the AT1R receptor plays an important role in the activation of the ERK $1 / 2$ after a session of strength exercise (Fig. 2-A and $B, P<0.05$ )._For the $P 38$ and JNK protein phosphorylation was not difference in groups compared to control (Fig. 2- C, D,E and $F$, respectively, $P<0.05)$.

FIGURE 2 


\section{DISCUSSION}

In this study, we investigated the involvement of AT1R in intracellular signaling induced by a session of strength exercise. The increased cardiac workload during the sessions of strength exercise is a good in vivo model for studying pressure overload on activation of intracellular signaling pathways responsible for changes in the cardiomyocytes $(25,30,34)$. The results show that a session of strength exercise was able to induce the activation of the AKT-mTOR and ERK $1 / 2$ in the heart through AT1R.

In a recent experimental study on strength training, the AT1 receptor blockade prevented the $\mathrm{CH}$ development suggesting the involvement of AT1 receptor in intracellular signaling associated with physiological $\mathrm{CH}$ induced by resistance training In that study, there was no change in the Ang 11 concentration, angiotensinconverting enzyme I and plasma renin activities and it was observed reduction of AGT expression in the heart, suggesting that participation of the AT1R in the activation of intracellular pathways by mechanical stretching (2). Similar results were found with swimming training that showed inhibition of cardiac hypertrophy in animals treated with losartan (33)

The presence of Ang $\|$ is a point that can differentiate the activation of intracellular pathways through the AT1 receptor. Zou et al. (40) found that the AT1 receptor acts as a mechanical sensor, activating the hypertrophic signaling pathways when submitted mechanical stretch in cultured cardiomyocytes in the absence of Ang $\|$ and this activation occurred with lower participation in $\mathrm{G}$ protein activation and 
greater activation via Jak2. Interestingly, Frank et al. (14) found that the AT1 receptor activated by mechanical stretching was responsible for the activation of genes involved with cardioprotection in cardiomyocytes culture and that this has occurred, probably by the ability of AT1 receptors to activate pathways that are independent of G protein. While Ang II has been shown to activate pathways through the G protein and promote the development of $\mathrm{CH}$ in pathological models such as the work of Wettschureck et al. (38), the authors showed that knockout animals for protein Gq/G11 does not develop $\mathrm{HC}$, after the animals have been submitted to pressure overload by constricting the transverse aortic. Moreover, Mende et al. (29) showed that chronic activation of protein Gq/G11 was sufficient to promote the development of $\mathrm{CH}$ pathology. However, the activation of $\mathrm{G}$ protein does not seem to be paramount to occur $\mathrm{CH}$, as shown by Zhai et al. (39). That work showed in animals that overexpress the AT1 receptor and that had deletion of $\mathrm{G}$ protein, a high degree of $\mathrm{CH}$ with the participation of AT1 receptor that in this case occurred by activation of pathways that are independent of G protein, as example, the pathway of Jak2/STAT2 (17). The authors also observed a reduction in fibrosis and apoptosis in animals heart supporting the data that the AT1 receptor can activate pathways independent of G protein, such as in exercise situations and promote the physiological adaptations observed in this training model.

Hormones involved in the increase in protein synthesis and hypertrophy of cardiomyocytes, as IGF-1 are increased in elite athletes (32) and trained rats (35). This increase in production of IGF-1 cardiac with physical training is associated with the physiological development of $\mathrm{CH}$. Knockout animals for the receptor of IGF-1, 
when submitted to swimming training confirmed the involvement of the receptor IGF$1 \mathrm{R}$ in physiological $\mathrm{CH}$ (21). Activation of IGF-1 receptor is associated with the pathway of PI3K-AKT-mTOR, as seen in studies using animals that do not express the $\mathrm{p} 110 \mathrm{a}$ subunit of $\mathrm{PI} \mathrm{K}$, or animals with gene inactivation for $A K T$, which had no $\mathrm{CH}$ when submitted to aerobic training (11)._Although, this approach has been suggested to induce physiological $\mathrm{CH}$ in animals after training protocol, swimming and treadmill_at moderate intensity or protocol of high intensity interval physical training $(11,20,28)$, an unexpected increase was observed in phosphorylation of AKT in the trained animals with inactivation of the receptor IGF-1R, suggesting another pathway for activation of AKT with physical training, which does not depend on the receptor IGF-1R.

Interestingly, in our work, we showed that the AT1 receptor is participating in the activation of $\mathrm{AKT}$, with a session of strength exercise in an animal model. While the AT1 receptor participates in the activation of cell signaling pathways involved in the development of pathological $\mathrm{CH}(12)$, we have shown that this receptor also activates the AKT-mTOR, characteristic of the physiological development of $\mathrm{CH}$. Although published data are not yet clear in showing the pathway $P 70^{56 K}$ participates in the development of physiological cardiac hypertrophy with physical training pathway PI3K-AKT-mTOR, our objective was to determine whether there was an increase in phosphorylation of this protein, that is directly involved with increased protein synthesis in the cell, with the participation of AT1 receptor pathway AKTmTOR (27). Previously, using this same of strength training our group had shown the development of concentric physiological cardiac hypertrophy with no dysfunction or 
reduction of the ventricular cavity, without changing the expression of two important markers of pathological cardiac hypertrophy such as ANP (atrial natriuretic peptide) and $\alpha \mathrm{MHC}$ ( $\alpha-$ myosin heavy chain) to- $\beta M H C$ ratio (1-3).

A study of animals submitted to an exercise protocol twice per week on a treadmill found increased phosphorylation of ERK 1/2, and these animals did not develop $\mathrm{CH}$ (31). On the other hand, in animals that already had $\mathrm{CH}$ when subjected to swimming training, there was no increase in phosphorylation of ERK 1/2 (28). In an elegant study to investigate the activation of MAPKs in the animals heart, it was found that protein phosphorylation ERK1/2 in response to exercise occurred immediately after a session of aerobic exercise, though this acute effect on the activation of this protein decreases gradually with training. These findings were observed in animals trained for eight weeks, when submitted to 30 minutes of exercise, which showed increased levels of phosphorylation of ERK $1 / 2$ while animals that were submitted to twelve weeks of training and $\mathrm{CH}$ had increased levels of phosphorylation of ERK $1 / 2$, after the protocol of 30 minutes of aerobic exercise (18). The data from our study show that activation of this protein occurred 30 minutes after the exercise protocol and the response of this protein to the strength of exercise was similar to those promoted by physical exercise aerobic. Classically, the activation of MAPKs occurs via $\mathrm{Gq}$ protein after stimulation of receptors such as adrenergic, endothelin-1 and AT1 in animals subjected to pressure overload model $(5,8)$. With the strength exercise, we found that the increase in phosphorylation of ERK 1/2 occurred through the AT1 receptor with a session of strength exercise, but we do not know what signaling pathway the AT1 receptor is activating the ERK1/2. Thus, our model is an interesting 
model to understand how it is being activated and regulated the gene expression of ERK 1/2, in physiological context of development of $\mathrm{CH}$.

Activation of JNK and P38 in animals submitted to physical exercise occurs with the peak of phosphorylation about 30 minutes after the exercise session in sedentary animals (18). Our study demonstrated that the phosphorylation of JNK and p38 did not increase after 5 and 30 minutes of exercise, this might have occurred probably due to the intensity of exercise, as it has been demonstrated that using the activation of these proteins is directly proportional to the intensity of running exercise (4).The fact of the JNK and p38 were not phosphorylated at the expected time of 30 minutes after exercise protocol used in this work with high intensity $80 \% 1 \mathrm{RM}$, may be a factor to differentiate the changes promoted by exercise of power adjustments promoted by aerobic and strength exercise on the heart.

Different studies have addressed the activation of protein PI3K-AKT-mTOR, comparing models of blood pressure overload by constricting the transverse aortic with the effect of aerobic training in experimental animals, which causes a volume overload in the heart. We believe that a model of strength training that promotes a physiological pressure overload appears to be the best comparison to the pressure overload imposed by constricting the transverse aortic in the heart and it is better suited for studying the signals responsible for morphologic features of the stimulus on blood pressure is physiological or pathological. 


\section{REFERÉNCIAS}

1. Barauna VG, Batista ML, Jr., Costa Rosa LF, Casarini DE, Krieger JE, and Oliveira EM. Cardiovascular adaptations in rats submitted to a resistance-training model. Clinical Experimental Pharmacology and Physiology 32: 249-254, 2005.

2. Barauna VG, Magalhaes FC, Krieger JE, and Oliveira EM. AT 1 receptor participates in the cardiac hypertrophy induced by resistance training in rats. American Joumal of Physical Medicine \& Rehabilitation 295: R381-387, 2008.

3. Barauna VG, Rosa KT, Irigoyen MC, and de Oliveira EM. Effects of resistance training on ventricular function and hypertrophy in a rat model. Clinical Medicine Research 5 : 114-120, 2007.

4. Boluyt MO, Loyd AM, Roth MH, Randall MJ, and Song EY. Activation of JNK in rat heart by exercise: effect of training. American Journal Physiology Heart Circulation Physiology 285: H2639-2647, 2003.

5. Bueno OF, De Windt LJ, Tymitz KM, Witt SA, Kimball TR, Klevitsky R, Hewett TE, Jones SP, Lefer DJ, Peng CF, Kitsis RN, and Molkentin JD. The MEKI-ERK1/2 signaling pathway promotes compensated cardiac hypertrophy in transgenic mice. EMBO Journal

19: $6341-6350,2000$

6. Cantley LC. The phosphoinositide 3-kinase pathway. Science 296: 1655-1657, 2002.

7. Catalucci D, Latronico MV, Ellingsen O, and Condorelli G. Physiological myocardial hypertrophy: how and why? Frontiers in Bioscience 13: 312-324, 2008.

8. Clerk A, Aggeli IK, Stathopoulou K, and Sugden PH. Peptide growth factors signal differentially through protein kinase $C$ to extracellular signal-regulated kinases in neonatal cardiomyocytes. Cell Signal 18: 225-235, 2006.

9. Clerk A, Cullingford TE, Fuller SJ, Giraldo A, Markou T, Pikkarainen S, and Sugden PH. Signaling path ways mediating cardiac myocyte gene expression in physiological and stress responses. Journal Cell Physiology 212: 311-322, 2007.

10. Crackower MA, Oudit GY, Kozieradzki I, Sarao R, Sun H, Sasaki T, Hirsch E, Suzuki A, Shioi T, Irie-Sasaki J, Sah R, Cheng HY, Rybin VO, Lembo G, Fratta L, Oliveira-dos-Santos AJ, Benovic JL, Kahn CR, Izumo S, Steinberg SF, Wymann MP, Backx PH, and Penninger JM. Regulation of myocardial contractility and cell size by distinct PI3K-PTEN signaling pathways. Cell 110: 737-749, 2002.

11. DeBosch B, Treskov I, Lupu TS, Weinheimer C, Kovacs A, Courtois M, and Muslin AJ. Aktl is required for physiological cardiac growth. Circulation 113: 2097-2 104, 2006

12. Dinh DT, Frauman AG, Johnston CI, and Fabiani ME. Angiotensin receptors: distribution, signalling and function. Clinical Science 100: 481-492, 2001.

13. Fleck SJ. Cardiovascular adaptations to resistance training. Medicine and Science in Sports and Exercise 20: S146-151, 1988.

14. Frank D, Kuhn C, Brors B, Hanselmann C, Ludde M, Katus HA, and Frey $\mathbf{N}$. Gene expression pattem in biomechanically stretched cardiomyocytes: evidence for a stretchspecific gene program. Hypertension 51: 309-318, 2008.

15. Gutkind JS, and Offermanns S. A new G(q)-initiated MAPK signaling pathway in the heart. Dev Cell 16: 163-164, 2009.

16. Hill JA, and Olson EN. Cardiac plasticity. N Engl J Med 358: 1370-1380, 2008. 
17. Hunyady L, and Catt KJ. Pleiotropic ATl receptor signaling path ways mediating physiological and pathogenic actions of angiotensin II. Molecular Endocrinology

20: 953-970, 2006.

18. Iemitsu M, Maeda S, Jesmin S, Otsuki T, Kasuya $Y$, and Miyauchi T. Activation pattem of MAPK signaling in the hearts of trained and untrained rats following a single bout of exercise. Journal of Applied Physiology 101: 151-163, 2006.

19. Kanakis C, and Hickson RC. Left ventricular responses to a program of lower-limb strength training. Chest 78: 618-621, 1980

20. Kemi OJ, Ceci M, Wisloff U, Grimaldi S, Gallo P, Smith GL, Condorelli G, and Ellingsen $\mathbf{O}$. Activation or inactivation of cardiac Akt/mTOR signaling diverges physiological from pathological hypertrophy. Joumal Cell Physiology 214: 316-321, 2008.

21. Kim J, Wende AR, Sena S, Theobald HA, Soto J, Sloan C, Wayment BE, Litwin SE, Holzenberger M, LeRoith D, and Abel ED. Insulin-like growth factor I receptor signaling is required for exercise-induced cardiac hypertrophy. Molecular Endocrinology 22: $2531-2543,2008$.

22. Kohara K, Tabuchi Y, Senanayake $\mathbf{P}$, Brosnihan KB, and Ferrario CM. Reassessment of plasma angiotensins measurement: effects of protease inhibitors and sample handling procedures. Peptides 12: 1135-1141, 1991.

23. Li JS, Sharifi AM, and Schiffrin EL. Effect of ATI angiotensin-receptor blockade on structure and function of small arteries in SHR. Joumal of Cardiovascular Pharmacology 30: 75-83, 1997.

24. Luo J, McMullen JR, Sobkiw CL, Zhang L, Dorfman AL, Sherwood MC, Logsdon MN, Horner JW, DePinho RA, Izumo S, and Cantley LC. Class IA phosphoinositide 3-kinase regulates heart size and physiological cardiac hypertrophy. Molecular and cellular biology 25: 9491-9502, 2005.

25. MacDougall JD, Tuxen D, Sale DG, Moroz JR, and Sutton JR. Arterial blood pressure response to heavy resistance exercise. Journal of Applied Physiology 58: 785-790, 1985 .

26. McMullen JR, and Jennings GL. Differences between pathological and physiological cardiac hypertrophy: novel therapeutic strategies to treat heart failure. Clinical and Experimental Pharmacology and Physiology 34: 255-262, 2007.

27. McMullen JR, Shioi T, Zhang L, Tarnavski O, Sherwood MC, Dorfman AL, Longnus S, Pende M, Martin KA, Blenis J, Thomas G, and Izumo $S$. Deletion of ribosomal S6 kinases does not attenuate pathological, physiological, or insulin-like growth factor 1 receptor-phosphoinositide 3-kinase-induced cardiac hypertrophy. Mol Cell Biol 24: $6231-6240,2004$.

28. McMullen JR, Shioi T, Zhang L, Tarnavski O, Sherwood MC, Kang PM, and Ixumo S. Phosphoinositide 3-kinase(pl10alpha) plays a critical role for the induction of physiological, but not pathological, cardiac hypertrophy. Proceedings of the National Academy of Sciences 100: 12355-12360, 2003.

29. Mende U, Kagen A, Cohen A, Aramburu J, Schoen FJ, and Neer EJ. Transient cardiac expression of constitutively active Galphaq leads to hypertrophy and dilated cardiomyopathy by calcineurin-dependent and independent pathways. Proc Natl Acad Sci US A 95: 13893-13898, 1998. 
30. Miyamoto T, Takeishi Y, Takahashi H, Shishido T, Arimoto T, Tomoike H, and Kubota I. Activation of distinct signal transduction pathways in hypertrophied hearts by pressure and volume overload. Basic Research in Cardiology 99: 328-337, 2004

31. Nakamura A, Yoshida K, Takeda S, Dohi N, and Ikeda S. Progression of dystrophic features and activation of mitogen-activated protein kinases and calcineurin by physical exercise, in hearts of mdx mice. FEBS Letters 520: 18-24, 2002.

32. Neri Semeri GG, Boddi M, Modesti PA, Cecioni I, Coppo M, Padeletti L, Michelucci A, Colella A, and Galanti G. Increased cardiac sympathetic activity and insulinlike growth factor-I formation are associated with physiological hypertrophy in athletes. Circulation Research 89: 977-982, 2001

33. Oliveira EM, Sasaki MS, Cerencio M, Barauna VG, and Krieger JE. Local reninangiotensin system regulates left ventricular hypertrophy induced by swimming training independent of circulating renin: a pharmacological study. $J$ Renin Angiotensin Aldosterone Syst 10: 15-23, 2009.

34. Ruwhof C, and van der Laarse A. Mechanical stress-induced cardiac hypertrophy: mechanisms and signal transduction pathways. Cardiovasc Research 47: 23-37, 2000.

35. Scheinowitz M, Kessler-Icekson G, Freimann S, Zimmermann R, Schaper W, Golomb E, Savion N, and Eldar $M$. Short- and long-term swimming exercise training increases myocardial insulin-like growth factor-I gene expression. Growth Horm IGF Res 13: $19-25,2003$

36. Tamaki T, Uchiyama S, and Nakano $\mathbf{S}$. A weight-lifting exercise model for inducing hypertrophy in the hindlimb muscles of rats. Med Sci Sports Exerc 24: 881-886, 1992.

37. Weber KT, and Brilla CG. Pathological hypertrophy and cardiac interstitium. Fibrosis and renin-angiotensin-aldosterone system. Circulation 83: 1849-1865, 1991.

38. Wettschureck N, Rutten H, Zywietz A, Gehring D, Wilkie TM, Chen J, Chien KR, and Offermanns $\mathbf{S}$. Absence of pressure overload induced myocardial hypertrophy after conditional inactivation of Galphaq/Galphall in cardiomyocytes. Nature Medicine 7: 12361240,2001

39. Zhai P, Yamamoto M, Galeotti J, Liu J, Masurekar M, Thaisz J, Irie K, Holle E, Yu X, Kupershmidt S, Roden DM, Wagner T, Yatani A, Vatner DE, Vatner SF, and Sadoshima $\mathbf{J}$. Cardiac-specific overexpression of ATl receptor mutant lacking G alpha $q / G$ alpha i coupling causes hypertrophy and bradycardia in transgenic mice. $J$ Clin Invest 115 : 3045-3056, 2005

40. Zou Y, Akazawa H, Qin Y, Sano M, Takano H, Minamino T, Makita N, Iwanaga K, Zhu W, Kudoh S, Toko H, Tamura K, Kihara M, Nagai T, Fukamizu A, Umemura S, liri T, Fujita T, and Komuro I. Mechanical stress activates angiotensin II type 1 receptor without the involvement of angiotensin II. Nature Cell Biology 6: 499-506, 2004. 


\section{Figure legends}

\section{Legend 2}

Figure 1 A.C.E Bottom Blot: representative Westem Blot of protein total and phosphorylate. B.D.F Effect of a session of strength exercise on phosphorylation of $\mathrm{AKT}\left(\mathrm{Ser}^{4 / 3}\right.$ ), $\mathrm{mT}$ or and $\mathrm{P} 70^{\mathrm{s} 6 \mathrm{k}}$ in rat left ventricles (normalized against protein total). Data are reported as means \pm SE of 6 animals each group. ${ }^{*} P<0.05$ vs. groups cont ou con los. \#P $<0,05$ vs. groups Exe 5 ou Exe 30 Los.

\section{Legend 2}

Figure 2 A.C.E Bottom Blot: representative Western Blot of protein total and phosphorylate. B.D.F Effect of a session of strength exercise on phosphorylation of ERK 1/2, P38 and JNK in rat left ventricles (normalized against protein total). Data are reported as means \pm SE of 6 animals each group. ${ }^{\star} P<0.05$ vs. groups cont ou con los. \#P $<0,05$ vs. groups Exe 5 ou Exe 30 Los.

\section{Table legend}

Data are reported as means \pm SD of 6 animal in each group. IRM, 1 repitition maximum; LV, left ventriculo $\mathrm{CO}$, control; $\mathrm{CO}$ Los, control treated with losartan; Exe 5, exercised and killed 5 min after exercise; Exe 5 los, treated with losartan, exercised and killed $5 \mathrm{~min}$ after exercise; Exe, exercised and killed $30 \mathrm{~min}$ after exercise; Exe 30 los, treat with losartan, exercised and killed 30 min after exercise.

Table 1. Body weight, repetition maximum, Left ventriculo and repetition maxinum normalized for the bodyweight

\begin{tabular}{ccccccc}
\hline & Con & Con los & Ex 5 & Exe 5 los & Exe 30 & Exe 30 los \\
\hline BW (g) & $273,3 \pm 3,1$ & $275,1 \pm 4,5$ & $275,3 \pm 3,6$ & $272,6 \pm 4,9$ & $274,3 \pm 3,6$ & $277,3 \pm 3,9$ \\
LV/BW (mg/g) & $2,04 \pm 0,02$ & $2,05 \pm 0,04$ & $2,04 \pm 0,03$ & $2,06 \pm 0,05$ & $2,05 \pm 0,04$ & $2,03 \pm 0,03$ \\
IRM (g) & $1212,5 \pm 46$ & $1208,3 \pm 51$ & $1216,6 \pm 66$ & $1225 \pm 44$ & $1220,3 \pm 60$ & $1208,3 \pm 43$ \\
IRM /BW(g/g) & $4,4 \pm 0,1$ & $4,39 \pm 0,16$ & $4,41 \pm 0,21$ & $4,49 \pm 0,17$ & $4,44 \pm 0,20$ & $4,35 \pm 0,16$ \\
\hline
\end{tabular}


$1 \mathrm{~A}$

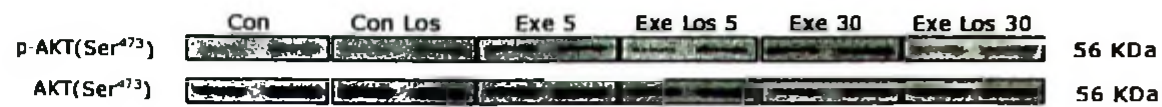

IB

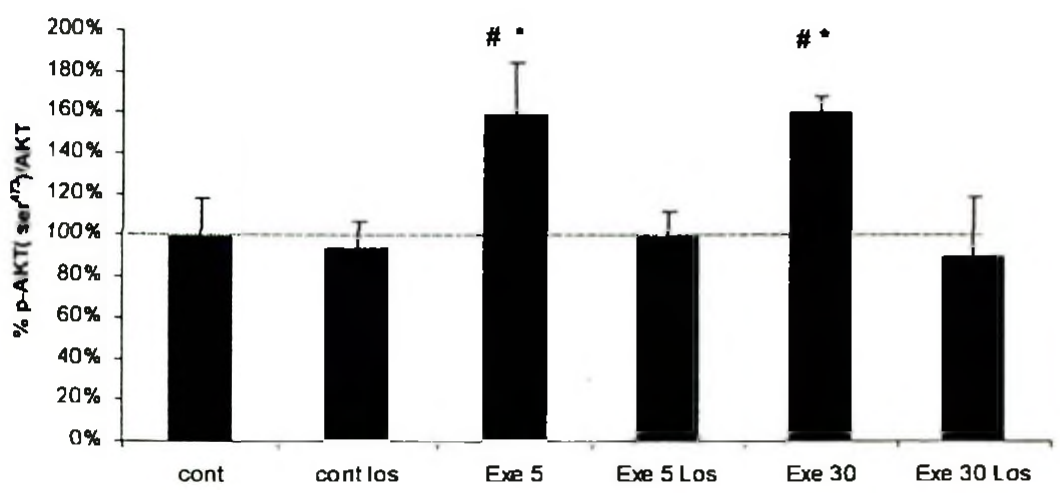

$1 C$

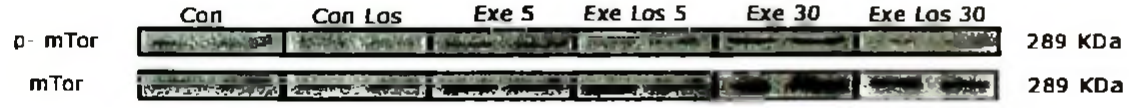

1D

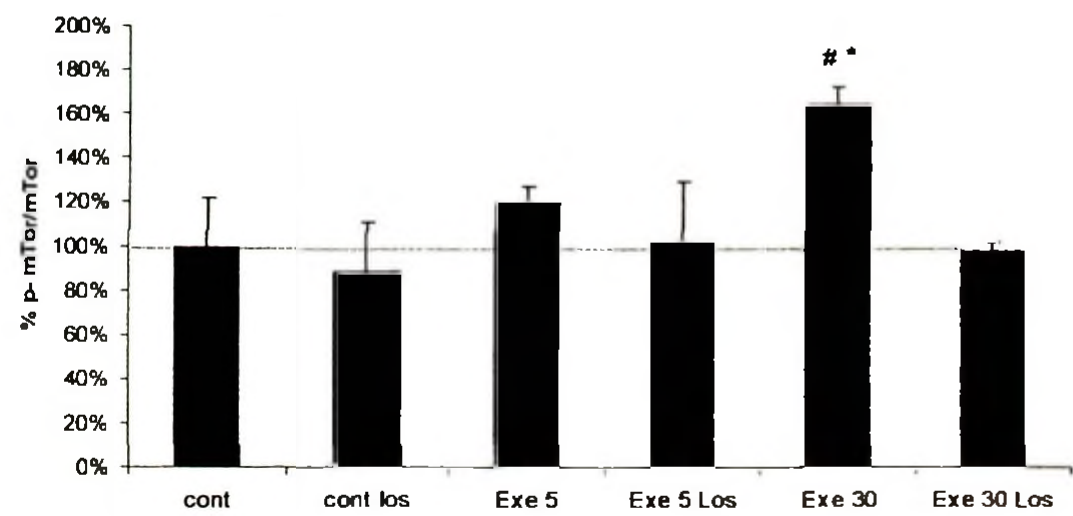




\section{A}

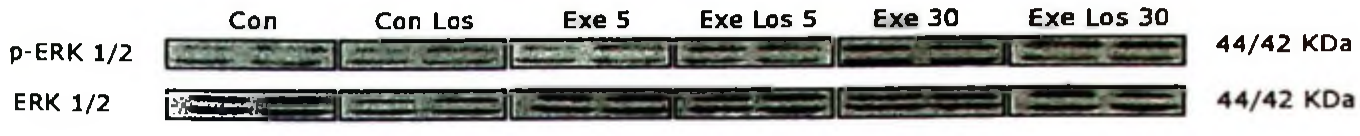

\section{B}

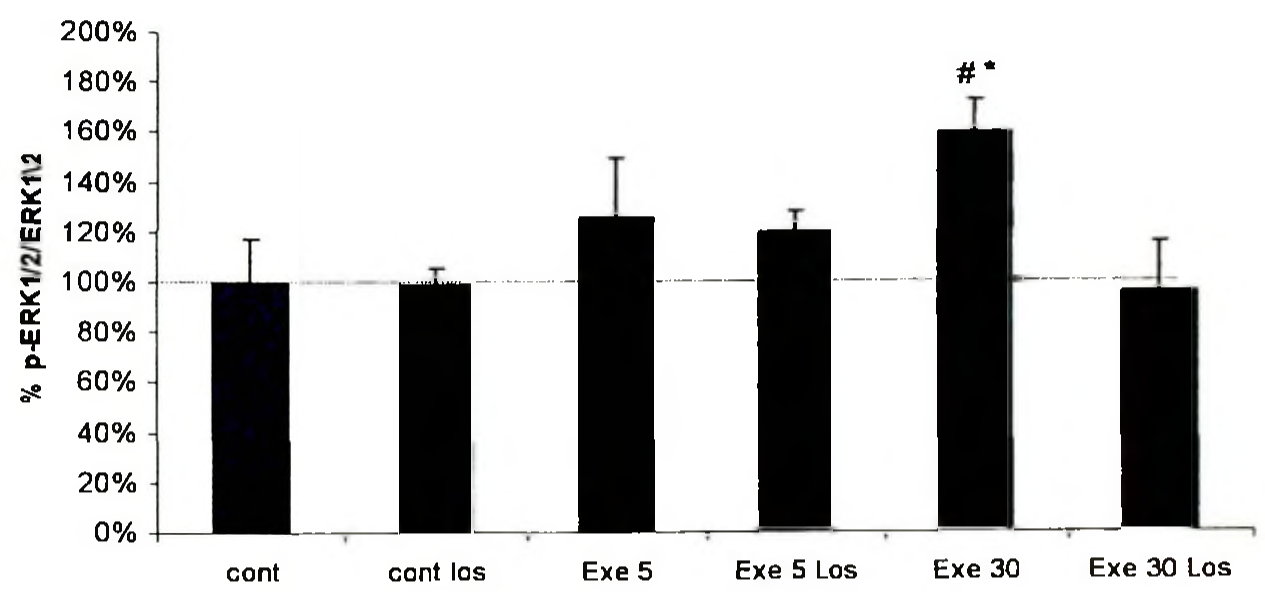

2C

p- P38

Con

Con Los

Exe 5

Exe Los 5

Exe $30 \quad$ Exe Los 30

P38

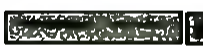

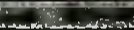

$2 D$

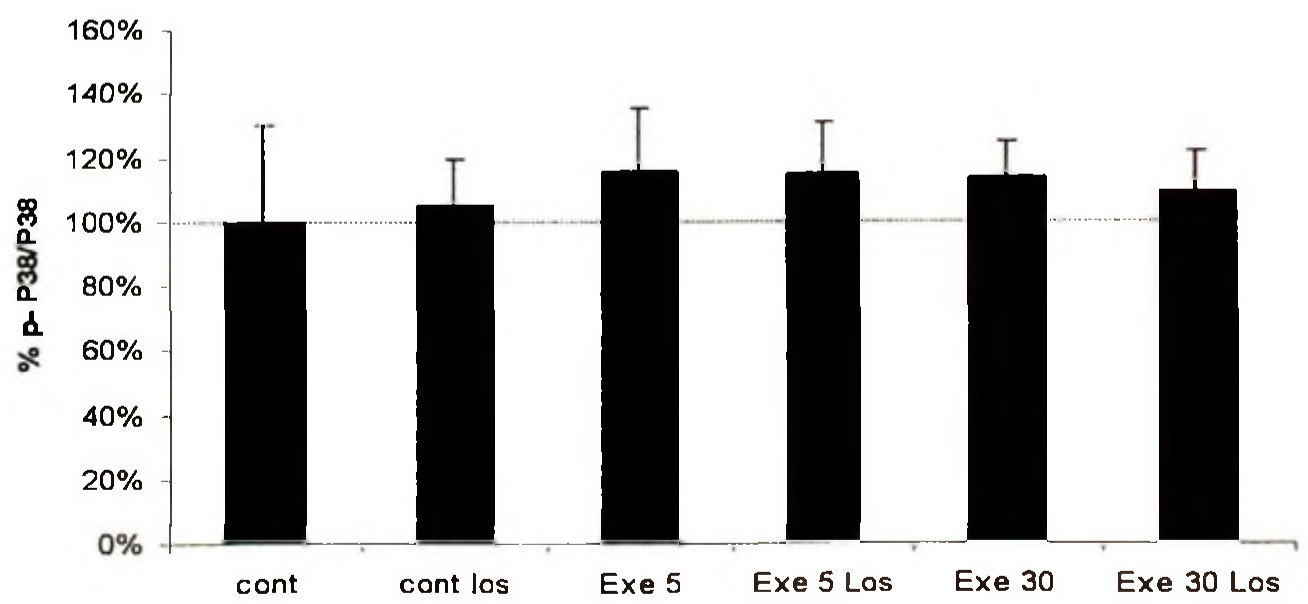


F. L. Rocha, E. C. Carmo, F. R. Roque, N. Y. Hashimoto, L. V. Rossoni, C. Frimm, I. Anéas, C. E. Negrão, J. E. Krieger and E. M. Oliveira

Am J Physiol Heart Circ Physiol 293:3575-3583, 2007. First published Sep 28, 2007;

doi:10.1152/ajpheart.01251.2006

You might find this additional information useful...

This article cites 46 articles, 18 of which you can access free at:

http://ajpheart.physiology.org/cgi/contenU/full/293/6/H3575HBIBL

Updated information and services including high-resolution figures, can be found at:

http://ajpheart.physiology.org/cgi/content/full/293/6/H3575

Additional material and information about AJP - Heart and Circulatory Physiology can be found at: http://www.the-aps.org/publications/ajpheart

This information is current as of May 25, 2009.

AJP - Ileart and Circulatory Phyxioloky publishes original investigations on the physiology of the heart, blood vessels, and lymphatics, including experimental and theoretical studies of cardiovascular fumction at all levels of organization ranging from the intact animal to the cellular, subcellular, and molecular levels. It is published 12 times a year (monthly) by the American

Physiological Society, 9650 Rockville Pike, Bcthesda MD 20814-3991. Copyright 2005 by the American Physiological Socicty. ISSN: 0363-6135, ESSN: 1522-1539. Visit our website at hitp://www.the-aps.ong/. 


\title{
Inabolic steroids induce cardiac renin-angiotensin system and impair he beneficial effects of aerobic training in rats
}

\author{
F. L. Rocha, ${ }^{1}$ E. C. Carmo,' F. R. Roque, ${ }^{1}$ N. Y. Hashimoto,' L. V. Rossoni, ${ }^{3}$ C. Frimm, ${ }^{2}$ I. $^{1}$ Anćas, ${ }^{2}$ \\ C. E. Negrão, ${ }^{1,2}$ J. E. Krieger, ${ }^{2}$ and E. M. Oliveira' \\ 'Laboratory of Biochemistry. School of Physical Education and Sport, University of Sāo Paulo; ${ }^{2}$ Hearn Institute (InCor). \\ University of Sāo Paulo Medical School; and ${ }^{3}$ Biomedical Sciences Institute, University of São Paulo, Sāo Paulo, Brazil
}

Submitted 15 November 2006; accepted in final form 25 Sepecmber 2007

Riocha FL, Carmo EC, Roque FR, Hashimoto NY, Rossoni LV, riman C, Anéas I, Negrão CE, Krieger JE, Oliveira EM. Anabolic ocids induce cardiac renin-angiotensin system and impair the benfrial effects of aerobic training in rats. Am $J$ Physiol Heart Circ ") siol 293: H3575-H3583, 2007. First published Scptember 28, 007: doi:10.1152/ajpheart.01251.2006. - We evaluated the effects is simming and anabolic steroids (AS) on ventricular function, othen synthesis, and the local renin-angiotensin system in rats. we Wistar rats were randomized into control $(C)$, steroid (S; nandrooc docanoate; $5 \mathrm{mg} / \mathrm{kg} \mathrm{sc}, 2 \times / \mathrm{wk}$ ), steroid + losartan (SL; 20 $\left.\mathrm{H}^{\prime} \cdot \mathrm{kg}^{-1} \cdot \mathrm{day}^{-1}\right)$, trained $(\mathrm{T})$, trained + steroid $(T+S)$, and trained + zroid + losartan (T+SL; $n=14 /$ group) groups. Swimming was erformed 5 times/wk for 10 wk. Serum testosterone increased in $S$ N $T+S$. Resting heart rate was lower in $T$ and $T+S$. Percent change a kfl ventricular (LV) weight-to-body weight ratio increased in $S, T$, $-d T+S$. LV systolic pressure declined in $S$ and $T+S$. LV contracLly increased in T $(P<0.05)$. LV relaxation increased in T $(P<$ (D5)]. It was significantly lower in $T+S$ compared with $C$. Collagen itumetric fraction (CVF) and hydroxyproline were higher in $S$ and $\rightarrow \mathrm{S}$ than in $\mathrm{C}$ and $\mathrm{T}(P<0.05)$, and the CVF and LV hypertrophy bere prevented by losartan treatment. LV-ANG I-converting enzyme ztwity increased (28\%) in the $S$ group (33\%), and type III collagen yeuhesis increased (56\%) in $T+S$ but not in $T$ group. A positive arrelation existed between LV-ANG I-converting enzyme activity is collagen type III expression ( $r^{2}=0.88 ; P<0.05$, for all groups). the ANG II and angiotensin type 1 a receptor expression increased in to $S$ and $T+S$ groups but not in $T$ group. Supraphysiological doses if AS cxacerbated the cardiac hypertrophy in exercise-trained rats. Etercise training associated with AS induces maladaptive remodeling at further deterioration in cardiac performance. Exercise training iscocialed with AS causes loss of the beneficial effects in LV function ituced by exercising. These results suggest that aerobic exercise plus is increases cardiac collagen content associated with activation of to local renin-angiotensin system.

ediac hyperrophy; collagen; renin-angiotensin system; ventricular intion

SMBOLC STEROIDS (AS) ARE Synthetic derivatives of testosterone sed in therapeutic dosages in medical practice (2). In addition, ugh doses of AS have been used by athletes to improve bysical performance (14). In athletes, AS increases protein rabolism and, consequently, strength, potency, and muscle azss $(14,38)$. However, high doses of AS have adverse effects o the hepatic, endocrine, and cardiovascular systems. In the ardiovascular system, AS promotes myocardial structural tanges $(18,33,38)$. Previous studies suggest that high doses

Adress for reprint requests and other correspondence: E. M. Oliveira, aboralory of Biochemistry. School of Physical Education and Spon, Av. Prof. Le ib Mtoracs, 65, Butantå. Cidade Universitária, CEP 05508-9000, Săo Paulo. anil (e-mail: cdilamar@usp.br). of AS associated with exercise training result in impaired lipid and lipoprotein metabolism, increased atherosclerosis, abnormal blood coagulation $(13,32)$, moderate cardiac hypertrophy with inadequate cardiac capillarization (39), increase in arterial blood pressure (26), apoptotic cell death of ventricular myocytes in vitro (46), and reduction in cardiac contractility in animals $(27,41)$ and athletes $(42)$. However, the nature and the molecular mechanisms of these processes involving cardiac hypertrophy remain poorly understood.

A possible modulating mechanism for this hypertrophy is higher activity of the systemic renin-angiotensin system (RAS), which plays a role in regulating cardiac growth. It is well known that, in both humans and animals, RAS is of primary regulatory importance for the remodeling of cardiac extracellular matrix (7).

We investigated $I$ ) the effects of AS administration associated with or without swimming in the cardiac remodeling process and in cardiac function in rats; and 2) the possible mediation of local RAS activity on cardiac remodeling promoted by $\mathrm{AS}$ administration in swimming-trained rats.

\section{MATERIALS AND METHODS}

\section{Experimental Groups}

Male Wistar rats (8-12 wk old; weighing $180-250 \mathrm{~g} ; n=56$ ) were used. All protocols and surgical procedures were in accordance with the guidelines of the Brazilian College for Animal Experimentation (COBEA) and were approved by the Ethics Commituce of the Medicine Faculty of the University of Säo Paulo. The rats were divided randomly into four groups, each with 14 rats: control (C), steroid (S), trained $(T)$, and trained + steroid $(T+S)$. Each group was subdivided in to two groups: one for hemodynamic, biochemical, and molecular studies, and the other for morphological and histological studies. For pharmacological treatment, a new group was divided randomly in four groups, each with six rats: $S, S$ treated with losartan [angiotensin type I (AT, )-reccptor blocker, $20 \mathrm{mg} \cdot \mathrm{kg}^{-1} \cdot \mathrm{day}^{-1}$ as drinking water] (SL). $T$, and $T+S$ treated with losartan $(T+S L)$. The animals were housed in standard cages and separated into groups (sedentary and trained). Food and water were provided ad libitum. Room temperature was kept at $23 \pm 1^{\circ} \mathrm{C}$. A 12:12-h light-dark cycle was maintained throughout the experiment. The rats were identified and weighed weekly. They were treated with the AS nandrolone decanoate (Decadurabolin; Organon, Roseland, NJ) administered subcutaneously twice a week, in a dosage of $5 \mathrm{mg} / \mathrm{kg}$ per injection, equaling 10 $\mathbf{m g} \cdot \mathbf{k g}^{-1} \cdot \mathbf{w k} \mathbf{k}^{-1}$.

The costs of publication of this anicle were defrayed in part by the payment of page charges. The anticle must therefore be hereby marked "'advertisement" in accordance with 18 U.S.C. Section 1734 solely to indicale this fact. 


\section{Insining Protocol}

The swimming training was performed as described previously 31). The physical training was execuled five times a week in a wimning system with warm water at $30-32^{\circ} \mathrm{C}$, for $60 \mathrm{~min}$, for 10 - I. with a gradual increase of work load [tail weight - \%body weight $B W)$ ] until it reached 5\% of BW. This protocol is defined as a wh-intensity, long training period, effective for promotion of cardioizcular adaptations and increase in muscle oxidative capacity (1).

\section{Hemodynamic Measurements}

V'entricular function. Rats were anesthelized with ketamine-xyla5ne-acepromazine (0.7:0.2:0.1 vol/vol/vol, $0.04 \mathrm{ml} / \mathrm{kg} \mathrm{im})$ and albwed to breathe room air spontaneously. A polyethylene catheter (PE-50, $8 \mathrm{~cm}$, filled with heparinized saline) was introduced through te right carotid artery into the left ventricle (LV). During this rracedure, arterial blood pressure and LV systolic and diastolic pressures and their first time derivatives (positive and negative, esimum $\mathrm{dP} / \mathrm{d} / \mathrm{n}$ an minimum $\mathrm{dP} / \mathrm{d}$ t, respectively) were recorded. For earth ral, the initial and LV end-diastolic pressure were determined. trterial and ventricular pressures were recorded continuously (Gould Sulham P23XI transducer, Oxnard, CA) in an eight-channel recorder (Gould, model 5900, Oxnard, CA). Heart rate (HR) and $\mathrm{dP} / \mathrm{d} \ell$ were felermined by a biotechnician, triggered by pulse pressure, and ra:orded simultaneously with the other variables.

Anerial blood pressure and $H R$. Twenty-four hours after the last trining session, the rats were anesthetized (ketamine $90 \mathrm{mg} / \mathrm{kg}$ and 1) Hazine $10 \mathrm{mg} / \mathrm{kg}$, intraperitoneally), and a catheter (PE-50) was - werled into the carotid artery, for direct measurement of arterial tiond pressure and HR. The catheter was heparinized and filled with wine, and the external extremity was occluded. The catheter was 'Jied subcutaneously and pulled out at the animal's back to facilitate tis handling of awake animals.

For the arterial blood pressure register, animals were individually maintained in cages for at least $24 \mathrm{~h}$ before the experimental proceines. Fony-eight hours after the last training session, the arterial Hond pressure was recorded for $30 \mathrm{~min}$ in quiet, conscious, unretrainod rats. The catheter was connected to a polyethylene tube (PE-100), and this to a pressure transducer (P23Db; Gould-Statham, Ornard, CA) connected to an amplifier (General Purpose AmplifierSiemtech). The arterial pressure was conveyed to an analog-digital jostem (Stemtech, Klamath Lake, OR), registered in real time in a icrocomputer with a CODAS System and analyzed through a hindows-compatible system, with a sampling frequency of 1,000 $H_{2} /$ channel. Through this program, the values of systolic blood messure (SBP), diastolic blood pressure (DBP), and mean blood pressure (MBP) were obtained beat to beat.

\section{Senum and Tissues Samples}

At the end of the experimental period, animals were killed, without prior anesthesia, by decapitation. Their blood was collected without 2] anlicoagulant for angiotensin I (ANG I)-converting enzyme (ACE) 2iajy. To determine plasma renin activity (PRA), the first $3 \mathrm{ml}$ of twuk blood (a mixture of venous and arterial blood) were rapidly collected into chilled glass tubes containing a mixture of potassium EDTA $(25 \mathrm{mM})$, o-phenanthrolene $(0.44 \mathrm{mM})$, pepstatin $A(0.12$ $\mathrm{mM}$ ), and 4-(chloromercuribenzoic acid; $1 \mathrm{mM}$ ). This mixture of protease inhibitors prevented the in vitro production and degradation of angiotensin peptides (25). The blood was centrifuged, and the plasma and serum were separated and stored at $-20^{\circ} \mathrm{C}$. In addition, tissues were harvested, and the heart was weighed and stored at $-80^{\circ} \mathrm{C}$ until biochemical and molecular analysis. The intraperitoneal fat was weighed and normalized by tolal BW of the animal.

\section{Cardiac Morphological and Morphometric Analysis}

To measure cardiac mass, the heart was removed from the thoracic cavity and dissected to separate the LV. To measure cardiac mass, the LV was dissected corresponding to the remaining tissue upon removal of atria and the free wall of the right ventricle. The interventricular septum remained as part of the LV. To evaluate cardiac hypertrophy, the heart (left and right ventricle) weight (HW) was normalized by total $\mathrm{BW}$ of the animal (HW/BW in $\mathrm{mg} / \mathrm{g}$ ).

For morphometric analysis, another group of animals was trained. After blood was collected, the chest was opened, and the hearts were stopped at diastole by perfusion with $14 \mathrm{mM} \mathrm{KCl}$. After the heart was weighed, the LV was fixed in $6 \%$ formaldehyde and embedded in paraffin, cut into 5- $\mu \mathrm{m}$ sections at the level of the papillary muscle, and subsequenlly stained with hematoxylin and eosin for the visualization of cellular structures. Two randornly selected sections from each animal were visualized by light microscopy using an oil immersion objective with a calibrated magnification $(\times 400)$. Myocytes with visible nuclei and intact cellular membranes were chosen for diameter determination. The width of individually isolated cardiomyocyles displayed on a viewing screen was manually traced, across the middle of the nuclei, with a digitizing pad, and determined by a computerassisted image analysis system (Quantimet 520; Cambridge Instruments, Woburn, MA). For each animal, $\sim 20$ visual fields were analyzed.

Myocardial interstitial collagen volumetric fraction (CVF) was determined using direct and polarized light of the Picrosirius red prepared tissues, as reported previously (23). In brief, 20 fields were selected from sections placed in a projection microscope $(\times 200)$, and interstitial collagen was determined by a computer-assisted image analysis system (Quantimet 520; Cambridge Instruments). CVF was calculated as the sum of all connective tissue areas divided by the sum of all muscle areas in all fields. Perivascular and patch cardiac (reparative fibrosis) were specifically excluded from this determination.

\section{Biochemical and Molecular Analysis}

Hydroxyproline determination. LV collagen was quantified from the hydroxyproline concentration by using a modified method, as described previously (3). All tissue samples (approximate $100 \mathrm{mg}$ wet wt) were taken from the same area of the LV wall.

The tissues were hydrolyzed in 1 of of $8 \mathrm{~N} \mathrm{HCl}$ at $115^{\circ} \mathrm{C}$ for $18 \mathrm{~h}$ under vacuum. Hydrolysis samples were fitered and vacuum dried. Oxidint (chloramine T; $0.5 \mathrm{ml}$ ) was added, vortexed, and allowed to

Table 1. Body weight, heart weight, intraperitoneal fat, heart weight-to-body weight ratio, and myocyte diameter in untrained and trained rats, with and without anabolic steroids

\begin{tabular}{|c|c|c|c|c|c|c|c|}
\hline & $n$ & Before $B W, B$ & Atier BW, B & Intraperitoneal Fal, mg & $H W, 8$ & IIW/BW, $\mathrm{mg} / \mathrm{g}$ & Myocyte Diameles, $\mu \mathrm{m}$ \\
\hline Contsol & 6 & $240 \pm 26$ & $396 \pm 26$ & $2.6 \pm 0.8$ & $1.00 \pm 0.03$ & $2.5 \pm 0.1$ & $6.7 \pm 0.2$ \\
\hline Seroid & 7 & $235 \pm 19$ & $354 \pm 26$ & $1.2 \pm 0.7$ & $0.96 \pm 0.1$ & $27 \pm 0.1 *$ & $6.9 \pm 0.3$ \\
\hline Trained & 6 & $238 \pm 18$ & $351 \pm 21$ & $1.2 \pm 0.5 *$ & $1.01 \pm 0.1$ & $2.9 \pm 0.2^{\star}$ & $7.6 \pm 0.5 * \ddagger$ \\
\hline Trained + steroid & 7 & $235 \pm 20$ & $321 \pm 22$ & $0.7 \pm 0.2^{\star}$ & $0.99 \pm 0.1$ & $3.1 \pm 0.1 \div \div$ & $7.6 \pm 0.6^{ \pm \div}$ \\
\hline
\end{tabular}

Values are means \pm SD; $n$, no of rats. BW, body weight; HW, heart weight; HW/BW, ratio of HW by BW. Signiticant difference vs. "control, t trained + teroid, and + seroid: $P<0.05$. 
able 2. Hemodynamic parameters

\begin{tabular}{|c|c|c|c|c|c|}
\hline & $n$ & Heart Rate, beats/min & SBP. $\mathbf{m m H}_{\mathbf{B}}$ & DBP, $\mathrm{mmH}_{\mathbf{B}}$ & MBP, $m m H_{8}$ \\
\hline merol & 6 & $328 \pm 16$ & $116 \pm 8$ & $97 \pm 6$ & $107 \pm 5$ \\
\hline renid & 6 & $318 \pm 26$ & $119 \pm 2$ & $93 \pm 4$ & $107 \pm 3$ \\
\hline aixed & 6 & $286 \pm 15^{*}$ & $118 \pm 14$ & $88 \pm 10$ & $103 \pm 11$ \\
\hline ined + steroid & 5 & $268 \pm 19 \div$ & $108 \pm 6$ & $81 \pm 5$ & $95 \pm 5$ \\
\hline
\end{tabular}

Vialues are means \pm SD; $n$, no of animals. SBP, systolic blood pressure; DBP, diastolic blood pressure; MBP, means blood pressure. Significant difference "urantrol and tsteroid: $P<0.05$.

eted rats were compared after normalization to the values of jclophilin [change in threshold cycle $\left(\Delta \mathrm{C}_{\mathrm{T}}\right)$ ]. Fold change in mRNA ypression was calculated using the differences in $\Delta C_{T}$ values beiten the two samples $\left(\Delta \Delta C_{T}\right)$ and the equation $2^{-\Delta \Delta C_{T}}$

Immunolisiochemistry. Cardiac samples for ANG II immunohisthemistry were obtained from $C, S, T$, and $T+S$ groups. LV atjons wcre deparaffinized in xylene and rehydrated in ethanol. erieval of ANG II immunoreactivity was obtained by incubating xtions in citrate buffer (0.01 M. pH 6.0) with further heating for 5 in in a microwave oven. The presence of ANG II was evaluated in $\checkmark$ tissue using anti-ANG II rabbit antiserum ( $1: 400$, Península, ielmont, CA). The antigen was marked by fast red dye, and the arificity of the secondary antibody was established in positive and cgative controls. Images were obtained with a computer-assisted Mphometric system (Leica Quantimet 500, Cambridge, UK). The mber of positive signals in cardiomyocyte was evaluated and ipressed as cells immunoreactive for ANG Il per millimeler squared.

instical Analysis

Results are represented as means \pm SD. Statistical analysis was oformed using randomized two-way ANOVA, and to evaluate the iW during the weeks we used two-way ANOVA for repeated mea'ico. Tukey's post hoc test was used for individual comparisons riween means when a significant change was observed with WOVA. $P<0.05$ were accepted as statistically significant.

¿SULTS

\section{Cardiac Hypertrophy}

The data referring to $\mathrm{BW}$, intraperitoneal fat, $\mathrm{HW}, \mathrm{HW} / \mathrm{BW}$, ad myocyte diameter are summarized in Table 1 . The BW xfore swimming training was similar among all groups. After swimming training protocol, $\mathrm{BW}$ decreased significantly in $T+S$ group, but not in the $C, S$, and $T$ groups. The tendency of $3 W$ was to decrease during the weeks of swimming training in and $T$ groups; however, in the $T+S$ group, it decreased ignificanly compared with that in the $\mathrm{C}$ group (Fig. LA). This oner weight gain might be associated with a decrease of rusperitoneal fat observed in the $S, T$, and $T+S$ groups (Table 1). Regarding the cardiac weight per se, no difference was seen inong groups. The LV weight (LVW) normalized by total BW alio, which was used as an index of hypertrophy (\%change
$\mathrm{LVW} / \mathrm{BW}, \mathrm{mg} / \mathrm{g}$ ), was significantly higher in $\mathrm{S}, \mathrm{T}$, and $\mathrm{T}+\mathrm{S}$ $(8,16$, and $24 \%$, respectively) (Fig. $1 B$ ). Interestingly, the $T+S$ group was also increased compared with $S$ and $T$ groups (15 and $7 \%$, respectively). Losartan treatment prevents the LV hypertrophy in $S$ and $T+S$ groups. The LVW normalized by total BW ratio, which was used as an index of hypertrophy (\%change LVW/BW, mg/g), was significantly higher in the S and $T+S(2.3 \pm 0.12$ and $2.4 \pm 0.13 \mathrm{mg} / \mathrm{g})$ groups compared with $S L$ and $T+S L(2.0 \pm 0.14$ and $2.0 \pm 0.19 \mathrm{mg} / \mathrm{g})$, respectively (Fig. 1C). Swimming, regardless of AS treatment, significantly increased myocyte diameter, but no significant change in myocyte diameter was observed after AS treatment (Table 1).

\section{Hemodynamic Parameters}

Blood pressure and HR. Table 2 summarizes SBP, DBP, $M B P$, and $H R$ results. SBP and MBP were not different among groups. DBP decreased in $\mathrm{T}+\mathrm{S}$ but not in $\mathrm{C}$. Exercise training significantly decreased resting $\mathrm{HR}$.

$L V$ function. Table 3 summarizes the results of $L V$ function. LV systolic pressure was significantly higher in $C$ and $T$ than in $S$ and $T+S$. $L V$ end-diastolic pressure was not different among the groups, but LV initial diastolic pressure was significantly lower in $\mathrm{T}$ than in $\mathrm{C}$. The $+\mathrm{dP} / \mathrm{d} t$ was significantly higher in $T$ than in $C, S$, and $T+S$. Similarly, $-d P / d t$ was significant lower in $S$ and $T+S$ than in $T$. It was decreased in $\mathrm{T}+\mathrm{S}$ compared with $\mathrm{C}$.

\section{Biochemical and Molecular Analysis}

Testosterone measurement. As expected, the chronic AS administration causes a significant increase in serum testosterone concentration (ng/dl) in $S(85.3 \pm 19.3)$ and $T+S$ (102.6 \pm 18.3$)$, but not in $C(13.4 \pm 6.5)$ and $T(20.5 \pm 9.9)$.

Collagen characteristics. Figure $2 A$ shows representative histological sections of myocardium. The rop panels show collagen fibers in the $\mathrm{LV}$ of the $\mathrm{C}$ and $\mathrm{T}$ groups. The bottom panels show the cardiac patch (reparative fibrosis), and the inset shows collagen fibers in the $L V$ of the $S$ and $T+S$ groups. Figure $2 B$ shows the quantitative analysis of collagen fibers in

able 3. Left ventricular function

\begin{tabular}{|c|c|c|c|c|c|c|}
\hline & $n$ & LVSP, $\mathbf{m m H g}$ & LVIDP, mmHg & LVICDP, mmHg & $+d P / d, m H_{g} / s$ & $-\mathrm{dP} / \mathrm{d}, \mathrm{mmH} / \mathrm{g}$ \\
\hline cecturol & 5 & $127 \pm 10$ & $-5.6 \pm 2.5$ & $3.5 \pm 1.3$ & $4,780 \pm 924$ & $4,333 \pm 785$ \\
\hline Eroid & 11 & $116 \pm 10^{*}$ & $-7.0 \pm 2.8$ & $2.5 \pm 1.8$ & $4,769 \pm 730$ & $3.794 \pm 578$ \\
\hline rä̈ned + stcroid & 8 & $111 \pm 7 *$ & $-7.8 \pm 1.6$ & $28 \pm 1.7$ & $4.054 \pm 653$ & $2.972 \pm 631 \div$ \\
\hline
\end{tabular}

Walues are means $\pm S D ; n$, no of animals. LVSP, lefi ventricular systolic pressure; LVIDP, left ventricular initial diastolic pressure; LVEDP, left ventricular id diastolic pressure; $+\mathrm{dP} / \mathrm{d} t$, left ventricular contractility; $-\mathrm{dP} / \mathrm{d} t$, left ventricular relaxation. Significant difference vs. control and trajed $(P<0.05)$; enmerol $(P<0.05)$; $\neq$ control $(P<0.01)$, steroid $(P<0.05)$, and trained + steroid $(P<0.005)$ : $\$$ steroid $(P<0.05)$ and trained + steroid $(P<0.0005)$. 
inl. The CVF increase was prevented by losartan treatment in $\mathrm{L}$ and $\mathrm{T}+\mathrm{SL}(0.89 \pm 0.07$ and $0.92 \pm 0.22 \mu \mathrm{m} / \mathrm{area})$ groups anpared wilh $S$ and $T+S(1.2 \pm 0.5$ and $1.59 \pm 0.38$ เuraria; $P<0.05$ ) groups (Fig. 3B).

Gene expression. Figure $4 A$ shows the relative gene exeession of collagen types $\mathrm{I}$ and $\mathrm{III}$ and $A \mathrm{~T}_{\mathrm{la}}$-receptor. The clative gene expression of collagen type 1 was increased in $\div$ $\div$ group conpared with $T$ group $(P<0.076)$. However, te relative gene expression of collagen type 111 was signifantly increased in $\mathrm{T}+\mathrm{S}$ group compared with $\mathrm{T}$ group, but , as nol increased in $\mathrm{T}(0.60 \pm 0.17$ vs. $0.37 \pm 0.01$, sbitrary units; $P<0.05$ ). Moreover, the relative gene rppression of $\mathrm{AT}_{1 \mathrm{a}}$-receptor was significantly increased in $\mathrm{S}$ rd $\mathrm{T}+\mathrm{S}(1.59 \pm 0.16$ vs. $1.61 \pm 0.1$ arbitrary units; $P<$ j.05) groups compared with $C(1.0 \pm 0.05$ arbitrary units) group and in $T+S$ group compared with $T(0.74 \pm 0.05$ sbitrary units; $P<0.05$ ) group. The relative gene expresion of $\mathrm{AT}_{2}$-receptor was not detected by the methodology sed. The relative gene expression of $\mathrm{ACE}$ to $\mathrm{C}, \mathrm{S}, \mathrm{T}$, and $i+S(1.0 \pm 0.19,1.21 \pm 0.34,1.18 \pm 0.2$ and $1.21 \pm 0.13$ arbitrary units, respectively) was not significantly different among the four groups.

Cardiac ACE activity and ANG II quantification. Figure 4A shows the LV-ACE activity (Fig. $4 B$ ) was significantly increased in $S$ and $T+S$ groups compared with $C$ and $T$ groups $(2.8 \pm 0.69$ and $2.9 \pm 0.4$ vs. $2.18 \pm 0.49$ and $2.1 \pm$ $0.34 \mathrm{nM}$ His-Leu-min ${ }^{-1} \cdot \mathrm{mg}^{-1}$, respectively; $P<0.01$ ). The ANG II quantification by immunohistochemistry methodology was significantly increased in $S$ and $T+S$ groups compared with $C$ group $(0.0044 \pm 0.00043$ and $0.0038 \pm$ 0.00056 vs. $0.0027 \pm 0.000135$ ANG $11 / \mathrm{mm}^{2}$, respectively; $P<0.05)$, and $\mathrm{T}$ group $\left(0.0033 \pm 0.00047 \mathrm{ANG}\left[1 / \mathrm{mm}^{2}\right)\right.$ was not significantly different from the $C$ group. However, the PRA in $C, S, T$, and $T+S(1.55 \pm 0.59,1.59 \pm 0.76$, $0.86 \pm 0.25$, and $1.05 \pm 0.38 \mathrm{ng} \mathrm{ANG} 1 \cdot \mathrm{ml}^{-1} \cdot \mathrm{h}^{-1}$, respectively) groups was not significantly different among the four groups.

Interestingly, considering the data from all groups, a close, positive correlation existed between LV-ACE activ- fiz 3. Effects of losartan treatment on colbyou fibers in the myocardium induced by drenic anabolic steroid use. $A$ : representatre bigological sections of the myocardium wher polarized lighe Representative section of collagen fibers in the LV of $S$ and SL Tramps (top panels), and $\mathrm{T}+\mathrm{S}$ and $\mathrm{T}+\mathrm{SL}$ zon:ps (boutom panels) are shown. $B$ : quantitrine analysis of collagen fibers in myocar$E=$ I $S . S L, T+S$, and $T+S L$ groups. isublts are presented as means \pm SD. *Sig$\because \mathrm{i}$ iant difference vs. $\mathrm{S}$ and $\mathrm{T}+\mathrm{S}$ groups, $P<0.05$.
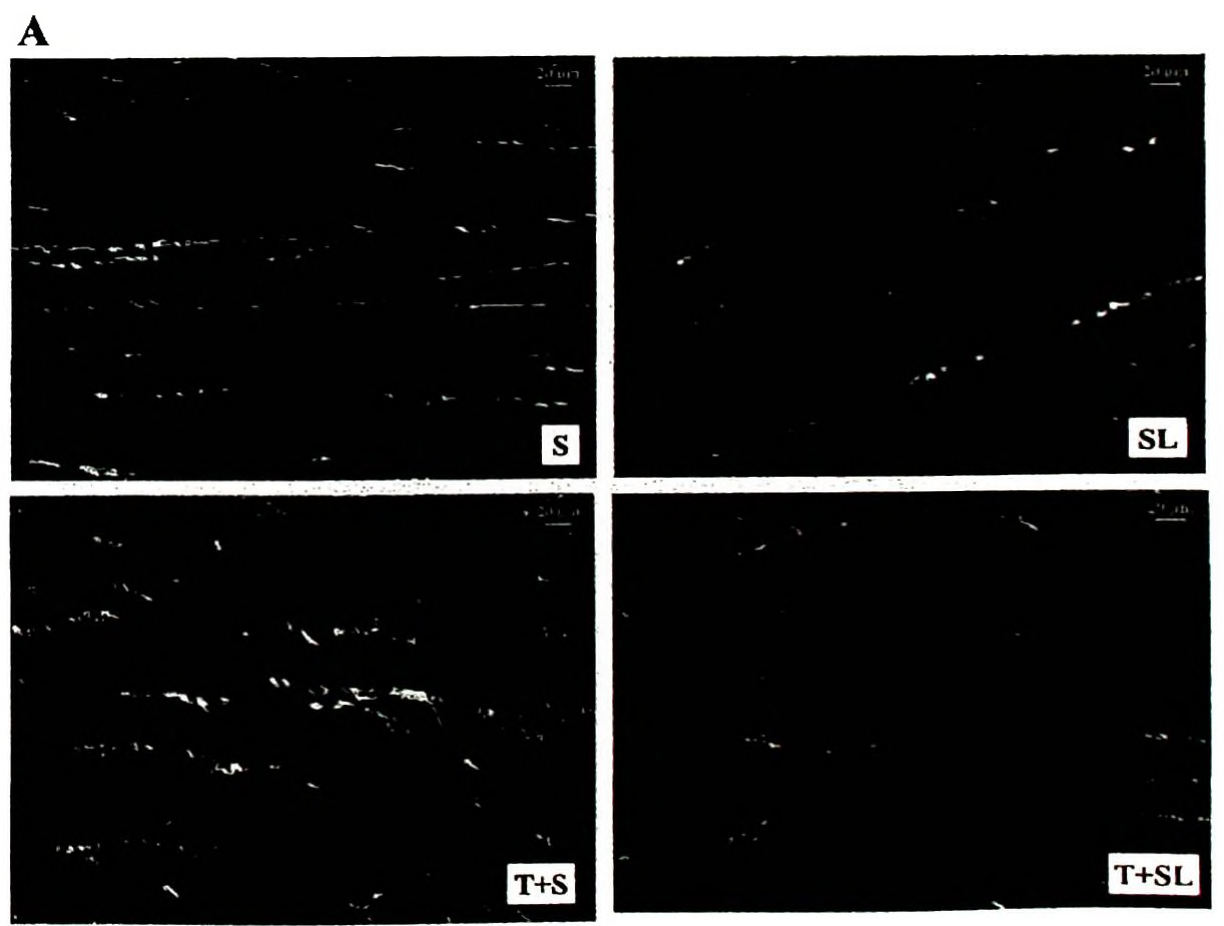

B

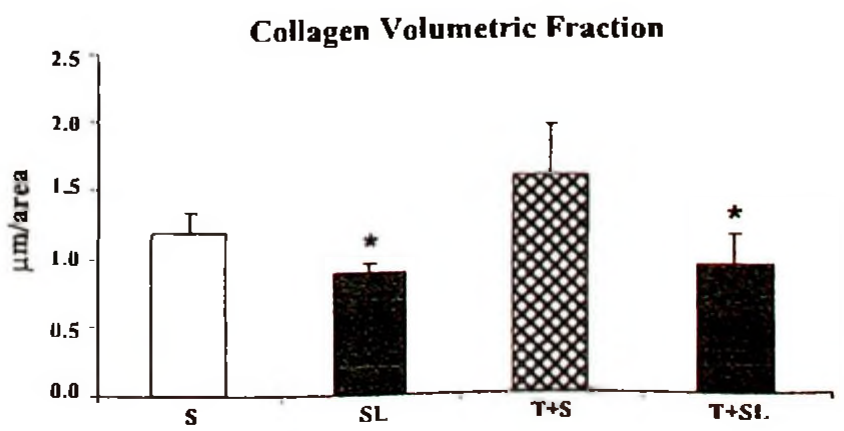


1

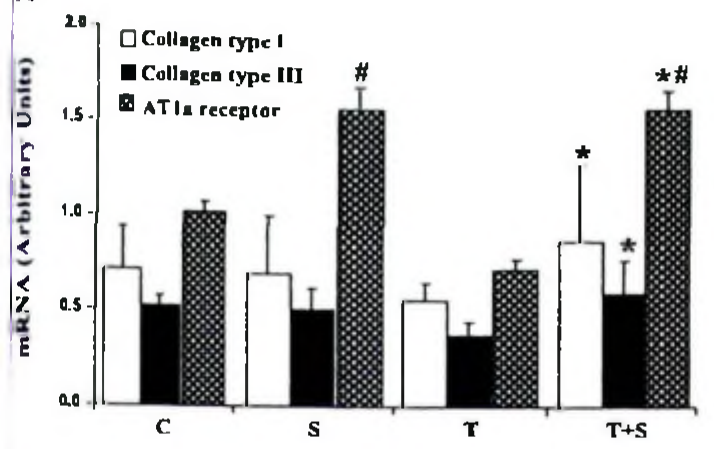

B

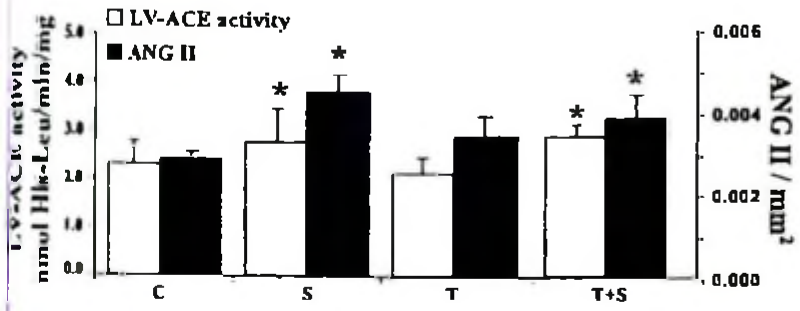

C

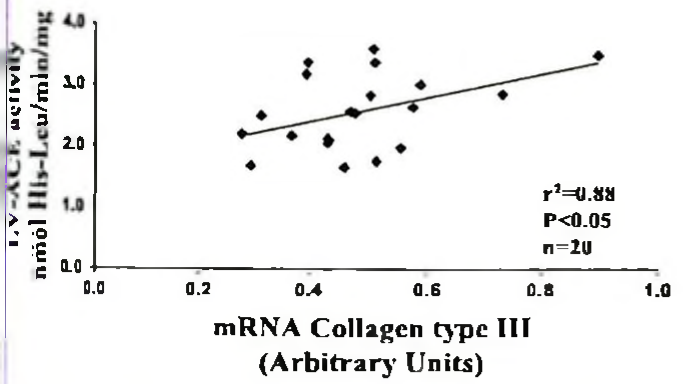

4. Eflect of anabolic steroids, swimming training, and swimming training swainted with anabolic steroids on mRNA collagen types I and IU, angioesn type la $\left(\mathrm{AT}_{\mathrm{I}_{2}}\right)$-receptor, and $\mathrm{LV}$-angiotensin I-converting enzyme $A C E$ activity. $A$ : effects on gene relative expression to collagen types $I$ and il and $A T_{1}$-receptor of $C, S, T$, and $T+S$ groups. "Significant difference vs. I for. collagen type $11 \mathrm{II}(P<0.05)$. collagen type I $(P=0.076)$, and $A T_{1 .- \text { receptor }}(P<0.05)$. \#Significam difference vs. C for AT $\mathrm{T}_{1,- \text { receptor }}(P<$ J10). $B$ : eflect on LV-ACE activity (nmol His-Leu $\mathrm{min}^{-1} \cdot \mathrm{mg}^{-1}$ ) of C, S, T, id $\mathrm{T}+\mathrm{S}$ groups. $P<0.01$ vs. $\mathrm{C}$ and $\mathrm{T}$ groups. Effects on angiotensin II IVG U) quantification (ANG IL/mm $\mathrm{mm}^{2} ; n=4 /$ group) an shown for C. S, T, ad $\mathrm{T}+\mathrm{S}$ groups. ${ }^{*} P<0.05$ vs. $\mathrm{C}$ group. $C$ : direct correlation between LV. ACE activity and gene relative expression to collagen type III $\left(r^{2}=0.88\right.$; $p<0.05)$. $n$, No. of animals.

Liy and collagen type 111 expression $\left(r^{2}=0.88 ; P<0.05\right)$ (Fig. 4C).

\section{DISCUSSION}

The main findings of the present study are as follows. 1) Swimming training associated with supraphysiological doses of AS causes exacerbated cardiac hypertrophy with interstilial fibrosis. This cardiac hypertrophy is associated with the cardiac RAS activation. 2) The improvement in LV functin promoted by exercise training is lost by AS treatment. The present study showed that chronic AS administration causes a significant increase in the serum testosterone concen- tration of $S$ and $T+S$ rats. These results are consistent with effects previously described in rats that underwent chronic AS treatment showing serum testosterone concentration higher than that in $C$ rats (41).

The reduction in $\mathrm{BW}$ in the $\mathrm{T}+\mathrm{S}$ groups is compatible with a reduction in intraperitoneal fat. These findings may reflect a higher body fat metabolism achieved by acrobic training and AS administration. A similar observation was described in previous studies in which the excess of androgen caused an increase in fat metabolism in adipose tissue (37). Yu-Yahiro et al. (45) reported a similar decrease in BW and showed that steroid treatment blunted appetite, resulting in less weight gain in rats. Beutel et al. (4) showed that chronic treatment with low and high doses of steroid decrease the $\mathrm{BW}$ of treated animals. In contrast, other studies show neither change (30) nor BW gain (24).

The resting bradycardia confirms the effectiveness of exercise training in this study, as our laboratory reported previously (31). In addition, this exercise training adaptation was maintained with AS treatment.

Endurance training is known to cause eccentric cardiac hypertrophy in which the adaptive responses are distributed across the LV wall. However, many factors influence exerciseinduced cardiac hypertrophy. Some are the mode, the intensity, the duration, and the frequency of the exercise regimen (17). In this study, the absolute weight of cardiac mass was not significantly different among groups. However, the swimming training protocol was efficient in increasing the $\mathrm{HW} / \mathrm{BW}$ at $16 \%$ compared with that in the $\mathrm{C}$ group. This index was followed by an increase in myocyte diameter of $13 \%$ compared with that in the $\mathrm{C}$ group. This response is typical of aerobic training by swimming and has been called physiological cardiac hypertrophy $(17,22,31)$. Moreover, for the physiological cardiac hypertrophy, the increase in cardiomyocyte volume results from the increase in the amount of contractile protein synthesis, which results in an increase predominantly in myofibril length. An increase in sarcoplasmic reticulum volume and mitochondria was observed (44). In this study, cardiac hypertrophy was followed by beneficial adjustments in the cardiovascular system, such as resting bradycardia and improvement in contractile performance of LV by increasing the positive derivative rate of the rise in pressure $(+\mathrm{dP} / \mathrm{d} t)$. Previous results show that this swimming training protocol can increase the myosin ATPase activity in LV and increase the percentage of V1 isoforms of cardiac myosin, improving the systolic function in hypertensive rats (36). Other findings that deserve attention are the reduction of the initial diastolic pressure and the increased $-d P / d t$ in the $\mathrm{T}$ group. This is an indication that lusitropism improved in trained hearts.

Another interesting finding was the higher cardiac bypertrophy index $(8 \%)$ observed in the untrained AS group compared with that in the $C$ group, which was proportional to the collagen concentration increase. The AS by itself alone produced cardiac hypertrophy. However, the diameter of the myocytes did not increase compared with those in the $\mathrm{C}$ group. In fact, a previous study reported the presence of androgen receptors in cardiac cells in both humans and animals (29). Moreover, evidence exists of the presence of endogenous pathways of androgen actions in cardiac hypertrophy development and a higher androgen receptor expression in hypertrophied hearts, in humans and rats (28). In this study, cardiac 
lpertrophy was due to higher collagen concentration, as ilomired by histological quantification of the CVF and juoxyproline methods. The physical exercise associated with S tratment increased the cardiac hypertrophy ratio to 24,15 , nd $7 \%$ compared with that in $C, S$, and $T$ groups, respectively. bese results on cardiac mass are similar to results previously :ported $(15,39)$. However, this apparent cardiac hypertrophy as: not detected in the diameter of the myocytes. The myocyte ianeler was similar in the $T+S$ and $T$ groups. This result tows that the AS were not involved in the hypertrophy of the ajocytes, suggesting that another component contributed to $x$ increase in cardiac mass. The cardiac hypertrophy and whagen syntheses induced by steroid treatment and by physal exercise associated with AS treatment were totally prevent i) losartan (AT 1 -receptor blocker) treatment.

llemodynamic and nonhemodynamic factors might be inofred in the disequilibrium between myocyte growth and ollagen turnover. Fibrillar collagens, types I and 111 , are the njor structural proteins of the myocardial collagen matrix. ype I collagen is usually present in the form of thick fibers, nd its concentration determines the stiffness of the myocar'ium. Type III collagen forms fine reticular networks and is core distensible than type I collagen (9). In this study, when be cardiac collagen of the $T+S$ group was investigated, a igher amount of collagen was found, as determined by the ydroxyproline method and histological quantification of the VF. This group also had an increase in collagen type $1(P=$ 1.076) and type $111(P<0.05)$ cardiac expression compared tib these in the $T$ group. These findings may contribute to the yger cardiac hypertrophy in this group. Thus these factors iplain the loss of benefits of aerobic physical training on emtricular function index $(+d \mathrm{P} / \mathrm{d} t,-\mathrm{dP} / \mathrm{d} t$, and $\mathrm{LV}$ initial (iastolic pressure) in the $T+S$ group compared with that in the group. The abundance of interstitial collagen observed in $S$ iret $T+S$ groups contributed to decreased LV systolic pressure $\mathrm{w} d-\mathrm{dP} / \mathrm{d} t$, a finding that was more exacerbated in the $\mathrm{T}+\mathrm{S}$ trowp. Thus the combined diastolic and systolic dysfunction of he LV occurs as the result of myocardium fibrosis, and this is ilevant for the development of heart failure. Reactive fibrosis accurs in the absence of myocyte necrosis and initially is an alaptive response that preserves the force-generating capacity of the hypertrophied myocardium. Later in hypertrophy, a reparative (or replacement) fibrosis occurs in response to cell los.s. Cardiac fibrosis can be accompanied initially by diastolic and ultimately by systolic ventricular dysfunction. Evidence aggests a clear association between such adverse structural emodeling and activation of the RAS (44).

An interesting feature of the present study was the higher ocal RAS activation. An important result observed was the acher local ACE activity found in the hearts from the $S$ and $T$ H groups vs. $C$ and $T$ groups and the close, positive conclation between LV-ACE activity and collagen type 111 $r=0.88 ; P<0.05)$. Moreover, the $\mathrm{AT}_{1 \mathrm{a}}$-receptor expression ais increased $\sim 60 \%$ in the hearts from the $S$ and $T+S$ groups s. $C$ group and $\sim 120 \%$ in $T+S$ group vs. $T$ group, and the AMG II was increased in the hearts from the $S(60 \%)$ and $T+S$ $40 \%$ groups vs. C group. This is evidence of the local RAS ranticipation in cardiac hypertrophy development observed in his model. Other studies showed that the cardiac ANG 11 oncentration contributes to the hyperplasia of cardiac fibrolasts and to the development of cardiac fibrosis (44), and the
ACE activation might be contributing to the development of heart fibrosis, as previously reported, showing that the fibrotic area in the heart has high levels of ACE activity $(11,34)$. Several experimental studies provide evidence that circulating and local RAS promote the development of myocardial fibrosis $(6,7)$, and ANG 11 can mediate myocardial fibrosis independently of the mechanical load (20). Other results demonstrated in cultured adult rat cardiac fibroblasts that ANG 11 increases collagen synthesis and inhibits matrix metalloproteinase activity, the key enzyme of interstitial collagen degradation $(8,9)$. In fact, several results suggest that ANG 11 exerts an important role in cardiac hypertrophy development throughout enhanced $\mathrm{ACE}$ activity. These findings are reinforced by the fact that ACE inhibitors and $\mathrm{AT}_{1}$-receptor antagonists promote cardiac hypertrophy regression in experimental animals (43) and humans (16) and in hypertensive patients $(7,15)$. ANG 11 stimulates collagen synthesis by both $\mathrm{AT}_{1}$-receptor and $\mathrm{AT}_{2}$-receptor activation in cultured adult rat cardiac fibroblasts, and ANG Il-induced inhibition of collagenase activity was specifically mediated by $\mathrm{AT}_{2}$-receptor (10). In support of these findings, the abolition of ANG II-induced cardiac fibrosis in mice lacking the $\mathrm{AT}_{2}$-receptor gene was demonstrated (21). On the other hand, considering that $\mathrm{ACE}$ also inactivates bradykinin, the increased ACE activity in the $S$ and $T+S$ groups increased the breakdown of bradykinin, which can reduce nitric oxide production, independent of the regulation of ANG $U$ production (40). Recently, it was demonstrated that exercise training induces enhancement of nitric oxide production; however, $\Lambda \mathrm{S}$ (nandrolone decanoate) treatment blocks this effect promoted by physical exercise, probably because this hormone damages the endothelial function of trained animals (13). These findings reveal the important influence of the RAS on the regulation of interstitial collagen and on cardiac function. The local RAS activation in heart remodeling induces direct consequences on cardiac function, reducing the benefits of physical training by the steroid association in the $T$ group.

In conclusion, this study showed that supraphysiological doses of AS exacerbated cardiac hypertrophy in exercisetrained rats. The AS alone or in combination with exercise training induces maladaptive remodeling and further deterioration of cardiac performance. The exercise training associated with AS causes loss of the beneficial effects of LV function induced by exercise training. We believe this is the first study to show that the combination of exercise and AS causes an increase in the heart collagen concentration associated with activation of the cardiac RAS.

\section{ACKNOWLEDGMENTS}

We gratefully acknowledge the technical assistance of Dr. Irene Noronha and Rita Cavagticri for ANG II immunoreactivity assays, and Dr. Dalton Vassallo for critical reading of the manuscript.

\section{GRANTS}

J. E. Kricger and C. E. Negrāo were supported by Fundação de Amparo a Pesquisa do Estado de Săo Paulo Grant 01/00009-0.

\section{REFERENCES}

1. Backer MA, Horvath SM. Influence of water temperature on oxygen uptake by swimming rats. I Appl Physiol 19: 1215-1218, 1964.

2. Bartan PA, Chretien C, Lau AH. The effects of nandrolone decanoatc on nutritional parameters in henodialysis patients. Clin Nephrol 58: $38-46,2002$ 
Rergman I, Ioxley R. New spectrophotometric method for the determiinjtivn of proline in tissue hydrolyzates. Anal Chem 42: 702-706, 1970.

Ihutel A, Bergantaschl CT, Campos RR. Effects of chronic anabolic ateroid treatment on tonic and rellex cardiovascular control in male rats. $J$ Jienoid Binchem Mol Biol 93: 43-48, 2005.

Bradford MIM. A rapid and sensitive method for the quantitation of Inicrogram quantities of protein utilizing the principie of protein-dye ibinding. Anal Biochem 72: 248-254, 1976.

Brilla CG, Funck RC, Rupp H. Lisinopril-medialed regression of myocantjal fibrosis in patients with hypertensive heart discase. Circulation 102: 1388-1393, 2000

Brilla CG, Maisch B, Weber KT. Renin-angiotensin system and myo cardial collagen matrix remodeling in hypcrensive hear disease: in vivo and in vitro studies on collagen matrix regulation. Clin Investig 71 S35-S41, 1993.

1. Brilla CG, Reams GP, Maisch B, Weber KT. Renin-angiotensin system and myocartial fibrosis in hypertension: regulation of the myocardial collagen matrix. Eur Heart $J$ 14: 57-61, 1993.

. Brilla CG, Zhou G, Matsubara L, Weber KT. Collagen metabolism in cultured adult rat cardiac fibroblasts: response 10 angiotensin II and aldoserone. J Mol Cell Cardiol 26: 809-820. 1994.

1 Brilla CG. Renin-angiotensin-aldosterone system and myocardial fibrosis. Cardiovasc Res 47: I-3, 2000.

I1. Bustto VC, Cicilini MA, Mill JG. Increased angiotensin-converting enzyme activity in the left ventricle after infarction. Braz $J$ Med Biol Res 30: $679-687,1997$.

Chomezynski P, Sacchi N. Single step method of RNA isolation by acid guanidinium thiocyanate-phenol-chloroform extraction. Anal Biochem 162: 156-159, 1987

i]. Cunha TS, Moura MJ, Bernardes CF, Tanno AP, Marcondes FK. Vascular sensitivity to phenylephrine in rats submitted to anaerobic uning and nandrolone treatment Hyperzension 46: 1010-1015, 2005

f. De Piccoli B, Giada F, Benettin A, Sartoti F, Piccolo E. Anabolic seroid use in body builders: an echocandiographic study of left ventricle morphology and function. Int J Sports Med 12: 408-412, 1991

S Di Bello V, Giongi D, Bianchi M, Bertini A, Caputo MT, Valenti G, Furioso O, Alessandri L, Paterni M, Giust C. Effects of anabolic androgenic steroids on weight-lifters myocardium: an ultrasonic video densitometric study. Med Sci Sports Exerc 31: 514-521, 1999.

15. Dunn FG, Oigman W, Ventura HO, Messerli FH, Kobrin I, Frohlich ED. Enalapril improves systemic and renal hemodynamics and allows regression of left ventricular mass in essential hypertension. Am J Cardiol 53. $105-108,1984$.

Erangclista FS, Brum PC, Krieger JE. Duration-controlled swimming exercise training induces cardiac hypertrophy in mice. Braz J Med Biol Res 36: 1751-1759, 2003.

L Finesclu V, Riczzo I, Centini F, Silingardl E, Licata M, Beduschi G, Karch SB. Sudden cardiac death during anabolic steroid abuse: morphologic and toxicologic finding in two fatal cases of bodybuilders. Int J Legal Med 15: 1-6, 2005

1). Gunja-Smith Z, Lin J, Woessner JF Jr. Changes in desmosine and pyndinoline crosslinks during rapid synthesis and degradation of elastin and collagen in the rat uterus. Matrix 9: 21-27, 1989.

n. Higaki J, Aoki M, Morishita R, Kida I, Teniyama $\mathbf{Y}$, Tomita N, Yamamoto $K$, Moriguchi A, Kancda $Y$, Ogihara $T$. In vivo evidence of the importance of cardiac angiotensin-converting enzyme in the pathogeneis of cardiac hypertrophy. Arterioscler Thromb Vasc Biol 20: 428-434, 2000 .

11. Ichihara S, Senbonmatsu T, Price E Jr, Ichiki T, Gaffney PA, Inagami T. Angiolensin II type 2 receptor is essential for left ventricular hypertro phy and cardiac fibrosis in chronic angiolensin Il-induced hypertension. Circulation 104: 346-351, 2001.

n Iemitsu M, Miyauchi T, Macda S, Sakai S, Kobayashi T, Fujli N, Mliyazaki H, Matsuda M, Yamaguchi I. Physiological and pathological cardiac hypertrophy induce different molecular phenotypes in the rat. Am J Physiol Regul Integr Comp Physiol 281: R2029-R2036, 2001.

Junqueira LC, Bignolas G, Brentani RR. Picrosirius staining plus polarization microscopy, a specific method for collagen detcelion in tissue ections. Histochem $J$ 11: 447-455, 1979.

1. Kochuklan CD, Robertson E, Bartlett MN. Sics and nature of protein anabolism stimulated by testosterone propionate in the rats. Am $J$ Physiol 163: 332-346, 1950.
25. Kohara K, Tabuclal Y, Senanayake P, Brosnihan KB, Ferrario CM. Reassessment of plasma angiotensins measurement: effects of protease inhibitors and samplc handling procedures. Peprides 12: 1135-1141, 1991.

26. Kuipers $H, W$, Wen JA, Hartgens F, Willems SM. Influence of anabolic steroids on body composition, blood pressure. lipid profile and liver function in body builders. Int $J$ Sports Med 12: 413-18, 1991.

27. Legros T, McConncall D, Murry T, Edavettal M, Racey-Bums LA, Shepherd RE, Bums AH. The effects of $17 \alpha$-methyltestosterone on myocardial function in vitro. Med Sci Sports Exerc 32: 897-903, 2000.

28. Llu PY, Death AK, Handelsman DJ. Androgens and cardiovascular disease. Endocr Rev 24: 313-340, 2003.

29. Marsh JD, Lehmann MH, Ritchle RH, Gwathmey JK, Green GF Schicbinger RJ. Androgen receptor mediates hypertrophy in cardiac myocytes. Circulation 98: 256-26I, 1998.

30. Masonis AE, McCarthy MP. Direct effects of the androgenic/anabolic steroid stanozolol and 17 alpha-methyltestosterone on benzodiazepine binding to the gamma-aminobutyric acid(a) receptor. Neurosci Lell 189 : 35-38, 1995.

31. Medeiros A, Oliveira EM, Gianolla R, Casarini DE, Negrão CE, Brum PC. Swimming training increases cardiac vagal activity and induces cardiac hypertrophy in rats. Braz $J$ Med Biol Rex 37: 1909-1917, 2004.

32. Nieminen MS, Ramo MP, Vitacalo M, Helkkila $P$, Karjalainen J, Mantyssari M, Heikkila J. Serious cardiovascular side effects of large doses of anabolic steroids in weight lifters. Eur Hean $J$ 17: 1576-1583, 1996.

33. Nottin S, Nguyen L.D, Terbah M, Obert P. Cardiovascular effects of androgenic anabolic steroids in malc bodybuilders determined by tissue Doppler imaging. Am J Cardiol 97: 912-915, 2006.

34. Oliveira EM, Krieger JE. Chronic $\beta$-adrenoceptor stimulation and cardiac hypertrophy with no induction of circulating renin. Eur $J$ Pharmacol 520: 135-141, 2005

35. Oliveira EM, Santos RAS, Krieger JE- Standardization of the fluorimetric assay for the determination of tissue angiotensin-converting enzyme activity in rats. Braz $J$ Med Biol Res 33: 755-764, 2000.

36. Schaible T, Malhotra A, Ciambrone GJ, Scheuer J. Chronic swimming reverses cardiac dysfunction and myosin abnornalities in hypertensive rats. J Appl Physiol 60: 1435-1441, 1986.

37. Schroeder ET, Zheng L, Ong MD, Martinez C, Flores C, Stewart Y, Azen C, Sattler FR. Effects of androgen therapy on adipose tissue and metabolism in older men. $J$ Clin Endocrinol Metab 89: 4863-4872, 2004.

38. Sullivan ML, Martinez CM, Gennis P, Gallagher EJ. The cardiac toxicity of anabolic steroids. Prog Cardiovase Dis 41: 1-15, 1998.

39. Tagarakis CV, Bloch W, Hartmann G, Hollmann W, Addicks $K$. Anabolic steroids impair the exercise induced growth of the cardiac capillary bed. Int J Sports Med 21: 412-418, 2000.

40. Takemoto M, Egashira K, Tomita H, Usui M, Okamoto H, Kitabatake A. Shimokawa $\mathbf{H}$, Sucishi $K$, Takeshita $\mathbf{A}$. Chronic angiotensin-convert ing enzyme inhibition and angiotensin type-I receptor blockade: effects on cardiovascular remodeling in rats induced by the long-term blockade of nitric oxide synthesis. Hypertension 30: 1621-1627, 1997.

41. Trifunovic B, Norton GR, Duffield MJ, A vraam P, Woodiwiss A. An androgenic steroid decreases left ventricular compliance in rats. Am J Physial Hearl Cinc Physiol 268: H1096-HI 105, 1995

42. Urhausen A, Holpes R, Kindermann W. One- and two- dimensional echocardiography in bodybuilders using anabolic steroids. Eur $J$ Appl Physial Occup Physiol 58: 633-640, 1989.

43. Varo N, Etayo JC, Zalba G, Beyumont J, Iraburu MU, Monticl C, GII MJ, Monreal I, Diez J. Losartan inhibits the pos-transcriptiona] synthesis of collagen type I and reverses left ventricular tibrosis in spontancously hypertensive rats. J Hypenens 17: 107-114, 1999.

44. Weber KT, Brilla CG. Pathological hypentophy and candiac interstitium Fibrosis and renin-angiotensin-aldosterone system. Circulation 83: 1849 1865, 1991

45. Yu-Yahiro JA, Michael RII, Nasrallah DV, Schofield B. Morphological and histologic abnomalities in female and male rats treated with anabolic steroid. Am J Spons Med 17: 686-689. 1989.

46. Zaugg M, Jamali NZ, Lucchinett E, Xu W, Alam M, Shafiq AS, Siddiqui MA. Anabolic-androgenic stcroids induce apoptotic cell death in adult rat ventricular myocytes. J Cefl Physiol 187: 90-95, 2001. 
Anabolic steroid plus exercise training: increase Renin Angiotensin Aldosterone System and inflammatory markers

Everton Crivoi do Carmo MSc ${ }^{a}$, Tiago Fernandes MSc ${ }^{a}$, Daniel Koike MSc ${ }^{b}$, Nathan Daniel da Silva Junior BSc ${ }^{a}$, Katt Coelho Mattos BSc ${ }^{a}$, Kaleizu Teodoro Rosa PhD ${ }^{\text {c }}$, Diego Barretti MSc ${ }^{a}$, Stephano Freitas Soares MSc ${ }^{a}$, Rogério B. Wichi PhD ${ }^{b}$, Maria Claudia Costa Irigoyen $\mathrm{MD} \mathrm{PhD}^{\mathrm{c}}$, Edilamar Menezes de Oliveira $\mathrm{PhD}^{\mathrm{a}}$

\footnotetext{
a School of Physical Education and Sport, University of São Paulo, São Paulo, Brazil;

${ }^{b}$ Human Movement Laboratory, Sao Judas Tadeu University - São Paulo/SP, Brazil

${ }^{c}$ Heart Institute (InCor), Medical School, University of São Paulo, Brazil
}

\section{No conflicts of interest}

Anabolic Steroid on Cardiac Hypertrophic: RAAS

Author for correspondence:

Edilamar Menezes de Oliveira, PhD

Escola de Educação Física e Esporte da Universidade de São Paulo

Departamento de Biodinâmica do Movimento do Corpo Humano

Av. Professor Mello Moraes, 65 - Butantã - São Paulo - SP

05508-900- Brazil

Telephone: (5511) 3091-3136 - FAX: (5511) 3813-5921

e-mail: edilamar@usp.br 


\section{Abstract}

We tested the hypothesis that anabolic steroids (AS) during swimming training (ST) activate the renin angiotensin aldosterone system (RAAS) causing deleterious cardiac effects . Male Wistar rats were randomized into 8 groups ( $n=14 /$ grp) : Control (C), Anabolic Steroid (AS), Trained (T), Trained AS (TAS), AS+Losartan (AS+L), Trained AS+Losartan (TAS $+\mathrm{L}), \quad \mathrm{AS}+$ Spironolactone $(\mathrm{AS}+\mathrm{S})$ and Trained AS + Spironolactone $(\mathrm{TAS}+\mathrm{S})$. AS was administered twice a week $(10 \mathrm{mg} / \mathrm{Kg} / \mathrm{wk})$ Training was for 10 weeks $(5 \mathrm{x} / \mathrm{wk})$. Losartan $(20 \mathrm{mg} / \mathrm{Kg} /$ day $)$ and Spironolactone $(10 \mathrm{mg} / \mathrm{Kg} /$ day) were administered in drinking water. Cardiac hypertrophy $(\mathrm{CH})$, was increased $10 \%$ by AS alone and even more (17\%) with AS plus training (TAS) $(p<0.05)$. In both groups there was an increase in cardiac collagen, collagen volumetric fraction (CVF) and cardiac collagen type III expression, and diastolic dysfunction ( $\mathrm{p}<0.05$ ). Losartan prevented $\mathrm{CH}$ and cardiomyocytes diameter increase in these groups. ATI receptors and mineralocorticoid receptor (MR) antagonists blocked increased CVF and collagen I and III and reversed the diastolic dysfunction associated with AS and TAS. AS increased aldosterone synthase (CYP11B2) and 11- $\beta$ hydroxysteroid dehydrogenase 2 (11 1 HSD2) gene expression and inflammatory markers, TGF $\beta$ and osteopontin. We conclude that AS and TAS increases RAAS activation which has detrimental effects on the heart.

Keywords: physical exercise, anabolic steroid, angiotensin II, aldosterone, cardiac hypertrophy. 


\section{Introduction}

Anabolic steroids (AS) abuse induces serious adverse effects on cardiovascular system, including myocardial structural changes and cardiac hypertrophy $(\mathrm{CH})[1]$. When combined with physical training, these effects may be exacerbated resulting in cardiac dysfunction, and the physiological $\mathrm{CH}$ induced by physical training changes to pathological $\mathrm{CH}[2,3]$. However, the nature and the molecular mechanisms of these processes involving $\mathrm{CH}$ are poorly understood.

In an earlier study our group showed, for the first time, that the combination of physical training and AS causes an increase in the heart collagen concentration and $\mathrm{CH}$ associated with activation of cardiac renin-angiotensin system (RAS). These findings were reinforced by the fact that AT1-receptor antagonist prevented $\mathrm{CH}$ and increased heart collagen in AS and AS trained groups [3]. The Renin Angiotensin Aldosterone System ( RAAS) plays an important role in regulating cardiac growth and remodeling of cardiac extracellular matrix [5]. The hypertrophic and pro-fibrotic effects may be associated with aldosterone actions [5].

Like the tissue angiotensin II [6], aldosterone synthesis is also detected in extra adrenal sites within cardiovascular tissue [7], and have highlighted aldosterone synthase gene (CYP11B2), as a key enzyme in this process $[7,8]$. An increase in CYP11B2 was associated with cardiovascular disorders, such as heart failure [8] and myocardial infarction [9]. The mineralocorticoid receptor (MR) and 11- $\beta$ hydroxysteroid dehydrogenase 2 (11ß-HSD2), which confers mineralocorticoid selectivity to aldosterone target tissue, have also been detected in hearts $[10,11]$. Increased in $11 \beta$ HSD2 appears to have deleterious effects on the heart, suggesting that aldosterone has an important role in the cardiovascular system $[12,13]$. 
The production of aldosterone in the myocardium may stimulate the extracellular matrix, increase cardiac fibrosis and remodeling [14], leading to increased myocardial stiffness and dysfunction, regardless of hemodynamic factors $[14,15]$. These effects may be mediated by inflammatory factors as TGF $\beta$ and osteopontin. TGF $\beta$, is associated with a growth factor connective (CTGF) increase, that can be responsible for cardiac fibrosis [16] and osteopontin is has a functional role in fibrosis and $\mathrm{CH}$ [17].

Based on previous studies cardiac RAS and aldosterone might be importantly involve in steroid effects on $\mathrm{CH}$ and fibrosis when associated with physical training [3]. However, the aldosterone effects, induced by AS treatment alone or associated with physical training, on $\mathrm{CH}$, fibrosis and cardiac function are unknown.

Therefore, we investigated the effect of AS with and without swimming training on : 1) the participation RAAS on $\mathrm{CH}$ and collagen expression induction; 2) cardiac function analyzed by echocardiography; and 3) on inflammatory markers. 


\section{Experimental groups}

Male Wistar rats (8-12 wk old, weighing $180-250 \mathrm{~g} ; \mathrm{n}=112$ ) were used. All protocols were in accordance with the guidelines of the Brazilian College for Animal Experimentation (COBEA - www.cobea.org.br) and were approved by the Ethics Committee of the School of Physical Education and Sports of the University of São Paulo. The rats were divided randomly into eight groups, each with 14 rats: Control (C), Anabolic Steroid (AS), Trained (T) and Trained AS (TAS), AS+Losartan (AS+L), AS + Spironolactone $(\mathrm{AS}+\mathrm{S}), \quad$ Trained AS+Losartan (TAS+L) and Trained AS+Spironolactone (TAS+S). Each group was subdivided into two groups: one for biochemical and molecular studies, and the other for histological studies

The ATI receptor antagonist, Losartan (Coozar $\$$, Merck Sharp) and the MR antagonist, Spironolactone (Aldactone $($, Pfizer S.R.L), was administered in the water of the animals at doses of $20 \mathrm{mg} / \mathrm{Kg} /$ day and $10 \mathrm{mg} / \mathrm{Kg} /$ day, respectively. As previously described each animal consumes an average of $40 \mathrm{ml} /$ day of water. The doses are described in the literature as sufficient to block the actions of angiotensin II and aldosterone respectively without interfering with the blood pressure (BP) of normotensive rats $[3,15,18]$.

The animals were housed in standard cages and separated into groups (sedentary and trained). Food and water were provided ad libitum. Room temperature was kept at $23 \pm 1^{\circ} \mathrm{C}$. A $12: 12$-h light-dark cycle was maintained throughout the experiment. The rats were identified and weighed weekly. They were treated with the AS nandrolone decanoate ( Decaburabolin; Organon, Roseland, NJ) administered subcutaneously twice a week, in a dosage of $5 \mathrm{mg} / \mathrm{Kg}$ per injection, equaling $10 \mathrm{mg} / \mathrm{Kg} / \mathrm{wk}$. 


\section{Training protocol}

The swimming training was performed as described previously [19]. The physical training was executed five times a week in a swimming system with warm water at 30$32^{\circ} \mathrm{C}$, for $60 \mathrm{~min}$, for $10 \mathrm{wk}$, with a gradual increase of work load [tail weight - \%body weight $(\mathrm{BW})]$ until it reached $5 \%$ of $\mathrm{BW}$. This protocol is defined as a low-intensity, long training period, effective for promotion of cardiovascular adaptations and increase in muscle oxidative capacity [19].

\section{Measurements and Procedures}

Hemodynamic Measurements

Blood pressure (BP) - Were determined non-invasively using a computerized tail-cuff system. Rats were acclimatized to the apparatus during daily sessions over 6 days, one week before starting the experimental period. For BP recording a rubber cuff was placed on the tail proximally, and connected to a sphygmomanometer to gradually inflate and deflate the cuff from 0 to $250 / 300 \mathrm{mmHg}$. In the most distal portion of the tail was attached to a pneumatic transducer to detect signs of passage of the pulse wave of BP in the artery and recorded on the system AT/CODAS (DataQ Instruments, Inc., Ohio, USA) with sampling frequency $1000 \mathrm{~Hz}$. BP was recorded at the time the pressure on the tail becomes slightly less than the value of intra-arterial pressure, allowing the detection of the pulse pressure.

For each animal, five measures of BP were taken and discarded the first and last steps then calculated the arithmetic mean of the remaining values. 
Echocardiography - was assessed in accordance with the recommendations of the American Society of Echocardiography [20,21]. Transthoracic echocardiography was performed after the experimental period, by an observer using Sequoia 512 equipment (ACUSON Corporation, Mountain View, CA) with a 10 to $14 \mathrm{MHz}$ multifrequency linear transducer placed on the animals shaved chest (lateral recumbence). Rats were anesthetized with a mixture of Xylazine $(10 \mathrm{mg} / \mathrm{kg})$ and Ketamine $(90 \mathrm{mg} / \mathrm{Kg})$. To optimize the image, a transmission gel was used between the transducer and the animals' chest (general imaging gel, ATL inc., Reedsville, PA). Animals were scanned from below at a depth of $2 \mathrm{~cm}$ with the focus optimized at $1 \mathrm{~cm}$. All measurements were performed by the same observer based on the average of 3 consecutive cardiac cycles. Wall thickeness and left ventricle (LV) dimensions were obtained from a short-axis view at the level of the papillary muscles. Two-dimensionally guided pulse Doppler recordings of LV transmitral flow were obtained from the apical 4-chamber view. The systolic function was determined by shortening fraction (SF-[(LVd+PWd+IWd $)^{3}-$ $\left.\mathrm{LVd}^{3}\right]$, where LVd is LV end-diastolic diameter and LVs is LV end-systolic diameter. Ejection fraction ( $\mathrm{EF}$ - was calculated according to the Teicholz formula). The diastolic function was determined at peak velocity of $\mathrm{E}$ wave, peak velocity of $\mathrm{A}$ wave, $\mathrm{E} / \mathrm{A}$ ratio and isovolumetric relaxation time (IVRT - was taken as the time from aortic valve closure to the onset of mitral flow).

\section{Tissue Samples}

At the end of the experimental period, animals were killed, without prior anesthesia, by decapitation. The heart was removed from the thoracic cavity and dissected to separate the LV, which was the tissue remaining after removal of atria and the free wall of the right ventricle. The interventricular septum remained as part of the 
LV. The LV was weighed and divided into two parts, one for histological analysis and other was stored at $-80^{\circ} \mathrm{C}$ for biochemical and molecular analysis.

\section{Cardiac Hypertrophy $(\mathrm{CH})$}

$\mathrm{CH}$ was determined by two different methods: echocardiography and ratio of LV weight to animal body weight.

Echocardiography - LV mass was calculated by the use of the following formula, assuming a spherical LV geometry and validated in rats: LV mass= $1,047 x\left[(\mathrm{LVd}+\mathrm{PWd}+\mathrm{IWd})^{3}-\mathrm{LVd}^{3}\right]$, where 1,047 is the specific gravity of muscle and PWd and IWd are end-diastolic posterior and interseptum wall thickness, respectively. Ratio of LV weight to animal body weight - LV hypertrophic was calculated by LV weight (LVW) normalized by total body weight (BW) of the animals (LVW/BW in $\mathrm{mg} / \mathrm{g})$

\section{Morphological and Morphometric Analysis}

Cardiomyocyte diameter - For morphometric analysis, the chest was opened, and the hearts were stopped at diastole by perfusion with $14 \mathrm{mM} \mathrm{KCl}$. After the $\mathrm{LV}$ was fixed in $6 \%$ formaldehyde and embedded in paraffin, cut into $5 \mu \mathrm{m}$ sections at the level of the papillary muscle, and subsequently stained with hematoxylin and eosin for the visualization of cellular structures. Two randomly selected sections from each animal were visualized by light microscopy using an oil immersion objective with a calibrated magnification (x400). Myocytes with visible nuclei and intact cellular membranes were chosen for diameter determination. The width of individually isolated cardiomyocytes displayed on a viewing screen was manually traced, across the middle of the nuclei, with a digitizing pad, and determined by a computer assisted image analysis system 
(Quantimet 520; Combridge Instruments, Woburn, MA). For each animal, 20 visual fields were analyzed.

Myocardial interstitial collagen volumetric fraction (CVF) - was determined using direct and polarized light of the Picrosirius red prepared tissues, as reported previously [22]. In brief, 20 fields were selected from sections placed in a projection microscope (x200), and interstitial collagen was determined by a computer-assisted image analysis system (Quantimet 520; Cambridge Instruments). CVF was calculated as the sum of all connective tissue areas divided by the sum of all muscle areas in all fields. Perivascular and patch cardiac (reparative fibrosis) were specifically excluded from this determination.

\section{Molecular and Biochemical Analysis}

Angiotensin-Converting Enzyme I (ACE) Activity - ACE activity in rat tissue extracts were determined using Abz-FRK(Dnp)P-OH derivatives as substrates by continuously measuring the fluorescence according to Alves et al. [23]. Tissue samples were quickly harvested, homogenized in Tris- $\mathrm{HCl}$ buffer, $\mathrm{pH} 7.0$, containing $50 \mathrm{mM} \mathrm{NaCl}$ and centrifuged at $1,000 \mathrm{~g}$ for $10 \mathrm{~min}$. The assays were performed at $37^{\circ} \mathrm{C}$ in $0.1 \mathrm{M}$ Tris$\mathrm{HCl}$ buffer, $\mathrm{pH} 7.0$, containing $50 \mathrm{mM} \mathrm{NaCl}$ and $10 \mu \mathrm{M} \mathrm{ZnCl}$. Hydrolysis rate of the intramoleculary quenched fluorogenic substrate Abz-YRK-(Dnp)p (10 mM) incubated with aliquots of tissue homogenate for $30 \mathrm{~min}$ at $37^{\circ} \mathrm{C}$ was assessed to obtain ACE enzymatic activity. Florescence increments along the time were read at $420 \mathrm{~nm}$ emission: $320 \mathrm{~nm}$ excitation. Cardiac ACE activity was expressed as arbitrary fluorescence units (UF)/mg of protein. The protein content was determined by the 
Bradford method [24] by using bovine serum albumin as the standard (Bio-Rad protein assay).

Cardiac protein expression - quantification of AT1 and AT2 receptors was performed by Western blot analysis. The frozen ventricles were thawed and minced into small pieces and homogenized in cell lysis buffer containing $100 \mathrm{mM}$ Tris- $\mathrm{HCl}, 50 \mathrm{mM} \mathrm{NaCl}$, $10 \mathrm{mM}$ EDTA, $1 \%$ Triton $\mathrm{X}-100$, and a mixture containing a mixture of protease inhibitors [potassium EDTA $(25 \mathrm{mmol}), o$-phenanthroline $(0.44 \mathrm{mmol})$, pepstatin A $(0.12 \mathrm{mmol})$, and 4 -(chloromercuribenzoic acid) $(1 \mathrm{mmol})]$ to prevent the in vitro production and degradation of angiotensin peptides [25]. Insoluble heart tissues were removed by centrifugation at $3,000 \mathrm{~g}, 4^{\circ} \mathrm{C}$, and $10 \mathrm{~min}$. Samples were loaded and subjected to SDS-PAGE in $10 \%$ polyacrylamide gels. After electrophoresis, proteins were electrotransferred to nitrocellulose membrane (Amersham Biosciences; Piscataway, NJ). Equal loading of samples $(60 \mu \mathrm{g})$ and even transfer efficiency were monitored with the use of $0.5 \%$ Ponceau S staining of the blot membrane. The blot membrane was then incubated in a blocking buffer ( $5 \%$ nonfat dry milk, $10 \mathrm{mM}$ Tris$\mathrm{HCl}, \mathrm{pH} 7.6,150 \mathrm{mM} \mathrm{NaCl}$, and $0.1 \%$ Tween 20 ) for $2 \mathrm{~h}$ at room temperature and then probed with a polyclonal antibody directed against AT1 or AT2 $(1: 1,000$; Santa Cruz Biotechnology, Santa Cruz, CA) at room temperature. Binding of the primary antibody was detected with the use of peroxidase-conjugated secondary antibodies, and enhanced chemiluminescence reagents (Amersham Biosciences; Piscataway, NJ) were used to visualize the autoradiogram, which was later exposed to photographic film. The film was developed, and the bands were analyzed using Scion Image software (Scion based on NIH image). $\alpha$-tubulin expression levels were used to normalize the results. 
Cardiac gene expression - The gene expression of collagen type I, collagen type III, CYP11B2 (aldosterone synthase gene), mineralocorticoids receptor (MR), $11 \beta$ hydroxysteroid dehydrogenase 2 (11 $\beta$-HSD2), transforming growth factor $\beta$ (TGF $\beta$ ) and osteopontin were determined by polymerase chain reaction (RT-PCR). The glyceraldehyde-3-phosphate dehydrogenase (GAPDH) gene level was used to normalize the results.

Frozen tissue samples $(150-200 \mathrm{mg})$ were homogenized in guanidinium thiocyanate solution ( $4 \mathrm{~mol} / \mathrm{l})$, and RNA was isolated according to the method described previously [26]. Samples were quantified spectrophotometrically at $260 \mathrm{~nm}$ and checked for integrity by EtBr-agarose gel electrophoresis. RNA were primed with $0.5 \mu \mathrm{g} / \mu \mathrm{l}$ oligo(dT) (12-18 bp) (Invitrogen Life Technologies, Strathclyde, UK) to generate the first strand of DNA. Reverse transcription (RT) was performed using SuperScript II Reverse Transcriptase (Invitrogen Life Technologies).

The cDNA segments amplification were carried out under the following conditions: $5-7 \mu \mathrm{l}$ of the reaction product of reverse transcription (cDNA), $2.5 \mu \mathrm{l}$ of $10 \mathrm{x}$ reaction buffer (20 mM Tris- $\mathrm{HCl}(\mathrm{pH} 8.4), 50 \mathrm{mM} \mathrm{KCl}), 0.75 \mu$ l of $\mathrm{MgCl}_{2} 50 \mathrm{mM}, 2 \mu 1$ of the mixture of $2.5 \mathrm{mM}$ dNTP, $0.5 \mu$ l of each primer $(12.5 \mu \mathrm{M})$ (primers are described in Table 1) and $0.25 \mu$ l of Taq Platinum DNA polymerase (Gibco) (2.5 units of enzyme) and sterile $\mathrm{H}_{2} \mathrm{O}$ to complete $25 \mu \mathrm{l}$. The PCR reactions were performed in MJ Research thermal cycler MiniCycler, following the conditions specified for each pair of primers. To analyze the formation of PCR products, aliquots of $10 \mu$ l of the reaction products were subjected to electrophoresis on agarose gel at $3 \%$. The molecular weight marker used was the DNA ladder of $100 \mathrm{bp}$ (Gibco-BRL). 
The bands were visualized by the effect of ultraviolet radiation in a darkroom equipped with a transluminator and images acquired by the program Chemilmager 5500 (Alpha Innotech, CA, USA). The intensity of the bands obtained was analyzed using the analysis program Scion Image densitometry, provided free by NIH (USA) online.

\section{Statistical Analysis}

Results are represented as means \pm standard deviation (SD). Statistical analysis was performed using the software BASIC STATISTIC, by two-way ANOVA. The groups were analyzed in three stages: first we compared the AS groups with the control groups. In a second step, the AS groups were compared with Losartan treated groups and in third step, we compared the AS groups with the Spironolactone treated groups. For analysis of blood pressure before and after the experimental treatment was performed using ANOVA for repeated measures. When F test was significant we applied post-hoc Duncan to multiple comparisons. Significance was $\mathrm{p} \leq 0.05$.

\section{Results}

\section{Hemodynamic Measurements}

The data referring to blood pressure (BP) and cardiac function by echocardiography are summarized in Table 2. There were no differences in BP among the groups before and after the experimental protocol. Table 2 shows that the AS treatment did not modify ventricular function in the sedentary group. However, the peak velocity of $\mathrm{E}$ wave and $\mathrm{E} / \mathrm{A}$ ratio was lower when $\mathrm{AS}$ treatment was combined with $\mathrm{ST}$ suggesting diastolic dysfunction in this group. When the TAS group was treated with 
Losartan $(\mathrm{TAS}+\mathrm{L})$ or Spironolactone $(\mathrm{TAS}+\mathrm{S})$ the treatments prevented the deleterious effects on diastolic function.

\section{Measurement of Cardiac Hypertrophy}

Figure 1 shows the $\mathrm{CH}$ analyzed by echocardiography and LVW/BW measurements. $\mathrm{CH}$ was observed in AS, T and TAS groups by echocardiography $(0.21 \pm 0.02,0.22 \pm 0.03$ and $0.24 \pm 0.02$, respectively $v s 0.17 \pm 0.04 ; P<0.05)$ and by LVW/BW $(0.23 \pm 0.01,0.22 \pm 0.01$ and $0.24 \pm 0.01$, respectively vs $0.20 \pm 0.01 ; P<0.05)$ $\mathrm{CH}$ was exacerbated in TAS compared to AS and T groups measured by LVW/BW (Fig. 1A). Losartan (Fig. 1B), but not Spironolactone (Fig. 1C) treatment prevented $\mathrm{CH}$ of the TAS group and in the AS group when measured by LVW/BW.

\section{Cardiomyocytes diameter and cardiac collagen}

$\mathrm{CH}$ induced by AS was associated with cardiac collagen expression and concentration (Figure 2). The collagen volumetric fraction (CVF) was significantly increased in AS and TAS when compared with $\mathrm{C}$ and $\mathrm{T}$ groups (2.32 \pm 0.28 and $2.0 \pm 0.11$ vs. $1.17 \pm 0.17$ and $1.33 \pm 0.2 \mu \mathrm{m} /$ area, respectively; $P<0.05$ ) (Fig. $2 \mathrm{~A}$ ). The CVF increase was prevented by Losartan (Fig. 2B) treatment in AS+L and TAS $+\mathrm{L}(1.49 \pm 0.11$ and $1.2 \pm 0.17$ ) groups, and also by Spironolactone (Fig. $2 \mathrm{C}$ ) treatment in $\mathrm{AS}+\mathrm{S}$ and $\mathrm{TAS}+\mathrm{S}$ $(1.46 \pm 0.53$ and $1.37 \pm 0.05)$ groups when compared with AS and TAS $(2.32 \pm 0.28$ and 2.0 0.11$)$ groups.

Figure 2D shows the relative gene expression of collagen. The gene expression of collagen type III was significantly increased in the AS and TAS groups when compared with the $\mathrm{C}$ and $\mathrm{T}$ groups (1.32 \pm 0.32 and $1.26 \pm 0.05$ vs $0.73 \pm 0.17$ and 
$0.88 \pm 0.12$ respectively, $\mathrm{P}<0.05$ ). The relative gene expression of collagen type $\mathrm{I}$ to $\mathrm{C}$, AS, T and TAS $(0.86 \pm 0.15,1.02 \pm 0.06,0.83 \pm 0.24$ and $1.12 \pm 0.2$ arbitrary units, respectively) was not significantly different among the 4 groups. The top panel shows the collagen type I, type III and GAPDH expression bands for the 4 groups

The relative gene expression of collagen type III increase was prevented by Losartan (Fig. 2E) treatment in $\mathrm{AS}+\mathrm{L}$ and TAS $+\mathrm{L}(0.90 \pm 0.1$ and $0.96 \pm 0.14)$ groups, also by Spironolactone (Fig. 2F) treatment in $\mathrm{AS}+\mathrm{S}$ and $\mathrm{TAS}+\mathrm{S}(1.01 \pm 0.07$ and $0.85 \pm 0.08)$ groups when compared with AS and TAS (1.32 \pm 0.32 and $1.26 \pm 0.05)$ groups, respectively. Moreover, the relative gene expression of collagen type I was decreased by Losartan (Fig. 2E) treatment in TAS $+\mathrm{L}(0.86 \pm 0.12)$ compared with TAS, and by Spironolactone (Fig. $2 \mathrm{~F})$ in $\mathrm{AS}+\mathrm{S}$ and $\mathrm{TAS}+\mathrm{S}(0.87 \pm 0.09$ and $0.88 \pm 0.05)$ groups

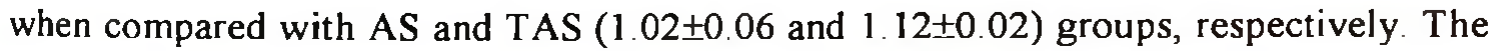
top panels (Fig. 2E and 2F) shows the collagen type I, type III and GAPDH expression bands to the 4 groups treated with (Losartan and Spironolactone), respectively

Figure 3 shows the average cardiomyocyte diameters in each group. These were significantly increased in AS, $\mathrm{T}$ and TAS groups $(21.72 \pm 0.41,22.77 \pm 0.93$ and $23.09 \pm 0.66$, respectively; $P<0.05)$ when compared with $C(20.57 \pm 0.28)$ group (Fig 3A). Also, they were increased in T and TAS when compared with AS group $(P<0.05)$.

The increase of cardiomyocyte diameter was prevented by Losartan (Fig. 3B) treatment in $\mathrm{AS}+\mathrm{L}$ and $\mathrm{TAS}+\mathrm{L}$ groups $(21.15 \pm 0.62$ and $22.01 \pm 0.23)$ when compared with TAS (23.09 \pm 0.66$)$ group. However, the cardiomyocyte diameter increase was not prevented by Spironolactone (Fig. 3C) treatment in $\mathrm{AS}+\mathrm{S}$ and $\mathrm{TAS}+\mathrm{S}(21.51 \pm 1$ and 


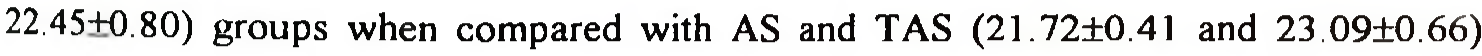
groups.

\section{Cardiac renin angiotensin aldosterone system.}

Figure 4 shows the LV-ACE activity, AT1 and AT2 receptors protein expression. The LV-ACE activity was increased in AS and TAS groups compared with $\mathrm{C}$ and $\mathrm{T}$ groups $(2083 \pm 161,1879 \pm 75,1445 \pm 115$ and $1377 \pm 44, \mathrm{UF} / \mathrm{mg}$ respectively; $\mathrm{P}<0.001$ ). The LV-ACE activity increase was prevented by Losartan (Fig. 4B) treatment in AS+L and TAS $+\mathrm{L}(1682 \pm 140$ and $1495 \pm 187)$ groups, also by Spironolactone (Fig. 4C) treatment in $\mathrm{AS}+\mathrm{S}$ and $\mathrm{TAS}+\mathrm{S}(1543 \pm 145$ and $1578 \pm 100)$ groups when compared with AS and TAS $(2083 \pm 161$ and $1879 \pm 75)$ groups, respectively. The AT1 and AT2 receptors protein expression in arbitrary units (AU) was increased in AS and TAS groups compared with $\mathrm{C}$ and $\mathrm{T}$ groups (AT1: $1.02 \pm 0.2,1.15 \pm 0.16,0.66 \pm 0.12$ and $0.76 \pm 0.06$, respectively; $\mathrm{P}<0.05 ;$ AT2: $1.16 \pm 0.18,1.21 \pm 0.15,0.87 \pm 0.08$ and $0.83 \pm 0.1$, respectively; $\mathbf{P}<0.05$ ). However, the receptor increase was not prevented by Losartan (Fig. 4D) treatment in $\mathrm{AS}+\mathrm{L}$ and TAS+L (AT1: $0.99 \pm 0.18$ and $1.09 \pm 0.14 ; \mathrm{AT} 2$ $0.95 \pm 0.25$ and $1.03 \pm 0.08$, respectively) groups, also it was no prevented by Spironolactone (Fig. 4F) treatment in AS+S and TAS+S (AT1: 1.14 \pm 0.18 and $1.18 \pm 0.05 ;$ AT2: $1.10 \pm 0.11$ and $1.11 \pm 0.12$, respectively) groups, compared with AS and TAS (AT1: $1.02 \pm 0.2$ and 1.15 $\pm 0.16 ; \mathrm{AT} 2: 1.16 \pm 0.18$ and $1.21 \pm 0.15$ ) groups, respectively. The top panels (Figures $4 \mathrm{D}, 4 \mathrm{E}$ and $4 \mathrm{~F}$ ) shows the representative AT1, AT2 and $\alpha$-tubulin expression bands to the 4 groups with AS, Losartan and Spironolactone treatment, respectively. 
Figure 5 shows the aldosterone synthase (CYP11B2) and 11ß-hydroxysteroid dehydrogenase type $2(11 \beta-H S D 2)$ gene expressions. The relative gene expression of CYP11B2 and 11ß-HSD2 (Fig. 5A) were significantly increased in AS (1.23 \pm 0.2 and $1.24 \pm 0.22)$ and TAS $(1.47 \pm 0.27$ and $1.49 \pm 0.28)$ groups when compared with C $(0.85 \pm 0.07$ and $0.88 \pm 0.08)$ and $T(0.87 \pm 0.15$ and $0.56 \pm 0.13)$ groups, respectively, $\mathrm{P}<0.05$. Also, the relative gene expression of $11 \beta-\mathrm{HSD} 2$ was significantly decreased in T group compared with $\mathrm{C}$ group $(\mathrm{P}<0.05)$.

The relative gene expression of CYP11B2 and 11ß-HSD2 increases were prevented by Losartan treatment (Fig. 5B) in AS $+\mathrm{L}(0.83 \pm 0.17$ and $0.97 \pm 0.25)$ and

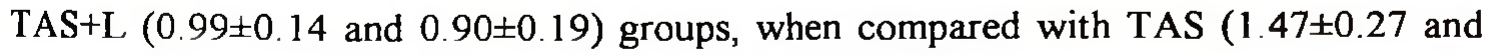
$1.49 \pm 0.28)$ group, but not when compared with AS group. The relative gene expression of CYP11B2 and 11ß-HSD2 increases were prevented by Spironolactone treatment (Fig. 5C) in $\mathrm{AS}+\mathrm{S}(0.82 \pm 011$ and $0.76 \pm 0.16)$ and $\mathrm{TAS}+\mathrm{S}(0.99 \pm 017$ and $0.86 \pm 0.25)$ groups when compared with TAS (1.47 \pm 0.27 and $1.49 \pm 0.28)$ group, respectively, and also when compared with AS (1.23 \pm 0.2 and $1.24 \pm 0.22)$ group, except the TAS+S group. The top panels (Fig. 5A,5B and 5C) shows the representative CYP11B2, $11 \beta-$ HSD2 and GAPDH expression bands to the 4 groups with AS, Losartan and Spironolactone treatment, respectively.

The mineralocorticoid receptors expression was not different among the studied groups (data not showed)

\section{Inflammatory factors}

Figure 6 shows the expression of transforming growth factor $\beta$ (TGF $\beta$ ) and osteopontin gene. 
Expression of these genes (Fig. 6A) was significantly increased in AS

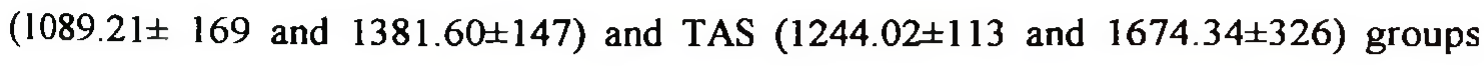
when compared with $C(839.27 \pm 122$ and $777.68 \pm 32)$ and $T(858.29 \pm 101$ and 1067.103 \pm 247$)$ groups, respectively, $(\mathrm{P}<0.05)$. Moreover, the osteopontin gene expression was exacerbated in TAS group compared with AS group $(\mathrm{P}<0.01)$.

The relative gene expression of TGF $\beta$ and osteopontin (Fig. 6B) increase were prevented by Losartan treatment in AS+L $(981.12 \pm 148$ and $899.31 \pm 131)$ and $\mathrm{TAS}+\mathrm{L}$ (907.92 \pm 83 and $996.14 \pm 107)$ groups, when compared with AS (1089.21 \pm 169 and $1381.60 \pm 147)$ and TAS (1244.02 \pm 113 and 1674.34 \pm 326$)$ groups, except when compared with AS group to TGF $\beta$ gene.

The relative gene expression of TGF $\beta$ and osteopontin (Fig. 6C) increase were prevented by Spironolactone treatment in $A S+S(833.37 \pm 187$ and $914 \pm 07 \pm 136)$ and TAS+S (833.75 \pm 80 and 935.28 \pm 157$)$ groups when compared with AS (1089.21 169 and $1381.60 \pm 147)$ and TAS (1244.02 \pm 113 and $1674.34 \pm 326)$ group, respectively.

The top panels (Fig. 6A, 6B and 6D) shows the representative TGF $\beta$, osteopontin and GAPDH expression bands to the 4 groups treated with AS, Losartan and Spironolactone treatment, respectively.

\section{Discussion}

The main findings of this study show that: 1) anabolic steroids induce $\mathrm{CH}$ that was exacerbated when associated with swimming exercise training. 2) $\mathrm{CH}$ in this protocol was prevented by Losartan, but not by Spironolactone treatment. Losartan, treatment prevented an increase in the cardiomyocyte diameter. 3) AT1 receptors and MR antagonists were effective in preventing increase CVF and collagen type I and III 
and also reversing the diastolic dysfunction induced by AS associated to exercise training. 4) the increase in CYP11B2 and 11ßHSD2 expression induced by AS treatment suggest the role of aldosterone is important to the cardiac deleterious effects. 5) the inflammatory genes appear to be involved in the deleterious effects resulting from AS treatment alone and in association with exercise training. These findings are consistent with a growing body of evidence that remodelling of the cardiac interstitium is a major determinant of pathological hypertrophy leading to cardiac dysfunction.

There were no changes in BP among the groups studied; showing that AS, Losartan or Spironolactone treatment did not alter the systemic RAAS regulation in normotensive animals. Previous results from our laboratory showed that AS treatment did not alter the renin and ACE plasma activity [3].

Endurance training is known to cause eccentric cardiac hypertrophy in which the adaptive responses are distributed across the LV wall. However, many factors influence exercise induced cardiac hypertrophy. Included are the mode, the intensity, the duration, and the frequency of the exercise regimen [27]. In this study, the swimming training protocol induced cardiac hypertrophy quantified by HW/BW (7.3\%) and by echocardiography (31.7\%) compared to the $\mathrm{C}$ group. This index was followed by an increase in cardiomyocyte diameter of $(10.7 \%)$ compared to controls, but not by cardiac collagen (CVF or collagen type I and III expression). This response is typical of aerobic training by swimming and reflects physiological cardiac hypertrophy $[3,19,27,28]$. In physiological cardiac hypertrophy, the increase in cardiomyocytes volume results from the increase in the amount of contractile protein synthesis, which predominantly increases myofibril length. The effects of exercise on the $\mathrm{CH}$ cause adaptive beneficial 
responses to the cardiovascular system [29] leading to an increase in cardiac mass without functional impairment as we showed by echocardiography.

AS or the exercise training associated to AS (TAS group) induced cardiac hypertrophy. The hypertrophy index was followed by an increase in: cardiomyocytes diameter compared with $\mathrm{C}$ group, and CVF and cardiac collagen type III compared with $\mathrm{C}$ and T groups. Moreover, in TAS group the cardiac hypertrophy was most pronounced compared to C, AS and T groups. However, the myocyte diameters were similar in the TAS and T groups, and not observed as a synergic effect between AS with exercise training. Also, in the TAS group $\mathrm{CH}$ was followed by an increase in cardiac collagen type I and diastolic dysfunction. Similar results were shown in previous studies where the AS administration seems to have been responsible for the increase of reparative fibrosis (cardiac patch) in the heart. This, suggests that exposure to supraphysiological anabolic steroids lead to tissue necrosis, resulting to structural changes similar to those observed in the early stages of heart failure $[3,30]$.

Hemodynamic and nonhemodynamic factors might be involved in the disequilibrium between myocytes growth and collagen turnover. Fibrillar collagens, types I and III, are the major structural proteins of the myocardial collagen matrix.

Type I collagen is usually present in the form of thick fibers, and its concentration determines the stiffness of the myocardium. Type III collagen forms fine reticular networks and is more distensible than type I collagen [31].

The increased collagen type MI expression might be responsible for the diastolic dysfunction in TAS group [32], by Echocardiography, observed in AS users have a decrease in peak velocity during early diastolic filling [32]. Diastolic dysfunction was observed in weight lifters who used AS compared to those who did not $[33,34]$. The 
diastolic dysfunction correlates with increased interstitial collagen, where the connective tissue is responsible for distributing the forces working on the heart, exerting an important influence on ventricular compliance [35].

Cardiac hypertrophy, cardiomyocytes diameter, CVF and collagen type III expression induced by AS treatment and collagen type I and III induced by physical exercise associated with AS treatment were totally prevented by losartan (AT 1-receptor blocker) treatment. These results confirm data found in previous studies from our group, suggesting the AT 1 receptors are involved on the increase of cardiac collagen induced by AS administration [3]. However, in the present study we show that Spironolactone was more effective in preventing collagen expression than Losartan treatment. Spironolactone prevented CVF in AS+S and TAS+S groups compared with their respective controls. Also, it prevented increasing collagen type I and type III expression in $\mathrm{AS}+\mathrm{S}$ and $\mathrm{TAS}+\mathrm{S}$ groups compared with TAS group, and collagen type I and III expression in TAS $+\mathrm{S}$ group compared with AS group. However, the Spironolactone treatment did not modify the cardiomyocytes diameter and cardiac hypertrophy as observed with Losartan treatment. These data might be the result of angiotensin II action through AT1 receptors, on cardiomyocytes. Cardiac angiotensin II is one of the most powerful promoters of cardiomyocyte hypertrophy [4]. Angiotensin II in an autocrine or paracrine form, activates a variety of molecular signaling pathways that induce hypertrophy [36]. The actions of angiotensin II through AT1 receptor are responsible for activating a variety of intracellular signaling pathways, increasing the expression of genes related to hypertrophy [4,36]. Blocking ATl receptors with Losartan, would be expected to reverse the effects of angiotensin II on cardiac hypertrophy and we have showed previously that Losartan prevented cardiac 
hypertrophy induced by swimming training [28]. AT1 receptors may act directly as mechanical stress sensors and activate signaling pathways responsible for $\mathrm{CH}$ [37].

Previously we have shown that swimming training associated with supraphysiological doses of AS exacerbated $\mathrm{CH}$ by interstitial fibrosis associated with cardiac RAS activation. Our present results show that the RAAS is nvolved in this interaction of steroids and exercise training. We confirmed the effects of Losartan and provide new information that Spironolactone prevents increased cardiac ACE activity in the AS and TAS groups. These results demonstrate that aldosterone participates in the deleterious effects of AS on the heart. Other studies showed that the cardiac angiotensin II concentration contributes to the hyperplasia of cardiac fibroblasts and to the development of cardiac fibrosis [38]. ACE activation might be contributing to the development of heart fibrosis, because there are high levels of ACE activity in the fibrotic area of the heart $[38,39]$. AT1 receptors are responsible for cell proliferation and hypertrophy [40,41], but the AT2 receptors appear to have opposite effects on AT1 receptors [42]. AT2 receptors involvement on the extracellular matrix was observed with administration of an antagonist of these receptors, with significantly increased fibronectin synthesis, showing their importance in the restoration of normal cardiovascular system [43]. This results, may help explain the increase in AT2 receptor expression observed with AS and TAS treatment in our study.

Some actions attributed to angiotensin II may be directly related to the synthesis and release of aldosterone [44]. Aldosterone has been associated with inflammatory responses, inducing tissue damage collagen synthesis and cardiac remodeling [13, $14,45]$, regardless of hemodynamic changes, suggesting local aldosterone effects [15]. 
Therefore, we investigated the MR receptor, CYP11B2 and the 11BHSD2 expression on the cardiac effects induced by AS

MR receptors expression was not modified by any treatment, but CYP11B2 expression was increased with AS (44.5\% and 41.8\%) and TAS (72.7\% and 69.4\%) treatments compared with $\mathrm{C}$ and $\mathrm{T}$ groups, respectively. The gene expression was totally prevented by Losartan and Spironolatone treatments in the TAS group and by Spironolactone in AS group. Increased CYP11B2 gene expression is related to high aldosterone concentrations, $\mathrm{CH}$ and cardiac collagen synthesis [8], and animals treated with ACE inhibitors had reduced aldosterone and CYP1 1B2 expression $[9,46]$.

The effects of aldosterone are modulated by binding to the MR, but aldosterone actions depend on various factors, including the glucocorticoids concentrations, which act as MR antagonist in heart by inhibiting the aldosterone actions [12]. 11ßHSD2 enzyme activity, which is responsible for the cortisol and corticosterone conversion in 11-keto cortisone and 11-dihydrocorticosterone, inactive metabolites binding to MR, contributing to increased aldosterone action on these receptors [47]. 11ßHSD2 enzyme expression was increased with AS (39.9\% and $121.5 \%)$ and TAS (68.6\% and $166.9 \%)$ treatments compared with $\mathrm{C}$ and $\mathrm{T}$ groups, respectively. The effects were totally prevented by Losartan treatment in TAS $+\mathrm{L}$ group compared with TAS group, and also by Spironolatone treatment in $\mathrm{AS}+\mathrm{S}$ and $\mathrm{TAS}+\mathrm{S}$ groups compared with $\mathrm{AS}$ and $\mathrm{TAS}$ groups. 11ßHSD2 expression increase is directly related to $\mathrm{CH}$ and fibrosis [12] and can be changed depending on the tissue and diseases analyzed [13]. Thus, in AS and TAS groups the $11 \beta \mathrm{HSD} 2$ expression increased might be associated with higher aldosterone concentration and deleterious effects induced by AS on the heart. There was an indication that aerobic training is associated with lower aldosterone actions because 
1 1 $\beta$ HSD2 expression was lower in the T group compared with $\mathrm{C}$ group. However more studies are needed to understand the effects of physical training on aldosterone levels.

An interesting feature of the present study was the higher expression of inflammatory factors TGF $\beta$ and osteopontin observed with AS treatment. Angiotensin II and aldosterone may exert their effects on $\mathrm{CH}$ and increasing collagen synthesis through inflammatory factors release. TGF $\beta$ and osteopontin expression were significantly increased with AS $(29.8 \%$ and $77.6 \%$, respectively; $p<0.05)$ and TAS $(48.2 \%$ and $115.3 \%$, respectively; $p<0.05)$ treatments compared with $\mathrm{C}$ group and in AS (26.9\% and $29.5 \%$, respectively; $p<0.05)$ and TAS $(44.9 \%$ and $56.9 \%$, respectively; $p<0.05)$ treatments compared with $T$ group. The TGF $\beta$ and osteopontin expression increase were totally prevented by Losartan and Spironolatone treatments in AS and TAS groups (TAS $+\mathrm{L}$ and TAS $+\mathrm{S}$ groups). Characteristic features of hyperaldosteronism include increased expression of inflammatory factors in the heart plus interstitial and perivascular fibrosis [48]. TGF $\beta$ and osteopontin are suggested to be related to the aldosterone actions on cardiac fibrosis. This hypothesis was confirmed in mice genetically modified with osteopontin deficiency, where the aldosterone actions on cardiac fibrosis are inhibited [17]. The aldosterone actions on myocardial fibrosis and cardiac remodeling mediated by osteopontin, have also been shown in studies with angiotensin II and aldosterone blockers that were effective in inhibiting the osteopontin expression in the myocardium of infarcted rats, reducing collagen and preventing the $\mathrm{CH}[48]$. The AT1 receptors activation increase TGF $\beta$, which exerts its actions on cardiomyocytes, leading to tissue necrosis, and on fibroblasts increasing the expression of proteins related to fibrosis [50]. TGF $\beta$ has also been shown to be released by aldosterone, leading to increased growth factors expression and connective tissue [51]. 
An interesting observation in this study was the similar effects observed with Losartan or Spironolactone treatments on cardiac RAAS regulation in preventing its deleterious effects on cardiac tissue. Losartan or Spironolactone treatments also prevented inflammatory factors effects, contributing to the beneficial effects observed in the treated groups. The results observed confirm our hypothesis that the AS administration increases the RAAS activation which has detrimental effects on the heart, whereas the AT1 receptors and MR blockers inhibited these effects. A mechanism of "cross-talk" between the MR and the AT1 receptor has been prosed $[52,53]$. Our results indicate that such cross talk is enhanced by anabolic steroids.

\section{Conclusion}

These findings shows that the RAAS participates on deleterious effects on the heart and interstitial collagen regulation induced by anabolic steroids and its association with exercise training, since both AT1 receptors and MR antagonists were effective in inhibiting these effects. AS alone or in combination with exercise training induces maladaptive cardiac remodeling and further deterioration of cardiac performance as observed by diastolic dysfunction in TAS group. We believe this is the first study showing the effects of AS and its association with physical training on cardiac aldosterone. An increase aldosterone synthase and the enzyme 11HSD2 genes expression were observed in steroid treated rats. Our results further demonstrate that AT1 receptor and MR antagonist attenuates the expression of the important inflammatory mediators as TGF $\beta$ and osteopontin in the AS and its association with exercise training. These findings are consistent with idea that remodelling of the cardiac 
interstitium is a major determinant of pathological hypertrophy induced by AS with or without exercise training, leading to cardiac dysfunction.

\section{Acknowledgments}

We gratefully acknowledge the Coordenação de Aperfeiçoamento de Pessoal de Nivel Superior (CAPES), for the EC Carmo fellowship to the present investigation and for Dr MI Phillips by the critical reading of the manuscript.

\section{References}

[1] Melchert RB, Welder AA. Cardiovascular effects of androgenic-anabolic steroids. Med Sci Sports Exerc. 1995; 27: 1252-62. Pereira Junior PP, Chaves EA, Souza RHC, Masuda MO, Carvalho ACC, Nascimento JHM. Cardiac autonomic dysfunction in rats chronically treated with anabolic steroid. Eur J Appl Physiol. 2006; 96(5): 487-94. Rocha FL, Carmo EC, Roque FR, Hashimoto NY, Rossoni LV, Frimm

$\mathrm{C}$, et al. Anabolic steroids induce cardiac renin-angiotensin system and impair the beneficial effects of aerobic training in rats. Am J Physiol Heart Circ Physiol. 2007; 293(6): H3575-83. Zhu YC, Zhu YZ, Lu N, Wang MJ, Wang YX, Yao T. Role of angiotensin AT 1 and AT2 receptors in cardiac hypertrophy and cardiac remodelling. Clin Exp Pharmacol Physiol. 2003; 30(12): 911-18. 
decrease type I collagen synthesis in patients with hypertrophic cardiomyopathy. Circ J.2005; 69: 1244-48

[6] Phillips MI, Speakman EA, Kimura B. Levels of angiotensin II and molecular biology of the tissue renin angiotensin systems. Regulatory Peptides $1993 ; 43: 1-20$.

[7] Silvestre JS, Robert V, Heymes C, Aupetit-Faisant B, Mouas C, Moalic JM, et al. Myocardial Production of Aldosterone and Corticosterone in the Rat. J Biol Chem. 1998; 273(9): 4883-91.

[8] Yoshimura M, Nakamura S, Ito T, Nakayama M, Harda E, Mizuno $Y$, et al. Expression of aldosterone synthase gene in failing human heart: Quantitative analysis using modified real-time polymerase chain reaction. J Clin Endocrinol Metabol. 2002; 87(8): 3936-40.

[9] Silvestre JS, Heymes C, Oubénaissa A, Robert V, Faisant BA, Carayon A. Activation of cardiac aldosterone production in rat myocardial infarction: Effect of angiotensin II receptor blockade and role in cardiac fibrosis. Circulation. 1999; 99(20): 2694-701.

Funder JW, Pearce PT, Smith R, Smith AI. Mineralocorticoid action: Target tissue specificity is enzyme, not receptor, mediated. Science. 1988; 242: $583-5$

[11] Lombes M, Oblin ME, Gasc JM, Baulieu E, Farman N, Bonvalet JP. Immunohistochemical and biochemical evidence for a cardiovascular mineralocorticoid receptor. Cir Res. 1992; 71(3): 503-10 
Transgenic model of aldosterone-driven cardiac hypertrophy and heart failure. Circ Res. 2003; 93(1): 69-76.

[13] Struthers AD. Aldosterone blockade in cardiovascular disease. Heart 2004; 90: 1229-34.

Robert V, Silvestre JS, Charlemagne D, Sabri A, Trouve P, Wassef M, et al. Biological determinants of aldosterone-induced cardiac fibrosis in rats. Hypertension. 1995; 26(6): 971-8.

[15] Brilla CG, Matsubara LS, Weber KT. Anti-aldosterone treatment and the prevention of myocardial fibrosis in primary and secondary hyperaldosteronism. $\mathbf{J}$ Mol Cell Cardiol. 1993; 25(5): 563-75.

[16] Sun Y, Zhang J, Lu L, Chen SS, Quinn MT, Weber KT. Aldosteroneinduced inflammation in the rat heart: role of oxidative stress. Am J Pathol. 2002; 161(5): 1773-81

[17] Sam F, Xie Z, Ooi H, Kerstetter DL, Colucci WS, Singh M, et al. Mice lacking osteopontin exhibit increased left ventricular dilation and reduced fibrosis after aldosterone infusion. Am J hypertens. 2004; 17(2): 188-93.

[18] Li JS, Sharifi AM, Schiffrin EL. Effect of AT1 angiotensin-receptor blockade on structure and function of small arteries in SHR. J Cardiovasc Pharmacol. 1997; 30(1): 75-83.

[19] Medeiros A, Oliveira EM, Gianolla R, Casarini DE, Negrão CE, Brum PC. Swimming training increases cardiac vagal activity and induces cardiac hypertrophy in rats. Braz J Med Biol Res. 2004; 37(12): 1909-17. 

quantitation in M-mode echocardiography: Results of survey of echocardiographic measurements. Circulation. 1978; 58(6): 1072-83.

[21] Schiller NB, Shah PM, Crawford M, Demaria A, Devereux R, Feigenbaum $\mathrm{H}$, et al. Recommendations for quantification of the left ventricle by two-dimensional echocardiopraphy. American Society of Echocardiography Committee on Standards, Subcommittee on Quantitation of Two-Dimensional Echocardiograms. J Am Soc Echocard. 1989; 2(5): 358-67. Kochakian CD, Robertson E, Bartlett MN. Sites and nature of protein anabolism stimulated by testosterone propionate in the rats. Am J Physiol. 1950; $163: 332-46$.

Alves MF, Araujo MC, Juliano MA, Oliveira EM, Krieger JE, Càsarini $\mathrm{DE}$, et al. A continuous fluorescent assay for the determination of plasma and tissue angiotensin I-converting enzyme activity. Braz J Med Biol Res. 2005; 38(6): 86168.

Bradford MM. A rapid and sensitive method for the quantitation of microgram quantities of protein utilizing the principle of protein-dye binding. Anal Biochem. 1976; 72: 248-54.

Kohara K, Tabuchi Y, Senanayake P, Brosnihan KB, Ferrario CM Reassessment of plasma angiotensins measurement: effects of protease inhibitors and sample handling procedures. Peptides. 1991; 12(5): 1135-41.

[26] Chomczynski P, Sacchi N. Single step method of RNA isolation by acid guanidinium thiocyanate-phenol-chloroform extraction. Anal Biochem. 1987; 162(1): 156-9. 

exercise training induces cardiac hypertrophy in mice. Braz J Med Biol Res. 2003; 36(12): 1751-9.

[28] Oliveira EM, Sasaki MS, Cerencio M, Barauna VG, Krieger JE. Local renin-angiotensin system regulates LV hypertrophy induced by swimming training independent of circulating renin: a pharmacological study. J Renin Angiotensin Aldosterone Syst. 2009; 10(1): 15-23.

[29] Lorell BH, Carabello BA. Left ventricular hypertrophic: pathogenesis, detection, and prognosis. Circulation. 2000; 102(4): 470-9.

[30] Lips DJ, deWindt LJ, Dave JW, Kraaij V, Doevendans PA. Molecular determinants of myocardial hypertrophy and failure: alternative pathways for beneficial and maladaptive hypertrophy. Eur Heart J. 2003; 24(10): 883-96.

[31] Brilla CG, Zhou G, Matsubara L, Weber KT. Collagen metabolism in cultured adult rat cardiac fibroblasts: response to angiotensin II and aldosterone. J Mol Cell Cardiol. 1994; 26(7): 809-20 Krieg A, Scharhg J, Alberts T, Kinderman W, Urhause A. Cardiac Tissue Doppler in Steroid Users. Int J Sports Med. 2007; 28(8): 638-43. Pearson AC, Schiff M, Mrosek D, Labovitz AJ, Williams GA. Left ventricular function in weightlifters. Am J Cardiol. 1986; 58(13): 1254-9. De Piccoli B, Giada F, Benettin A, Sartori F, Piccolo E. Anabolic steroid use in body builders: An echocardiographic study of left ventricle morphology and function. Int J Sports Med. 1991; 12(4): 408-12. 
Fibrosis an renin-angiotensin-aldosteerone system. Circulation. 1991; 83(6): 184965.

[36] Sarkar S, Vellaichamy E, Yong D, Sem S. Influence of cytokines and growth factors in ang II-mediated collagen upregulation by fibroblasts in rats: role of myocytes. Am J Physiol. Heart Circ Physiol. 2004; 287(1): H107-17. Barauna VG, Magalhaes FC, Krieger JE, Oliveira EM. AT1 receptor participates in the cardiac hypertrophy induced by resistence training in rats. Am $\mathbf{J}$ Physiol Regul Integr Comp Physiol. 2008; 295(2):R381-87. Oliveira EM, Krieger JE. Chronic $\beta$-adrenoceptor stimulation and cardiac hypertrophy with no induction of circulating renin. Eur J Pharmacol. 2005; 520 (13): $135-41$ Busatto VC, Cicilini MA, Mill JG. Increased angiotensin-converting enzyme activity in the left ventricle after infarction. Braz J Med Biol Res. 1997; 30(5): 679-87.

[40] Matsubara, H. Pathophysiological role of angiotensin II type 2 receptor in cardiovascular and renal diseases. Circ Res. 1998; 83(12): 1182-91.

[41] Unger $T$. The angiotensin type 2 receptor: Variations on an enigmatic theme. J Hypertens. 1999; 17(12): 1775-86.

$$
\text { Paul M, Mehr AP, Kreutz R. Physiology of local renin-angiotensin }
$$
systems. Physiol Rev. 2006; 86(3): 747-803.

Gasparo M, Catt KJ, Inagami JW, Unger YH. International Union of Pharmacology. XXIII. The Angiotensin II Receptors. Pharmacol Rev. 2000; 52(3): $415-72$. 
Eplerenone offsets cardiac and adverse remodeling in spontaneously hypertensive rats. Inter J Cardiol. 2006; 114(1): 1-7.

Santos CF, Greene AS, Salgado MC, Oliveira EB. Conversion of renin substrate tetradecapeptide to angiotensin II by rat MAB elastase-2. Can J Physiol Pharmacol. 2004; 82(11): 1000-5.

Wehling M. Cardiac and vascular synthesis of aldosterone: yes, but...

Current Opinion in Endocrinological, Diabetes and Obesity. 2005; 12: $211-4$.

$$
\text { Nagata K, Obata K, Xu J, Ichihara S, Noda A, Kimata } H \text {, et al. }
$$

Mineralocorticoid receptor antagonism attenuates cardiac hypertrophy and failure in low-aldosterone hypertensioe rats. Hypertension. 2006; 47(4): 656-64.

Rocha R, Rudolph AE, Frierdick GE, Nachowiak DA, Kekec BK, Blomme EA, et al. Aldosterone induces a vascular inflammatory phenotype in rat heart. Am. J. Physiol. Heart Circ. Physiol. 2002; 283(5): H1802-10. Zhang YL, Zhou SX, Lei J, Yuan GY, Wang JF. Blockades of angiotensin and aldosterone reduce osteopontin expression and interstitial fibrosis infiltration in rats with myocardial infarction. J Clin Med. 2008; 121(21): 2192-6. Booz GW, Baker KM. Molecular signalling mechanisms controlling growth and function of cardiac fibroblast. Cardiovasc Res. 1995; 30(4): 537-43.

Satoh M, Nakamura M, Saitoh H, Satoh H, Akatsu T, Iwasaka J, et al. Aldosterone synthase (CYP11B2) expression and myocardial fibrosis in the failing human heart. Clin Sci. 2002; 102(4): 381-6. 
induced by cross-talk between angiotensin II and aldosterone. J Mol Med. 2008; 86(6): 673-8

Min LJ, Mogi M, Li JM, Iwanami J, Iwai M, Horiuchi M. Aldosterone and angiotensin II synergistically induce mitogenic response in vascular smooth muscle cells. Circ Res. 2005; 97(5):434-42.

\section{Figure legends}

Figure 1 - Cardiac hypertrophic. The cardiac hypertrophic in control $(C, n=7)$, anabolic steroid (AS, n=7), trained $(T, n=7)$, trained anabolic steroid (TAS, n=7) (A), anabolic steroid + Losartan $(A S+L, n=7)$, trained anabolic steroid + Losartan $(T A S+L, n=7)(B)$, anabolic steroid + Spironolactone $(A S+S, n=7)$ and trained anabolic steroid + Spironolactone (TAS+S, n=7) (C) groups. The $\mathrm{CH}$ was evaluated by ratio of Left ventricular weight (LVW) to animal body weight (BW) (LVW/BW, 口) and echocardiography ( $\bullet$ ). Data are presented as mean \pm SD. $† P<0.05$ vs $C, \# P<0.05$ vs T, $\ddagger$ $P<0.05$ vs AS, $\& P<0.05$ vs TAS

Figure 2 - Cardiac Collagen. Collagen volumetric fraction (CVF) (on the left) and collagen cardiac type I ( $\square$ ) and type III ( $\square$ ) expression (on the right) in control (C, n=7), anabolic steroid (AS, $n=7$ ), trained ( $T, n=7$ ), trained anabolic steroid (TAS, $n=7$ ) (A and D), anabolic steroid + Losartan $(\mathrm{AS}+\mathrm{L}, \mathrm{n}=7)$, trained anabolic steroid + Losartan 
$(\mathrm{TAS}+\mathrm{L}, \mathrm{n}=7)(\mathrm{B}$ and $\mathrm{E})$, anabolic steroid + Spironolactone $(\mathrm{AS}+\mathrm{S}, \mathrm{n}=7)$ and trained anabolic steroid + Spironolactone $(\mathrm{TAS}+\mathrm{S}, \mathrm{n}=7)(\mathrm{C}$ and $\mathrm{F})$ groups. A representative blots of collagen type I and III expression were above the figure D, E and F. Targeted bands were normalized to cardiac GAPDH. Data are presented as mean \pm SD. $\dagger P<0.05$ vs $\mathrm{C}, \# P<0.05$ vs $\mathrm{T}, \ddagger P<0.05$ vs AS, $\& P<0.05$ vs TAS.

Figure 3 - Cardiomyocytes diameter. Cardiomyocytes diameter in Control (C, $n=7)$, anabolic steroid (AS, n=7), trained $(T, n=7)$, trained anabolic steroid (TAS, $n=7$ ) (A) anabolic steroid + Losartan ( AS+L, n=7), trained anabolic steroid + Losartan (TAS $+\mathrm{L}$, $\mathrm{n}=7)(\mathrm{B})$, anabolic steroid + Spironolactone $(\mathrm{AS}+\mathrm{S}, \mathrm{n}=7)$ and trained anabolic steroid + Spironolactone (TAS $+\mathrm{S}, \mathrm{n}=7)(\mathrm{C})$ groups. Data are presented as mean $\pm \mathrm{SD} . \dagger P<0.05$ vs C, \#P<0.05 vs $\mathrm{T}, \ddagger P<0.05$ vs AS, $\& P<0.05$ vs TAS.

Figure 4 - Cardiac Renin-Angiotensin System. Cardiac angiotensin converting enzyme (ACE) activity (on the left), AT1 ( $\square$ ) and AT2 ( $\bullet$ ) receptors expression (on the right) in Control $(C, n=7)$, anabolic steroid (AS, $n=7)$, trained $(T, n=7)$, trained anabolic steroid (TAS, $n=7)(A$ and $B$ ) anabolic steroid + Losartan ( $A S+L, n=7)$, trained anabolic steroid + Losartan (TAS+L, n=7) (C and D), anabolic steroid + Spironolactone (AS+S, $n=7)$ and trained anabolic steroid + Spironolactone $(\mathrm{TAS}+\mathrm{S}, \mathrm{n}=7)$ ( $\mathrm{E}$ and $\mathrm{F}$ ) groups. Representative blots of AT1 and AT2 receptors expression were above the figure B, D and $F$. Targeted bands were normalized to cardiac $\alpha$-tubulin. Data are presented as mean \pm SD. $\dagger P<0.05$ vs $\mathrm{C}, \# P<0.05$ vs $\mathrm{T}, \ddagger P<0.05$ vs $\mathrm{SA}, \& P<0.05$ vs TAS. 
Figure 5 - Cardiac aldosterone synthase gene (CYP11B2) and $11 \beta$-hydroxysteroid

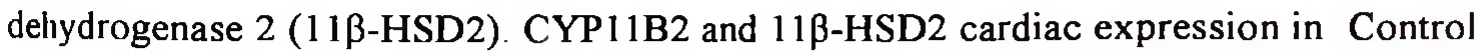
$(C, n=7)$, anabolic steroid (AS, $n=7)$, trained $(T, n=7)$, trained anabolic steroid (TAS, $n=7)(A)$, anabolic steroid + Losartan (AS $+L, n=7)$, trained anabolic steroid + Losartan $(\mathrm{TAS}+\mathrm{L}, \mathrm{n}=7)(\mathrm{B})$, anabolic steroid + Spironolactone $(\mathrm{AS}+\mathrm{S}, \mathrm{n}=7)$ and trained anabolic steroid + Spironolactone $(\mathrm{TAS}+\mathrm{S}, \mathbf{n}=7)(\mathrm{C})$ groups. Representative blots of CYP11B2 and $11 \beta$-HSD2 expression were above the figures. Targeted bands were normalized to cardiac GAPDH. Data are presented as mean \pm SD. $\dagger P<0.05$ vs $C, \# P<0.05$ vs $\mathrm{T}$, $\ddagger$ $P<0.05$ vs AS, \& $P<0.05$ vs TAS

Figure 6 - Inflammatory Factors. Transforming growth factor $\beta$ (TGF $\beta, \square$ ) and osteopontin ( $\square$ ) cardiac expression in Control (C, $n=7$ ), anabolic steroid (AS, $n=7)$, trained $(T, n=7)$, trained anabolic steroid (TAS, $n=7)(A)$, anabolic steroid + Losartan $(\mathrm{AS}+\mathrm{L}, \mathrm{n}=7)$, trained anabolic steroid + Losartan $(\mathrm{TAS}+\mathrm{L}, \mathrm{n}=7)(\mathrm{B})$, anabolic steroid + Spironolactone $(\mathrm{AS}+\mathrm{S}, \mathrm{n}=7)$ and trained anabolic steroid + Spironolactone $(\mathrm{TAS}+\mathrm{S}$, $n=7)(C)$ groups. Representative blots of TGF $\beta$ and osteopontin expression were above the figure. Targeted bands were normalized to cardiac GAPDH. Data are presented as mean \pm SD. $\dagger P<0.05$ vs $\mathrm{C}, \# P<0.05$ vs $\mathrm{T}, \ddagger P<0.05$ vs SA, $\& P<0.05$ vs TAS. 
Tables

TABLE 1 - Primers sequence used for RT.PCR

\begin{tabular}{|c|c|c|}
\hline Gene & Primers sequence $(5-3)$ & Amplicon \\
\hline $\begin{array}{c}\text { Col la1 } \\
(\text { Col type 1) }\end{array}$ & $\begin{array}{l}\text { AGAGAGCATGACCGA TGGA } \\
\text { GAGGTTGCCAGTCTGTTOG }\end{array}$ & $172 \mathrm{pb}$ \\
\hline $\begin{array}{c}\text { Col 3 } \alpha_{1} \\
\text { (Col type II) }\end{array}$ & $\begin{array}{l}\text { AAGGTCCACGAGGTGACAA } \\
\text { AGGGCCTGGACTACCAACT }\end{array}$ & $143 \mathrm{pb}$ \\
\hline CYP11B2 & $\begin{array}{l}\text { GGATGTCCAGCAAAGTCTC } \\
\text { ATTAGTGCTGCCACAATGC }\end{array}$ & $324 \mathrm{pb}$ \\
\hline$M R$ & $\begin{array}{l}\text { GCTTTGATGGTAGCTGCG } \\
\text { TGAGCACCAATCCGGTAG }\end{array}$ & $154 \mathrm{pb}$ \\
\hline $11 \beta-H S D 2$ & $\begin{array}{l}\text { CCGGTTGTGACAC TGGTTTT } \\
\text { GGGGTATGGCATGTCTCCTG }\end{array}$ & $419 \mathrm{ph}$ \\
\hline TGF $\beta$ & $\begin{array}{l}\text { GGCGGTGCTCGCTTTGTA } \\
\text { GCGGGTGACTTCTTTGGC }\end{array}$ & $106 \mathrm{pb}$ \\
\hline Osteopontin & $\begin{array}{l}\text { GTCCTTCACTGCCAGCACAC } \\
\text { GAACTCGCCTGACTGTCGAT }\end{array}$ & $450 \mathrm{pb}$ \\
\hline GAPDH & $\begin{array}{l}\text { ATGGGTGTGAACCACGAGAA } \\
\text { CGAGTACTGGTGTCAGGTA }\end{array}$ & $141 \mathrm{pb}$ \\
\hline
\end{tabular}


TABLE 2- Blood pressure and ventricular fonction

\begin{tabular}{|c|c|c|c|c|c|c|c|c|}
\hline \multirow{2}{*}{ Graups } & \multicolumn{2}{|c|}{$\mathrm{BP}(\mathrm{mm} \mathrm{mg})$} & \multicolumn{2}{|c|}{ Systolic Function } & \multicolumn{4}{|c|}{ Dieslolic Function } \\
\hline & Eefore & After & LVEF (\%) & LVFS (\%) & PEWV (m/s) & PAWV (m/s) & E/A ralio & IVRT $(m / n)$ \\
\hline $\mathrm{C}$ & $120.8 \pm 9.2$ & $124,8 \pm 5,7$ & $81,05 \pm 4,38$ & $44,30 \pm 3,44$ & $0,61 \pm 0,07$ & $0,43 \pm 0,08$ & $1.53 \pm 0,08$ & $25.2 \pm 1.7$ \\
\hline AS & $126,5 \pm 11,2$ & $126,8 \pm 8,1$ & $79,03 \pm 5,17$ & $0,39 \pm 4,09$ & $0,56 \pm 0.06$ & $0,4 \pm 0,03$ & $1.34 \pm 0.12$ & $24,2 \pm 2,5$ \\
\hline$A S+L$ & $120,4 \pm 4,4$ & $124,5 \pm 4,3$ & $80,92 \pm 3,01$ & $44,21 \pm 4,42$ & $0,58 \pm 0,05$ & $0,38 \pm 0,06$ & $1,40 \pm 0,19$ & $25,7 \pm 0.9$ \\
\hline$A S+S$ & $127,9 \pm 7,7$ & $125.5 \pm 1,9$ & $79,71 \pm 5,33$ & $41,67 \pm 3,67$ & $0,60 \pm 0,05$ & $0,4 \pm 0,05$ & $1,38 \pm 0,23$ & $27,5 \pm 1,9$ \\
\hline$T$ & $120,0 \pm 10,8$ & $126,8 \pm 6,7$ & $78,55 \pm 2,95$ & $4,23 \pm 2,74$ & $0,62 \pm 0,06$ & $0,40 \pm 0,09$ & $1,68 \pm 0,23$ & $30,6 \pm 2,8$ \\
\hline TAS & $128,0 \pm 8,03$ & $124,4 \pm 4,3$ & $79,02 \pm 3.76$ & $40,77 \pm 3,78$ & $0,42 \pm 0,101$ & $0,38 \pm 0,04$ & $1.07 \pm 0.251$ & $23,5 \pm 2,3$ \\
\hline TAS+L & $125,5 \pm 8,2$ & $126,4 \pm 2,3$ & $82,12 \pm 2,74$ & $42,08 \pm 2,76$ & $0,59 \pm 0.07^{\star}$ & $0,40 \pm 0,09$ & $1.39 \pm 0,12 *$ & $28,3 \pm 1,15$ \\
\hline TAS+S & $125.6 \pm 3,9$ & $128,1 \pm 9,6$ & $78,66 \pm 3,03$ & $40,42 \pm 3.71$ & $0,57 \pm 0,07^{\star}$ & $0.42 \pm 0,05$ & $1,46 \pm 0,14^{\circ}$ & $2 x, 7 \pm 1$ \\
\hline
\end{tabular}

Coniral (C), Tralned (T), Anabolic Sterald (AS), Tralned Anabalic Steraid (TAS), Anabolic Sterald + Losartan (AS + L), Tralnad Anabollc Sterald * Losarian TAS+LIAnabolic Sterald * Splranolactane (AS+S) and Trained Anabalic Steraid + Splronalactane (IAS+ST.

Value are means \pm SD; BP, blood pressure; LVEF, left ventricular ejectlon fraction; LVFS, left ventricular fractional sharienlng; PEWV, peak velocity wave $E_{;}$PAWN, peak velocity wave A; IVRT, isolumetric relaxion time. Significant difference $v \leq$ IC, $\& A S: P<0.05$. 
FIGURE 1
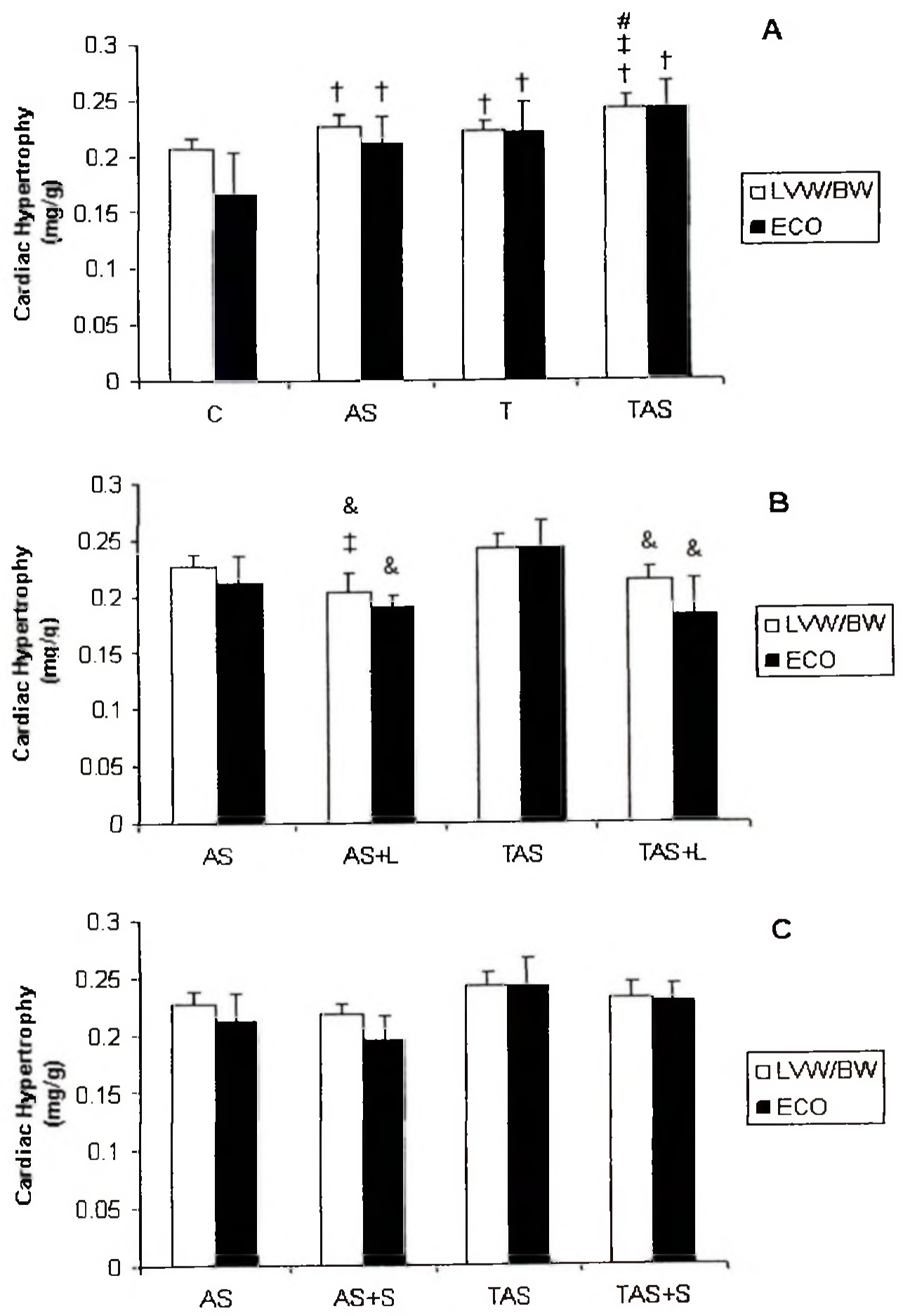
FIGURE 3
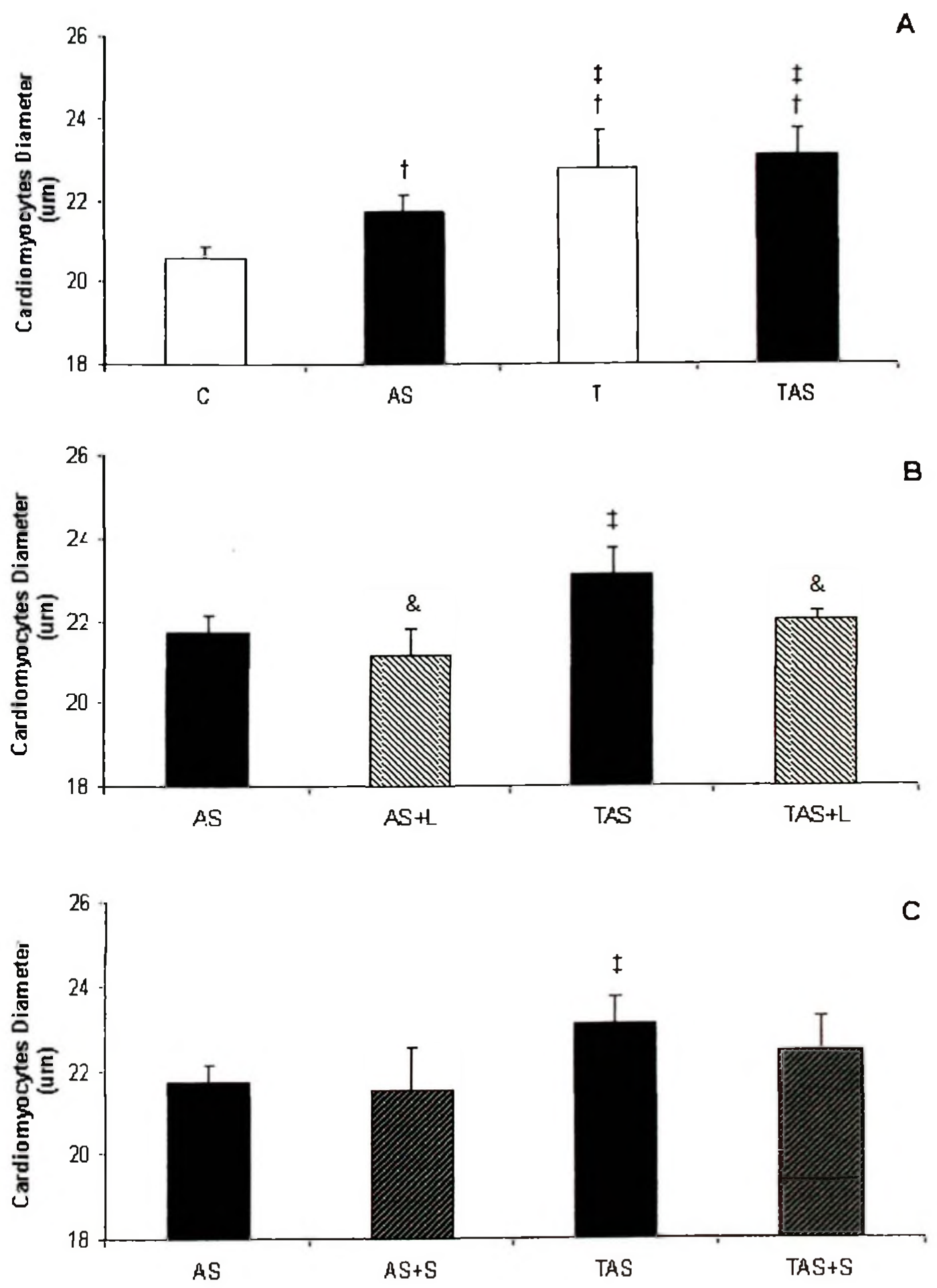
FIGURE 5
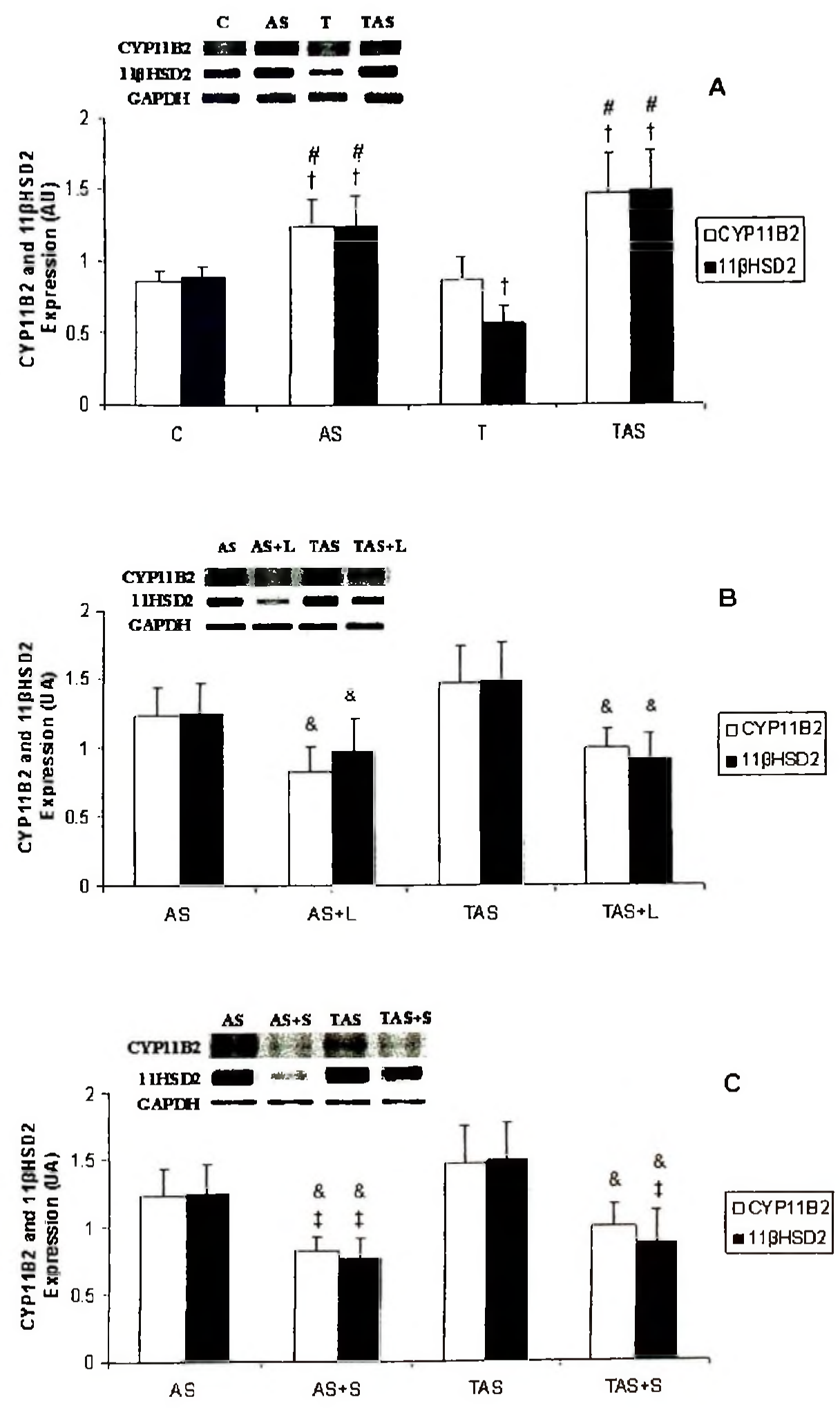


\section{FIGURE 6}
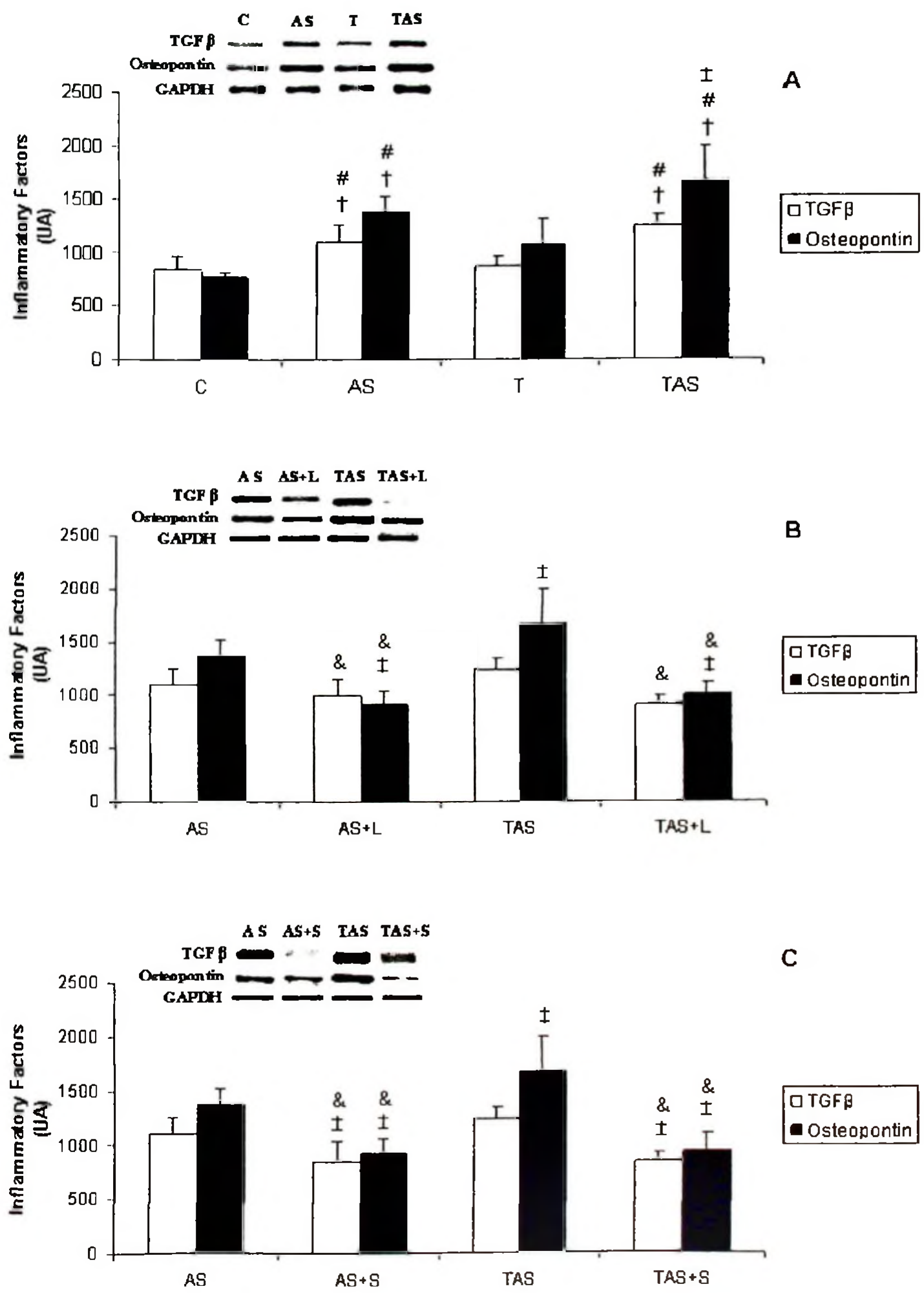
CHRONIC USE OF ANABOLIC STEROID ASSOCIATED WITH AEROBIC

EXERCISE TRAINING IMPAIRS CORONARY BLOOD FLOW IN

NORMOTENSIVE RATS

F. R. Roque ${ }^{1}$, K. De Angelis ${ }^{2,3}$, U. P. R. Soci ${ }^{1}$, M. A. Coelho', M. C. Irigoyen ${ }^{2}$, J. J. F. Sarkis $^{4}$, E. M. Oliveira ${ }^{1}$.

' Laboratory of Biochemistry, School of Physical Education and Sports, University of São Paulo, São Paulo, SP, Brazil;

${ }^{2}$ Hypertension Unit, Heart Institute, Medical School, University of São Paulo, São Paulo, SP, Brazil.

${ }^{3}$ Human Movement Laboratory, São Judas Tadeu University - São Paulo, SP, Brazil.

${ }^{4}$ Department of Biochemistry, Federal University of Rio Grande do Sul, Rio Grande do Sul, RS, Brazil.

Short title: Anabolic Steroid \& exercise impair coronary blood flow

Corresponding Author: Edilamar Menezes de Oliveira

Laboratory of Biochemistry, School of Physical Education and Sport, University of São Paulo, Brazil.

Av. Prof. Mello Moraes, 65, Butantã, Cidade Universitária, 05508-900, São Paulo-SP, Brazil.

Phone: 55-11-3091-3136, Fax: 55-11-3813-5921

e-mail address: edilamar@usp.br 


\section{Abstract}

Anabolic steroids (AS) cause adverse cardiovascular effects. Despite this fact, AS have been widely used by athletes and non-athletes in training. The aim of the present study was to investigate the cardiovascular effects of nandrolone decanoate administration during swimming training on coronary blood flow, cardiac capillary density and adenosine formation. Male Wistar rats were randomized into sedentary (S), sedentary AS treated (SA), trained (T), and trained AS treated (TA). AS (nandrolone decanoate; $10 \mathrm{mg} / \mathrm{kg} /$ week) was administered during 10 weeks of swimming training ( 5 times/ wk). Colored microspheres (mi) were used to evaluate coronary blood flow and cardiac output. Capillary density was evaluated by light microscopy. Adenosine formation was measured by adenine nucleotides hydrolysis enzymes. The baseline coronary blood flow (S 4142 \pm 461, SA $3848 \pm 522$, TA $2938 \pm 551$ vs. T $6631 \pm 494$ number of $\mathrm{mi} / \mathrm{heart}$ weight, $P=0.001$ ) increased with training and the use of AS in trained group abolished this adaptation. The cardiac output (S $146.6 \pm 5.6$, SA $146.2 \pm 15.4$, T $169.5 \pm 29.9$ vs. TA $\left.82.3 \pm 9.5 \mathrm{~mL} . \mathrm{kg}^{-1} \cdot \mathrm{min}^{-1}, P=0.029\right)$ and capillary density (S 77 $\pm 5, \mathrm{SA} 77 \pm 3, \mathrm{~T} 77 \pm 5 \mathrm{vs}$. TA $55 \pm 4 \mathrm{~mm}^{2}, P=0.02$ ) decreased in TA group. Swimming training increased enzyme activity response to circulating adenosine formation (ATP 43\%, ADP 62\%, AMP 34\% hydrolysis vs. S group) and the AS precluded this response to training. Supraphysiological dose of AS decreased cardiac output and abolished the exercise training induced coronary blood flow improvement, probably related to a decreased capillary density and lowered circulating adenosine formation.

Keywords: Nandrolone decanoate, swimming training, adenosine. 


\section{Introduction}

Anabolic steroids (AS) are synthetic derivatives of testosterone, which were produced for clinical use. However, because of their anabolic properties they have been widely used by athletes to enhance performance (1). Moreover, an increasing number of the young people have made abusive use of these substances to improve their physical appearance $(24,37)$

The chronic use of these drugs causes adverse effects, particularly in the cardiovascular system, and it is dose and type dependent (29). Several cardiovascular effects have been reported in AS users, including heart failure, thrombosis, cardiac hypertrophy, ventricular fibrillation, hypertension and sudden death $(20,33)$. The majority of these studies are related to strength athletes, however, the increasing use of these substances by aerobic sports athletes and non-athletes demonstrate the importance of investigating the interactions between AS abuse and physical training. Also, in experimental animals we have shown that AS combined with aerobic training induces exacerbated cardiac hypertrophy with interstitial fibrosis (41). The cardiac hypertrophy is associated with activation of the cardiac renin angiotensin system (RAS) and the improvement in LV function promoted by exercise training is lost by AS treatment.

In contrast to AS effects, aerobic training induces beneficial cardiovascular adaptations, including resting bradycardia $(25,31)$, physiological cardiac hypertrophy $(18,31)$ and improvement of the cardiovascular function (28), which increased cardiac perfusion. The presence of local vasodilatation by metabolic factors allows a better tissue perfusion. Adenosine has been considered an important physiological modulator for this vasodilatation. Thus, adenosine, a metabolite of adenine nucleotides, exerts a variety of functions in several organs and the vasodilatation might be the major action 
of the adenosine. Studies demonstrate that both running and swimming training increased the $5^{\prime}$-nucleotidase enzyme activity in the heart $(26,39)$. This is the main enzyme responsible for the degradation of extracellular nucleotides of adenine, leading to the adenosine formation.

The aim of the present study was to investigate the effects of administration of an AS, nandrolone decanoate, in combination with swimming training of rats. The effects were measured in coronary blood flow response, cardiac capillary density and adenosine formation as factors that may contribute to heart perfusion.

\section{Methods}

\section{Animals}

Male Wistar rats (180-250g) were housed in standard cages, and standard rat chow and water were provided ad libitum. The environmental temperature was kept at $23 \pm 1{ }^{\circ} \mathrm{C}$ and a $12: 12$-h dark-light cycle was maintained throughout the experiment. Animals were weighed every week. All protocols and surgical procedures used were in accordance with the guidelines of the Brazilian College for Animal Experimentation and were approved by the Ethics Committee for Ethics in Research of School of Physical Education and Sport of the University of Sao Paulo (protocol number 2006/05)

Two groups were randomly assigned with twenty-eight rats each, and separated for use in different experimental protocols: 1) for morphological, morphometric and biochemical analysis and, 2) for hemodynamics and blood flow analysis. In each group, the rats were randomly subdivided into 4 groups: sedentary (S), sedentary AS-treated (SA), trained (T) and trained AS-treated (TA). In AS-treated groups nandrolone 
decanoate (Deca-durabolin; Organon, Roseland, NJ) was subcutaneously administered the dose of $10 \mathrm{mg} \cdot \mathrm{kg}^{-1} \cdot \mathrm{wk}^{-1}(5 \mathrm{mg} / \mathrm{kg}$ body weight per injection twice a week). This dose is comparable to the dose frequently used by abusers of AS (40).

\section{Training Protocol}

The training protocol has been previously described $(31,35)$. The swimming training was performed during the dark cycle of the rat and consisted of 5 days/ week swimming sessions of 60 minutes duration for 10 weeks in a swimming system with warmed water at $30-32^{\circ} \mathrm{C}$. Exercise duration and workload were increased gradually until the rats could swim for 60 min wearing caudal dumbbells weighting $5 \%$ of their body weight. Thereafter, duration and workload were constant. All animals were weighed once a week and the workload adjusted to body weight variations. Sedentary groups were placed in the swimming apparatus for 10 minutes twice a week without workload to control for being in the water. Oxygen $\left(\mathrm{O}_{2}\right)$ uptake of rats swimming individually is about $50-65 \%$ of maximum $\mathrm{O}_{2}$ uptake. This low intensity long period training protocol is effective for promotion of cardiovascular adaptations and for increase of muscle oxidative capacity $(5,31)$. This protocol has already been used previously in our laboratory (35).

\section{Cardiac Morphological and Morphometric Analysis}

Twenty-four hours after the last exercise session rats were killed by decapitation and the heart was removed.

To measure cardiac mass, the heart was removed from thoracic cavity and dissected to obtain the left ventricle (LV; free wall plus septum) weight. To evaluate 
cardiac hypertrophy the LV weight was normalized by total body weight (BW) of the animal (LV/BW in $\mathrm{mg} / \mathrm{g})$.

For morphometric analysis, after weighed, the LV was fixed in $6 \%$ formaldehyde and embedded in paraffin, cut in $5 \mu \mathrm{m}$ sections at the level of papillary muscle and subsequently stained with Periodic Acid Schiff (PAS) to visualize cellular structures. Three randomly selected sections from each animal were visualized by light microscopy using an oil immersion objective with a calibrated magnification ( $x 400)$. The image was amplified and the measurements were performed. The analysis of capillary density (vessels with $\leq 12 \mu \mathrm{m}$ ) was expressed as the number of vessels per millimeter squared $\left(\mathrm{mm}^{2}\right)$, as described previously $(3,32)$.

\section{Hemodynamics and blood flow analysis}

The coronary blood flow was evaluated by the colored microspheres technique as previously described $(14,21)$. Briefly, twenty-four hours after the last exercise session, the rats were anesthetized with ketamine $(90 \mathrm{mg} / \mathrm{kg})$ and xilasine $(10 \mathrm{mg} / \mathrm{kg}$, ip) to implant 2 catheters filled with saline solution into the femoral artery and left ventricle. A catheter of PE-10 tubing was positioned into the abdominal aorta through the femoral artery for direct measurements of arterial pressure (AP). The second catheter of PE-50 was inserted into the left ventricle through the right carotid artery for colored microspheres infusion. The catheter position was determined by observing the characteristic left ventricular pressure waveform at surgery, and confirmed on necropsy. The catheters were anchored with silk sutures and exteriorized at the back of the neck. Rats receiving food and water ad libitum were studied one day after the procedure and the animals were conscious and allowed to move freely during the experiments. 
The arterial femoral cannula was connected to a strain-gauge transducer (Narco Bio-Systems Miniature Pressure Transducer RP 1500, Houston, TX, USA) and arterial pressure signals were monitored continuously, except during microsphere infusion and withdrawal of a reference blood sample. The AP signals were recorded and processed with a microcomputer equipped with an analog-to-digital converter board (CODAS, 1kHz sampling frequency; Dataq Instruments, Inc., Akron, OH, USA). The recorded data were analyzed on a beat-to-beat basis to quantify changes in mean AP and heart rate (HR).

Dye-Trak colored microspheres (15 $\mu \mathrm{m}$; Triton Technology, San Diego, CA, USA) were infused at rest $(200,000$ red microspheres) for blood flow and cardiac output (CO) determination. Then, the animals were killed and the hearts removed. The reference blood samples and tissues were processed and blood flow and $\mathrm{CO}$ were calculated as previously described $(13,21,23)$. The minimum acceptable absorbance was 0.010 absorbance units $(\mathrm{AU})$. The tissue flow rate was represented as number of microspheres in the tissue normalized by heart weight of the animal and by blood flow in the tissue $\left(\mathrm{mL} \cdot \mathrm{kg}^{-1} \cdot \mathrm{min}^{-1}\right)$.

\section{Biochemical Analysis}

Blood samples were drawn after decapitation and blood serum fraction was isolated by subsequently centrifuged in plastic tubes at $5000 \mathrm{~g}$ for 15 minutes at $4^{\circ} \mathrm{C}$. The serum samples obtained were stored on $-20^{\circ} \mathrm{C}$ until used in the experiments.

ATP diphosphohydrolase activity 
ATP and ADP hydrolysis were determined using a modification of the method described by Yegutkin (51). The enzyme activity in the blood serum fraction was routinely determined at $37^{\circ} \mathrm{C}$ in the following incubation-medium: $112.5 \mathrm{mM}$ Tris- $\mathrm{HCl}$, $\mathrm{pH} 8.0$, with approximately $1.0 \mathrm{mg}$ of serum protein for 40 minutes in a final volume of $0.2 \mathrm{~mL}$. The reactions were initiated by ADP or ATP addition as substrate $(2.0 \mathrm{mM}$ and $3.0 \mathrm{mM}$, respectively) and the reaction mixture was preincubated for $10 \mathrm{~min}$ at $37^{\circ} \mathrm{C}$ Incubation times and protein concentration were chosen in order to ensure the linearity of the reaction. The reactions were stopped by the addition of $0.2 \mathrm{~mL}$ of $10 \%$ trichloroacetic acid (TCA). All the samples were chilled on ice and the amount of $P_{i}$ liberated was measured by according to the procedure of Lanzetta (27). In order to correct non-enzymatic hydrolysis, we performed controls by adding the serum after the reaction was stopped with TCA.

\section{5'-nucleotidase activity}

The enzyme activity was routinely determined at $37^{\circ} \mathrm{C}$ in the following incubation medium in the blood serum as previously described (12): the reaction mixture containing AMP as a substrate $(2.0 \mathrm{mM})$ in $100 \mathrm{mM}$ Tris- $\mathrm{HCl}$, pH 7.5 was incubated with $1.0-1.5 \mathrm{mg}$ protein serum at $37^{\circ} \mathrm{C}$ in a final volume of $0.2 \mathrm{~mL}$. As described above, all others procedures were the same as for ATP-diphosphohydrolase activity

Enzymes activities were expressed as nanomoles of $P_{i}$ released per minute per milligram of protein ( $\mathrm{nmol} \mathrm{P}_{\mathrm{i}} \cdot \mathrm{min}^{-1} \cdot \mathrm{mg}^{-1}$ protein). The protein content was determined by the Bradford method (11) by using bovine serum albumin as the standard (Bio-Rad protein assay). 
Testosterone Measurement

The testosterone was determined by radioimmunoassay in plasma using the kit COAT-A-COAT Total Testosterone from Diagnostic Products Corporation (human) kit (Los Angeles, CA).

\section{Statistical Analysis}

Data are reported as mean \pm standard error of mean (SEM). Statistical analysis was performed using two-way ANOVA to evaluate body weight, at the initial and final protocol, and one-way ANOVA to all others statistical analyses. Duncan's post hoc test was used for individual comparisons between means when a significant change was observed with ANOVA. $P<0.05$ was accepted as statistically significant.

\section{Results}

Body weight and heart weight

The body weight at the beginning of the study was similar among the groups, however at the end of 10 weeks of experimental protocol SA, T and TA groups' body weight was lower when compared to $\mathrm{S}$ group $(P<0.01$; Table 1$)$. Table 1 shows the values of the $\mathrm{LV}$ weight and $\mathrm{LV} / \mathrm{BW}$ ratio. The $\mathrm{LV}$ weight was similar among groups and the $\mathrm{LV} / \mathrm{BW}$ ratio showed an increase of $5 \%$ in the SA group (not statistically significant; $P=0.11)$ and of $13 \%$ and $17 \%$ in the T and TA groups $(P<0.00 I)$, respectively, when compared to $\mathrm{S}$ group.

\section{Testosterone Measurement}


Results showed that chronic nandrolone administration increased the serum

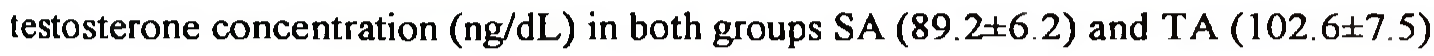
when compared to non-treated $S(10 \pm 1.1)$ and $\mathrm{T}(17.4 \pm 6.6)$ groups $(P<0.00 I)$.

Mean Arterial Pressure and Heart Rate

The mean AP values were similar among groups, however a reduced resting HR was observed in both trained groups compared to sedentary groups (S and SA vS. T and TA; $P<0.01$ ) (Table 1). Furthermore, a strong tendency of decreased HR was observed in both AS treated groups when compared to sedentary group (SA vs. $\mathrm{S} ; \boldsymbol{P}=0.06$ ) and trained group (TA vs. T; $P=0.08$ ).

Cardiac Output and Coronary Blood Flow

Figure 1 shows that resting $\mathrm{CO}$ was similar between $\mathrm{S}, \mathrm{SA}$ and $\mathrm{T}$ groups, however a significant reduction was observed in TA group compared to the others ( $\mathrm{S}$ 146.6 \pm 5.6 , SA $146.2 \pm 15.4$, T $169.5 \pm 29.9$ vs. TA $\left.82.3 \pm 9.5 \mathrm{~mL} . \mathrm{kg}^{-1} \cdot \mathrm{min}^{-1}, P=0.029\right)$. Coronary blood flow, estimated by the number of microspheres in the heart (Figure 2A) increased in T group when compared to the others groups (T $6631 \pm 494 \mathrm{vs.}$ S $4142 \pm 461$, SA $3848 \pm 522$, TA $2938 \pm 551$ number of mi/ heart weight, $P<0.001$ ). However, when the flow was represented as $\mathrm{mL} . \mathrm{kg}^{-1} \cdot \mathrm{min}^{-1}$ (S 3.11 10.29 , SA $3.22 \pm 0.39, \mathrm{~T} 5.49 \pm 1.45, \mathrm{TA} 2.39 \pm 0.26, P=0.06$ ) the increase observed in T group was significant in relation to TA group $(P=0.02)$ and a strong tendency was observed in relation to $\mathrm{S}$ and SA groups $(P=0.053)$ (Figure $2 \mathrm{~B})$.

Capillary density 
Figure 3 shows the analysis of heart capillary density. The AS or the swimming training alone did not change the capillary density in the heart, however in the TA group, there was a reduction when compared with others groups ( $\mathrm{S} 77 \pm 5, \mathrm{SA} 77 \pm 3, \mathrm{~T}$ $77 \pm 5$ vs. TA $55 \pm 4$ capillary density/ $\mathrm{mm}^{2}, P=0.02$ ).

Extracellular adenine nucleotides hydrolysis

Hydrolysis of adenine nucleotides in the blood serum fraction is presented in figure 4 (A, B and C). Results did not reveal any significant alteration in the nucleotides hydrolysis of SA group, but a greater hydrolysis of ATP was observed in both trained groups in relation to sedentary groups (S $0.61 \pm 0.04$, SA $0.50 \pm 0.03$ vs. T $0.90 \pm 0.08$, TA $0.91 \pm 0.07 \mathrm{nmol} \mathrm{P}_{\mathrm{i}} \cdot \mathrm{min}^{-1} \cdot \mathrm{mg}^{-1}$ protein; $\left.P<0.001\right)$. In the trained group, increased ATP degradation was also followed by increases in ADP (S 0.88 40.07 , SA $0.83 \pm 0.06$, TA $1.05 \pm 0.09$ vs. T $1.44 \pm 0.08 \mathrm{nmol} \mathrm{P}_{\mathrm{i}} \cdot \mathrm{min}^{-1} \cdot \mathrm{mg}^{-1}$ protein; $\left.P<0.00 I\right)$ and AMP (S $0.46 \pm 0.03$, SA $0.36 \pm 0.03$, TA $0.46 \pm 0.03$ vs. T $0.61 \pm 0.04 \mathrm{nmol} \mathbf{P}_{\mathrm{i}} \cdot \mathrm{min}^{-1} \cdot \mathrm{mg}^{-1}$ protein; $P<0.001$ ) hydrolysis. Anabolic steroid impairs the increased ADP and AMP hydrolysis observed with training.

\section{Discussion}

The current study showed for the first time that a chronic treatment with supraphysiological doses of nandrolone, harm the improvement in coronary blood flow promoted by aerobic exercise training. Reduced formation of circulating adenosine contributes to lower coronary blood flow and decreased capillary density which would contribute to impairment of blood perfusion in the heart of anabolic steroid trained rats 
This finding may be relevant to the cardiac dysfunction reported in human athletes abusing steroids

Body weight reduction in trained ( $\mathrm{T}$ and $\mathrm{TA}$ ) groups at the end of the protocol was observed and this is consistent with a reduction in intraperitonial fat observed in a previous study performed in our laboratory (41). The fat reduction would be expected because of the increased energy expenditure demand by the swimming training and represents physiological adaptation of the body to regular physical exercise. These changes suggest an increased metabolic rate and are in accordance with previously published data in rats exercised by swimming (47). The body weight of trained rats was lower than that of the sedentary controls, while food intake was higher (47).

In this study, as expected, chronic AS administration caused a significant increase in the serum testosterone concentration in both nandrolone treated groups (SA and TA) and the reduced body weight observed in this group and demonstrated by others $(7,46)$, might be explained by the excess androgens that promote an increase in the adipose tissue metabolism (44), beyond a reduction in the food ingestion (52). Testosterone concentration is inversely correlated with the fat mass and testosterone administration improved fat-free mass in androgen deficiency young men (8).

AS abuse has been associated with hypertension (7), but without consensus in the literature (34). In this study mean AP was not altered as an effect of AS treatment or swimming training. Concerning the cardiovascular effects, resting bradycardia has been considered the hallmark of the aerobic exercise training adaptation and in swimmingtrained rats occurs as a consequence of an increased cardiac vagal effect (31). Resting bradycardia, was observed in both trained groups. 
Left ventricular hypertrophy and remodeling can result from physiological or pathological stimulus. Physiological hypertrophy may occur in response to exercise training and there are many factors influencing the exercise-induced cardiac hypertrophy. These include the mode, intensity, duration and frequency of the exercise regimen $(17,22)$. Physiological hypertrophy is characterized by a uniform ventricular wall and septum growth that is matched with an increase of the chamber dimension. In contrast, pathological cardiac hypertrophy is associated with a ventricular wall and septum growth but decreased ventricular chamber dimensions. In addition pathological hypertrophy is associated with cardiac fibrosis and cardiac dysfunction (22). In the present study, the absolute weight of cardiac mass was not significantly different among the groups. However, the heart weight/ body weight ratio increased to $14 \%$ in the $T$ group compared to $\mathrm{S}$ group. This increase is due to an increase in myocytes diameter (41). Swimming exercise training is related to a volume overload that leads to eccentric cardiac hypertrophy, which is associated with predominant longitudinal myocyte growth and improvement in cardiac performance $(17,31)$

Studies with experimental animals observed that the chronic use of AS by itself promote cardiac growth $(7,46)$. Marsh et al. (30) showed the presence of androgen receptors in the heart in mammalian cultured myocytes, besides demonstrating that testosterone induced a hypertrophic response by acting directly on cardiac muscle cells. Nandrolone administration in this study induced a non-significant increase of cardiac mass of $5 \%$ in the SA group and contributed to cardiac hypertrophy in the TA group (17\%) when compared to S group. However, in contrast with the fact that AS induce myocyte hypertrophy, a previously study from our laboratory demonstrated that only exercise training contributed to the hypertrophy induced by increases on myocyte 
diameter (41), suggesting that another component had been contributing to the increase cardiac index on AS treated groups. The cardiac hypertrophy observed in sedentary AStreated and more exacerbated cardiac hypertrophy in trained AS-treated group could be due to increased inflammatory response and interstitial collagen concentration. This effect is induced in the heart by activation of the cardiac renin angiotensin system (41).

The modest increase on myocardial oxygen extraction induced by exercise training is due to an already near maximal oxygen extraction even in untrained state (49). The high degree of oxygen extraction at rest and the unchanged oxygen-carrying capacity of the blood following exercise training suggest that requirements for additional oxygen must be met by increased coronary blood flow (15). To maintain the performance of the cardiac pump, the degree of cardiac hypertrophy observed with exercise training is followed by increased coronary blood flow (42). Our results corroborate this data, showing that endurance exercise training promotes cardiac hypertrophy followed by increased coronary blood flow, at rest. The increased coronary blood flow may reflect the augmented diastolic filling observed in response to endurance exercise training (28). Since peak coronary flow occurs during diastole, the bradycardia may contribute to the increased coronary blood flow. The bradycardia observed in the trained group would increase this filling because when HR is decreased, the time spent in diastole during each heart beat is longer.

Our results demonstrated that the combination of supraphysiological doses of nandrolone decanoate and swimming training promote cardiac hypertrophy, but not increased coronary blood flow. In this group (TA), we also observed a decreased cardiac output, which could be result of decreased HR and coronary blood flow, beyond an increased peripheral vascular resistance (7). Furthermore, in a previous study of our 
laboratory we demonstrated combined diastolic and systolic dysfunction of the left ventricle occurred as effect of this combination (41).

Adaptations within the coronary vasculature or decrease in the extravascular compressive forces acting on the intramural coronary microvessels are necessary to increase coronary blood flow (15). Coronary vascular adaptations in response to exercise training can be divided into structural and functional, that include angiogenesis and vascular remodeling, and also changes in neurohumoral control or in local vascular control mechanisms (metabolic, myogenic, and endothelial control), respectively (15).

In this study we investigated a possible mechanism of local vascular control that was not demonstrated before despite of others already showed as nitric oxide and superoxide anion production NO (43). Adenosine is a metabolic messenger with an important vasodilator function. In the heart, this nucleoside increases cardiac oxygen supply by increasing coronary flow (36). The mechanism of adenosine generation is through extracellular adenine nucleotide degradation (53). In the present study we observed that the swimming training protocol increased activity of both enzymes responsible by nucleotides hydrolysis in the senum, indicating more circulating adenosine. These results corroborate with others as effects of chronic swimming training, $(26,39)$.

In contrast with exercise trained group, the combination of AS and swimming training decreased the enzymes activity that produces circulating adenosine. In this study, the association showed two different responses: increased ATP hydrolysis, similarly to the T group, forming ADP, but decreasing ADP degradation. It is worth to emphasize that ADP is a potent platelet aggregation factor, and in fact, other study demonstrated that the use of anabolic steroids can stimulate platelet aggregation and 
thrombosis (19). Furthermore, the 5'-nucleotidase activity decreased was also observed in the TA group and these responses may compromise the circulating adenosine formation.

Differences in adenosine formation may contribute to physiological effects observed on the heart, including the higher oxygen delivery capacity due to the potent adenosine vasodilator effects, however adenosine is only one metabolic factor that would contribute to regulate coronary blood flow. Moreover, others properties of this substance may indirectly contribute to coronary artery vasodilatation, for example, increasing nitric oxide half-life trough inhibition of superoxide anion production, another important coronary vasodilator mechanism (43)

Structural adaptations are also related with exercise training. White et al. (50) demonstrated in details the effect of chronic exercise on numerical density and arteriolar diameter of coronary arterioles. Evidence supports that increased capillary density occurs early during the training program, but with prolonged training this increase is proportional to the increase of left ventricular mass (15). These structural changes in the coronary vascular bed are responsible for functional changes that occur with the exercise training (10). Thus, reduced cardiac capillary density demonstrated in this study and by others (45) in response to combination of AS and swimming training is another negative effect for cardiac perfusion.

Numerous reports link the adverse effects of AS on the cardiovascular system and the serious risk of sudden death as consequence of AS abuse $(6,20,48)$. In conclusion, the results observed in this study showed that supraphysiological dose of AS associated with exercise training negate the beneficial effects of exercise by a decrease in the cardiac output and capillary density and a loss of circulating adenosine 
production. Taken together and extrapolating to humans, all these factors contribute to impaired heart perfusion which could increased the risks of cardiovascular disease and sudden cardiac death by AS abuse in athletes.

\section{Acknowledgements}

We gratefully acknowledge the assistance of Prof ${ }^{\circ}$ Dr. Dalton Vassallo and Dr MI

Phillips for the critical reading of the manuscript. FR Roque was the recipient of a FAPESP scholarship ( $\mathrm{n}^{\circ}$ 05/52100-2) and UPR Socci was the recipient of a CNPqPIBIC scholarship. 


\section{References}

1. Alaranta A, Alaranta H, Holmila J, Palmu P, Pietila K, Helenius I. Self-reported attitudes of elite athletes towards doping: differences between type of sport. Int $J$ Sports Med 27: 842-846, 2006.

2. Alves MJ, Dos Santos MR, Dias RG, Abreu Akiho C, Camaroti Laterza M, Rondon MU, de Moraes Moreau RL, Negrão CE. Abnormal neurovascular control in anabolic androgenic steroids users. Med Sci Sports Exerc (Dec 4, 2009). Doi:10.1249/ MSS.0b013e3181c07b74. 
3. Amaral SL, Zorn TM, Michelini LC. Exercise training normalizes wall-to-lumen ratio of the gracilis muscle arterioles and reduces pressure in spontaneously hypertensive rats. J Hypertens 18: 1563-1572, 2000.

4. Andrade TU, Santos MC, Busato VC, Medeiros AR, Abreu GR, Moysés MR, Bissoli NS. Higher physiological doses of nandrolone decanoate do not influence the Bezold-Jarish reflex control of bradycardia. Arch Med Res 39: 27 32,2008 .

5. Baker MA, Horvath SM. Influence of water temperature on oxygen uptake by swimming rats. J Appl Physiol 19: 1215-1218, 1964.

6. Basaria S. Androgen abuse in Athletes: Detection and consequences. J Clin Endocrinol Melab (Feb 5, 2010). Doi: 10.1210/jc. 2009-1579.

7. Beutel A, Bergamaschi CT, Campos RR. Effects of chronic anabolic steroid treatment on tonic and reflex cardiovascular control in male rats. J Steroid Biochem Mol Biol 93: 43-48, 2005.

8. Bhasin S, Buckwalter JG. Testosterone supplementation in older men: a rational idea whose time has not yet come. $J$ Androl 22: 718-731, 2001.

9. Bissoli NS, Medeiros AR, Santos MC, Busato VC, Jarkes RD, Abreu GR, Moysés MR, de Andrade TU. Long-term treatment with supraphysiological doses of nandrolone dacanoate reduces the sensitivity of Bezold-Jarisch reflex control of heart rate and blood pressure. Pharmacol Res 59: 379-384, 2009.

10. Bloor CM. Angiogenesis during exercise and training. Angiogenesis 8: 263-271, 2005. 
11. Bradford MM. A rapid and sensitive method for the quantitation of microgram quantities of protein utilizing the principle of protein-dye binding. Anal Biochem 72: $248-254,1976$.

12. Bruno AN, Oses JP, Bonan CD, Walz R, Battastini AM, Sarkis JJ. Increase of nucleotidase activities in rat blood serum after a single convulsive injection of pentylenetetrazol. Neurosci Res 43: 283-288, 2002.

13. De Angelis K, Gama VM, Farah VA, Irigoyen MC. Blood flow measurements in rats using four color microspheres during blockade of different vasopressor systems. Braz JMed Biol Res 38: 119-125, 2005.

14. De Angelis K, Ogawa T, Sanches IC, Rigatto KV, Krieger EM, Irigoyen MC. Impairment on cardiac output and blood flow adjustments to exercise in LNAME-induced hypertensive rats. J Cardiovasc Pharmacol 47: 371-376, 2006.

15. Duncker DJ, Bache RJ. Regulation of coronary blood flow during exercise. Physiol Rev 88: 1009-1086, 2008.

16. El-Mas MM, Afify EA, Mohy El-Din MM, Omar AG, Sharabi FM. Testosterone facilitates the baroreceptor control of réflex bradycardia: role of cardiac sympathetic and parasympathetic components. J Cardiovasc Pharmacol 38: 754-763, 2001.

17. Evangelista FS, Brum PC, Krieger JE. Duration-controlled swimming exercise training induces cardiac hypertrophy in mice. Braz JMed Biol Res 36: 1751 1759,2003

18. Fagard RH. Effect of training on left ventricular structure and functioning of the normotensive and the hypertensive subject. Blood Press Monit 2: 241-245, 1997. 
19. Ferenchick GS. Anabolic/androgenic steroid abuse and thrombosis: is there a connection? Med Hypotheses 35: 27-31, 1991.

20. Fineschi V, Riezzo I, Centini F, Silingardi E, Licata M, Beduschi G, Karch SB Sudden cardiac death during anabolic steroid abuse: morphologic and toxicologic findings in two fatal cases of bodybuilders. Int J Legal Med 121: 4853, 2007

21. Hakkinen JP, Miller MW, Smith AH, Knight DR. Measurement of organ blood flow with colored microspheres in the rat. Cardiovasc Res 29: 74-79, 1995.

22. Heineke J, Molkentin JD. Regulation of cardiac hypertrophy by intracellular signalling pathways. Nat Rev Mol Cell Biol 7: 589-600, 2006.

23. Heymann MA, Payne BD, Hoffman J, Rudolph AM. Blood flow measurements with radionuclide-labeled particles. Prog Cardiovasc Dis 20: 55-79, 1977.

24. Irving LM, Wall M, Neumark-Sztainer D, Story M. Steroid use among adolescents: findings from Project EAT. J Adolesc Health 30: 243-252, 2002.

25. Katona PG, McLean M, Dighton DH, Guz A. Sympathetic and parasympathetic cardiac control in athletes and nonathletes at rest. J Appl Physiol 52: 1652-1657, 1982.

26. Langfort J, Czarnowski D, Pilis W, Wojcik B, Gorski J. Effect of various types of exercise training on 5'-nucleotidase and adenosine deaminase activities in rat heart: influence of a single bout of endurance exercise. Biochem Mol Med 59: 28-32, 1996.

27. Lanzetta PA, Alvarez LJ, Reinach PS, Candia OA. An improved assay for nanomole amounts of inorganic phosphate. Anal Biochem 100: 95-97, 1979. 
28. Levy WC, Cerqueira MD, Abrass IB, Schwartz RS, Stratton JR. Endurance exercise training augments diastolic filling at rest and during exercise in healthy young and older men. Circulation 88: 116-126, 1993.

29. Maravelias C, Dona A, Stefanidou M, Spiliopoulou C. Adverse effects of anabolic steroids in athletes. A constant threat. Toxicol Lett 158: 167-175, 2005.

30. Marsh JD, Lehmann MH, Ritchie RH, Gwathmey JK, Green GE, Schiebinger RJ. Androgen receptors mediate hypertrophy in cardiac myocytes. Circulation 98: $256-261,1998$.

31. Medeiros A, Oliveira EM, Gianolla R, Casarini DE, Negrao CE, Brum PC. Swimming training increases cardiac vagal activity and induces cardiac hypertrophy in rats. Braz JMed Biol Res 37: 1909-1917, 2004.

32. Melo RM, Martinho E JR, Michelini LC. Training-induced, pressure-lowering effect in SHR: wide effects on circulatory profile of exercised and nonexercised muscles. Hypertension 42: 851-857, 2003.

33. Nieminen MS, Ramo MP, Viitasalo M, Heikkila P, Karjalainen J, Mantysaari M, Heikkila J. Serious cardiovascular side effects of large doses of anabolic steroids in weight lifters. Eur Heart J 17: 1576-1583, 1996.

34. Nottin S, Nguyen LD, Terbah M, Obert P. Cardiovascular effects of androgenic anabolic steroids in male bodybuilders determined by tissue doppler imaging. Am J Cardiol 97: 912-915, 2006.

35. Oliveira EM, Sasaki MS, Cerêncio M, Baraúna VG, Krieger JE. Local reninangiotensin system regulates left ventricular hypertrophy induced by swimming training independent of circulating renin: a pharmacological study. $J$ Renin Angiotensin Aldosterone Syst 10: 15-23, 2009 
36. Opie LH. Cardiac Metabolism - Emergence, decline and resurgence. Cardiov Res 26: 721-830, 1992.

37. Parkinson AB, Evans NA. Anabolic androgenic steroids: a survey of 500 users. Med Sci Sports Exerc 38: 644-651, 2006.

38. Pereira-Junior PP, Chaves EA, Costa-E-Souza RH, Masuda MO, de Carvalho AC, Nascimento JH. Cardiac autonomic dysfunction in rats chronically treated with anabolic steroid. Eur J Appl Physiol 96: 487-494, 2006.

39. Pierce GN, Sekhon PS, Meng HP, Maddaford TG. Effects of chronic swimming training on cardiac sarcolemmal function and composition. J Appl Physiol 66: $1715-1721,1989$

40. Pope HG Jr, Katz DL. Affective and psychotic symptoms associated with anabolic steroid use. Am J Psychiatry 145: 487-490, 1988.

41. Rocha FL, Carmo EC, Roque FR, Hashimoto NY, Rossoni LV, Frimm C, Aneas I, Negrão CE, Krieger JE, Oliveira EM. Anabolic steroids induce cardiac reninangiotensin system and impair the beneficial effects of aerobic training in rats. Am J Physiol Heart Circ Physiol 293: H3575-H3583, 2007.

42. Schaible TF, Scheuer $\mathbf{J}$. Effects of physical training by running or swimming on ventricular performance of rat hearts. J Appl Physiol 46: 854-860, 1979.

43. Schrader, J. Adenosine: a homeostatic metabolite in cardiac energy metabolism. Circulation $81: 389-391,1990$

44. Schroeder ET, Zheng L, Ong MD, Martinez C, Flores C, Stewart Y, Azen C, Sattler FR. Effects of androgen therapy on adipose tissue and metabolism in older men. J Clin Endocrinol Metab 89: 4863-4872, 2004. 
45. Tagarakis CV, Bloch W, Hartmann G, Hollmann W, Addicks K. Anabolic steroids impair the exercise induced growth of the cardiac capillary bed. Intern $J$ Sports Med 21: 412-418, 2000

46. Takahashi M, Tatsugi Y, Kohno T. Endocrinological and pathological effects of anabolic-androgenic steroid in male rats. Endocr J 51 : 425-434, 2004.

47. Tatchum-Talom R, Schulz R, McNeill JR, Khadour FH. Upregulation of neuronal nitric oxide synthase in skeletal muscle by swim training. Am J Physiol 279: H1757-H1766, 2000.

48. Van Amsterdam J, Opperhuizen A, Hartgens F. Adverse health effects of anabolic androgenic steroids. Regul Toxicol Pharmacol (Feb 12, 2010). Doi: 10.1016/ j.yrtph.2010.02.001

49. Von Restorff W, Holtz J, Bassenge E. Exercise induced augmentation of myocardial oxygen extraction in spite of normal coronary dilatory capacity in dogs. Pflugers Arch 372: 181-185, 1977.

50. White FC, Bloor CM, MCKirnan MD, Carroll SM. Exercise training in swine promotes growth of arteriolar and capillary angiogenesis in heart. $J$ Appl Physiol 85: $1160-1168,1998$.

51. Yegutkin GG. Kinetic analysis of enzymatic hydrolysis of ATP in human and rat blood serum. Biochemistry 62: 619-622, 1997

52. Yu-Yahiro JA, Michael RH, Nasrallah DV, Schofield B. Morphologic and histological abnormalities in female and male rats treated with anabolic steroids. Am J Sports Med 17: 686-689, 1989.

53. Zimmermann H. Extracellular metabolism of ATP and other nucleotides. Naunyn-Schmiedeberg 's Arch Pharmacol 362: 299-309, 2000. 
Figure legends 
Figure 1. Baseline cardiac output (CO) in sedentary $(S, n=6)$; sedentary AS-treated $(S A, n=4)$; trained $(T, n=5)$; trained AS-treated $(T A, n=4)$ groups. Values are mean \pm SEM. Significance difference vs. ${ }^{*} \mathrm{~S}, \mathrm{SA}$ and $\mathrm{T}$ groups: $P<0.05$

Figure 2. Coronary blood flow in sedentary (S); sedentary AS-treated (SA); trained (T); trained AS-treated (TA) groups. Values are mean \pm SEM. (A) Baseline coronary blood flow represented in number of microspheres (mi). S ( $n=7), S A(n=9), T(n=6)$, TA $(\mathrm{n}=6)$. Significance difference vs. ${ }^{*} \mathrm{~S}, \mathrm{SA}$ and TA groups: $P<0.01$. (B) Baseline coronary blood flow represented in $\mathrm{mL} \cdot \mathrm{kg}^{-1} \cdot \mathrm{min}^{-1} . \mathrm{S}(\mathrm{n}=5), \mathrm{SA}(\mathrm{n}=7), \mathrm{T}(\mathrm{n}=5), \mathrm{TA}$ $(\mathrm{n}=4)$. Significance difference vs. ${ }^{*}$ TA group: $P<0.05$

Figure 3. Cardiac capillary density in sedentary $(S, n=6)$; sedentary AS-treated (SA, $\mathrm{n}=6)$; trained $(T, n=6)$; trained AS-treated (TA, $n=4)$ groups. Values mean $\pm S E M$ Significance difference vs. ${ }^{*} \mathrm{~S}, \mathrm{SA}$ and T groups: $P<0.05$.

Figure 4. Enzymes activity in the blood serum fraction. Sedentary (S); sedentary AStreated (SA); trained (T); trained AS-treated (TA); Values are mean \pm SEM. (A) ATP hydrolysis: $S(n=9), S A(n=10), T(n=8), T A(n=9)$. Significance difference vs. ${ }^{*} S$ and SA groups: $P<0.01$. (B) ADP hydrolysis: $S(n=10), S A(n=12), T(n=9)$, TA $(n=10)$. Significance difference vs. ${ }^{*} \mathrm{~S}, \mathrm{SA}$ and TA groups: $P<0.01$ and $\dagger \mathrm{SA}$ group: $P<0.05$ (C)AMP hydrolysis: S $(n=9)$, SA $(n=10), T(n=8)$, TA $(n=10)$. Significance difference vs. ${ }^{*} \mathrm{~S}, \mathrm{SA}$ and TA groups: $P<0.01$. 
Table 1. Morphological and Hemodynamic parameters.

\begin{tabular}{lcccccc}
\hline & BW inilial, $\mathrm{g}$ & BW fimal, g & LV, mg & LV/BW, mg/g & MAP, mml Ig & HR, beats $/ \mathrm{min}$ \\
\hline Sedentary & $215 \pm 5.5$ & $446 \pm 4.2$ & $0.94 \pm 0.01$ & $2.09 \pm 0.04$ & $108 \pm 1.9$ & $332 \pm 6.6$ \\
Sedentary+AS & $215 \pm 3.9$ & $395 \pm 15^{*}$ & $0.92 \pm 0.04$ & $2.20 \pm 0.05$ & $108 \pm 1.7$ & $311 \pm 10$ \\
Trained & $211 \pm 4.8$ & $390 \pm 6.5^{*}$ & $0.92 \pm 0.02 * \dagger$ & $2.37 \pm 0.05$ & $108 \pm 2.6$ & $283 \pm 5.5^{*} \dagger$ \\
Trained+AS & $212 \pm 6.3$ & $399 \pm 8.1^{*}$ & $0.98 \pm 0.03^{*} \dagger$ & $2.45 \pm 0.04$ & $105 \pm 2.6$ & $264 \pm 7.2^{*} \dagger$ \\
\hline
\end{tabular}

Values are means $\pm \mathrm{SEM}$; $=5-7$ each group. AS, anabolic steroid; $\mathrm{BW}$, body weight;

LV, left ventricle; MAP, mean arterial pressure; $H R$, heart rate. Significance difference vs. *sedentary and $\nmid$ sedentary plus AS groups: $P<0.05$. 


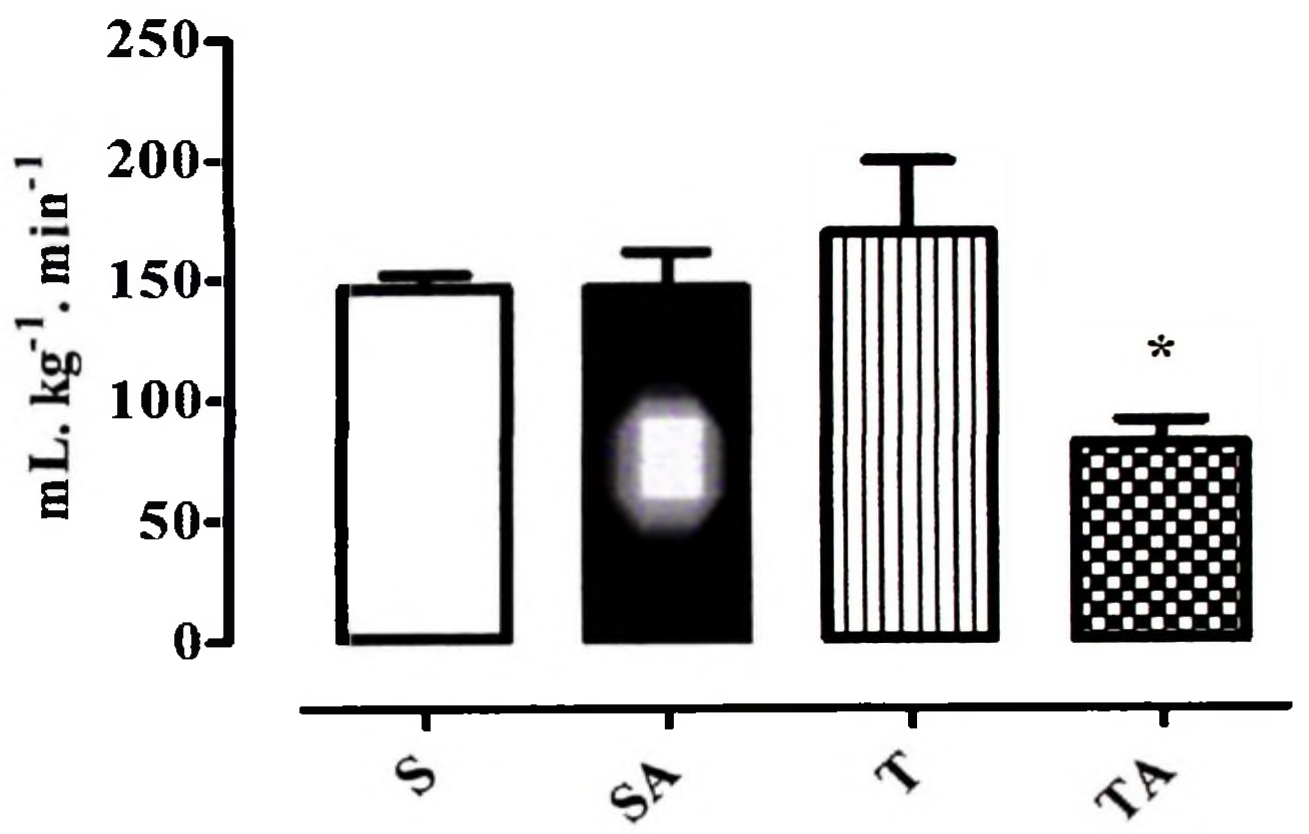


A

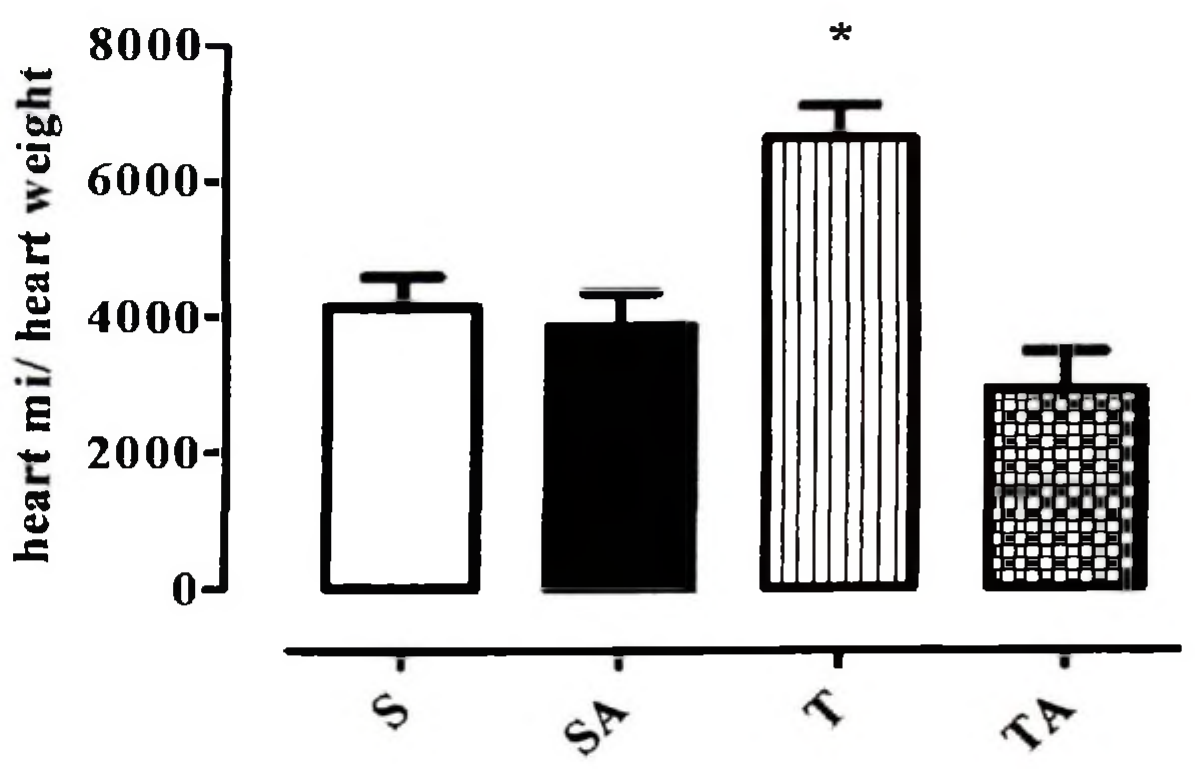

B

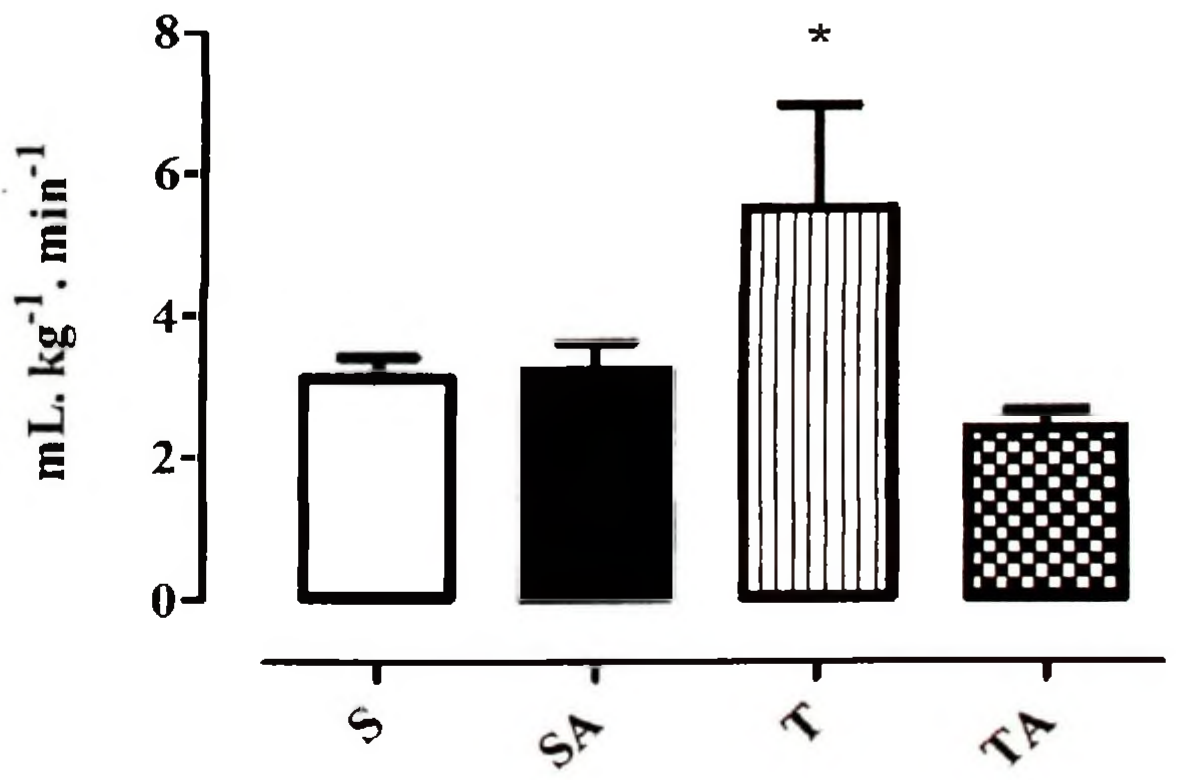




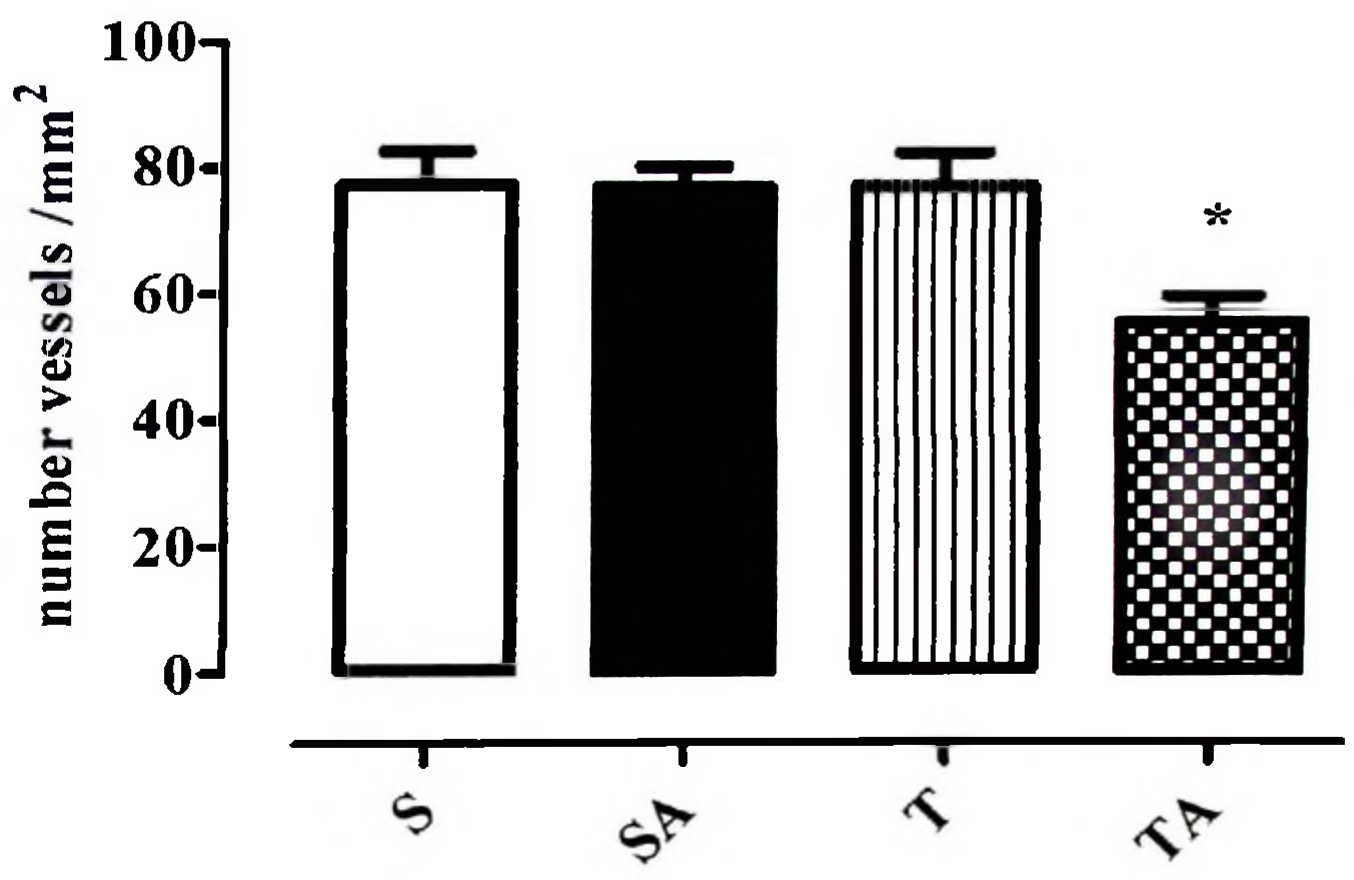


A

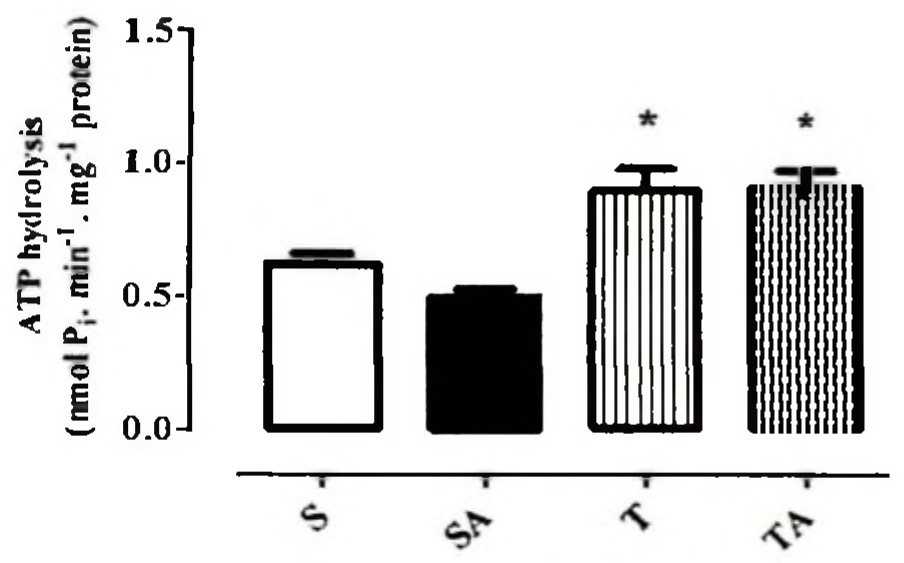

B

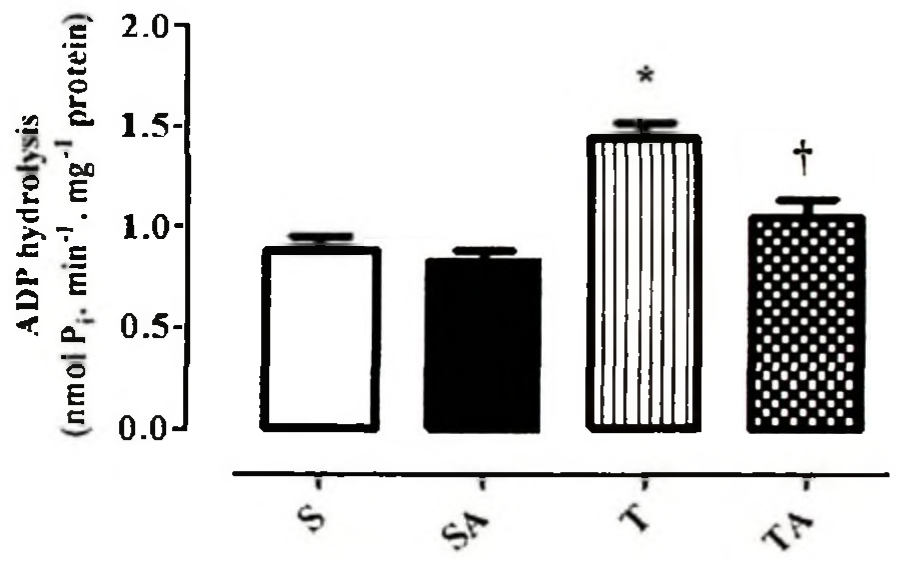

C

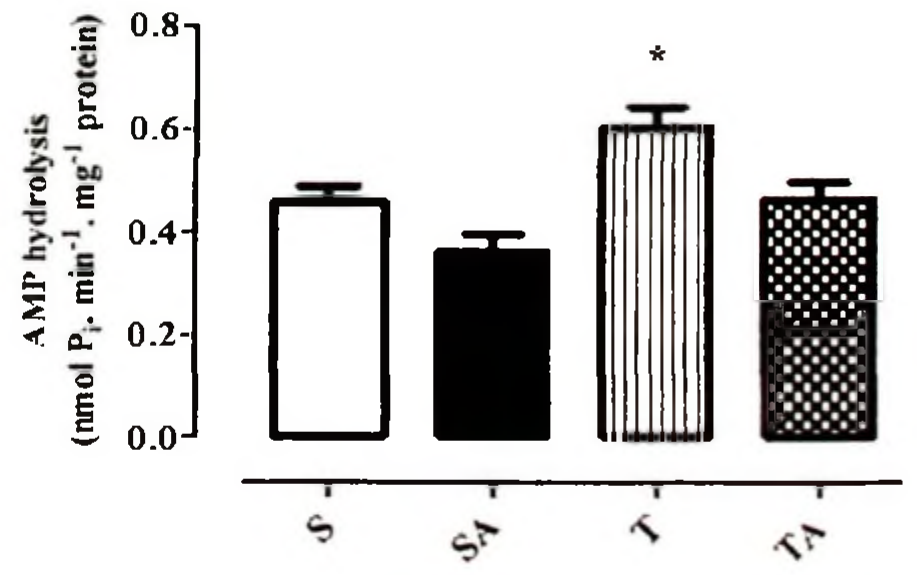




\section{Esteróide anabolizante inibe a angiogênese induzida pelo treinamento físico de natação em músculo sóleo de ratos normotensos}

CDD. 20.ed. 796.022 796.073

797.2

\author{
Ursula Paula Reno SOCI' \\ Fernanda Roberta Roque REDONDO' \\ Tiago FERNANDES \\ Kátia De ANGELIS ".* \\ Maria Cláudia IRIGOYEN"* \\ Marcele COELHO' \\ Edilamar Menezes de OLIVEIRA*
}

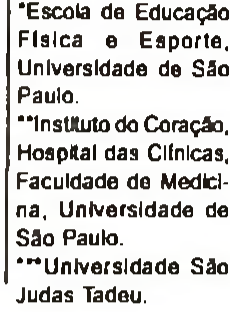

\section{Resumo}

Os esteróides anabolizantes androgênicos (EAA) são sintéticos de testosterona desenvolvidos para fins terapêuticos. São também utilizados por populações fisicamente ativas, que normalmente excedem nas doses, o que potencializa danos à saúde. Para estudar alguns dos efeitos de EAA sobre o sistema cardiovascular, ratos "Wistar" foram divididos em quatro grupos: sedentário controle (SC), sedentário anabolizado (SA). treinado controle (TC) e treinado anabolizado (TA). Foram avaliados os efeitos da associação do uso de EAA (Decanoato de nandrolona $-5 \mathrm{mg} / \mathrm{kg} \mathrm{sc}, 2 \times / \mathrm{sem}$ ) e do treinamento fisico de natação (TFN - $60 \mathrm{~min} / \mathrm{dia}$, $5 \mathrm{x}$ ) sem, durante $10 \mathrm{sem}$ ) sobre o débito cardiaco (DC) e fluxo sanguineo basal (DCbasal, Obasal) e após infusão do vasodilatador acetilcolina (DC Ach, Q Ach) para observar a vasodilatação endotélio dependente (OAch), razão capilar/fibra (rc/f) e expressão do fator de crescimento endotelial vascular (VEGF) em músculo sóleo (predominància de fibras oxidativas). A testosterona plasmática aumentou nos grupos com uso de EAA e foi observada bradicardia de repouso como efeito do TFN. O DC foi menor para o Grupo TA, tanto na condição basal quanto sob infusão de Ach. $O$ Qbasal não foi diferente entre os grupos no músculo estudado. 0 QAch foi maior no grupo TC, entretanto, no grupo TA este efeito benéfico do TFN foi prejudicado pela associação com - EAA. Aumento da rc/fe VEGF foi observado somente no grupo TC. Estes resultados sugerem que a associação do EAA ao TFN atenua a angiogênese e arteriogênese observadas como efeito do treinamento fisico aeróbio e causa prejuizo ao fluxo sanguineo muscular, o que poderia predispor o praticante de esportes e atividades fisicas e usuário destas substâncias a problemas vasculares.

Untrermos: Doping; Fluxo sanguineo; Capilares; Músculo esquelético; Treinamento fisico; Natação.

\section{Introdução}

Os esteróides anabolizantes androgênicos (EAA) sāo sintéticos com atividade similar à testosterona, utilizados para fins terapêuticos e no meio esportivo devido à suas propriedades anabólicas e androgênicas (CElótTI \& Cesi, 1992; Hebert. Haupt, George \& Rovere, 1984; KuHN, 2002). Estas drogas são frequentemente utilizadas em academias e centros de treinamento físico sem qualquer critério e controle, o que representa risco à saúdc dos usuários (ANDERSEN, BARTLETT, Morgan \& Brownell, 1995; Fuller, 1993). As doses costumam ser de 10 a 100 vezes maiores que a terapêutica, e 2/3 dos abusos ocorrem entre não atletas (Cunhi, Moura, Bernardes, 'Tanno \& Marcondes, 2005; Kam \& Yarrow, 2005; Pope JUNIOR \& KA'IZ, 1988). 
O uso abusivo de EAA causa diversos efeitos deletérios para o organismo, com consequências adversas de ordem metabólica, endócrina, cardiovascular, hepática, neural, estética, comportamental e psiquiátrica (KindermanN, 2006; Manetta \& SIIVeira, 2000; Redondo, 2007; Rocha, Carmo, Roque, Hashimoto, Rosson, Frimm, Aneas, Negráo, Krieger \& Oliveira, 2007; Tagiarakis, Bloch, Hartmann, Holumann \& Addicks, 2000; Takahashi, Tatsugi $\&$ Kohno, 2004).

As adaptaçōes funcionais e morfológicas da musculatura esquelética e outros sistemas decorrentes de treinamento fisico de nataçāo (TFN) são bem descritas, resultando em modificações metabólicas (capacidade oxidativa muscular e otimização nos sistemas de produçáo de energia) e circulatórias centrais e periféricas (débito cardraco, fluxo sanguíneo muscular, aumento de capilares) (Costill, Magilischo \& Richardson, 1992). Destas, no músculo esquelético, considera-se a angiogênese uma importante adaptaçáo decorrente do treinamento de resistência aeróbia. $\mathrm{O}$ aumento no número de capilares ao redor da fibra pode ser até $50 \%$ maior nos músculos de membros superiores de nadadores em relaçáo aos sedentários, o que permite uma melhor permuta de gases, calor e substratos energéticos entre o sangue e fibra muscular ativa (Costill, Maglischo \& RiCHARDSON, 1992; INGJER \& BRODAL, 1978; SAITIN \& Rowell, 1980). Esta adaptação é deflagrada fisiologicamente por poucas situaçōes como o ciclo ovariano, desenvolvimento placentário e em resposta ao aumento do estresse de cisalhamento e ao estiramento mecânico celular no músculo esquelético que recebe sobrecargas como a estimulaçăo elétrica e o exercício físico (PRIOR, YANG \& TERJUNG, 2004).

OTFN, bem como outros tipos de treinamento de resistência aeróbia, é capaz de induzir a um aumento na proliferaçáo de células endoteliais em fibras do tipo I e II no músculo esquelético, mostrando a expressão aumentada de compostos angiogênicos, como o VEGF (Vascular-Endothelial Growth Factor) no músculo c circulação (JENSEN, Bangsbo \& Hellsten, 2004; Kraus, Stalungs, Yeager \& Gavin, 2004; Waters, Rotevatin, Ping, ANEXX \& YAN, 2004). Este fator de crescimento é especifico para a microvasculatura, sendo um potente mitógeno de células endoteliais relacionado ao controle da formação de novos capilares, e o principal implicado na resposta angiogênica ao exercicio (Amaral, Papanek \& Greene, 2001;
Bornes, Boulard, Hieblot, Zanibeliato, Iacovoni, Prats \& Touriol, 2004; Kraus, Stallings, Yeager \& Gavin, 2004).

VEGF e seus receptores atualmente são considerados elementos críticos para a ocorrência da angiogênese "in vivo". A interação entre o receptor VEGFR2 e VEGF estimula a proliferação e migração de células endoteliais, através de uma cascata de sinalizaçáo Tirosina quinase, que ativa consequentemente Fosfolipase-C- $\gamma$ (PLC- $C \gamma$, que catalisa hidrólise de ligaçóes éster em fosfolipídcos), Fosfoinositol-3-quinase (PI3K, enzima que fosforila inositol e que participa de múltiplos papéis na ativação celular) e proteina quinase C- $\epsilon$ (PKC- $€$, enzima que está envolvida também em muitos eventos de transdução de sinais, sendo ativa em resposta a estŕmulos hormonais, neuronais e como neste caso, de fatores de crescimento e catalisando a transferência de um grupo fosfato do ATP a diversas proteínas substrato) que estimulam expressão de genes, incluindo de eNOS (sintetase catalisadora da produção de Oxido Nitrico endotelial - NO) cuja atividade é crítica para a sinalização do VEGF (Amaral, Papanek \& Greene, 2001; Bornes et al., 2003; Kraus et al., 2004; Prior, Yang \& Terjung, 2004, Waters et al., 2004).

Por outro lado, é bem estabelecido que a associação de dose suprafisiológica de EAA com treinamento físico causa efeitos delecérios para diversos sistemas, dentre eles o cardiovascular, resultando em diminuiçáo da capilarização no músculo cardfaco e esquelético de animais (Redondo, 2007; Soares \& Duarte, 1991; Tacarakas et al., 2000), porém não se sabe como os compostos angiogênicos, como o VEGF, se comportam nesta associação.

Embora se conheça vários efeitos benéficos do treinamento físico de resistência acróbia em relação ao músculo esquelérico, pouco se sabe sobre sua associação com o uso de EAA. A maioria dos estudos relaciona o uso destes recursos a atletas de força ou que treinam em alta intensidade. Pouco foi elucidado sobre os efeitos da associação do TFN e de doses suprafisiológicas de EAA na angiogênese no músculo esquelético. Desca forma, o presente estudo teve como objetivo avaliar os efeitos de dose suprafisiológica de EAA sobre o remodelamento da microvasculatura, expressão protéica do VEGF e fluxo sanguíneo no músculo sólco, o músculo com maior potencial de adaptabilidade ao treinamento de resistência aeróbia, verificando se a droga é capaz de alterar a angiogênese induzida pelo TFN. 


\section{Materiais e métodos}

\section{Grupos experimentais}

Ratos "Wistar" (8-12 semanas, $180-250 \mathrm{~g}, \mathrm{n}=56$ ), foram separados em quatro grupos randômicos conforme o protocolo experimental: Sedentário Controle (SC, $n=14$ ), Sedentário Anabolizado (SA, $n=14)$, Treinado Controle (TC, $n=14$ ) e Treinado Anabolizado (TA, $n=14$ ), identificados, mantidos com raçāo e água "ad libitum", em gaiolas plásticas a temperatura controlada $\left(23 \pm 1^{\circ} \mathrm{C}\right)$ e ciclo claro-escuro invertido a cada $12: 12$ h durante o experimento. Foi realizado controle ponderal dos animais semanalmente. Cada grupo foi subdividido em dois grupos, um utilizado para análises bioquímicas, moleculares, morfológicas e morfométricas e outro para análises hemodinâmicas e de perfusão regional.

Os grupos SA e TA foram tratados com Decanoato de Nandrolona (Decadurabolin; Organon, Roseland, NJ) administrado por injeçōes subcutâneas duas vezes por semana, totalizando 10 $\mathrm{mg} \mathrm{kg-1/semana.} \mathrm{Esta} \mathrm{dosagem} \mathrm{representa} \mathrm{aproxi-}$ madamente 100 vezes a dosagem terapêutica (POPE JUNIOR \& KATZ, 1988). As injeçōes foram preparadas com diluição em óleo vegetal e aplicadas sempre no perfodo da tarde. Os grupos que nāo foram tratados com a droga (SC e TC) receberam a administraçāo de óleo vegetal.

Todos os procedimentos cirúrgicos e prococolos foram realizados de acordo com os Princípios Éticos de Experimentação Animal (Colégio Brasileiro de Exterimentaça Animal - COBEA, 1991).

\section{Treinamento físico de natação}

O TFN (TC e TA) foi realizado conforme descrito por Medeiros, Oltveira, Glanolla , Casarini, Negrao e Brum (2004) (FIGURA 1), com frequência de cinco vezes por semana em um sistema com água aquecida entre $30-32{ }^{\circ} \mathrm{C}$, duração de $60 \mathrm{~min} / \mathrm{dia}$ por $10 \mathrm{semanas}$ com sobrecarga de trabalho (peso adaprado à cauda) de $5 \%$ do peso corporal (FIGURA 1). Este é um protocolo de baixa intensidade e longa duração, efetivo para a promoção de adaptaçōes cardiovasculares e aumento na capacidade oxidativa muscular-esquelética (Medeiros et al., 2004).

Para o estudo de perfusāo regional, 24 horas após o final do protocolo experimental os animais foram submetidos ao processo cirúrgico para realização do experimento com as microesferas coloridas, o qual foi realizado 24 horas após o procedimento cirúrgico, seguido do sacrificio dos animais e coletas.

Para realização de análises morfológicas, morfométricas, bioquímicas e moleculares, o outro grupo foi sacrificado 24 horas após o final do protocolo experimental e o músculo sóleo foi retirado e adequadamente armazenado para as diferentes análises.

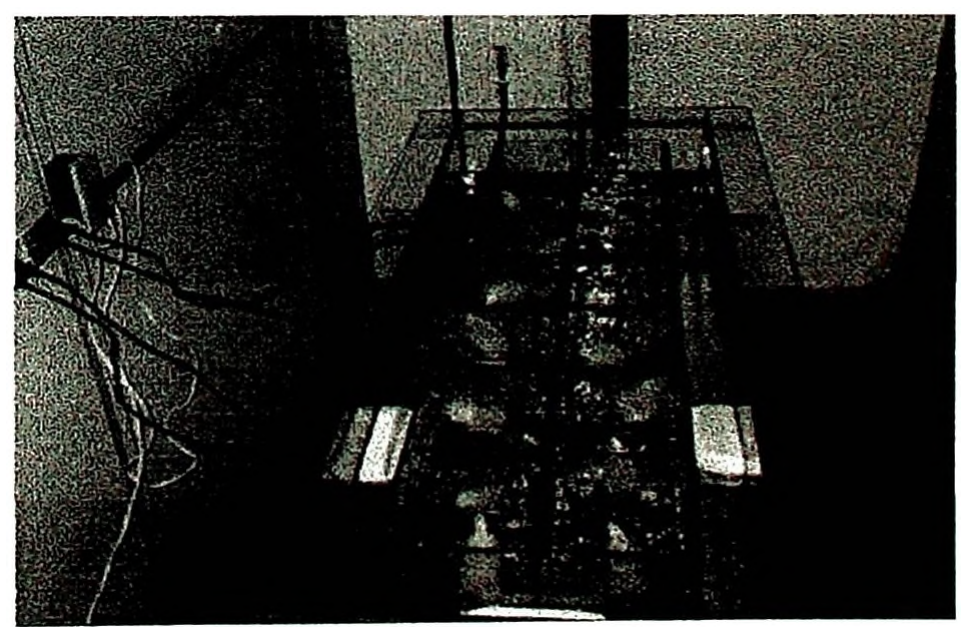

FIGURA 1 - Sistema aquecido de natação para ratos. 


\section{Análises morfológicas e morfoméricas}

\author{
Análise histológica \\ Quantificação do número de capilares
}

Ao final do protocolo experimental os animais foram sacrificados e seus músculos sóleos foram removidos e pesados. Os músculos foram seccionados transversalmente, fixados em formaldeido a $6 \%$ por 24 horas e processados por desidratação, diafanizaçāo e banho de parafina a $60^{\circ} \mathrm{C}$. Após foi realizada a inclusão dos mesmos em cassetes contendo parafina fundida, que ao solidificar deu origem a um bloco de parafina para cada sujeito da amostra, dos quais se obteve cortes microtômicos de $3 \mu \mathrm{m}$ de espessura, submetidos à montagem de lâminas para análise histológica, com coloração de PAS (Periodic Acid Schiff), para visualizaçāo dos vasos capilares.

A análise histológica foi realizada com urilizaçāo do sistema de análise de imagens Quantimet Leica®, (Leica, Cambridge, United Kingdom) por intermédio de estudo cego. A lâmina foi observada inicialmente em aumentos menores, sendo escolhido um local em que não havia ranhuras ou bolhas e que contenham o maior número de fibras de corte transvcrsal. Escolhido - local, a imagem foi ampliada 400x para realizar as medidas. Para análise do número de capilares, a mesma área foi igualmente delimitada, com o auxilio do cursor para mensurar o diâmetro de cada vaso. Segundo critérios estabelecidos, o diâmetro foi o principal parâmetro para identificação dos capilares, sendo considerado capilar, vasos com diâmetro igual ou menor que $12 \mu \mathrm{m}$.

Foram analisados cinco campos de visão das lâminas de cada amostra nas quais foi quantificado o número total de fbras musculares e de capilares por campo de visão e a partir destes valores foi calculada a razão Capilar/Fibra (rc/f) de cada animal, como preditor de capilarização no tecido estudado.

\section{Hipertrofia muscular esquelética}

A hipertrofia foi avaliada através da relação entre o peso de cada músculo (peso úmido) e o peso corporal. Os resultados são expressos como razão peso do sóleo/peso corporal do animal (mg/g).

\section{Fluxo sanguíneo muscular Técnica das microesferas coloridas}

O fluxo sanguíneo para o músculo sóleo foi avaliado pela técnica de microesferas coloridas como previamente descrito por HAKkinen, MILleR, SmIth e KNIGHT (1995). Vinte e quatro horas após a última sessão de exercício os ratos foram anestesiados com ketamina $(90 \mathrm{mg} / \mathrm{kg})$ e xilasina (10 mg/kg, ip). Cateteres preenchidos com salina foram implantados na artéria femoral para a retirada de uma amostra de sanguc referência c dentro do ventrículo esquerdo para infusāo das microesferas coloridas. Uma terceira cânula foi introduzida na veia femoral direita, para administraçăo do vasodilatador acecilcolina (Ach).

Durante o experimento, que foi realizado 24 horas após o processo ci rúrgico, os animais permaneceram conscientes e foi permitido que se movessem livremente. A cânula da artéria femoral foi conectada a um transdutor de pressão e os sinais de pressão arterial foram continuamente monitorados, exceto durante a infusão de microesferas e a retirada das amostras de sangue referência. Os dados registrados foram analisados batimento a batimento para quantificar mudanças na pressão arterial média e frequência cardlaca.

Durante o repouso microesferas coloridas vermelhas (200.000) foram infundidas e utilizadas para a determinação do fluxo sangulneo muscular esquelérico e débito cardíaco. Em uma segunda etapa o procedimento foi repetido com microesferas na cor branca, porém antecedido pela administração de um vasodilatador (acetilcolina - Ach) na dose de $30 \mu \mathrm{g} /$ $\mathrm{kg}$, através da cânula localizada na veia femoral direira. Esta etapa foi realizada para avaliar a resposta vasodilatadora endotélio-dependente dos animais.

Após este procedimento os animais foram sacrificados e os músculos sóleos foram retirados para a determinação do fluxo sanguíneo. As amostras foram digeridas e processadas com reagentes preparados segundo especificaçōes do fabricante das microesferas (Triton 'Technology, San Diego, CA, USA). A infusão de microesferas c processamento das amostras de sangue $\mathrm{e}$ dos recidos foram realizados pelo método de HAKKINEN et al. (1995). A absorbância minima aceitável foi de 0,010 unidades de absorbância (AU). Para cada infusão os valores de fluxo foram representados como número de microesferas dentro do tecido e/ou como $\mathrm{ml} / \mathrm{kg}^{-1} / \mathrm{min}^{-1}$. O fluxo sanguíneo $\left(\mathrm{ml} / \mathrm{kg}^{-1} / \mathrm{min}^{-1}\right)$ e o débito card/aco foram calculados como previamente descrito (HAKKINEN et al., 1995).

$\mathrm{O}$ número de microesferas nos músculos estudados foi normalizado pelo respectivo peso muscular. Para determinação do número de microcsferas nos tecidos (brancas ou vermelhas) soluçōes com número conhecido de microesferas foram processadas. A média da absorbância destas 
amostras permite determinar uma constante de lcitura do espectofotômetro para as microesferas vermelhas e brancas. Desta forma o número de microesferas nos tecidos foi calculado a partir de fórmulas previamente especificadas. O tempo de retirada da amostra de sangue (min) foi calculado pela divisão do volume de sangue retirado durante a infusāo das microesferas vermelhas e brancas, pela velocidade da bomba de retirada $(0,5 \mathrm{ml} / \mathrm{min})$. A constante de retirada do sangue ( $Q$ sangue, $\mathrm{ml} / \mathrm{min}$ ) foi determinada pela divisão do volume de sangue (ml) pelo tempo de retirada da amostra (HAKKINEN et al., 1995).

\section{Análises bioquímicas e moleculares}

\section{Testosterona plasmática}

A concentração de testosterona plasmática foi determinada por Radioimunoensaio (COAT-ACOUNT total Testosterone da Diagnostic Products Corporation - humano) em plasma coletado com EDTA (ácido etilendinitrolotetracético). Os resultados foram expressos em $\mathrm{ng} / \mathrm{dl}$ de testosterona.

Análise da expressão de proteínas ("Western Blotting")

As amostras de músculo coletadas foram congeladas e mantidas em freezer $-80^{\circ} \mathrm{C}$ até serem homogeneizadas e urilizadas. O preparo para a análise de expressāo de proteinas consistiu na homogeinizaçáo das amostras campão de extração contendo (Trizma base $100 \mathrm{mM}$, SDS $10 \%$, para-hidroximercuriobenzoato $(\mathrm{p}-\mathrm{OHHgBz}) 1$ $\mathrm{mM}$; fenilmetilsulfonilfluoreto (PMSF) 1 mM; pepstarina A $1 \mathrm{mM}$; orto-fenantrolina $30 \mathrm{mM}$ e ácido etilendinitrolotetracético (EDTA) $(10 \mathrm{mM})$ e colocadas em banho a $100^{\circ} \mathrm{C}$ por $10 \mathrm{~min}$. O homogeneizado do músculo foi mantido no gelo, rapidamente centrifugado (3.000 $\mathrm{rpm} \times 10 \mathrm{~min}$ ) e o sobrenadante armazenado a $-20^{\circ} \mathrm{C}$. Parte do sobrenadante foi utilizado para quantificar a concentraçāo total de protelnas (BRADFORD, 1976). Cada amostra foi diluida em tampão Laemmli (LAEMMLI, 1970) na proporção de 1:4 contendo DDT (Ditiotreitol) 100 $\mathrm{mM}$ e aquecidos em água fervente por $5 \mathrm{~min}$. Cada amostra contendo o Laemmli mais o precipitado foi submetida a uma rotação ("spin") de $4000 \mathrm{rpm}$ por 30 segundos e o sobrenadante foi submetido à eletroforese em gel de poliacrilamida (SDS- sodium dodecyl sulfate, PAGE 10\%) no aparelho para minigel (Mini-Protean, Bio- Rad, Hercules, CA,
EUA). Em cada gel foi aplicado como padrão um marcador de peso molecular com valores cstabelecidos cm: miosina (205-195 kDa), $\beta$ galactosidasc (116 kDa), albumina bovina ( $80 \mathrm{kDa})$ e ovalbumina $(49,5 \mathrm{kDa})$.

\section{"Immunoblotting"}

A transferência das proteinas separadas no gel foi feita eletricamente para uma membrana de nitrocelulose utilizando-se o sistema "serni-dry" (TransBlot Semi-Dry Transfer Cell - Bio-Rad, Hercules, CA, EUA) e durou por volta de 40 minutos sob 20 volts, conforme descrito por Polvino, Saravis, Sampson e Cook (1983). No tampão usado para realizar a transferência foi acrescentado SDS $0,1 \%$ para melhorar a eluição das proteínas de alto peso molecular. A ligaçáo inespecifica de proteinas na membrana de nitrocelulose foi inibida pela incubaçāo destas com $10 \mathrm{ml}$ de solução bloqueadora (leite desnatado Molico $5 \%$, Tris $10 \mathrm{mM}$, $\mathrm{NaCl} 150 \mathrm{mM}$ e Tween $200,02 \%$ ) por $2 \mathrm{~h}$ na temperatura ambiente. As membranas com a amostra foram incubadas com o anticorpo primário para VEGF (SC1 52 da Santa Cruz Biorechnology; Santa Cruz, CA, EUA, diluição de 1:500) diluldo em soluçāo bloqueadora (leite desnatado $3 \%$, Tris $10 \mathrm{mM}, \mathrm{NaCl}$ $150 \mathrm{mM}$ e Tween $200,02 \%$ ) e incubadas a $4{ }^{\circ} \mathrm{C}$ "overnight". No dia seguinte, foram incubadas por 23 horas com o anticorpo secundário "anti-rabbit" (Zymed laboratories, South San Francisco, CA, EUA, 1:5000) e posteriormente foram lavadas três vezes por 10 minutos com solução basal. As bandas de proteínas especificas existentes nas membranas incubadas foram visualizadas através do uso do "Kit" para deteç̧ão por quimiluminescência (ECL General Eletric Healthcare, Little Chalfont, Buckinghamshire, England). A seguir os filmes de raio-x foram expostos às membranas por aproximadamente 15 minutos. Para se medir a intensidade das bandas nas auro-radiografias, as figuras escaneadas foram analisadas utilizando o programa de análise de densitometria óptica Scion Imagc, fornecido gratuitamente pela NIH (USA) via internet (http:// w w w.s cion corp.com/pages/ scion_image_windows.htm).

\section{Estatística}

Os dados estão expressos na forma de média \pm erro padrāo da média. Foi utilizada análise de variância de dois fatores (ANOVA) para análises bioquimicas, moleculares, morfológicas e morfométricas. 
Para dados de fluxo sanguíneo e débito cardíaco foi utilizada ANOVA de dois fatores para medidas repetidas para as diferenças entre grupos.
Após os tratamentos estatísticos foi realizado o testc Post-hoc de Duncan para significâncias estatisticas, tendo sido adotado grau de significancia para $\mathrm{p}<0,05$.

\section{Resultados}

\section{Peso corporal dos animais}

A TABELA 1 mostra os dados de peso corporal dos animais antes e após a realização do protocolo experimental.
No início do protocolo experimencal năo haviam diferenças no peso corporal entre os grupos, porém ao final do treinamento os grupos SA, TC e TA apresentaram peso corporal estatisticamente diminuldo em relação aos animais SC, sem diferenças entre si.
SC =Sedentário Controle; $S A=$ Sedentáflo Arabolizado:

TCC = Treinado Controle $\mathrm{TA}=$ Treinado Anabolizado.

- = diferença significante em relaçăo aos grupos sedentários;

- = diferença significante em relaça an grupo $\mathrm{SC}$ e TC;

$f=$ diferença significante em relaço a o grupo $S A$ $p<0,05$.

TABELA 1 - Efeito do protocolo de treinamento, da administração do EAA e da associaçāo de ambos sobre o peso corporal inicial e final (PC inicial e PC final, frequência cardíaca - FC e pressāo arterial média - PAM).

\begin{tabular}{ccccc}
\hline & PC inicial $(\mathrm{g})$ & PC final $(\mathrm{g})$ & FC $(\mathrm{bpm})$ & PAM $\left(\mathbf{m m} \mathrm{Hg}_{\mathrm{g}}\right.$ \\
\hline SC & $215 \pm 12$ & $440 \pm 8,2$ & $328 \pm 7,3$ & $107 \pm 2,1$ \\
SA & $218 \pm 4,5$ & $399 \pm 3,1^{*}$ & $308 \pm 18,1$ & $106 \pm 1,4$ \\
TC & $195 \pm 1,7$ & $394 \pm 1,1^{*}$ & $285 \pm 6,7^{* *}$ & $103 \pm 5,1$ \\
TA & $206 \pm 0,6$ & $398 \pm 0,4^{*}$ & $268 \pm 8,5^{* *} \dagger$ & $96 \pm 1,3$ \\
\hline
\end{tabular}

\section{Nível plasmático de testosterona}

Os resultados de nível de testosterona plasmático estão mostrados na FIGURA 2. Conforme esperado, a administração crônica de EAA causou um significante aumento na concentração de testosterona plasmática $(\mathrm{ng} / \mathrm{dl}, \mathrm{SA}-85,3 \pm 19,3$; TA $-102,6 \pm 18,3$ vs. SC $-13,4 \pm 6,5$; TC $-20,5 \pm$ $9,9)$. As concentraçōes plasmáticas de testosterona foram superiores nos grupos que receberam tratamento com a droga (EAA) a dizer SA e TA quando comparados aos grupos SC e TC.
$S C=$ Sedentánio Controle; $S A=S e d e n t a ́ r l o$ Anabolizado:

IC = Treinado Controle

I $A=T$ i e I n a d o Anabolizado.

- $=$ diferença significante em relação aos grupos sedentários - = diferenca significante em relaça ao grupo $\mathrm{SC}$ \& TC; $1=$ diferença slgnificante em relaço ao grupo SA. $\rho<0,05$

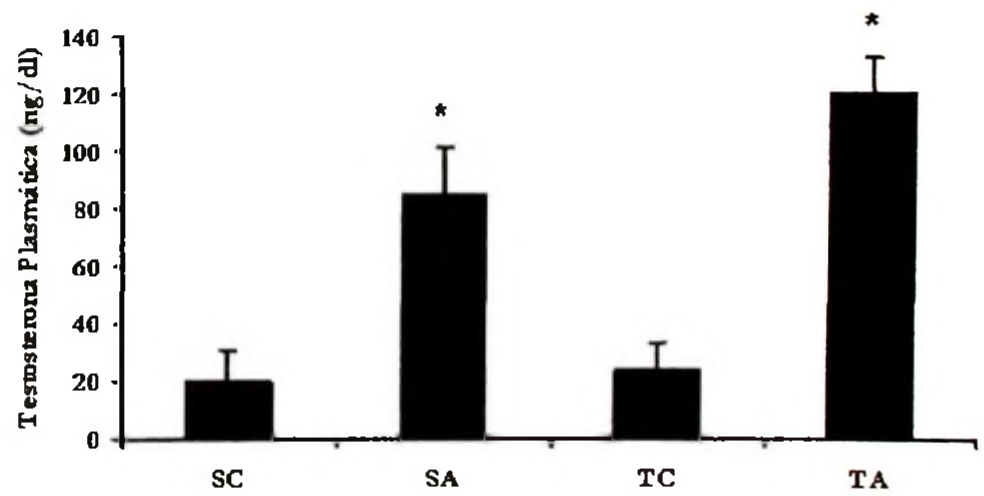

FIGURA 2 - Nível plasmático de testosterona após protocolo experimental. 


\section{Medidas hemodinâmicas}

\section{Frequência cardíaca de repouso}

Os dados de frequência cardlaca (FC) ao final do protocolo de trcinamenm estāo demonstrados naTABELA 1. Pode-se observar que o treinamento físico promoveu rodução da FC de repouso no grupo TC eTA.

\section{Pressão arterial média}

A pressão arterial média (PAM) não sofreu alteraçāo significante entre os grupos, conforme indicado na TABELA 1.

\section{Débito cardíaco}

A FIGURA 3 mostra o débito cardíaco (DC) dos grupos experimentais na situação basal (DC basal) e após a administração de acetilcolina (DC Ach). O DC basal do grupo TA $(98 \pm 18 \mathrm{ml} / \mathrm{min})$ apresentou redução significativa comparado ao grupo TC $(150 \pm 36 \mathrm{ml} / \mathrm{min})$ e comparado aos grupos SA $(161 \pm 13 \mathrm{ml} / \mathrm{min})$ sem diferenças em relação ao grupo $\mathrm{SC}(146 \pm 15 \mathrm{ml} / \mathrm{min})$. O valor de DC Ach do grupo TA permaneceu reduzido (85 $\pm 10 \mathrm{ml} / \mathrm{min}$ ), com redução significativa em relação ao grupo TC (151 $\pm 26 \mathrm{ml} / \mathrm{min})$, SC (147 \pm 18 $\mathrm{ml} / \mathrm{min})$ e $S A(145 \pm 20 \mathrm{ml} / \mathrm{min})$.

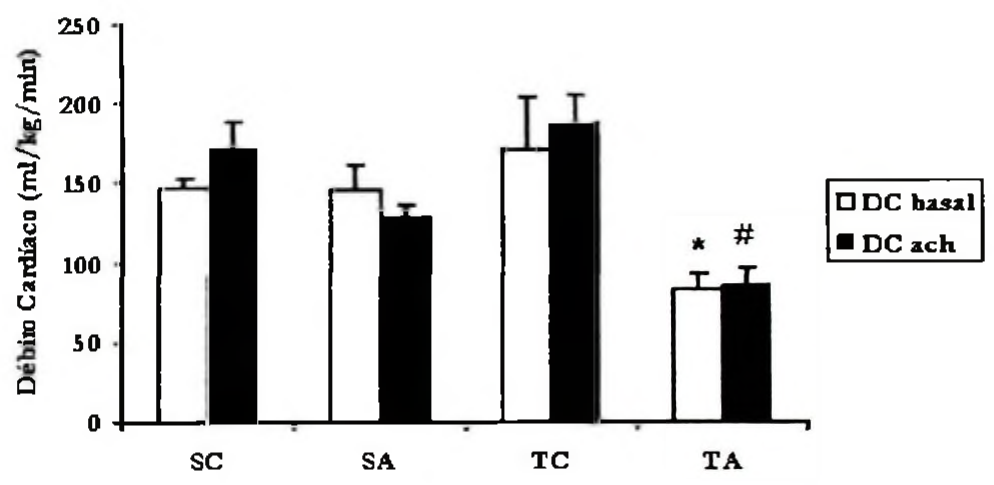

$S C=$ Sedentánio Controle; S A $=$ Sedentárlo Anabolizach; TC = Treinado Controle TA=Treinado Anabolrado. - = Diferença significaUva em relaçăo ao grupo TA basal; $\#=$ Diferença significathva em relação ao grupo TA sob administra çăo de acetilcolina ( $p<$ 0,05 ).

FIGURA 3 - Débito cardíaco (DC) basal e após administração de acetilcolina (ml/min).

\section{Fluxo sanguíneo}

A FIGURA 4 A mostra os resultados de perfusāo regional $(Q)$ do músculo sóleo na condição basal $(Q$ basal) e sob administração de acerilcolina ( $Q$ Ach). Não houve diferença significativa entre os grupos para os valores de $\mathrm{Q}$ basal. Após a administração de acetilcolina houve diminuição significariva dos grupos TA $(0,82 \pm 0,20 \mathrm{ml} / \mathrm{min})$ e SC $(1,20 \pm 0,15 \mathrm{ml} / \mathrm{min})$ em relação ao grupo TC $(2,60 \pm 0,39 \mathrm{ml} / \mathrm{min})$. Os animais TC tiveram $Q$ Ach significativamente aumencada em relaçāo à sua $Q$ basal $(0,79 \pm 0,24 \mathrm{ml} /$ min), o que não ocorreu com os outros grupos.

Este aumento não foi observado nos grupos sedentários, $\mathrm{c}$ o grupo TA apresentou uma diminuição significativa de $Q$ Ach em relação ao grupo TC, não apresentando diferenças quando comparado a ambos os grupos sedentários (SC e SA). 
$S C=$ Sedentáno Controle: $S A=S$ ede n I árlo Arabolizadh;

TC = Truhado Controle

TA=TrenadoArabolrach

" = diferença slgnifica.

tiva dos animals TC sob

adminlstraçăo de

acetilcolina em relaço aos grupos TA e SC;

$\#=$ dlferença significa.

tiva do grupo TC em re-

laçăo à sua condlçăo basal. $(p<0,05)$.

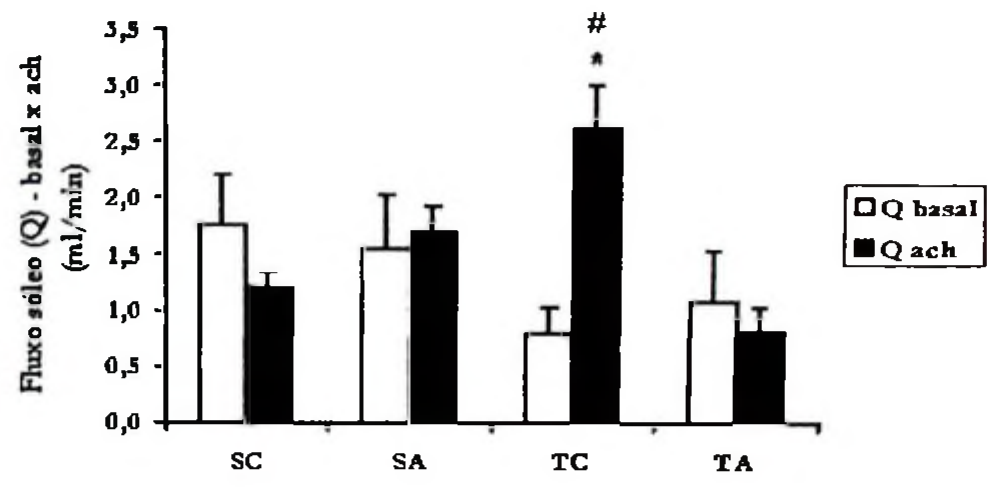

FIGURA 4 - Fluxo sanguíneo basal (Q basal) e sob administração de acetilcolina (Q Ach) para o músculo sóleo.

\section{Morfologia muscular esquelética Hipertrofia}

Os resultados da avaliação de hipertrofia da musculatura esquelética obtidos pelo peso do músculoesquelérico normalizado pelo peso corporal do animal (sóleo: $\mathrm{SC}=0,49 \pm 0,02, \mathrm{SA}=0,48 \pm 0,01, \mathrm{TC}=0,44$ $\pm 0,03, \mathrm{TA}=0,48 \pm 0,01 \mathrm{mg} / \mathrm{g}$ ) mostram que nem o TFN, nem o uso de EAA foram eficazes em causar hipertrofia no músculo estudado.

\section{Morfometria muscular esquelética Número de capilares por fibra}

Os resultados da análise histológica para sóleo estâo apresentados na FIGURA 5. Foram encontrados aumentos significativos na razäo capilar/fibra $(\mathrm{rc} / \mathrm{f})$ do grupo TC $(2,29 \pm 0,08)$ comparado aos grupos TA $(1,82 \pm 0,09), \mathrm{SC}(1,74 \pm 0,12)$ e SA $(1,58 \pm 0,07)$, ou seja, o número de capilares por fibra muscular esquelérica encontra-se aumentado no grupo TC em relaçáo aos outros grupos para o músculo estudado.

\section{Expressāo de VEGF \\ ("Vascular-Endotelial Growth Factor")}

A FIGURA 6 mostra os resultados de expressāo de VEGF para sóleo, corrigidos pelos respectivos resultados de expressáo da protefna normalizadora, a Gliceraldeldo 3-fosfato desidrogenase (GAPDH Glyceraldehyde 3-phosphate dehydrogenase). Não houve diferença estatística entre os grupos para a protefna normalizadora GAPDH. Para a expressão de VEGF, expressa como Razão VEGF/GAPDH houve aumento significativo aumentou no grupo TC $(1,75$ $\pm 0,25$ ) comparado aos outros grupos, ou seja, a expressão do VEGF se encontra $31 \%$ aumentada neste grupo em relação aos grupos TA $(1,02 \pm 0,08), 58 \%$ em relação ao grupo SC $(0,73 \pm 0,09)$ e $39 \%$ em relação ao grupo $\mathrm{SA}(1,07 \pm 0,13)$.
$\mathrm{SC}=$ Sedentánin Controte: $S A=S$ ede níárlo Anabolizado;

IC = Treinado Controle TA=TreinadoAnabolizado. $"=$ Aumentos significaimos para o grupo TC comparado aos grupos TA, SA e SC.

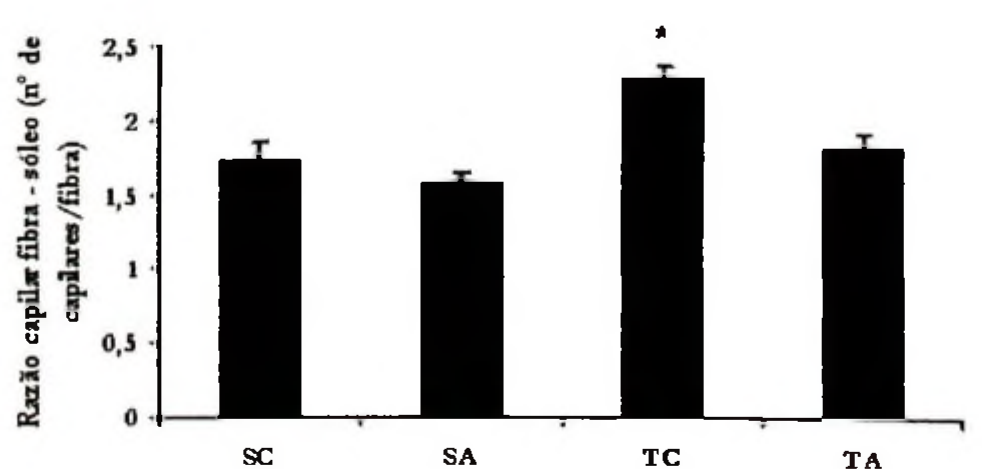

FIGURA 5A - Razão capilar/fibra para o músculo sóleo. 

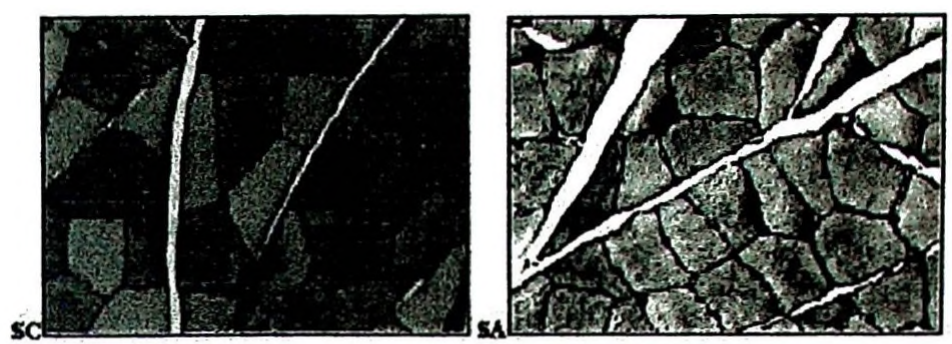

$S C=$ Sedentárín Controle; $S A=S$ edentérlo Arabolizado;

$T C=$ Treinado Controle

TA=TrenadoAnabolbach
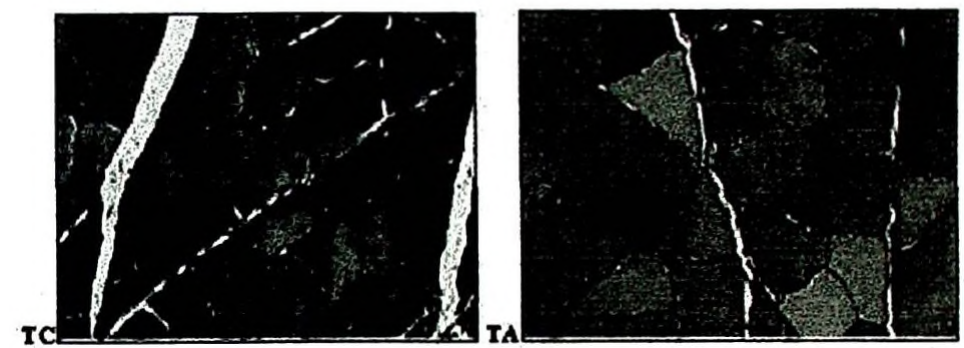

FIGURA 5B - Fotos ilustrativas dos campos observados através de microscopia ótica do músculo sólco através de lentes com aumento de $40 x$ para os quatro grupos.
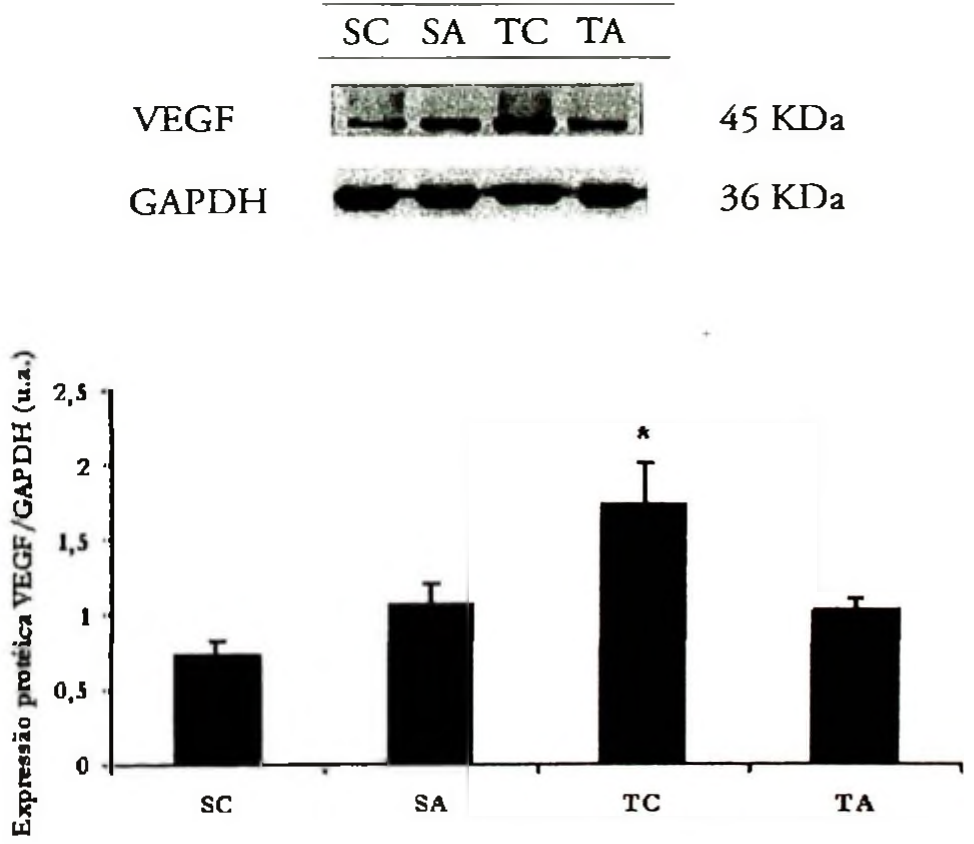

$S C=$ Sodentário Controta; S A = Sedentárlo Anabolizado:

TC = Treinado Controle TA=TreinadoAnaboloach Resultados expressos como média \pm erro padrăo. $(p<0,05)$.

- = Aumentos significa. ivos do grupo TC comparado aos grupos $T A$ $\mathrm{SC}$ e SA. $p<0,05$.

FIGURA 6 - Expressão proteíca de VEGF e GAPDH para sóleo (Western Blot): razão VEGF/GAPDH para o músculo sóleo. 


\section{Discussão}

Os principais resultados encontrados nesse estudo demonstram que o uso de doses suprafisiológicas de EAA associado ao treinamento de nataçāo provoca diminuiçāo da resposta vasodilatadora endorélio dependente (QAch), no sóleo, devido ao prejutzo de fluxo sob administraçáo de Ach. Fste prejufzo se reflete na expressão de VEGF, gerando diminuição no número de capilares por fibra muscular esquelética no músculo estudado.

O presente estudo mostrou que a administraçāo de EAA causa um aumento na concentração de testosterona plasmática nos animais TA e SA. Estes resultados são consistentes com efeitos descritos previamente com a concentração de testosterona plasmática mais alta em ratos submeridos a tratamento crônico com EAA (Trifunovic, NorTon, Duffield, Avraam \& Woodiwiss, 1995).

Houve reduçāo na progressāo do PC no decorrer do protocolo. Os grupos TC, SA e TA apresentaram menor PC final em relação aos animais do grupo SC. Esses resultados refletem um maior metabolismo de lipideos alcançado pelo treinamento aeróbio e pela administraçāo do EAA. Os resultados apresentados neste estudo estão em acordo com os resultados obtidos por Rochi et al. (2007), que demonstraram um menor peso corporal ao final do protocolo experimental, nos animais do grupo SA, TC e TA, quando comparados ao SC. Esta diferença de peso foi relacionada à reduçāo da gordura intraperitonial destes grupos.

Resultados similares foram descritos em estudos onde o excesso de andrógenos causou um aumento no metabolismo de lipideos no tecido adiposo o que resulta em menor ganho de peso (BEUTEL, Bergamaschi \& Campos, 2005; SchroederZheng, Ong, Martinez, Flores, Stewart, Azen \& Sattler, 2004; Yu-Yahiro, Michael, Nasralah \& SHofield, 1989). Esses resultados ainda são controversos na literatura, pois existem estudos que não demonstraram diminuiçōes nem acréscimos no peso corporal (MASONIS \& MCCARTHY, 1995), o que parece ser reflexo do tipo de droga utilizada, dosagem e protocolo experimental empregado.

Os resultados de peso do músculo corrigido pelo peso corporal sugerem que não ocorreu hipertrofia no músculo estudado. Estes resultados são condizentes com os efeitos do treinamento aeróbio, em intensidades baixas, na área de secção transversa do músculo, que tem um potencial hipertrófico diminuldo em relação a treinamentos mais intensos e a músculos com predominância de fibras brancas (Maughan, Gleeson \& Greenhaff, 2000).
A bradicardia de repouso dos animais TA e TC confirma a efetividade do treinamento flsico aeróbio neste estudo, como já relatado previamente por outros estudos realizados em nosso laboratório (REDONDO, 2007; RochA et al., 2007). Esta adaptaçāo ao exercício crônico foi mantida com o tratamento com EAA.

O DC do grupo TA se encontrou diminuido em relaçāo aos outros grupos, em condiçōes basais (DC basal) e sob administraçáo de acetilcolina (DC Ach). Dados já publicados relatam que doses suprafarmacológicas de EAA geram diminuição da resposta inourópica do coraçáo devido à presença de hipertrofia patológica e aumento de fibrose por deposição de colágeno uipo I e III (Rochis et al., 2007). É possivel que a associação dos efeitos deletérios citados anteriormente, oriundos da administraçāo da droga em conjunto à bradicardia de repouso, observada também no grupo $\mathrm{TA}$, resulte em uma diminuiçāo significativa de DC, no grupo TA, tanto por diminuir o volume sistólico, em decorrência de prejuizo inotrópico, quanto por redução da FC, em decorrência do treinamento. Este efeito que é normalmente considerado como uma adapmação benéfica sem o uso da droga, devido a um aumento compensado no volume sistólico (VS), parece nocivo para o usuário de EAA que o associa ao treinamento aeróbio, no qual uma diminuição da FC nāo é compensada pelo aumento no VS.

Em condição basal ( $Q$ basal) nāo foi observada alteração na perfusão regional para o músculo sóleo entre os grupos. No entanto, é importante ressaltar que, devido à diminuiçāo do DC observada no grupo TA esta condição pode refletir numa diminuição perfusional de outros sistemas orgânicos, que provavelmente operam de forma deficitária de oxigênio e substratos em funçāo da diminuição de fluxo oriunda da diminuição do DC.

Ao avaliar a vasodilataçăo endotélio dependente com a infusão por Ach $\mathrm{cm}$ músculas sóleo, o grupo TC obreve aumento de fluxo sanguineo em relaçáo aos grupos $S C$, SAeTA. Adicionalmente, neste músculo, que apresenta predominio do merabolismo oxidativo o grupo TC apresentou $Q$ Ach aumencado em relaçáo sua condição basal (Q basal) o que não foi observado nos outros grupos. Ambos os resultados mostram uma capacidade vasodilatadora endotélio dependente aumentada em função do efeito do treinamento sobre a vasculatura muscular. A funçăo endotelial é essencial para a manutenção do fluxo sangúneo, e para o controle vasomotor de vasos de condutância e resistência e o 
cxcrcício crônico aumenta a vasodilatação endotelial dependente de NO cm ambos os vasos (GrEen, Maiorana, O'Driscoll \& Taylor, 2004).

Por outro lado, é passivel de observação que os grupos SC e SA nāo apresentaram diferenças no fluxo sob ação da Ach (Q Ach) em relação à sua condição basal ( $Q$ basal). E possivel que isto tenha ocorrido em função de uma menor sensibilidade à Ach destes grupos, não por apresentar prejứzo na sua capacidade vasodilatadora endotélio dependente, mas provavelmente porque, devido a não ser submetido ao TFN, perifericamente nāo apresenta uma capacidade vasodilatadora endotélio dependente desenvolvida o suficiente para responder à quantidade de Ach infundida, sendo que no sóleo, para estes grupos, não apresentam caracteristicas adaptativas ao treinamento, como os do grupo TC. Contrariamente ao estudo de REDONDO (2007), que observou aumento de $Q$ Ach dos animais $S C$ em relação à $Q$ basal no coração, este estudo mostra que os animais sedentários podem não apresentar resposta vasodilatadora pronunciada em relação a sua condição basal, porque seu fenótipo não está adapcado ao treinamento. Ainda, como o experimento das esferas é realizado com o animal em repouso, o músculo esquelético não constitui em um sistema prioritário como o coração nesta situaçẩo. Estes resultados são compat́veis com outro estudo que mostra que tanto a sensibilidade quanto a resposta máxima à Ach de roedores sedentários está diminulda, e que ambas são aumentadas com o treinamento em esteira (McAuster, Newcomer \& LaUghlin, 2008).

No grupo TA após a infusāo de Ach foram observados os maiores prejulzos sobre vasculatura músculo-esquelérica, evidenciando as consequências do abuso do EAA associado ao treinamento aeróbio. A resposta vasodilatadora dependente de endotélio deste grupo foi inibida no músculo sóleo, o que sugere que a associação de doses abusivas de EAA com o treinamento aeróbio apresenta resposta diminuŕda à Ach, com capacidade vasodilatadora dependente de endotélio prejudicada em relação ao grupo que treinou e não recebeu o EAA. A capacidade de vasodilacação endorélio dependente é um aspecto importante durante o exercício, permitindo um aporte adequado de sangue e substratos para os músculos ativos e para manter a saúde vascular (GrFen et al., 2004).

O estímulo físico do aumento de fluxo como ocorre, por exemplo, durante o exercício flsico é capaz de disparar a biossintese de fatores de crescimento angiogênicos protetores contra doenças vasculares (Prior, Yang \& Terjung, 2004). Com a resposta de fluxo sob ação de Ach prejudicada no grupo TA, provavelmente durante o cxerclcio existe diminuição da perfusão através do controle dos vasos de resistência (arteríolas), com prejuizo da reatividade vascular e também diminuição do estresse de cisalhamento no lúmen dos vasos, o que prejudica a angiogênese induzida pelo exercício.

Os resulmados deste estudo são compativeis com o de CunHa etal. (2005), que mostra que a menor sensibilidade de anéis de aorta de ratos à substância vasoconstritora fenilefrina obrida pelo treinamento anaeróbio foi revertida pelo grupo treinado e tramdo com nandrolona, o que sugere que o tratamento com o EAA gera prejulio em algum mecanismo importante envolvido nos processos de vasodilatação dependente de endotélio, como a biossintese de óxido nitrico (NO), por exemplo.

Adicionalmente, o TFN é um estímulo que pode gerar o alargamento de um vaso arterial (arteriogênese) em resposta ao fluxo sanguíneo aumentado. A elevação do estresse de cisalhamento na superficie endotelial gera não apenas uma distensão na parede do vaso devido a uma pressão intraluminal aumentada, mas um aumento em seu diâmetro e dimensōes da parede, decorrente do remodelamento de células endoteliais, musculares lisas e de fibroblastos. Este estímulo tem relação com o aumento do estresse de cisalhamento no lúmen arterial, causado pelo aumento do fluxo circulante, sendo que o vaso se alarga para normalizálo respondendo com um espessamento da parede. Ao contrário, se o fluxo é reduzido na resposta ao exercício o diâmetro da artéria se reduz, em resposta a um menor estresse de cisalhamento e o aporte de sangue é reduzido para o tecido (Prior, Yang \& Terjunc, 2004)

Adicionalmente, os resultados mostram que o EAA associado ao TFN, atenuou o aumento no número de capilares por fibra muscular esquelética, sendo a angiogênese como efeito do treinamento inibida no grupo TA, que apresentam os valores de rc/f similar aos valores dos grupos sedentários (SC e SA). O prejuízo apresentado pelo músculo sóleo do grupo TA no $Q$ Ach, ao invés de ser compensado por um aumento no número de capilares por fibra muscular, foi agravado por uma proliferação inibida no grupo TA, o que reforça a hipórese de que esta associação é capaz de gerar anormalidades na resposta vascular ao exercício no músculo estudado (DE Angells, OGawa, Sanches, Rigatto, Krieger \& Irigoyen, 2006; Soares \& DuarTe, 1991; Tacarakis et al., 2000).

Além da diminuição do fluxo regional derivada de um provável prejulzo na vasodilatação dependente de endotélio, e contrariamente ao grupo de animais TC, foi observada rarefação de capilares nos 
músculos estudados no grupo TA. Existem estudos que mostram resultados similares no leito capilar cardfaco e muscular esquelético de ratos submetidos a protocolos que associam treinamento em esteira e EAA (Dimauro, Balnave \& Shorey, 1992; Hudlicka, Dodd, Renkin \& Grey, 1982; Soares \& Duarte, 1991; Tagiarakis et al., 2000).

A análise da expressāo protéica de VEGF confirma os resultados de angiogênese no grupo TC, além de explicar a rarefação no grupo TA comparado ao grupo TC, apresentando adicionalmente valores similares aos grupos SC e SA. Há aumentos de expressão de VEGF e de valores de $\mathrm{r}$ c/f no grupo TC sem alteração para TA, SC e SA.

É preciso considerar que o grupo TA apesar de ser submetido ao treinamento de natação apresenta valores iguais ( $\mathrm{r} / \mathrm{f}$ e VEGF) que os grupos SC e SA. Estes resultados sugerem que apesar de estar sendo submetido ao estresse do exercício físico, a capacidade adaptativa microvascular, que é benéfica à saúde $e$ decorrente do exercício crônico está prejudicada. Os grupos SC e SA não apresentam esta altreraçăo, o que é justificado pelo fato dos mesmos não serem submetidos ao TFN. O grupo TA sofre prejuizo funcional e estrutural sem as adaptações benéficas causadas pelo TFN por si só, importantes para que os efeitos do estresse sobre a musculatura possam ser compensados e sejam benéficos à saúde, já que além de apresentarem capacidade vasodilacadora endotélio dependente diminulda apresentam também uma menor expressão de VEGF, e uma atenuação não esperada para um animal treinado na quantidade de capilares funcionais por fibras musculares esqueléticas.

VEGF é considerado o principal fator de crescimento envolvido na angiogênese e sua expressão é iniciada pela hipóxia e fortemente estimulada pelo estresse de cisalhamento decorrente do aumento do fluxo sangulneo nas sessōes de exercício durante o treinamento aeróbio (Prior, YANG \& TerJung, 2004). No grupo TA sua expressão se encontra diminulda em relação ao grupo TC sem diferenças em relação aos grupos sedentários.

A atenuação dos valores de $\mathrm{r} c / f \mathrm{e}$ da expressão de VEGF foi consistente no músculo estudado, indicando que o grupo TA, além de apresentar DC e Q Ach diminuldo, também apresenta uma menor quantidade de capilares por fibra muscular esquelérica, que parece ser uma consequência relacionada à diminuição do fluxo, aliada ao advento de diminuição na expressáo de VEGF e suas vias de sinalizaçáo.

Diversos estudos confirmam o papel de VEGF na angiogênese induzida pelo exercício mostrando aumentos nos nivcis de mRNA e de expressāo protéica de VEGF em ratos e relacionando estes aumentos a uma quantidade aumentada de capilares funcionais (Amaral, Linderman, Morse \& Greene, 2001; Amaral, Papanek \& Greene, 2001; Kraus et al.; 2004; Milkiewics, Huducka, Brown \& Silgran 2005), resultados que coincidem nesse estudo com os aumentos de expressão de VEGF e de $\mathrm{r}$ c/f do músculo estudado no grupo TC. O reconhecimento de que há uma responsividade melhorada para o remodelamento microvascular de individuos treinados comparados a sedentários pode contribuir para a associação geral entre um estilo de vida ativo e menor incidência de doenças vasculares.

Contrariamente, os resultados do grupo TA sugerem que associar EAA ao TFN gera atenuaçāo da angiogênese ocasionada pelo treinamento de resistência aeróbia por si só, o que leva a crer que esta associação é deletéria para o endotélio e para os capilares no músculo esquelético, o que predispõe o praticante de esportes e atividades físicas a problemas vasculares. O estudos de D'Ascenzo, Millinagi, Di Masimo, Saccani-Jotti, Botre, Carta, Tozzi-Ciancarelli, Pavan e Dolo (2009) e Ray, Herring, Markel, Crisostomo, Wang, Weil, Lahm e Meldrum (2008), ambos empregando cultura de células, mostram "in vitro" os efeitos deletérios da testosterona e seus derivados em doses suprafisológicas em células endoreliais da veia umbilical e na produção de VEGF em células tronco mesenquimais de ratos. Estes reforçam a hipótese de que os EAA são capazes de alterar a homeostase das células endoteliais e que podem diminuir a produção de fatores de crescimento que protegem contra doenças vasculares. Esses estudos mostram que a exposição a doses suprafisiológicas de EAA altera o crescimento das células endoteliais com um forte efeito antiproliferativo, induzindo apoptose e modificando as concentraçōes intracelulares de cálcio, um marcador para ativação precoce de células endoteliais, que provoca a produção e lançamento de citocinas e fatores predisponentes a dano vascular (WaTANABE, Tanaka, Wen \& Yoshida, 1996). Os resultados do presente estudo sugerem que é posslvel a ocorrência de efeiros similares "in vivo" no músculo sóleo, ocasionando prejufzo na reatividade vascular que culminaram na diminuição no número de capilares funcionais e perda do efeito de rreinamento para o grupo que associou al tas doses de EAA e o treinamento aeróbio.

$E ́$ interessante elucidar no futuro quais mecanismos estāo envolvidos nessa atenuaçāo gerada pela associaçāo 
dc EAA c treinamento fisico no músculo esquelético com diferentes predominâncias de fibras, além da participaçāo do VEGF, já que o envolvimento de diversos outros fatores de crescimento, vias de sinalização e suas interaçóes coordenadas na angiogênese induzida pelo exerclcio atualmente são reconhecidos na literatura (CONWAY, COLLEN \& Carmeliet, 2001 ; Prior, Yang 8 'Terjung, 2004).

Finalmente, este estudo mostra evidência de que a associação entre EAA e TFN é deletéria para o endotélio e para a microvasculatura no músculo sóleo, o que tem relação com a diminuição na expressão de VEGF comparado ao resultado observado como efeito do treinamento físico por si só. Esta diminuição está relacionada à diminuição do fluxo sangulneo muscular em resposta ao exerclcio, que provavelmente é uma consequência da diminuição do débito cardlaco em repouso e durante o exercício. Desta forma, esse estudo mostra que não é possivel garantir manutenção da saúde vascular para usuários de EAA mesmo quando associados à atividade física.

\begin{abstract}
Anabolic steroid impairs the angiogenesis induced by swimming training in soleus muscle of normotensive rats

Androgenic anabolic steroids (EAA) are synthetic derivatives of testosterone, used in therapeutic dosages in medical practice and in high doses by physically active people that could be health damaging. To study the effects of EAA on the cardiovascular system. Wistar rats were randomized into Sedentary Control (SC). Sedentary Steroid (SA), Trained Control (TC) and Trained Steroid (TA) groups. We evaluated the effects of swimming training $(60 \mathrm{~min} /$ day, $5 x /$ week during 10 week) and AAS (nandrolone decanoate - $5 \mathrm{mg} / \mathrm{kg} \mathrm{sc}, 2 x /$ week) on cardiac output, basal blood flow ( $\mathrm{Ob}, \mathrm{DC}$ basal) and after injection of a vasodilator to observe the endothelium dependent vasodilatation (acetylcholine - $Q$ Ach $)(O A c h, D C$ Ach), capillary to fiber ratio ( $\mathrm{r} / \mathrm{f}$ ) and vascular-endothelial growth factor expression (VEGF) in soleus muscle (oxidative fibers). Serum testosterone increased in SA and TA. Exercise training significantly decreased resting heart rate. $\mathrm{Qb}$ was not different among groups, and QAch was higher in TC group. however in TA group this beneficial effect of swimming exercise training was lost by association with EAA. Rc/f and VEGF were higher only in TC group. These results suggest that swimming training associated with EAA inhibit angiogenesis and arteriogenesis observed as effects of aerobic training, and impairs the red skeletal muscle blood flow which predispose physically active AAS users to vascular diseases.
\end{abstract}

Uniterms: Doping; Blood flow; Capillary; Skeletal muscle; Swimming training.

\title{
Referências
}

AMARAL, S.L.; PAPANEK, P.E.; GREENE A.S. Angiorensin II and VEGF are involved in angiogenesis induced by short-cerm exercise training. American Journal of Physiology: Heart and Circulatory Physiology, Bethesda, v.281, p.H1163-9, 2001.

AMARAL, S.L.; LINDERMAN, R.J.; MORSE, M.M.; GREENE, A.S. Angiogenesis induced by electrical scimulacion is mediated by angiotensin II and VEGF. Microcirculation, New York, v.8, p.57-67, 2001

ANDERSEN, R.E.; BARTLETT, S.J.; MORGAN, G.D.; BROWNELL, K.D. Weight loss, psychological and nutricional patterns in competitive male body builders. Intemacional Journal of Eating Disorders, New York, v. 18, n. 1, p.49-57, 1995. BEUTEL, A.; BERGAMASCHI, C.T., CAMPOS, R.R. Effects of chronic anabolic steroid treatment on tonic and reflex cardiovascular control in male rats. The Joumal of Stcroids Biochemistry and Molecular Biology, Oxford, v.93, p.43-8, 2005. BORNES, S.; BOULARD, M.; HIEBLOT, C.; ZANIBELLATO, C.; IACOVONI, J.S.; PRATS, H.; TOURIOL, C. Control of the vascular endothelial growth factor internal ribosome entry site (IRES) activity and translation iniciation by alternarively spliced coding sequences. The Joumal of Biological Chemistry, Baltimore, v.279, n. 18, p. 18717-26. 2004. 
BRADFORD, M.M. A rapid and sensicive method for the quantization of microgram quanticies of protein urilizing the principle of protein-dye binding. Analytical Biochemistry, New York, v.72, p.248-54, 1976.

CELOTT1, F:; CESI, P.N. Anabolic steroids: a review of their effects on the muscle, of their possible mechanisms of action and of their use in athletics. The Journal of Steroids Biochemistry and Molecular Biology, Oxford, v.43, p. 469$77,1992$.

COLÉGIO BRASILEIRO DE EXPERIMENTAÇĀO ANIMAL (COBEA). Princípios éticos na experimentação animal, 1991. Disponível em: <htrp://cobea.org.br/érica/htm\#3>. Acesso em: set. 2006.

CONWAY, E.M.; COLLEN, D.; CARMELIET, P. Molecular mechanisms of blood vessel growth. Cardiovascular Research, London, v.49, p.507-21, 2001.

COSTILL, D.L.; MAGLISCHO, E.W.; RICHARDSON, A.B. Handbook of sports medicine and science-swimming, an IOC medical commission publication, FINA. Oxford: Blacwell Science, 1992. cap.12, p.133-43.

CUNHA, T.S.; MOURA, M.J.C.S.; BERNARDES, C.F; TANNO, A.P.; MARCONDES, FK. Vascular sensiviry to phenylephrine in rats submitted to anaerobic rraining and nandrolone creatmenc. Hypertension, Dallas, v.46, p.1010-5, 2005.

D'ASCENZO, S.; MILlIMAGI, D.; DI MASSIMO, C; SACCANI-JOTTI, G.; BOTRË, F; CARTA, G.; TOZZICIANCARELLI, M.J.; PAVAN, A.; DOLO, V. Detrimental effecrs of anabolic sceroids on human endorhelial cells. Toxicology Letters, Amsterdam, v. 169, n.2, p. 129-36, 2006.

DE ANGELIS, K.; OGAWA, T; SANCHES, I.C.; RIGATTO, K.V.; KRIEGER, E.M; IRIGOYEN, M.C. Impairment on cardiac output and blood flow adjustments to exercise in L-NAME-induced hypertensive rats. Journal of Cardiovascular Pharmacology, New York, v.47, p.371-6, 2006.

DIMAURO, J.; BALNAVE, R.J.; SHOREY, C.D. Effecrs of steroids and high intensity exercise on rat skeleral muscle fibres and capillarization. A morphometric study. European Joumal of Applied Physiology and Occupational Physiology, Berlin, v.64, p.204-12, 1992.

FULLER, M.G. Anabolic-androgenic steroids: use and abuse. Comprehensive Therapy, Harvard, v. 19, p.69-72. 1993. GREEN, D.J.; MAIORANA, A; O'DRISCOLL; TAYLOR, R. Effect of exercise rraining on endorhelium-derived nitric oxide in humans. The Journal of Physiology, London, v.561, p.1-25, 2004.

HAKKINEN, J.P.; MILLER, M.W.; SMITH, A.H.; KNIGHT, D.R. Measurement of organ blood flow wirh colored microspheres in rar. Cardiovascular Research, London, v.29, p.74-9, 1995.

HEBERT, A.; HAUPT, M.D.; GEORGE, D.; ROVERE, M. Anabolic sreroids: a review of rhe lirerarure. The American Journal of Sports Medicine, Baltimore, v.12, p.469-84, 1984.

HUDLICKA, O.; DODD, L.; RENKIN, E.M.; GRAY, S.D. Early changes in fiber profile and capillaries in various muscles. Respiratory Physiology, Amsterdam, v.44, p.87-111, 1982.

INGJER, F; BRODAL, P. Capillary supply of skelecal musde fibers in untrained and endurance-trained women. European Journal of Applied Physiology, Berlin, v.38, p.291-9, 1978.

JENSEN, L.; BANGSBO. J.; HELLSTEN, Y. Effecr of high intensity training on capillarization and presence of angiogenic factors in human skelecal muscle. The Journal of Physiology, London, v.557(Pr 2), p.571-82, 2004.

KAM, P.C.A.; YARROW, M. Anabolic steroid abuse: physiological and anaeschecic considerations. Anaesthesia, London, v.60, p.685-92, 2005.

KINDERMANN, W. Cardiovascular side effects of anabolic-androgenic steroids. Herz, Munchen, v.31, p.566-73, 2006.

KUHN, C.M. Anabolic steroids. Recent Progress in Hormone Research, New York, v. 57, p.411-34, 2002.

KRAUS, R.M.; STALIINGS, H.W.; YEAGER, R.C.; GAVIN, T.P. Circularing plasma VEGF response ro exercise in sedencary and endurance-trained men. Journal of Applied Physiology, Washingron, v.96, p. 1445-50, 2004.

LAEMMLI, U.K. Cleavage of structural proteins during the assembly of the head of bacteriophage T4. Nature, London, v.227, n.259, p.680-5, 1970.

MASONIS A.E.; MCCARTHY M.P. Direct effects of the androgenic/anabolic steroid stanozolol and 17 alphamerhyltestasrerone on benzodiazepine binding to the gamma-aminobutyric acid(a) receptor. Neuroscience Letrers, Amsterdam, v.189, p.35-8, 1995.

McALLISTER, R.M.; NEWCOMER, S.C.; LAUGHLIN, M.H. Vascular nitric oxide: effects of exercise training in animals. Applied Physiology, Nutrition, and Metabolism, Otawa, v.33, n.1, p.173-8, 2008.

MANETTA, M.C.D.P.; SILVEIRA, D.X. Uso abusivo de anabolizantes androgênicos. Psiquiatria na Prática Médica, Săo Paulo, v.33, p. 1-3, 2000.

MAUGHAN, R.; GLEESON, P.L.; GREENHAYF, P.L. Adapração metabólica ao treinamento. In: do exercicio e trcinamento. Barueri: Manole, 2000. cap.8, p.179-211. Bioquímica xo8 - Rev. bras. Educ. Fis. Esporte, São Paulo, v.23, n.3, p.195-209, jul./set. 2009 
MIEDEIROS, A.; OLIVEIRA, E.M.; GIANOLLA, R.; CASARINI, D.E.; NEGRÃO, C.E.; BRUM, P.C. Swimming training increases cardiac vagal activity and induces cardiac hypertrophy in mes. Brazilian Journal of Medical and Biological Research, Ribeirão Preto, v.37, p. 1909-17, 2004.

WIILIEWICS, M.; HUDLICKA, O.; BROWN, M.D.; SILGRAN, H. Nitric Oxide, VEGF, and VEGFR-2: interaccions irs activity-induced angiogenesis in rat skeletal muscle. American Joumal of Heart an Circulatory Physiology, Bethesda, v. 289, p.H336-43, 2005.

POLVINO, W.].; SARAVIS, C.A.; SAMPSON, C.E.; COOK, R.B. Improved protein analysis on nitrocellulose rembrane. Electrophoresis, Weinheim, v.4, p.368, 1983.

POPE JUNIOR, H.G.; KATZ, D.L. Affective and psichotic syndromes associated with use of anabolic-androgenic soeroids. American Joumal of Psychiatry, Hanover, v.145, p.487-90. 1988.

XRIOR, B.M.; YANG, H.T.; TERJUNG, R.L. What makes vessels growth with exercise training? Journal of Applied Thysiology, Washington, v.97, p.1119-28, 2004.

FAY, R.; HERRING, C.M.; MARKEL, T.A.; CRISOSTOMO P.R.; WANG, M.; WEIL, B.;LAHM, T.; MELDRUM, D.R. Deleterious effects of endogenous and exogenous testosterone on mesenchymal sem cell VEGF production. The Amerion Journal of Physiology: Regulatory, Integrative and Compararive Physiology, Bethesda, v.294, p. R1498-1 503, 2008.

REDONDO, F.R.R. Efeitos do uso de esteróides anabolizantes associados ao treinamento físico de natação sobre o Huro sangúneo para o miocárdio de ratos normotensos. 2007. $126 \mathrm{f}$. Dissertaçäo (Mestrado em Bioquímica da Arividade Morora) - Escola de Educação Fisica e Esporre, Universidade de São Paulo, São Paulo, 2007 ROCHA, FL.; CARMO, E.C.;ROQUE,E.R.; HASHIMOTO, N. Y.; ROSSONI, L.V.; FRIMM, C.; ANÉES, I.; NEGRĀO, C.E.; KRIEGER, J.E.; OLIVEIRA, E.M. Anabolic steroids induce cardiac renin-angiotensin system and impair the beneficial effects of aerobic training in rats. American Journal of Physiology. Hearr and Circulatory Physiology, Bethesda, v.293, p.H3575-83, 2007.

SALTIN, B.; ROWELI., L.B. Funcrional adaptations to physical accivity and inactivity. Federation Proceedings, Washington, v.39, p.1506-13, 1980.

SCHROEDER, E.T.; ZHENG, L.; ONG, M.D.; MARTINEZ, C.; FLORES, C.; STEWART, Y.; AZEN, C.; SATTLER, FR. Effecss of androgen therapy on adipose rissue and metabolism in older men. The Journal of Clinical Endocrinology and Metabolism, Springfield, v.89, p.4863-72, 2004.

SOARES, J.M.; DUARTE, J.A. Effects of training and an anabolic steroid on murine red skeletal muscle. A stereological analysis. Acta Anatomica, Basel, v.142, p.183-7. 1991.

TAGARAKIS, C.V.; BLOCH, W.; HARTMANN, G.; HOLIMANN, W.; ADDICKS, K N nabolic steroids impair the exercise-induced growth of the cardiac capillary bed. Intemational Joumal of Sports Medicine, Sturcgarr, v.2, p.412-8, 2000. TAKAHACHI, M.; TATSUGI, Y.; KOHNO, T. Endocrinal and pathological effects of anabolic-androgenic steroid in male rats. Endocrine Joumal, Tokyo, v.51, p.425-34, 2004.

TRIFUNOVIC, B.; NORTON, G.R.; DUFFIELD, M.J.; AVRAAM, P.; WOODIWISS, A.J. An androgenic steroid decreases left ventricular compliance in rats. American Joumal of Physiology: Heart and Circulatory Physiology, Bechesda, v.268, p. H1096-1105, 1995.

WATANABE, K.; TANAKA, H.; WEN, F.Q.; YOSHIDA, M. Effect of cyrokines on thrombin-scimulated increases in intracellular calcium and PGI2 production by cultured human umbilical vein endochelial cells. Cellular Signalling, Oxford, v.8, p.247-51, 1996.

WATERS, R.E.; ROTEVATIN, S.; PING, L.; ANEXX, B.H.; YAN, Z Volunary running induces fiber cype-specific angiogenesis in mouse skeletal muscle. American Journal of Physiology. Cell Physiology, Bechesda, v.287, p.C1342-8, 2004. VU-YAHIRO, J.A.; MICHAEL, R.H.; NASRALLAH, D.V.; SCHOFIELD, B. Morphological and histologic abnormalities in female and male rats treated with anabolic steroid. American Joumal of Sports Medicine, Baltimore, v.17, p.686-9, 1989.

Edilamar Menezes de Oliveira Departamento de Biodinâmica do Movimento do Corpo Humano Escola de Educação Física e Esporte - USP Av. Prof. Mello Moraes, 65 05508-030 - Sāo Paulo - SP - BRASIL

Recebido para publicaçāo: 20/10/2008 Revisado: 04/05/2009

Aceito: 02/06/2009 